
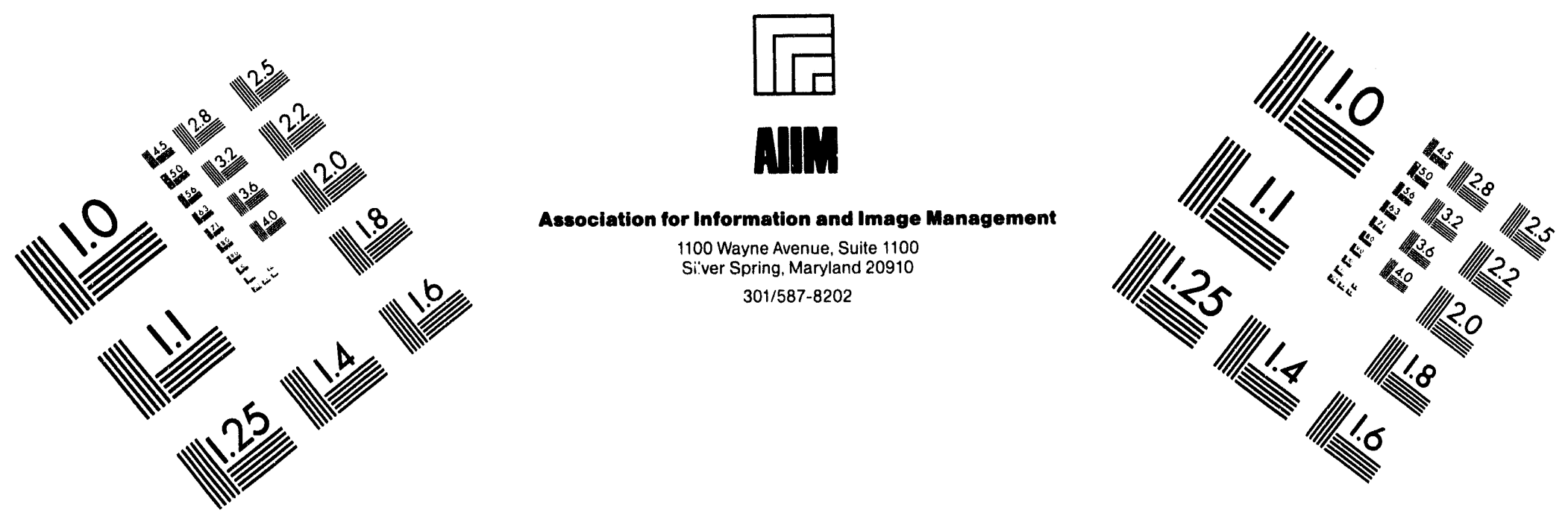

\title{
Centimeter
}

إس

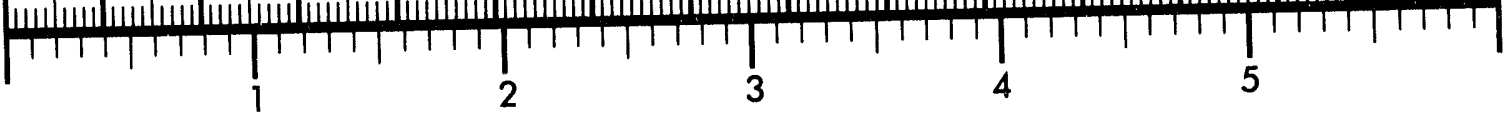
Inches
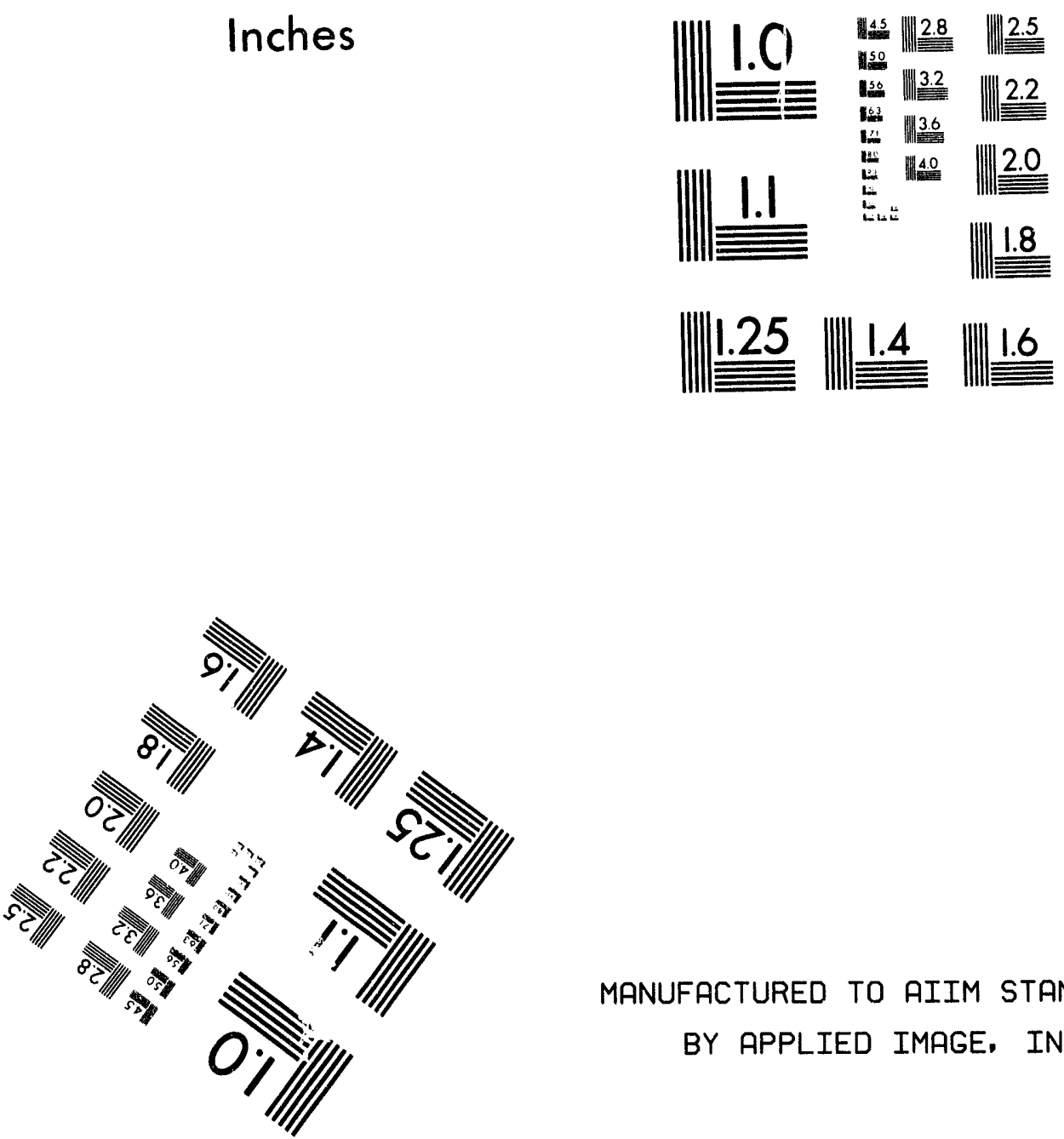

MANUFACTURED TO AIIM STANDARDS

BY APPLIED IMAGE, INC.

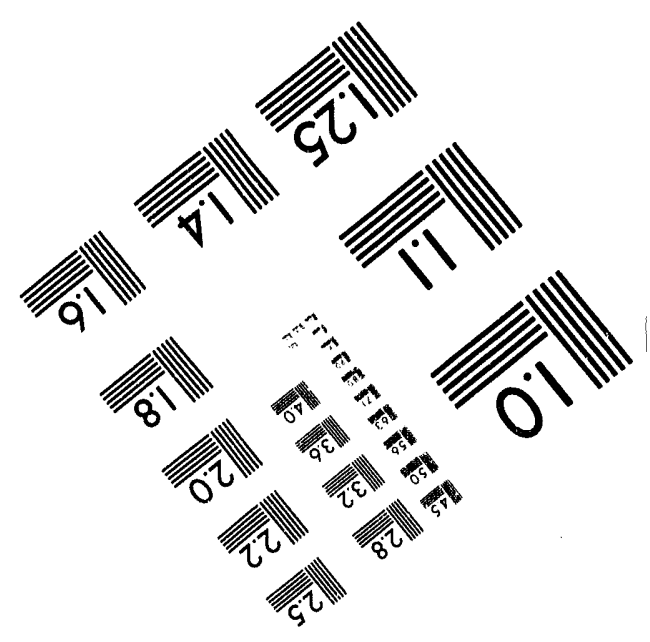



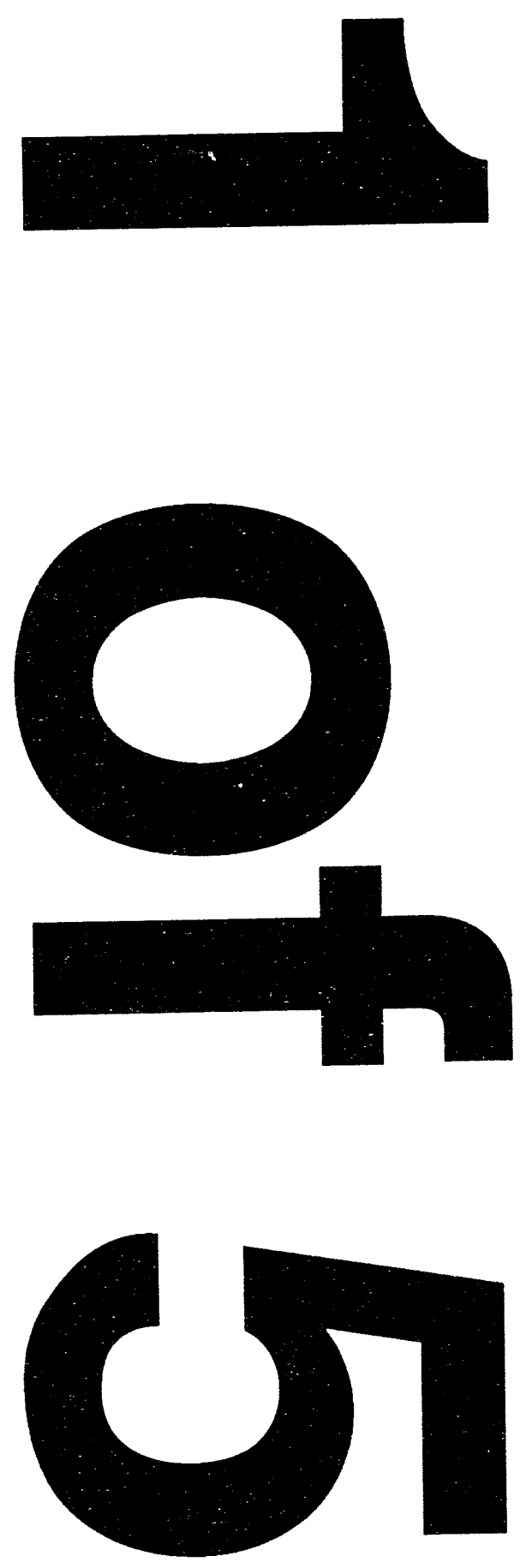
WHC-EP-0707, REV 0

(Formerly RHO-ST-45)

\section{6-U-10 Pond and 216-Z-19 Ditch Characterization Studies}

G. V. Last

Contributing Authors

D. W. Duncan

M. J. Graham

M. D. Hall

V. W. Hall

D. S. Landeen

J. G. Leitz

R. M. Mitchell

Date Published

February 1994

Prepared for the U.S. Department of Energy

\footnotetext{
(2) Westinghouse $\begin{aligned} & \text { P.O. Box } 1970 \\ & \text { Hanford Company } \\ & \text { Richland, Washington } 99352\end{aligned}$

Hanford Operations and Engineering Contractor for the

U.S. Department of Energy under Contract DE-ACO6-87RL10930
}

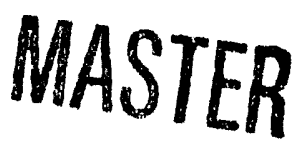

Original Manuscript: 1980

Revised Manuscript: September 1981

Published: December 1993

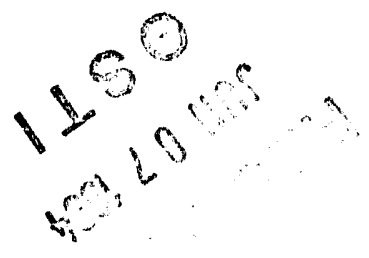




\section{RELEASE AUTHORIZATION}

Document Number: WHC-EP-0707, Rev.0

Document Title: $\quad 216-U-10$ Pond and 216-Z-19 Ditch Characterization Studies

Release Date: $\quad 4 / 27 / 94$

$* * * * * * * * * * * * * * * * *$

This document was reviewed following the prosedures described in WHC-CM-3-4 and is:

\section{APPROVED FOR PUBLIC RELEASE}

$* * * * * * * * * * * * *$

WHC Information Release Administration Specialist:

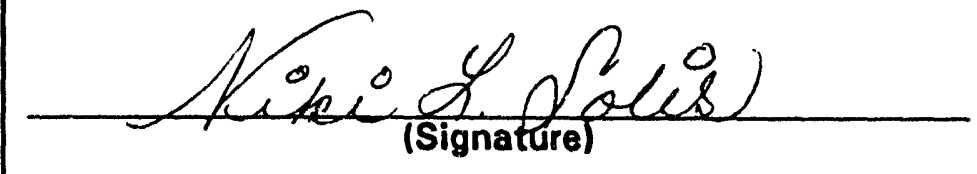

$\frac{4 / 27 / 94}{\text { (Date) }}$




\section{Preface}

This document was originally drafted in 1980 for the Long-Term Transuranic Defense Waste Program managed by Rockwell Hanford Operations under contract to the U.S. Department of Energy. Termination of the program suspended the funding necessary for issuance of the original manuscript. Part of the subject matter was, however, published in 1980 to support the design of decontamination and decommissioning of the 216-U-10 (U-) Pond and its associated ditches (Last and Duncan 1980).

In September 1981, modifications were made to the original manuscript and a second draft was completed in support of the Contaminated Soils and Sediment Technologies Program, also managed by Rockwell Hanford Operations under contract to the U.S. Department of Energy. At that time, the manuscript was given document number RHO-ST-45 and a limited number of draft copies were produced for peer review and comment. Again, termination of the program suspended the funding for resolution of the comments and for issuance of the final document.

In 1983, a summarization of the contents of this document was published in Last (1983), and in 1984, U-Pond and its associated ditches were decommissioned. In 1986, Landeen and Mitchell published their findings regarding the uptake of radionuclides by trees surrounding U-Pond.

Current environmental restoration and waste management activities being conducted by Westinghouse Hanford Company (successor to Rockwell Hanford Operations), again under contract to the U.S. Department of Energy, have sparked renewed interest in publication of this manuscript. With funding from Westinghouse Hanford Company, the text and tables of the manuscript were retyped. The figures remain in their original manuscript state and many suffer because the originals were used for other purposes and are unavailable at this time of publication. With the exceptions of the recently resolved comments and cursory edit, the manuscript remains essentially as it was last drafted in September 1981. Thus, the text of the document refers to the U-Pond system as if it were still active and refers to organizations and programs that are no longer relevant.

The authors wish to thank Westinghouse Hanford Company for supporting the publication of this document and Pacific Northwest Laboratory for lead author, editor, and text processing services.

\section{References}

Landeen, D. S. and R. M. Mitchell. 1986. "Radionuclide Uptake by Trees at a Radwaste Pond in Washington State." Health Physics 50(6):769-774.

Last, G. V. 1983. Radionuclide Distributions Around a Low-Level Radioactive Waste Disposal Pond and Ditch System at the Hanford Site. RHO-HS-SA-19 P, Rockwell Hanford Operations, Richland, Washington; Presented at Waste Management '83, Tucson, Arizona, March 3, 1983.

Last, G. V. and D. W. Duncan. 1980. Radionuclide Distributions in Soils of the U-Pond Disposal System. RHO-CD-1119, Rockwell Hanford Operations, Richland, Washington. 
WHC-EP-0707, Rev. 0

\section{Acknowledgments}

Appreciation is expressed to the many individuals whose effort assisted in the collection and interpretation of data. Assistance with geologic sampling and well drilling activities was provided by M. D. Betts, D. E. Conoyer, W. A. Jordan, E. J. Rink, P. J. Wiater, and R. V. Cram.

R. F. Giddings, A. R. Johnson, D. S. Landeen, J. G. Leitz, and J. A. Bates performed the biological sampling.

R. M. Emery, D. C. Klopfer, and L. E. Bruns provided additional unpublisheo data and answered many questions early in the study.

D. W. Duncan assisted the statistical review and interpretation of the geologic data and aided preparation and editing of this document. D. E. Conover and T. L. Liikala also aided in the preparation of this document.

G. W. Givan and the Environmental Monitoring Unit supplied all Radiation Monitoring support and assisted in the collection of samples.

Gratitude is also expressed to the many individuals whose work has been included in this document but could not be referenced.

Special thanks are extended to G. L. Wagenaar and T. J. Wood for their dedication and innovative ideas in solving unique sampling problems, and to $\mathrm{L}$. L. Weaver for his dedication in taking and interpreting in situ analyses. 


\begin{abstract}
The chemical reprocessing of spent nuclear fuels at the U.S. Department of Energy's Hanford Site has generated large volumes of radioactive liquid effluents. The majority of these effluents have been used strictly for cooling or other supportive functions and have been discharged to ditches and ponds. The 216-U-10 (U-) Pond and 216-Z-19 (Z-19) Ditch are two such disposal facilities. These facilities are components of an integrated system of ditches, ponds, and overflow facilities collectively referred to as the U-Pond disposal system. The U-Pond system has been used since 1943 and has received a large variety of radioisotopes from several sources.

A study of the U-Pond disposal system was conducted from 1979 to 1981 . This study covered the major aspects of the environment, including wind resuspension, biological uptake and transport, geologic distribution in surface and subsurface sediments, and ground-water impacts. In this study, previous information was compiled and reviewed and supplementary sampling schemes were developed. Numerous surface and subsurface samples were collected (including vegetation, animals, sediment, air, and water), utilizing various sampling methods (including the drilling of 20 boreholes). Analyses of the collected samples and analyses conducted in situ were used to delineate the specirtion, concentration, and distribution of radionuclides found in each aspect of the U-Pond disposal system environs.

The long-term use of U-Pond and the Z-19 Ditch has resulted in the localized accumulation of transuranic and fission product inventories as a result of sorption and filtration of particulates onto the uppermost sediments. The various radionuclides have different distributions because of their individual discharge sources and behaviors in this type of a disposal system. Cesium-137 is the most widely distributed radionuclide and was used as an index radionuclide to define the maximum extent of contamination. Its $400-\mathrm{pCi} / \mathrm{g}$ isopleth indicates surface contamination of approximately 19 ha at U-Pond and the 216-U-11 Overflow Basin. This contamination is localized in the top $10 \mathrm{~cm}$ of soil and decreases rapidly with depth. The Z-19 Ditch and its backfilled predecessors, the 216-Z-11 and 216-Z-1 ditches, received ${ }^{238,239.240} \mathrm{Pu}$ and ${ }^{241} \mathrm{Am}$ discharges and retained more than $90 \%$ of the plutonium inventory discharged to the U-Pond disposal system.
\end{abstract}




\section{Summary}

The area studied is an active low-level radioactive liquid waste disposal system on the U.S. Department of Energy's Hanford Site. The disposal system consists primarily of 216-U-10 (U-) Pond and its associated influent and overflow facilities. This disposal system was created in the early 1940s to receive large volumes of relatively uncontaminated waste water from 200 West Area separations facilities. The waste water has come from a variety of sources, including plutonium processing and reclamation facilities, a laundry, a uranium recovery plant, several support facilities, and (most recently) an evaporator, which has contributed greater than $90 \%$ of U-Pond's current water supply. Large volumes of low-level waste water and unplanned isolated releases of higher-level discharges have resulted in the accumulation of significant transuranic and fission product inventories throughout the disposal system, including $8.22 \mathrm{~kg}$ of ${ }^{239} \mathrm{Pu}$.

U-Pond and its associated 216-Z-19 (Z-19) Ditch were selected as being representative of other surface liquid disposal systems at Hanford. The objective of this study was to delineate the concentration, distribution, and speciation of radionuclides released to the U-Pond disposal system.

The study of these facilities covers many aspects of the local environment and is presented in four sections based on these environmental aspects.

\section{Atmospheric Resuspension}

Review of past studies and environmental monitoring results have shown that ${ }^{90} \mathrm{Sr},{ }^{137} \mathrm{Cs}$, ${ }^{238,239,200} \mathrm{Pu}$, and ${ }^{241} \mathrm{Am}$ are resuspended by wind from this system and may have been redistributed downwind.

\section{Biology}

The U-Pond system supports a unique ecological community adapted to the physical and chemical conditions created by treatment of low-level transuranic wastes and fission products. The primary biological concerns are related to uptake and transport of radioactive materials by the biota.

The vast majority of ${ }^{239,240} \mathrm{Pu}$ and ${ }^{241} \mathrm{Am}$ at the Z-19 Ditch are contained in the ditch-bottom sediments, with lesser amounts in the top $15 \mathrm{~cm}$ of soil along the ditch bank; the lowest inventories are observed at the $15-$ to $30-\mathrm{cm}$ soil depths. Levels of ${ }^{239.240} \mathrm{Pu}$ in cattails were high, comprising $83 \%$ of total ${ }^{239,240} \mathrm{Pu}$ found in ditch vegetation. The other aquatic species contained low levels of ${ }^{239,240} \mathrm{Pu}$, perhaps because of shallower root systems and lack of confinement to water. Detectable levels of ${ }^{90} \mathrm{Sr},{ }^{137} \mathrm{Cs}$, and ${ }^{239,240} \mathrm{Pu}$ were found throughout the U-Pond system. Highest values of ${ }^{137} \mathrm{Cs}$ were observed in surface soil, followed by root, leaves, twigs, and tree core samples. The opposite trend 
was seen for ${ }^{90} \mathrm{Sr}$, with highest concentrations found in leaves and twigs, followed by cores, roots, and soils. Total radionuclide inventories were estimated for trees at U-Pond from biomass and average radionuclide values. Total ${ }^{137} \mathrm{Cs}$ tree inventory was estimated at $23,170 \mu \mathrm{Ci}$, total ${ }^{90} \mathrm{Sr}$ at $16,499 \mu \mathrm{Ci}$, and total ${ }^{239,240} \mathrm{Pu}$ at $18,226 \mu \mathrm{Ci}$. At Z-19 Ditch and U-Pond, highest values for radionuclides in small mammals occurred in deer mice and house mice. This is probably because of their omnivorous food habits and preference for mesic communities.

Results reported here represent the first quantitative tree data from the Hanford Site. It has been determined that the burning or removal of these trees would pose no health hazard to humans.

\section{Geology}

Previous geologic information on the U-Pond area was reviewed and supplementary sampling was performed in areas where little or no previous data were available. A total of 971 surface and nearsurface samples were collected, and 20 boreholes were drilled, resulting in 322 samples. These data indicate that ${ }^{90} \mathrm{Sr},{ }^{137} \mathrm{Cs},{ }^{238,239,240} \mathrm{Pu}$, and ${ }^{241} \mathrm{Am}$ exceed Rockwell Hanford Operations' surface soil limits (Booth 1979). Cesium-137 is the most widely distributed radionuclide in the 216-U-14 Ditch, U-Pond, and the 216-U-11 (U-11) Overflow Basin, and thus is used as an index radionuclide to define the maximum extent of contamination. Based on ${ }^{137} \mathrm{Cs}$, the extent of surface contamination is approximately 19 ha at U-Pond and the U-11 Overflow Basin. Most of the contamination is in the top $10 \mathrm{~cm}$ of soil. This contamination boundary could be reduced by approximately $47 \%$ after removal of the top $10 \mathrm{~cm}$ of soil.

The Z-19, 216-Z-11 (Z-11), and 216-Z-1 (Z-1) ditches received ${ }^{238,239,240} \mathrm{Pu}$ and ${ }^{241} \mathrm{Am}$ discharges and probably retained more than $90 \%$ of the plutonium inventory of the U-Pond disposal system. The Z-1 Ditch is estimated to contain between 3 and $10 \mathrm{~kg}$ of plutonium, while concentrations in the Z-11 and Z-19 ditches are estimated to be an order of magnitude lower $(0.3$ to $1.0 \mathrm{~kg}$ plutonium in each ditch).

\section{Hydrology}

The physical and chemical characteristics of the unconfined aquifer under the U-Pond area were studied. The physical characteristics of the unconfined aquifer and the impacts of water percolating from U-Pond on the flow of the aquifer were evaluated using computer models. The resulting data indicated that the large volumes of waste water discharged to U-Pond have impacted the hydrologic conditions at these sites and have raised the water table as much as $26 \mathrm{~m}$, creating numerous perched water zones beneath U-Pond. No severe impacts on the ground-water quality have been observed. 
WHC-EP-0707, Rev. ó

\section{Contents}

Preface $\ldots \ldots \ldots \ldots \ldots \ldots \ldots \ldots \ldots \ldots \ldots \ldots \ldots \ldots \ldots \ldots \ldots \ldots$

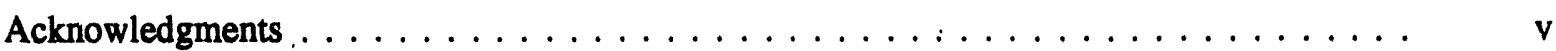

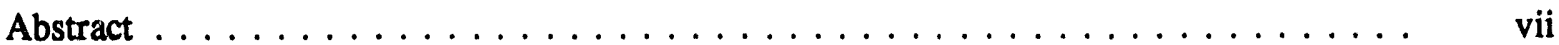

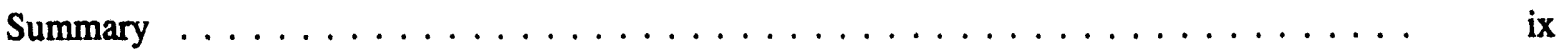

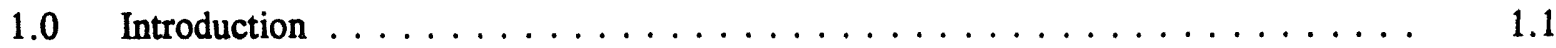

2.0 History of the 216-U-10 Pond Disposal System . . . . . . . . . . . 2.1

2.1 Construction Details $\ldots \ldots \ldots \ldots \ldots \ldots \ldots \ldots \ldots \ldots \ldots$

2.1 .1 Influent Ditches $\ldots \ldots \ldots \ldots \ldots \ldots \ldots \ldots \ldots \ldots \ldots$

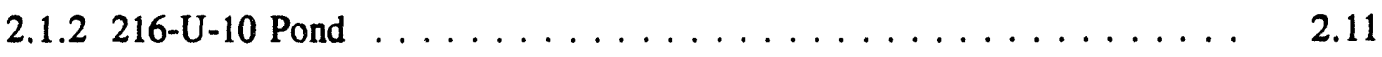

2.1 .3 Overflow Facilities $\ldots \ldots \ldots \ldots \ldots \ldots \ldots \ldots \ldots \ldots \ldots$

2.2 Operational Use and Disposal History . . . . . . . . . . 2.11

2.3 Routine Environmental Monitoring . . . . . . . . . . . . . . 2.18

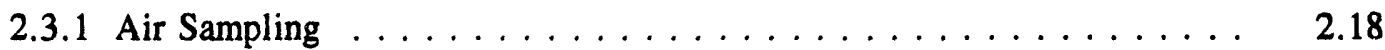

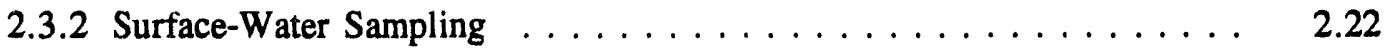

2.3.3 Vegetation Sampling . . . . . . . . . . . . . . . . . . . 2.22

2.3.4 Sediment Sampling . . . . . . . . . . . . . . . . . 2.25

2.3.5 Ground-Water Sampling $\ldots \ldots \ldots \ldots \ldots \ldots \ldots \ldots$

3.0 Environmental Characteristics $\ldots \ldots \ldots \ldots \ldots \ldots \ldots \ldots \ldots \ldots \ldots$

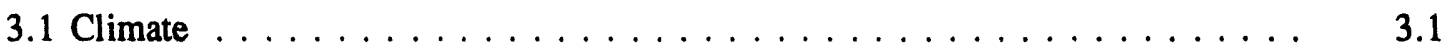

3.2 Biology $\ldots \ldots \ldots \ldots \ldots \ldots \ldots \ldots \ldots \ldots \ldots \ldots \ldots \ldots$

3.3 Geology $\ldots \ldots \ldots \ldots \ldots \ldots \ldots \ldots \ldots \ldots \ldots \ldots \ldots \ldots . \ldots \ldots$

3.4 Hydrology $\ldots \ldots \ldots \ldots \ldots \ldots \ldots \ldots \ldots \ldots \ldots \ldots \ldots \ldots \ldots$ 
3.4.1 Occurrence of Ground Water $\ldots \ldots \ldots \ldots \ldots \ldots \ldots$

3.4.2 Aquifer Properties . . . . . . . . . . . . . . . . . . . 3.7

3.4.3 Flow Dynamics . . . . . . . . . . . . . . . . . . . . . 3.9

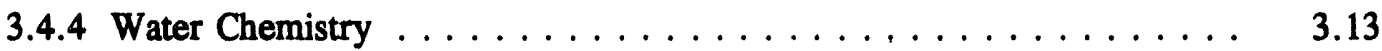

4.0 Previous Studies of the 216-U-10 Pond Disposal System $\ldots \ldots \ldots \ldots \ldots \ldots \ldots$

4.1 Atmospheric Resuspension Studies $\ldots \ldots \ldots \ldots \ldots \ldots \ldots \ldots \ldots$

4.2 Biological Studies $\ldots \ldots \ldots \ldots \ldots \ldots \ldots \ldots \ldots \ldots \ldots \ldots \ldots$

4.3 Geologic Studies $\ldots \ldots \ldots \ldots \ldots \ldots \ldots \ldots \ldots \ldots \ldots$

4.3.1 1958 Through $1959 \ldots \ldots \ldots \ldots \ldots \ldots \ldots \ldots$

4.3.2 1972 Through $1974 \ldots \ldots \ldots \ldots \ldots \ldots \ldots \ldots . \ldots \ldots . \ldots \ldots$

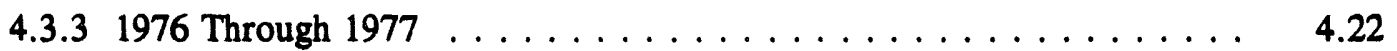

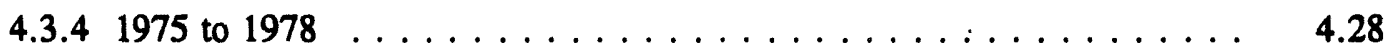

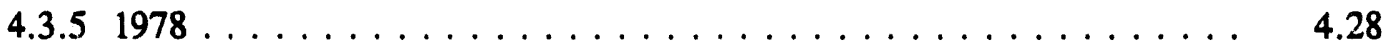

4.4 Hydrologic Studies $\ldots \ldots \ldots \ldots \ldots \ldots \ldots \ldots \ldots \ldots . \ldots \ldots$. . . . . . . . . . . 40

5.0 Current 216-U-10 Pond and 216-Z-19 Ditch Characterization Studies $\ldots \ldots \ldots \ldots$.

5.1 Atmospheric Studies $\ldots \ldots \ldots \ldots \ldots \ldots \ldots \ldots \ldots \ldots$

5.2 Biological Studies $\ldots \ldots \ldots \ldots \ldots \ldots \ldots \ldots \ldots \ldots \ldots \ldots$

5.2.1 Methods and Materials $\ldots \ldots \ldots \ldots \ldots \ldots \ldots . \ldots \ldots$

5.2.2 Sampling Results for the $216-Z-19$ Ditch $\ldots \ldots \ldots \ldots . \ldots . \ldots$

5.2.3 Sampling Results for the $216-\mathrm{U}-10-$ Pond $\ldots \ldots \ldots \ldots . \ldots . \ldots .24$

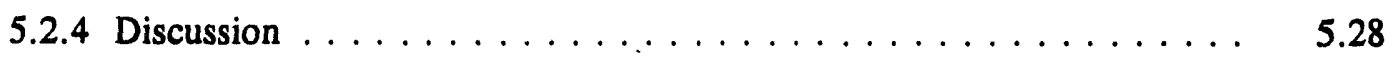

5.3 Geologic Studies $\ldots \ldots \ldots \ldots \ldots \ldots \ldots \ldots \ldots \ldots \ldots$

5.3.1 Methods and Materials $\ldots \ldots \ldots \ldots \ldots \ldots . \ldots \ldots$

5.3 .2 Results $\ldots \ldots \ldots \ldots \ldots \ldots \ldots \ldots \ldots \ldots$ 
WHC-EP-0707, Rev. 0

5.3 .3 Discussion $\ldots \ldots \ldots \ldots \ldots \ldots \ldots \ldots \ldots \ldots \ldots \ldots . \ldots \ldots$

5.4 Hydrologic Studies $\ldots \ldots \ldots \ldots \ldots \ldots \ldots \ldots \ldots \ldots \ldots$

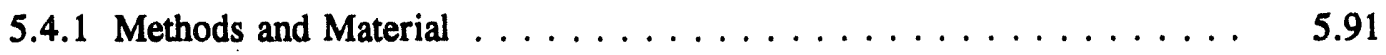

5.4 .2 Results and Discussion $\ldots \ldots \ldots \ldots \ldots . \ldots \ldots 4$

5.4 .3 Ground-Water Contamination $\ldots \ldots \ldots \ldots \ldots \ldots . \ldots \ldots$

6.0 Summary and Conclusions $\ldots \ldots \ldots \ldots \ldots \ldots \ldots \ldots \ldots \ldots \ldots$

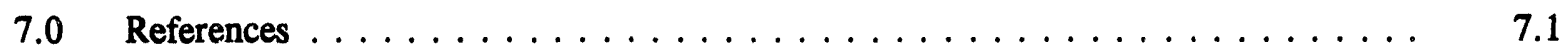

Appendix A - Sediment Analyses from U-Swamp and 234-5 Ditch $\ldots \ldots \ldots \ldots$ A.1

Appendix B - 216-U-10 Pond Sampling $\ldots \ldots \ldots \ldots \ldots \ldots \ldots \ldots \ldots \ldots$

Appendix C - Determination of Flow Patterns in the 216-U-10 Pond $\ldots \ldots \ldots \ldots$ C.1

Appendix D - 216-U-10 Pond-Bottom Sediments from BNW's Grid Sampling . . . . . . D.1

Appendix E - 1974 Analyses of the 216-U-10 Pond Shoreline Samples . . . . . . . . E.1

Appendix F - Estimates of Plutonium to the 216-Z-19 Ditch $\ldots \ldots \ldots \ldots$ F.1

Appendix $G$ - Minutes of Team Meeting Decommissioning of the
\[ 216-U-10 \text { Pond } \ldots \ldots \ldots \ldots \ldots \ldots \ldots \ldots \ldots \ldots \]

Appendix H - Analytical Data from Surface and Near-Surface Sediment Samples _ . . . . H.1

Appendix I - Analytical Data from Subsurface Sediment Samples $\ldots \ldots \ldots \ldots \ldots$

Appendix $\mathrm{J}$ - Geologic and Radioactivity Logs $\ldots \ldots \ldots \ldots \ldots \ldots . \ldots \ldots$ 


\section{Figures}

1.1 Location of the 216-U-10 Pond Disposal System $\ldots \ldots \ldots \ldots \ldots$

2.1 Original Plan for What is Now Called the 216-U-10 Pond Disposal System . . . . $\quad 2.2$

2.2 Photograph of the 216-U-10 Pond Disposal System in 1948, Showing Use of the 216-Z-1 Ditch . . . . . . . . . . . . . . 2.3

2.3 Sketch of the 216-U-10 Pond Disposal System at Its Maximum Extent in the Mid-1950s . . . . . . . . . . . . . . . . . . . . . .

2.4 Photograph of the 216-U-10 Pond Disposal System in 1965, Showing Use of the 216-Z-11 Ditch . . . . . . . . . . . . . . . . . .

2.5 Photograph of the 216-U-10 Pond Disposal System in 1980, Showing Use of

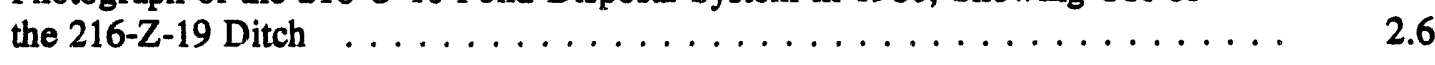

2.6 Schematic of the $216-\mathrm{U}-10$ Pond Disposal System $\ldots \ldots \ldots \ldots \ldots \ldots$

2.7 Relationship of the 216-U-10 Pond Disposal System Components to the Discharge Sources and Discharge Volumes . . . . . . . . . . . . 2.14

2.8 Map of the $216-\mathrm{U}-10$ Pond Monitoring Sites $\ldots \ldots \ldots \ldots \ldots \ldots$

2.9. Location of Surface Soil Samples Taken Adjacent to the 216-Z-19 Ditch $\ldots \ldots \ldots$

3.1 Prevailing Wind Directions Near the $216-\mathrm{U}-10$ Pond $\ldots \ldots \ldots \ldots \ldots \ldots$

3.2 Pasco Basin Stratigraphic Nomenclature $\ldots \ldots \ldots \ldots \ldots \ldots \ldots \ldots \ldots$

3.3 Generalized Geologic Cross Section Through the Hanford Site . . . . . . . . . . 3.6

3.4 Geologic Cross Section Beneath the 216-U-10 Pond and 216-Z-19 Ditch . . . . $\quad 3.8$

3.5 Clastic Dike in the 241-SY Tank Farm Excavation . . . . . . . . . 3.10

3.6 Patterned Ground in the Decommissioned 216-S-17 Pond . . . . . . . . . 3.11

3.7 Water-Table Contour Map Showing Location of Pertinent Wells and Ground-Water Flow Directions . . . . . . . . . . . . . . . . 3.12

4.1 Range of Downwind Airborne ${ }^{137} \mathrm{Cs}$ Concentrations at the $216-\mathrm{U}-10$ Pond and 216-Z-19 Ditch Compared to Fallout Levels 
4.2 Range of Airborne Plutonium Concentrations at the 216-U-10 Pond

Compared to Fallout Levels . . . . . . . . . . . . . . . . . . . . 4.2

4.3 Range of Airborne ${ }^{241}$ Am Concentrations at the 216-U-10 Pond and 216-Z-19 Ditch Compared to Fallout Levels . . . . . . . . . . . . . . .

4.4 Representation of Ecological Compartments and Plutonium Export Routes

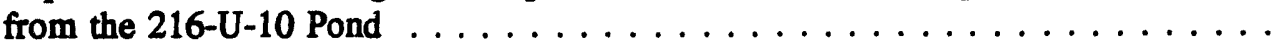

4.5 Plutonium Distribution in the 216-Z-1 Ditch as Interpreted from 1959 Mud Analyses . . . . . . . . . . . . . . . . . . . .

4.6 Total Gamnj Activity Around the 216-U-10 Pond from the 1973 Aerial Radiological Measurement Systems Survey . . . . . . . . . . . . . . .

4.7 Cesium-137 Activity Around the 216-U-10 Pond from the 1973 Aerial

Radiological Measurement Systems Survey . . . . . . . . . . . . . . .

4.8 Americium-241 Activity Around the 216-U-10 Pond from the 1973 Aerial Radiological Measurement Systems Survey . . . . . . . . . . . . . . . . 4.15

4.9 Location of the 216-U-10 Pond Perimeter Sampling, $1973 \ldots \ldots \ldots \ldots$. . . . . 4.17

4.10 Areas of Likely Waste Deposition in the $216-\mathrm{U}-10$ Pond $\ldots \ldots \ldots \ldots \ldots$

4.11 Detailed Total Plutonium Distribution in 216-U-10 Pond-Bottom Sediments $\ldots \ldots$

4.12 Detailed Total Uranium Distribution in 216-U-10 Pond-Bottom Sediments . . . . 4.24

4.13 Location of $216-\mathrm{U}-10$ Pond Shoreline Samples, $1974 \ldots \ldots \ldots \ldots \ldots$

4.14 Location of Dosimeter Transects . . . . . . . . . . . . . . . . . 4.29

4.15 Location of Dosimeters Relative to the 216-Z-19 Ditch Bottom . . . . . . . . . 4.30

4.16 Relative Grouping of Hanford Site Ponds and Ditches Based on Dose Rate of Sediments and Activity Concentrations in Water . . . . . . . . . .

5.1 Transect Locations at the 216-Z-19 Ditch in Relation to ${ }^{241}$ Am Survey . . . . . . 5.3

5.2 Quadrants Designated for Plant Sampling Locations at the 216-U-10 Pond . . . . 5.4

5.3 Cross Section of the 216-Z-19 Ditch Corridor, Showing Relative Locations of Shallow Core Samples Taken Along Each Transect . . . . . . . . . . . . .

5.4 Shallow Core Soil Sampling Along the 216-Z-19 Ditch Transects . . . . . . . . . 
WHC-EP-0707, Rev. 0

5.5 Subsampling of the Retrieved Soil Cores $\ldots \ldots \ldots \ldots \ldots$

5.6 Values of ${ }^{239,240} \mathrm{Pu}$ in Soil at the $216-\mathrm{Z}-19$ Ditch $\ldots \ldots \ldots \ldots \ldots \ldots$

5.7 Values of ${ }^{241} \mathrm{Am}$ in Soil at the $216-Z-19$ Ditch $\ldots \ldots \ldots \ldots \ldots \ldots \ldots$

5.8 Values of ${ }^{299,200} \mathrm{Pu}$ in Soil at the $216-\mathrm{Z}-19$ Ditch $\ldots \ldots \ldots \ldots \ldots \ldots \ldots$

5.9 Values of ${ }^{241} \mathrm{Am}$ in Soil at the $216-Z-19$ Ditch $\ldots \ldots \ldots \ldots \ldots \ldots$

5.10 Values of ${ }^{209,200} \mathrm{Pu}$ in Aquatic Vegetation at the $216-\mathrm{Z}-19$ Ditch $\ldots \ldots \ldots \ldots .22$

5.11 Values of ${ }^{137} \mathrm{Cs}$ for Surface-Soil Samples Collected at the $216-\mathrm{U}-10$ Pond . . . . 5.25

5.12 Values of ${ }^{137} \mathrm{Cs}$ for Tree-Root Samples Collected at the $216-\mathrm{U}-10$ Pond $\ldots \ldots \ldots$.

5.13 Values of ${ }^{137} \mathrm{Cs}$ for Leaf/Twig Samples Collected at 1.3-m Height at the 216-U-10 Pond ....................... 5.26

5.14 Values of ${ }^{90} \mathrm{Sr}$ for Leaf/Twig Samples Collected at $1.3-\mathrm{m}$ Height at the 216-U-10 Pond .........................

5.15 Values of ${ }^{137} \mathrm{Cs}$ for Leaf/Twig Samples Collected at $4.5-\mathrm{m}$ Height at the 216-U-10 Pond . . . . . . . . . . . . . . . . . . . .

5.16 Values of ${ }^{137} \mathrm{Cs}$ for Tree-Core Samples Collected at the $216-\mathrm{U}-10$ Pond $\ldots \ldots \ldots . \quad 5.27$

5.17 Values of ${ }^{90} \mathrm{Sr}$ for Tree-Core Samples Collected at the $216-\mathrm{U}-10$ Pond $\ldots \ldots \ldots . \quad 5.28$

5.18 Values of ${ }^{137} \mathrm{Cs}$ for Sandbar Willow Leaf/Twig Samples Collected at the 216-U-10 Pond . . . . . . . . . . . . . . . . . . .

5.19 Values of ${ }^{137} \mathrm{Cs}$ for Mice Collected at the $216-\mathrm{U}-10$ Pond $\ldots \ldots \ldots \ldots \ldots . \ldots . . . \ldots$

5.20 Field Survey and Sample Locations at the $216-\mathrm{Z}-19$ Ditch, $1978 \ldots \ldots \ldots . \ldots$

5.21 Establishment of the 216-U-10 Pond Delta Grid $\ldots \ldots \ldots \ldots \ldots \ldots$

5.22 Core Sampling at $30-\mathrm{cm}$ Depth $\ldots \ldots \ldots \ldots \ldots \ldots \ldots \ldots \ldots$

5.23 Hand Auger Sampling $\ldots \ldots \ldots \ldots \ldots \ldots \ldots \ldots \ldots \ldots \ldots \ldots \ldots$

5.24 Location of Perimeter Surface Samples and Pond-Bottom Core Samples Taken in Late 1979 . . . . . . . . . . . . . . . . . . . . . . . . . . . . . . .

5.25 Cookie-Cutter-Type Surface Sampling $\ldots \ldots \ldots \ldots \ldots \ldots \ldots \ldots$ 
WHC-EP-0707, Rev. 0

5.26 Giant Syringe Core Sampling of the $216-\mathrm{U}-14$ Ditch $\ldots \ldots \ldots \ldots \ldots \ldots \ldots$

5.27 Establishment of Grid Points $\ldots \ldots \ldots \ldots \ldots \ldots \ldots \ldots \ldots$

5.28 Dev Van IA in Situ Analysis of Grid Points $\ldots \ldots \ldots \ldots \ldots \ldots \ldots . \ldots \ldots$

5.29 Core Sampling of the $216-$ Z-19 Ditch-Bottom Sediments $\ldots \ldots \ldots \ldots \ldots \ldots$

5.30 Subsampling of the 216-Z-19 Ditch-Bottom Cores $\ldots \ldots \ldots \ldots \ldots \ldots$

5.31 Location of the 216-Z-19 Ditch-Surface Samples $\ldots \ldots \ldots \ldots \ldots \ldots \ldots$

5.32 Establishment of the 216-U-14 Ditch-Sampling Transects $\ldots \ldots \ldots \ldots \ldots \ldots$

5.33 Head-End Core Sample Locations in the 216-U-14 Ditch . . . . . . . . . 5.50

5.34 Core Sampling from the 4-m-High 216-U-14 Ditch Head Wall $\ldots \ldots \ldots \ldots \ldots .5 .51$

5.35 Location of Monitoring and Exploration Wells $\ldots \ldots \ldots \ldots \ldots$

5.36 Cable-Tool-Drilling Rig $\ldots \ldots \ldots \ldots \ldots \ldots \ldots \ldots \ldots \ldots \ldots$

5.37 Drive-Barrel Sampling $\ldots \ldots \ldots \ldots \ldots \ldots \ldots \ldots \ldots \ldots \ldots$

5.38 Tripod Drilling of Well $299-W 23-228 \ldots \ldots \ldots \ldots \ldots \ldots \ldots \ldots \ldots$

5.39 Grain-Size Nomenclature $\ldots \ldots \ldots \ldots \ldots \ldots \ldots \ldots \ldots$

5.40 Subsurface Distribution of ${ }^{137} \mathrm{Cs}$ in the $216-\mathrm{U}-10$ Pond Delta Area $\ldots \ldots \ldots . . .65$

5.41 Values of ${ }^{239,240} \mathrm{Pu}$ in Soil at the $216-\mathrm{Z}-19$ Ditch $\ldots \ldots \ldots \ldots \ldots \ldots$

5.42 Values of ${ }^{241} \mathrm{Am}$ in Soil at the $216-\mathrm{Z}-19$ Ditch $\ldots \ldots \ldots \ldots \ldots . \ldots \ldots$

5.43 Values of ${ }^{238,239,240} \mathrm{Pu}$ in Soil at the $216-\mathrm{Z}-19$ Ditch $\ldots \ldots \ldots \ldots \ldots$

$5.44 \begin{aligned} & \text { Schematic Cross Section Along the } 216-Z-19 \text { Ditch, Showing } \\ & { }_{209,200} \mathrm{Pu} \text { Concentrations } \ldots \ldots \ldots \ldots \ldots \ldots \ldots \ldots \ldots \ldots \ldots \ldots\end{aligned}$

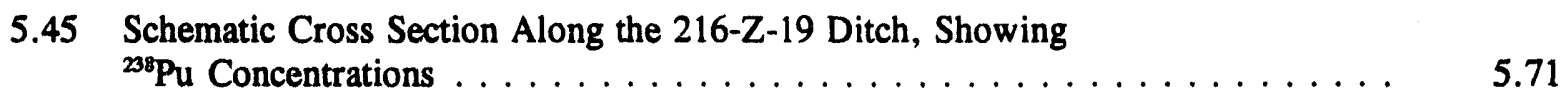

5.46 Values of ${ }^{241} \mathrm{Am}$ in Soil at the $216-\mathrm{Z}-19$ Ditch $\ldots \ldots \ldots \ldots \ldots \ldots . \ldots \ldots$

5.47 Schematic Cross Section Along the 216-Z-19 Ditch, Showing
${ }_{241}$ Am Concentrations

xvii 
WHC-EP-0707, Rev. 0

5.48 Schematic Cross Section of ${ }^{239.240} \mathrm{Pu}$ Contamination Associated with the

216-Z-1 Ditch . . . . . . . . . . . . . . . . . . . . . . . . .

5.49 Schematic Cross Section of ${ }^{239.240} \mathrm{Pu}$ Contamination Associated with the

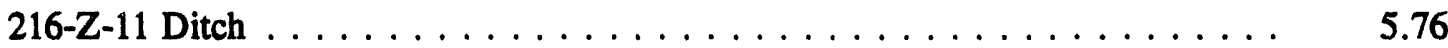

5.50 Schematic Cross Section of ${ }^{241}$ Am Contamination Associated with the 216-Z-1 Ditch . . . . . . . . . . . . . . . . . . .

5.51 Schematic Cross Section of ${ }^{241}$ Am Contamination Associated with the 216-Z-11 Ditch . . . . . . . . . . . . . . . . . . . 5.78

5.52 Distribution of ${ }^{137} \mathrm{Cs}$ Relative to Elevation $\ldots \ldots \ldots \ldots \ldots \ldots \ldots$

5.53 Distribution of ${ }^{239,240} \mathrm{Pu}$ in Z-Ditches Relative to Elevation $\ldots \ldots \ldots \ldots \ldots$

5.54 Location Map and Geologic Map of Study Area . . . . . . . . . . . . . . . . . 5.89

5.55 Comparison of Hantush Analytical and Numerical Solution . . . . . . . . . . 5.92

5.56 Comparison of Pump Test Data at Well 699-43-88 with Computer-Generated Data . . . . . . . . . . . . . . . . . . . . . . . . . .

5.57 Comparison of Pump Test Data at Well 699-37-82 with Computer-Generated Data . . . . . . . . . . . . . . . . . . . . . . . .

5.58 Pre-Hanford Site Water-Table Elevation $\ldots \ldots \ldots \ldots \ldots \ldots \ldots \ldots$

5.59 Water-Table Elevation, $1956 \ldots \ldots \ldots \ldots \ldots \ldots \ldots \ldots$

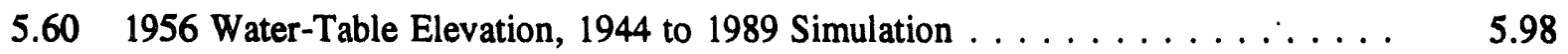

5.61 Residual Error Map, $1956 \ldots \ldots \ldots \ldots \ldots$

5.62 Predicted Water-Table Decline, $1989 \ldots \ldots \ldots \ldots \ldots \ldots \ldots \ldots$

5.63 Tritium Plumes Within the 200 East and 200 West Areas, $1980 \ldots \ldots \ldots \ldots$. . . 5.102 


\section{Tables}

2.1 Historical Annual Discharge Inventories to the 216-U-10 Pond Disposal

System through $1980 \ldots \ldots \ldots \ldots \ldots \ldots \ldots \ldots$

2.2 Operational Use of the 216-U-10 Pond Components and Some Associated

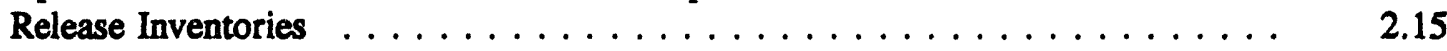

2.3 Waste Stream Descriptions and Estimated Inventories for the 216-Z-1, 216-Z,-11, and 216-Z-19 Ditches . . . . . . . . . . . . . . . 2.17

$2.4216-U-10$ Pond Influent Monitoring $\ldots \ldots \ldots \ldots \ldots \ldots \ldots \ldots \ldots \ldots$

$2.5 \quad 216-Z-19$ Ditch Air Sampler Results During $1979 \ldots \ldots \ldots \ldots \ldots \ldots$

2.6 Plutonium in Surface Soil Samples Collected Adjacent to the 216-Z-19

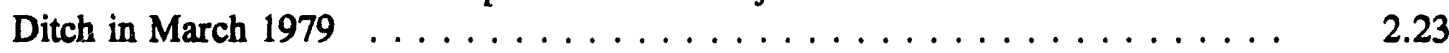

2.7 Surface-Water Sampling Results During $1979 \ldots \ldots \ldots \ldots \ldots \ldots$

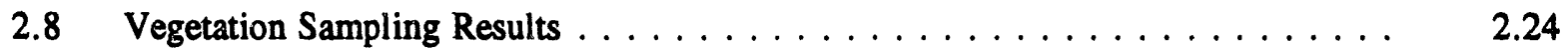

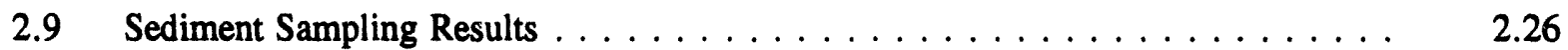

2.10 Concentration of Radionuclides in Berm Soil Along the 216-U-14 Ditch

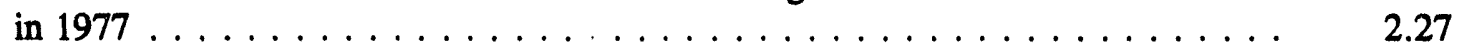

3.1 Average Particle-Size Distributions of the Eolian Unit and Major Hanford Formation Units Beneath the 216-U-10 Pond and the 216-Z-19 Ditch . . . . . . 3.9

3.2 Major Cation and Anion Concentrations in Aquifer Water from Well 699-35-78 and Perched Water from Well 299-W23-228 . . . . . . . . . . . 3.13

4.1 Isotopic Ratios in Pond Biota and Sediment $\ldots \ldots \ldots \ldots \ldots \ldots$

4.2 Radionuclide Values for the 216-U-10 Pond and 216-Z-19 Ditch Samples Taken During Calendar Years 1977, 1978, and $1979 \ldots \ldots \ldots \ldots$

4.3 March 1973 Results from Detailed Sampling of $1-\mathrm{m}^{2}$ near the 216-U-10 Pond ... $\quad 4.16$

4.4 Analyses of 216-U-10 Pond Perimeter Samples, $1973 \ldots \ldots \ldots \ldots$

4.51974 Analyses of 216-U-10 Pond Shoreline Samples . . . . . . . . . . . 4.26 
4.6 Special Soil and Vegetation Samples from the 216-Z-19 Ditch in March and

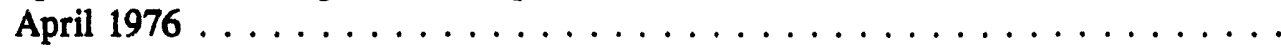

5.1 Values for ${ }^{89,90} \mathrm{Sr},{ }^{137} \mathrm{Cs},{ }^{209,200} \mathrm{Pu}$, and ${ }^{241} \mathrm{Am}$ in Sediment and Soil Samples Collected from the 216-Z-19 Ditch . . . . . . . . . . .

5.2 Values for ${ }^{89,90} \mathrm{Sr},{ }^{137} \mathrm{Cs}$, and ${ }^{239,220} \mathrm{Pu}$ in Vegetation

Samples Collected from the $216-Z-19$ Ditch $\ldots \ldots \ldots \ldots \ldots \ldots$

5.3 Values for ${ }^{90} \mathrm{Sr}$, ${ }^{137} \mathrm{Cs}$, and ${ }^{239,200} \mathrm{Pu}$ in Aquatic Vegetation

Samples Collected from the $216-Z-19$ Ditch $\ldots \ldots \ldots \ldots \ldots \ldots$

5.4 Values for ${ }^{90} \mathrm{Sr},{ }^{137} \mathrm{Cs}$, and ${ }^{209.220} \mathrm{Pu}$ in Mice Collected

from the $216-Z-19$ Ditch $\ldots \ldots \ldots \ldots \ldots \ldots \ldots \ldots$

5.5 Vegetation Parameters and Biomass Values at the 216-Z-19

Ditch for the Major Plant Species $\ldots \ldots \ldots \ldots \ldots \ldots$

5.6 Vegetation Parameters and Biomass Values for Trees at the 216-U-10 Pond . . . .

5.7 Numbers of Surface and Near-Surface Sediment Samples and Analyses . . . . . .

5.8 Subsurface Samples and Analyses $\ldots \ldots \ldots \ldots \ldots \ldots \ldots \ldots \ldots$

5.9 Surface Soil Contamination Limits $\ldots \ldots \ldots \ldots \ldots \ldots \ldots \ldots$

5.10 Radionuclides Detected in the 216-U-10 Pond and 216-U-11 Basin . . . . . . . 5.62

5.11 Summary of Pump Test Results in the Unconfined Aquifer in the 200 East and 200 West Areas Between 1969 and 1980

5.12 Concentrations of Radionuclides in Well 299-W18-15, Perched Water in Well 299-W23-228, and Concentration Guides for Water in an Uncontrolled Area . . . . . . . . . . . . . . . . . . . . . .

5.13 May 15, 1981 Inorganic Chemical Analysis of Water Sample from Well $299-W 18-15 \ldots \ldots \ldots \ldots \ldots \ldots \ldots \ldots \ldots \ldots \ldots \ldots$ 


\subsection{Introduction}

Rockwell Hanford Operations (Rockwell), under contract to the U.S. Department of Energy (DOE), has responsibility for management of nuclear defense wastes at the DOE's Hanford Site. One particular area of waste management involves disposal of low-level liquid effluents to the unsaturated surficial sediments. There are 14 classifications of such liquid effluent sites used at the Hanford Site. Knowledge of the environmental characteristics of each type of disposal site is essential for evaluating current disposal practices and future waste management alternatives.

Several representative liquid disposal sites have been studied as part of the Long-Term Transuranic Defense Waste and Contaminated Soils and Sediments Technologies programs. These include the 216-Z-1A Crib (Price et al. 1979), 216-B-5 Reverse Well (Smith 1980), 241-T-106 Tank Leak (Routson et al. 1979), 216-Z-8 French Drain (Marriatt et al. 1985), 216-Z-12 Crib (Kasper 1982), and 216-S-1 and -S-2 cribs (Van Luik and Smith 1982). Discussed herein is the study performed at the 216-U-10 (U-) Pond and 216-Z-19 (Z-19) Ditch.

U-Pond and Z-19 Ditch are parts of a much larger disposal system, referred to as the U-Pond disposal system, located in the southwest corner of the 200 West Area on the Hanford Site (Figure 1.1). The purpose of this document is to provide available site-specific information needed to assess the alternatives for the ultimate disposition of U-Pond and Z-19 Ditch. The principal objective of the study is to delineate the geologic distribution of radionuclides beneath and adjacent to each facility; particularly those areas exceeding 10,000 pCi transuranic elements per gram of soil. Atmospheric resuspension studies, biological studies, and hydrologic studies are also discussed because they affect the distribution and migration of the radionuclide contaminants. These various studies were combined, whenever possible, by using common sampling schemes to ensure consistency of the data and good correlations between studies. The general approach of these studies was to 1) compile and review all previously existing data, 2) identify significant gaps in the existing data base, and 3) characterize these areas through sampling and analyses.

Additional objectives of this study are to 1) determine the speciation and concentration of contaminants that might be redistributed by the wind if U-Pond were allowed to go dry and 2) provide detailed radiological data on all components of the U-Pond disposal system in support of decontamination and decommissioning designs (Bates 1981). 


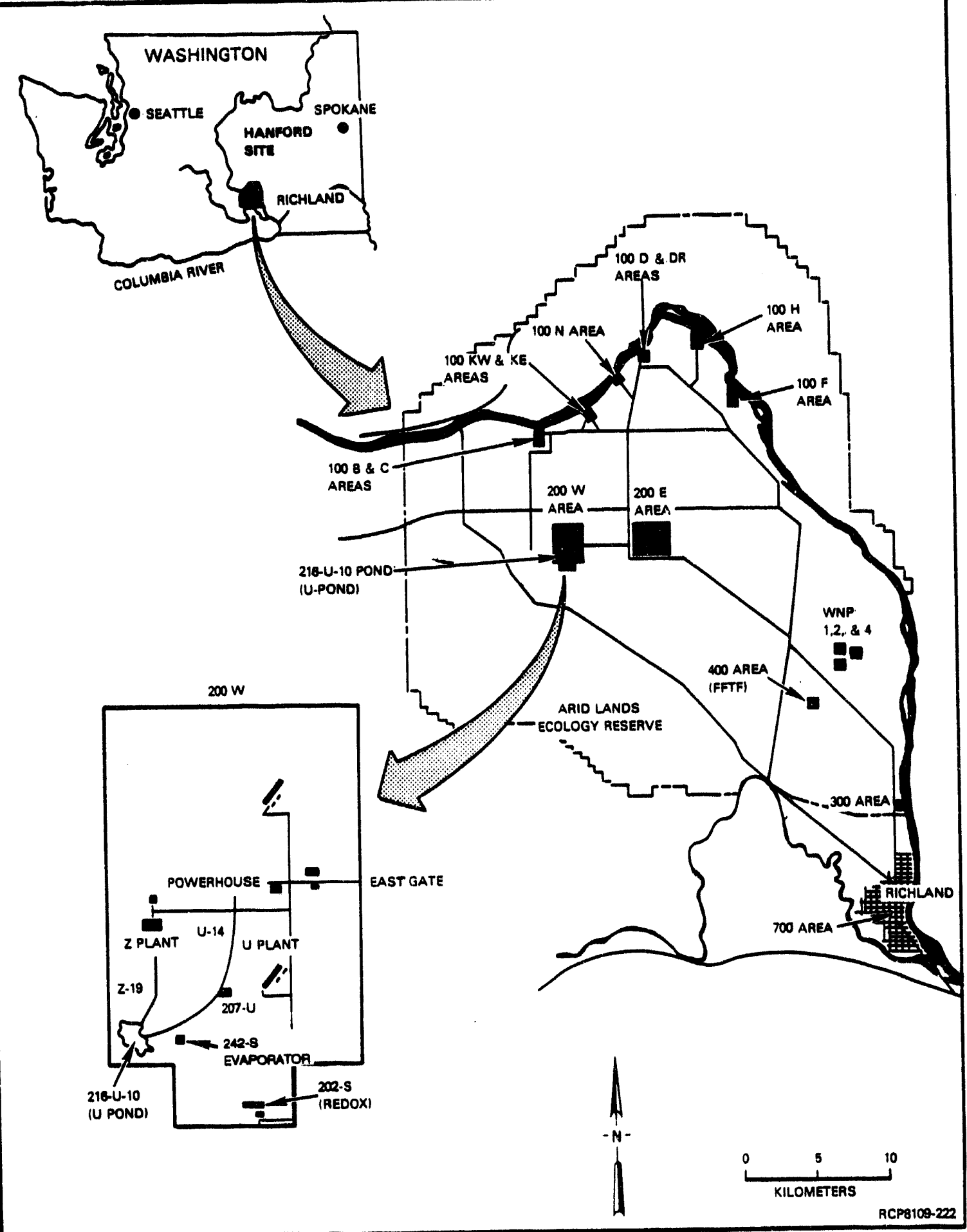

Figure 1.1. Location of the 216-U-10 Pond Disposal System 
WHC-EP-0707, Rev. 0

\subsection{History of the 216-U-10 Pond Disposal System}

The DOE's Hanford Site was constructed and operated for the production and purification of plutonium under the U.S. Government's Manhattan Project during World War II (ERDA 1975). Operation of the reprocessing and separation facilities generated large volumes of industrial liquid waste.

Or' ginally, all the high-level radioactive wastes were to be stored in underground steel and reinforced concrete tanks (Brown and Ruppert 1950). In contrast, the large volumes of Columbia River water used in the operations were to be discharged to the ground in seepage areas rather than returned to the river via sewers (Chambers 1944). It was then determined that some of the river water would receive low-level contamination; however, the large volumes precluded the practicability of storing the water in tanks and the limited amounts of radioactive elements were insufficient for economical recovery (Brown and Ruppert 1950). At that time, it was determined that these low-level wastes could be disposed of safely in the seepage areas if the wastes were diluted with uncontaminated waste water and monitored in concrete retention basins prior to release.

The high evaporation rate at the Hanford Site gave rise to the concept of using evaporation ponds to dispose of the large volumes of waste water. However, the potential hazards of the seepage areas drying up, with subsequent redistribution of contamination by wind, were also soon recognized (Brown and Ruppert 1948). The more significantly contaminated (intermediate-level) waste waters, therefore, were to be disposed of in underground infiltration facilities, collectively termed cribs (Brown and Ruppert 1948). Only the lowest-level wastes and the uncontaminated effluents remained to be discharged to the seepage areas. These seepage areas were later transformed into ponds with maintained water levels, further reducing the potential hazards and enabling both infiltration and evaporation to dispose of the waste waters.

The first facility planned for the surface disposal of industrial waste waters from the separations processes on the Hanford Site was the 216-U-10 (U-)Pond disposal system. As originally planned, the U-Pond disposal system was a network of ditches to divert waste waters from 200 West Area separations processes out to a large natural basin in the Cold Creek Valley (Figure 2.1). There, the fluid would be distributed over such a large surface area as to ensure rapid and almost immediate infiltration. Early geologic reconnaissance, however, had questioned the infiltration capacity of some of these deposits and had raised the possibility of creating an unplanned pond in part, if not all, of the proposed area. About that same time, it was suggested that large volumes of waste water could be evaporated from such a large pond because of the Hanford Site's high evaporation rates (Chambers 1944).

In 1943, construction of this disposal system began. Originally, two drainage ditches, the 216-U-14 (U-14) and 216-Z-1 (2-1) ditches, were constructed to divert waste waters to a slight natural depression, in the southwest corner of the 200 West Area. From here, an overflow ditch was 


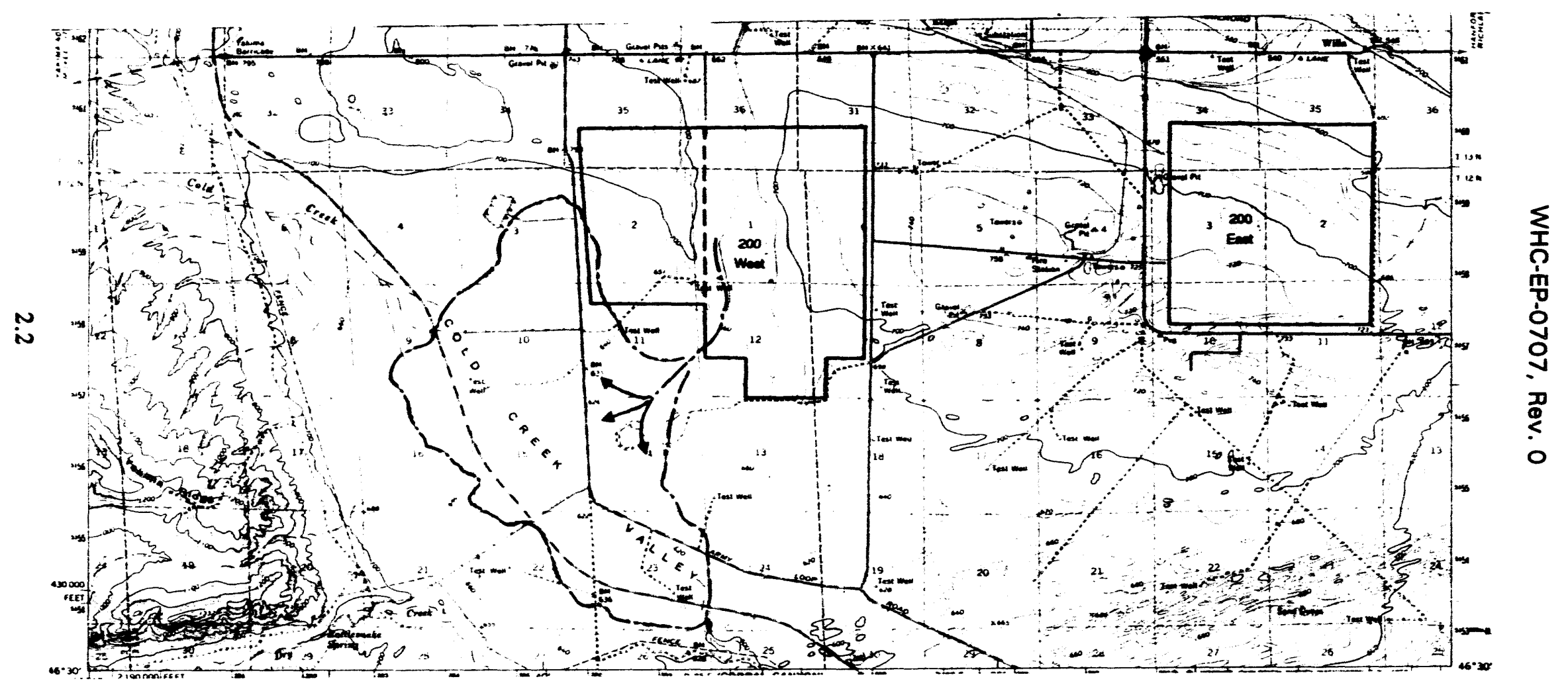

Figure 2.1. Original Plan for What is Now Called the 216-U-10 Pond Disposal System 
constructed (the old 216-U-11 [U-11] Ditch) ${ }^{(a)}$ to carry excess waste waters outside of the 200 West Area into Cold Creek Valley. In 1948, the pond was merely a swampy seepage area of less than $2.3 \mathrm{ha}$ (Figure 2.2) and there is no evidence that the overflow ditch was ever used. As discharges to the disposal system increased, the water level rose in the slight depression, forming a small pond. By the mid-1950s, U-Pond had reached its maximum size of approximately 16 ha (Figure 2.3). In the late 1950 s and early 1960s, the size of U-Pond dec eased until it reached its present size of approximately 5.7 ha (Figures 2.4 and 2.5).

\subsection{Construction Details}

The U-Pond aisposal system (Figure 2.6) consists of three basic components: 1) the influent ditches, 2) U-Pond, and 3) the overflow facilities.

\subsubsection{Influent Ditches}

The influent ditches transport waste waters from their originating facilities to the pond. These ditches are unlined, open excavations that enable infiltration and evaporation to reduce the influent volumes before entering the pond. There are currently three active influent ditches: the

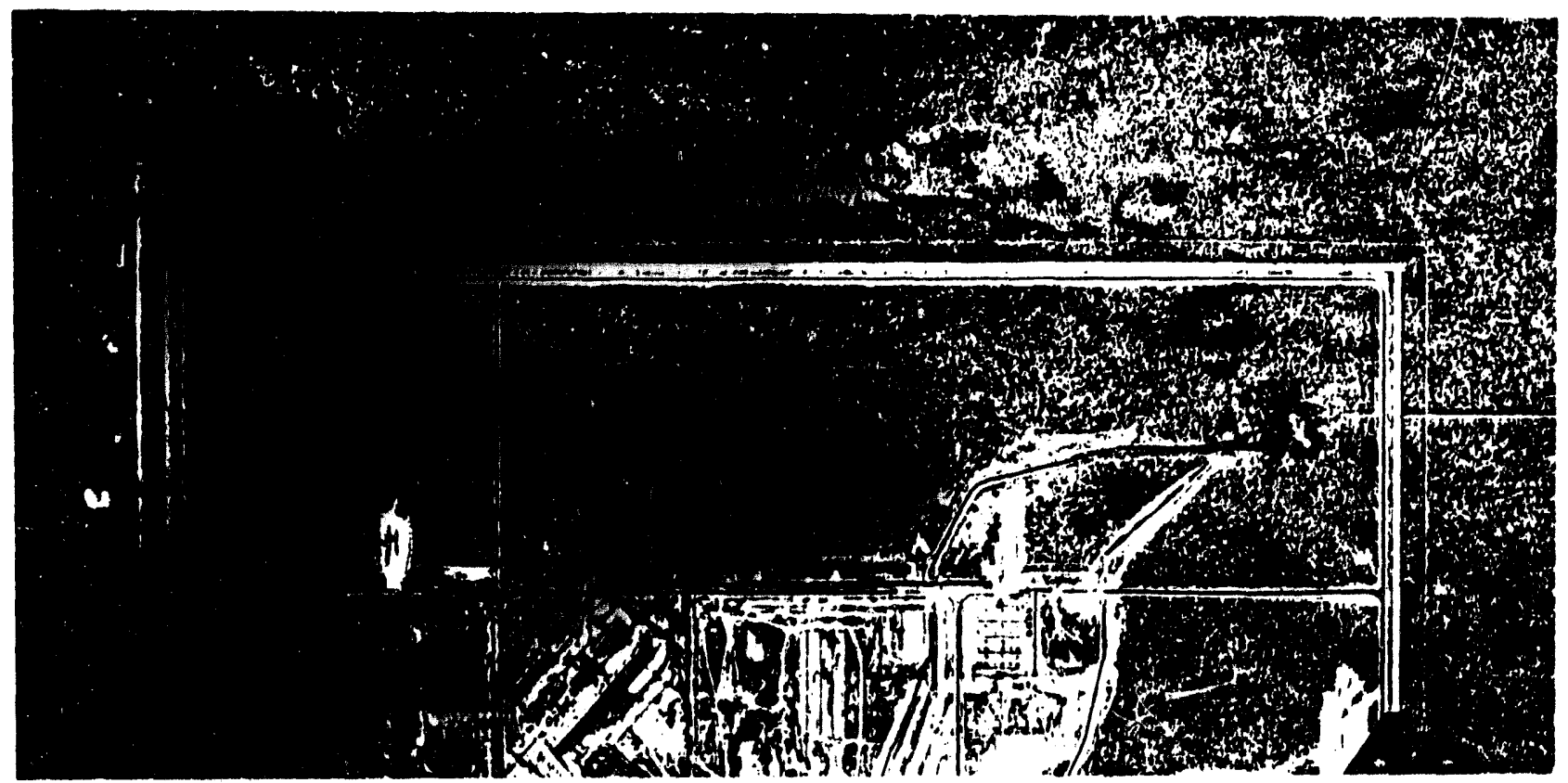

Figure 2.2. Photograph of the $216-\mathrm{U}-10$ Pond Disposal System in 1948 , Showing Use of the 216-Z-1 Ditch

(a) The old 216-U-11 Ditch was partially backfilled and partially incorporated into the new 216-U-11 Ditch. 
WHC-EP-0707, Rev. 0

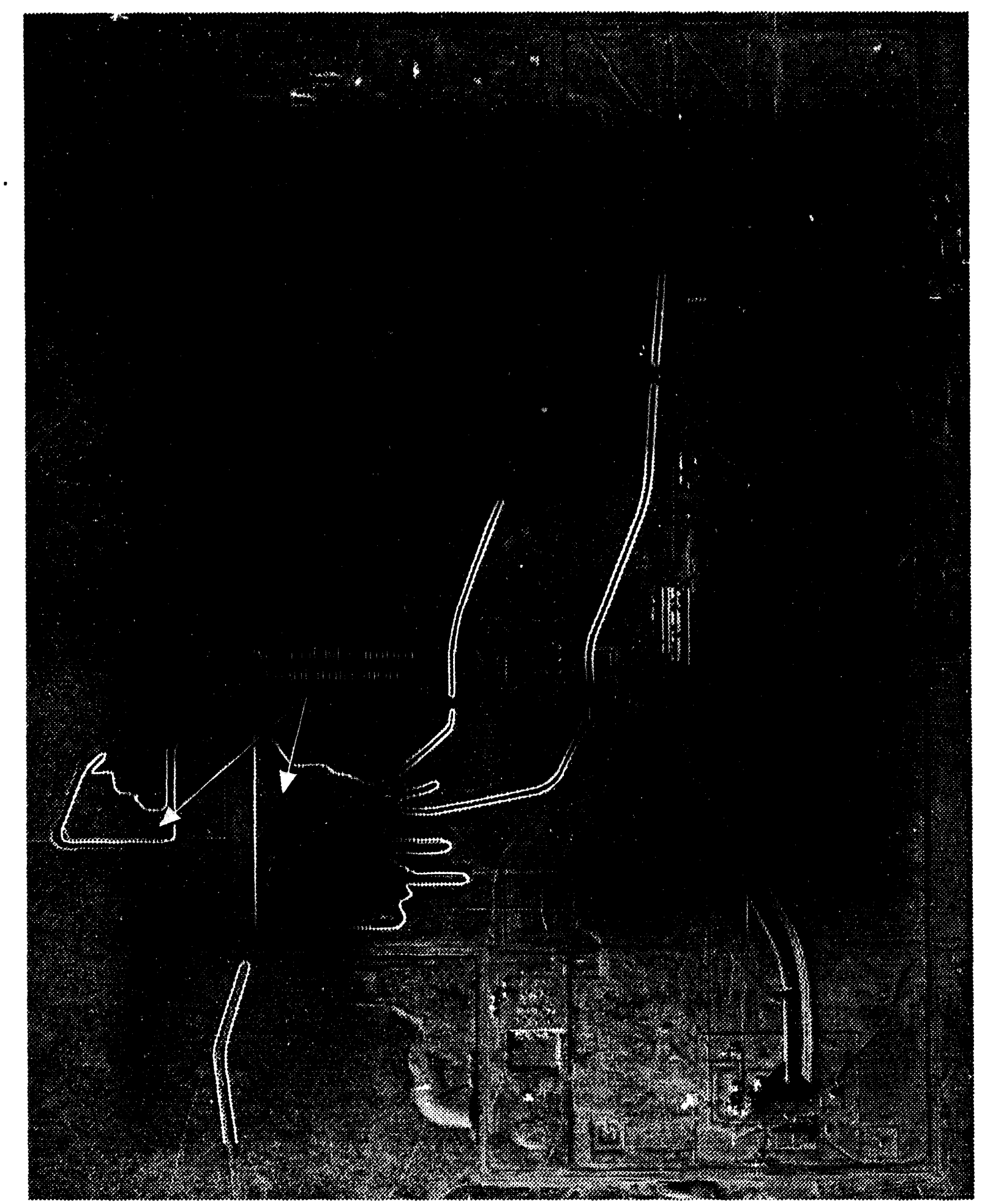

S9311032.2

Figure 2.3. Sketch of the 216-U-10 Pond Disposal System at Its Maximum Extent in the Mid-1950s (as interpreted from the maximum extent of surface contamination) 
WHC-EP-0707, Rev. 0

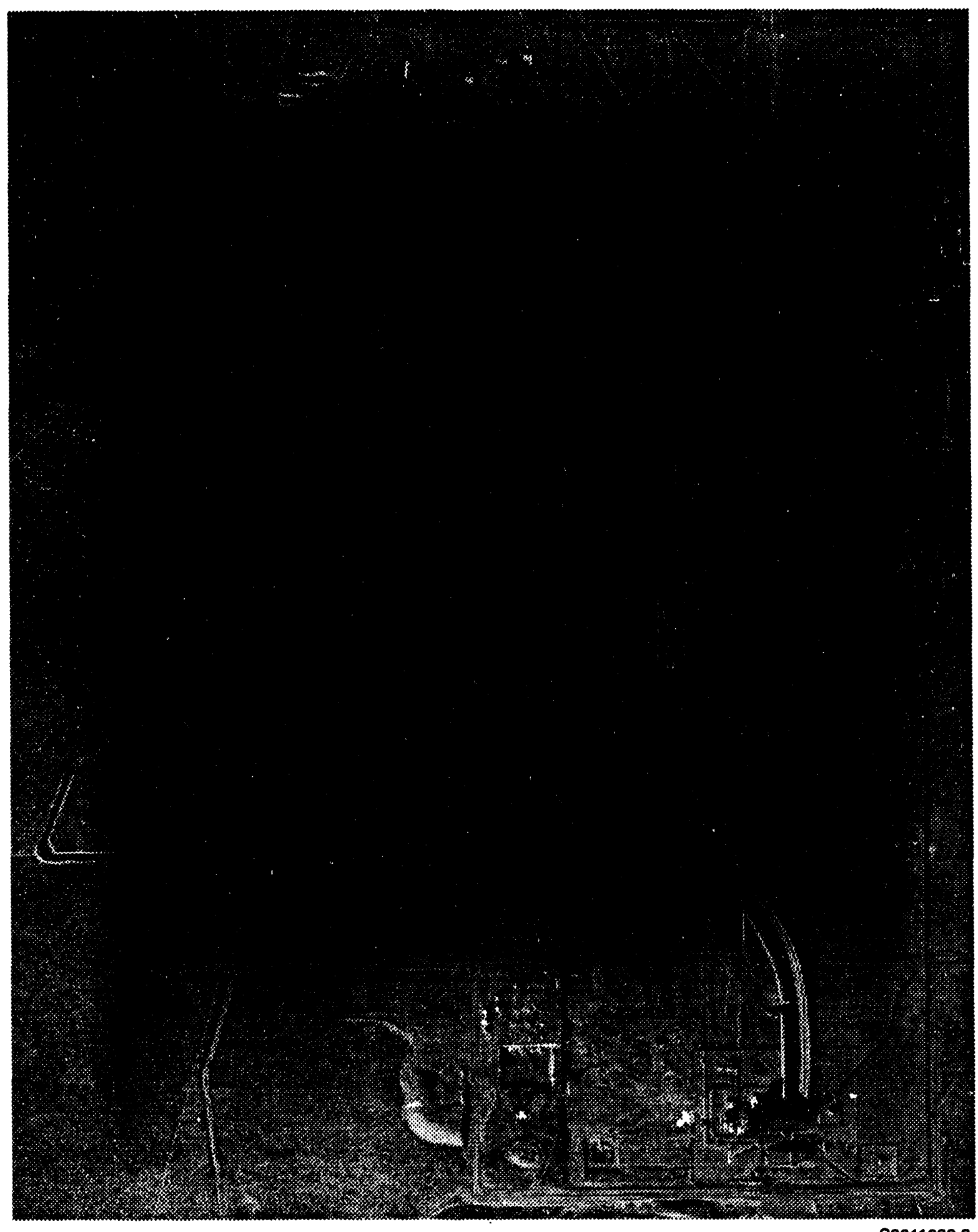

S9311032.3

Figure 2.4. Photograph of the 216-U-10 Pond Disposal System in 1965, Showing Use of the 216-Z-11 Ditch 


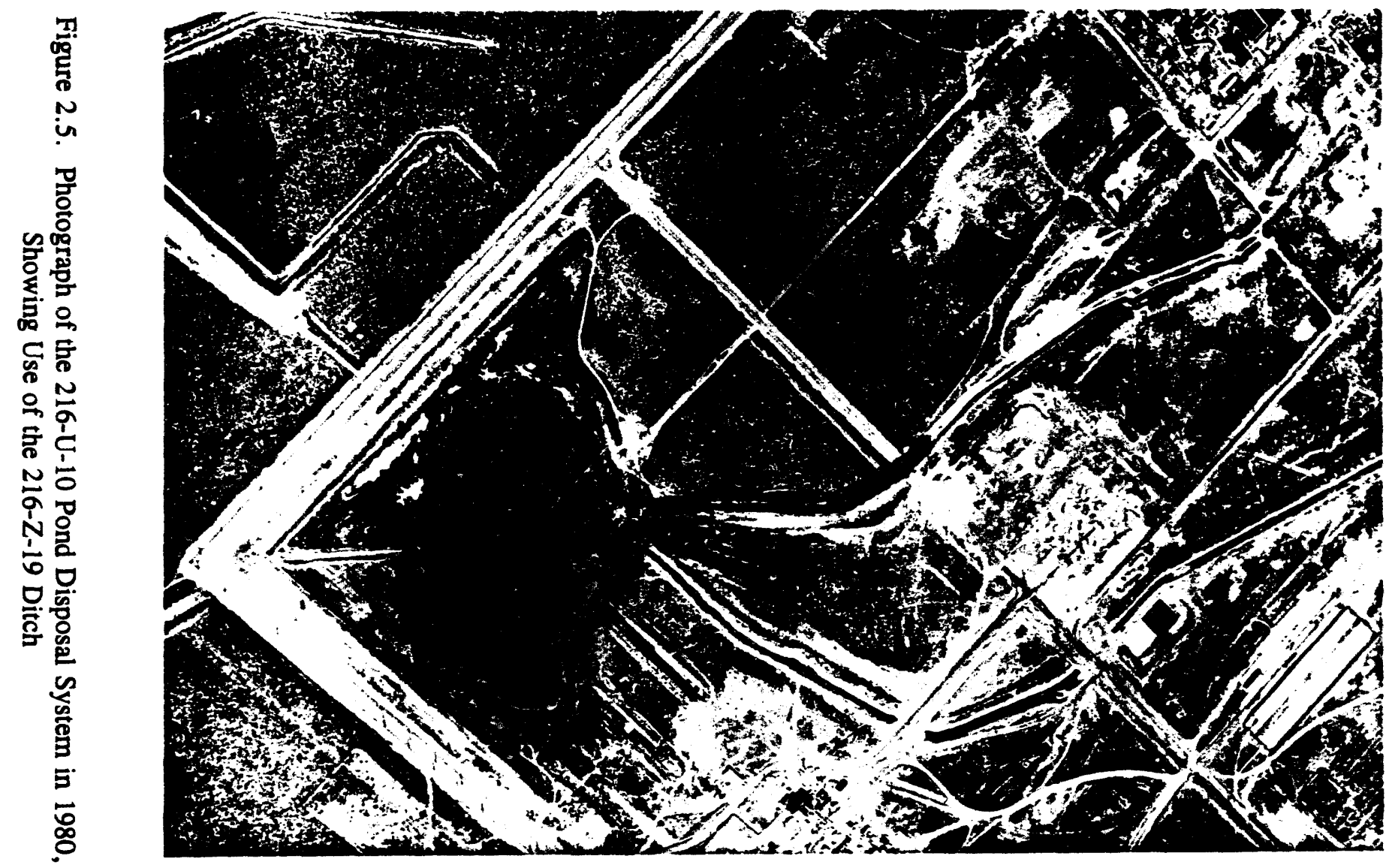


WHC-EP-0707, Rev. 0

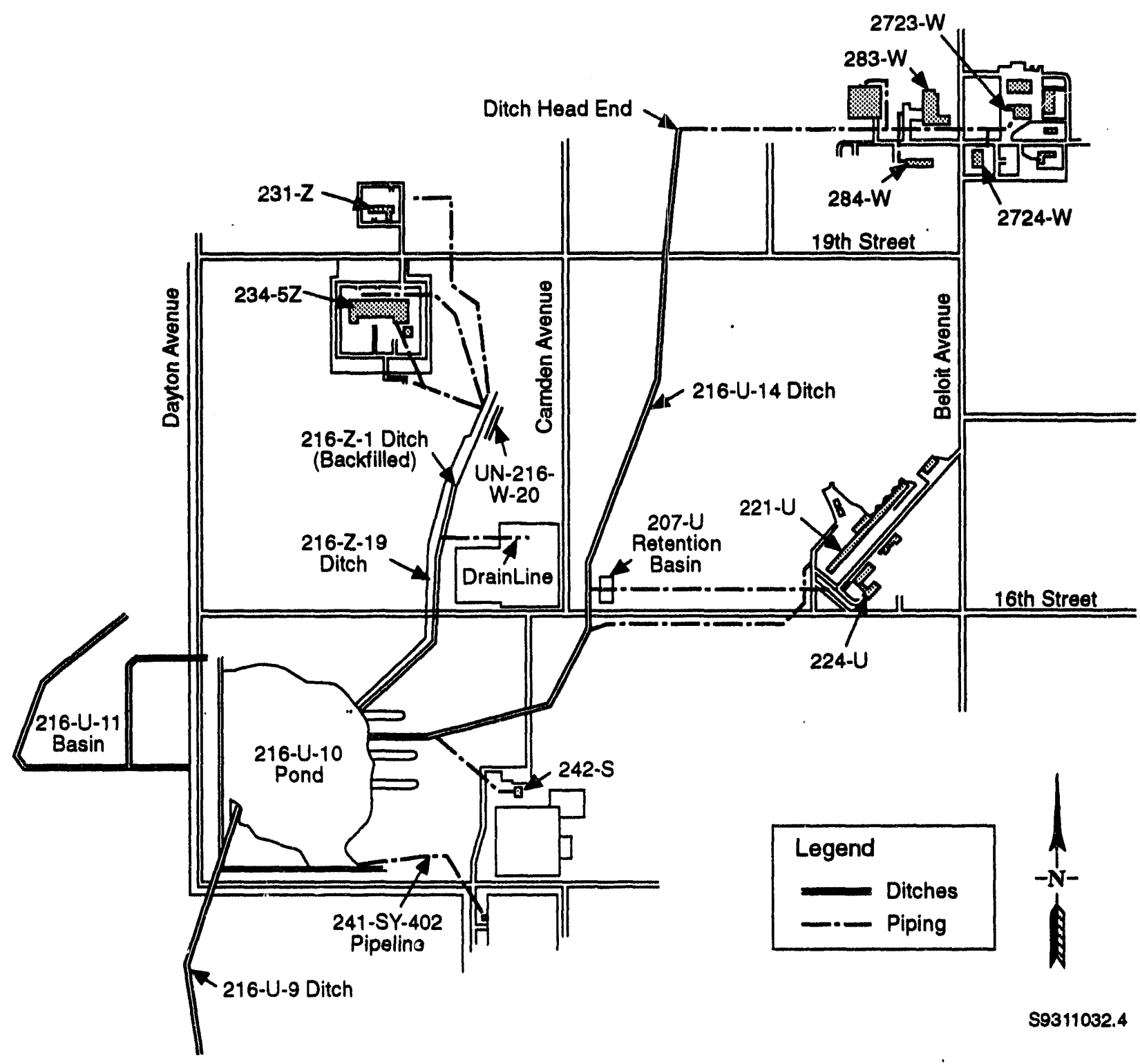

Figure 2.6. Schematic of the $216-U-10$ Pond Disposal System 
U-14 Ditch, the 216-Z-19 (Z-19) Ditch, and the influent pipeline from the 241-SX-402 Condenser (not an open ditch). Two other influent ditches (see Figure 2.6) are no longer in use and have been backfilled: the Z-1 Ditch and the 216-Z-11 (Z-11) Ditch (predecessors to the currently active Z-19 Ditch).

\section{6-U-14 Ditch}

The U-14 Ditch is the oldest and longest used of the influent ditches. This ditch was constructed and perhaps in service as early as 1943; however, the earliest-published data are from July 1944 (Brown and Ruppert 1948). The ditch is an unlined, open excavation, which approximately follows the most easterly $207-\mathrm{m}$ topographic contour in the 200 West Area. The ditch was originally excavated with 2.5:1 side slopes and 2.4-m-wide bottom to a length of over $1740 \mathrm{~m}$. The head end of the ditch is located approximately $720 \mathrm{~m}$ southeast of the 241-TX Tank Farm, at an elevation of $208 \mathrm{~m}$ above mean sea level (MSL). The ditch extends $1335 \mathrm{~m}$ to the south and southwest, passing between the 241-U Tank Farm and 207-U Retention Basin (see Figure 2.6). The ditch then extends another $405 \mathrm{~m}$ in a westerly direction, terminating at an elevation of $201 \mathrm{~m}$ MSL in the U-Pond delta. Hanford Site coordinates of the ditches' origination and termination points are N41270, W74710 and N36845, W76910, respectively.

Waste waters enter the ditch at three general locations (see Figure 2.6). The first discharge point is at the head end of the ditch. Here, waste waters from the 2724-W Building (Laundry), the 2723-W Building (Mask Cleaning Station), the 283-W Building (Water Treatment Plant), and the 284-W Building (Powerhouse) enter the ditch via a common 107-cm-diameter reinforced concrete pipeline. The second discharge point is located $1050 \mathrm{~m}$ downstream (south), where the ditch passes under 16th Street. Here, waste water from the 221-U Building (U-Plant) and the 224-U Building ( $\mathrm{UO}_{3}$-Plant) is discharged from the 207-U Retention Basin via a $61-\mathrm{cm}$-diameter vitreous clay pipe. A small, 10-cm-diameter waste line from the 241-U-110 and 241-U-104 tanks also entered the ditch here via the 216-U-3 Crib. This line has been removed from service. Thirty-seven meters farther downstream, the chemical sewer from the U-Plant complex (221-U and 271-U) discharges into the ditch via a 46-cm-diameter vitreous clay pipeline. The third discharge point is located another $370 \mathrm{~m}$ downstream, where the ditch runs westward. At this point, waste waters from the 242-S Building (Evaporator) are discharged from a $61-\mathrm{cm}$-diameter corrugated metal pipeline. This facility, which usually supplies greater than $90 \%$ of the influents entering U-Pond, is temporarily shut down, with permanent shutdown scheduled for the near future. Makeup water is presently being added into the ditch via fire hoses from two nearby fire hydrants to maintain the pond water level. Below this discharge point, the ditch extends another $215 \mathrm{~m}$ to its original terminus; from here, it now follows a shallow dog-legged extension for $150 \mathrm{~m}$ to the pond.

The water level in the U-14 Ditch varies considerably along its length because of the variation in infiltration and evapotranspiration rates and the impedance of water flow down the ditch. The accumulation of fly ash, scale, and lint from the powerhouse and laundry discharges, and possibly their chemical constituents, reduces the infiltration capacity of the head end of the ditch, as does the accumulation of dead plant material throughout the rest of the ditch. The growth of live plants and the buildup of 
dead plant material (tumbleweeds, etc.) cause localized damming, reducing the flow rate of waste waters down the ditch. In combination, these can result in backups in the discharge systems. To prevent such backups, the ditch has been periodically dredged, particularly the area between the head wall and 19th Street (see Figure 2.6). Sediments removed during dredging activities are commonly piled on top of the existing berm along the west bank. Sampling of this sediment on the berm revealed surficial radionuclide contamination. To reduce the potential for contamination spread, this berm was removed between the head wall and 19th Street and between Camden Avenue and the U-Pond delta area in 1979, and the berm material buried in a low-level waste burial ground.

\section{6-Z-19 Ditch}

The Z-19 Ditch is the last of three ditches used consecutively to transport waste waters from the Z-Plant facilities to U-Pond (see Figure 2.6).

The original "Z-Ditch," now designated the Z-1 Ditch, was placed in service in December 1944 (Lundgren 1971) to serve only the 231-Z Building, and its original head wall was located approximately $60 \mathrm{~m}$ east of the building. The ditch was an unlined, open excavation $1295 \mathrm{~m}$ (Owens 1979) long, with a bottom width of $1.2 \mathrm{~m}$, side slopes of $2.5: 1$, and a minimum grade of $0.05 \%$.

In July 1949, a 45.7-cm-diameter vitreour clay pipeline was constructed as part of the 234-5Z Building (Z-Plant construction to replace the upper portion of the Z-1 Ditch. The new head wall was located approximately $457 \mathrm{~m}$ (Emery and Klopfer 1974) downstream at an elevation of $203 \mathrm{~m}$ MSL. The bypassed portion of the original ditch was then backfilled, and the upper $183 \mathrm{~m}$ of the remaining ditch were cleaned. At or about this same time, two other head walls were constructed: the storm sewer and high tank overflow outfall from the Z-Plant complex, located $30.5 \mathrm{~m}$ downstream, and the 234-5Z process sewer, located $43 \mathrm{~m}$ downstream. The waste streams are discharged via a $36.5-\mathrm{cm}$ corrugated iron pipe and a 38-cm-diameter vitrified clay pipe, respectively. Only one other waste line came into the early Z-1 Ditch-the 5712 Drain Line from a valve box for the 244-UR Tank Vault. This waste line entered the ditch $280 \mathrm{~m}$ downstream from the 234-5Z Outfall. The ditch continued its south-southwesterly course for another $482 \mathrm{~m}$, where it terminated in the U-Pond delta area at an elevation of $201 \mathrm{~m} \mathrm{MSL}$. Waste waters from the ditch then flowed south, mixing with influents from the U-14 Ditch, and entered the pond.

In March 1959, another $611 \mathrm{~m}$ (from the 234-5Z Outfall to 16th Street) of the remaining Z-1 Ditch were backfilled after high plutonium contamination was discovered. This middle portion of the ditch was backfilled using material excavated from construction of the Z-11 Ditch (the second "Z-Ditch").

The Z-11 Ditch was excavated parallel to and just east of the old Z-1 Ditch, and its construction was similar to that of Z-1. The new ditch cut back into the Z-1 Ditch at its lower end, approximately $203 \mathrm{~m}$ north of U-Pond. The entire ditch was then redesignated the Z-11 Ditch. ${ }^{(*)}$ The total length of

(a) Some drawings and references suggest the Z-11 Ditch was separate from the Z-1 Ditch all the way to U-Pond. 
the Z-11 Ditch was $797 \mathrm{~m}$, with the upper $36.5 \mathrm{~m}$ and the lower $202.6 \mathrm{~m}$ in common with the Z-1 Ditch. All discharge points to the ditch remained the same, except possibly the 5712 Drain Line for which there is little information. ${ }^{\left({ }^{(}\right)}$

The Z-19 Ditch is the third "Z-Ditch" and is the only one still in use. The upper $43 \mathrm{~m}$ of the new Z-19 Ditch remain common with the Z-1 and Z-11 ditches. The new Z-19 Ditch was constructed parallel to and just west of the Z-11 Ditch (at the site of the buried Z-1 Ditch). During its construction (April 1971), approximately $130 \mathrm{~m}$ of contaminated sediment were inadvertently excavated and exposed before the mistake was realized. At this point, the contaminated spoils pile was buried in a trench (UN-216-W-20, see Figure 2.6) dug parallel to and just east of the Z-11 Ditch, and the Z-19 Ditch was turned farther to the west. The ditch then followed a new course approximately $10.6 \mathrm{~m}$ west of and parallel to the Z-1 Ditch until just north of 16th Street. Here, the new ditch was redirected back to the old Z-11 Ditch road culvert and followed the existing ditch to the pond. This routing was later abandoned and backfilled in October 1971, when a new culvert was installed approximately $15 \mathrm{~m}$ to the west and excavation of the new Z-19 Ditch was continued approximately $305 \mathrm{~m}$ to the pond. Material excavated from the new Z-19 Ditch was used to backfill the Z-11 Ditch. The $\mathrm{Z}-19$ Ditch is approximately $815 \mathrm{~m}$ long and has a bottom width of approximately $1.2 \mathrm{~m}$. This includes the outfalls and upper $43 \mathrm{~m}$ that are common with both the Z-1 and Z-11 ditches and the additional $130 \mathrm{~m}$ that is common with the Z-1 Ditch. Construction is similar to all other "Z-ditches." Hanford Site coordinates for the influent and effluent points are N39420, W75991 and N37050, W76950, respectively.

In late March 1976, an accidental release of contamination occurred, and modifications were then made to contain the contaminants in the ditch. These modifications included reduced waste water discharges from the 234-5Z Building and construction of a series of three dams at intervals along the length of the upper ditch. These dams were installed to raise the water level in the ditch, thereby covering the old contaminated water line, and to stop the water flow from reaching U-Pond. At this same time, a water sprinkler system was installed to keep the lower part of the ditch, between the lowermost dam and the pond, from drying out. On March 30,1978, the sprinkling was stopped, and the dams were opened, but water never reached the pond again and the lower part is still dry today.

\section{1-SX-402 Pipeline}

The pressurized cooling water pipeline from the 241-SX-402 Condenser is the only other influent source to U-Pond. This 20-cm-diameter pipeline and its (blanked off) sister pipeline from the 241-SX-401 Condenser terminate at a small head wall located in the southeast corner of U-Pond. Here, the influents to U-Pond either run overland for approximately $60 \mathrm{~m}$ to U-Pond or infiltrate directly into the sediments.

(a) On March 3, 1980, a well driller found what was later confirmed to be water from the $\mathbf{5 7 1 2}$ Drain Line coming to the surface near the Z-11 Ditch. 


\subsubsection{6-U-10 Pond}

U-Pond was originally a seepage area at the end of the U-14 and Z-1 ditches, disposing of waste water mainly by infiltration. But as waste water discharges increased, it developed into a moderatesized pond, combining infiltration and evaporation to dispose of the waste waters.

U-Pond was originally (1943) created in a slight natural depression, which was later (1952-1953) diked on the south and west edges. About this same time, three finger-like extensions (leach trenches) had been added to the east side of the pond to provide increased volume and infiltration capacity. The pond reached its maximum extent of approximately $16 \mathrm{ha}$ in the early to mid-1950s. Today, the doughnut-shaped pond covers an area of approximately $5.7 \mathrm{ha}$; with a mean depth of $0.4 \mathrm{~m}$, its volume is estimated at $22,700 \mathrm{~m}^{3}$ (Emery and McShane 1978).

\subsubsection{Overflow Facilities}

The overflow facilities were constructed to handle periodic increases in the influent volumes. The old U-11 Ditch (see Figure 2.6) was the first of these overflow facilities, having been constructed in 1943 as part of the original disposal system. The ditch excavation was $597 \mathrm{~m}$ long, with a $1.5-\mathrm{m}$ bottom width, and was constructed to direct the overflow into the large Cold Creek Valley (see Figure 2.1).

The ditch was replaced by a dike-enclosed basin (U-11 Ditch) in the early to mid-1950s. The new facility occupies the middle portion of the old ditch. The U-11 Ditch is a horseshoe-shaped ditch, $1050 \mathrm{~m}$ long, with a $1.2-\mathrm{m}$-wide bottom, surrounded by a 3-m-high earthen dike that encloses a basin area of approximately $7.8 \mathrm{ha}$. The first $15 \mathrm{~m}$ of the ditch bottom were covered with a $15-\mathrm{cm}$-thick layer of gravel.

In 1952, a second overflow facility (the 216-U-9 [U-9] Ditch) was constructed to divert the overflow southwest of U-Pond and into the 216-S-17 (S-17) Pond. This ditch was $2 \mathrm{~m}$ wide and $1066 \mathrm{~m}$ long. Almost immediately, the ditch received some overflow and a year later was reportedly contaminated. In the spring of 1954, the ditch was partially backfilled with $60 \mathrm{~cm}$ of dirt. In 1973, the U-9 Ditch was reexcavated and rerouted to the 216-S-16 Pond, with the first $150 \mathrm{~m}$ in common with the old ditch.

\subsection{Operational Use and Disposal History}

The U-Pond disposal system is probably the longest-used low-level radioactive liquid effluent disposal site on earth, possibly receiving a larger variety of radioisotopes than any other.

The major purpose of this disposal system was to receive and infiltrate large volumes of relatively uncontaminated waste waters from the 200 West Area facilities. This disposal system use began in 
1943, when waste water from the 284-W Powerhouse and the 2723-W Laundry(a) were routed to U-Pond via the U-14 Ditch. Approximately a year later, discharges from the 231-Z Building were added to the system via the newly constructed Z-1 Ditch (radioactive releases from this source were judged to be quite small). In late 1949, the 234-5Z Building was constructed, and waste water from drains, cooling water from the $234-5 Z$ and $231-Z$ buildings, plus pump- and compressor-seal water were routed to the new head wall of the Z-1 Ditch. Significant amounts of plutonium are thought to have been released via the 64-cm-diameter vacuum pump-seal water from the 234-5Z Building. In 1951 and 1952, the Waste Metal Recovery Program was started to recover the uranium stored with the mixed fission products in underground waste storage tanks in the 200 East and 200 West Areas. During this program, a solvent extraction process was installed and operated in the spare 221-U Canyon from 1952 through 1957. Cooling water from this process was discharged midway down the U-14 Ditch; significant, but unmeasured, amounts of cesium and strontium were thought to have been released here during 1956. The 224-U Building also began operations in 1952 and discharged cooling water to the U-14 Ditch; this water released significant amounts of slightly depleted uranium. In 1965, condenser cooling water from the vapor vent system of the newly constructed 15-tank 241-SX Tank Farm was routed directly to U-Pond. This source also discharged small amounts of cesium and strontium.

Additional discharges came from several support facilities and, most recently, from the 242-S Evaporator.

The large volumes of low-level waste waters and occasional isolated releases of considerably higher level, nonroutine discharges have resulted in the accumulation of transuranics $\left({ }^{388} \mathrm{Pu},{ }^{239,200} \mathrm{Pu},{ }^{241} \mathrm{Am}\right)$, fission products $\left({ }^{90} \mathrm{Sr},{ }^{106} \mathrm{Ru},{ }^{137} \mathrm{Cs}\right.$, $\left.{ }^{155} \mathrm{Eu}\right)$, and activation product $\left({ }^{60} \mathrm{Co},{ }^{54} \mathrm{Mn},{ }^{154} \mathrm{Eu}\right)$ inventories throughout the various components of the disposal system. Other radioisotopes were discharged to the system but at marginally detectable levels.

Table 2.1 lists the annual discharge inventories released to the U-Pond disposal system from 1944 through 1980. The sum of these inventories represents the best available discharge inventory for the U-Pond system as a whole. Inventories for individual discharge sources were not recorded until 1968, and no discharge inventories were ever recorded for individual components of the disposal system. Figure 2.7 illustrates the complex relationships between the discharge sources, the U-Pond system components, and the historical discharge sources. The large number of discharge sources, their operational service dates, and the operational service dates of the U-Pond components complicate any attempt to derive total inventories for the individual U-Pond components. However, partial inventories have been calculated for the influent ditches by summing the individual discharge source inventories recorded since 1968 (Table 2.2).

(a) This facility became the mask cleaning station after a new laundry (2724-W Building) was constructed. 
Table 2.1. Historical Annual Discharge Inventories to the 216-U-10 Pond Disposal System through 1980(a)

\begin{tabular}{|c|c|c|c|c|c|c|c|c|c|}
\hline & Year & Volume (L) & Plutonium (g) & Beta (Ci) & ${ }^{\infty} \mathrm{Sr}(\mathrm{Ci})$ & ${ }_{\mathrm{Ru}}(\mathrm{Ci})$ & ${ }^{137} \mathrm{Cs}$ (Ci) & ${ }^{\infty} \mathrm{Co}(\mathrm{Ci})$ & Unanium $(\mathbf{k g})$ \\
\hline$\frac{N}{\omega}$ & $\begin{array}{l}1944 \\
1945 \\
1946 \\
1947 \\
1948 \\
1949 \\
1950 \\
1951 \\
1952 \\
1953 \\
1954 \\
1955 \\
1956 \\
1957 \\
1958 \\
1959 \\
1960 \\
1961 \\
1962 \\
1963 \\
1964 \\
1965 \\
1966 \\
1967 \\
1968 \\
1969 \\
1970 \\
1971 \\
1972 \\
1973 \\
1974 \\
1975 \\
1976 \\
1977 \\
1978 \\
1979 \\
1980 \\
\text { Totel } \\
\text { Total Decay }\end{array}$ & $\begin{array}{l}0.162 E+09 \\
0.967 E+09 \\
0.967 E+09 \\
0.967 E+09 \\
0.967 E+09 \\
0.124 E+10 \\
0.152 E+10 \\
0.152 E+10 \\
0.404 E+10 \\
0.115 E+11 \\
0.113 E+11 \\
0.117 E+11 \\
0.119 E+11 \\
0.112 E+11 \\
0.107 E+11 \\
0.198 E+10 \\
0.358 E+10 \\
0.361 E+10 \\
0.224 E+10 \\
0.272 E+10 \\
0.250 E+10 \\
0.272 E+10 \\
0.241 E+10 \\
0.399 E+10 \\
0.330 E+10 \\
0.298 E+10 \\
0.251 E+10 \\
0.271 E+10 \\
0.234 E+10 \\
0.197 E+10 \\
0.581 E+10 \\
0.532 E+10 \\
0.633 E+10 \\
0.572 E+10 \\
0.578 E+10 \\
0.454 E+10 \\
0.355 E+10 \\
0.158 E+12 \\
0.158 E+12\end{array}$ & $\begin{array}{c}0.100 \mathrm{E}+00 \\
0.100 \mathrm{E}+00 \\
0.100 \mathrm{E}+00 \\
0.100 \mathrm{E}+00 \\
0.300 \mathrm{E}+00 \\
0.300 \mathrm{E}+00 \\
0.300 \mathrm{E}+00 \\
0.300 \mathrm{E}+00 \\
0.390 \mathrm{E}+01 \\
0.660 \mathrm{E}+01 \\
0.850 \mathrm{E}+01 \\
0.160 \mathrm{E}+02 \\
0.412 \mathrm{E}+02 \\
0.235 \mathrm{E}+02 \\
0.372 \mathrm{E}+02 \\
0.660 \mathrm{E}+01 \\
- \\
- \\
- \\
- \\
- \\
- \\
0.786 \mathrm{E}+04 \\
0.204 \mathrm{E}+02 \\
<0.979 \mathrm{E}+01 \\
<0.380 \mathrm{E}+01 \\
<0.349 \mathrm{E}+02 \\
<0.298 \mathrm{E}+02 \\
<0.839 \mathrm{E}+01 \\
<0.350 \mathrm{E}+01 \\
<0.320 \mathrm{E}+01 \\
<0.750 \mathrm{E}+02 \\
<0.205 \mathrm{E}+02 \\
<0.243 \mathrm{E}+01 \\
<0.141 \mathrm{E}+01 \\
<0.785 \mathrm{E}+00 \\
0.822 \mathrm{E}+04 \\
0.822 \mathrm{E}+04\end{array}$ & $\begin{array}{c}0.100 E-01 \\
0.100 E-01 \\
0.100 E-01 \\
0.100 E-01 \\
0.500 E-01 \\
0.500 E-01 \\
0.500 E-01 \\
0.400 E-01 \\
0.420 E+01 \\
0.188 E+03 \\
0.229 E+03 \\
0.160 E+03 \\
0.150 E+02 \\
0.620 E+01 \\
0.440 E+01 \\
0.630 E+00 \\
0.195 E+02 \\
0.830 E+01 \\
0.180 E+02 \\
0.530 E+01 \\
0.114 E+02 \\
0.105 E+02 \\
0.434 E+02 \\
0.839 E+01 \\
<0.649 E+01 \\
<0.312 E+01 \\
<0.529 E+01 \\
<0.352 E+01 \\
<0.847 E+00 \\
<0.127 E+01 \\
<0.118 E+02 \\
<0.800 E+00 \\
<0.824 E+00 \\
<0.331 E+00 \\
<0.351 E+01 \\
<0.523 E+01 \\
0.765 E+03 \\
<0.560 E+02\end{array}$ & 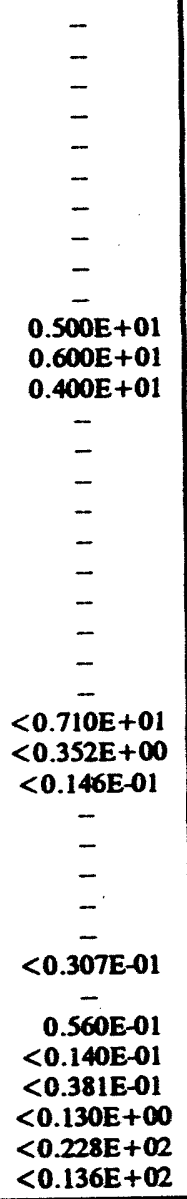 & $\begin{array}{c}- \\
- \\
- \\
- \\
- \\
- \\
- \\
- \\
0.100 \mathrm{E}+01 \\
0.830 \mathrm{E}+02 \\
0.101 \mathrm{E}+03 \\
0.710 \mathrm{E}+02 \\
0.700 \mathrm{E}+01 \\
0.300 \mathrm{E}+01 \\
0.200 \mathrm{E}+01 \\
- \\
0.900 \mathrm{E}+01 \\
0.400 \mathrm{E}+01 \\
0.800 \mathrm{E}+01 \\
0.200 \mathrm{E}+01 \\
0.500 \mathrm{E}+01 \\
0.400 \mathrm{E}+01 \\
<0.800 \mathrm{E}+01 \\
<0.107 \mathrm{E}+01 \\
<0.240 \mathrm{E}+00 \\
- \\
- \\
- \\
- \\
<0.755 \mathrm{E}-01 \\
\overline{-} \\
<0.187 \mathrm{E}-01 \\
<0.175 \mathrm{E}-01 \\
<0.106 \mathrm{E}-01 \\
<0.731 \mathrm{E}-02 \\
0.309 \mathrm{E}+03 \\
<0.169 \mathrm{E}-01 \\
\end{array}$ & $\begin{array}{l}\overline{-} \\
\overline{-} \\
\overline{-} \\
\overline{-} \\
\overline{-} \\
\overline{-} \\
0.300 \mathrm{E}+01 \\
0.400 \mathrm{E}+01 \\
0.300 \mathrm{E}+01 \\
\overline{-} \\
\overline{-} \\
\overline{-} \\
\overline{-} \\
\overline{-} \\
- \\
\overline{-} \\
<0.450 \mathrm{E}+01 \\
<0.787 \mathrm{E}+00 \\
<0.466 \mathrm{E}+00 \\
\overline{-} \\
\overline{-} \\
\overline{-} \\
<0.443 \mathrm{E}-01 \\
\overline{-} \\
<0.149 \mathrm{E}-02 \\
<0.131 \mathrm{E}-01 \\
<0.151 \mathrm{E}+01 \\
<0.218 \mathrm{E}+01 \\
<0.194 \mathrm{E}+02 \\
<0.134 \mathrm{E}+02\end{array}$ & 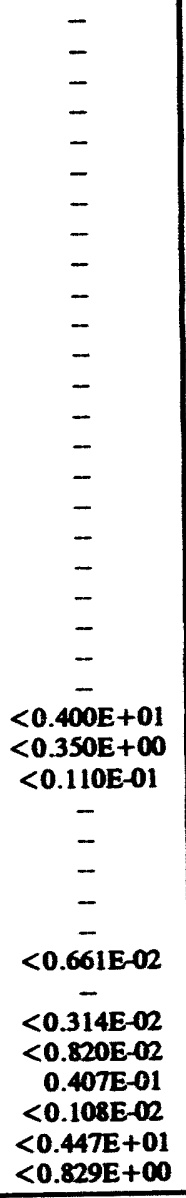 & $\begin{array}{l}0.800 E+01 \\
0.800 E+01 \\
0.800 E+01 \\
0.800 E+01 \\
0.100 E+02 \\
0.120 E+02 \\
0.130 E+02 \\
0.390 E+02 \\
0.950 E+02 \\
0.930 E+02 \\
0.970 E+02 \\
0.980 E+02 \\
0.920 E+02 \\
0.880 E+02 \\
0.160 E+02 \\
0.290 E+02 \\
0.220 E+02 \\
0.194 E+03 \\
0.148 E+03 \\
0.148 E+03 \\
0.380 E+02 \\
0.590 E+02 \\
0.478 E+02 \\
0.160 E+02 \\
0.240 E+02 \\
0.993 E+01 \\
0.134 E+02 \\
<0.786 E+01 \\
<0.559 E+01 \\
<0.415 E+02 \\
<0.421 E+02 \\
<0.499 E+02 \\
<0.440 E+02 \\
<0.467 E+02 \\
<0.342 E+04 \\
<0.397 E+03 \\
<0.548 E+04 \\
<0.548 E+04 \\
<04\end{array}$ \\
\hline
\end{tabular}

(a) Adapted from Ardereon (1976a, 1976b), Mirabelia (1977), Anderson and Poremba (1978, 1979), Slicer (1980), and Aldrich and Slicer (1981). 


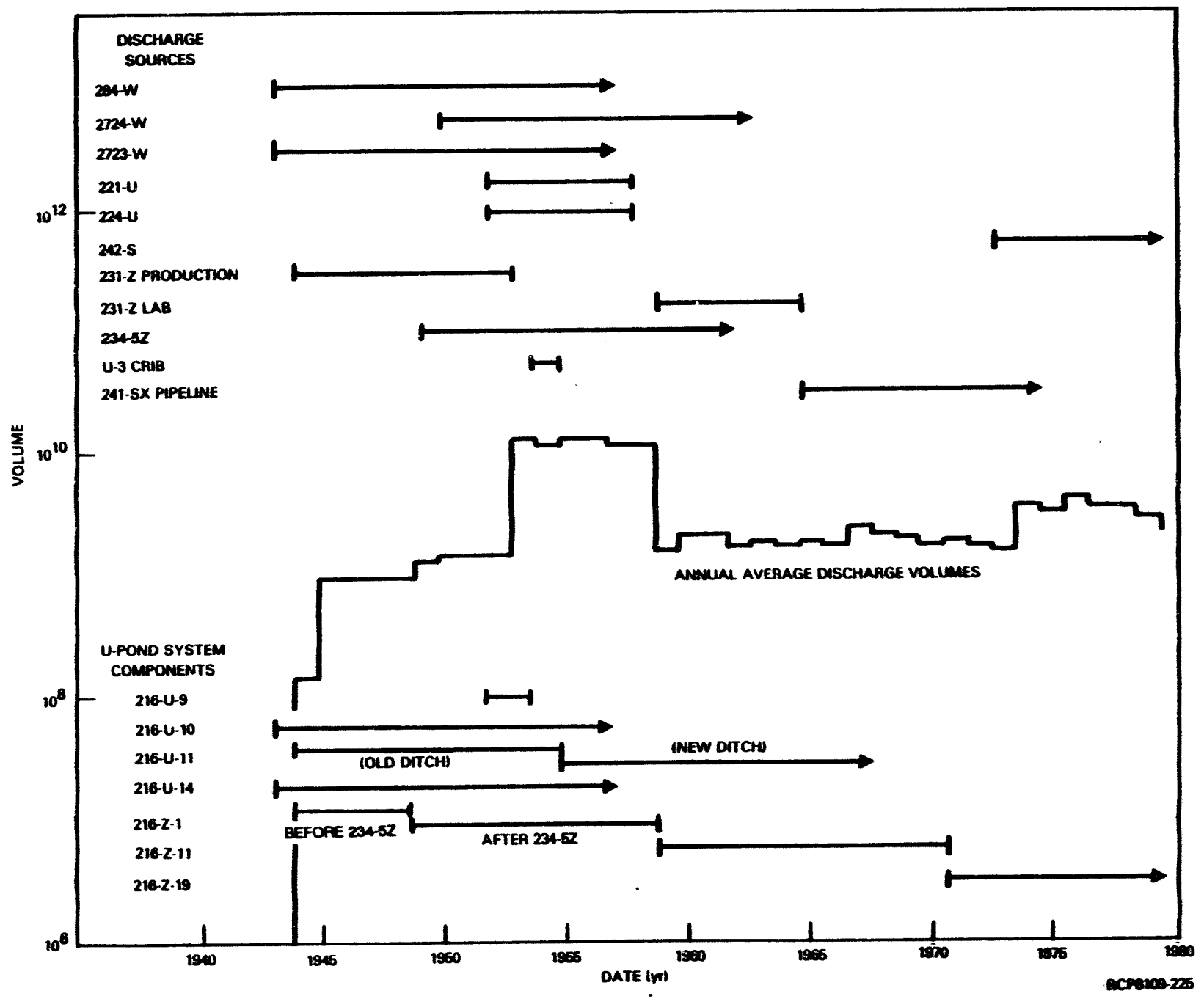

Figure 2.7. Relationship of the 216-U-10 Pond Disposal System Components to the Discharge Sources and Discharge Volumes 
Table 2.2. Operational Use of the 216-U-10 Pond Components and Some Associated Release Inventories (1968 to 1980)(-)

\begin{tabular}{|c|c|c|c|c|c|c|c|}
\hline Facilities & Service Dates & Volume (L) & Pu (g) & Beta (Ci) & ${ }^{9} S_{x}\left(C_{i}\right)$ & ${ }^{157} \mathrm{Cs}(\mathrm{Ci})$ & $20\left(C_{i}\right)$ \\
\hline \multicolumn{8}{|c|}{ Inflow } \\
\hline 216-U-14 Ditch ${ }^{(4)}$ & $\begin{array}{l}07 / 44 \text { to } 01 / 68 \\
01 / 68 \text { to } 12 / 80\end{array}$ & $\begin{array}{c}\text { (b) } \\
2.8 \mathrm{E}+10\end{array}$ & $\begin{array}{c}\text { (b) } \\
<3.0 \mathrm{E}+\infty\end{array}$ & $\begin{array}{c}\text { (b) } \\
<6.5 E+\infty\end{array}$ & $\begin{array}{c}\text { (b) } \\
<8.6 \mathrm{E}-02\end{array}$ & $\begin{array}{c}\text { (b) } \\
<1.8 \mathrm{E}+\infty\end{array}$ & $\begin{array}{c}\text { (b) } \\
<3.8 \mathrm{E}+03\end{array}$ \\
\hline 216-Z-1 Ditch ${ }^{(c)}$ & $12 / 44$ to $03 / 59$ & (b) & (b) & (b) & (b) & (b) & (b) \\
\hline 216-Z-11 Ditch'o & $\begin{array}{l}03 / 59 \text { to } 01 / 68 \\
01 / 69 \text { to } 12771\end{array}$ & $\begin{array}{c}\text { (b) } \\
6.7 \mathrm{E}+08\end{array}$ & $\begin{array}{c}\text { (b) } \\
<6.7 \mathrm{E}+01\end{array}$ & $\begin{array}{c}\text { (b) } \\
<8.6 \mathrm{E}+\infty\end{array}$ & $\begin{array}{l}\text { (b) } \\
\text { (b) }\end{array}$ & (b) & (b) \\
\hline 216-Z-19 Ditch(e) & $12 / 71$ to $12 / 80$ & $7.0 E+09$ & $<1.4 \mathrm{E}+02$ & $<6.9 \mathrm{E}+\infty 0$ & $<7.6 \mathrm{E}-02$ & $<1.8 \mathrm{E}+\infty$ & $<2.7 \mathrm{E}+02$ \\
\hline $\begin{array}{l}\text { 216-U-10 Pond } \\
\text { (summary) }\end{array}$ & $07 / 44$ to $12 / 80$ & $1.6 E+12$ & $<8.2 \mathrm{E}+04$ & $<7.7 \mathrm{E}+03$ & $<2.3 \mathrm{E}+03$ & $<1.4 \mathrm{E}+02$ & $<5.5 E+04$ \\
\hline \multicolumn{8}{|c|}{ Outflow } \\
\hline $\begin{array}{l}\text { 216-U-11 (old } \\
\text { trench) }\end{array}$ & $01 / 44$ to $07 / 55$ & (b) & (b) & (b) & (b) & (b) & (b) \\
\hline $\begin{array}{l}\text { 216-U-9 (ditch to } \\
\text { S-12 Pond) }\end{array}$ & $03 / 52$ to $04 / 54$ & (b) & (b) & (b) & (b) & (b) & (b) \\
\hline $\begin{array}{l}\text { 216-U-11 (new } \\
\text { trench and basin) }\end{array}$ & $07 / 55$ to $12 / 80$ & (b) & (b) & (b) & (b) & (b) & (b) \\
\hline
\end{tabular}
(a) Active.
(b) No data available.
(c) Backfilled.
(d) Partially backfilled. 
The discharges of principal interest to this study are those to the Z-ditches, the Z-19 Ditch, and its predecessors, $Z-1$ and Z-11. These discharges, which are the primary source of plutonium contamination to the disposal system, originate from plutonium reclamation and the processing facilities. A description of the waste streams and their sources is listed for each Z-ditch in Table 2.3.

Waste waters from the plutonium processing activities have been continually discharged to the Z-ditches, but plutonium releases, usually at low levels, have occurred on an intermittent basis (Emery and Klofper 1974). The discharge inventories (see Table 2.1) indicate a total of $8.22 \mathrm{~kg}$ of plutonium were released to the U-Pond disposal system; all but negligible amounts of these were released to the $\mathrm{Z}$-ditches. A comparison of the annual plutonium discharges and the service dates of three Z-ditches provides rough estimates of the proportion of this inventory received by each ditch (see Table 2.3). The discharge records show small annual inventories from 1944 to 1953 , with a sum of only $1.6 \mathrm{~g}$ released during this time period. (The reliability of these early discharge values is not known.) The annual plutonium discharge values increased significantly from 1953 through 1960 , to a total of $144 \mathrm{~g}$. No plutonium discharge values are reported for the period from 1961 through 1966. During this period, the first purifled ${ }^{277} \mathrm{~Np}$ and ${ }^{200} \mathrm{Pu}$ were produced for the Space Nuclear Auxiliary Power (SNAP) program. Waste water from this operation was mixed with the normal weapons-grade ${ }^{209.200 \mathrm{Pu} \text { waste }}$ discharges (Emery and Klopfer 1974). An accumulative discharge for the period from 1959 through 1967 was reported for 1967 as $7.86 \mathrm{~kg}$ (96\% of the total plutonium inventory) (Emery and Klopfer 1974). In 1968, only $20.4 \mathrm{~g}$ of plutonium were reportedly discharged. Discharge values reported from 1969 through 1980 have all been reported as "less than values" because of the sum of many waste streams, which had less than detectable concentrations of plutonium. Total plutonium inventory for . this period is less than $193 \mathrm{~g}$.

Some uncertainty exists concerning the accuracy of the reported plutonium discharge values. It is quite possible that many of the reported values were calculated excessively high because of unknown amounts of ${ }^{238} \mathrm{Pu}$ present in the waste steams. Plutonium separations were probably made on the waste stream samples but the assay was done mostly by alpha count (Emery and Klopfer 1974). Thus, the conversion of plutonium activity to weight could cause excessively high plutonium weight values (Emery and Klopfer 1974). However, there have also been indications that the reported plutonium discharge values are excessively low. One such possibility is that the periodic sampling of the waste streams could have missed some of the intermittent plutonium discharges and/or simply were not representative.

One such detected intermittent discharge from the 231-Z Building occurred on March 25, 1976, and contained an estimated $60 \mathrm{~g}$ of plutonium, based on several assumptions. The assumptions demonstrate the uncertainties of any discharge values (Appendix A). Some of the more complicating factors that required an assumed value are the irregular discharge rates and the unrepresentative sampling of particulate in the waste stream. Another similar release was reported in January and February 1977, with $91.2 \mathrm{~g}$ reportedly discharged.

The most significant indication that the plutonium discharge records are excessively low is based on comparison with plutonium inventories determined from analysis of sediment samples from the 
Table 2.3. Waste Stream Descriptions and Estimated Inventories for the 216-Z-1, 216-Z-11, and 216-Z-19 Ditches

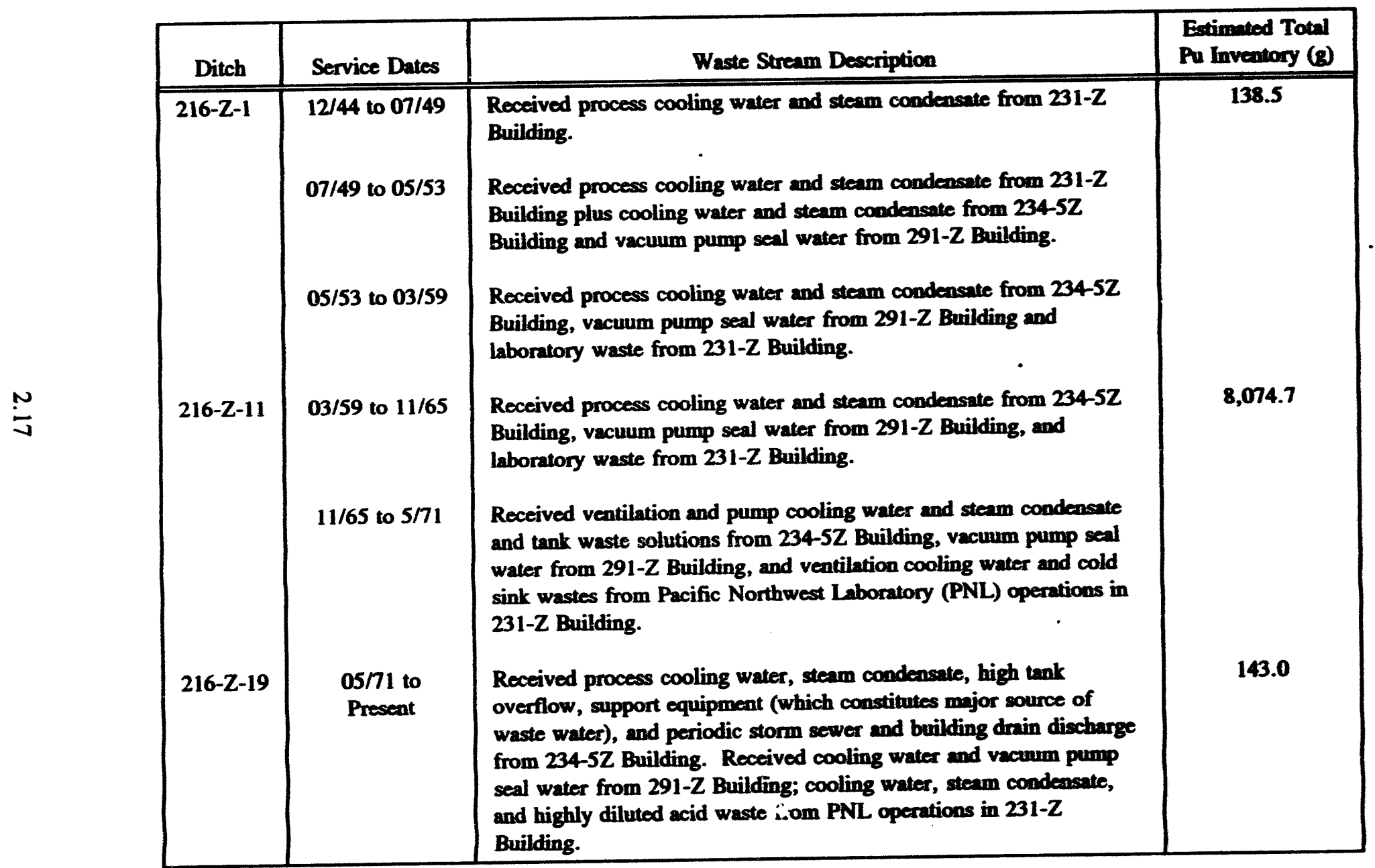

(After Lundgren 1971; Jacobs and Uebelacker 1969, 1970, 1971; Jacobs and Anderson 1972; Anderson 1973,

1974, 1975, 1976a, 1976b; Mirabella 1977; Anderson and Poremba 1978, 1979; Slicer 1980; and Aldrich and Slicer 1981). 
Z-1 Ditch. From samples taken in 1959,3 to $10 \mathrm{~kg}$ were estimated to be in the ditch at that time (see Appendix A). In 1971, the first $137 \mathrm{~m}$ of the Z-1 Ditch were mistakenly uncovered, and the contamination levels found supported this earlier estimate. When compared to the $138.5 \mathrm{~g}$ reportedly discharged during the operation of the Z-1 Ditch, these values show a signiflcant increase in the plutonium inventory.

The many uncertainties regarding the plutonium inventory estimates will cause problems when attempts are made to balance the discharges with estimates of total plutonium in the disposal system based on sampling.

\subsection{Routine Environmental Monitoring}

The U-Pond disposal system is monitored to provide documentation of effluent discharges and general ditch/pond maintenance operations. These activities are designed to detect off-standard conditions to initiate corrective actions in a timely manner (Wheeler and Law 1980). The current practices include influent sampling and monitoring, pond-level control, ditch/pond maintenance, and environmental sampling.

Influent monitoring consists of periodic sampling at designated sites along the ditches, at the pond, and at several of the contributing facilities. The methods and frequencies of sampling are variable (Table 2.4).

Water-level control measures at U-Pond are designed to maintain surface-water levels within specific limits to prevent overflow and to minimize exposure of the contaminated shoreline.

Maintenance operations, such as grading roads, application of herbicides, dredging, and vegetation removal, are routinely conducted to maintain monitoring and surveillance access and to prevent the spread of contamination.

Environmental sampling provides air, surface-water, vegetation, sediment, and ground-water data used in evaluating potential contamination spread. This routine sampling from various locations in the U-Pond disposal system (Figure 2.8) also provides information concerning the relative levels of activity in this disposal system as compared to other similar systems at the Hanford Site. Sampling results also provide data on the species of radionuclides present and their concentration levels within various parts of the U-Pond disposal system.

\subsubsection{Air Sampling}

During 1979, only one continuous air sampler monitored the U-Pond disposal system, located near the head end of the Z-19 Ditch (sampling location 1 [Figures 2.8 and 2.9]). Sample analyses from this location are shown in Table 2.5 . 
Table 2.4. 216-U-10 Pond Influent Monitoring

\begin{tabular}{|c|c|c|c|c|c|c|}
\hline Site & Location & Source & Type & Frequency & Analysis & Comment \\
\hline \multirow[t]{4}{*}{ 216-U-14 Ditch } & 2724-W Building & $\begin{array}{l}\text { Regulated laundry wash " } \\
\text { cycle }\end{array}$ & Sequential & Weekly & $\begin{array}{l}\text { Total slpha, total } \\
\text { beta, strontium }\end{array}$ & $\begin{array}{l}\text { Frequently } \\
\text { inoperative }\end{array}$ \\
\hline & Head of Ditch & $\begin{array}{l}\text { Combined 216-U-14 Ditch } \\
\text { effluents }\end{array}$ & Dip (dixie cup) & Weekly & $\begin{array}{l}\text { Total alpha, total } \\
\text { beta }\end{array}$ & - \\
\hline & 242-S Evaporator & Steam condensate & Proportional & Daily & $\begin{array}{l}\text { Total alpha, total } \\
\text { beta, } \mathbf{p H} \text {, } \\
\text { uranium, }{ }^{3} \mathbf{H}\end{array}$ & - \\
\hline & 242-S Evaporator & Cooling water & Proportional & Daily & $\begin{array}{l}\text { Total alpha, total } \\
\text { beta, pH, } \\
\text { uranium }\end{array}$ & - \\
\hline \multirow[t]{2}{*}{ 216-Z-19 Ditch } & & $\begin{array}{l}\text { Process cooling water, } \\
\text { steam condensate }\end{array}$ & & & $\begin{array}{l}\text { Total alpha, total } \\
\text { beta, pH }\end{array}$ & - \\
\hline & Head of Ditch & $\begin{array}{l}234-5 Z \text { effluents, } 291-Z \\
\text { vacuum pump seal water, } \\
231-Z \text { cooling condensate }\end{array}$ & Sequential & Weekly & $\begin{array}{l}\text { Total alpha, total } \\
\text { beta }\end{array}$ & $\begin{array}{l}\text { Frequently } \\
\text { inoperative }\end{array}$ \\
\hline 216-U-10 Pond & Center of Pond & $\begin{array}{l}\text { 216-U-14, 216-Z-19 } \\
\text { Ditches }\end{array}$ & Sequential & Weekly & $\begin{array}{l}\text { Total alpha, total } \\
\text { beta }\end{array}$ & $\begin{array}{l}\text { Frequently } \\
\text { inoperative }\end{array}$ \\
\hline
\end{tabular}


WHC-EP-0707, Rev. 0

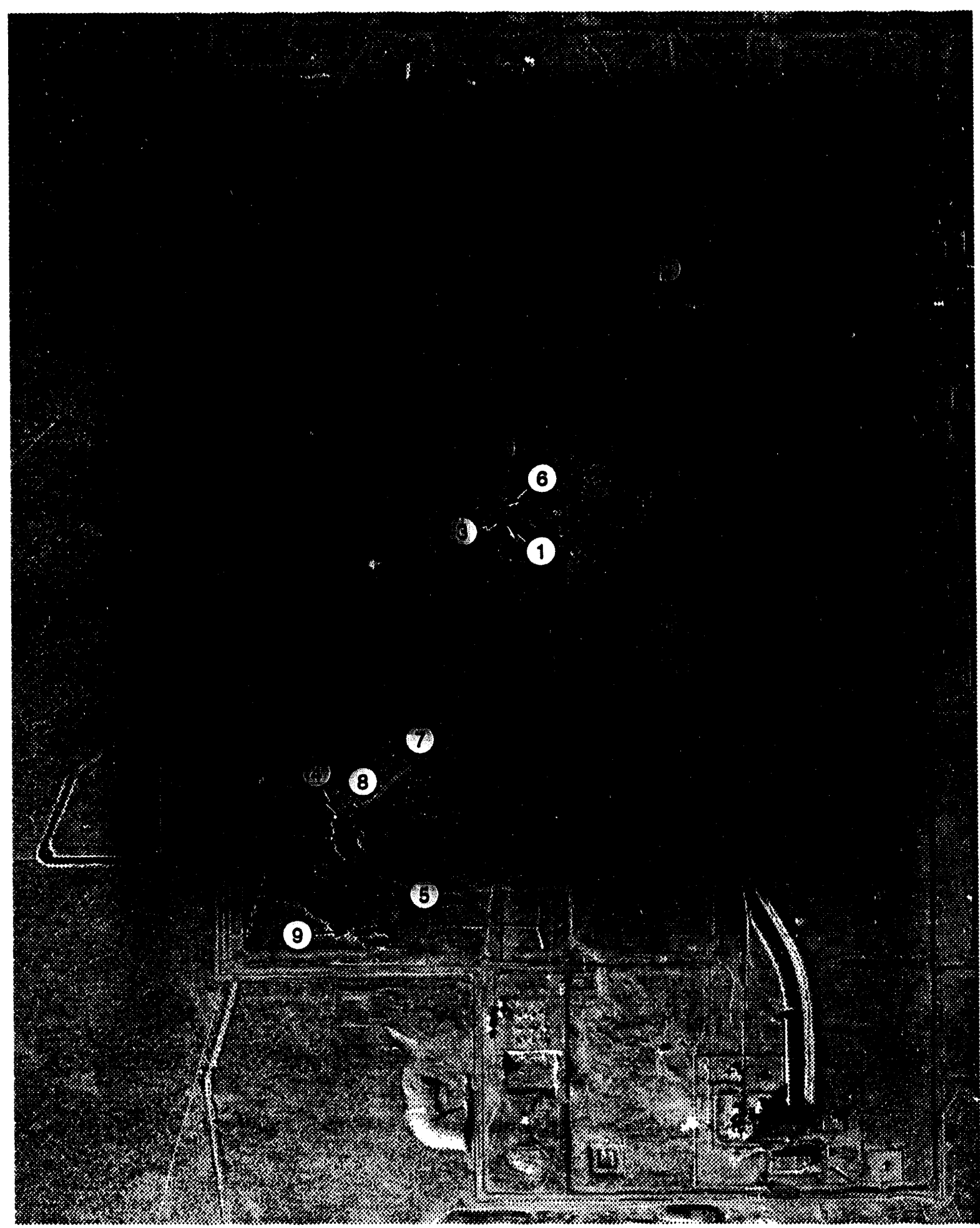

$\$ 9311032.1$

Figure 2.8. Map of the $216-\mathrm{U}-10$ Pond Monitoring Sites 
WHC-EP-0707, Rev. 0

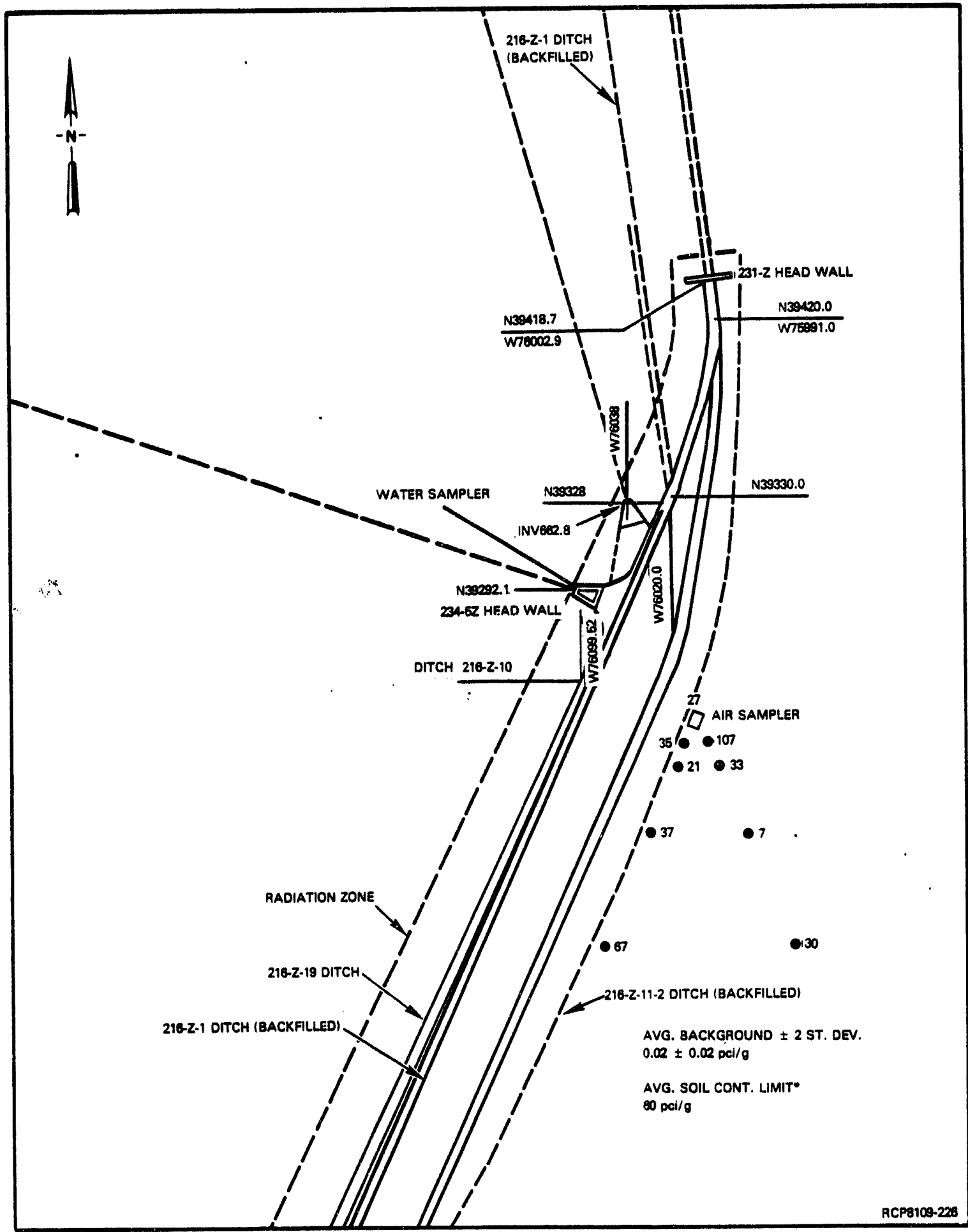

Figure 2.9. Location of Surface Soil Samples Taken Adjacent to the 216-Z-19 Ditch (Soil contamination standards established by Rockwell Hanford Operations [Boothe 1979] based on U.S. Energy Research and Development Administration [1977] guidelines) 
Table 2.5. 216-Z-19 Ditch Air Sampler Results (in $\mu \mathrm{Ci} / \mathrm{mL}$ ) During 1979 (after Wheeler and Law 1980)

\begin{tabular}{|l|c|c|c|}
\hline Radionuclide & Annual Average & Maximum Value & $\begin{array}{c}\text { Annual Average }{ }^{(a)} \\
\text { Guideline }\end{array}$ \\
\hline${ }^{90} \mathrm{Sr}$ & $2.25 \mathrm{E}-15$ & $3.16 \mathrm{E}-15$ & $3.0 \mathrm{E}-11$ \\
${ }^{137} \mathrm{Cs}$ & $1.76 \mathrm{E}-14$ & $5.27 \mathrm{E}-14$ & $5.0 \mathrm{E}-10$ \\
${ }^{209} \mathrm{Pu}$ & $1.41 \mathrm{E}-14$ & $2.33 \mathrm{E}-14$ & $6.0 \mathrm{E}-14$ \\
Uranium Total & $1.56 \mathrm{E}-16$ & $2.37 \mathrm{E}-16$ & $2.0 \mathrm{E}-12$ \\
\hline
\end{tabular}

(a) Table II, ERDA (1977).

The ${ }^{239} \mathrm{Pu}$ concentrations in the air at the head end of the Z-19 Ditch were the highest-recorded values in the 200 Areas during 1979 . The average ${ }^{209} \mathrm{Pu}$ values $(1.41 \mathrm{E}-14 \mu \mathrm{Ci} / \mathrm{mL})$ were 640 times the average concentration of similar stations at perimeter locations and $24 \%$ of the Table II guidelines (ERDA 1977). There was no significant difference between 1978 and 1979 concentrations (ERDA 1977).

Previous to July 1979 , the air sampler was located on the ground. During July 1979, a new air sampler was installed approximately $1 \mathrm{~m}$ above the ground, but subsequent analyses showed no significant differences (ERDA 1977).

In March 1979, several surface soil samples were collected near the Z-19 Ditch air sampling station (Table 2.6; see Figure 2.9). The ${ }^{209} \mathrm{Pu}$ in the samples ranged from 7 to $107 \mathrm{pCi} / \mathrm{g}, 350$ to 5350 times greater than the average background at the Hanford Site and 0.12 to 1.8 times the average soil contamination standards. ${ }^{(a)}$ The elevated plutonium levels in the soil adjacent to the Z-19 Ditch were attributed to 1) migration of material from the contaminated Z-19 Ditch since it was put into service in 1971 and/or 2) residual activity that resulted from the excavation of the buried contaminated Z-1 Ditch in 1971.

\subsubsection{Surface-Water Sampling}

Water samples are collected weekly from the head end of the U-14 (sampling location 2 [see Figure 2.8]) and Z-19 ditches and from the northwest bank of U-Pond. During 1979, the following results (Table 2.7) were observed.

\subsubsection{Vegetation Sampling}

Vegetation samples were taken at six locations in the U-Pond disposal system during July 1979 (see Figure 2.8). Table 2.8 shows significant levels of ${ }^{90} \mathrm{Sr}$ and ${ }^{137} \mathrm{Cs}$ in the U-14 Ditch vegetation.

(a) Soil contamination standards were established by Rockwell based on DOE guidelines (Boothe 1979). 
Table 2.6. Plutonium in Surface Soil Samples Collected Adjacent to the 216-Z-19 Ditch in March 1979 (after Wheeler and Law 1980).

\begin{tabular}{|l|c|}
\hline \multicolumn{1}{|c|}{ Sample Location } & $\mathrm{pCi}^{239} \mathrm{Pu} / \mathrm{g}$ \\
\hline At air sampler station & 27.2 \\
$10 \mathrm{ft}$ southwest of air sampler & 35.3 \\
$20 \mathrm{ft}$ southwest of air sampler & 20.5 \\
$50 \mathrm{ft}$ southwest of air sampler & 36.6 \\
$100 \mathrm{ft}$ southwest of air sampler & 66.8 \\
$10 \mathrm{ft}$ south of air sampler & 107.0 \\
$20 \mathrm{ft}$ south of air sampler & 33.2 \\
$50 \mathrm{ft}$ south of air sampler & 6.8 \\
$100 \mathrm{ft}$ south of air sampler & 29.8 \\
Average background \pm 2 standard & $0.02 \pm 0.02$ \\
deviations (Houston and Blumer 1980) & \\
Average soil contamination limit & 60.0 \\
Approximate detection limit & 0.009 \\
\hline
\end{tabular}

Table 2.7. Surface-Water Sampling Results During 1979 (after Wheeler and Law 1980)

\begin{tabular}{|c|c|c|c|c|c|}
\hline \multirow[b]{3}{*}{ Sample Sito } & \multirow[b]{3}{*}{$\begin{array}{l}\text { Sampling Location } \\
\text { (Figure 2.8) }\end{array}$} & \multicolumn{4}{|c|}{ Concentration (pCi/mL) } \\
\hline & & \multicolumn{2}{|c|}{ Total Beta } & \multicolumn{2}{|c|}{ Total Alphe } \\
\hline & & $\begin{array}{c}\text { Annual } \\
\text { Average }\end{array}$ & $\begin{array}{c}\text { Monthly } \\
\text { Maximum }\end{array}$ & $\begin{array}{c}\text { Annual } \\
\text { Average }^{(b)}\end{array}$ & $\begin{array}{l}\text { Monthly } \\
\text { Maximum }\end{array}$ \\
\hline 216-U-14 Ditch & 2 & 0.2 & 0.8 & 0.04 & 0.1 \\
\hline 216-Z-19 Ditch & 3 & $<0.1$ & 0.2 & 0.1 & 0.8 \\
\hline 216-U-10 Pond & 4 & 0.1 & 0.3 & $<0.04$ & 0.2 \\
\hline
\end{tabular}

Note: Seo ERDA (1977) for background lovels resulting from worldwide fallout.

(a) ERDA (1977) Tables I and II limits are 10.0 and $0.03 \mathrm{pCi} / \mathrm{mL}$, respectively.

(b) ERDA (1977) Tables I and II limits are 100.0 and $5.0 \mathrm{pCi} / \mathrm{mL}$, respectively.

The highest levels of ${ }^{209} \mathrm{Pu}$ in vegetation from any 200 Area pond or ditch were found at the 234-5Z Outfall near the head end of the Z-19 Ditch. The levels found were generally similar to previous years' results and were attributed to deposition from airborne radioactivity and uptake from contaminated sediments. 
Table 2.8. Vegetation Sampling Results

\begin{tabular}{|c|c|c|c|c|c|c|}
\hline \multirow[b]{2}{*}{ Sample Site } & \multirow{2}{*}{$\begin{array}{c}\text { Sampling } \\
\text { Location } \\
\text { (Figure 2.8) } \\
\end{array}$} & \multicolumn{5}{|c|}{ Concentration in $\mathrm{pCi} / \mathrm{g}$ dry weight } \\
\hline & & ${ }^{40} \mathrm{~K}$ & ${ }^{90} \mathrm{Sr}$ & ${ }^{137} \mathrm{Cs}$ & ${ }^{239} \mathrm{Pu}$ & ${ }^{241} \mathrm{Am}$ \\
\hline $\begin{array}{l}\text { 216-U-14 Laundry Ditch, } \\
\text { Inlet to U-Pond }\end{array}$ & 5 & $<18.0$ & 6.9 & 299.0 & 1.5 & $<11.0$ \\
\hline 216-U-14 Laundry Ditch & 2 & $<11.0$ & 51.3 & 196 & $<1.0$ & $<5.3$ \\
\hline $\begin{array}{l}\text { 216-Z-19 Ditch, 234-5 } \\
\text { Outfall }\end{array}$ & 3 & 21.0 & 1.9 & 0.7 & 11.2 & 8.9 \\
\hline $\begin{array}{l}216-Z-19 \text { Ditch, } 231-Z \\
\text { Outfall }\end{array}$ & 6 & $<19.0$ & $<0.9$ & $<1.1$ & 1.5 & $<0.6$ \\
\hline $\begin{array}{l}\text { 216-Z-19 Ditch, 16th } \\
\text { Street Crossing }\end{array}$ & 7 & $<22.0$ & 9.0 & $<0.7$ & 5.6 & $<21.0$ \\
\hline $\begin{array}{l}\text { 216-Z-19 Ditch, Inlet to } \\
\text { U-Pond }\end{array}$ & 8 & $<13.0$ & 5.8 & $<1.3$ & 4.6 & 6.2 \\
\hline U-Pond, North Side ${ }^{(a)}$ & 4 & -- & -- & -- & -- & - \\
\hline U-Pond, South Side ${ }^{(a)}$ & 9 & - & - & - & -- & - \\
\hline $\begin{array}{l}\text { Background, Average } \\
\pm 2 \text { Standard } \\
\text { Deviations }^{(b)}\end{array}$ & & $13 \pm 11$ & $0.11 \pm 0.27$ & $0.16 \pm 0.24$ & $0.003 \pm 0.001$ & \\
\hline
\end{tabular}

Note: No entry indicates no analysis.
(a) No sample taken.
(b) Houston and Blumer (1980). 


\subsubsection{Sediment Sampling}

Sediment samples were collected at the same time and near the same locations as the vegetation samples (see Figure 2.8). Table 2.9 lists the analytical values of these samples.

The Z-19 Ditch, inlet to U-Pond, and 234-5Z Outfall samples showed the highest concentrations of ${ }^{299} \mathrm{Pu}$ and ${ }^{241} \mathrm{Am}$ of all ponds and ditches. These high concentrations (up to $5930 \mathrm{pCi} / \mathrm{g}{ }^{29} \mathrm{Pu}$ and 1270 $\left.\mathrm{pCi} / \mathrm{g}^{211} \mathrm{Am}\right)$ were attributed to accidental releases from $234-5 \mathrm{Z}$ since use of the ditch started in 1971 (Wheeler and Law 1980).

All other radionuclides measured in sediments were at their highest concentration in the U-14 Ditch samples. Manganese-54, ${ }^{60} \mathrm{Co},{ }^{90} \mathrm{Sr},{ }^{144} \mathrm{Ce},{ }^{155} \mathrm{Eu}$, and ${ }^{239} \mathrm{Pu}$ were most prevalent in the sample from the head end of the ditch; whereas the highest concentration of ${ }^{137} \mathrm{Cs}$ was measured near the inlet to U-Pond (Wheeler and Law 1980).

In 1977, seven nonroutine environmental monitoring sediment samples were collected along the spoils piles north and west of the U-14 Ditch. These spoils piles are the result of past dredging operations. Table 2.10 shows the analytical results of each sample.

The presence of the relatively short-lived radioisotopes in the U-14 Ditch is attributed to the 2724-W Laundry, which washes protective clothing and other contaminated garments from the 100 Area reactor sites, the 200 Areas fuel reprocessing and waste management facilities, and the 300 Area (Wheeler and Law 1980).

\subsubsection{Ground-Water Sampling}

Only one ground-water monitoring well, associated with the U-Pond system, was sampled during 1979. This well, 299-W15-5, monitored the ground water beneath the system of retired (Z-1 and $Z-11)$ and active (Z-19) ditches. Water samples from this well show average concentrations of less than $1.70 \mathrm{E}-02 \mathrm{pCi} / \mathrm{mL}$ total alpha, less than $7.50 \mathrm{E}-02 \mathrm{pCi} / \mathrm{mL}$ total beta, $2.25 \mathrm{E}+00 \mathrm{pCi} / \mathrm{mL}{ }^{3} \mathrm{H}$, and $1.2 \mathrm{E}+01 \mathrm{ppm} \mathrm{NO}_{3}^{-}$. All radionuclide values are well below Table II limits (ERDA 1977) and the $\mathrm{NO}_{3}^{-}$value is well below drinking water standards (Wheeler and Law 1980). 
Table 2.9. Sediment Sampling Results (after Wheeler and Law 1980)

\begin{tabular}{|c|c|c|c|c|c|c|c|c|c|c|}
\hline \multirow[b]{2}{*}{ Sample Site } & \multicolumn{10}{|c|}{ Concentration in $\mathrm{pCi} / \mathrm{g}$ dry weight } \\
\hline & ${ }^{\infty} \mathrm{K}$ & ${ }^{\mathbf{s}} \mathbf{M n}$ & ${ }^{50} \mathrm{Co}$ & ${ }^{90} \mathrm{Sr}$ & ${ }^{157} \mathrm{Cs}$ & ${ }^{24} \mathrm{Ce}$ & ${ }^{14} \mathrm{Eu}$ & ${ }^{2 N E u}$ & ${ }^{200} \mathrm{Pu}$ & ${ }^{201} \mathrm{Am}$ \\
\hline $\begin{array}{l}\text { 216-U-14 Ditch, inlet to 216- } \\
\text { U-10 Pond }\end{array}$ & 18.0 & (a) & 99.4 & 29.0 & 876 & (a) & 21.6 & 14.3 & 88.3 & 50.4 \\
\hline 216-U-14 Ditch, near head end & $<25.0$ & 118 & 902 & 2,310 & 142 & 49.8 & (a) & 174 & 147 & \\
\hline 216-Z-19 Ditch, 234-5 Outfal! & 12.8 & (a) & (a) & $<8.5$ & 0.8 & (a) & (a) & (a) & 2,010 & 166 \\
\hline 216-Z-19 Ditch, 231-Z Outfall & 15.5 & (a) & (a) & $<9.6$ & 1.3 & (a) & (a) & (a) & 4.2 & $<15$ \\
\hline 216-Z-19 Ditch, 16th Street & 1.7 & (a) & (a) & $<3.5$ & 0.1 & (a) & (a) & (a) & 34.8 & 570 \\
\hline 216-Z-19 Ditch, inlet to & 8.9 & (a) & (a) & $<8.7$ & 6.1 & (a) & (a) & (a) & 5,930 & 1,270 \\
\hline 216-U-10 Pond & & & & & & & & & & \\
\hline 216-U-10 Pond, north side & 14.7 & (a) & 2.2 & 3.2 & 594 & (a) & (a) & (a) & 58.3 & 63 \\
\hline 216-U-10 Pond, south side ${ }^{(1)}$ & & & & & & & & & & \\
\hline $\begin{array}{l}\text { Background levels in surface } \\
\text { soil, average } \pm 2 \text { standard } \\
\text { deviations }\end{array}$ & $15 \pm 5.3$ & - & - & $0.22 \pm 0.24$ & $0.7 \pm 0.81$ & $0.39 \pm 0.2$ & (a) & - & $0.02 \pm 0.02$ & - \\
\hline
\end{tabular}
(a) Less than detectable.
(b) No sample taken.
(c) Houston and Blumer (1980). 
Table 2.10. Concentration of Radionuclides in Berm Soil Along the 216-U-14 Ditch in 1977

\begin{tabular}{|c|c|c|c|c|c|c|c|c|c|c|c|c|c|c|c|}
\hline \multirow{2}{*}{ Sample } & \multirow[b]{2}{*}{$\begin{array}{c}\text { Sample } \\
\text { Location }\end{array}$} & \multicolumn{14}{|c|}{ Concentration in $\mathrm{pCi} / \mathrm{g}$ (dry weight) } \\
\hline & & ${ }^{\circ} \mathrm{K}$ & ${ }^{x} \mathrm{Mn}$ & ${ }^{80} \mathrm{Co}$ & ${ }^{{ }^{0} \mathbf{S}} \mathbf{S}$ & ${ }^{123} \mathrm{Sb}$ & ${ }^{15} \mathrm{Cs}_{\mathrm{S}}$ & ${ }^{14} \mathrm{Ce}$ & ${ }^{12} \mathrm{Eu}$ & ${ }^{15} \mathrm{Eu}$ & ${ }^{125} \mathrm{Eu}$ & ${ }^{2 \times} \mathrm{R}_{\mathrm{a}}$ & ${ }^{200} \mathbf{P u}$ & ${ }^{200200 \mathrm{Pu}}$ & ${ }^{211} \mathrm{Am}$ \\
\hline ES-1105 & $\begin{array}{l}\text { Near inlet to } \\
\text { U-Pond (old } \\
\text { berm) }\end{array}$ & $<190$ & - & - & 12.6 & - & 14,000 & - & - & - & - & - & 4.2 & 61 & - \\
\hline ES-1104 & $\begin{array}{l}213 \mathrm{~m} \text { from } \\
\text { U-Pond (old } \\
\text { berm) }\end{array}$ & 16.3 & - & 7.3 & 5.2 & - & 1290 & - & - & 1.96 & 9.3 & - & 11.1 & 130 & - \\
\hline ES-1109 & \begin{tabular}{|l|} 
Near 242-S \\
Road (old \\
berm)
\end{tabular} & 14 & - & 52.4 & 9.4 & - & 736 & - & - & 8.3 & 9.3 & - & - & 30 & - \\
\hline ES-1114 & $\begin{array}{l}61 \mathrm{~m} \text { from } \\
\text { ditch head end } \\
\text { (old berm) }\end{array}$ & $<12$ & 12.9 & 1020 & 219 & - & 251 & - & 10.8 & 2800 & 192 & - & 5.5 & 26.9 & 16.5 \\
\hline ES-1110 & $\begin{array}{l}\text { Near ditch } \\
\text { head end (old } \\
\text { berm) }\end{array}$ & $<7.3$ & 8.5 & 358 & 36 & 3.76 & 52 & - & - & 63.5 & 43.3 & 6.6 & 2.4 & 21.7 & - \\
\hline ES-1112 & $\begin{array}{l}46 \mathrm{~m} \text { from } \\
\text { ditch head end } \\
\text { (rocent } \\
\text { dredging) }\end{array}$ & $<14$ & 177 & 1200 & 586 & 12.9 & 111 & 60.7 & 93.4 & 524 & 397 & - & 13.1 & 85.3 & 17.4 \\
\hline ES-1113 & $\begin{array}{l}61 \mathrm{~m} \text { from } \\
\text { ditch head end } \\
\text { (recent } \\
\text { dredging) }\end{array}$ & $<11$ & 30.4 & 686 & 41.8 & - & 152 & 12.1 & - & 119 & 83.7 & 10.4 & 12.7 & 38.1 & - \\
\hline
\end{tabular}




\subsection{Environmental Characteristics}

Climate, biology, geology, and hydrology have all had varying effects on the radionuclide distribution around the 216-U-10 (U-) Pond disposal system, and because it is still an active site and open to the environment, they will continue to have some effects. A discussion of these environmental characteristics is presented below.

\subsection{Climate}

The Hanford Site is situated in the rain shadow of the Cascade Range. The prevailing direction of storm fronts from the Pacific Ocean eastward over these high mountains results in mild year-round temperatures and low precipitation. July is the hottest and driest month; January is the coolest and wettest. The average annual precipitation recorded at the Hanford Meteorological Station is $16 \mathrm{~cm}$; 42\% of that amount falls between November and January (Stone et al. 1972). The average annual temperature is $11.7^{\circ} \mathrm{C}$; however, temperatures in excess of $38^{\circ} \mathrm{C}$ or below $0^{\circ} \mathrm{C}$ are common. Prevailing winds are from the northwest, while prevailing high winds are from the southwest. Easterly winds are not uncommon, as depicted in the wind rose in Figure 3.1. Brown and Isaacson (1977) and ERDA (1975) give further details on the Hanford Site's climate.

\subsection{Biology}

The Hanford Site is referred to as a shrub-steppe grassland (Daubenmire 1970). The area surrounding the reprocessing and separations facilities can be further classified as a sagebrush/ cheatgrass community, based on its dominant vegetation. Within this community are several riparian habitats (water), consisting of ditches and ponds, created for the disposal of liquid effluents. These riparian habitats provide food, cover, and shelter for many animals, including waterfowl.

The U-Pond disposal system has received low-level liquid effluents longer than any other surface disposal facility at the Hanford Site. The pond now supports a unique ecological community adapted to the existing chemical, thermal, and radiological conditions. The primary biological concern in the U-Pond disposal system is uptake and potential transport of radioactive materials by aquatic organisms, birds, small mammals, and vegetation.

In addition to plutonium and americium discharges, the U-Pond disposal system has also received low-level fission products, such as cesium and strontium. At one time in the mid-1950s, U-Pond extended over an area of $16 \mathrm{ha}$; the pond presently supports a surface area of approximately $5.7 \mathrm{ha}$. U-Pond receives effluents from three major sources: 216-Z-19 (Z-19) Ditch, 216-U-14 (U-14) Ditch, and 242-S Building (Evaporator). The discharge from the 242-S Evaporator is waste cooling water, which supplies a significant heat load to the pond. Water from the U-14 Ditch provides a large source 


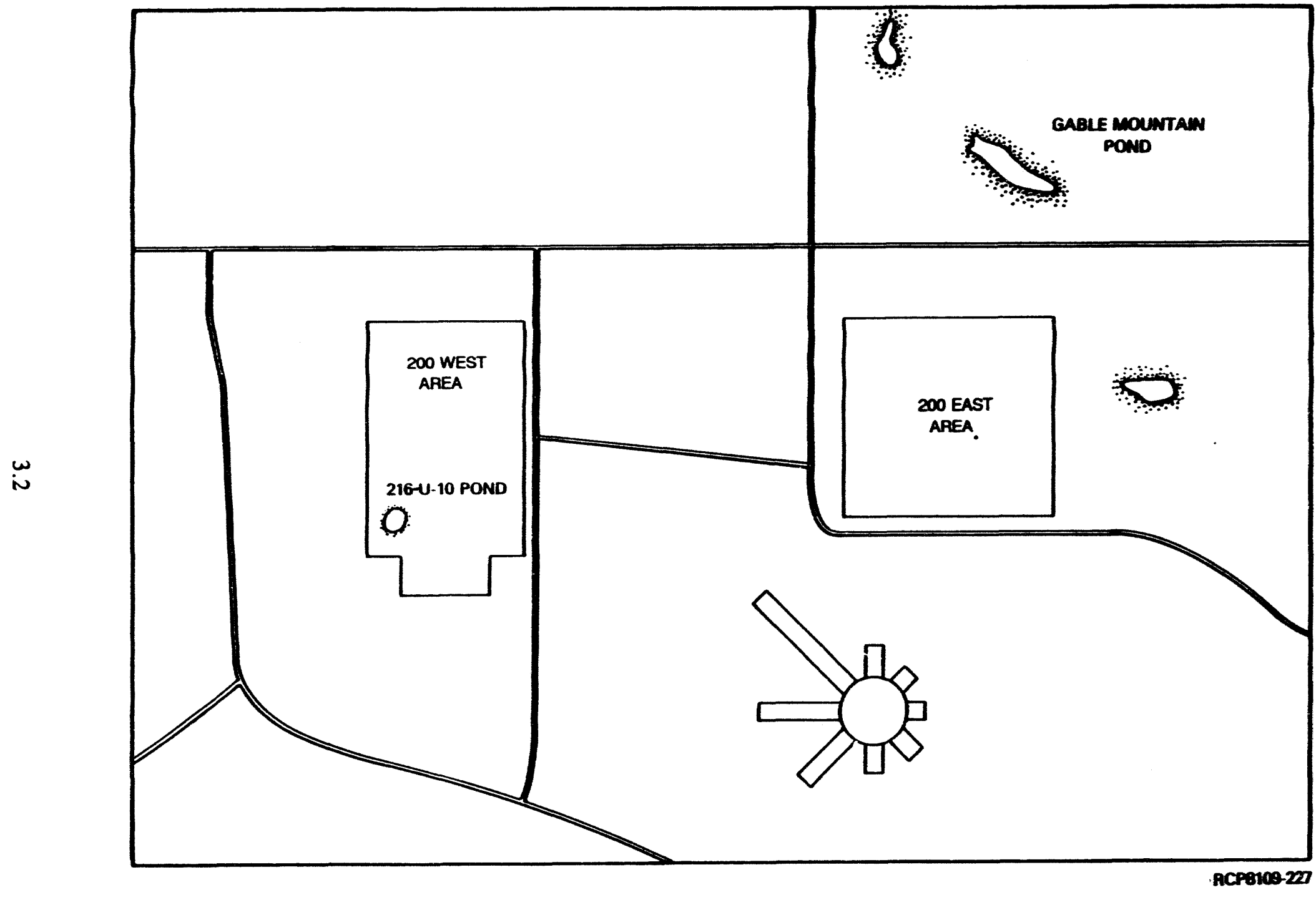

Figure 3.1. Prevailing Wind Directions Near the 216-U-10 Pond 
of nutrients in the form of phosphorous, nitrogen, and silicates. The small amounts of water supplied historically by the Z-19 Ditch do not appear to play a significant role in the pond's water or nutrient budget.

There are no outlets from U-Pond; $95 \%$ of the water loss is by percolation (Emery and Klopfer 1974; Emery and McShane 1978). The depth of the pond ranges from 0.3 to $1.8 \mathrm{~m}$ and the sediments range from 0 to $40 \mathrm{~cm}$ thick. Wind action has played a significant role in distributing the sediments nonuniformly around the pond, thereby limiting the establishment of submergent macrophytes (large plants) (Emery and Klopfer 1974; Emery and McShane 1978). In 1974, floating docks constructed for research purposes resulted in stabilizing much of the sediments on their leeward side and has allowed submergent macrophytes and associated periphytic (attached) algae to become established. As a result of the nutrients supplied by the U-14 Ditch and optimum growing conditions created by the warm water from the 242-S Evaporator, U-Pond presently supports a highly diverse algae and ipvertebrate community and is classifled as a eutrophic (high-nutrient-content) system. U-Pond supports the most diverse algal and macrophitic growths of all the Hanford Site aquatic systems. The masses of these filamentous, colonial, and unicellular algaes eventually decompose and settle to the pond bottom. However, as winds develop, the mass of these algal flocs are moved to the perimeter of the pond where they accumulate and dry in thick mats along the shoreline. These algal flocs are of considerable biological importance to the U-Pond disposal system and because of their high abundance, they provide a large organic food base for waterfowl and many invertebrates, including dragonfly larva (Ischnura sp.), water fleas (Daphnia sp.), snails (Physa sp.), midges, and beetles. These algal flocs are also the primary biotic concentrators of plutonium and americium.

Other common plant species that occur in the U-Pond disposal system are the cattail (Typha latifolia), bulrush (Scirpus sp.), pondweed (Potamogeton sp.), duckweed (Lemna sp.), smartweed (Polygonum persicaria), and horsetail (Equisetum sp.). Cottonwood (Populous deltoides) and peachleaf willow (Salix amygdaloides) trees grow along much of the pond's perimeter. The peachleaf willow is the most abundant tree, with low-growing sandbar willows (S. exigua) also interspersed around the pond's edge. Both the vascular plants and trees provide food, cover, and shelter for many species of wildlife. These riparian (streamside) habitats also act as attractants for several species of wildlife that would not normally be found in the dry Hanford Site environs. Dabbling and diving ducks and shorebirds are very common, and a relatively large population of goldfish (Carassius sp.) inhabits the pond.

The variety of algae in the Z-19 Ditch is not as diverse as U-Pond, but there is a wide variety of vascular plant life, including willow and cottonwood trees. There are no fish in the Z-19 Ditch. The ecological diversity of the U-Pond disposal system makes it an ideal area in which to collect information relevant to the biotic transport of radionuclides in an aquatic ecosystem. 


\subsection{Geology}

The Hanford Site is located near the center of a broad structural and topographic depression, the Pasco Basin, within the intermontane basin of the Columbia Plateau physiographic province. The major geologic units beneath the Hanford Site are in general ascending order: basement rocks of undetermined origin; the Columbia River Basalt Group, with intercalated sediments of the Ellensburg Formation; the Ringold Formation; the early Palouse soil (informal name); and the Hanford formation (informal name; Ledgerwood et al. 1978). River-deposited sediments, landslide debris, and colian sediments locally veneer the surface of the Pasco Basin (Figures 3.2 and 3.3).

The Columbia River basalts were extruded from linear fissure systems in the eastern and southern portions of the plateau. The uppermost flow beneath the U-Pond disposal system, the Elephant Mountain Member, lies at an elevation of between 18 and $55 \mathrm{~m}$ MSL, dipping slightly to the southwest.

Following the emplacement of this uppermost basalt flow, thick sequences of sediment were transported from the surrounding highlands and accumulated in the still-forming Pasco Basin. These Ringold Formation sediments overlie and are generally conformable to the basalt surface. Beneath the U-Pond disposal system, the Ringold Formation averages $140 \mathrm{~m}$ thick and has been divided into four units on the basis of texture: the sand and gravel of the basal Ringold unit; clay, silt, and fine sand, with lenses of gravel, of the lower Ringold unit; occasionally cemented sand and gravel of the middle Ringold unit; and silt and fine sand of the upper Ringold unit. The water table lies near the top of the middle Ringold unit.

The surface of the Ringold Formation beneath U-Pond is an erosional unconformity, with portions of the upper Ringold unit missing. The surface is capped with a 6-m-thick eolian silt and fine sand unit, the early Palouse soil.

Lying unconformably on the early Palouse soil is the Hanford formation. These thick sequences (averaging $37 \mathrm{~m}$ ) of glaciofluvial sediments were deposited by catastrophic flood waters caused by the periodic breakup of glacially produced ice dams in northern Idaho. These sediments beneath the U-Pond disposal system are of the coarser grained, Pasco gravels facies, and characteristically display a large variability of sediment size and degree of sorting.

Three major textural units in the Hanford formation have been identifled beneath the U-Pond disposal system. These are in ascending order: a 16-m-thick, slightly silty, medium to fine sand unit; a 10-m-thick, slightly silty, coarse to fine sand unit; and an 8-m-thick, silty, sandy, medium to fine pebble unit. Several other minor units are present but are discontinuous.

The uppermost geologic unit is a 3-m-thick eolian silty fine sand unit; reworked from the Hanford formation sediments. This unit is not continuous over the whole U-Pond disposal system but only occurs locally. A cross section through the upper geologic units immediately beneath the U-Pond and 


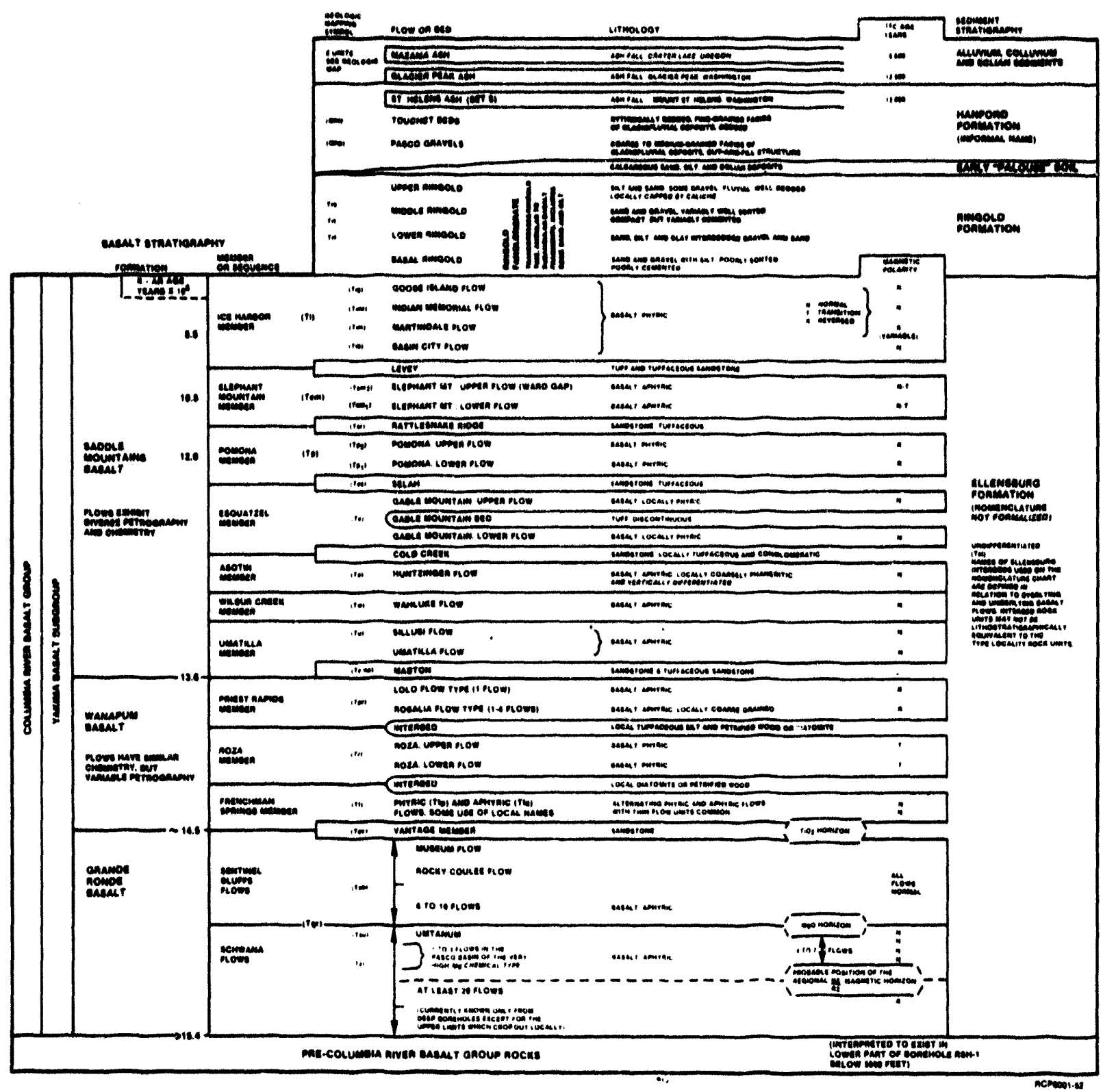

Figure 3.2. Pasco Basin Stratigraphic Nomenclature (Ledgerwood et al. 1978) 

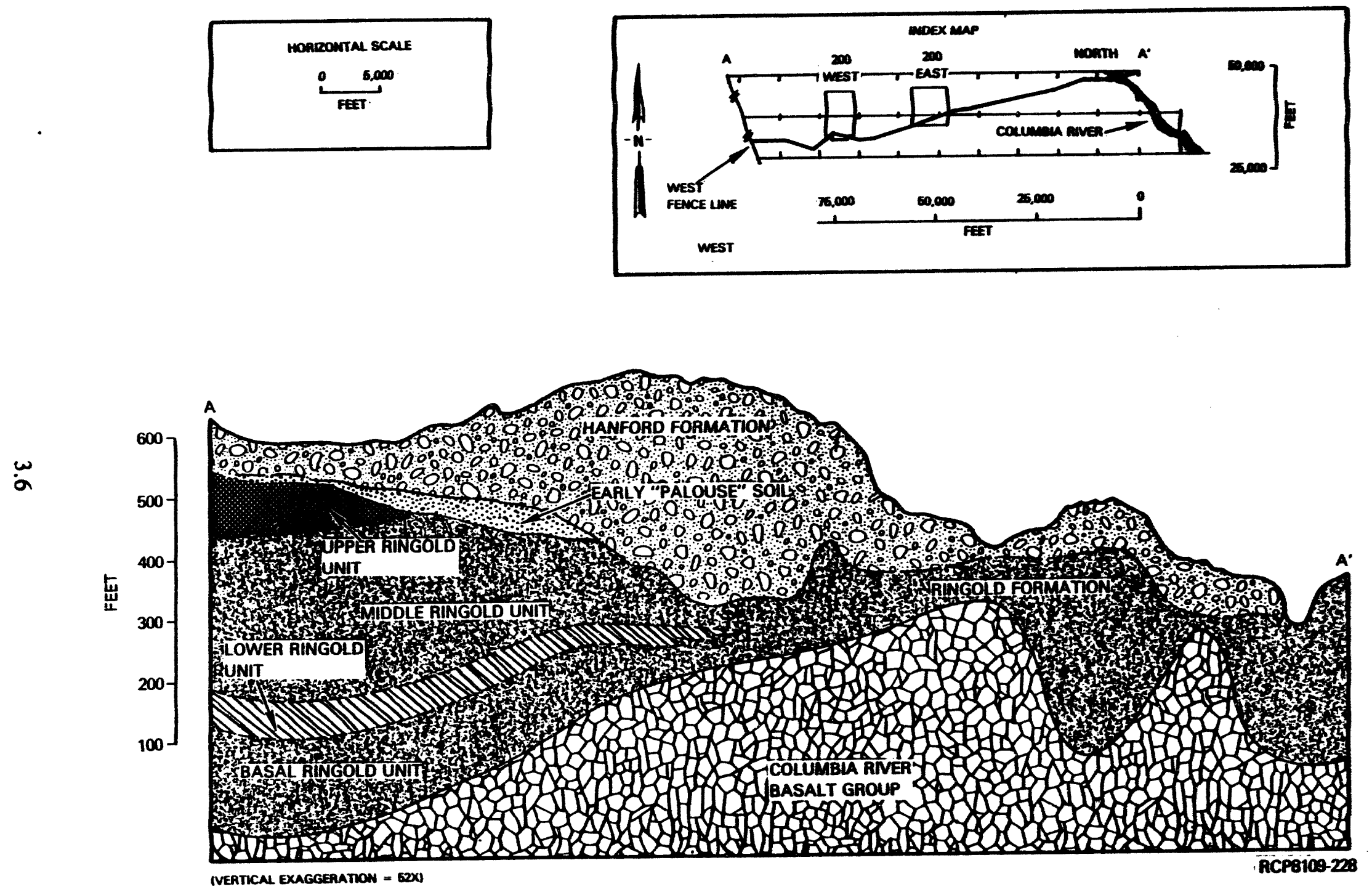

Figure 3.3. Generalized Geologic Cross Section Through the Hanford Site 
Z-19 Ditch is illustrated in Figure 3.4. The average particle-size distributions of the eolian, silty, fine sand unit, and the Hanford formation sediment units delineated by this cross section are presented in Table 3.1.

The sediments of the Hanford formation and the surface eolian sand are the most significant geologic units in the transport of radionuclides from the U-Pond disposal system. These sediments effectively isolate and sorb most of the radiocontaminants (half-life greater than 1 year) discharged. Their general horizontal bedding promotes lateral spreading of moisture and retards downward transport of radionuclides (Tallman et al. 1979).

Other geologic features, such as clastic dikes, may promote downward moisture flow or impede horizontal movement. The existence of clastic dikes in sediments beneath U-Pond is not confirmed but can easily be inferred by their presence in the 241-SY Tank Farm, east of U-Pond, and in the presence of their associated patterned ground in the old 216-S-17 Pond (Figures 3.5 and 3.6) southwest of U-Pond.

\subsection{Hydrology}

\subsubsection{Occurrence of Ground Water}

Ground water under U-Pond occurs under unconfined and confined conditions. Of primary importance to this study is the unconfined system. The water table under U-Pond has risen approximately $26 \mathrm{~m}$ over pre-Hanford Site conditions as a result of liquid waste discharged to the ground inflitrating to the unconfined aquifer. Beneath the unconfined aquifer are a series of confined aquifers contained within the sedimentary interbeds and/or interflow zone that occur between the basalt flows of the Columbia River Basalt Group. The lower and basal Ringold units also contain a confined aquifer.

The unconfined aquifer is contained within the Ringold Formation. The bottom of the aquifer under U-Pond is a clay zone in the lower member of the Ringold Formation. The bottom of the aquifer is the basalt bedrock surface in other areas. Basalt subcrops and outcrops extend above the water table and act as barriers of lateral ground-water flow (Figure 3.7).

The unconfined aquifer is approximately $70 \mathrm{~m}$ thick under U-Pond. Several perched water zones have been encountered during the drilling of wells in the vicinity of U-Pond.

\subsubsection{Aquifer Properties}

The hydrologic properties of the unconfined aquifer in the study area are determined from pump tests (Graham et al. 1981) and from the shape of the ground-water mound under U-Pond Newcomb et al. 1972). The well closest to U-Pond in which a pump test was performed is 699-37-82 (see Figure 3.7). A hydraulic conductivity of $2.7 \mathrm{~m} /$ day and a coefficient of storage 0.002 were obtained from the constant discharge test (Graham et al. 1981). Newcomb et.al. (1972) used a geometric model 


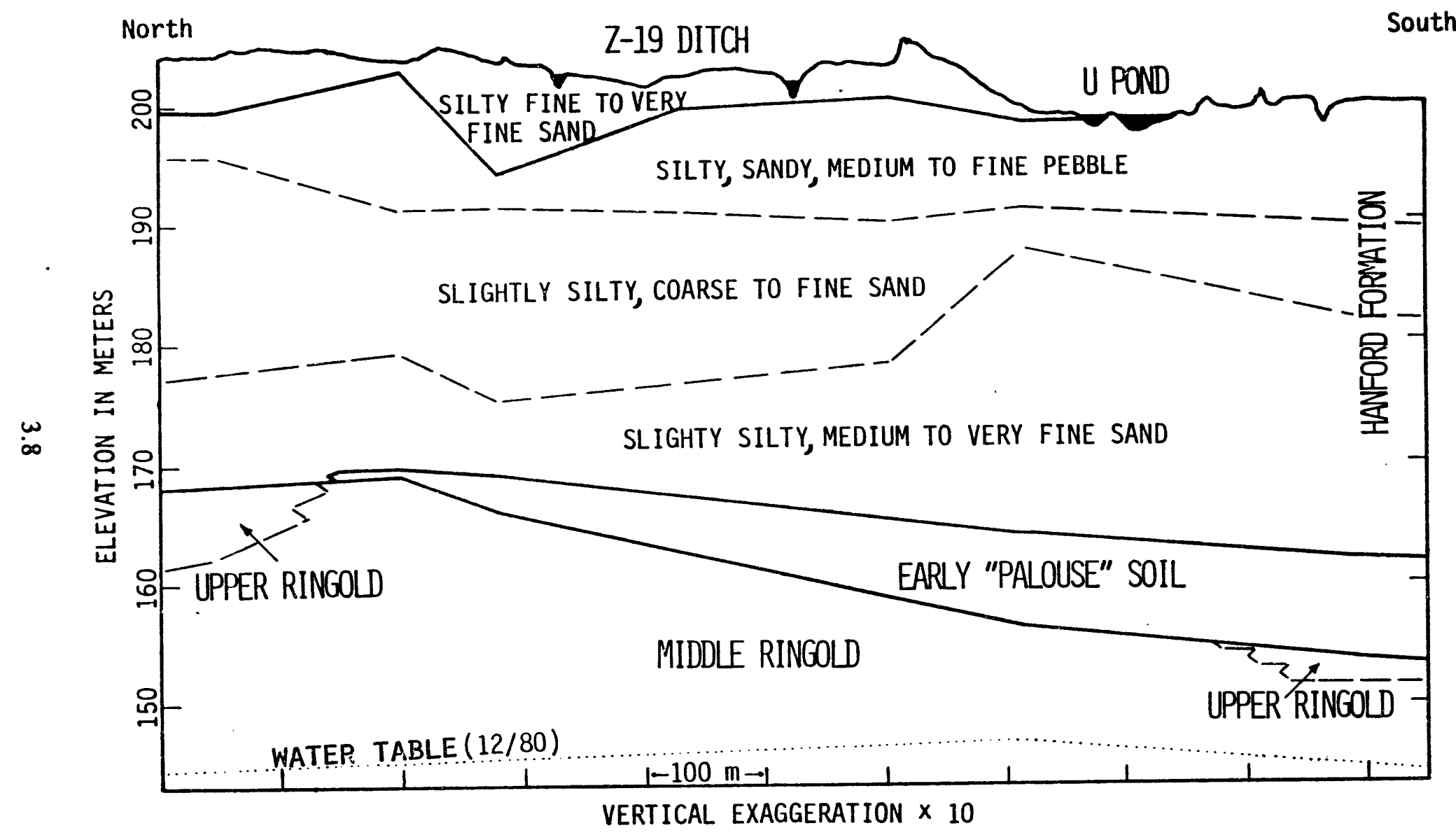

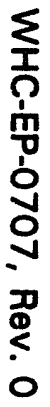

Figure 3.4. Geologic Cross Section Beneath the 216-U-10 Pond and 216-Z-19 Ditch 
Table 3.1. Average Particle-Size Distributions of the Eolian Unit and Major Hanford Formation Units Beneath the 216-U-10 Pond and the 216-Z-19 Ditch (in wt\%)

\begin{tabular}{|c|c|c|c|c|c|c|c|c|}
\hline \multirow[b]{2}{*}{ Geologic Unit } & \multirow{2}{*}{$\begin{array}{l}\text { Pebbles } \\
\text { and } \\
\text { Cobbles }\end{array}$} & \multicolumn{5}{|c|}{ Sand } & \multirow[b]{2}{*}{$\begin{array}{l}\text { Silt and } \\
\text { Clay }\end{array}$} & \multirow[b]{2}{*}{$\mathrm{CaCO}_{3}$} \\
\hline & & $\begin{array}{l}\text { Very } \\
\text { Coarse }\end{array}$ & Coarse & Medium & Fine & $\begin{array}{l}\text { Very } \\
\text { Fine }\end{array}$ & & \\
\hline $\begin{array}{l}\text { Eolian Unit } \\
\text { Silty, fine to very } \\
\text { fine sand }\end{array}$ & 0.2 & 1.3 & 7.5 & 14.1 & 28.3 & 29.1 & 19.4 & 0.7 \\
\hline $\begin{array}{l}\text { Hanford formation } \\
\text { Silty, sandy, medium } \\
\text { to fine pebble }\end{array}$ & 45.9 & 18.8 & 12.6 & 8.5 & 6.1 & 4.0 & 7.2 & 1.0 \\
\hline $\begin{array}{l}\text { Slightly silty, coarse } \\
\text { to fine sand }\end{array}$ & 1.2 & 5.7 & 18.4 & 28.5 & 21.3 & 14.9 & 11.0 & 1.2 \\
\hline $\begin{array}{l}\text { Slightly silty, medium } \\
\text { to very fine sand }\end{array}$ & 0.5 & 2.2 & 9.3 & 25.2 & 32.6 & 20.3 & 7.4 & 1.2 \\
\hline
\end{tabular}

to estimate the porosity, hydraulic conductivity, and transmissivity in the vicinity of the ground-water mound under U-Pond. An average transmissivity value of $316 \mathrm{~m}^{2} /$ day, a hydrauiic conductivity of $4.3 \mathrm{~m} /$ day, and a porosity of $11 \%$ were calculated from this technique. These values are within the reported range of aquifer parameters derived from pump tests within the study area.

\subsubsection{Flow Dynamics}

Recharge to the unconfined aquifer occurs both naturally and artificially. Natural recharge of the unconfined aquifer under U-Pond occurs along Cold Creek Valley. Artificial recharge from liquid waste disposal practices is the greatest source of inflow to the unconfined aquifer under the 200 East and 200 West Separations areas (Graham et al. 1981).

Flow lines are drawn perpendicular to the water-table contour (i.e., equipotential lines), indicating directions of ground-water flow (see Figure 3.7). Ground-water flow patterns are dominated by the ground-water mound under U-Pond. The movement of ground water from west of U-Pond is redirected around the mound. Flow from the U-Pond mound is primarily toward the east; gradients are steep (greater than $10 \mathrm{~m} / \mathrm{km}$ ). The aquifer discharges to the Columbia River, and travel time estimates from the 200 West Area to the Columbia River range from 80 to 120 years (Graham et al. 1981;

Brown et al. 1979). 


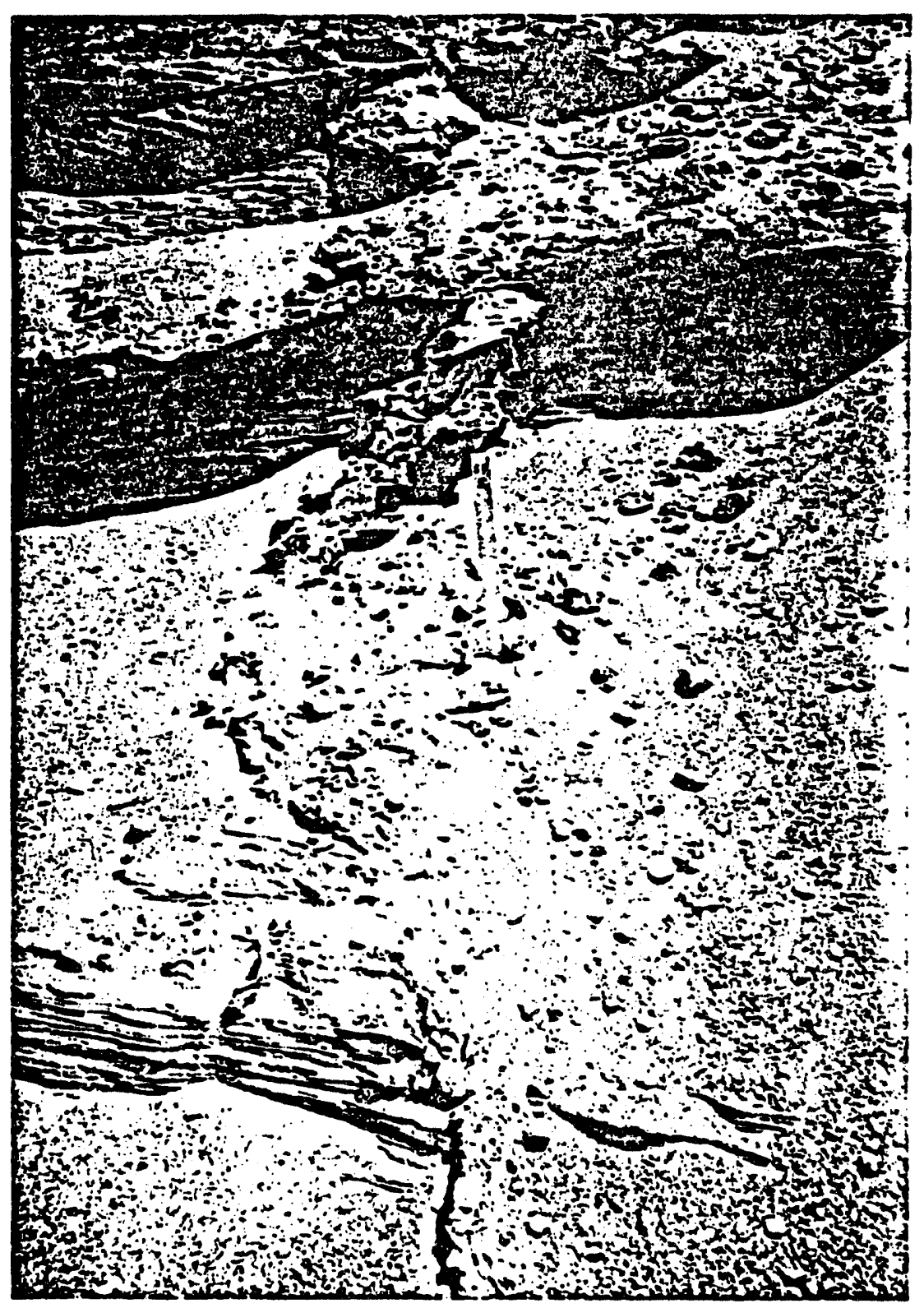

Figure 3.5. Clastic Dike in the 241-SY Tank Farm Excavation 


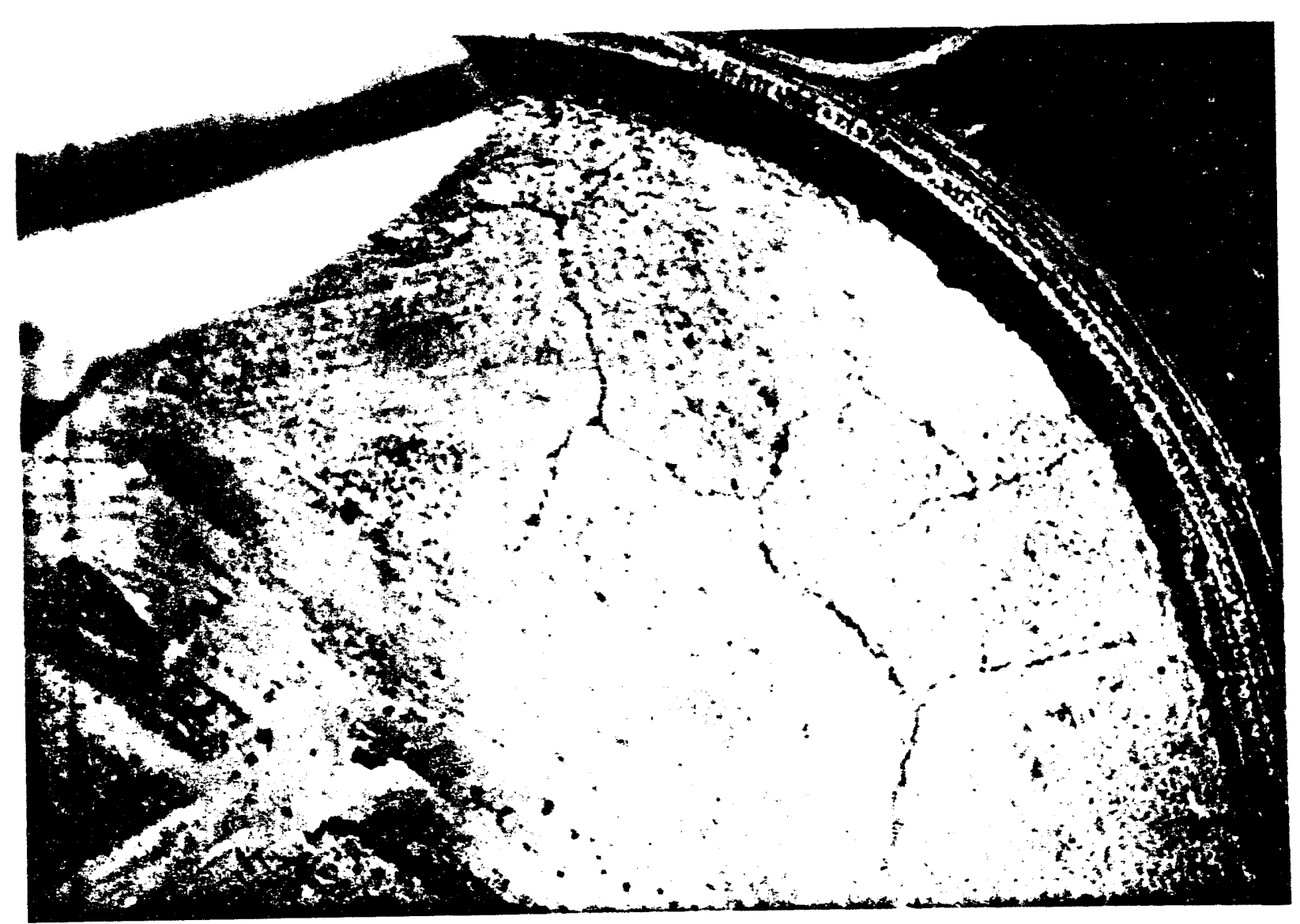

Figure 3.6. Patterned Ground in the Decommissioned 216-S-17 Pond 
WHC-EP-0707, Rev. 0

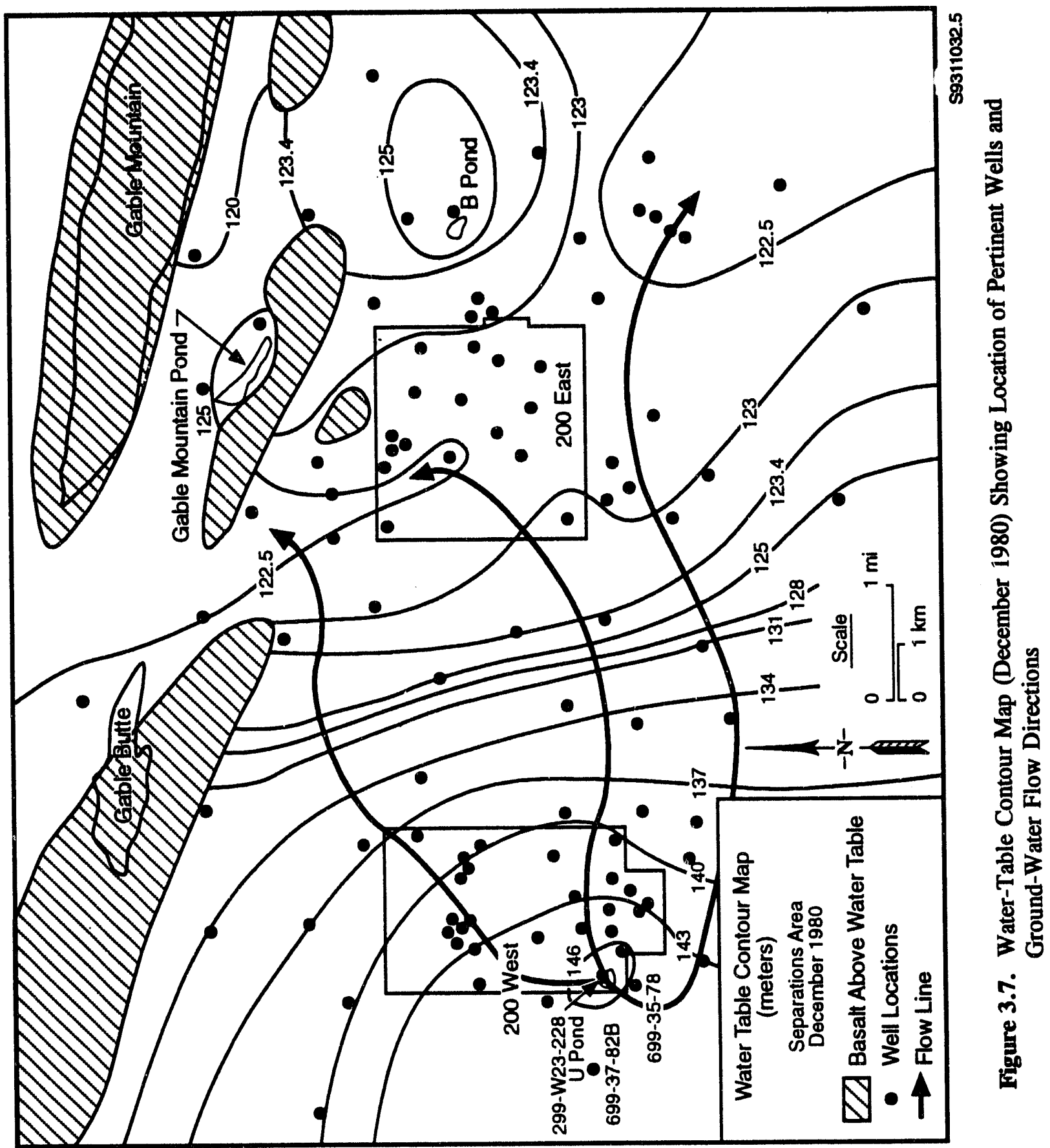




\subsubsection{Water Chemistry}

In the U-Pond area, the chemical composition of the unconfined aquifer water can be classed as calcium, sodium-bicarbonate (Graham et al. 1981). The major cation and anion concentrations in a sample collected in 1977 from well 699-35-78 (see Figure 3.7) are given in Table 3.2. Analysis of a sample of perched water encountered in well 299-W23-228 (see Figure 3.7) at $6.4 \mathrm{~m}$ is also given in Table 3.2 .

Table 3.2. Major Cation and Anion Concentrations in Aquifer Water from Well 699-35-78 and Perched Water from Well 299-W23-228

\begin{tabular}{|c|c|c|c|c|c|c|c|c|c|}
\hline \multirow{2}{*}{ Water } & \multicolumn{8}{|c|}{ Concentration (ppm) } \\
\cline { 2 - 10 } & $\mathrm{Ca}^{++}$ & $\mathrm{Mg}^{++}$ & $\mathrm{Na}^{+}$ & $\mathrm{K}^{+}$ & $\mathrm{HCO}_{3}^{-}$ & $\mathrm{SO}_{4}^{-}$ & $\mathrm{Cl}^{-}$ & $\mathrm{NO}_{3}^{-}$ & $\mathrm{F}^{-}$ \\
\hline Aquifer & 19.0 & 6.4 & 23.0 & 3.2 & 120.0 & 13.0 & 6.9 & 1.1 & 0.5 \\
\hline Perched & 27.3 & 4.1 & 4.9 & 2.0 & $(\mathrm{a})$ & 22.7 & 2.0 & 1.3 & 0.6 \\
\hline
\end{tabular}

(a) Not analyzed. 


\subsection{Previous Studies of the 216-U-10 Pond Disposal System}

A review of the published literature on the 216-U-10 (U-) Pond disposal system revealed that very little information, other than generalized discharge data, was available prior to the 1970s. During the 1970s, several studies were conducted to assess the environmental impacts from U-Pond. The primary concern of these studies was centered around biological and atmospheric transport of plutonium, which was considered to be of the most immediate concern. During this search for previous data, numerous unpublished or informal reports and letters were found and have been included when applicable. A major objective of the literature review was to provide direction for field sampling programs that would supplement the previous studies.

In this regard, the previous studies have been subdivided for discussion of their pertinence to the various portions of the current study.

\subsection{Atmospheric Resuspension Studies}

Several studies were conducted in the early to mid-1970s to determine the significance of atmospheric transport of contaminants away from U-Pond. One of the most significant findings, pertinent to this study, was that the downwind air concentrations of ${ }^{90} \mathrm{Sr},{ }^{137} \mathrm{Cs},{ }^{238.239 .240} \mathrm{Pu}$, and ${ }^{241} \mathrm{Am}$ exceeded background levels. However, these concentrations were still far below occupational maximum permissible air concentrations. Figures 4.1, 4.2, and 4.3 illustrate the observed concentrations (Sehmel 1977).

Another significant finding was that the plutonium was attached to both respirable $(<10-\mu \mathrm{m})$ and nonrespirable ( $>10-\mu \mathrm{m}$ ) particle sizes. Resuspension of these larger particles (and probably the smaller ones as well) was considered to represent a mechanism for transporting plutonium to the surrounding land, contributing significantly to downwind concentrations (Sehmel 1977). This conclusion is supported by an aerial gamma survey documented by Bruns (1975).

It was also learned from these studies that the rates at which the contaminated particles are resuspended vary with wind speed, particle size, and a weathering half-life (Sehmel and Lloyd 1977). These studies were considered sufficiently detailed and, therefore, acquisition of new data was not planned. However, as support for the Low-Level Waste Program increased, concerns arose that the fluctuating background and high uranium inventory of U-Pond might suggest the presence of gaseous radon daughters. New air sampling data were needed to respond to this concern. The reader is referred to Bruns (1975), Horst (1976), Sehmel (1977), and Sehmel and Lloyd (1977) for further details and discussion. 


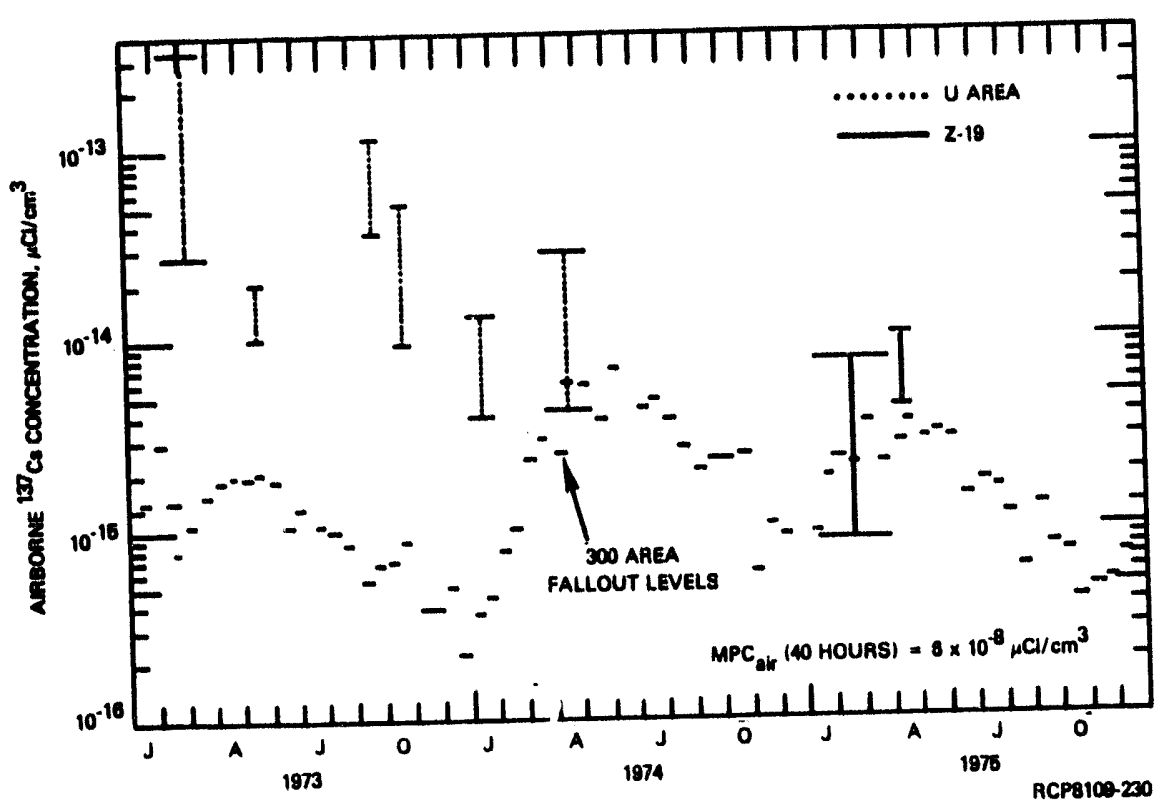

Figure 4.1. Range of Downwind Airborne ${ }^{137} \mathrm{Cs}$ Concentrations at the $216-\mathrm{U}-10$ Pond and 216-Z-19 Ditch Compared to Fallout Levels (Sehmel 1977)

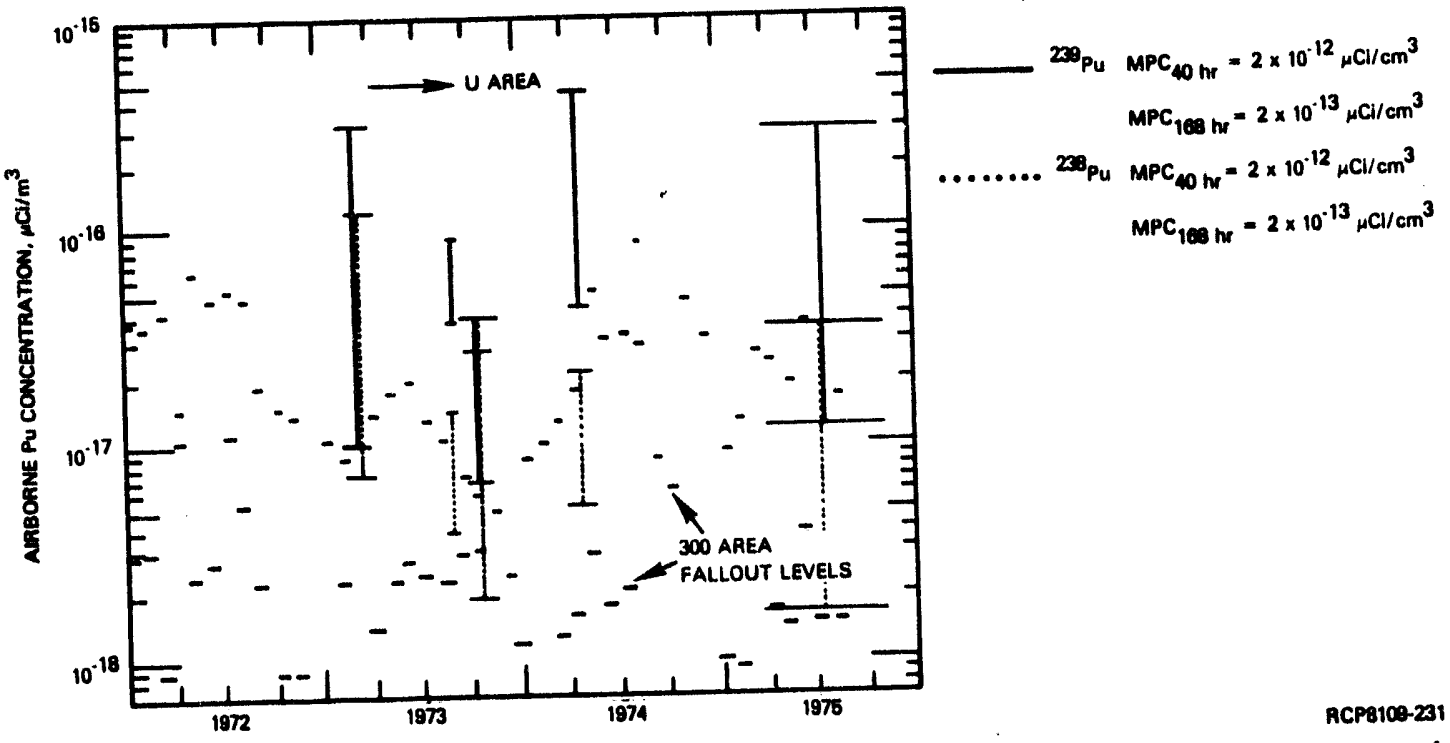

Figure 4.2. Range of Airborne Plutonium Concentrations at the 216-U-10 Pond Compared to Fallout Levels (Sehmel 1977) 


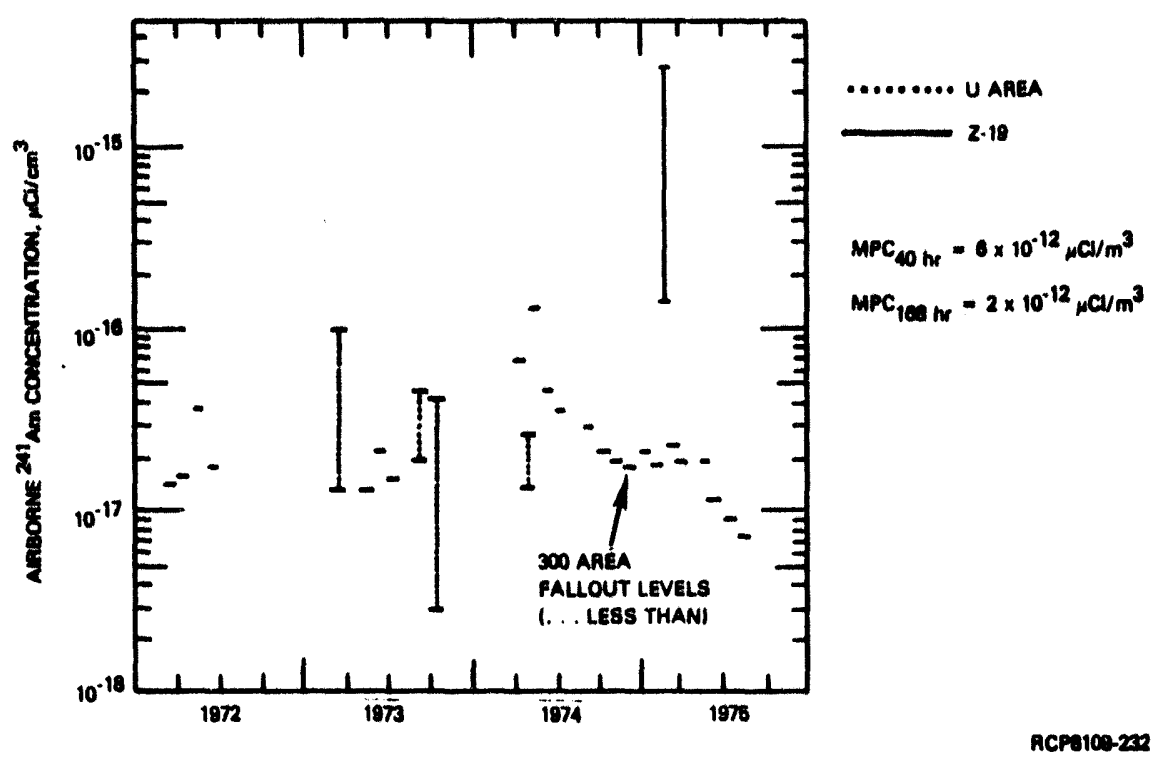

Figure 4.3. Range of Airborne ${ }^{211} \mathrm{Am}$ Concentrations (above detection limits) at the 216-U-10 Pond and 216-Z-19 Ditch Compared to Fallout Levels (Sehmel 1977)

\subsection{Biological Studies}

Emery and Garland (1974) and Emery and Klopfer (1974) characterized U-Pond's limnology and assessed the ecological distribution of plutonium and americium. The official figure for historic release of plutonium into Z-ditches leading to U-Pond is $8.1 \mathrm{~kg}$, but only $21 \mathrm{~g}(<0.5 \%)$ were found in the pond-bottom sediments to a depth of $10 \mathrm{~cm}$. Plutonium and americium were concentrated almost entirely in the sediments and appeared to be randomly distributed across the pond bottom. Because the sediment was the principal repository of plutonium and americium, all biotic concentrations were compared to those levels in the sediment. Mean sediment concentrations of ${ }^{208} \mathrm{Pu}$ and ${ }^{239.200} \mathrm{Pu}$ were 194 and $195 \mathrm{pCi} / \mathrm{g}$, respectively. Concentrations of ${ }^{241} \mathrm{Am}$ in the sediment averaged $83 \mathrm{pCi} / \mathrm{g}$. The ratio of

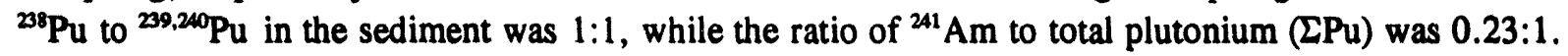
Only approximately $9 \%$ of $\Sigma \mathrm{Pu}$ and $7 \%$ of ${ }^{241} \mathrm{Am}$ in the sediment appeared to be available for food web concentrations. The remaining fractions of plutonium and americium were tightly bound to sediment particles. In pond v/ater, concentrations of $\Sigma \mathrm{Pu}$ were approximately $0.01 \mathrm{pCi} / \mathrm{L}$. Levels of ${ }^{211} \mathrm{Am}$ in the water were approximately $1.1 \mathrm{pCi} / \mathrm{L}$. Ratios of ${ }^{288} \mathrm{Pu}$ to ${ }^{209.200} \mathrm{Pu}$ in the water were $3.5: 1$, while the ratio of ${ }^{241} \mathrm{Am}$ to $\mathrm{\Sigma Pu}$ was $120: 1$. Plant material in the pond appeared to be an active concentrator of plutonium and americium. Algal floc (decomposing algal cells) was the major concentrator of plutonium and americium, with approximately $2000 \mathrm{pCi}$ of $\Sigma \mathrm{Pu} / \mathrm{g}$ and $248 \mathrm{pCi}$ of ${ }^{211} \mathrm{Am} / \mathrm{g}$. All other organisms analyzed (except watercress [Rorippa Nasturium-Aquatica]) had mean plutonium concentrations below those of sediment. Plant material with the highest plutonium accumulation had ratios of ${ }^{238} \mathrm{Pu}$ to ${ }^{239,240} \mathrm{Pu}$ ranging from $1.3: 1$ to $1.6: 1$. Ratios of ${ }^{241} \mathrm{Am}$ to $\mathrm{\Sigma Pu}$ in the pond's biological components were generally higher than those of sediment. Ratios of ${ }^{241} \mathrm{Am}$ to $\Sigma \mathrm{Pu}$ were lower than 
sediment only for algal floc and emerging chironomids, both at $0.13: 1$. Watercress had a ratio equal to that of sediment-0.23:1. Ratios of ${ }^{24}$ Am to $\Sigma P u$ for other biota sampled ranged from 0.4:1 to 2.0:1. Most ${ }^{20} \mathrm{Pu}$ to ${ }^{20,200 \mathrm{Pu}}$ ratios for pond organisms exceeded $1: 1$, indicating that biological availability of

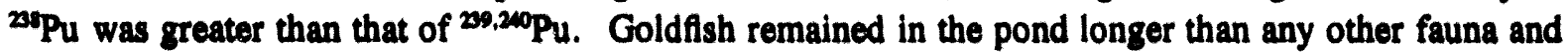
fed most heavily on plant, algae, and organic debris, but concentrated only relatively small amounts of $\mathrm{EPu}(20 \mathrm{pCl} / \mathrm{g})$ and ${ }^{21} \mathrm{Am}(12 \mathrm{pCi} / \mathrm{g})$. After reaching an equilibrium level of approximately $20 \mathrm{pCi} / \mathrm{g}$ EPu within a fow days, goldish may remain active for many months without further accumulation. Figure 4.4 depicts U-Pond ecosystem compartments and plutonium export routes determined thus far.

Emery and Garland (1974) complemented the study by Emery and Klopfer (1974) with a discussion of radiochemical factors to be considered in understanding the behavior of transuranics in the U-Pond ecosystem. High levels of ${ }^{25} \mathrm{U}(\sim 1400 \mathrm{~kg})$ discharged into trenches leading to U-Pond and potential quantities of other unknown isotopes created a problem in interpreting the ecological behavior of plutonium and americium because of potential toxicity of these elements to many organisms. Although . weapons-grade plutonium processing operations should have discharged wastes containing ratios of

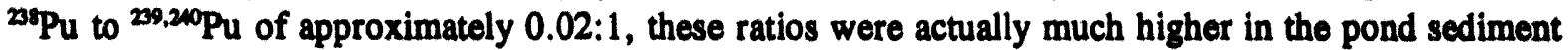
(approximately 1.0:1). Ratios of ${ }^{238} \mathrm{Pu}$ and ${ }^{241} \mathrm{Am}$ to ${ }^{209,200} \mathrm{Pu}$ were significantly higher in pond biota than in pond sediment (Table 4.1). These results indicated that transuranics were being made "available" and/or used by pond organisms in ratios that were not reflected by pond sediment concentrations. Ratios of ${ }^{21} \mathrm{Am}$ to ${ }^{20} \mathrm{Pu}$ in U-Pond biota were signiflcantly different from those of sediments,

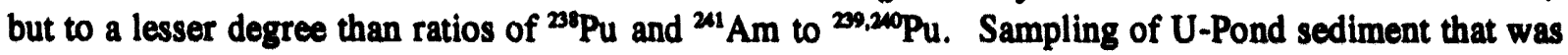
done frequently in the same location showed a substantial range in ${ }^{238} \mathrm{Pu}$ and ${ }^{209,210} \mathrm{Pu}$ concentrations, which may have been because of a wide range in plutonium particle size existing in U-Pond sediment. Considering the rapid exchange rate of water in U-Pond (approximately $40 \mathrm{~h}$ ) and previously mentioned observations, the authors concluded it was possible that the source of plutonium and americium that was "available" to pond biota was not U-Pond sediment, but sediment from the 216-2-9 (Z-19) Ditch.

Fitzner and Rickard (1975) investigated avian species using waste management ponds. In terms of radionuclide dispersal from the ponds, aquatic birds are the most important, based on food habits, abundance, migratory habits, and importance as food in human diet. The single most important species considered in biological dispersal of radionuclides from ponds was the American coot (Fulica americana).

Other birds attracted to U-Pond include grebes, ducks, gulls, owls, herons, hawks, and shorebirds. Well-developed tree-shrub shoreline vegetation at U-Pond attracted 55 species of perching and other small birds, more than twice the number recorded at any other pond studied (Fitzner and Rickard 1975).

A comparative study of Hanford Site waste ponds and streams was conducted by Emery and McShane (1978) to determine whether their radiological conditions affect the biota in terms of occurrence, diversity, and productivity. The study indicated that U-Pond algal and macrophyte populations 


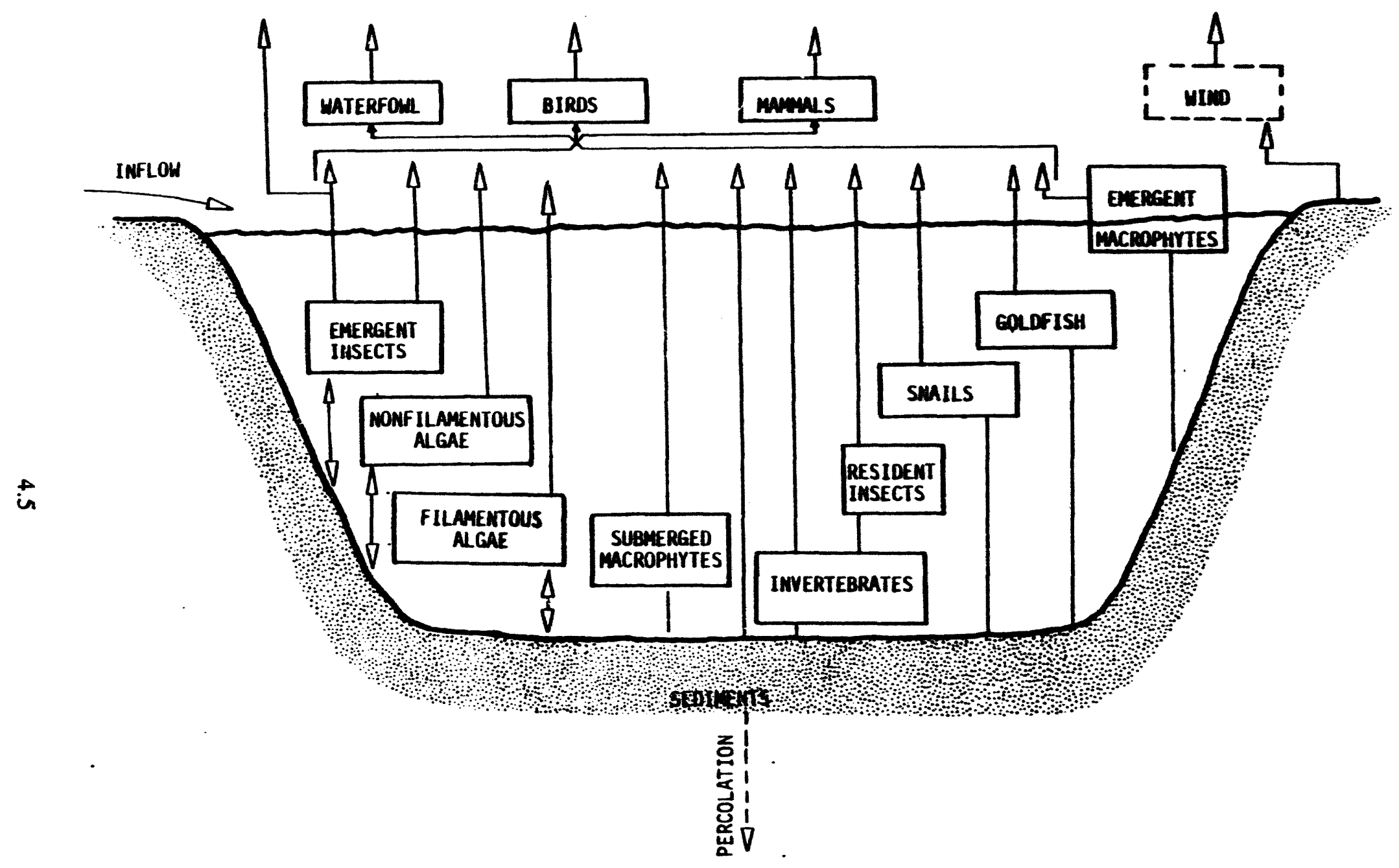

Figure 4.4. Representation of Ecological Compartments and Plutonium Export Routes from the 216-U-10 Pond (after Emery and Klopfer 1974) 
Table 4.1. Isotopic Ratios in Pond Blota and Sediment

\begin{tabular}{|l|c|c|c|}
\hline \multicolumn{1}{|c|}{ Sample Type } & $\begin{array}{c}\text { Mean }{ }^{200} \mathrm{Pu} \text { to } \\
\text { Ratio }\end{array}$ & $\begin{array}{c}\text { Mean }{ }^{211} \text { Am to } \\
\text { Ratio }\end{array}$ & $\begin{array}{c}\text { Mean }{ }^{201} \text { Am to } \\
\text { 200u Ru Ratio }\end{array}$ \\
\hline Sediment & $0.85: 1$ & $0.49: 1$ & $0.61: 1$ \\
Plant material & $0.42: 1$ & $1.36: 1$ & $1.17: 1$ \\
Insect larvae & $1.58: 1$ & $1.19: 1$ & $0.14: 1$ \\
Noninsect larvae & $1.47: 1$ & $1.40: 1$ & $0.88: 1$ \\
Goldfish & $1.61: 1$ & $1.22: 1$ & $0.78: 1$ \\
\hline
\end{tabular}

were the most diverse among the Hanford Site's aquatic systems. Invertebrate populations were also diverse, and there was a prolific goldfish population. Seston (suspended particulates) concentrations and alkalinity were also relatively high. The study found that the Z-19 Ditch also had relatively high seston and alkalinity, as well as high phosphate and silicate concentrations. The ditch contained only small amounts of ammonia. Algal variety was relatively small and invertebrate populations were low. Collectively, the data did not provide conclusive evidence that nuclear wastes discharged to Hanford Site ponds and streams affected colonization, diversity, or activity of biological organisms.

Gano (1979) investigated small mammals inhabiting the U-Pond ecosystem. That study provided a determination of which species of small mammals lived adjacent to the area, the radiation exposures they received, and level and type of radionuclides accumulated in body tissues. The species of mice inhabiting the area were the Great Basin pocket mouse (Peroghathus parvus), deer mouse (Peromyscus maniculatus), house mouse (Mus musculus), and western harvest mouse (Reithrodontomys megalotis). Pocket mice preferred the generally noncontaminated sagebrush-cheatgrass habitat adjacent to the Z-19 Ditch over the riparian habitat surrounding the pond. The other three species of mice preferred the denser vegetation around the pond. Composite samples from mice collected for the study were analyzed for gamma-emitting radionuclides, plutonium, and americium. Cesium-137 was the most abundant gamma emitter. House mice captured near the Z-19 Ditch had the highest content of ${ }^{137} \mathrm{Cs}$, with one gastrointestinal tract sample containing $1600 \mathrm{pCi} / \mathrm{g}$ dry weight. Other tissue types from this species collected at the Z-19 Ditch also contained high values of ${ }^{137} \mathrm{Cs}$, the lowest being $470 \mathrm{pCi} / \mathrm{g} \mathrm{dry}$ weight. Of the other three species, the western harvest mouse had the highest ${ }^{137} \mathrm{Cs}$ values $(32.0$ to $5400.0 \mathrm{pCi} / \mathrm{g}$ dry weight), while the pocket mouse values were lowest $(0.44$ to $27.0 \mathrm{pCi} / \mathrm{g}$ dry weight).

Composite samples were also used for isotopic plutonium analysis. Results indicated that the amount of plutonium being taken up by small mammals was very low. House mice living along the Z-19 Ditch and in the area adjacent to U-Pond between the inlets of the 216-U-14 (U-14) and Z-19 ditches contained the highest plutonium concentrations, with a fur-skin sample yielding $2.03 \mathrm{pCi}$ ${ }^{209,200} \mathrm{Pu} / \mathrm{g}$ dry weight. The highest ${ }^{201} \mathrm{Am}$ value $(1.67 \mathrm{pCi} / \mathrm{g}$ dry weight) was found in a liver composite from Z-19 Ditch house mice. Samples representing the other three species showed values for plutonium and americium of less than $0.5 \mathrm{pCi} / \mathrm{g}$ dry weight. Small mammals were also investigated for 
external gamma exposure by surgically implanted thermoluminescent dosimeters. Mice living in the area adjacent to U-Pond between the inlets of the U-14 and Z-19 ditches received the highest exposures. House mice had the highest-average dose at $55 \mathrm{R} / \mathrm{yr}$. The next highest-average dose was $43 \mathrm{R} / \mathrm{yr}$ for pocket mice and the lowest was $21 \mathrm{R} / \mathrm{yr}$ for deer mice.

Dosimeters were placed in the soil along small mammal trapping transects at each decimeter (dm) of soil to a depth of $\mathbf{5} \mathrm{dm}$. It was revealed that the top decimeter of soil contained the strongest gamma exposures. The highest-mean exposure was $75 \mathrm{R} / \mathrm{yr}$ in the first decimeter of soil between the inlets of the U-14 and Z-19 ditches. Exposure levels diminished rapidly with depth, with the lowest-average value at $5 \mathrm{dm}$ equal to $0.10 \mathrm{R} / \mathrm{yr}$. The highest-mean neutron exposure was $37 \mathrm{mrad} / \mathrm{yr}$, again in the first decimeter of soil between the inlets of the U-14 and Z-19 ditches. Again, the dose rate tapered down with depth to $0.86 \mathrm{mrad} / \mathrm{yr}$ at $5 \mathrm{dm}$.

The role of the American coot in exporting radionuclides from several Hanford Site ponds was evaluated in a study by Cadwell et al. (1979). The coot is the most abundant waterfowl species to use the ponds, and concentrations of ${ }^{137} \mathrm{Cs}$ in coot flesh were consistently higher than in other waterfowl (Cushing and Watson 1974; Fix and Blumer 1977). Between 1974 and 1977, 18 coots were collected at U-Pond. Samples of muscle, liver, bone, and intestinal tract contents were analyzed for gammaemitting radionuclides. Average concentration of ${ }^{137} \mathrm{Cs}$ was the only value provided for U-Pond coots. Gut contents contained the highest-average ${ }^{137} \mathrm{Cs}$ value of $1300.0 \mathrm{pCi} / \mathrm{g}$ dry weight, while bone samples had the lowest-average value of $70.0 \mathrm{pCi} / \mathrm{g}$ dry weight.

As part of the Rockwell environmental surveillance program, sediment and aquatic vegetation samples are collected from ponds and ditches in the 200 Areas. Results are reported annually and the latest report available is for calendar year (CY) 1979 (Wheeler and Law 1980).

For CY 1977 (Panesko et al. 1978), there was only one aquatic vegetation and one sediment sampling location at the Z-19 Ditch. At U-Pond, there were two aquatic vegetation and two sediment sampling points. In CY 1978 (Panesko et al. 1980), there were two sampling locations for both aquatic vegetation and sediment sampling at U-Pond. At the Z-19 Ditch, there were also two aquatic vegetation sampling locations, but sediment sampling locations were increased to four points. For CY 1979 (Wheeler and Law 1980), there were four locations at the Z-19 Ditch and two locations at U-Pond for collection of sediment and aquatic vegetation samples. However, no aquatic vegetation samples and only one sediment sample were actually taken at U-Pond.

Sediment samples are compared to Rockwell's surface soil contamination standard limits of $400 \mathrm{pCi} / \mathrm{g}$ for ${ }^{90} \mathrm{Sr}$ and ${ }^{137} \mathrm{Cs}$ and $60 \mathrm{pCi} / \mathrm{g}$ for ${ }^{201} \mathrm{Pu}$ and ${ }^{239.200} \mathrm{Pu}$ (Boothe 1979). During CY 1977 (Panesko et al. 1978), the Z-19 Ditch sediment sample was above the limits set for ${ }^{29,200} \mathrm{Pu}$ and ${ }^{211} \mathrm{Am}$ and at U-Pond, one sample exceeded the ${ }^{137} \mathrm{Cs}$ and ${ }^{241} \mathrm{Am}$ limits. For CY 1978 (Panesko et al. 1980), all Z-19 Ditch sediment samples were above the limit for ${ }^{209,200} \mathrm{Pu}$ and three samples exceeded the ${ }^{221} \mathrm{Am}$ limit. The ${ }^{137} \mathrm{Cs}$ limit was exceeded at U-Pond by only one sample. In CY 1979 (Wheeler and Law 1980), two sediment samples were above the ${ }^{239.410} \mathrm{Pu}$ limit at the Z-19 Ditch and three samples 
were above the ${ }^{211} \mathrm{Am}$ limit. The U-Pond samples exceeded the ${ }^{137} \mathrm{Cs}$ and ${ }^{211} \mathrm{Am}$ limits. Table 4.2 lists the high and low values for sediment and aquatic vegetation samples collected at U-Pond and Z-19 Ditch during CYs 1977, 1978, and 1979.

Other incidental studies include a survey and census of birds at Hanford Site waste ponds by Fitzner and Price (1973), a report on the 200 Areas plateau ecology by Rogers and Rickard (1977), and an investigation of the nesting biology of the American coot by Fitzner and Schreckhise (1979).

These previous biological studies and environmental monitoring efforts at U-Pond and Z-19 Ditch have left unanswered a number of questions concerning the impacts that radioactive materials have had on the surrounding environment and the types and levels of radionuclides incorporated into the biological systems. This information is essential to be able to determine the potential for transport of radionuclides by biological vectors away from the U-Pond environs. There are a number of questions regarding the reliability of the sampling and analyses of liquid effluents discharged to the Z-ditch system (including 216-Z-1 [Z-1] and 216-Z-11 [Z-11]), and a high degree of uncertainty exists concerning the accuracy of the 8.1-kg figure that is the official number (Anderson 1973) for the total amount of plutonium historically discharged to the Z-ditches. Studies by Emery and Klopfer (1974) and others have not been successful in determining whether the plutonium discharged into the Z-ditches has been bound up in the sediment of the ditches or eventually made its way to U-Pond. Additionally, there are no data for effluents discharged to the Z-ditches from 1961 to 1966 and there are no discharge records maintained for americium. The old Z-1 and Z-11 ditches were deactivated as the result of inadvertent plutonium contamination. These ditches were covered with soil and the Z-1 Ditch was accidentally exhumed; there is a general spread of plutonium contamination in the surrounding soils. The exact boundaries of these old ditches were not documented.

In the early work conducted on U-Pond (Emery and Garland 1974; Emery and Klopfer 1974; Emery and McShane 1978), the principal emphasis was on biological interactions of the radionuclides in the U-Pond disposal system, rather than waste management concerns. For this reason, a number of areas related to waste site characterization were not addressed. Although a number of different organisms were sampled, the sample sizes were fairly small (on the order of one or two) and also of very small creatures (some weighing micrograms). Both of these situations lead to concerns that reported plutonium values may be consistently high. Also, estimates for total biomass of the biological compartments (e.g., algal floc) were not made. Therefore, a determination of the total amounts of radionuclides complexed by these organisms and contained within that compartment could not be ascertained. For example, though the algal floc compartment concentrated the highest amounts of $\mathbf{\Sigma P u}$ $(\bar{x}=1924 \mathrm{pCi} / \mathrm{g}$ ) in the U-Pond disposal system (Emery and Klopfer 1974), on a dry weight basis, there may only be a total of a few pounds of this material contained within the system and, therefore, the compartmental inventory of plutonium contained in algal floc could be relatively small. For these reasons, the organisms with the greatest biomass (willows, cottonwoods, and cattails) should be sampled thoroughly. Although they may contain relatively small amounts of radionuclides on a per gram basis, their greater size will provide for a large inventory. The size and total inventory of biological components are important considerations in possible future planning of how best to deactivate and decommission the U-Pond disposal system. 
Table 4.2. Radionuclide Values (in pCi/g dry weight) for the 216-U-10 Pond and 216-Z-19 Ditch Samples Taken During Calendar Years 1977, 1978, and 1979 (after Wheeler and Law 1980 and Panesko et al. 1978, 1980, respectively)

\begin{tabular}{|c|c|c|c|c|c|c|c|c|}
\hline \multirow[b]{2}{*}{ Sample Site } & \multicolumn{4}{|c|}{ Aquatic Vegetation Samples } & \multicolumn{4}{|c|}{ Sediment Samples } \\
\hline & ${ }^{90} \mathrm{Sr}$ & ${ }^{137} \mathrm{Cs}_{8}$ & ${ }^{239,210} \mathrm{Pu}$ & ${ }^{241} \mathrm{Am}$ & ${ }^{90} \mathbf{S}$ & ${ }^{137} \mathrm{Cs}$ & ${ }^{299.210} \mathrm{Pu}$ & ${ }^{201} \mathrm{Am}$ \\
\hline \multicolumn{9}{|l|}{ 216-U-10 Pond } \\
\hline High & & 1230.00 & 2.50 & & & & & $156.00^{(b)}$ \\
\hline Low & 9.80 & 35.30 & 0.05 & (a) & 1.40 & 72.50 & 0.20 & \\
\hline \multicolumn{9}{|l|}{ 216-Z-19 Ditch } \\
\hline High & 3360.00 & 25.20 & 8.50 & $936^{(b)}$ & $\overline{-}$ & $2 . \overline{70^{(b)}}$ & $\begin{array}{c}- \\
6570.00^{(b)}\end{array}$ & $38,000.00^{(6)}$ \\
\hline Low & 6.30 & 5.00 & 1.20 & & & & & \\
\hline \multicolumn{9}{|c|}{1978} \\
\hline \multicolumn{9}{|l|}{ 216-U-10 Pond } \\
\hline High & 27.80 & 77.80 & 16.40 & (a) & 3.20 & 744.50 & 57.50 & 10.30 \\
\hline Low & 21.90 & 10.70 & 9.80 & (a) & 1.00 & 49.90 & 39.50 & 2.70 \\
\hline \multicolumn{9}{|l|}{ 216-Z-19 Ditch } \\
\hline High & 5.30 & 5.20 & 52.20 & - & 1.40 & 18.90 & 7304.00 & 6092.00 \\
\hline Low & 1.70 & 4.60 & 1.60 & $15.6^{(b)}$ & 0.50 & 3.10 & 116.30 & 20.20 \\
\hline \multicolumn{9}{|c|}{1979} \\
\hline 216-U-10 Pond & (c) & (c) & (c) & (c) & $3.20^{(\mathrm{b})}$ & $594.00^{(b)}$ & $58.30^{(6)}$ & $62.40^{(b)}$ \\
\hline 216-Z-19 Ditch & & & & & & & & \\
\hline High & 9.00 & $<1.30$ & 11.20 & $<21.00$ & $<9.60$ & 1.30 & 5930.00 & .1270 .00 \\
\hline Low & $<0.90$ & $<0.70$ & 1.50 & $<0.60$ & $<3.50$ & 0.10 & 4.20 & $<15.00$ \\
\hline
\end{tabular}
(a) Sample below detection limit
(b) Only one sample taken.
(c) No sample taken. 
None of these previous studies addressed the levels of ${ }^{90} \mathrm{Sr}$ in the sediments and biological components of the U-Pond disposal system, though ${ }^{90} \mathrm{Sr}$ has been consistently released to U-Pond via the U-14 Ditch. Also, ${ }^{90} \mathrm{Sr}$ is one of the most soluble radionuclides and because it acts as an analog of calcium, is readily taken up and concentrated to high levels in plants and animals.

Much of the work conducted at U-Pond and the Z-19 Ditch consisted of composited samples. Although this reduces the costs of sampling analyses, it does not always produce a clear picture of the uptake and potential transport of radionuclides by biological vectors. Composited samples generally provide average values and do not give ranges showing low and high values. In waste management, the high or "worst case" values are those that indicate a need for possible remedial action. Additionally, in the case of mobile animals, such as mice, the mode of radionuclide transport is by the individual animal. Therefore, a composite of the lungs, liver, or skin of a large number of animals does not provide a valid picture of the actual radionuclide levels being mobilized by these organisms.

Past environmental monitoring practices at the U-Pond disposal system used only grab samples collected once over a year's period and not necessarily from a specific location, where comparisons could be made over time. Additionally, plants and animals have been collected for analyses without information as to species, size, whether submerged, etc., making evaluation of the data extremely difficult.

A comprehensive site characterization of the U-Pond disposal system could provide an answer to many of these questions from a waste management perspective. A detailed knowledge of the types, levels and locations of radionuclides present and available in the system would allow for optimization of engineering designs and considerations for possible future decommissioning. The collection of these kinds of data would provide needed documentation of information relevant to the biotic uptake and transport of radionuclides by aquatic and terrestrial organisms and establish a baseline from which to evaluate future operational perturbations or decommissioning efforts.

\subsection{Geologic Studies (Soil Sampling)}

\subsubsection{Through :959}

The earliest radiological data on sediment samples from the U-Pond disposal system come from mud samples collected in late 1958 and early 1959 from the Z-1 Ditch and the U-Pond shoreline (see Appendix A). From analytical results of these samples, the amount of plutonium in the Z-1 Ditch was estimated to be between 3 and $10 \mathrm{~kg}$. A reinterpretation of these data, shown in Figure 4.5, indicates that the entire Z-1 Ditch exceeded $10,000 \mathrm{pCi} / \mathrm{g}$. The plutonium contamination along the U-Pond shoreline was found to be on the order of $0.2 \mathrm{pCi} / \mathrm{g}$. 


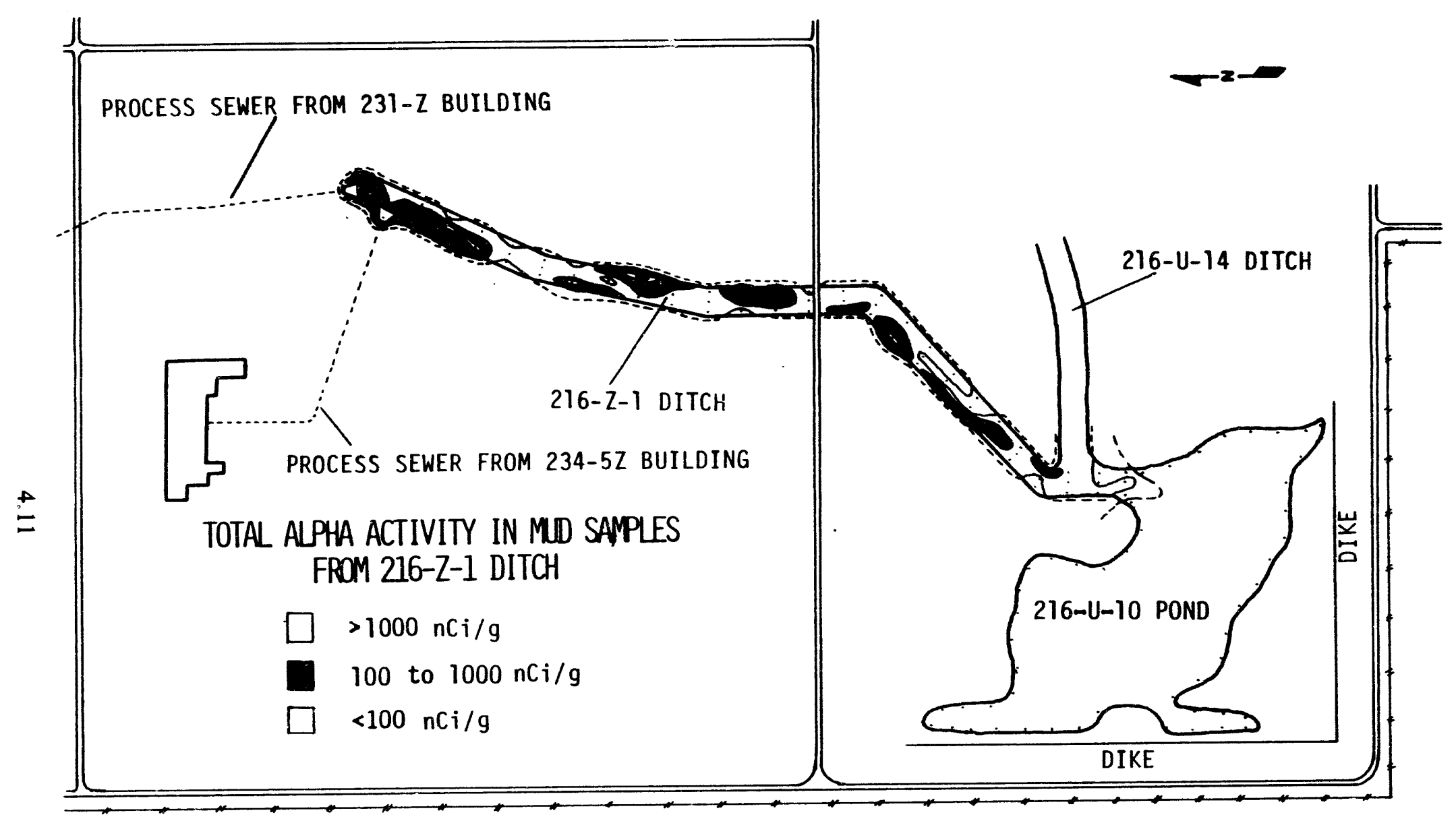

Notes: 1) $\approx 97 \%$ of alpha activity in Z-1 Ditch is attributed to ${ }^{209} \mathrm{Pu}$.

2) $\approx 30 \%$ of alpha activity in U-Pond is attributed to ${ }^{239} \mathrm{Pu}$.

Figure 4.5. Plutonium Distribution in the 216-Z-1 Ditch as Interpreted from 1959 Mud Analyses 


\subsubsection{Through 1974}

In the early 1970s, several studies were conducted to assess the distribution of contamination in the U-Pond sediments. From 1972 to 1973, Atlantic Richfield Hanford Company (ARHCO) initiated a development project aimed at evaluating the use of aerial radiological measurement systems (ARMS). Results of this survey were published in Bruns (1975) and are shown in Figures 4.6, 4.7, and 4.8.

The ${ }^{137} \mathrm{Cs}$ plot (see Figure 4.7) indicates approximately $25 \mathrm{Ci}$ of "equivalent" ${ }^{137} \mathrm{Cs}$ surface activity around U-Pond. The total gamma plot (see Figure 4.6) shows a difference when compared with the ${ }^{137} \mathrm{Cs}$ plot because of the presence of other gamma emitters, such as ${ }^{60} \mathrm{Co},{ }^{241} \mathrm{Am}$, and others. Approximately $20 \%$ of activity measured was reported to be caused by buried high-level and intermediate-level waste and an attenuation factor of three was assumed. From this, a value of $75 \mathrm{Ci}$ of ${ }^{137} \mathrm{Cs}$ on 150 ha was calculated. A similar estimate for total gamma was reported as $100 \mathrm{Ci}$. The total dose per year caused by gamma ranged between 1 to $44 \mathrm{rem} / \mathrm{yr}$. The plot of ${ }^{241} \mathrm{Am}$ activity, where it was not masked by other gamma emitters, was shown in Figure 4.8. The ${ }^{241} \mathrm{Am}$ values provide only approximations of the plutonium concentrations because the low-level effluents from the various portions of Z-Plant often originated from locations in the processes wherein the americium and plutonium had been separated. The above surficial gamma activity estimates were considered good to $\pm 50 \%$.

Surface sampling and a ground-based neutron survey were also conducted to support this project (refer to Appendix B). The initial sampling results come from the detailed analysis of a $1-\mathrm{m}^{2}$ plot in the U-Pond delta. The upper $7.6 \mathrm{~cm}$ of this plot consisted of partially decayed vegetation that was removed and analyzed separately. The two $30-\mathrm{cm}$-deep cores were taken and subsampled, and the remaining upper $5 \mathrm{~cm}$ of sediment were removed from the plot and analyzed. The results are shown in Table 4.3. Levels of ${ }^{137} \mathrm{Cs}$ varied from $1.0 \mathrm{E}-02$ to $6.0 \mathrm{E}-03 \mathrm{Ci} / \mathrm{g}$ for top soil. The ${ }^{90} \mathrm{Sr}$ to ${ }^{137} \mathrm{Cs}$ curie ratio varied from $4.5 \mathrm{E}-03$ to $1.0 \mathrm{E}-03$. The ${ }^{239,240} \mathrm{Pu}$ values were in the $10^{-8} \mathrm{~g} / \mathrm{g}$ of soil range or 10 to $20 \mathrm{~g} / \mathrm{ha}$. The neutron survey of the exposed pond area showed significant neutron counts. Initial calibration indicated values as high as $\mathbf{4 0 0} \mathrm{g}$ of plutonium per hectare near the ditch inlets.

Several ring (surface) samples were also taken along the exposed shoreline, but only a few analyses are available. These results were never reported. Figure 4.9 indicates the sampling location for which analyses are available, and Table 4.4 lists the analytical results (refer to Appendix B).

Shortly after these initial samples were taken, ARHCO and Battelle, Pacific Northwest Laboratories (BNW) jointly coordinated their respective programs involving U-Pond to augment each other and to eliminate any duplication. ARHCO's efforts were directed toward characterizing the U-Pond soil's radionuclide distribution, the physical and chemical characteristics of the radionuclides, and the pertinent soil chemistry; BNW contributed by collecting samples of the pond-bottom sediment.

One of the first activities completed under the joint ARHCO/BNW program was the determination of flow patterns in the pond (see Appendix $C$ ). The purpose of the study was to gain qualitative 
WHC-EP-0707, Rev. 0

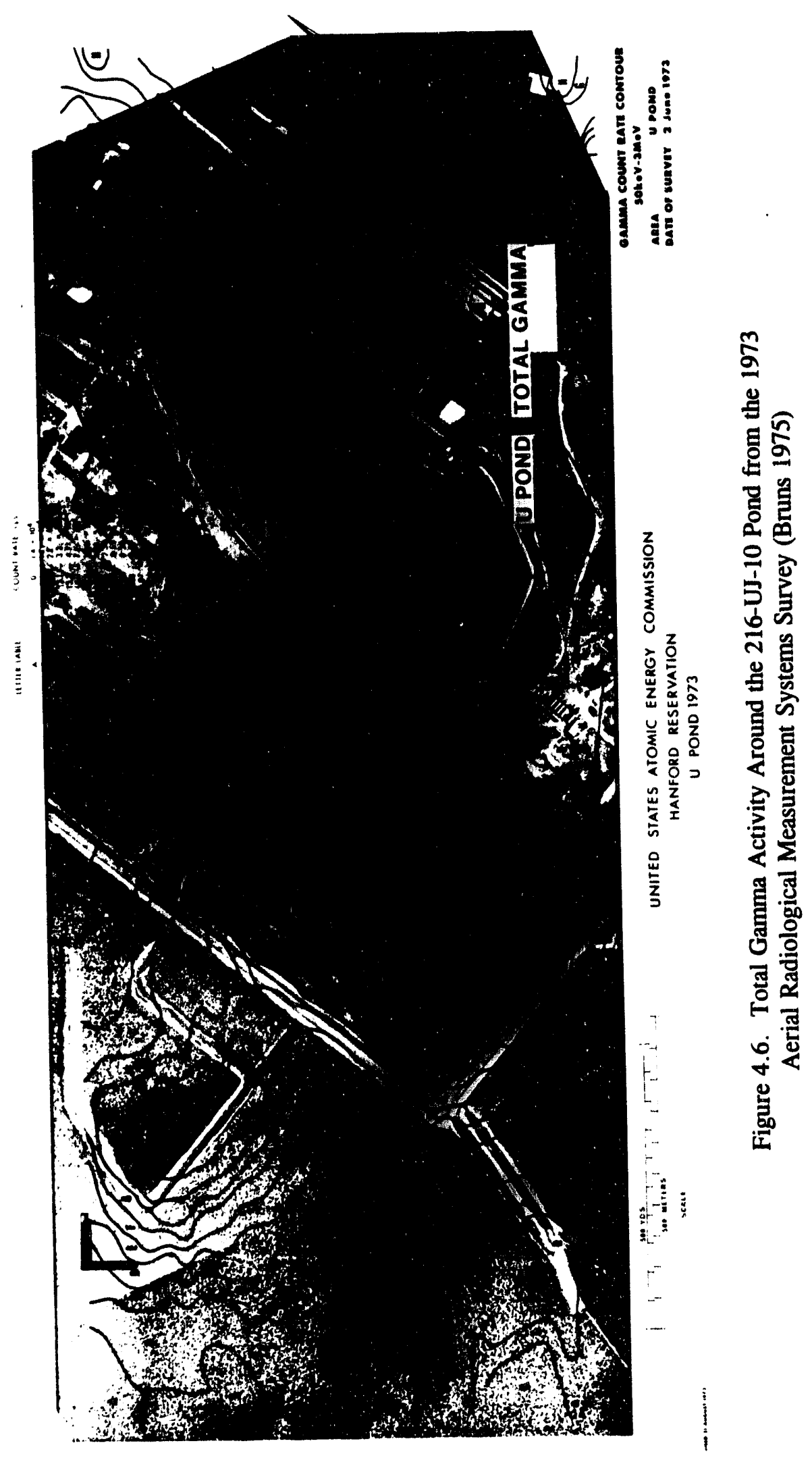




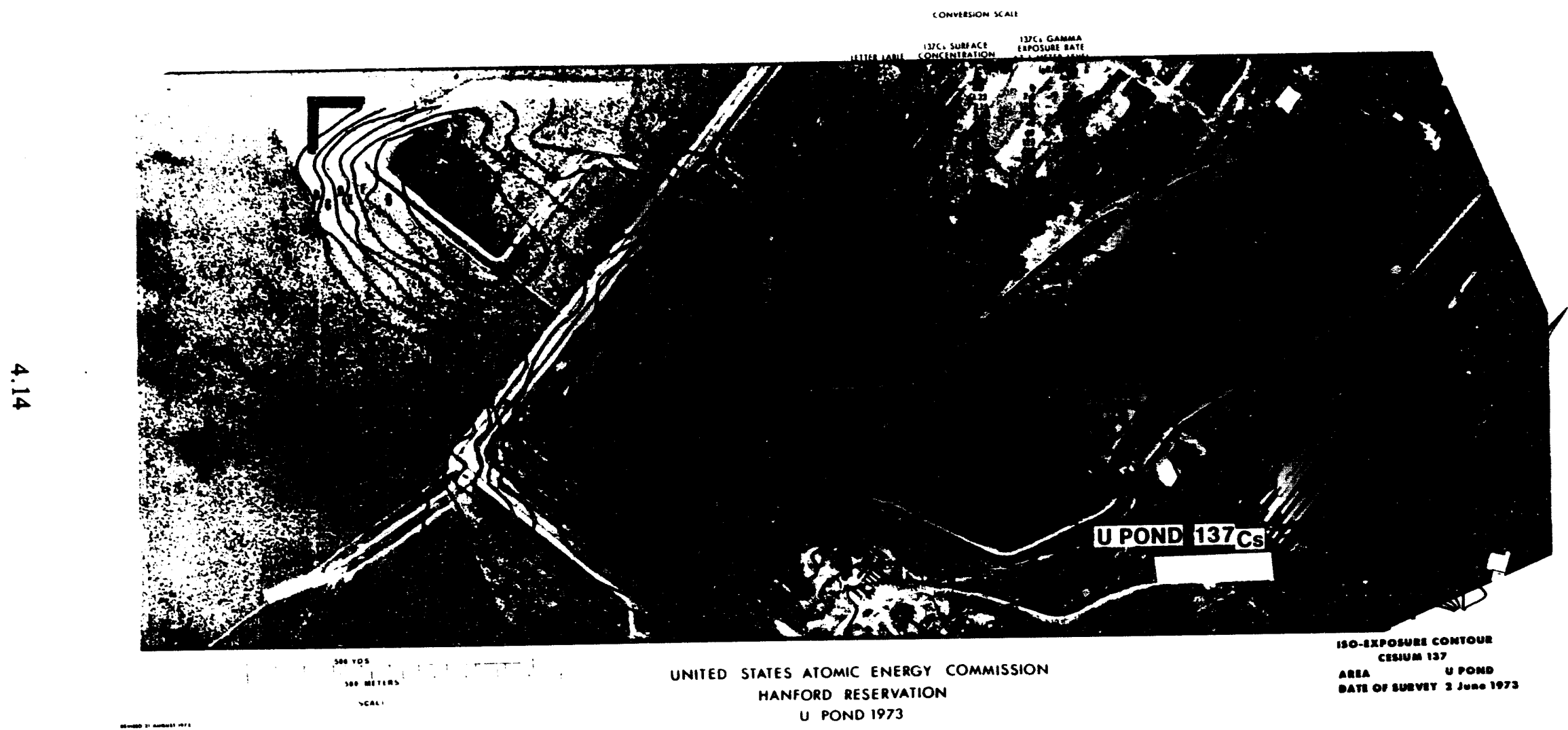

Figure 4.7. Cesium-137 Activity Around the 216-U-10 Pond from the 1973 Aerial Radiological Measurement Systems Survey (Bruns 1975) 

WHC-EP-0707, Rev. 0

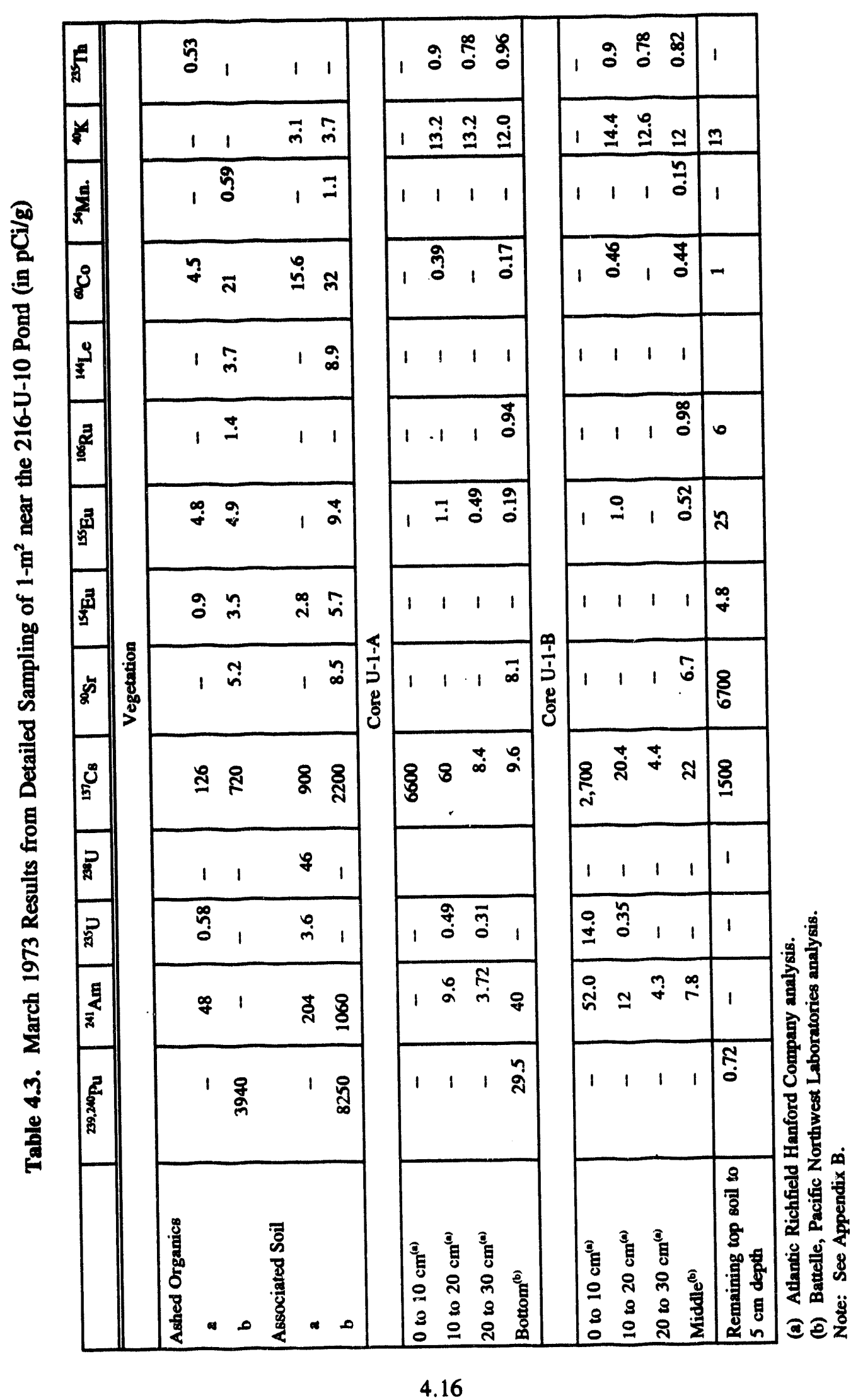


WHC-EP-0707, Rev. 0

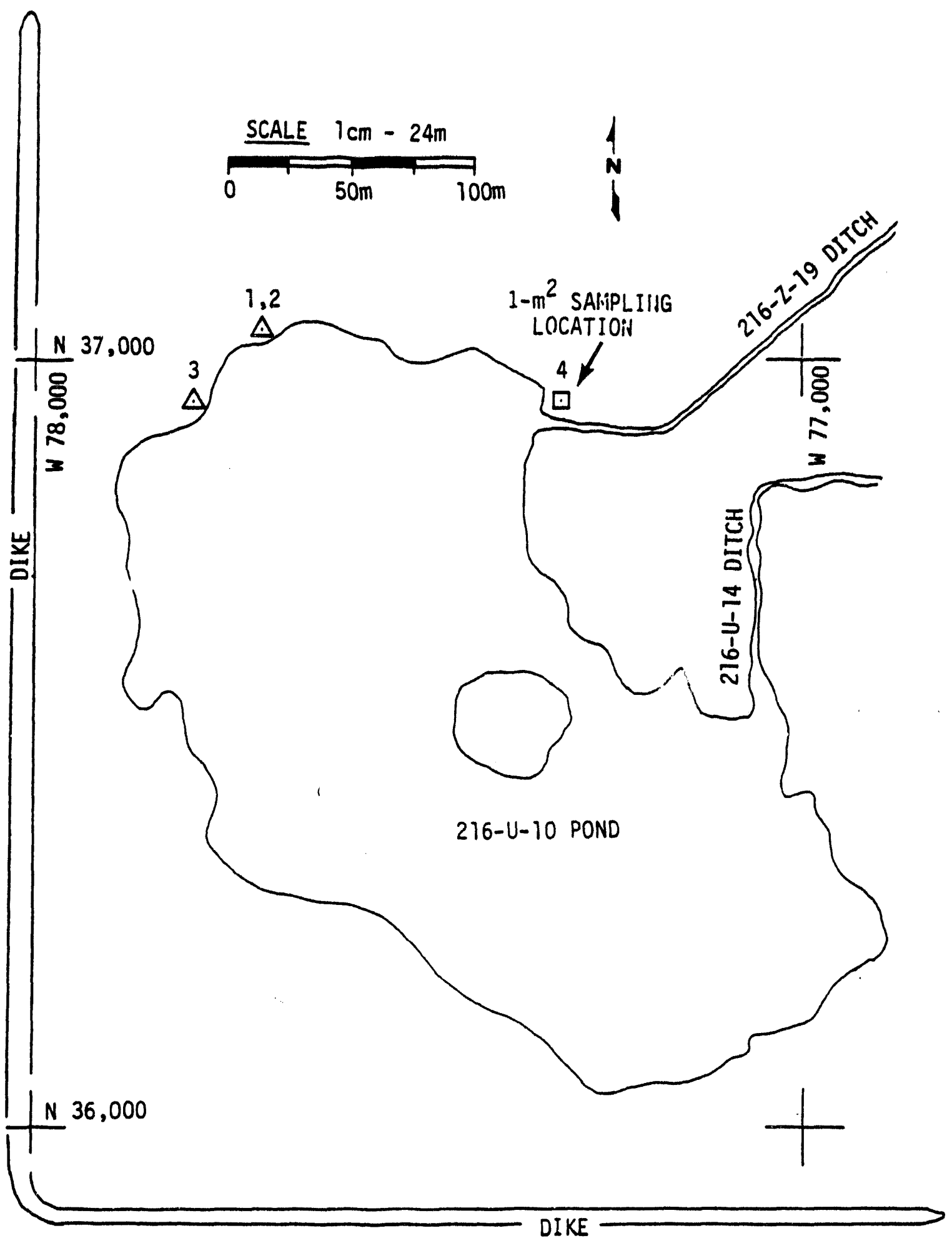

Figure 4.9. Location of the 216-U-10 Pond Perimeter Sampling, 1973 
Table 4.4. Analyses of 216-U-10 Pond Perimeter Samples, 1973

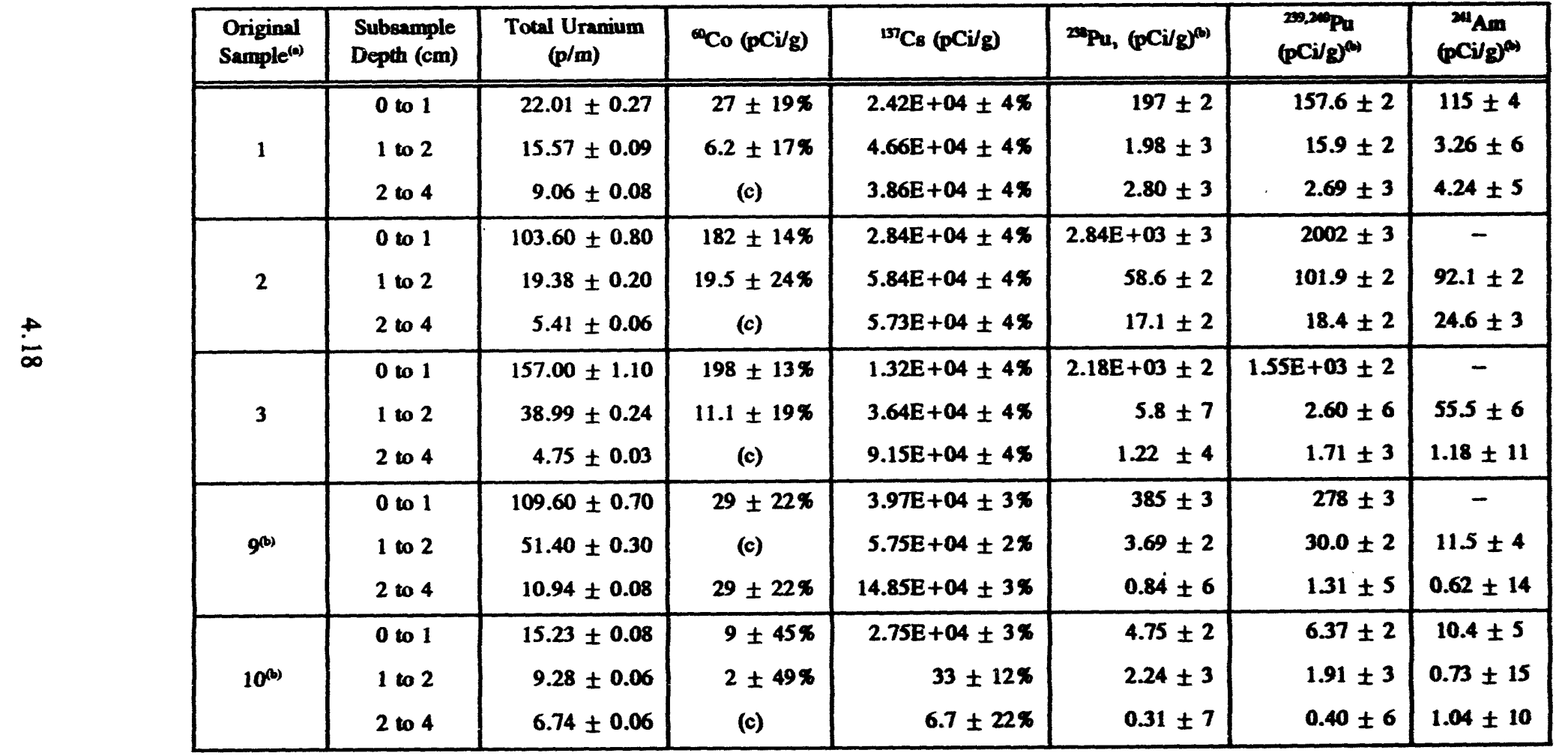

(a) For location gee Figure 4.9.

(b) Location unknown.

(c) Not determined. 
information on settling locations of waste material entering the pond via the three different sources. On December 4,1973, visible and infrared aerial surveys of dye tracer techniques were conducted to determine surface temperature patterns and discharge movement rates. Computer analysis of the survey data showed clockwise circulation in the pond and showed that the U-14 Ditch was the dominant flow entering the pond. Surface flow patterns were also affected by wind and suggested, because of the shallowness of the pond, that radionuclide distribution in the pond sediments may also be affected. The flow patterns observed from this study suggested that the majority of the waste material deposition on the pond bottom occurs along the east and south banks because the prevailing winds are from the northwest (Figure 4.10). Shortly after this study, the flow rate of the U-14 Ditch was greatly increased by startup of the 242-S Evaporator.

The most complete information produced from the joint ARHCO/BNW studies was published in two phases. Phase I (Emery and Klopfer 1974) documents the physical and chemical characteristics of U-Pond and the distribution of plutonium and americium in the pond-bottom sediment. At the time of the study (1973), both the U-14 and Z-19 ditches supplied effluent to the pond at a combined rate of approximately $1.0 \mathrm{E}+04) \mathrm{L} / \mathrm{min}$. The major source was from the $\mathrm{U}-14 \mathrm{Ditch}$, where the $242-\mathrm{S}$ Evaporator accounted for approximately $8.0 \mathrm{E}+03 \mathrm{~L} / \mathrm{min}$. This water was used for cooling and supplied a significant heat load to the pond. The laundry accounted for approximately $1.4 \mathrm{E}+03 \mathrm{~L} / \mathrm{min}$ but also provided a large supply of nutrients to the pond. The Z-19 Ditch supplied approximately $0.5 E+03 \mathrm{~L} / \mathrm{min}$, mostly via the $234-5 \mathrm{Z}$ Building (Z-Plant). Because there were no surface outflows from the pond, the waste water exited by percolation (95\%), with only some evaporative loss $(5 \%)$. The pond volume was estimated at $2.27 \mathrm{E}+07 \mathrm{~L}$, with an exchange rate of approximately $40 \mathrm{~h}$. The rate of water loss was reported to decrease as the pond level was lowered, indicating that the central basin of the pond was less permeable than the outer perimeters. Thus, a large portion of the estimated $1.0 \mathrm{E}+04-\mathrm{L} / \mathrm{min}$ loss must occur near the perimeter. Interruptions in flow showed that the pond did not lose one-half its volume in $48 \mathrm{~h}$.

Physical dimensions of the pond were 5.7 ha in lateral extent, with a maximum depth of $1.6 \mathrm{~m}$ and an average depth of $0.4 \mathrm{~m}$.

The average thickness of sediment overlying the desert soil base was estimated to be approximately $10 \mathrm{~cm}$. This sediment was not uniformly distributed and ranged in thickness from 0 to $40 \mathrm{~cm}$. Wind action on the pond's flow patterns was reportedly the cause of sediment distribution into the pondbottom depressions and on leeward shorelines. Observed changes in the pond after the construction of walkways indicated that, in the past, there was extensive and continuous movement of the pond-bottom sediment caused by wind action. Some wind protection was also noted on the west and south banks as noted by the growth of willows and cattails.

The heat load added to the pond via the 242-S Evaporator effluent was reportedly confined to the southeast portion of the pond. The pond's annual temperature range was found to be between $32^{\circ} \mathrm{C}$ in July to $0^{\circ} \mathrm{C}$ in January, when portions of the pond were covered with ice. Chemical analysis of the 
WHC-EP-0707, Rev. 0
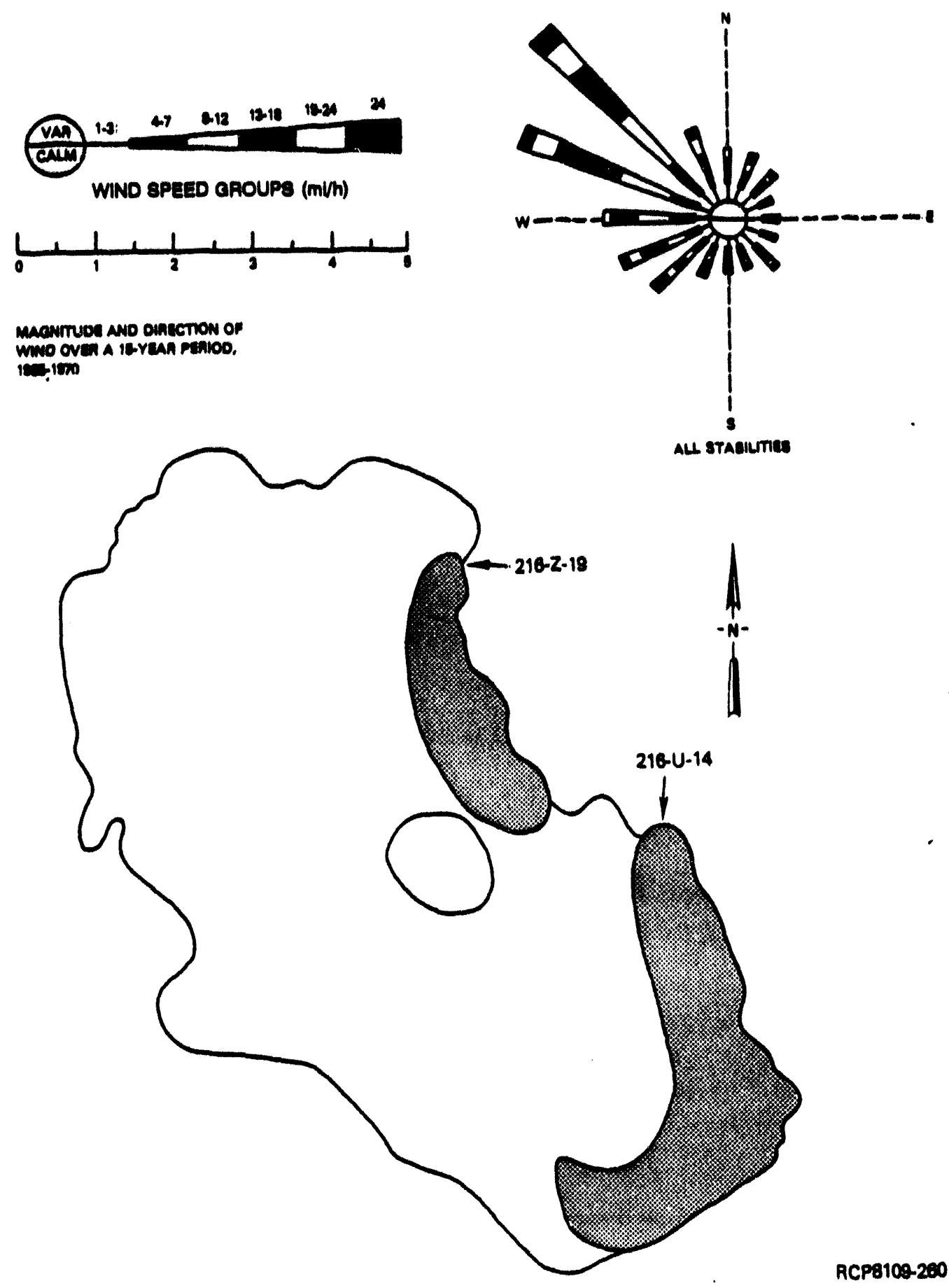

RCP8100-200

Figure 4.10. Areas of Likely Waste Deposition in the 216-U-10 Pond 
pond water indicated a moderate hardness $(39 \mathrm{mg} / \mathrm{L} \mathrm{CaCO})$, alkalinity $(92 \mathrm{mg} / \mathrm{L} \mathrm{CaCO}$ ), and conductivity $\left(1000\right.$ to 2500 micromhos $/ \mathrm{cm}$ at $\left.25^{\circ} \mathrm{C}\right)$ and was found to be highly enriched with nutrients from the laundry waste waters. Total phosphorous inflow to the pond was estimated at approximately $10 \mathrm{~kg} /$ day, with a mean pond concentration of $0.2 \mathrm{mg} / \mathrm{L}(\mathrm{n}=5)$. Inorganic nitrogen inflow was approximately $4 \mathrm{~kg} / \mathrm{day}$, with a mean pond concentration of $0.2 \mathrm{mg} / \mathrm{L}(\mathrm{n}=20)$. Silicate-silicon inflow was also high at $31 \mathrm{~kg} / \mathrm{day}$, sustaining a mean pond concentration of $1.4 \mathrm{mg} / \mathrm{L}$.

The pH levels (May to October) fluctuated between 7.0 at sunrise to 4.5 by mid-afternoon, and the dissolved oxygen levels varied from 4 to $13 \mathrm{mg} / \mathrm{L}$, respectively, indicating signiflcant biological effects.

The pond-bottom sediment was found to be the principal repository for plutonium and americium, with a mean concentration of $390 \mathrm{pCi} / \mathrm{g} \mathrm{\Sigma Pu}$ in the upper $10 \mathrm{~cm}$. Concentrations ranged between 7 and $2200 \mathrm{pCi} / \mathrm{g}$. The average concentration of ${ }^{236 \mathrm{Pu}}$ was $194 \mathrm{pCi} / \mathrm{g}$ and $29,200 \mathrm{Pu}$ was $195 \mathrm{pCi} / \mathrm{g}$, with an overall ratio of ${ }^{20} \mathrm{Pu}$ to ${ }^{20,200 \mathrm{Pu}}$ of $1: 1$. The mean concentration of ${ }^{211} \mathrm{Am}$ to plutonium was $23: 1$.

Statistical analysis of the sampling data indicated that plutonium was randomly distributed both temporally and spatially in the pond-bottom sediment. From sequential extraction processes, it was found that 73\% to $93 \%$ of the plutonium was not removed from the sediment. Plutonium that was removed was found to be very tightly bound in the surface samples (2\% to $5 \%$ removed) and less tightly bound in the subsurface samples (20\% to $22 \%$ removed). Only $1 \%$ to $3 \%$ of the plutonium was loosely bound-this is comparable to levels of plutonium found in the interstitial water. Americium was also found to be strongly bound to the surface sediments and less tightly bound to subsurface sediments, but generally less tightly bound than plutonium.

Levels of plutonium in the interstitial water ranged from 0.6 to $12.6 \mathrm{pCi} / \mathrm{g}$ and were predominantly "nonionic" in the subsurface and cationic at the surface. Americium levels ranged from 0.6 to $2.8 \mathrm{pCi} / 8$ and were predominantly cationic in nature, with higher propcrtions of anionic ${ }^{211} \mathrm{Am}$ occurring in the surficial samples.

In the pond water, only trace amounts of plutonium and ${ }^{241} \mathrm{Am}$ were detected in three large-volume water samples. Plutonium ranged from $0.007 \mathrm{pCi}{ }^{230} \mathrm{Pu} / \mathrm{L}$ to $0.002{ }^{209.200} \mathrm{Pu} / \mathrm{L}$, with higher levels of ${ }^{21} \mathrm{Am}$ found $(1.1 \mathrm{pCi} / \mathrm{L})$. Approximately $50 \%$ to $60 \%$ of the plutonium and $10 \%$ of americium were found to be in a soluble form, with $60 \%$ to $80 \%$ of the soluble plutonium and $30 \%$ of the soluble americium in cationic form.

The total amount of plutonium in the pond-bottom sediment down to $10 \mathrm{~cm}$ was estimated to be $1.54 \mathrm{Ci}{ }^{201} \mathrm{Pu}$ and $155 \mathrm{Ci}{ }^{20,200} \mathrm{Pu}$ or $0.04 \mathrm{~g}$ of ${ }^{209} \mathrm{Pu}$ and $21 \mathrm{~g}$ of ${ }^{209} \mathrm{Pu}$, which was less than $0.5 \%$ of the historic release figure of $8.1 \mathrm{~kg}$. It was suggested that there may be substantial plutonium beneath the $10-\mathrm{cm}$ depth or large quantities of plutonium located in the Z-ditches. 
The pond-bottom sediment contamination data have been reinterpreted with additional unpublished data (Appendix D) to provide some idea of the spatial distribution of the plutonium, americium, and uranium within the top $10 \mathrm{~cm}$ of pond-bottom sediment. Figures 4.11 , and 4.12 were derived by averaging all the previously available analyses for each of the 15 grid sections established by BNW.

Phase II of this study (Emery and Garland 1974) documented the radiochemical factors of the transuranic elements in the U-Pond ecosystem and expertly puts into perspective the complex source terms and actinide ratios discharged to the pond. Some of the more geologically important findings are reported below:

- Comparison of the measured concentrations in U-Pond sediment to that of reported release figures indicated an inventory of approximately four t.mes more ${ }^{234} U$ than that reported. No explanations were provided, however

- A rough comparison of total alpha counts per liter discharged to the Z-19 Ditch versus measured levels in U-Pond water (for the first 6 months of 1974) indicated that most of the discharged plutonium and americium did not reach U-Pond

- A repeated sampling of sediment from the same location over a short time interval showed a substantial variation in concentrations of ${ }^{200} \mathrm{Pu}$ and ${ }^{20,200} \mathrm{Pu}$. This was suggested to indicate the particulate nature of the plutonium in these sediments. Because the plutonium and americium that reach U-Pond must first travel down the length of the Z-19 Ditch, very large particulates of these radionuclides would be expected to settle out before reaching the pond, assuming the density is around 10. Estimates of the particle sizes to reach U-Pond were made. These maximum sizes were approximately $4 \mu \mathrm{m}$ for a ${ }^{288} \mathrm{PuO}^{2}$ particle. A small change in particle size would make a large change in activity of an individual particle; therefore, a substantial range of particle sizes within U-Pond could help explain the wide range of plutonium concentrations found by the repetitive sampling. The greater ${ }^{211} \mathrm{Am}$ to ${ }^{209.200} \mathrm{Pu}$ ratios of the U-Pond sediment compared to that of the expected maximum for weapons-grade plutonium provide evidence that there were other sources of ${ }^{21} \mathrm{Am}$.

In 1974, ARHCO collected additional surface soil samples along the U-Pond shoreline (Figure 4.13). These data were never reported but are now summarized in Table 4.5 (see Appendix E).

\subsubsection{Through 1977}

An assessment of the Z-19 Ditch was made in 1976 and 1977 to determine its impact on the surrounding environment (Appendix F). Routine monitoring samples of mud, water, and vegetation were reviewed. Special soil and vegetation samples were collected and analyzed and the aerial gamma survey (Bruns 1975) was reviewed. Analyses of the special soils and vegetation samples are shown in Table 4.6. Ground-water samples collected from wells 299-W15-5 and 299-W18-7 since 1973 were 


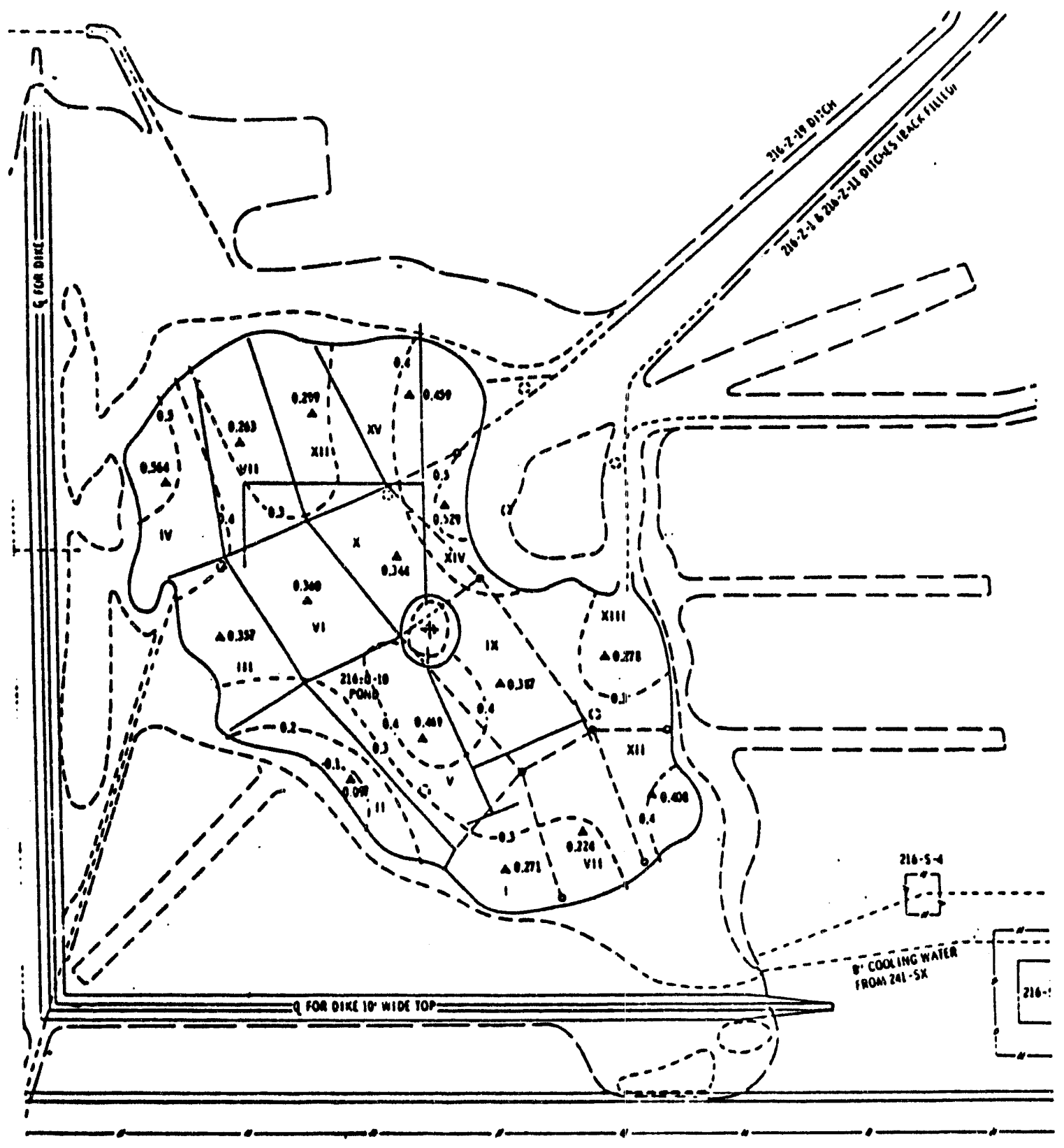

rorat pu conct IN nClig

- oata rolints ana lo con arto call vram IIII. is s rorks inverion inca

Figure 4.11. Detailed Total Plutonium Distribution in 216-U-10 Pond-Bottom Sediments 


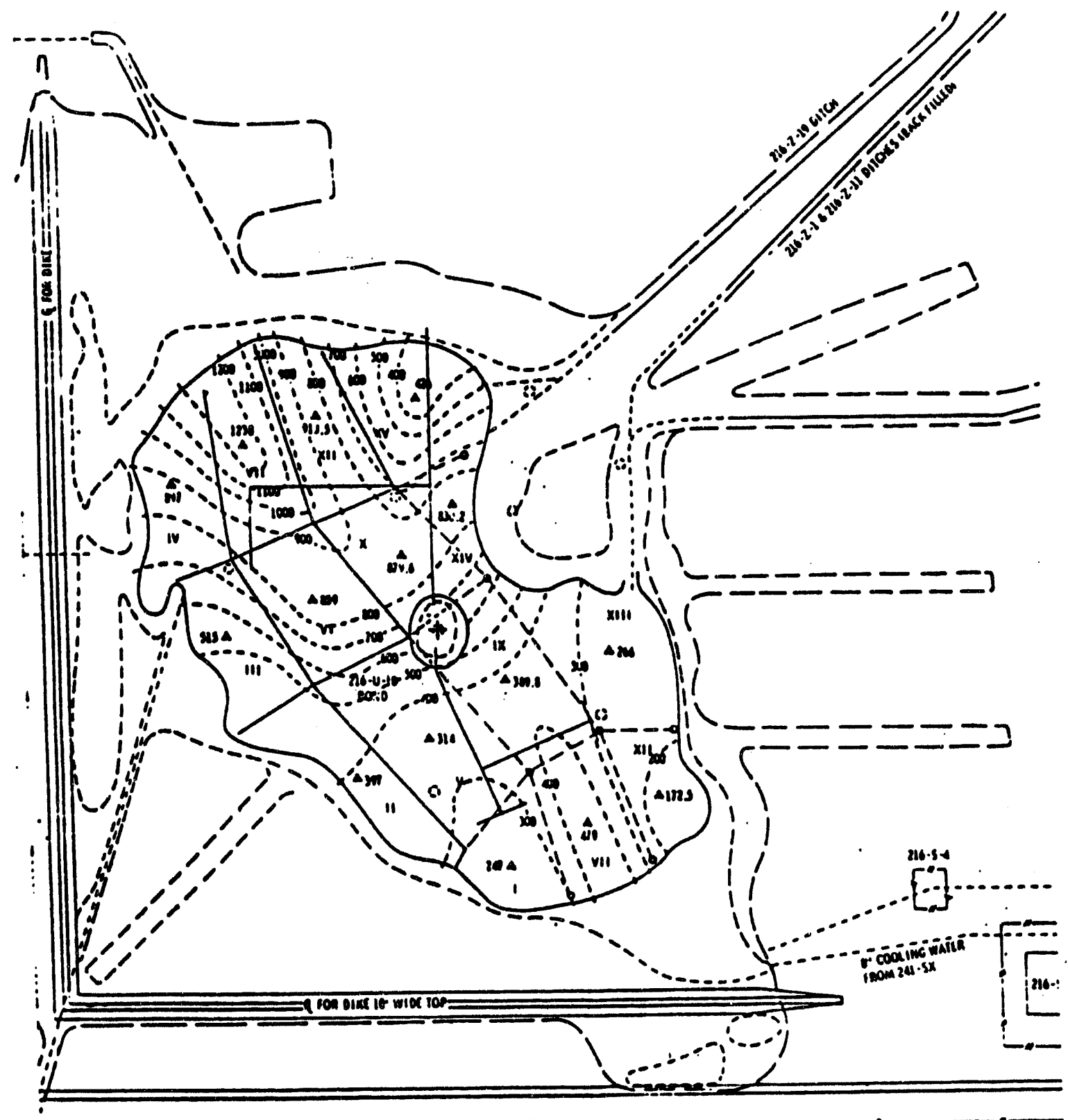

GOYAL U COMCEMTEATIOMS in ope

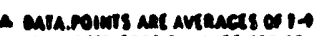
- cor call coal sumprs ma caio

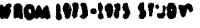

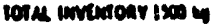

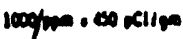
mosits

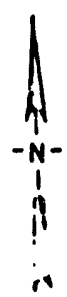

Figure 4.12. Detailed Total Uranium Distribution in 216-U-10 Pond-Bottom Sediments 


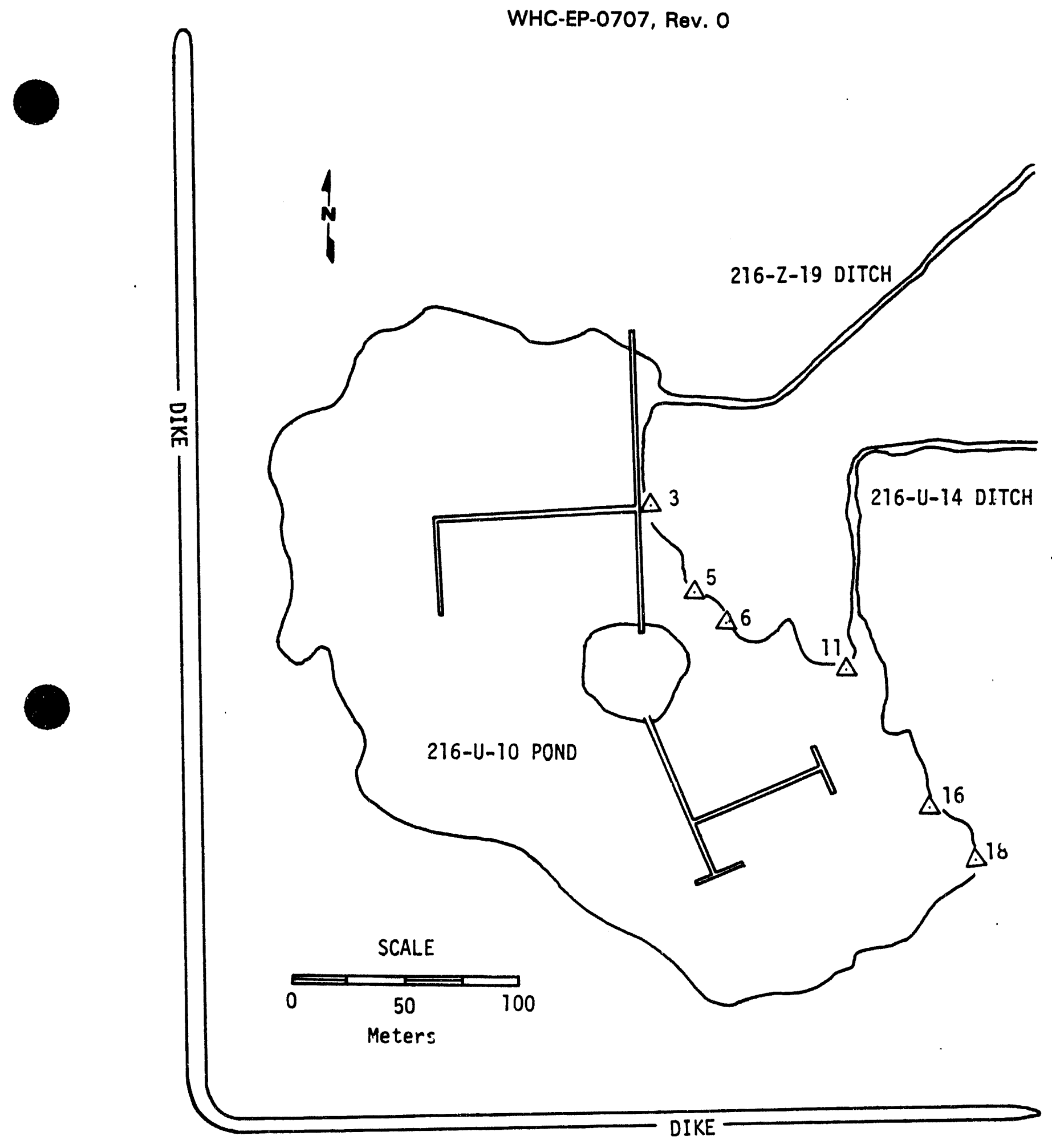

Figure 4.13. Location of 216-U-10 Pond Shoreline Samples, 1974 
Table 4.5. 1974 Analyses of 216-U-10 Pond Shoreline Samples

\begin{tabular}{|c|c|c|c|c|c|c|}
\hline $\begin{array}{l}\text { Original } \\
\text { Sample }\end{array}$ & $\begin{array}{l}\text { Sample Depth } \\
\text { (cm) }\end{array}$ & $\begin{array}{l}\text { Sample Mass } \\
\text { (cm) }\end{array}$ & ${ }^{241} \mathrm{Am}(\mathrm{pCi} / \mathrm{g})$ & ${ }^{26} \mathrm{Ra}(\mathrm{pCi} / \mathrm{g})$ & ${ }^{137} \mathrm{Cs}(\mathrm{pCi} / \mathrm{g})$ & ${ }^{\infty} \mathrm{K}(\mathrm{pCi} / \mathrm{g})$ \\
\hline $3 \mathrm{C}$ & 20.0 to 30.0 & 120.25 & $<1.4$ & $<1.0$ & $18.7 \pm 0.54+1 \%$ & $16.5 \pm 0.24+2 \%$ \\
\hline $5 C$ & 20.0 to 30.0 & 131.65 & $<4.5$ & $<3.7$ & $813.5 \pm 0.79+0 \%$ & $13.7 \pm 0.25+2 \%$ \\
\hline 6C & 20.0 to 30.0 & 125.62 & $<1.7$ & $<1.40$ & $80.56 \pm 0.26+1 \%$ & $13.46 \pm 0.26+2 \%$ \\
\hline $16 B$ & 12.5 to 25.0 & 112.36 & $3.357 \pm 0.28+2 \%$ & $<2.0$ & $152.9 \pm 0.20+1 \%$ & $16.36 \pm 0.25+2 \%$ \\
\hline 18B & 10.0 to 20.0 & 125.33 & $<0.85$ & $0.9033 \pm 0.28+2 \%$ & $2.7 \pm 0.14+2 \%$ & $11.59 \pm 0.28+2 \%$ \\
\hline $17 \mathrm{C}$ & 20.0 to 30.0 & 119.32 & $<2.7$ & $<2.2$ & $251.2 \pm 0.15+1 \%$ & $16.15 \pm 0.24+2 \%$ \\
\hline
\end{tabular}


Table 4.6. Special Soil and Vegetation Samples from the 216-Z-19 Ditch in March and April 1976

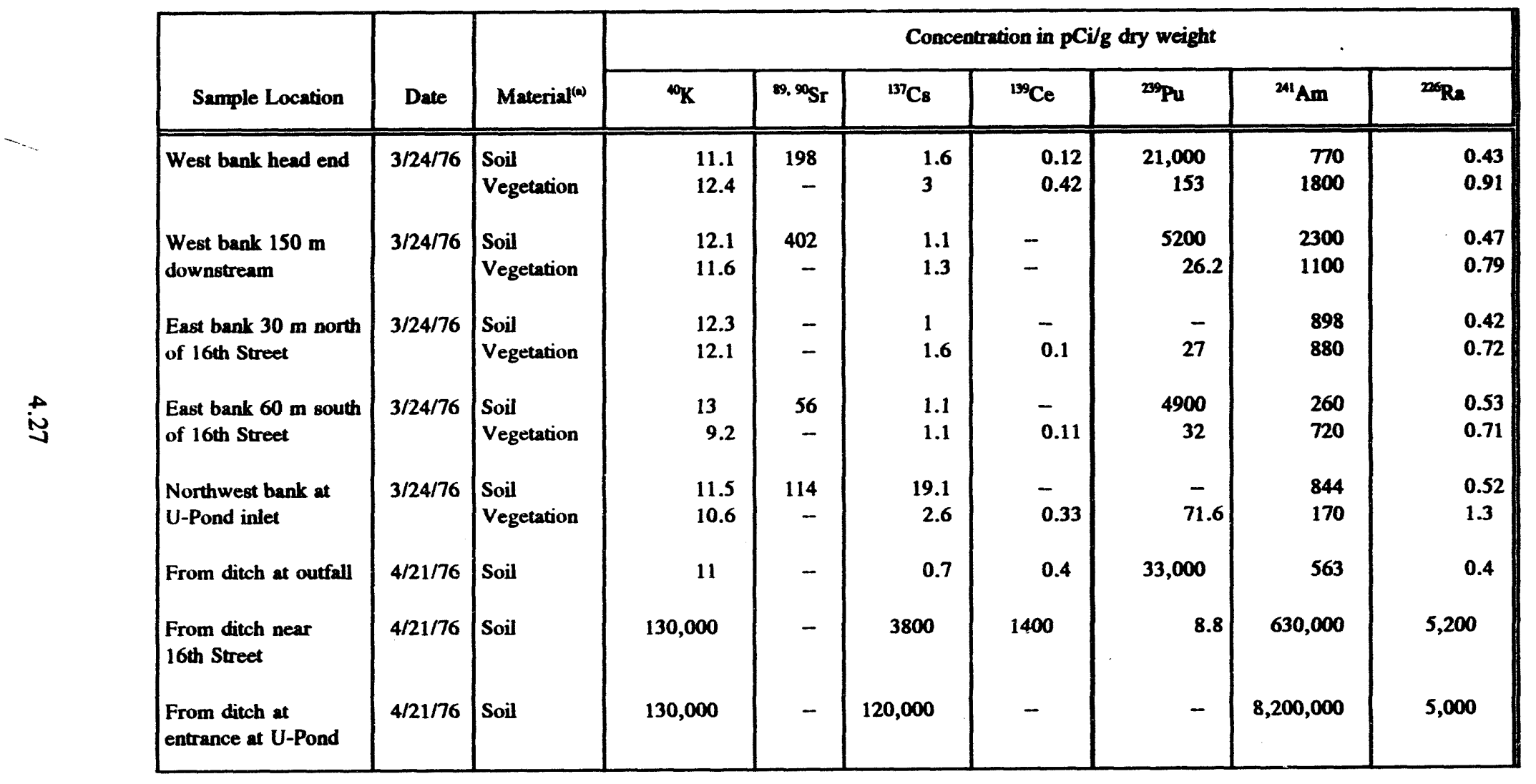

(a) The dry vegetation samples were separated from the soil samples by sieving and analyzed as a separate phase. 
reviewed. The indicated gross alpha activity of $0.017 \mathrm{pCi} / \mathrm{mL}$ was well below Table II limits (ERDA 1977). A radiation survey with portable alpha meter found an 8- to $15-\mathrm{m}^{2}$ area approximately $70 \mathrm{~m}$ upstream from $U$-Pond (in the delta area) that had maximum readings of 18,000 disintegrations per minute (dpm).

From this data review, the plutonium discharge was estimated at $196 \mathrm{~g}$ (equal to the discharge records), with most of the plutonium accumulated near the head end, while the ${ }^{241} \mathrm{Am}$ had migrated toward U-Pond.

No significant levels of plutonium or americium contamination were found to be reaching the ground water.

\subsubsection{5 to 1978}

From 1975 to 1978, a study was conducted on the small mammal populations inhabiting the environs around U-Pond (Gano 1979). As part of that study, dosimeters were buried in the soil at various depths to measure the exposure $d$ stribution along four transects. These transects (shown in Figure 4.14) were located near U-Pond, $L-19$, and U-14 ditches, with one control transect. Both gamma and neutron exposures were measured. The strongest-gamma exposures were found in the top $10 \mathrm{~cm}$ of soil from the meadow transect (near U-Pond in the delta area), with a mean of $75 \mathrm{R} / \mathrm{yr}$. The gamma exposure levels diminished rapidly with depth at all transects, except the control, which was constant. The neutron exposures were also highest in the first $10 \mathrm{~cm}$ of soil in the delta area, with an average exposure of $37 \mathrm{mrad} / \mathrm{yr}$. All but the Z-19 Ditch transect showed decreasing exposure with increasing depth. The exposures along the Z-19 Ditch showed somewhat the reverse, with the highest exposures $(7.8 \mathrm{mrad} / \mathrm{yr})$ at the $40-\mathrm{cri1}$ depth and the lowest $(1.9 \mathrm{mrad} / \mathrm{yr})$ at the $10-\mathrm{cm} \mathrm{depth}$ and at the surface. This reversed (exposure-depth) relationship was attributed to the location of the dosimeters relative to the ditch bottom (Figure 4.15).

\subsubsection{8}

In 1978, a comparative study was conducted on all the ponds and streams on the Hanford Site (Emery and McShane 1978). That study provides good comparative information on the U-Pond and the Z-19 Ditch sediments.

The maximum dose rates from the sediments and the radionuclide concentrations in the water were used to group all the ponds and streams into one of three groups. U-Pond and Z-19 Ditch were placed in the mid-range group (Figure 4.16). The Z-19 Ditch had the highest concentrations of alpha activity in water, with a maximum of $4.6 \mathrm{E}+06 \mathrm{pCi} / \mathrm{L}$. Total beta concentrations in water were $5.0 \mathrm{E}+03 \mathrm{pCi} / \mathrm{L}$ in $\mathrm{U}-\mathrm{Pond}$ and $1.0 \mathrm{E}+04 \mathrm{pCi} / \mathrm{L}$ in the $\mathrm{Z}-19 \mathrm{Ditch}$. U-Pond and Z-19 Ditch showed maximum dose rates from the bottom sediments of between $10^{2}$ and $10^{3} \mathrm{mR} / \mathrm{wk}$. 
WHC-EP-0707, Rev. 0

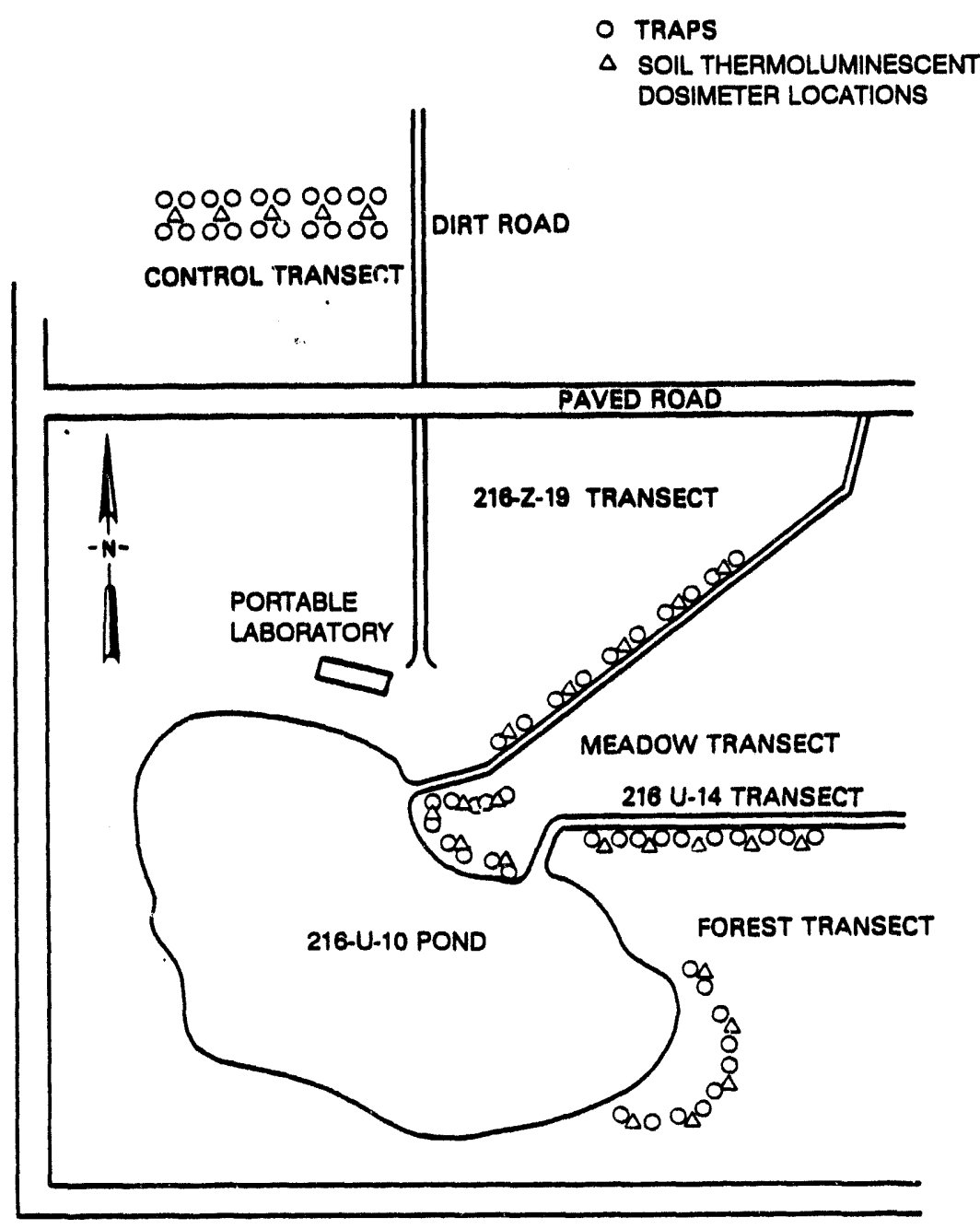

Figure 4.14. Location of Dosimeter Transects (after Gano 1979)

The previous studies have provided good information on the plutonium contamination of the Z-1 Ditch and on the chemical and radiological characteristics of U-Pond-bottom sediment. However, radiological data are missing in two general areas: (1) the surface and near-surface soil surrounding U-Pond and Z-19 Ditch and (2) the subsurface sediment beneath and adjacent to all the Z-ditches and U-Pond. Radiologic characterization data on these two areas are needed to define the distribution and lateral extent of the contamination and to determine the depth to which the contamination has migrated. An additional need for subsurface data is to locate and sample the old $\mathrm{Z}$-ditches to estimate what proportion of the $\mathrm{EPu}$ discharge inventory is located within each ditch. 


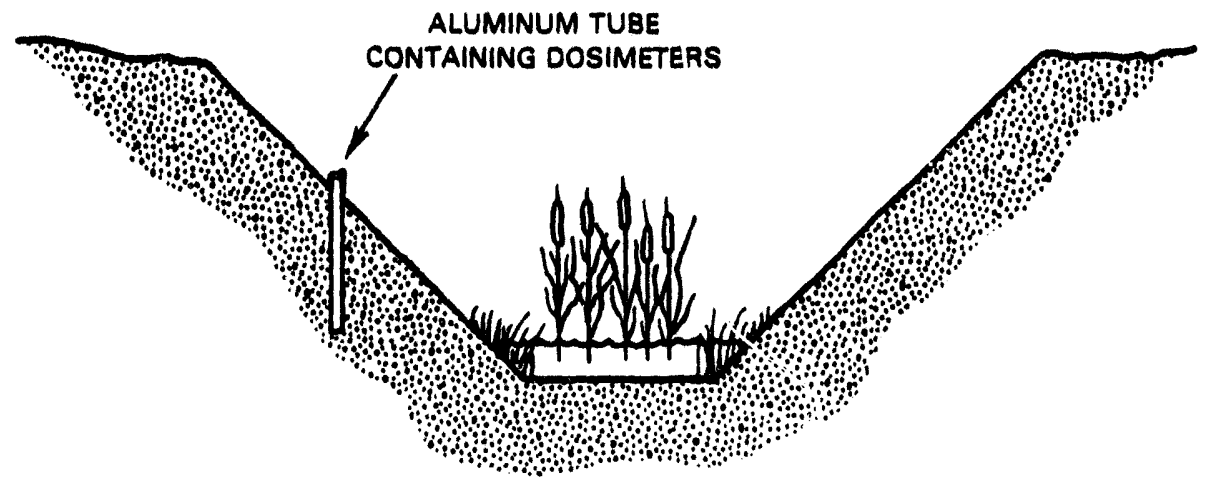

RCP8109-261

Figure 4.15. Location of Dosimeters Relative to the 216-Z-19 Ditch Bottom

\subsection{Hydrologic Studies}

Numerous past investigations have been made on the hydrology of the Hanford Site. Woris by Bierschenk (1957a, 1959a, 1959b) and Newcomb et al. (1972) help define aquifer properties of the unconfined aquifer. Gephart et al. (1979) compiled a cominprehensive document of the hydrology of the 200 East and 200 West areas and thereby established a hydrologic data base of unconfined aquifer properties for the U-Pond vicinity.

The effects of large volumes of liquid waste disposal on the unconfined aquifer are discussed by Bierschenk (1957b, 1957c), McConiga (1955), and Bierschenk and McConiga (1957). Essentially, these reports give water-taile elevation contour maps for various years between 1944 and 1956 and describe the basic waste disposal-aquifer system in terms of aquifer properties of the unconfined system and discharge histories of various liquid waste disposal sites (including U-Pond).

Tomlinson et al. (1970) used the variable-time-transport finite-difference computer model to simulate the impact of proposed infiltration basins on the unconfined aquifer below the Hanford Site. Proposed infiltration was simulated at sites north of Gable Butte, in the vicinity of the Hanford Town Site, and in the 300 Area. Water-level increase maps were prepared, showing the impact of the various proposal sites on the unconfined aquifer.

Veatch (1971) reviewed the impact of U-Pond infiltration on the unconfined aquifer to predict future water-table rises associated with discharges from the 242-S Evaporator.

From a review of these previous studies, it was found that there were three distinct water-table changes associated with variable inflow into U-Pond. From 1944 to 1951 , the water table rose $7.6 \mathrm{~m}$ from a pre-Hanford Site elevation of 122 to $130 \mathrm{~m} \mathrm{MSL}$. Between 1951 and late 1956, the water table rose an additional $16.8 \mathrm{~m}$. From 1957 to 1970 , water levels in the area around U-Pond remained 
WHC-EP-0707, Rev. 0

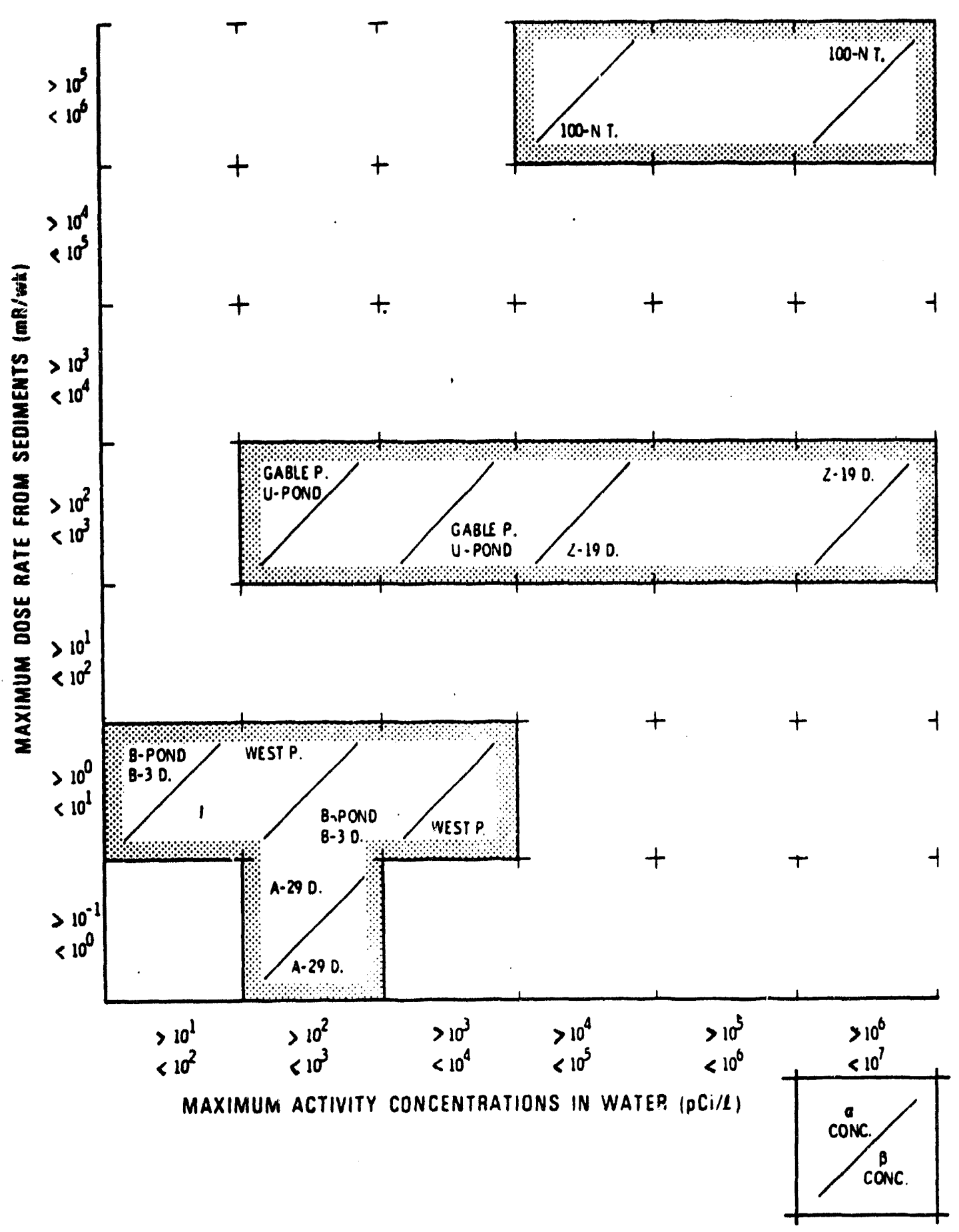

Figure 4.16. Relative Grouping of Hanford Site Ponds and Ditchis Based on Dose Rate of Sediments and Activity Concentrations in Water (Emery and Klopfer 1974) 
somewhat stable, fluctuating between 143 to $147 \mathrm{~m} \mathrm{MSL}$. Veatch (1971) predicted that 242-S Evaporator discharges would raise the water table to a height of between 152 and $157 \mathrm{~m}$. This prediction was found to be invalid; increased discharge from the 242-S Evaporator had little effect on the unconfined aquifer.

Gephart et al. (1976) used the variable-time-transport computer model to simulate water-table changes associated with increasing discharges to Gable Mountain Pond and B-Pond. Discharges to the various ponds were given and the resulting impact on the unconfined aquifer were displayed as watertable maps. Using 1976-projected discharges to Gable Mountain Pond and B-Pond, in 8 years the water-table elevation around Gable Mountain Pond was predicted to increase by approximately $2.4 \mathrm{~m}$ and was predicted to remain somewhat stable around the B-Pond area.

Numerous studies have been made on the chemical nature and quality of ground waters in the unconfined aquifer. The first comprehensive document on the radiological contamination in the unconfined aquifer appeared in the literature in 1970. Denham (1970) provided detailed information on total beta, tritium, and nitrate concentrations for various wells in PNL's 600 Area ground-water monitoring network. Concentration plume maps were generated from given data. Periodic status reports for the contamination in the unconfined aquifer have been generated through 1979 (Eddy and Wilbur 1980). Average concentrations of total beta, tritium, and nitrate for 1980 were given in Graham et al. (1981). Plume maps for the contamination in the Separations Areas were created, showing widespread tritium and nitrate contamination, but isolated beta contamination. Contamination originating in the 200 West Area has not migrated as far as the contamination coming from the 200 East Area. Graham et al. (1981) attributed this difference to the different flow systems and the change in hydraulic properties from west to east in the unconfined aquifer. 


\subsection{Current 216-U-10 Pond and 216-Z-19 Ditch Characterization Studies}

The objective of this study was to delineate the concentration, distribution, and speciation of radionuclides released to the 216-U-10 (U-) Pond Disposal System and to give some consideration to their impacts on the environment. Of primary concern was the spatial distribution of transuranic elements in the surface and subsurface sediments.

The general approach of this study was to 1) compile and review all the previously existing data, 2) identify the significant gaps in the existing data base, and 3) characterize these areas to provide an increased statistical acceptability of the data base.

During the initial phases of this study, the need arose to determine what potential impacts may result from the proposed shutdown of the 242-S Evaporator and subsequent drying up of the U-Pond sediments. A second need, also supporting the low-level waste program, was soon identifled. This need was to provide specific radiological data on the entire U-Pond disposal system and to aid the engineering design for the decontamination and decommissioning of these facilities.

The needs resulted in the acquisition of a considerable amount of data from a wide range of studies involving different disciplines. The experimental design and results of these many studies are discussed by discipline in the sections below. Although efforts were made to coordinate sampling efforts, the discipline-oriented studies remain essentially independent; thus, there is some redundancy in the discussions.

\subsection{Atmospheric Studies}

Air samples were collected for radon analysis from the U-Pond area and from the Yakima Barricade (background). Analytical results showed radon levels were $<0.037 \%$ of Table I and $<1.2 \%$ of Table II guidelines (ERDA 1977). These values were well within the guidelines for controlled areas. No health hazard from radon daughters was indicated (Appendix $G$ ).

\subsection{Biological Studies}

This section contains a discussion of the methods and materials used in biological studies, the results of these studies for the 216-Z-19 (Z-19) Ditch and U-Pond, and a discussion based on these results. 


\subsubsection{Methods and Materials}

The biological studies were keyed to a stratified random-sampling scheme. Nine transects were located along the Z-19 Ditch according to ${ }^{21} \mathrm{Am}$ iso-exposure contours from a 1973 aerial radiological survey (Tipton 1973). Two levels of surface contamination are represented: $1=<3.2 \mu \mathrm{Ci} / \mathrm{m}^{2}$, and II $=>3.2 \mu \mathrm{Ci} / \mathrm{m}^{2}$. Because level I accounted for $35 \%$ of total ditch length, three transects were placed in these areas. The remaining six transects were placed in level II areas, which represented approximately $65 \%$ of the total ditch length (Figure 5.1). For purposes of plant sampling, U-Pond was divided into four quadrants (Figure 5.2). At least ten different willow or cottonwood trees were sampled per quadrant.

\section{Soil Sampling}

Soil and ditch-bottom sediment sampling were performed in coordination between the biological and geologic studies and are discussed in both places. Soil-sampling points were established along each transect at the Z-19 Ditch for seven locations (Figure 5.3). Points A and E were located $3 \mathrm{~m}$ out on either side of the ditch depression. Sample points B and D were staked out just above the existing water level. Sample point F was placed over the area where the old 216-Z-11 (Z-11) Ditch was presumed to be located and point $G$ was located $15 \mathrm{~m}$ from point F. Sample points labeled $C$ were ditch-bottom sediment-sampling sites located in the center of the ditch (see Figure 5.3). For clarification purposes in this document, soil-sampling locations will be referred to by transect and point. For example, sample point 7A refers to a soil sample taken at transect 7, point A. Shallow soil core samples were taken using a split-tube core sampler.

The sampler had a diameter of $5 \mathrm{~cm}$ and a length of $61 \mathrm{~cm}$ and consisted of a split barrel, head, core retainer fingers, and drive shoe. A 5-cm-diameter, 96-cm-long extension rod was threaded onto the sampler. A hand-driven-type fence-post driver was slipped over the extension rod and the sampler was driven to a depth of $40 \mathrm{~cm}$ (Figure 5.4). The sampler was retrieved and surveyed by a radiation monitor for contamination before being broken down to expose the core sample. After the soil was surveyed by the monitor, it was partitioned into sections, representing depths of 0 to 5,5 to 15 , and 15 to $30 \mathrm{~cm}$ (Figure 5.5). The samples were then sealed in plastic bags and placed in prelabeled pint-size paper cartons. A total of 162 soil samples were collected in this manner. Samples were transported to the Rockwell Laboratory ${ }^{(a)}$ and gamma energy analyses (GEAs) were conducted on all samples. The 0 - to 5- and 5- to $15-\mathrm{cm}$ segments for each core were then composited prior to ${ }^{90} \mathrm{Sr},{ }^{239,240} \mathrm{Pu}$, and ${ }^{241} \mathrm{Am}$ analyses.

At least six soil samples per quadrant associated with tree samples were taken at U-Pond. Surface litter was scraped away before topsoil $(0$ to $5 \mathrm{~cm})$ plugs were removed with a cookie cutter device and trowel. Samples were placed in prelabeled pint-size paper cartons lined with plastic bags. United States Testing Corporation (U.S. Testing) analyzed the samples for gamma energy emitters. Based on these results, ${ }^{90} \mathrm{Sr}$ and/or plutonium analyses were requested for selected samples.

(a) The Rockwell Laboratory is housed in the 222-S Building. 


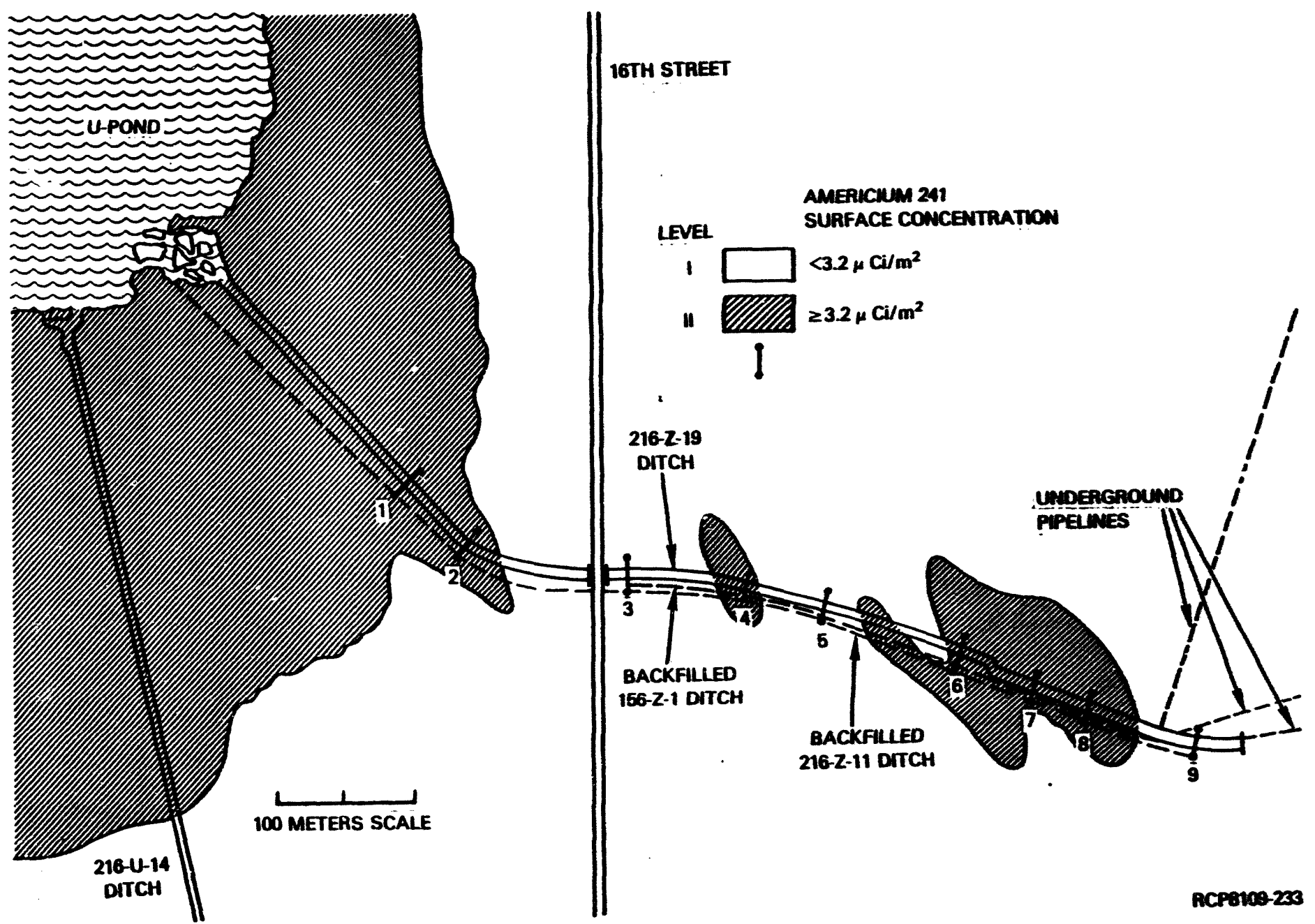

Figure 5.1. Transect Locations at the 216-Z-19 Ditch in Relation to ${ }^{241}$ Am Survey 


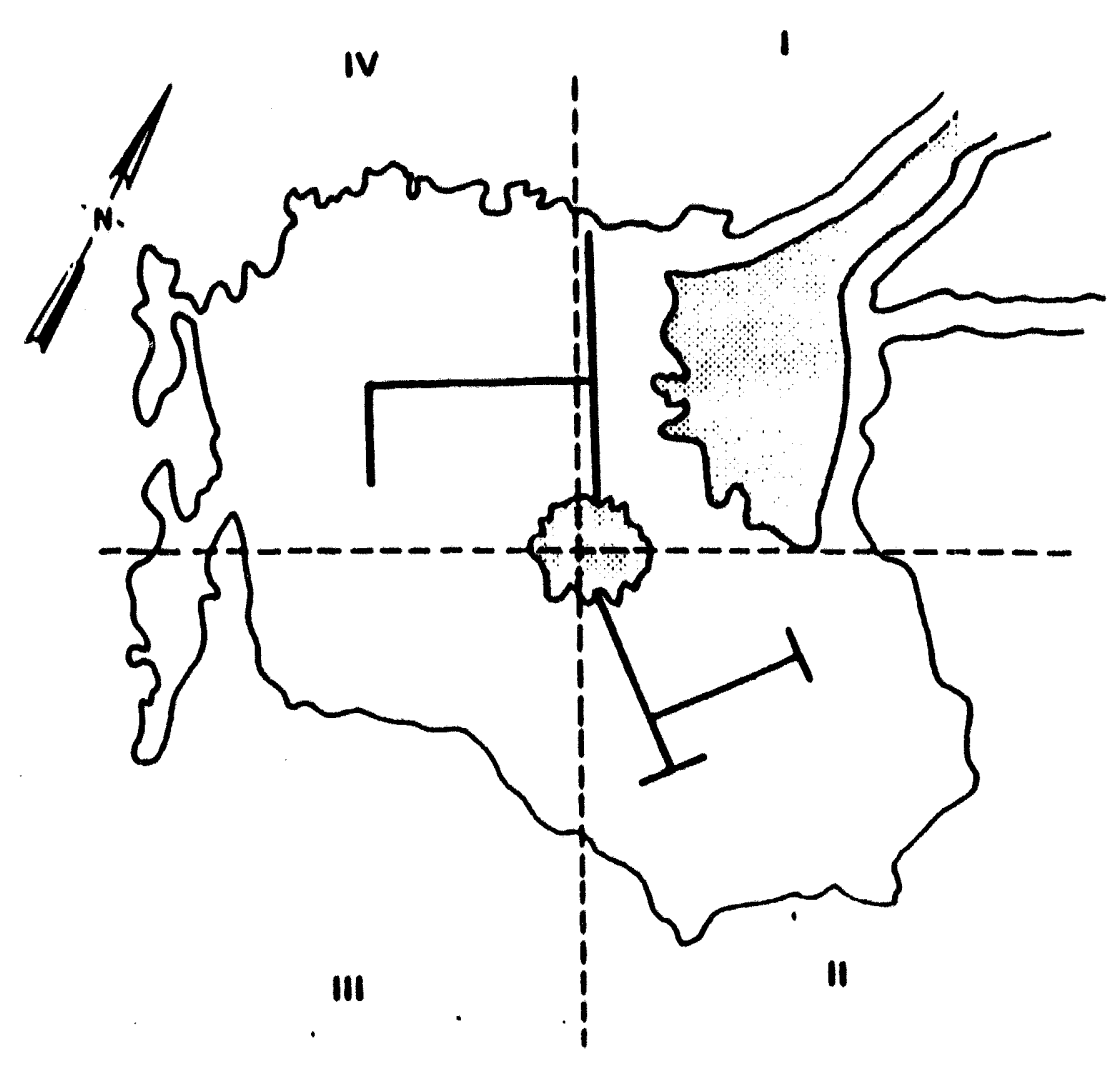

Figure 5.2. Quadrants Designated for Plant Sampling Locations at the 216-U-10 Pond

\section{Ditch-Bottom Sediment Sampling}

At point $\mathrm{C}$ for each Z-19 transect (see Figure 5.3), ditch-bottom sediment sampling was performed from a portable aluminum catwalk used to span the ditch (refer to Section 5.3.1 for details). A 2-m-long, 5-cm-diameter, thick-walled Lexan plastic pipe was manually driven $40 \mathrm{~cm}$ into the ditch sediment. The sediment sample remained intact as the pipe was extracted by suction created by an airtight rubber stopper inside the pipe. Following extraction, the sampling pipe was sawed into 0 - to 5-, 5- to 15-, and 15- to 30-cm lengths and every $10 \mathrm{~cm}$ after that. Samples from the center of each subcore were placed in prelabeled Petri dishes and surveyed by a radiation monitor for contamination. Selected sediment samples were analyzed at the Rockwell Laboratory for ${ }^{209,200} \mathrm{Pu}$ and ${ }^{2{ }_{1}} \mathrm{Am}$.

\section{Terrestrial Vegetation Sampling}

Terrestrial vegetation samples were collected for radioanalyses from the surface area bordering the Z-19 Ditch. Ten samples of tumbleweed (Salsoa kali) and five samples each of cheatgrass (Bromus tectorum) and Indian ricegrass (Oryzopsis hymenoides) were taken along the length of the ditch. Each tumbleweed and ricegrass sample consisted of one plant, while each cheatgrass sample was a composite 

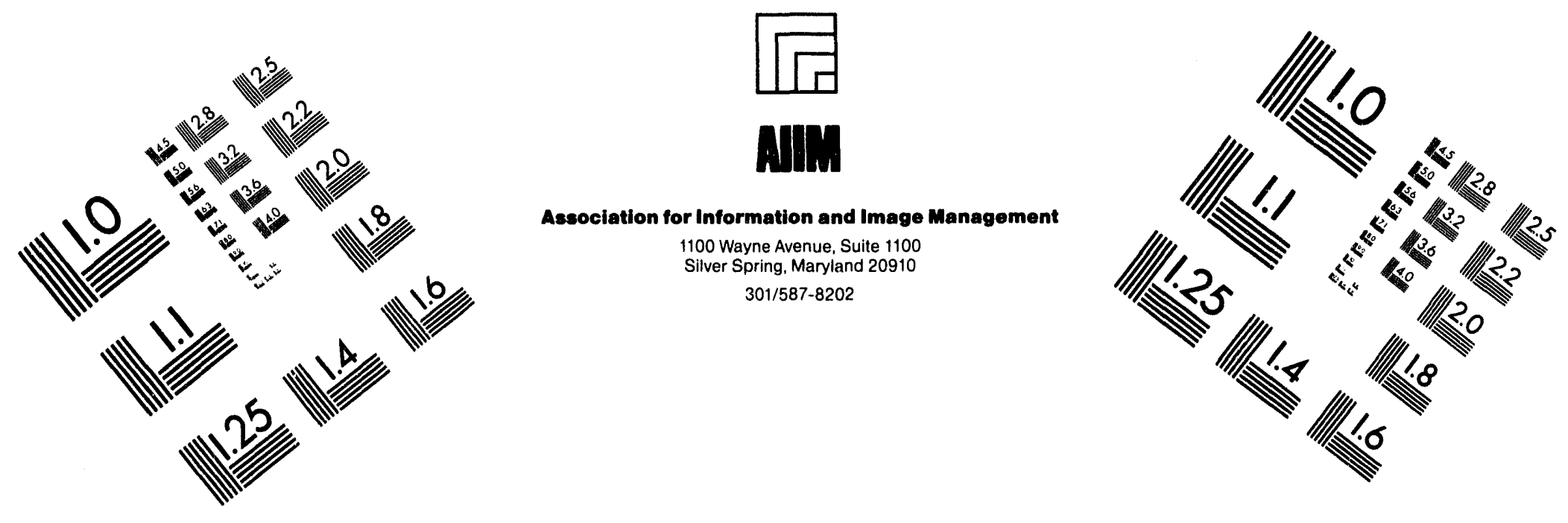

\section{Centimeter}

$\begin{array}{llllllllllllllll}1 & 2 & 3 & 4 & 5 & 6 & 7 & 8 & 9 & 10 & 11 & 12 & 13 & 14 & 15 & \mathrm{~mm}\end{array}$

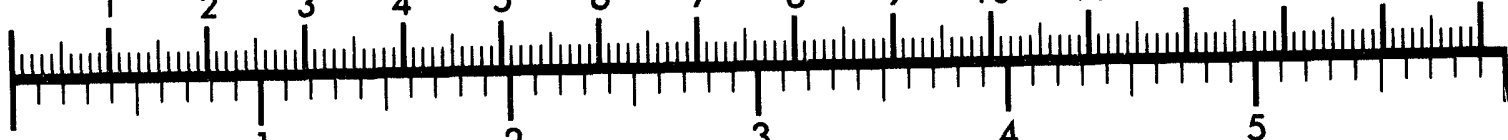
Inches
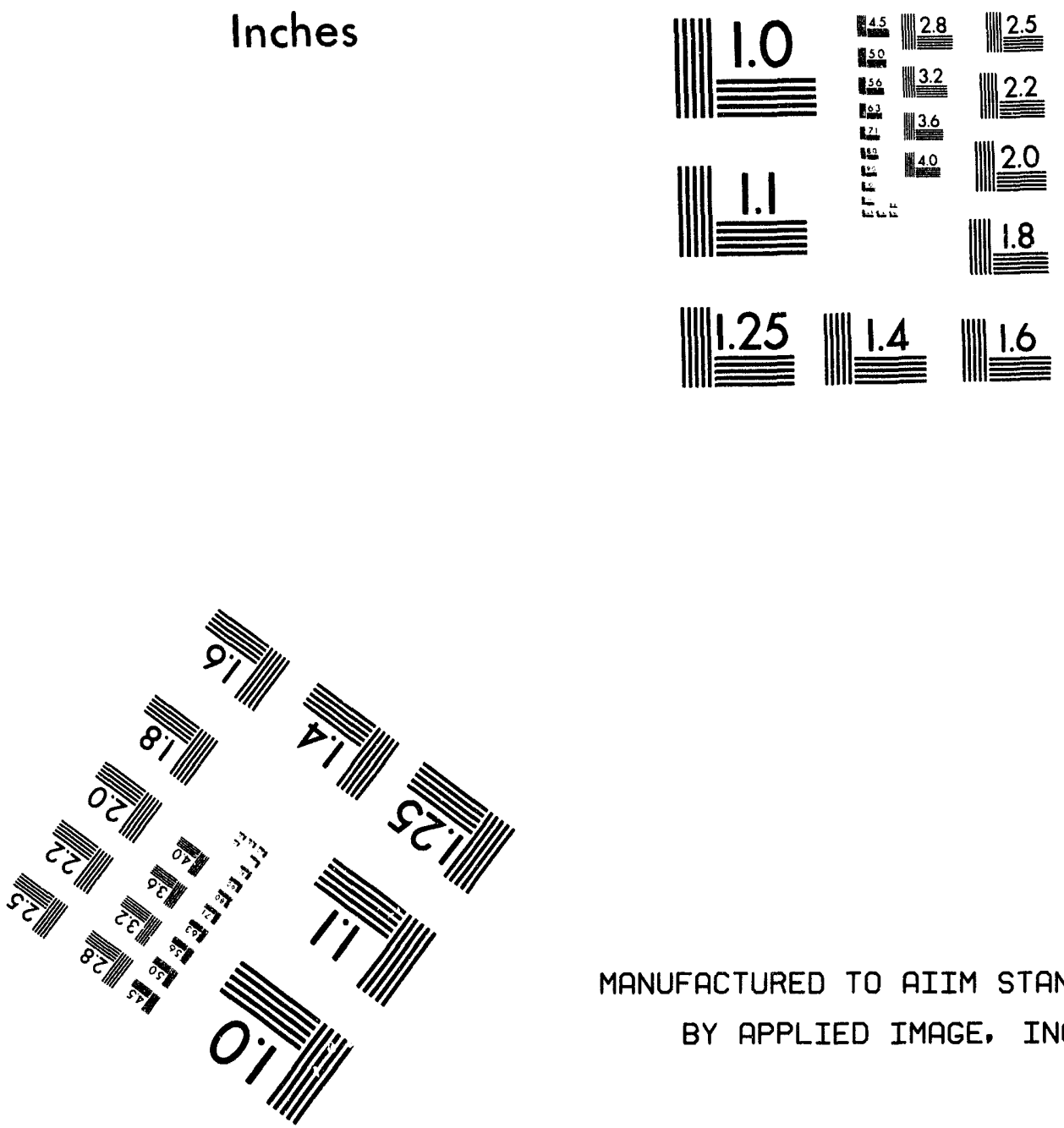

MANUFACTURED TO AIIM STANDARDS BY APPLIED IMAGE, INC.

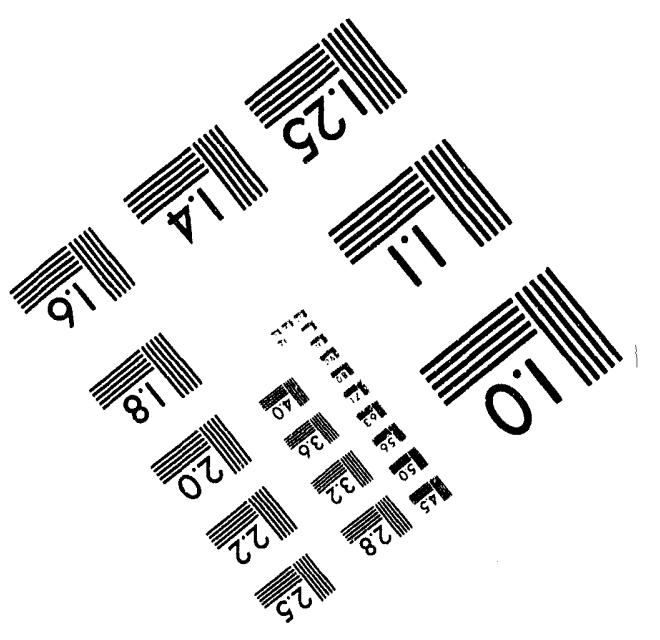



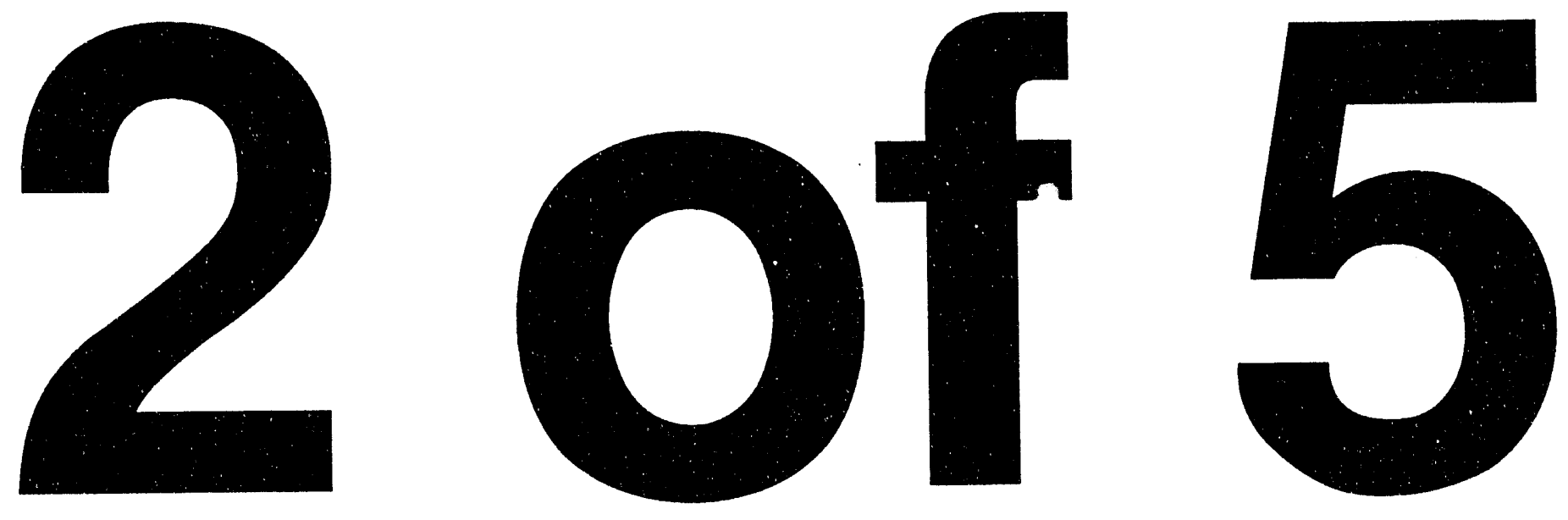


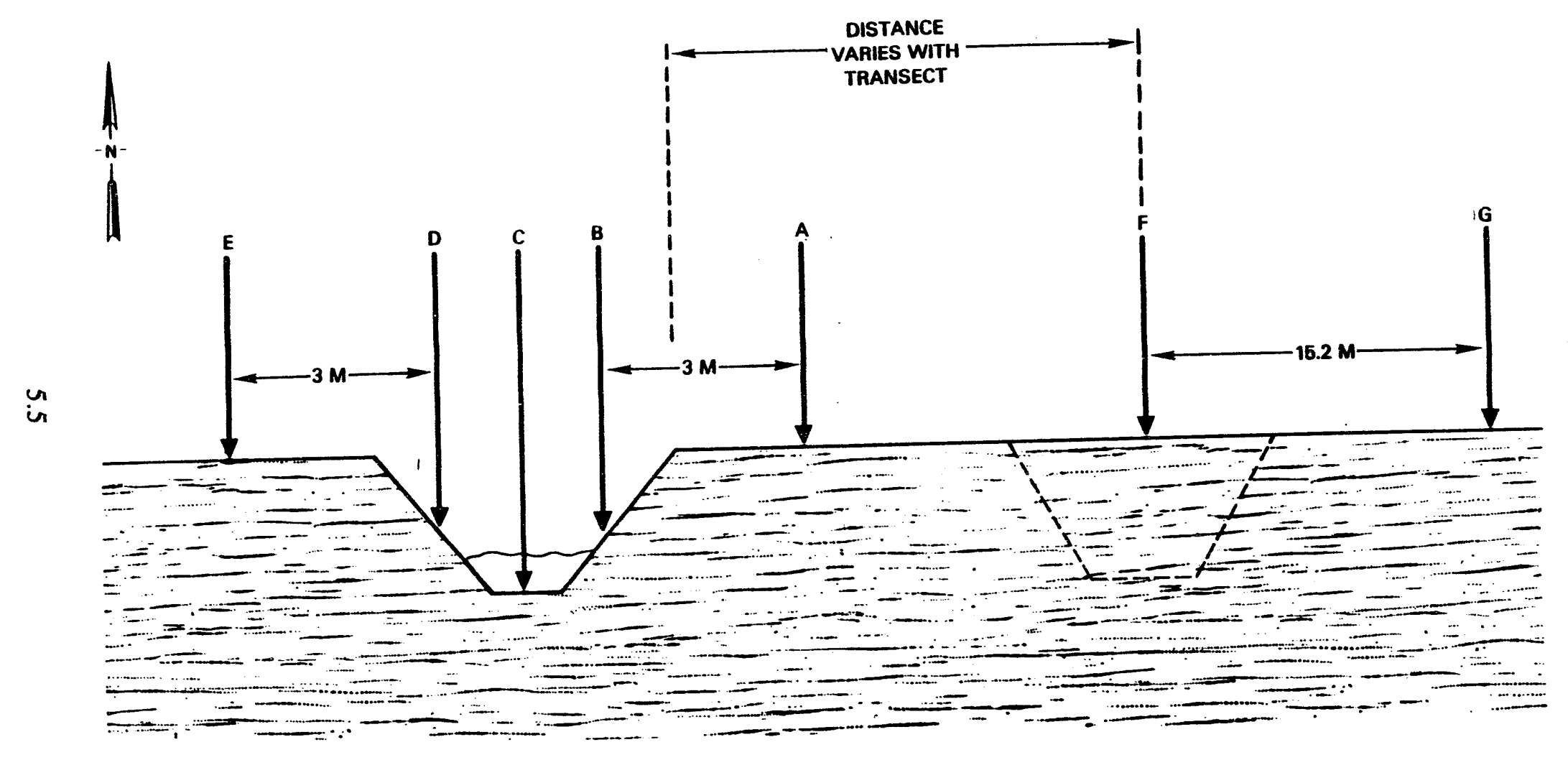

Figure 5.3. Cross Section of the 216-Z-19 Ditch Corridor, Showing Relative Locations of Shallow Core Samples Taken Along Each Transect 
WHC-EP-0707, Rev. 0

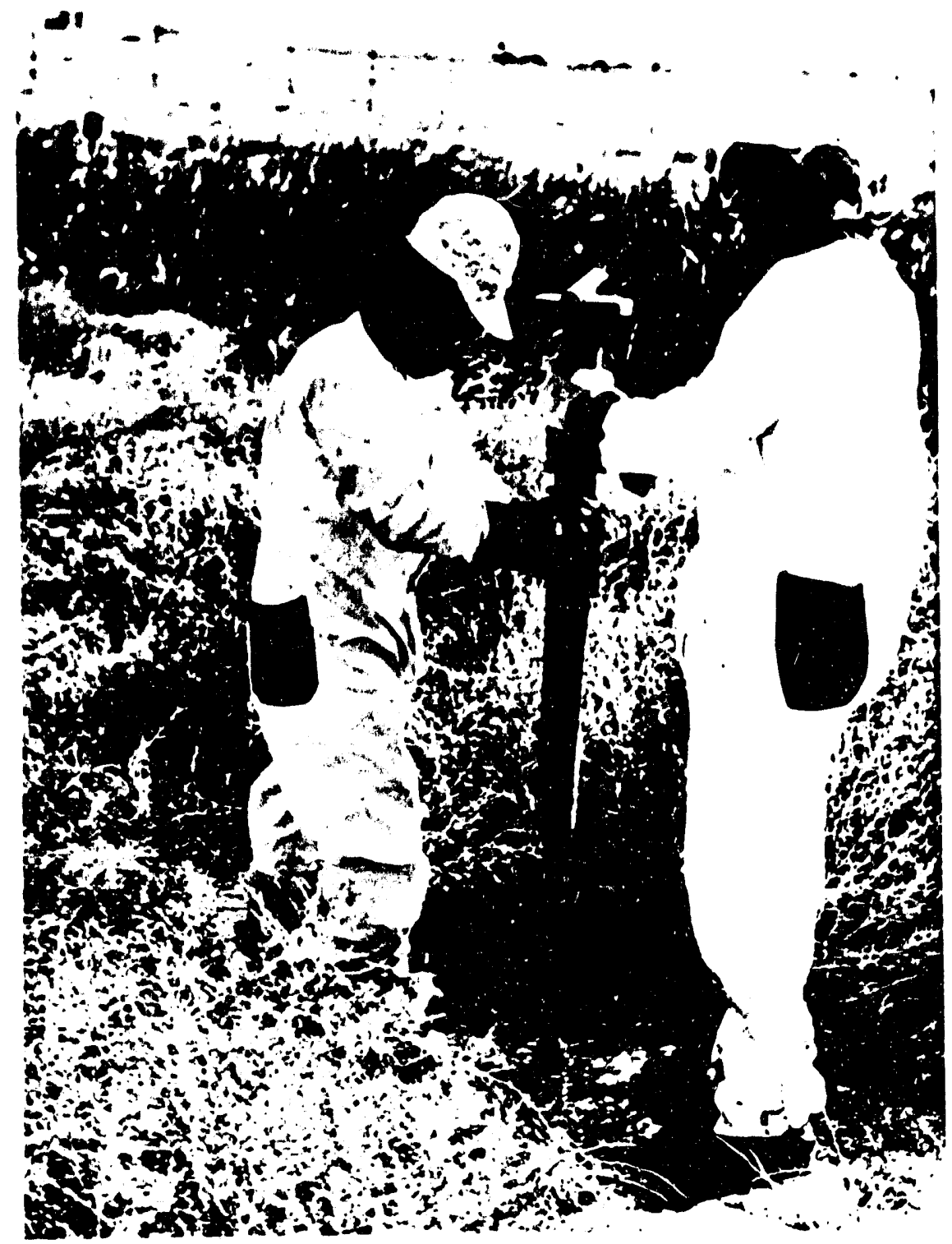

Figure 5.4. Shallow Core Soil Sampling Along the 216-Z-19 Ditch Transects 


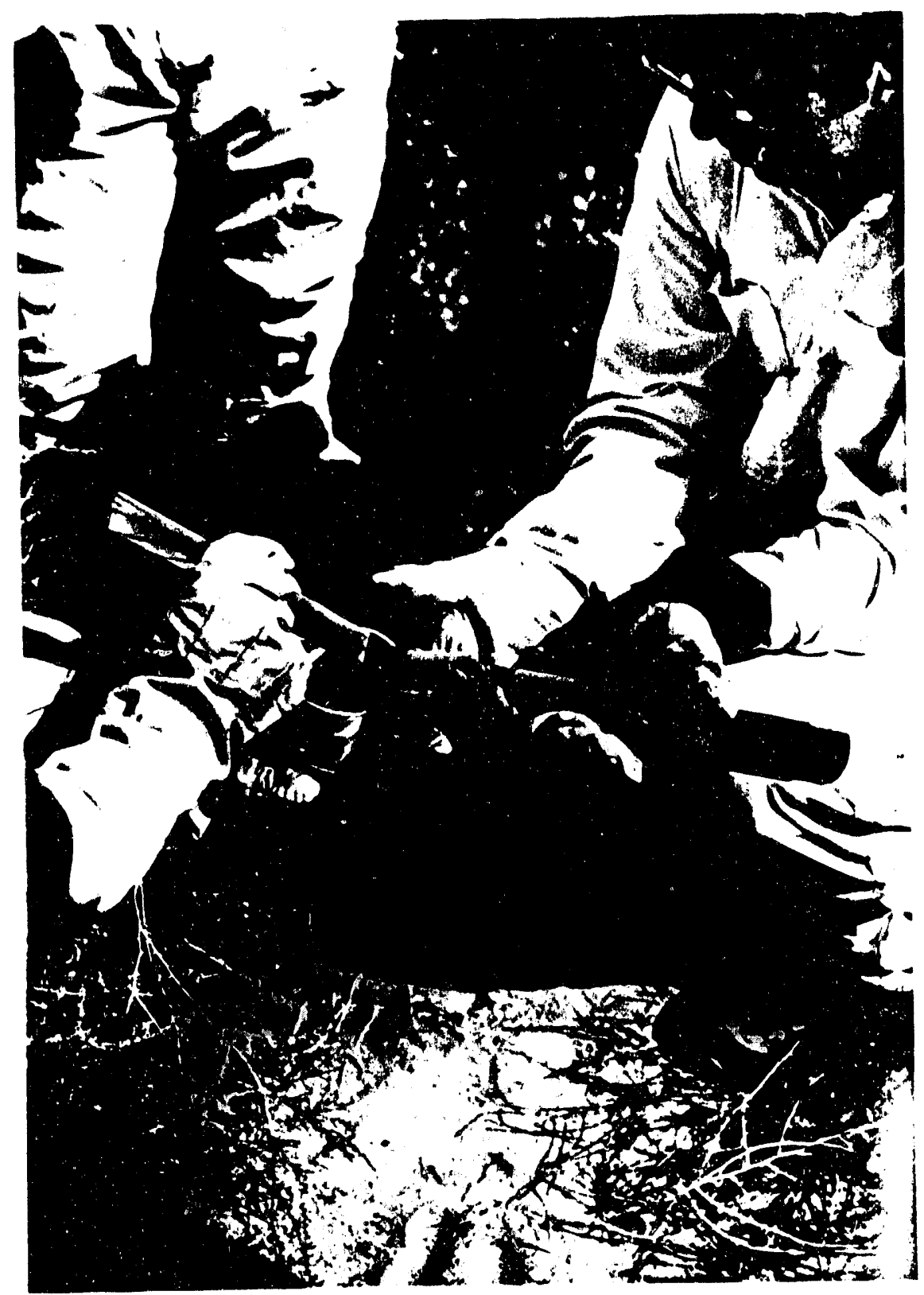

Figure 5.5. Subsampling of the Retrieved Soil Cores 
of 20 to 30 plants. Only aboveground portions of the three species were taken. Tumbleweed samples were taken from both sides of the ditch at odd-numbered transects (see Figure 5.1). One cheatgrass sample and one ricegrass sample were taken from the east side of the ditch at odd-numbered transects. Samples were placed in prelabeled paper bags and sealed with tape. The Rockwell Laboratory analyzed the samples for ${ }^{90} \mathrm{Sr},{ }^{299,240} \mathrm{Pu},{ }^{241} \mathrm{Am}$, and gamma energy emitters. At U-Pond, leaf and twig samples from peachleaf willows and cottonwoods were clipped at breast height $(1.3 \mathrm{~m})$ from each of the 10 trees sampled per quadrant. On at least six of these trees, leaf and twig samples were also taken at a height of $4.5 \mathrm{~m}$. Tree core and root samples were taken from at least two of the trees in each quadrant. Core samples were extracted with a hand drill and an axe was used to collect root samples. The outermost root layer was peeled off to minimize contamination from adhering sediment. At least one sandbar willow leaf and twig sample was taken per quadrant from near one of the tree samples. These samples were clipped at breast height. All vegetation samples were placed in prelabeled paper bags lined with plastic bags and air dried. They were sent to U.S. Testing for GEAs. Based on these results, ${ }^{90} \mathrm{Sr}$ and/or ${ }^{239,240} \mathrm{Pu}$ analyses were requested for selected samples.

\section{Animal Sampling}

Small mammal sampling was conducted along the west side of the Z-19 Ditch. Museum-special snap traps were baited with grain and placed in pairs near the edge of the ditch depression at each of the nine transects. All nine transects were represented, with a minimum sample of one animal. Data, including species, weight, sex, reproductive condition, abnormalities, and catch location, were recorded for each animal. Museum-special snap traps were placed near the Z-19 and 216-U-14 (U-14) ditch inlets to the pond in quadrant I, with a few in quadrants II and IV. A total of 20 mice were trapped at U.Pond. All animal samples collected were submitted to U.S. Testing for ${ }^{90} \mathrm{Sr}$, ${ }^{239,240} \mathrm{Pu}$, and GEAs.

\section{Cover-Class Evaluation}

Daubenmire's (1959) method for canopy-cover evaluation was used to characterize the Z-19 Ditch vegetation. The ditch was divided into individual segments of $20 \mathrm{~m}$ each. For each of these segments, a cover-class estimate was assigned to individual plant species growing within the ditch. Absolute cover, relative cover, absolute frequency, and relative frequency for each species were determined from these data.

At the same time the cover-class evaluations were performed, the Z-19 Ditch vegetation was mapped. Perimeters for each species distribution were drawn as they occurred within 5-m intervals along the ditch. A planimeter was used in conjunction with the map to determine the total ditch area covered by each plant species. This information was utilized il determining the number and types of aquatic vegetation samples to be collected and in biomass estimations. 


\section{Aquatic Vegetation Sampling}

A total of 35 aquatic vegetation samples were collected from the Z-19 Ditch. Species included willow, cattail, bulrush, smartweed, thistle (Cirsium brevifolium), horseweed (Conyza canadensis), and wild lettuce (Lactuca serriola). Cattail and bulrush species were considered as one lifeform. Two of these plants were included per sample. Samples of the remaining plant species consisted of the total growth of a species that was located inside a $1 / 10-\mathrm{m}$ plot frame. Density estimates were made using the 1/10-m plot frame. All samples included both above- and belowground plant parts. Sediment was removed from the roots by washing or peeling off the outermost layer. The plants were cut into small pieces and placed in plastic bags to air dry. They were transported to U.S. Testing for ${ }^{90} \mathrm{Sr},{ }^{239.240} \mathrm{Pu}$, and GEAs.

\section{Point-Quarter and Biomass}

Tree density, frequency, and cover at U-Pond were estimated by using the point-quarter method (Cottam and Curtis 1956; Greigh-Smith 1964). Concurrently, tree-height measurements were taken using a range finder. These measurements were used in estimating tree biomass. Biomass equations best suited for the area were determined after consulting with Dr. Richard Waring (Oregon State University) and reviewing several research papers (Grier and Waring 1974; Waring et al. 1977; Gholz et al. 1979). Specific equations used were:

$$
\begin{gathered}
Y_{1}=0.02+2.09 X-0.0015 \mathrm{X}^{2} \\
Y_{2}=0.5124+0.1298 \mathrm{X}
\end{gathered}
$$

where $Y_{1}=$ total aboveground wood plus bark biomass

$Y_{2}=$ total foliage biomass

$\mathrm{X}=\mathrm{DBH}^{2} \times \mathrm{HTO} / 100$ (DBH = stem diameter at breast height and HTO = plant height). Biomass is expressed in kilograms.

Biomass estimites were also made for the Z-19 Ditch aquatic vegetation species. Average density per square meter was multiplied by average dry weight to estimate unit biomass. Multiplying this figure by the total area covered by a species resulted in total Z-19 Ditch biomass for that species.

\subsubsection{Sampling Results for the 216-Z-19 Ditch}

\section{Sediment}

In the top $5 \mathrm{~cm}$ of the ditch bottom, values for $239,240 \mathrm{Pu}$ ranged from 160 to $97,800 \mathrm{pCi} / \mathrm{g}$ (Figure 5.6) and ${ }^{241} \mathrm{Am}$ values ranged from 89 to $29,000 \mathrm{pCi} / \mathrm{g}$ (Table 5.1 and Figure 5.7). On transects 1 to 7 , all of the plutonium values were above $1300 \mathrm{pCi} / \mathrm{g}$. The average value of ${ }^{239,240} \mathrm{Pu}$ was $20,139 \mathrm{pCi} / \mathrm{g}$, and the average value for ${ }^{241} \mathrm{Am}$ was $4697 \mathrm{pCi} / \mathrm{g}$. Additional information on the ditchbottom sediments is provided in Section 5.3.2. 


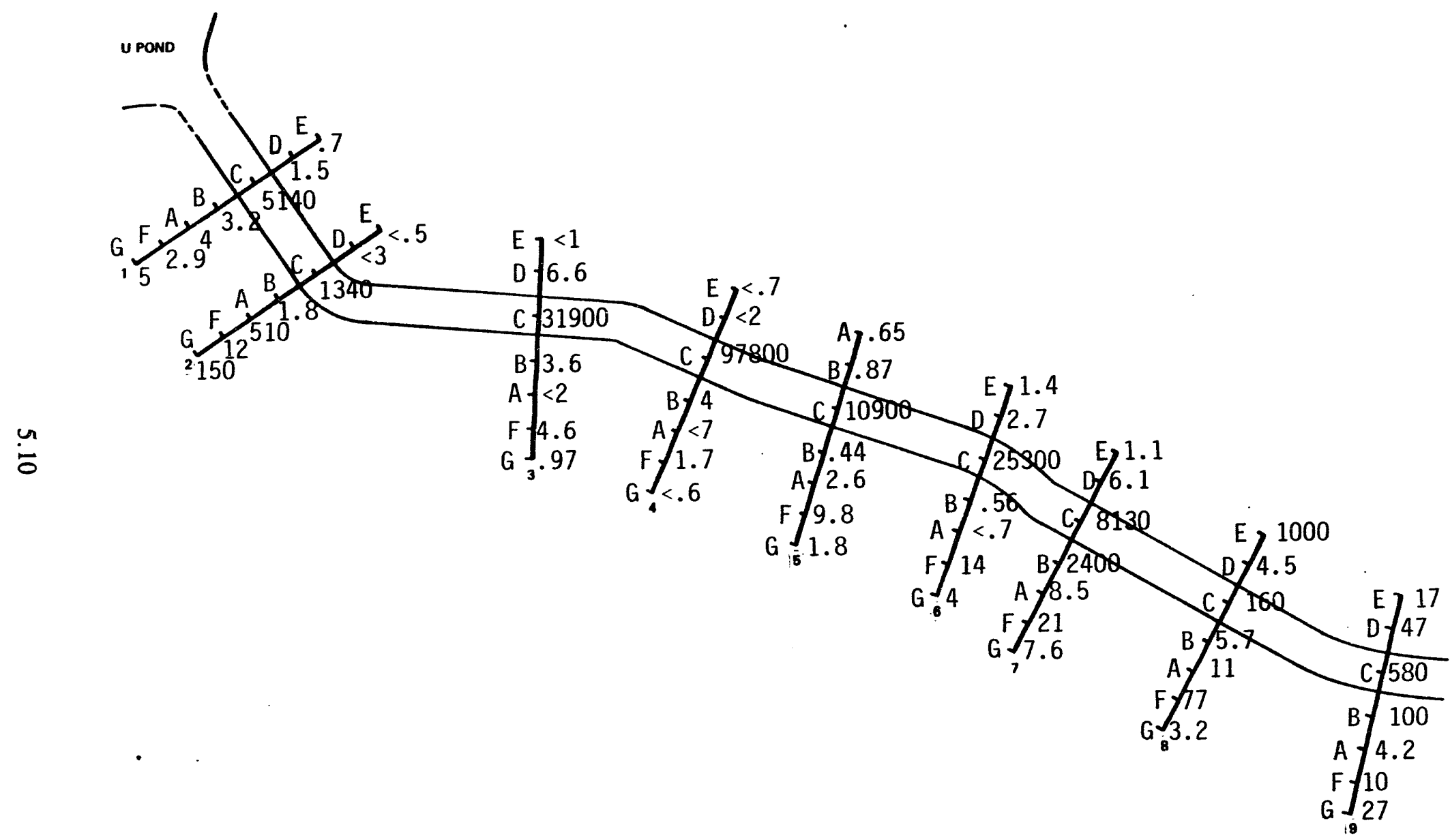

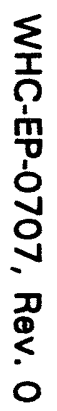

Figure 5.6. Values of ${ }^{299.240} \mathrm{Pu}(\mathrm{pCi} / \mathrm{g})$ in Soil $(0$ to $15 \mathrm{~cm})$ at the $216-\mathrm{Z}-19$ Ditch 
WHC-EP-0707, Rev. 0

Table 5.1. Values for ${ }^{89.90} \mathrm{Sr},{ }^{137} \mathrm{Cs},{ }^{239.240} \mathrm{Pu}$, and ${ }^{241} \mathrm{Am}$ in Sediment and Soil Samples Collected from the 216-Z-19 Ditch

\begin{tabular}{|c|c|c|c|c|c|c|}
\hline \multirow[b]{2}{*}{ Transect } & \multirow[b]{2}{*}{ Sample Point } & \multirow[b]{2}{*}{ Depth $(\mathrm{cm})$} & \multicolumn{4}{|c|}{ Concentration in $\mathrm{pCi} / \mathrm{g}$} \\
\hline & & & ${ }^{39,90} \mathrm{Sr}^{(\mathrm{w})}$ & ${ }^{137} \mathrm{Cs}$ & ${ }^{259.240} \mathrm{Pu}^{(\mathrm{u})}$ & ${ }^{2 * 1} \mathrm{Am}^{(\omega)}$ \\
\hline 1 & $\bar{A}$ & 0 to 5 & & $<0.33$ & 4.00 & $<0.90$ \\
\hline 1 & A & 5 to 15 & & $<0.31$ & 4.00 & $<0.90$ \\
\hline 1 & $A$ & 15 to 30 & & $<0.33$ & 1.10 & $<0.40$ \\
\hline 1 & B & 0 to 5 & & $<0.31$ & 3.20 & $<0.90$ \\
\hline 1 & B & 5 to 15 & & 1.47 & 3.20 & $<0.90$ \\
\hline 1 & B & 15 to 30 & & $<0.33$ & 5.00 & $<0.50$ \\
\hline 1 & C & 0 to 5 & & & 5140.00 & 121.00 \\
\hline 1 & D & 0 to 5 & & $<0.31$ & 1.50 & $<0.80$ \\
\hline 1 & D & 5 to 15 & & 1.01 & 1.50 & $<0.80$ \\
\hline 1 & D & 15 to 30 & & $<0.25$ & $<0.70$ & $<0.60$ \\
\hline 1 & E & 0 to 5 & & $<0.43$ & 0.70 & $<0.70$ \\
\hline 1 & $\mathbf{E}$ & 5 to 15 & & $<0.50$ & 0.70 & $<0.70$ \\
\hline 1 & E & 15 to 30 & & $<0.25$ & 1.10 & $<0.60$ \\
\hline 1 & $\mathbf{F}$ & 0 to 5 & & 1.80 & 2.90 & $<0.70$ \\
\hline 1 & $\mathbf{F}$ & 5 to 15 & & $<0.10$ & 2.90 & $<0.70$ \\
\hline 1 & $\mathbf{F}$ & 15 to 30 & & $<0.10$ & 0.41 & $<0.50$ \\
\hline 1 & G & 0 to 5 & & $<0.40$ & 5.00 & $<0.70$ \\
\hline 1 & o & 5 to 15 & & 0.80 & 5.00 & $<0.70$ \\
\hline 1 & G & 15 to 30 & & $<0.10$ & 0.67 & $<0.60$ \\
\hline 2 & A & 0 to 5 & 0.96 & $<0.62$ & 510.00 & 64.00 \\
\hline 2 & A & 5 to 15 & 0.96 & $<0.34$ & 510.00 & 64.00 \\
\hline 2 & $A$ & 15 to 30 & & $<0.35$ & 1600.00 & 160.00 \\
\hline 2 & B & 0 to 5 & 1.00 & $<0.59$ & 1.80 & $<0.90$ \\
\hline 2 & B & 5 to 15 & 1.00 & $<0.48$ & 1.80 & $<0.90$ \\
\hline 2 & B & 15 to 30 & & $<0.36$ & 3.70 & $<0.60$ \\
\hline 2 & C & 0 to 5 & & & 1340.00 & 232.00 \\
\hline 2 & D & 0 to 5 & $<0.90$ & $<0.29$ & $<3.00$ & $<0.70$ \\
\hline 2 & D & 5 to 15 & $<0.90$ & $<0.28$ & $<3.00$ & $<0.70$ \\
\hline 2 & D & 15 to 30 & & $<0.36$ & $<0.80$ & $<0.50$ \\
\hline 2 & E & 0 to 5 & & 0.97 & $<0.50$ & $<0.80$ \\
\hline 2 & E & 5 to 15 & & $<0.35$ & $<0.50$ & $<0.80$ \\
\hline 2 & E & 15 to 30 & & $<0.58$ & 4.00 & $<0.40$ \\
\hline 2 & $F$ & 0 to 5 & & $<0.40$ & 12.00 & $<0.70$ \\
\hline 2 & $F$ & 5 to 15 & & $<0.10$ & 12.00 & $<0.70$ \\
\hline 2 & $\mathrm{~F}$ & 15 to 30 & & 0.37 & 2.20 & $<0.50$ \\
\hline
\end{tabular}


WHC-EP-0707, Rev. 0

Table 5.1. (contd)

\begin{tabular}{|c|c|c|c|c|c|c|}
\hline \multirow[b]{2}{*}{ Transect } & \multirow[b]{2}{*}{ Sample Point } & \multirow[b]{2}{*}{ Depth (cm) } & \multicolumn{4}{|c|}{ Concentration in $\mathrm{pCi} / \mathrm{g}$} \\
\hline & & & ${ }^{89.90} \mathrm{Sr}^{(4)}$ & ${ }^{137} \mathrm{Cs}$ & ${ }^{239,200} \mathrm{Pu}^{(2)}$ & ${ }^{221} \mathrm{Am}^{(\omega)}$ \\
\hline 2 & G & 0 to 5 & & 0.14 & 150.00 & 21.00 \\
\hline 2 & $\mathbf{0}$ & 5 to 15 & & 0.46 & 150.00 & 21.00 \\
\hline 2 & o & 15 to 30 & & $<0.10$ & 34.00 & $<0.50$ \\
\hline 3 & A & 0 to 5 & & $<0.35$ & $<2.00$ & $<0.70$ \\
\hline 3 & $\mathbf{A}$ & 5 to 15 & & 1.44 & $<2.00$ & $<0.70$ \\
\hline 3 & A & 15 to 30 & & $<0.34$ & 0.40 & $<0.40$ \\
\hline 3 & B & 0 to 5 & $<1.00$ & $<0.34$ & 3.60 & $<0.70$ \\
\hline 3 & B & 5 to 15 & $<1.00$ & $<0.35$ & 3.60 & $<0.70$ \\
\hline 3 & B & 15 to 30 & & $<0.36$ & $<0.80$ & $<0.40$ \\
\hline 3 & C & 0 to 5 & & & $31,900.00$ & 6550.00 \\
\hline 3 & D & 0 to 5 & $<1.00$ & $<0.48$ & 6.60 & $<0.60$ \\
\hline 3 & D & 5 to 15 & $<1.00$ & $<0.36$ & 6.60 & $<0.60$ \\
\hline 3 & D & 15 to 30 & & $<0.60$ & $<2.00$ & $<0.90$ \\
\hline 3 & E & 0 to 5 & & 1.32 & $<1.00$ & $<0.90$ \\
\hline 3 & E & 5 to 15 & & $<0.35$ & $<1.00$ & $<0.90$ \\
\hline 3 & E & 15 to 30 & & $<0.68$ & $<4.00$ & $<0.70$ \\
\hline 3 & $\mathbf{F}$ & 0 to 5 & & 27.0 & 4.60 & $<1.00$ \\
\hline 3 & $\mathbf{F}$ & 5 to 15 & & $<0.3$ & 4.60 & $<1.00$ \\
\hline 3 & $\mathbf{F}$ & 15 to 30 & & $<0.1$ & 0.97 & $<0.50$ \\
\hline 3 & o & 0 to 5 & & $<0.7$ & 24.00 & $<0.70$ \\
\hline 3 & o & 5 to 15 & & $<0.1$ & 24.00 & $<0.70$ \\
\hline 3 & o & 15 to 30 & & $<0.1$ & 0.51 & $<0.80$ \\
\hline 4 & A & 0 to 5 & 0.73 & $<0.32$ & $<7.00$ & $<0.90$ \\
\hline 4 & A & 5 to 15 & 0.73 & $<0.35$ & $<7.00$ & $<0.90$ \\
\hline 4 & A & 15 to 30 & 340 & $<0.35$ & 0.60 & $<1.00$ \\
\hline 4 & B & 0 to 5 & 3.40 & $<0.35$ & 4.00 & $<1.00$ \\
\hline 4 & B & 5 to 15 & & $<0.33$ & 4.00 & $<1.00$ \\
\hline 4 & B & 15 to 30 & & $<0.36$ & 1.00 & $<1.00$ \\
\hline 4 & C & 0 to 5 & & & $97,800.00$ & 504.00 \\
\hline 4 & D & 0 to 5 & $<1.00$ & $<0.35$ & $<2.00$ & 11.00 \\
\hline 4 & D & 5 to 15 & $<1.00$ & $<0.35$ & $<2.00$ & 11.00 \\
\hline 4 & D & 15 to 30 & & $<0.35$ & 1.70 & $<0.80$ \\
\hline 4 & E & 0 to 5 & & 1.95 & $<0.70$ & $<0.70$ \\
\hline 4 & E & 5 to 15 & & $<0.54$ & $<0.70$ & $<0.70$ \\
\hline 4 & $\mathbf{E}$ & 15 to 30 & & $<0.34$ & 3.10 & $<0.60$ \\
\hline
\end{tabular}


WHC-EP-0707, Rev. 0

Table 5.1. (contd)

\begin{tabular}{|c|c|c|c|c|c|c|}
\hline \multirow[b]{2}{*}{ Transect } & \multirow[b]{2}{*}{ Sample Point } & \multirow[b]{2}{*}{ Depth $(\mathrm{cm})$} & \multicolumn{4}{|c|}{ Concentration in $\mathrm{pCi} / \mathrm{g}$} \\
\hline & & & ${ }^{89,90} \mathrm{Sr}^{(2)}$ & ${ }^{177} \mathrm{Cs}$ & ${ }^{239,240} \mathrm{Pu}^{(2)}$ & ${ }^{241} \mathrm{Am}^{(n)}$ \\
\hline 4 & $\mathbf{F}$ & 0 to 5 & & $<0.40$ & 1.70 & $<0.50$ \\
\hline 4 & $\mathbf{F}$ & 5 to 15 & & $<0.20$ & 1.70 & $<0.50$ \\
\hline 4 & $\mathbf{F}$ & 15 to 30 & & $<0.10$ & 0.44 & $<0.50$ \\
\hline 4 & G & 0 to 5 & & $<0.40$ & $<0.60$ & $<0.90$ \\
\hline 4 & o & 5 to 15 & & $<0.10$ & $<0.60$ & $<0.90$ \\
\hline 4 & o & 15 to 30 & & $<0.10$ & 0.33 & $<0.50$ \\
\hline 5 & $\mathbf{A}$ & 0 to 5 & & $<0.46$ & 2.60 & $<0.70$ \\
\hline 5 & $\mathbf{A}$ & 5 to 15 & & $<0.54$ & 2.60 & $<0.70$ \\
\hline 5 & $\mathbf{A}$ & 15 to 30 & & $<0.34$ & $<0.80$ & $<0.60$ \\
\hline 5 & B & 0 to 5 & & $<0.36$ & 0.44 & $<1.00$ \\
\hline 5 & B & 5 to 15 & & $<0.34$ & 0.44 & $<1.00$ \\
\hline 5 & B & 15 to 30 & & $<0.34$ & 0.91 & $<0.60$ \\
\hline 5 & C & 0 to 5 & & & $10,900.00$ & 3450.00 \\
\hline 5 & D & 0 to 5 & & $<0.45$ & 0.87 & $<0.80$ \\
\hline 5 & D & 5 to 15 & & $<0.48$ & 0.87 & $<0.80$ \\
\hline 5 & D & 15 to 30 & & $<0.36$ & 1.10 & $<0.90$ \\
\hline 5 & E & 0 to 5 & & $<0.47$ & 0.65 & $<0.90$ \\
\hline 5 & $\mathbf{E}$ & 5 to 15. & & $<0.34$ & 0.65 & $<0.90$ \\
\hline 5 & $\mathbf{E}$ & 15 to 30 & & $<0.35$ & 3.00 & $<0.70$ \\
\hline 5 & $\mathbf{F}$ & 0 to 5 & & $<0.40$ & 9.80 & $<1.00$ \\
\hline 5 & $F$ & 5 to 15 & & $<0.20$ & 9.80 & $<1.00$ \\
\hline 5 & F & 15 to 30 & & $<0.20$ & 11.00 & $<0.60$ \\
\hline 5 & G & 0 to 5 & & 2.0 & 1.80 & $<0.60$ \\
\hline 5 & $\sigma$ & 5 to 15 & & 1.10 & 1.80 & $<0.60$ \\
\hline 5 & G & 15 to 30 & & $<0.10$ & $<0.70$ & $<0.70$ \\
\hline 6 & A & 0 to 5 & & $<0.34$ & $<0.70$ & $<0.70$ \\
\hline 6 & A & 5 to 15 & & $<0.33$ & $<0.70$ & $<0,70$ \\
\hline 6 & A & 15 to 30 & & $<0.26$ & 2.70 & $<0.70$ \\
\hline 6 & B & 0 to 5 & & $<0.33$ & 0.56 & $<0.80$ \\
\hline 6 & B & 5 to 15 & & $<0.35$ & 0.56 & $<0.80$ \\
\hline 6 & B & 15 to 30 & & $<0.35$ & $<0.60$ & $<0.90$ \\
\hline 6 & C & 0 to 5 & & & $25,300.00$ & 1170.00 \\
\hline 6 & D & 0 to 5 & & $<0.35$ & 2.70 & $<0.80$ \\
\hline 6 & D & 5 to 15 & & $<0.34$ & 2.70 & $<0.80$ \\
\hline 6 & $D$ & 15 to 30 & & $<0.66$ & 1.20 & $<0.60$ \\
\hline
\end{tabular}


WHC-EP-0707, Rev. 0

Table 5.1. (contd)

\begin{tabular}{|c|c|c|c|c|c|c|}
\hline \multirow[b]{2}{*}{ Transect } & \multirow[b]{2}{*}{ Sample Point } & \multirow[b]{2}{*}{ Depth $(\mathrm{cm})$} & \multicolumn{4}{|c|}{ Concentration in $\mathrm{pCi} / \mathrm{g}$} \\
\hline & & & ${ }^{90,90} \mathrm{Sr}^{(\mathrm{al})}$ & ${ }^{137} \mathrm{Cs}$ & ${ }^{299,200} \mathrm{Pu}^{(2)}$ & ${ }^{241} \mathrm{Am}^{(4)}$ \\
\hline 6 & $\mathbf{E}$ & 0 to 5 & & $<0.32$ & 1.40 & $<1.00$ \\
\hline 6 & E & 5 to 15 & & $<0.36$ & 1.40 & $<1.00$ \\
\hline 6 & $\mathbf{E}$ & 15 to 30 & & $<0.35$ & 1.40 & $<0.90$ \\
\hline 6 & $\mathbf{F}$ & 0 to 5 & & 2.20 & 14.00 & 2.80 \\
\hline 6 & $\mathbf{F}$ & 5 to 15 & & $<0.40$ & 14.00 & 2.80 \\
\hline 6 & $\mathbf{F}$ & 15 to 30 & & $<0.10$ & $<0.60$ & $<0.60$ \\
\hline 6 & G & 0 to 5 & & 1.50 & 4.00 & $<1.30$ \\
\hline 6 & o & 5 to 15 & & $<0.20$ & 4.00 & $<1.30$ \\
\hline 6 & o & 15 to 30 & & $<0.10$ & $<2.00$ & $<0.70$ \\
\hline 7 & A & 0 to 5 & & $<0.34$ & 8.50 & $<1.00$ \\
\hline 7 & A & 5 to 15 & & $<0.59$ & 8.50 & $<1.00$ \\
\hline 7 & $\mathbf{A}$ & 15 to 30 & & $<0.36$ & 50.00 & 5.40 \\
\hline 7 & B & 0 to 5 & & $<0.36$ & 2400.00 & 150.00 \\
\hline 7 & B & 5 to 15 & & $<0.36$ & 2400.00 & 150.00 \\
\hline 7 & B & 15 to 30 & & $<0.36$ & 2.20 & $<1.00$ \\
\hline 7 & C & 0 to 5 & & & 8130.00 & 1160.00 \\
\hline 7 & D & 0 to 5 & & $<0.36$ & 6.10 & $<0.70$ \\
\hline 7 & D & 5 to 15 & & $<0.36$ & 6.10 & $<0.70$ \\
\hline 7 & D & 15 to 30 & & $<0.36$ & 1.40 & $<0.80$ \\
\hline 7 & E & 0 to 5 & & $<0.65$ & 1.10 & $<0.80$ \\
\hline 7 & $\mathbf{E}$ & 5 to 15 & & $<0.36$ & 1.10 & $<0.80$ \\
\hline 7 & E & 15 to 30 & & $<0.35$ & 2.50 & $<2.00$ \\
\hline 7 & F & 0 to 5 & & 1.20 & 21.00 & $<1.10$ \\
\hline 7 & $\mathbf{F}$ & 5 to 15 & & $<0.20$ & 21.00 & $<1.10$ \\
\hline 7 & $\mathbf{F}$ & 15 to 30 & & 0.30 & 440.00 & 0.60 \\
\hline 7 & G & 0 to 5 & & 1.40 & 7.60 & $<0.60$ \\
\hline 7 & o & 5 to 15 & & $<0.10$ & 7.60 & $<0.60$ \\
\hline 7 & G & 15 to 30 & & $<0.10$ & 2.00 & $<0.50$ \\
\hline 8 & $\mathbf{A}$ & 0 to 5 & & $<0.35$ & 11.00 & $<2.00$ \\
\hline 8 & A & 5 to 15 & & $<0.35$ & 11.00 & $<2.00$ \\
\hline 8 & $A$ & 15 to 30 & & $<0.35$ & 8.40 & $<0.60$ \\
\hline 8 & B & 0 to 10 & & $<0.32$ & 5.70 & $<0.60$ \\
\hline 8 & $B$ & 5 to 15 & & $<0.36$ & 5.70 & $<0.60$ \\
\hline 8 & B & 15 to 30 & & $<0.33$ & 2.30 & $<0.70$ \\
\hline 8 & C & 0 to 10 & & & 160.00 & 2900.00 \\
\hline
\end{tabular}


WHC-EP-0707, Rev. 0

Table 5.1. (contd)

\begin{tabular}{|c|c|c|c|c|c|c|}
\hline \multirow[b]{2}{*}{ Transect } & \multirow[b]{2}{*}{ Sample Point } & \multirow[b]{2}{*}{ Depth (cm) } & \multicolumn{4}{|c|}{ Concentration in $\mathrm{pCi} / \mathrm{g}$} \\
\hline & & & ${ }^{09.90} \mathrm{Sr}^{(\mathrm{as})}$ & ${ }^{137} \mathrm{Cs}$ & ${ }^{239.240} \mathrm{Pu}^{(2)}$ & ${ }^{201} \mathrm{Am}^{(2)}$ \\
\hline 8 & D & 0 to 5 & & $<0.35$ & 4.50 & $<1.00$ \\
\hline 8 & D & 5 to 15 & & $<0.36$ & 4.50 & $<1.00$ \\
\hline 8 & D & 15 to 30 & & $<0.37$ & 0.78 & $<1.00$ \\
\hline 8 & B & 0 to 5 & & $<0.47$ & 1000.00 & 130.00 \\
\hline 8 & B & 5 to 15 & & $<0.35$ & 1000.00 & 130.00 \\
\hline 8 & $\mathbf{B}$ & 15 to 30 & & $<0.37$ & 30.00 & $<1.00$ \\
\hline 8 & $\mathbf{F}$ & 0 to 5 & & $<0.40$ & 77.00 & 6.10 \\
\hline 8 & $\mathbf{F}$ & 5 to 15 & & $<0.10$ & 77.00 & 6.10 \\
\hline 8 & $\mathbf{F}$ & 15 to 30 & & $<0.10$ & 49.00 & 5.80 \\
\hline 8 & 0 & 0 to 5 & & $<0.40$ & 3.20 & $<0.80$ \\
\hline 8 & $\mathbf{G}$ & 5 to 15 & & $<0.10$ & 3.20 & $<0.80$ \\
\hline 8 & G & 15 to 30 & & $<0.10$ & 14.00 & $<4.70$ \\
\hline 9 & $\mathbf{A}$ & 0 to 5 & & $<0.34$ & 4.20 & $<0.60$ \\
\hline 9 & $\mathbf{A}$ & 5 to 15 & & $<0.47$ & 4.20 & $<0.60$ \\
\hline 9 & $\mathbf{A}$ & 15 to 30 & & $<0.35$ & 2.60 & $<1.00$ \\
\hline 9 & B & 0 to 5 & & 1.33 & 100.00 & 11.00 \\
\hline 9 & B & 5 to 15 & & $<0.35$ & 100.00 & 11.00 \\
\hline 9 & B & 15 to 30 & & $<0.35$ & 2.00 & $<1.00$ \\
\hline 9 & C & 0 to 10 & & & 580.00 & 89.00 \\
\hline 9 & D & 0 to 5 & & 1.95 & 47.00 & 4.00 \\
\hline 9 & D & 5 to 15 & & $<0.36$ & 47.00 & 4.00 \\
\hline 9 & D & 15 to 30 & & 1.80 & 13.00 & $<0.80$ \\
\hline 9 & $\mathbf{E}$ & 0 to 5 & & $<0.35$ & 17.00 & $<0.80$ \\
\hline 9 & $\mathbf{E}$ & 5 to 15 & & $<0.48$ & 17.00 & $<0.80$ \\
\hline 9 & $\mathbf{E}$ & 15 to 30 & & $<0.34$ & 27.00 & $<1.00$ \\
\hline 9 & $\mathbf{F}$ & 0 to 5 & & $<0.09$ & 10.00 & $<0.70$ \\
\hline 9 & F & 5 to 15 & & $<0.10$ & 10.00 & $<0.70$ \\
\hline 9 & $\mathbf{F}$ & 15 to 30 & & $<0.10$ & $<1.00$ & $<3.00$ \\
\hline 9 & G & 0 to 5 & & 1.60 & 27.00 & 2.70 \\
\hline & $G$ & 5 to 15 & & $<0.70$ & 27.00 & 2.70 \\
\hline $\begin{array}{l}9 \\
9\end{array}$ & G & 15 to 30 & & $<0.10$ & $<0.40$ & $<0.50$ \\
\hline
\end{tabular}

(a) For strontium, plutonium, and americium analysis, depths of 0 to 5 and 5 to $15 \mathrm{~cm}$ have been composited. 


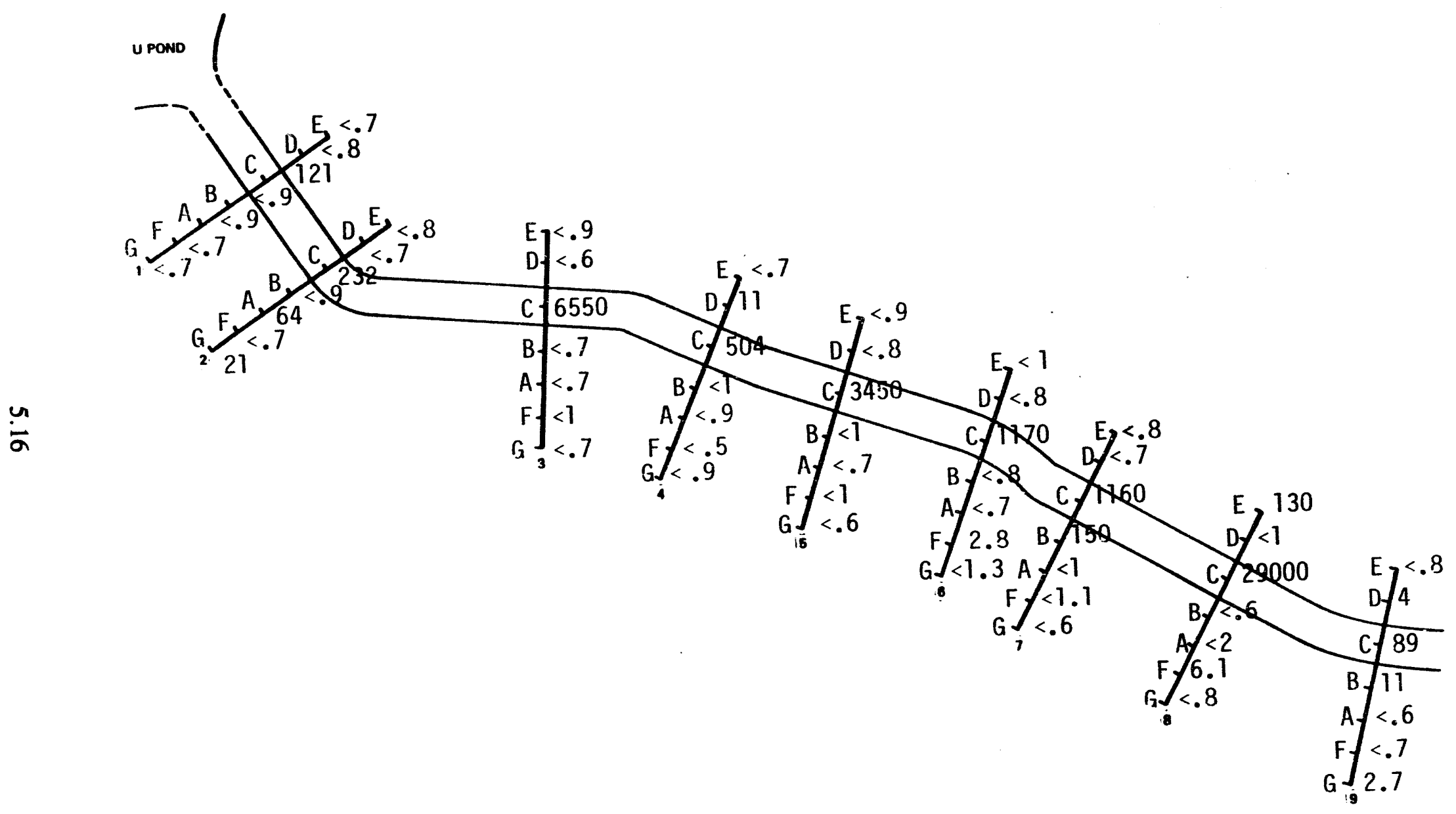

Figure 5.7. Values of ${ }^{241} \mathrm{Am}(\mathrm{pCi} / \mathrm{g})$ in Soil $(0$ to $15 \mathrm{~cm})$ at the $216-\mathrm{Z}-19$ Ditch 


\section{Soil}

Values for ${ }^{137} \mathrm{Cs}$ and ${ }^{90} \mathrm{Sr}$ were very low (see Table 5.1). The highest average of either radionuclide was $1.2 \mathrm{pCi} / \mathrm{g}$ of ${ }^{137} \mathrm{Cs}$ at the 0 - to $5-\mathrm{cm}$ depth. Cesium- 137 averaged $<0.40 \mathrm{pCi} / \mathrm{g}$ at the $5-$ to $15-\mathrm{cm}$ depth and averaged $<0.31 \mathrm{pCi} / \mathrm{g}$ at the $15-$ to $30-\mathrm{cm}$ depth. Samples from the $0-$ to $5-$ and $5-$ to $15-\mathrm{cm}$ sampling depths were composited for ${ }^{90} \mathrm{Sr},{ }^{239 / 240} \mathrm{Pu}$, and ${ }^{241} \mathrm{Am}$. Strontium-90 ranged from 0.73 to $3.40 \mathrm{pCi} / \mathrm{g}$ and averaged $1.1 \mathrm{pCi} / \mathrm{g}$ at the $0-$ to $15-\mathrm{cm}$ depth (see Table 5.1). Plutonium-239,240 values ranged from 0.56 to $2400 \mathrm{pCi} / \mathrm{g}$ at the $0-$ to $15-\mathrm{cm}$ depth, with an average of $83.7 \mathrm{pCi} / \mathrm{g}$; whereas, ${ }^{209,200} \mathrm{Pu}$ values ranged from 0.33 to $1600 \mathrm{pCi} / \mathrm{g}$ at the $15-$ to $30-\mathrm{cm}$ level and averaged $43 \mathrm{pCi} / \mathrm{g}$ (see Figures 5.6 and 5.8). Americium-241 values ranged from 0.5 to $150 \mathrm{pCi} / \mathrm{g}$ at the $0-$ to $15-\mathrm{cm} \mathrm{depth}$ and averaged $8.1 \mathrm{pCi} / \mathrm{g}$, while the ${ }^{241} \mathrm{Am}$ values at the 15 - to $30-\mathrm{cm}$ depth ranged from 0.4 to $160 \mathrm{pCi} / \mathrm{g}$ and averaged $3.9 \mathrm{pCi} / \mathrm{g}$ (see Figures 5.7 and 5.9). The highest levels for ${ }^{239,240} \mathrm{Pu}$ were found at sample points $2 \mathrm{~A}, 2 \mathrm{G}, 7 \mathrm{~B}, 7 \mathrm{~F}, 8 \mathrm{E}, 8 \mathrm{~F}$, and $9 \mathrm{~B}$ (see Figures 5.6 and 5.8).

\section{Terrestrial Vegetation}

Values for ${ }^{90} \mathrm{Sr},{ }^{137} \mathrm{Cs}$, and ${ }^{239,240} \mathrm{Pu}$ in the terrestrial vegetation were low (Table 5.2). Values for ${ }^{239,240} \mathrm{Pu}$ ranged from 0.75 to $8.0 \mathrm{pCi} / \mathrm{g}$ and averaged $1.3 \mathrm{pCi} / \mathrm{g}$. The highest value of $8.0 \mathrm{pCi} / \mathrm{g}$ was located at transect 9 in a cheatgrass sample. Strontium- 90 values ranged from 0.41 to $6.0 \mathrm{pCi} / \mathrm{g}$ and averaged $2.0 \mathrm{pCi} / \mathrm{g}$.

\section{Aquatic Vegetation}

Cesium-137 and ${ }^{90} \mathrm{Sr}$ values in the aquatic vegetation were very low, with the exception of one willow at transect 3 that contained $68.5 \mathrm{pCi} / \mathrm{g}$ of ${ }^{137} \mathrm{Cs}$ (Table 5.3). Cesium-137 ranged from 0 to $68.5 \mathrm{pCi} / \mathrm{g}$, with an average of $3.1 \mathrm{pCi} / \mathrm{g}$, and ${ }^{95} \mathrm{Sr}$ ranged from 0 to $0.67 \mathrm{pCi} / \mathrm{g}$, with an average of $0.22 \mathrm{pCi} / \mathrm{g}$. Values for ${ }^{239.240} \mathrm{Pu}$ ranged from 0.50 to $8470.0 \mathrm{pCi} / \mathrm{g}$, with an average of $406.8 \mathrm{pCi} / \mathrm{g}$ (Figure 5.10). The average value for ${ }^{239.240} \mathrm{Pu}$ in cattails alone was $894 \mathrm{pCi} / \mathrm{g}$, with the highest levels occurring at transects 4, 5, 6, and 7 (see Figure 5.10).

\section{Small Mammals}

Cesium-137 values in small mammals ranged from 0 to $84.1 \mathrm{pCi} / \mathrm{g}$, with an average of $6.4 \mathrm{pCi} / \mathrm{g}$ (Table 5.4). The highest value of $84.1 \mathrm{pCi} / \mathrm{g}$ was a deer mouse captured at transect 8 . Strontium-90 values ranged from 0 to $48.5 \mathrm{pCi} / \mathrm{g}$, with an average of $4.2 \mathrm{pCi} / \mathrm{g}$ (see Table 5.4). The high value of $48.5 \mathrm{pCi} / \mathrm{g}$ was for the same mouse at transect 8 . Plutonium-239,240 values ranged from 0.06 to $2.56 \mathrm{pCi} / \mathrm{g}$, with an average of $0.47 \mathrm{pCi} / \mathrm{g}$ (see Table 5.4).

\section{Vegetation Parameters}

Results from the cover-class evaluations indicated that the species composition of the ditch consisted mostly of cattails, willows, bulrushes, smartweed, and horseweed (Table 5.5). Total biomass estimated of these species is also presented in Table 5.5. Results from the biomass estimate indicate that there are $4684 \mathrm{~kg}$ of living vegetation in the Z-19 Ditch, with willows, cattails, and bulrushes being the dominant species. 


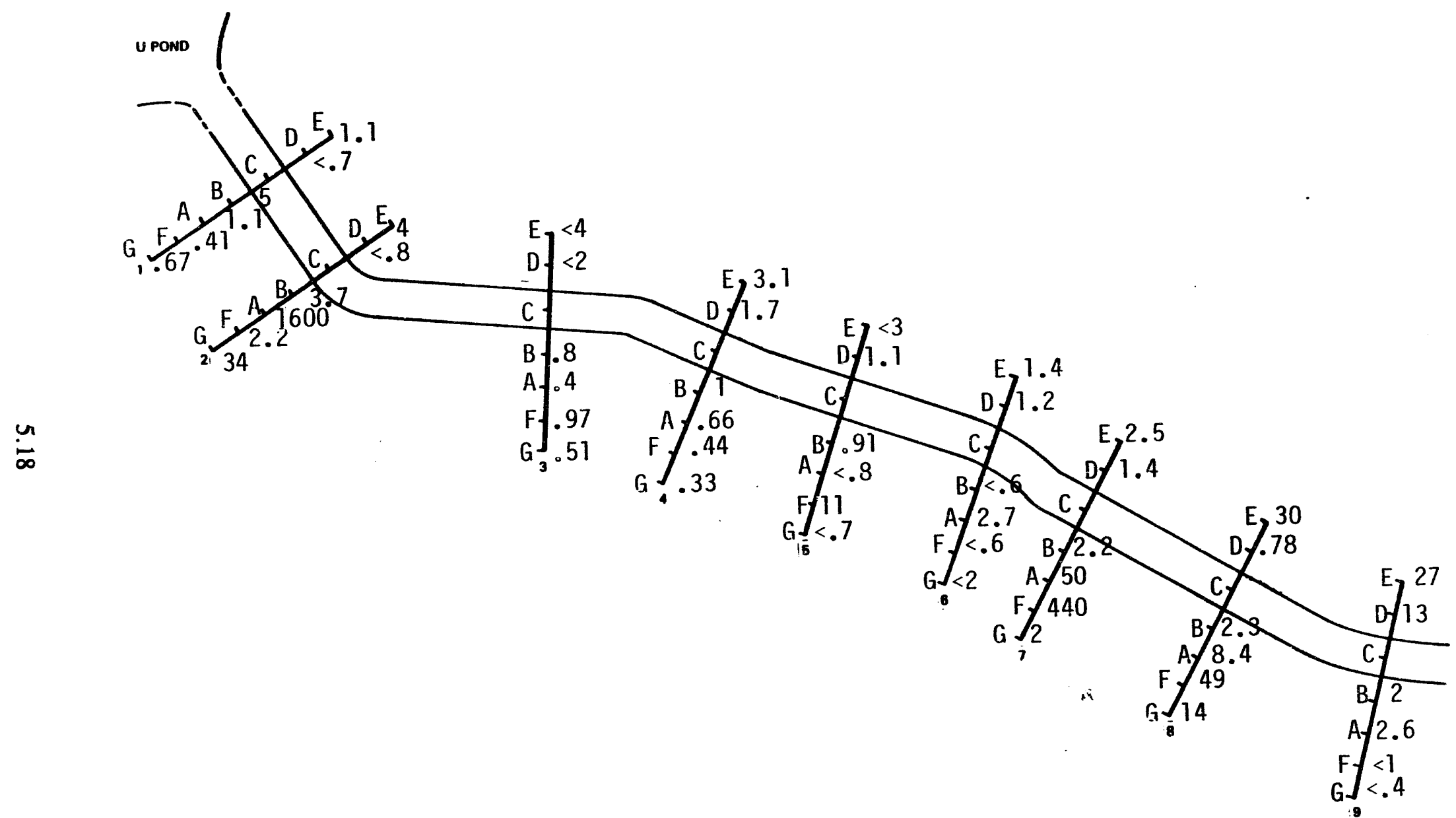

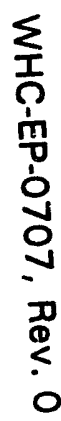

Figure 5.8. Values of ${ }^{239,240} \mathrm{Pu}(\mathrm{pCi} / \mathrm{g})$ in Soil $(15$ to $30 \mathrm{~cm})$ at the $216-\mathrm{Z}-19$ Ditch 
WHC-EP-0707, Rev. 0

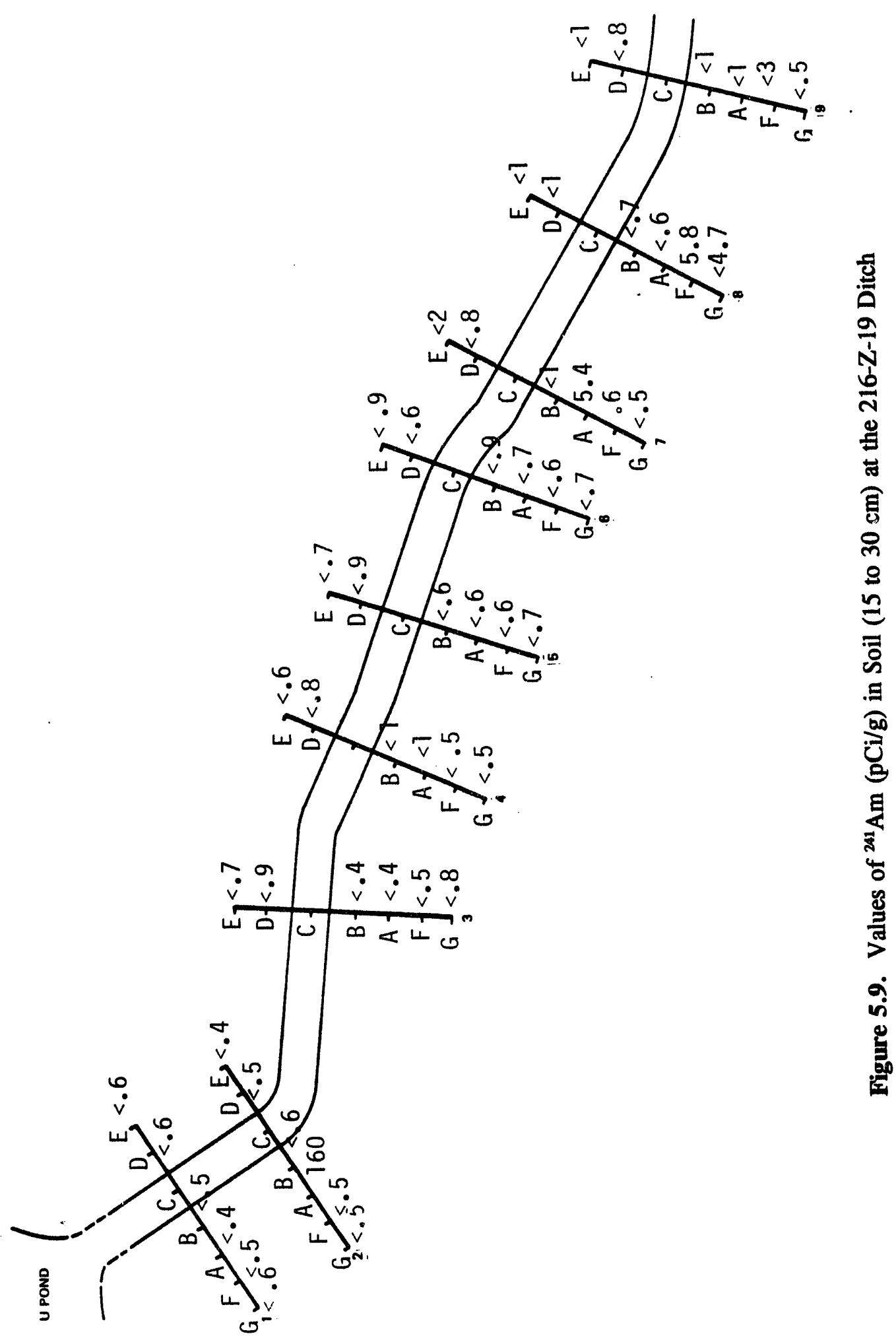


Table 5.2. Values for ${ }^{89,90} \mathrm{Sr}$, ${ }^{137} \mathrm{Cs}$, and ${ }^{239,240} \mathrm{Pu}$ in Vegetation Samples Collected from the 216-Z-19 Ditch

\begin{tabular}{|c|c|c|c|c|c|}
\hline \multirow[b]{2}{*}{ Transect } & \multirow{2}{*}{$\begin{array}{c}\text { Side of } \\
\text { Ditch }\end{array}$} & \multirow[b]{2}{*}{ Common Name } & \multicolumn{3}{|c|}{ Concentration in $\mathbf{p C i} / \mathrm{g}$} \\
\hline & & & $89,90 \mathrm{Sr}$ & ${ }^{137} \mathrm{Cs}$ & $239,240 \mathrm{Pu}$ \\
\hline 1 & East & Cheatgrass(a) & $<4.00$ & $<0.01$ & $<0.10$ \\
\hline 3 & East & Cheatgrass & $<6.00$ & $<0.01$ & $<0.60$ \\
\hline 5 & East & Cheatgrass & $<5.00$ & $<0.01$ & $<0.50$ \\
\hline 7 & East & Cheatgrass & 3.50 & $<0.01$ & $<5.00$ \\
\hline 9 & East & Cheatgrass & $<4.00$ & $<0.01$ & 8.00 \\
\hline 1 & East & Rice grass ${ }^{(b)}$ & $<0.40$ & $<0.01$ & 0.31 \\
\hline 3 & East & Rice grass & $<0.60$ & 0.00 & 1.40 \\
\hline 5 & East & Rice grass & 0.61 & $<0.01$ & 0.19 \\
\hline 7 & East & Rice grass & $<2.00$ & 0.00 & 0.89 \\
\hline 9 & East & Rice grass & $<1.00$ & 0.00 & 2.30 \\
\hline 1 & West & Tumbleweed ${ }^{(\mathrm{c})}$ & $<4.00$ & 0.00 & 0.34 \\
\hline 1 & East & Tumbleweed & 0.80 & 0.01 & $<0.20$ \\
\hline 3 & West & Tumbleweed & $<2.00$ & 0.00 & 1.00 \\
\hline 3 & East & Tumbleweed & 0.41 & 0.00 & - \\
\hline 5 & West & Tumbleweed & 0.75 & 0.00 & $<0.10$ \\
\hline 5 & East & Tumbleweed & 1.10 & 0.00 & 0.15 \\
\hline 7 & West & Tumbleweed & $<2.00$ & 0.00 & $<0.70$ \\
\hline 7 & East & Tumbleweed & 0.45 & 0.00 & $<0.10$ \\
\hline 9 & West & Tumbleweed & 0.85 & 0.00 & 1.00 \\
\hline 9 & East & Tumbleweed & $<2.00$ & 0.00 & 1.00 \\
\hline
\end{tabular}

(a) Species: Bromus tectorum

(b) Species: Oryzopsis hymenoides

(c) Species: Salsoa kali 
Table 5.3. Values for ${ }^{90} \mathrm{Sr},{ }^{137} \mathrm{Cs}$, and ${ }^{239,240} \mathrm{Pu}$ in Aquatic Vegetation Samples Collected from the 216-Z-19 Ditch

\begin{tabular}{|c|c|c|c|c|c|}
\hline \multirow[b]{2}{*}{ Traneect } & \multirow[b]{2}{*}{ Sample } & \multirow[b]{2}{*}{ Common Name } & \multicolumn{3}{|c|}{ Concentration $(\mathrm{pCi} / \mathrm{g})$} \\
\hline & & & ${ }^{90} \mathrm{Sr}$ & ${ }^{137} \mathrm{C}_{8}$ & $239.210 \mathrm{Pu}$ \\
\hline \multirow[t]{6}{*}{3} & D31282 & Willow ${ }^{(a)}$ & - & 68.50 & 0.88 \\
\hline & D31281 & Willow & - & $0.0 x^{(b)}$ & 0.59 \\
\hline & D31280 & Willow & - & $-0.03^{(b)}$ & - \\
\hline & D31247 & Catrail(0) & 0.28 & 0.38 & 14.50 \\
\hline & D31246 & Cattail & 0.28 & $-0.03^{(b)}$ & 0.44 \\
\hline & D31245 & Thistle(d) & 0.67 & 0.52 & 0.99 \\
\hline \multirow[t]{5}{*}{4} & D31278 & Willow & - & $0.08^{(b)}$ & 1.39 \\
\hline & D31277 & Willow & - & $0.06^{(b)}$ & 1.66 \\
\hline & D31244 & Cattail & 0.14 & $0.03^{(b)}$ & 177.00 \\
\hline & D31243 & Cattail & 0.18 & $0.06^{(b)}$ & 1110.00 \\
\hline & D31242, & Smartwoed $(0)$ & 0.19 & $-0.03^{(b)}$ & 1.13 \\
\hline \multirow[t]{4}{*}{5} & D31276 & Willow & - & 0.14 & 3.98 \\
\hline & D31241 & Cattail & 0.08 & $0.02^{(b)}$ & 42.80 \\
\hline & D31240 & Smartweed & 0.34 & $0.10^{(b)}$ & 2.09 \\
\hline & D31239 & Cattail & 0.46 & 0.31 & 536.00 \\
\hline \multirow[t]{5}{*}{6} & D31275 & Willow & - & $-0.07^{(b)}$ & 0.55 \\
\hline & D31274 & Willow & - & $-0.05^{(b)}$ & 4.52 \\
\hline & D31273 & Willow & - & $-0.09(b)$ & 5.39 \\
\hline & D31238 & Cattail & 0.12 & $0.08^{(b)}$ & 1710.00 \\
\hline & D31236 & Horseweed(n) & $0.00^{(3)}$ & 0.25 & 0.50 \\
\hline \multirow[t]{4}{*}{7} & D31234 & Cattrail & 0.61 & 0.80 & 8470.00 \\
\hline & D31233 & Cattail & 0.20 & $0.00^{(b)}$ & 8.63 \\
\hline & D31232 & Smartweed & $0.06^{(b)}$ & 0.28 & 0.84 \\
\hline & D31231 & Horseweed & - & 1.18 & 4.05 \\
\hline \multirow[t]{3}{*}{8} & D31230 & Cattail & $0.01^{(8)}$ & $-0.13^{(b)}$ & 1.23 \\
\hline & D31229 & Cattail & 0.30 & 0.73 & 2.96 \\
\hline & D31228 & Smartwoed & 0.12 & 0.34 & 0.80 \\
\hline \multirow[t]{5}{*}{9} & D31227 & Horseweed & 0.39 & $0.12^{(b)}$ & 5.53 \\
\hline & D31226 & Bulrush ${ }^{(\boldsymbol{l})}$ & $0.02^{(b)}$ & $-0.06^{(b)}$ & 17.50 \\
\hline & D31225 & Thistle & 0.25 & $0.06^{(b)}$ & 21.90 \\
\hline & D31224 & Cattail & $0.04^{(b)}$ & 1.78 & 1.32 \\
\hline & D31223 & Cattail & $0.04^{(b)}$ & $0.29(b)$ & 3.12 \\
\hline
\end{tabular}

\footnotetext{
(a) Species: Salix.

(b) Values below detoction limit.

(c) Specios: Typha latifolia.

(d) Species: Cirsium brevifolium.

(o) Species: Potygonum persicaria.

(f) Specios: Conyza canadensis.

(g) Species: Scirpus sp.

NOTE: Strontium analysis was not requested for willow samples.
} 


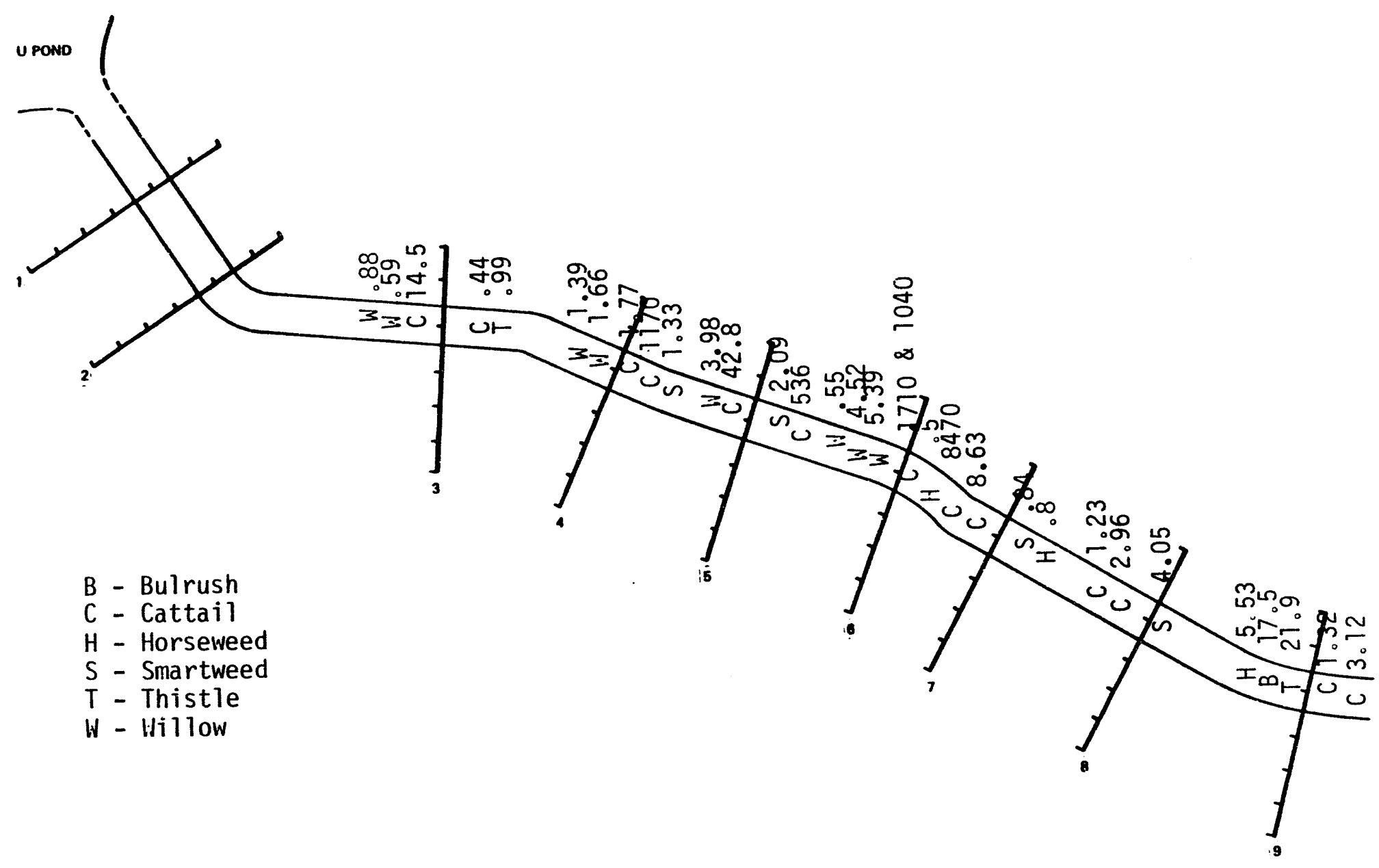

Figure 5.10. Values of ${ }^{239,220} \mathrm{Pu}(\mathrm{pCi} / \mathrm{g})$ in Aquatic Vegetation at the 216-Z-19 Ditch 
Table 5.4. Values for ${ }^{90} \mathrm{Sr},{ }^{137} \mathrm{Cs}$, and ${ }^{239,240} \mathrm{Pu}$ in Mice Collected from the $216-\mathrm{Z}-19 \mathrm{Ditch}$

\begin{tabular}{|c|c|c|c|c|}
\hline \multirow{2}{*}{ Transect } & \multirow{2}{*}{ Species } & \multicolumn{3}{|c|}{ Concentration $(\mathrm{pCi} / \mathrm{g})$} \\
\hline & & ${ }^{90} \mathrm{Sr}$ & ${ }^{137} \mathrm{Cs}$ & ${ }^{239,240} \mathrm{Pu}$ \\
\hline \multirow[t]{2}{*}{1} & Deer mouse ${ }^{(a)}$ & 0.10 & 1.48 & 0.28 \\
\hline & Deer mouse & (b) & (b) & (b) \\
\hline \multirow[t]{3}{*}{2} & Deer mouse & 0.76 & 1.10 & (b) \\
\hline & Deer mouse & 1.73 & 0.26 & 2.56 \\
\hline & Pocket mouse ${ }^{(c)}$ & (b) & (b) & (b) \\
\hline \multirow[t]{2}{*}{3} & Deer mouse & $0.00^{(d)}$ & $0.10^{(d)}$ & 0.12 \\
\hline & Deer mouse & 0.22 & $0.05^{(\mathrm{d})}$ & 0.18 \\
\hline \multirow[t]{3}{*}{4} & Deer mouse & $0.01^{(d)}$ & $-0.02^{(d)}$ & (b) \\
\hline & Deer mouse & $0.04^{(d)}$ & 0.32 & 0.11 \\
\hline & Pocket mouse & (b) & (b) & (b) \\
\hline 5 & Deer mouse & 0.10 & $0.14^{(d)}$ & (b) \\
\hline \multirow[t]{2}{*}{6} & Deer mouse & 0.18 & 0.60 & 0.06 \\
\hline & Deer mouse & $0: 11$ & 0.78 & 0.06 \\
\hline \multirow[t]{4}{*}{8} & Deer mouse & 48.50 & 84.10 & 0.35 \\
\hline & Deer mouse & 0.10 & 0.58 & (b) \\
\hline & Deer mouse & (b) & (b) & (b) \\
\hline & Deer mouse & (b) & (b) & (b) \\
\hline \multirow[t]{4}{*}{9} & Deer mouse & 0.15 & $0.00^{(d)}$ & 0.56 \\
\hline & Deer mouse & 6.62 & $0.26^{(\mathrm{d})}$ & 0.38 \\
\hline & Deer mouse & (b) & (b) & (b) \\
\hline & Deer mouse & (b) & (b) & (b) \\
\hline
\end{tabular}

(a) Species: Peromyscus maniculatus.

(b) Samples lost by laboratury.

(c) Species: Peroghathus parvus.

(d) Values below detection limit. 
Table 5.5. Vegetation Parameters and Biomass Values at the 216-Z-19 Ditch for the Major Plant Species

\begin{tabular}{|l|l|c|c|c|}
\hline Common Name & \multicolumn{1}{|c|}{ Species } & $\begin{array}{c}\text { Relative Cover } \\
(\%)\end{array}$ & $\begin{array}{c}\text { Relative } \\
\text { Frequency (\%) }\end{array}$ & Biomass (kg) \\
\hline \hline Willow & Salix sp. & 33.1 & 21.1 & 2013.2 \\
Cattail & Typha latifolia & 23.7 & 15.5 & 1832.6 \\
Bulrush & Scirpus sp. & 4.8 & 4.9 & 1932.6 \\
Horseweed & Conyza canadensis & 9.9 & 8.4 & 227.4 \\
Thistle & Cirsium brevifolium & 7.8 & 13.4 & 120.2 \\
Smartweed & Polygonum persicaria & 10.1 & 11.9 & 490.3 \\
Wild lettuce & Lactuca serriola & 3.9 & 14.1 & - \\
Poplar & Populus sp. & 5.5 & 8.4 & - \\
Asparagus & Asparagus officinales & 0.19 & 1.4 & - \\
Mullein & Verbascum thapsus & 0.97 & 0.70 & - \\
\hline \multicolumn{2}{|c|}{ Total } & \multicolumn{4}{|c|}{} \\
\hline
\end{tabular}

\subsubsection{Sampling Results for the 216-U-10-Pond}

\section{Soils}

Cesium-137 values for surface soil samples around the perimeter of U-Pond ranged from 1.86 to $26,200 \mathrm{pCi} / \mathrm{g}$, with an average of $4544 \mathrm{pCi} / \mathrm{g}$. Consistently higher values (all above $4310 \mathrm{pCi} / \mathrm{g}$ ) for ${ }^{137} \mathrm{Cs}$ were obtained from quadrant 1 near the inlet of the Z-19 and U-14 ditches (Figure 5.11).

\section{Trees (Roots)}

Tree-root samples ranged from 2.58 to $328.0 \mathrm{pCi} / \mathrm{g}$ of ${ }^{137} \mathrm{Cs}$ (Figure 5.12), with an average value of $57.2 \mathrm{pCi} / \mathrm{g}$. The highest value occurred in quadrant 1 (Figure 5.13 ) for ${ }^{137} \mathrm{Cs}$, with an average of $42.7 \mathrm{pCi} / \mathrm{g}$, and values for ${ }^{90} \mathrm{Sr}$ ranged from 0.66 to $70.40 \mathrm{pCi} / \mathrm{g}$ (Figure 5.14), with an average of $12.8 \mathrm{pCi} / \mathrm{g}$. Values for ${ }^{137} \mathrm{Cs}$ in leaf and twig samples at $4.5 \mathrm{~m}$ ranged from 0.82 to $1.95 \mathrm{pCi} / \mathrm{g}$ (Figure 5.15) and averaged $33.7 \mathrm{pCi} / \mathrm{g}$. Cesium-137 values ranged from 1.54 to $146 \mathrm{pCi} / \mathrm{g}$ in tree cores, with an average of $30.5 \mathrm{pCi} / \mathrm{g}$, and ${ }^{90} \mathrm{Sr}$ ranged from 1.48 to $129 \mathrm{pCi} / \mathrm{g}$ (Figures 5.16 and 5.17), with an average of $27.4 \mathrm{pCi} / \mathrm{g}$. Plutonium-239,240 levels were very low for both leaf $/$ twig samples and tree cores, with an average of $0.03 \mathrm{pCi} / \mathrm{g}$. The average value for ${ }^{137} \mathrm{Cs}$ in the leaf/twig and core samples was $33.2 \mathrm{pCi} / \mathrm{g}$; for ${ }^{90} \mathrm{Sr}, 16.2 \mathrm{pCi} / \mathrm{g}$. The highest values for the majority of the samples again occurred in quadrant 1 . 


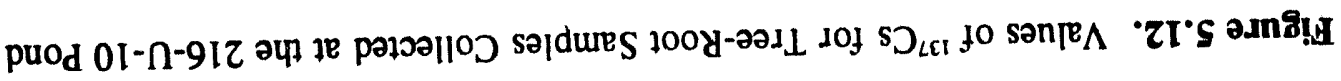

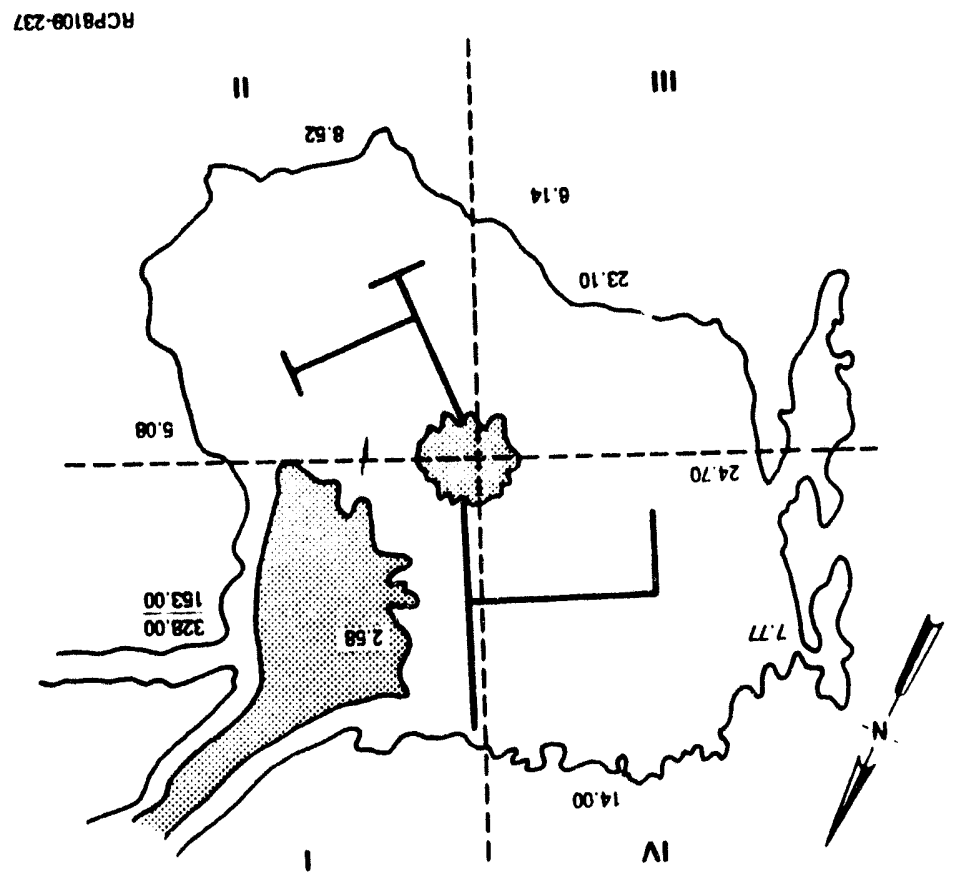

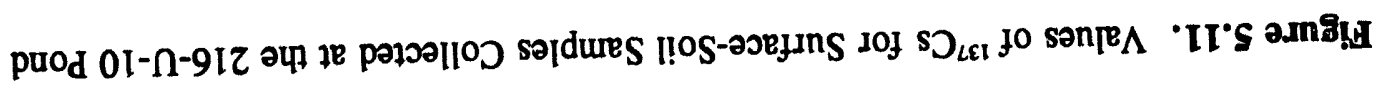

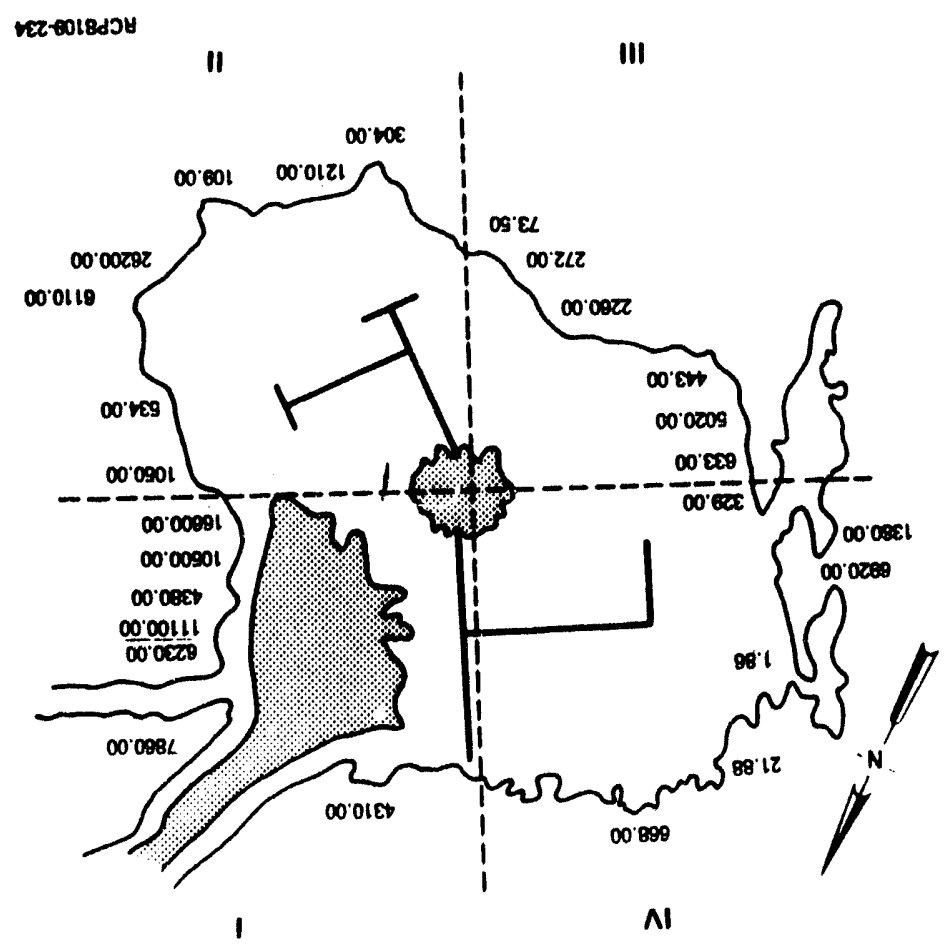

$0 \cdot \wedge \theta y$ ' $\angle O L O-d \exists-J H M$ 
WHC-EP-0707, Rev. 0

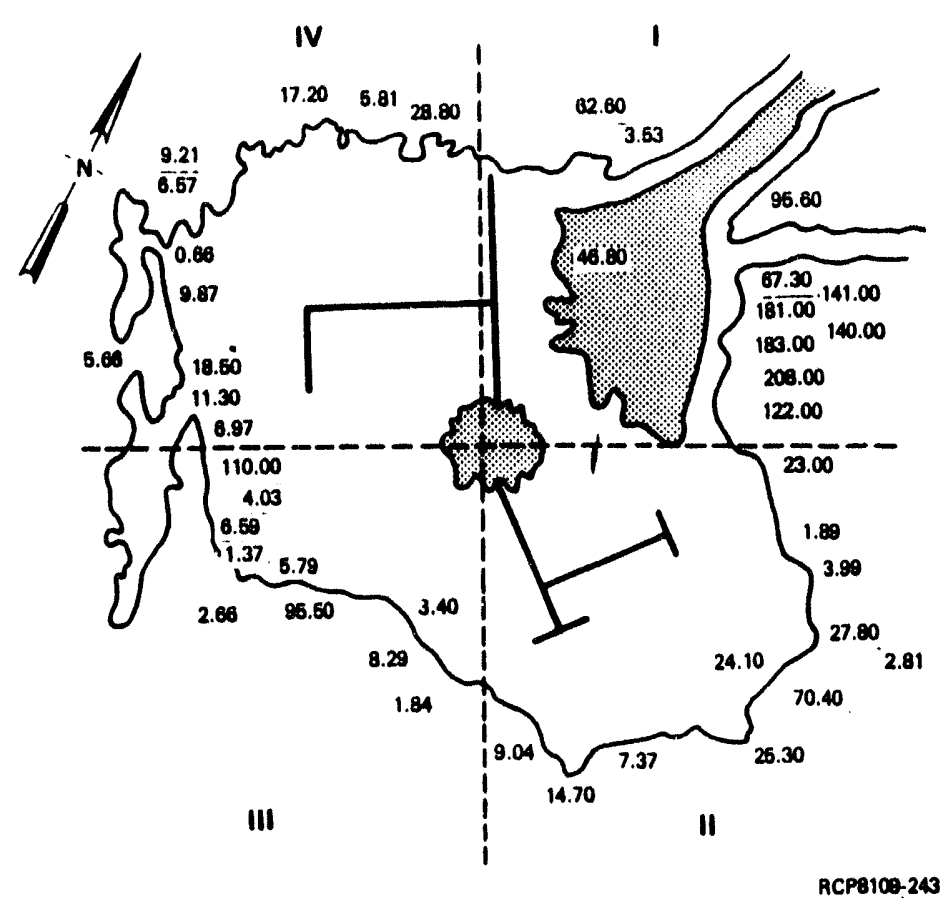

Figure 5.13. Values of ${ }^{137} \mathrm{Cs}$ for Leaf/Twig Samples Collected at 1.3-m Height at the 216-U-10 Pond

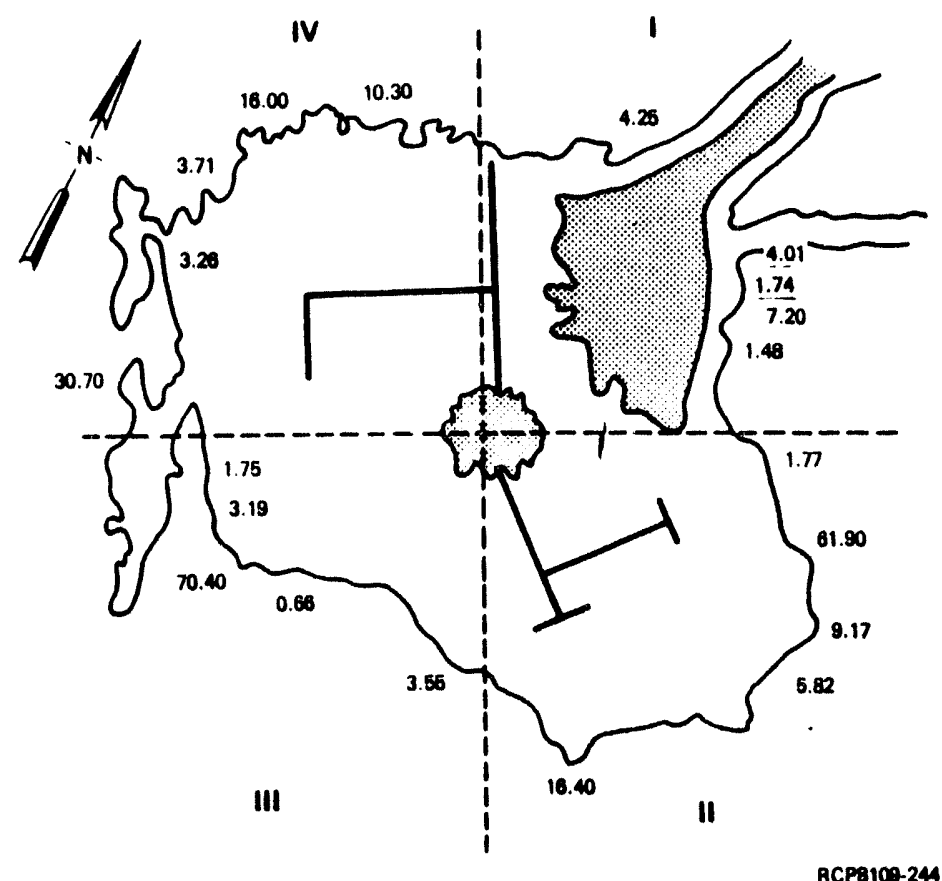

Figure 5.14. Values of ${ }^{90} \mathrm{Sr}$ for Leaf/Twig Samples Collected at 1.3-m Height at the 216-U-10 Pond 


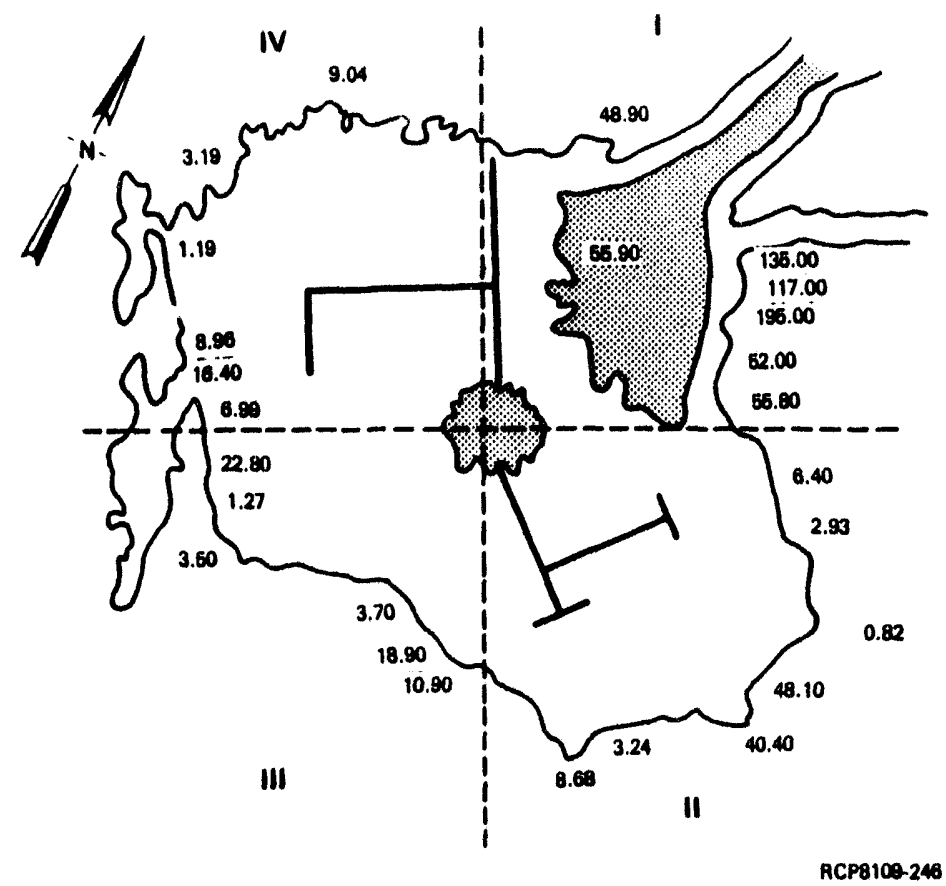

Figure 5.15. Values of ${ }^{137} \mathrm{Cs}$ for Leaf/Twig Samples Collected at 4.5-m Height at the $216-\mathrm{U}-10$ Pond

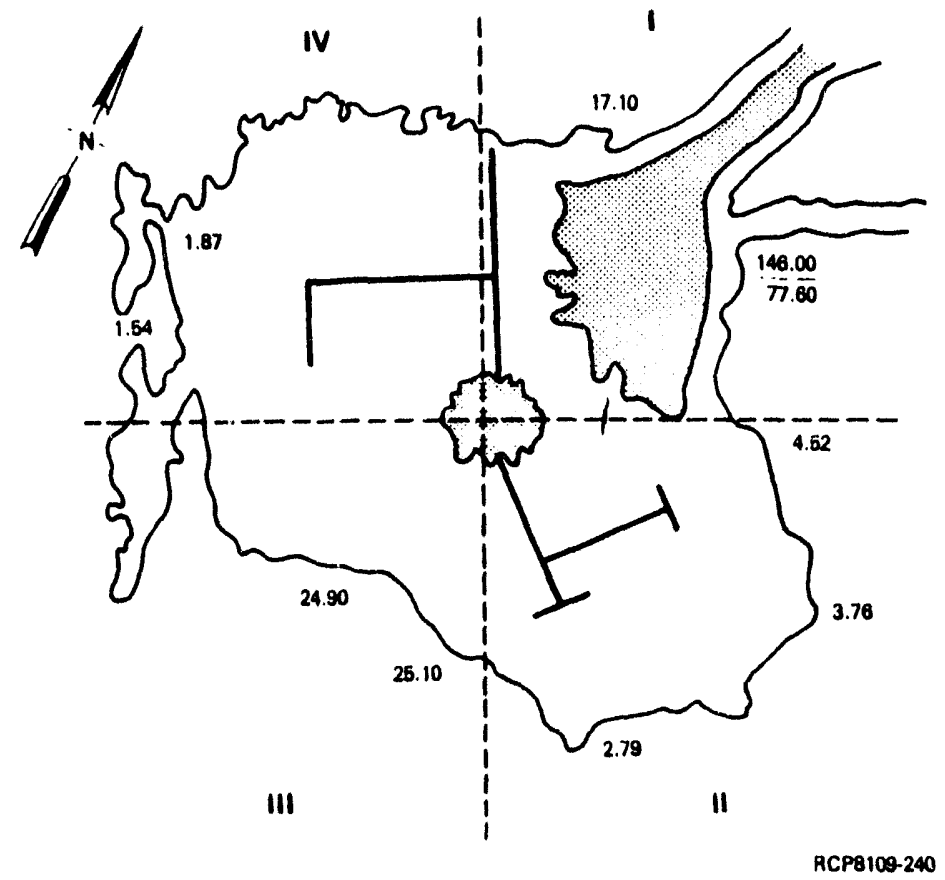

Figure 5.16. Values of ${ }^{137} \mathrm{Cs}$ for Tree-Core Samples Collected at the 216-U-10 Pond 


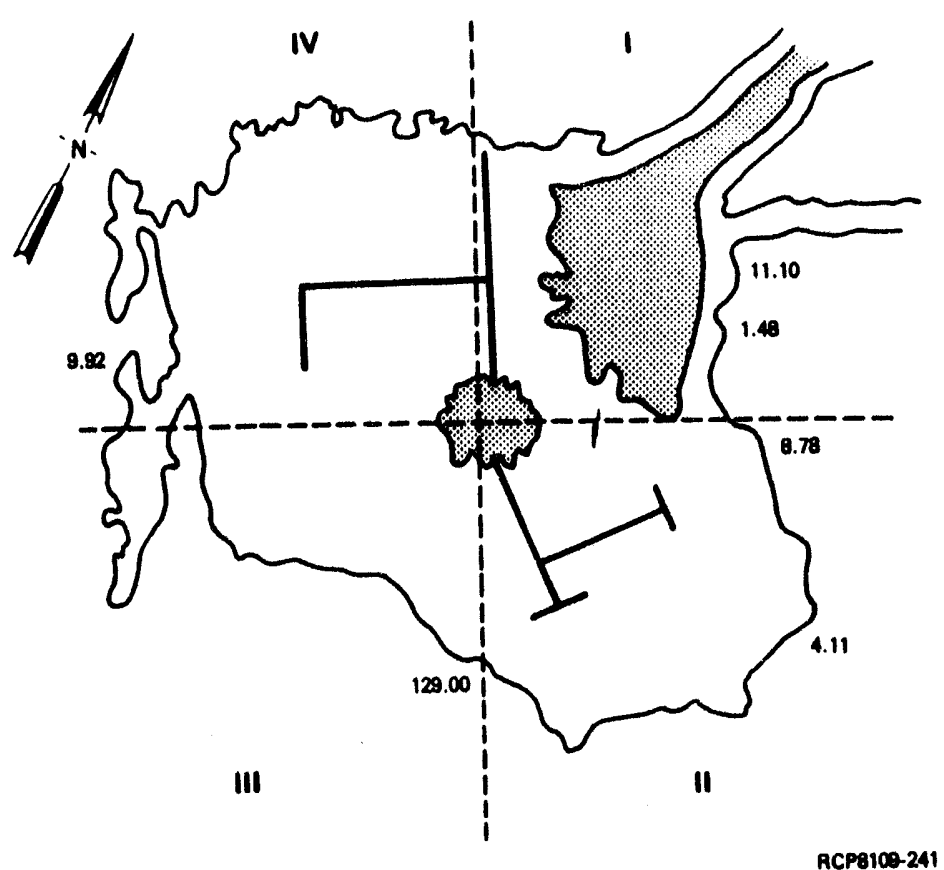

Figure 5.17. Values of ${ }^{90} \mathrm{Sr}$ for Tree-Core Samples Collected at the $216-\mathrm{U}-10$ Pond

\section{Sandbar Willow (Leaf and Twig Samples)}

The five samples that were collected from sandbar willow ranged from 1.25 to $30 \mathrm{pCi} / \mathrm{g}$ of ${ }^{137} \mathrm{Cs}$, with the highest value in quadrant 1 (Figure 5.18). The average value was $10.5 \mathrm{pCi} / \mathrm{g}$ of ${ }^{137} \mathrm{Cs}$.

\section{Small Mammals}

Values for small mammals collected at U-Pond ranged from 2.27 to $231.00 \mathrm{pCi} / \mathrm{g}$ of ${ }^{137} \mathrm{Cs}$, with an average of $53.5 \mathrm{pCi} / \mathrm{g}$ (Figure 5.19).

\section{Vegetation Parameters}

The two major tree species that inhabit the U-Pond area are the cottonwood and peachleaf willow. The peachleaf willow is the most dominant tree in terms of cover, density, and frequency (Table 5.6). The total estimated number of all trees at U-Pond is 880 and the average biomass per tree is $276 \mathrm{~kg}$. This provides a total biomass estimate of $242,800 \mathrm{~kg}$ for all the trees at U-Pond (see Table 5.6).

\subsubsection{Discussion}

Previous studies regarding the Z-19 Ditch have not been oriented toward waste management considerations; therefore, information regarding radionuclides in the soils and biological components in the Z-19 Ditch is not available. Thus, the current study represents baseline information with regard to the Z-19 Ditch and provides additional data on U-Pond. 
WHC-EP-0707, Rev. 0

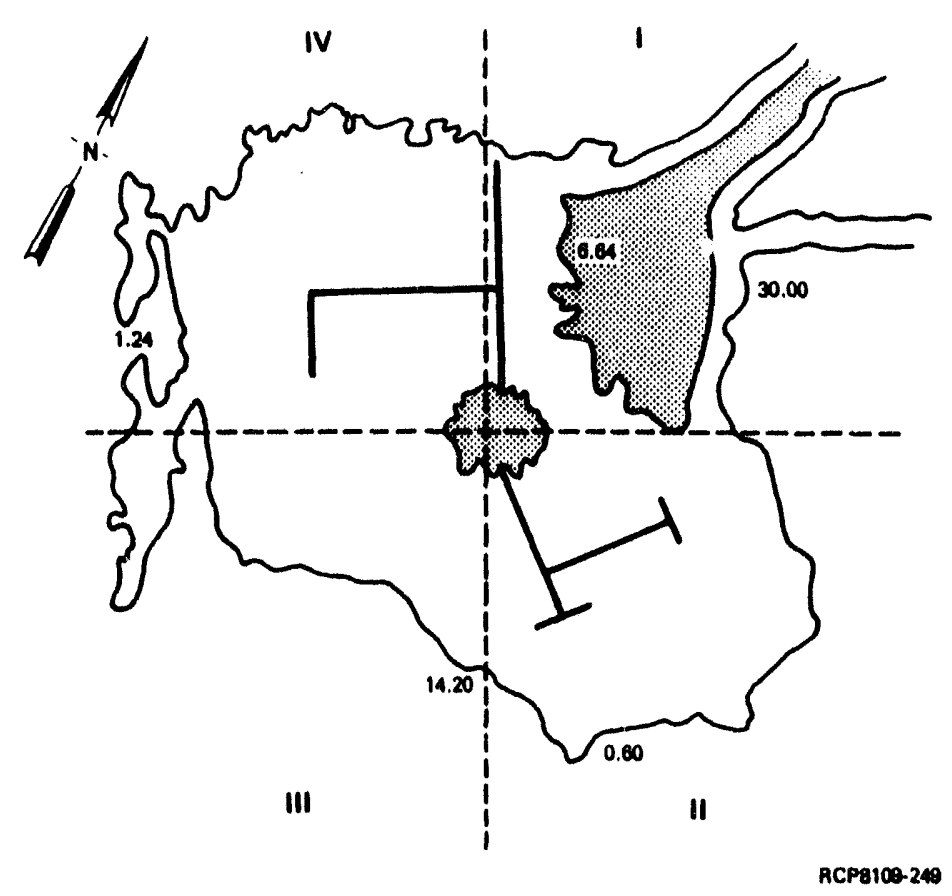

Figure 5.18. Values of ${ }^{137} \mathrm{Cs}$ for Sandbar Willow Leaf/Twig Samples Collected at the 216-U-10 Pond

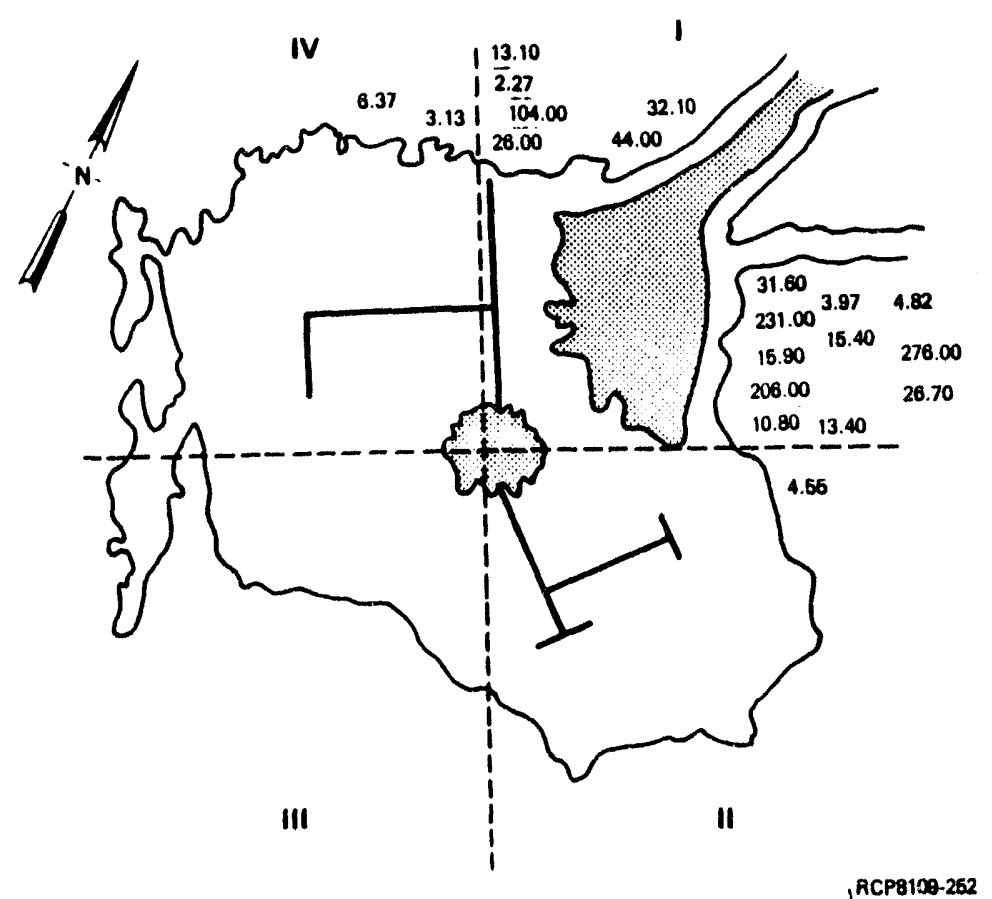

Figure 5.19. Values of ${ }^{137} \mathrm{Cs}$ for Mice Collected at the $216-\mathrm{U}-10$ Pond 
Table 5.6. Vegetation Parameters and Biomass Values for Trees at the 216-U-10 Pond

\begin{tabular}{|l|l|r|r|r|}
\hline & & \multicolumn{3}{|c|}{ Percentage } \\
\cline { 3 - 5 } Common Name & \multicolumn{1}{|c|}{ Species } & $\begin{array}{c}\text { Relative } \\
\text { Cover }\end{array}$ & $\begin{array}{c}\text { Relative } \\
\text { Density }\end{array}$ & $\begin{array}{c}\text { Relative } \\
\text { Frequency }\end{array}$ \\
\hline Peachleaf willow & Salix amygdaloides & 97.0 & 96.0 & 91.0 \\
Cottonwood & Populus deltoides & 3.0 & 4.0 & 9.0 \\
\hline
\end{tabular}

The average value derived from this study for ${ }^{239,240} \mathrm{Pu}$ in the sediments of the Z-19 Ditch of $20,139 \mathrm{pCi} / \mathrm{g}$ is two orders of magnitude greater than the average value of $390 \mathrm{pCi} / \mathrm{g}$ for U-Pond indicated by Emery and Klopfer (1974). The same relationship holds true for ${ }^{241} \mathrm{Am}$ ( $\mathrm{x}-\mathrm{=}=4697$ versus $83 \mathrm{pCi} / \mathrm{g}$ ). This would appear to provide a possible answer to the question raised by Emery and Garland (1974) of why a material balance of plutonium and americium levels found in U-Pond could not be calculated from the discharge data. Although the accuracy of the discharge figures may be of concern, the principal reason appears to be that the major portions of the plutonium and americium are being deposited in the ditch sediments and have not made their way to U-Pond. Although the damming of the Z-19 Ditch in 1976 because of an accidental release from the 234-5Z Building (Z-Plant) would certainly limit the movement of sediments to U-Pond, at the time of the study the Z-19 Ditch had been flowing directly to U-Pond for 2 years. Additional evidence that discharged plutonium and americium were historically tied up on the ditch sediments is that samples from below the dammed areas also contained high plutonium and americium values. However, Emery's and Klopfer's (1974) value for the average of total plutonium $(\Sigma \mathrm{Pu})$ contained in U-Pond sediments was $390 \mathrm{pCi} / \mathrm{g}$, while the value obtained for this study was $195 \mathrm{pCi} / \mathrm{g}{ }^{239.240} \mathrm{Pu}\left({ }^{239.240} \mathrm{Pu}\right.$ represent approximately $90 \%$ of $\left.\Sigma \mathrm{Pu}\right)$. The difference in value can probably be accounted for by the damming of the Z-19 Ditch and the fact that plutonium- and americium-laden water and sediments are no longer being deposited in U-Pond.

The values obtained for uptake of plutonium in aquatic plants in the Z-19 Ditch were also much higher for cattails, which were sampled and analyzed in both studies. The average value for ${ }^{209,200} \mathrm{Pu}$ in Z-19 Ditch cattails was $894 \mathrm{pCi} / \mathrm{g}$, whereas Emery and Klopfer (1974) reported an average value of $59.2 \mathrm{pCi} / \mathrm{g}$.

The work done by Gano (1979) concentrated on small mammals found at U-Pond and the lower portions of the Z-19 Ditch only. Although the sample analyses are not directly comparable, because Gano's samples were composites and whole mice were analyzed in this study, general comparisons of ranges and values can be made. Gano (1979) found that the plutonium values for mice collected at the Z-19 Ditch were very low, ranging from 0 to $2.03 \mathrm{pCi} / \mathrm{g}$, with an average of approximately $0.5 \mathrm{pCi} / \mathrm{g}$. Plutonium-239,240 values for mice at the Z-19 Ditch in this study averaged $0.47 \mathrm{pCi} / \mathrm{g}$ and ranged from 0.06 to $2.56 \mathrm{pCi} / \mathrm{g}$. The highest ${ }^{137} \mathrm{Cs}$ value at the $\mathrm{Z}-19$ Ditch was for a house mouse, wherein the gastrointestinal tract contained $1600 \mathrm{pCi} / \mathrm{g}$ (Gano 1979). However, because this was a single animal, it is very likely that the high cesium value can be attributed to U-Pond rather than the Z-19 Ditch, where values were much lower and ranged from 0 to $84.1 \mathrm{pCi} / \mathrm{g}$, with an average of $6.4 \mathrm{pCi} / \mathrm{g}$. Strontium-90 values, which were not obtained by Gano (1979), averaged $4.2 \mathrm{pCi} / \mathrm{g}$ (range 0 to $48.5 \mathrm{pCi} / \mathrm{g})$. 
At U-Pond, Gano (1979) again found mice with higher values for ${ }^{137} \mathrm{Cs}$, ranging from 0 to $504 \mathrm{pCi} / \mathrm{g}$. However, the ${ }^{137} \mathrm{Cs}$ values in this study, though lower than those reported by Gano (1979), were consistently higher than values reported for the Z-19 Ditch. The U-Pond mice ranged from 2.27 to $231.0 \mathrm{pCi} / \mathrm{g}$ of ${ }^{137} \mathrm{Cs}$, with an average of $53.5 \mathrm{pCi} / \mathrm{g}$.

High levels of ${ }^{239,200} \mathrm{Pu}$ and ${ }^{241} \mathrm{Am}$ at the Z-19 Ditch were found in the sediments on transects 3 through 7. The highest levels of ${ }^{239,240} \mathrm{Pu}$ occurring in soil were at the head of the ditch, with the exception of two high values at sample points $2 \mathrm{~A}$ and $2 \mathrm{G}$. The location of the "hot" samples at $2 \mathrm{G}$ at the $0-$ to $15-\mathrm{cm}$ depth may indicate past contamination from the old $216-\mathrm{Z}-1(\mathrm{Z}-1)$ and $\mathrm{Z}-11$ ditches. The high values for ${ }^{239,200} \mathrm{Pu}$ on transects 7,8 , and 9 seem to indicate that this is probably contamination that can be attributed to past Z-19 Ditch operations because there were no high values found at sample point $G$ on any of these transects. This is also indicated by the fact that six of the nine highest values for ${ }^{209,210} \mathrm{Pu}$ occurred in the top $15 \mathrm{~cm}$ of soil. It is interesting to note that the three high ${ }^{221} \mathrm{Am}$ values in the soil also occur on transects $2 \mathrm{~A}, 7 \mathrm{~B}$, and $8 \mathrm{E}$, where there were also high ${ }^{299,200 \mathrm{Pu} \text { values. }}$ Similar trends were observed for both plutonium and americium values in the sediments and soils at the Z-19 Ditch. The highest-average values for both radionuclides were found in the sediments, with the next highest values found in the 0 - to $15-\mathrm{cm}$ soils, and the lowest values observed at the $15-$ to $30-\mathrm{cm}$ depth. In the sediment, ${ }^{239,200} \mathrm{Pu}$ averaged $20,139 \mathrm{pCi} / \mathrm{g}$; in the ditch bank soils, ${ }^{239,240} \mathrm{Pu}$ averaged $83.9 \mathrm{pCi} / \mathrm{g}$ at the $0-$ to $15-\mathrm{cm}$ depth and $43.0 \mathrm{pCi} / \mathrm{g}$ at the $15-$ to $30-\mathrm{cm}$ depth. Americium-241 values were $4697 \mathrm{pCi} / \mathrm{g}$ in the sediments and $8.1 \mathrm{pCi} / \mathrm{g}$ at the $0-$ to $15-\mathrm{cm}$ depth and $3.9 \mathrm{pCi} / \mathrm{g}$ at the $15-$ to 30-cm depth in the ditch bank. In both instances, it appears that the vast majority of the radionuclides are contained in the sediment, with lesser amounts in the top $15 \mathrm{~cm}$ of ditch-bank soil.

Similar trends in the concentration of ${ }^{137} \mathrm{Cs}$ were also observed for the soils and trees at U-Pond. The average ${ }^{137} \mathrm{Cs}$ value in the soil was $4544 \mathrm{pCi} / \mathrm{g}$, tree roots averaged $57.2 \mathrm{pCi} / \mathrm{g}$, the $1.3-\mathrm{m}$ leaf/ twig samples averaged $42.7 \mathrm{pCi} / \mathrm{g}$, and leaf/twig samples at a height of $5.4 \mathrm{~m}$ averaged $33.7 \mathrm{pCi} / \mathrm{g}$. Plutonium-239,240 values averaged $0.3 \mathrm{pCi} / \mathrm{g}$ in the trees, which is identical to the values reported for similar studies at Oak Ridge National Laboratory (Witkamp and Frank 1964; Garten 1980). In fact, the results reported here represent the first quantitative tree data from the Hanford Site and, as such, were valuable from a scientific viewpoint. We now know that trees at the Hanford Site are capable of taking up ${ }^{90} \mathrm{Sr}$ and ${ }^{137} \mathrm{Cs}$ and that measurable levels can be detected in the roots, cores, and leaves.

Radionuclide levels in soil and tree samples were consistently higher in quadrant 1 where the Z-19 and $U-14$ ditches enter the pond. Quadrant 3 was the next highest area in terms of radionuclide concentrations, probably because this is where the overflow area is located and where the water level fluctuates the most. It has been determined that the burning or removal of these trees would pose no health hazard to humans.

The ${ }^{299,240} \mathrm{Pu}$ values reported here for the aquatic vegetation in the Z-19 Ditch are surprisingly high because ${ }^{239,200} \mathrm{Pu}$ is not known to be readily taken up by plants. There may be a few reasons why these high levels of ${ }^{239,240} \mathrm{Pu}$ are seen in cattails:

- Very little work has been done outside laboratory conditions to document the uptake of ${ }^{239,240} \mathrm{Pu}$ by cattails; hence, the values reported represent field conditions, especially because aquatic species are known to concentrate higher levels in their roots. 
- Although care was taken to remove all the debris and sediment from the collected plants, it was extremely difficult to ensure that all the sediment from the roots of the cattails was removed. Therefore, some of these high values could reflect small portions of sediment that remained attached.

The highest values in the vegetation were found on transects $4,5,6$, and 7 . It was surprising not to have obtained high values from transects 8 and 9 because one would have predicted finding the highest levels on transects 8 and 9 . None of the other aquatic species, which included willow, smartweed, horseweed, and thistle, contained higher levels of ${ }^{209,200} \mathrm{Pu}$. This may be because of a shallower root system and the fact that these species are not always confined to the water.

At both the Z-19 Ditch and U-Pond, the highest values of cadionuclides in small mammals occurred in deer mice and house mice. Deer mice, and especially house mice, live in close association with humans. One reason for seeing elevated levels in deer mice and house mice and not in pocket mice is probably because of their omnivorous (wide variety) food habits. Pocket mice, on the other hand, are almost entirely granivorous (seed eaters) and do not forage as much on riparian vegetation. Pocket mice also prefer more xeric (dry) areas in which to reside, whereas house mice and deer mice prefer more mesic (wet) communities. As a result, the house mice and deer mice, which live in closer association with the Z-19 Ditch and U-Pond, have a greater opportunity to accumulate radionuclides. It should also be noted that there is an order of magnitude difference in the ${ }^{137} \mathrm{Cs}$ levels of small mammals at U-Pond compared to small mammals at the Z-19 Ditch. The U-Pond ${ }^{137} \mathrm{Cs}$ values for small mammals averaged $53.5 \mathrm{pCi} / \mathrm{g}$, and the Z-19 Ditch values averaged $6.5 \mathrm{pCi} / \mathrm{g}$. This is what would be predicted by observing the data on. ${ }^{137} \mathrm{Cs}$ levels in soil and vegetation at U-Pond and the Z-19 Ditch. Both soil and vegetation averages for ${ }^{137} \mathrm{Cs}$ were at least an order of magnitude higher at $\mathrm{U}$-Pond. The small mammals at U-Pond picked up ${ }^{137} \mathrm{Cs}$ in the same levels as those found in the tree roots. The tree roots averaged $57.2 \mathrm{pCi} / \mathrm{g}$, and the small mammals averaged $53.5 \mathrm{pCi} / \mathrm{g}$. By using a conservative estimate of 250 small mammals as the population size at U-Pond, this would give a total estimated ${ }^{137} \mathrm{Cs}$ inventory of $337.0 \mathrm{nCi}$ in small mammals.

The biomass values obtained for the vegetation (see Tables 5.5 and 5.6) at the Z-19 Ditch and U-Pond make it possible to estimate the total radionuclide content associated with each ecological compartment. At the Z-19 Ditch, there is an estimated total of $1901 \mu \mathrm{Ci}$ of ${ }^{239.240} \mathrm{Pu}$ contained within the vegetative community, $1583 \mu \mathrm{Ci}$ of which are contained within the cattail-bulrush complex. It appears that ${ }^{239,200} \mathrm{Pu}$ becomes more available to submerged plants, which results in increased uptake in these aquatic species. Because high levels of ${ }^{239,200} \mathrm{Pu}$ were not observed in the terrestrial vegetation, it would appear that ${ }^{209,240} \mathrm{Pu}$ is more available to submerged aquatic species. These data indicate that terrestrial vegetation should not generally be used as an accurate indicator of plutonium uptake in biological systems.

Again, by using the biomass estimates and average radionuclide values, the total radionuclide inventory can be estimated for the trees at U-Pond. At the present, $3934 \mu \mathrm{Ci}$ of ${ }^{90} \mathrm{Sr}$ and $9278 \mu \mathrm{Ci}$ of ${ }^{137} \mathrm{Cs}$ can be accounted for in the trees (aboveground growth) and $13,892 \mu \mathrm{Ci}$ of ${ }^{137} \mathrm{Cs}$ in the tree roots, for a total ${ }^{137} \mathrm{Cs}$ radionuclide tree inventory of $23,170 \mu \mathrm{Ci}$. 


\subsection{Geologic Studies}

The purpose of the geologic studies was to delineate the speciation, concentration, and distribution of radionuclides in the surface and subsurface materials. Therefore, the soils, pond and ditch-bottom sediment, and underlying geologic units were studied as one medium, referred to as sediments (a geologic term for unconsolidated sands, silts, and gravels).

\subsubsection{Methods and Materials}

The general approach of these studies was to integrate information from existing studies with new data collected to complement previous data. The first step was to examine the constructional design and operational use of the disposal system to predict what type of contamination might be expected to occur in each component of the system. The next step was to compile and review all previous studies, at which time the existing data were either accepted, reinterpreted, or discarded. These data were then used to identify specific areas that needed sample data and to guide the sampling designs. The only areas determined to not need sample data were 1) the top $10 \mathrm{~cm}$ of the U-Pond-bottom sediments, which were adequately sampled for plutonium, americium, and uranium by Emery and Klopfer (1974) and Emery and Garland (1974) and 2) the 216-U-9 Ditch, which was found to be uncontaminated in 1969 and 1973. The remaining portions of the pond system were to be sampled and two main sampling groups were identifled: 1) surface and near-surface sediment sampling and 2) subsurface sampling. These sampling groups were then subdivided by the component of the disposal system to be sampled.

\section{Surface and Near-Surface Sediment Sampling}

The U-Pond, U-11 Overflow Basin, Z-19 Ditch, and U-14 Ditch were sampled at the surface and near surface for spread of contamination.

216-U-10 Pond and 216-U-11 Overflow Basin. Samples were collected both at the surface and at shallow depths in various parts of the pond basin area according to several sampling schemes identified below. Additionally, different analysis techniques were used, including the use of a developmental van (Dev Van IA) with its in-field capability for "laboratory type" sample-to-detector analyses or in situ analyses. Laboratory analyses were conducted at the Rockwell Laboratory and two off-site laboratories. Analyses included spectral gamma (GEA), plutonium, americium, and ${ }^{90} \mathrm{Sr}$. A brief description of sampling and analyses follows (Table 5.7).

In November 1978, 10 special surface grab samples were collected in the delta area (where the U-14 and Z-19 ditches entered U-Pond) when a field survey (Figure 5.20) found high levels of alpha activity. These samples were selectively collected from surface hot spots using $65-\mathrm{cm}^{3}$ sample containers. The samples mostly consisted of decayed organic material that formed a crust on the soil surface. Observations made during the field survey and collection of these samples indicated that the contamination was an order of magnitude higher in the organic crust than in the sandy soil just beneath it. These samples were analyzed in November 1979 for ${ }^{239.240} \mathrm{Pu},{ }^{241} \mathrm{Am}$, and fission products, using 
Table 5.7. Numbers of Surface and Near-Surface Sediment Samples and Analyses

\begin{tabular}{|c|c|c|c|c|c|c|c|c|}
\hline \multirow[b]{2}{*}{ Sample Type } & \multirow[b]{2}{*}{$\begin{array}{l}\text { Total Number of } \\
\text { Samples Collected }\end{array}$} & \multicolumn{4}{|c|}{ Laboratory Analyes } & \multicolumn{2}{|c|}{$\begin{array}{c}\text { Dov Van IA Sample } \\
\text { Analyeos } \\
\end{array}$} & \multirow[b]{2}{*}{$\begin{array}{c}\text { Dev Van IA } \\
\text { In Situ } \\
\text { Analyees }\end{array}$} \\
\hline & & $\begin{array}{l}\text { Gamma } \\
\text { Energy } \\
\text { Analysis }\end{array}$ & Pu/Am & ${ }^{90} \mathrm{sr}$ & Total U & $G e(L i)$ & si(Li) & \\
\hline \multicolumn{9}{|c|}{ 216-U-10 Pond and 216-U-11 Ditch } \\
\hline Special Surface & 10 & -(a) $^{(a)}$ & - & - & - & 10 & 10 & - \\
\hline 30- x 30-m Delta Grid Cores & 53 & 30 & 6 & 5 & 4 & 40 & 39 & - \\
\hline Perimeter Surface & 21 & 21 & 16 & 16 & - & - & - & - \\
\hline Pond Bottom Cores & 17 & 17 & 4 & 4 & - & - & - & - \\
\hline 60- x 60-m Grid In Situ & $\mathbf{0}$ & - & - & - & - & - & - & 133 \\
\hline 60- x 60-m Grid Surface & 96 & 32 & 34 & 34 & 51 & - & - & - \\
\hline 60- x 60-m Grid Cores & 284 & 27 & - & - & 7 & 48 & - & - \\
\hline Leach Trench Cores & 13 & 13 & - & - & - & - & - & - \\
\hline Subtotal & 494 & 140 & 60 & 59 & 62 & 98 & 49 & 133 \\
\hline \multicolumn{9}{|c|}{ 216-Z-19 Ditch } \\
\hline Transect Cores & $249^{(b)}$ & $168^{(b)}$ & $201^{(B)}$ & 16 & - & - & 48 & - \\
\hline Surface & 13 & - & 13 & - & - & - & - & - \\
\hline Subtotal & 262 & 168 & 214 & 16 & - & - & 48 & - \\
\hline \multicolumn{9}{|c|}{ 216-U-14 Ditch } \\
\hline Transect Cores & $144^{(c)}$ & $144^{(c)}$ & - & - & - & - & - & - \\
\hline Center Cores & 24 & 23 & - & - & 21 & - & - & - \\
\hline Head End Cores & 47 & 47 & 2 & 22 & - & - & - & - \\
\hline Subtotal & 215 & 214 & 2 & 22. & 21 & - & - & - \\
\hline Total & 971 & 522 & 276 & 97 & 83 & 98 & 97 & 133 \\
\hline
\end{tabular}

(a) - No sample taken.

(b) Biological Sciences collected and analyzed 162 of these samples.

(c) Biological Sciences collected and analyzed all 144 of these samples. 
WHC-EP-0707, Rev. 0

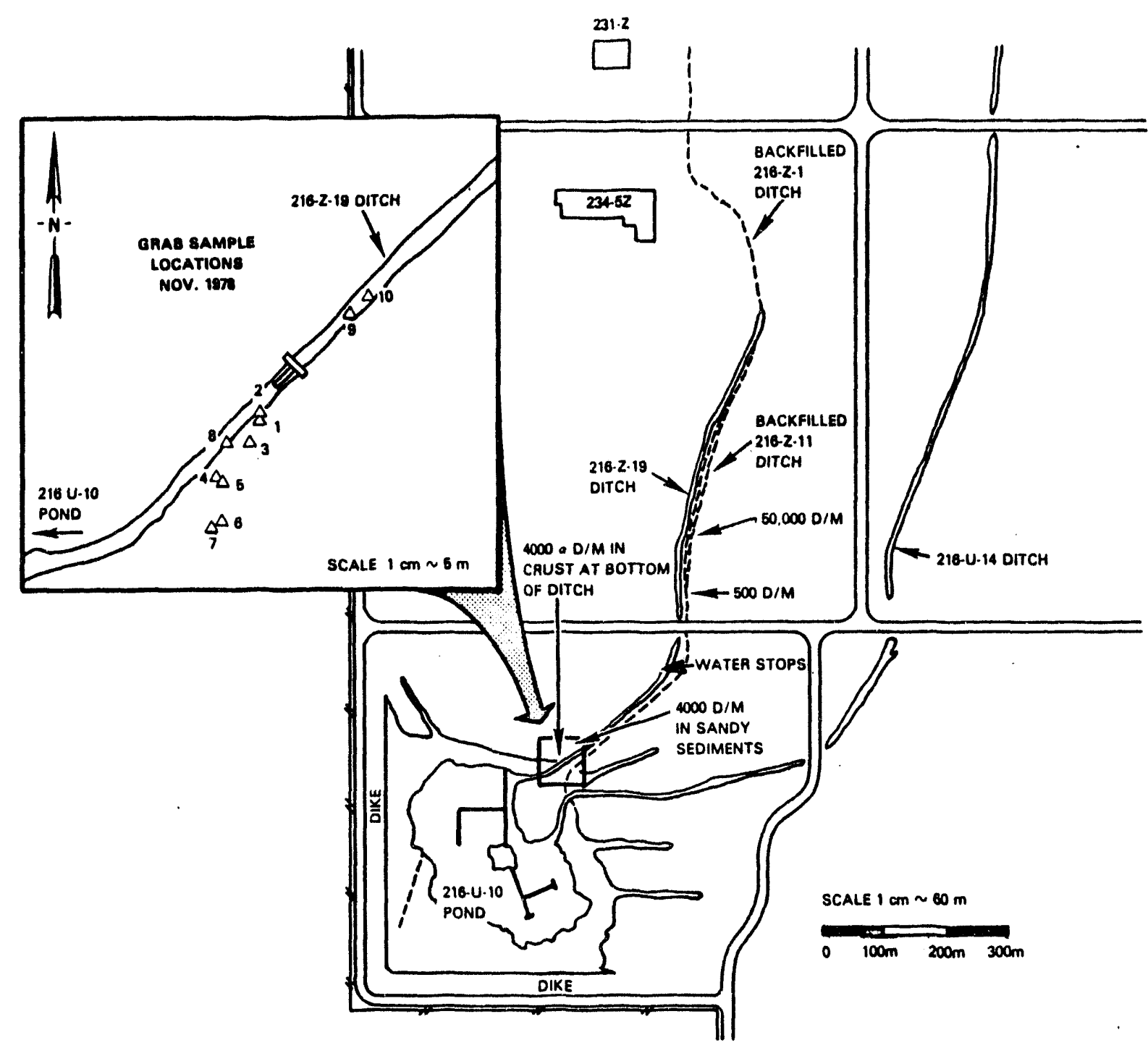

RCP8109-262

Figure 5.20. Field Survey and Sample Locations at the 216-Z-19 Ditch, 1978

Dev Van IA's uplooking lithium drifted silicon (Si[Li]) and downlooking lithium drifted germanium (Ge[Li]) detectors, respectively (Appendix $\mathrm{H}$ ).

In early May 1979, a 30- x 30-m square grid was established by the tape and compass method (Compton 1962) over the delta area where the aerial gamma survey (Tipton 1973; Bruns 1975) had identified the highest levels of contamination (Figure 5.21). A 30-cm-deep core sample was taken at every other grid point, except those that were not accessible (Figure 5.22). This core was then subsampled at $10-\mathrm{cm}$ increments, taking care to prevent cross contamination of the subsamples. Following the core sampling, a hand auger with a $20-\mathrm{cm}$ sampling interval was used to collect sediment from 


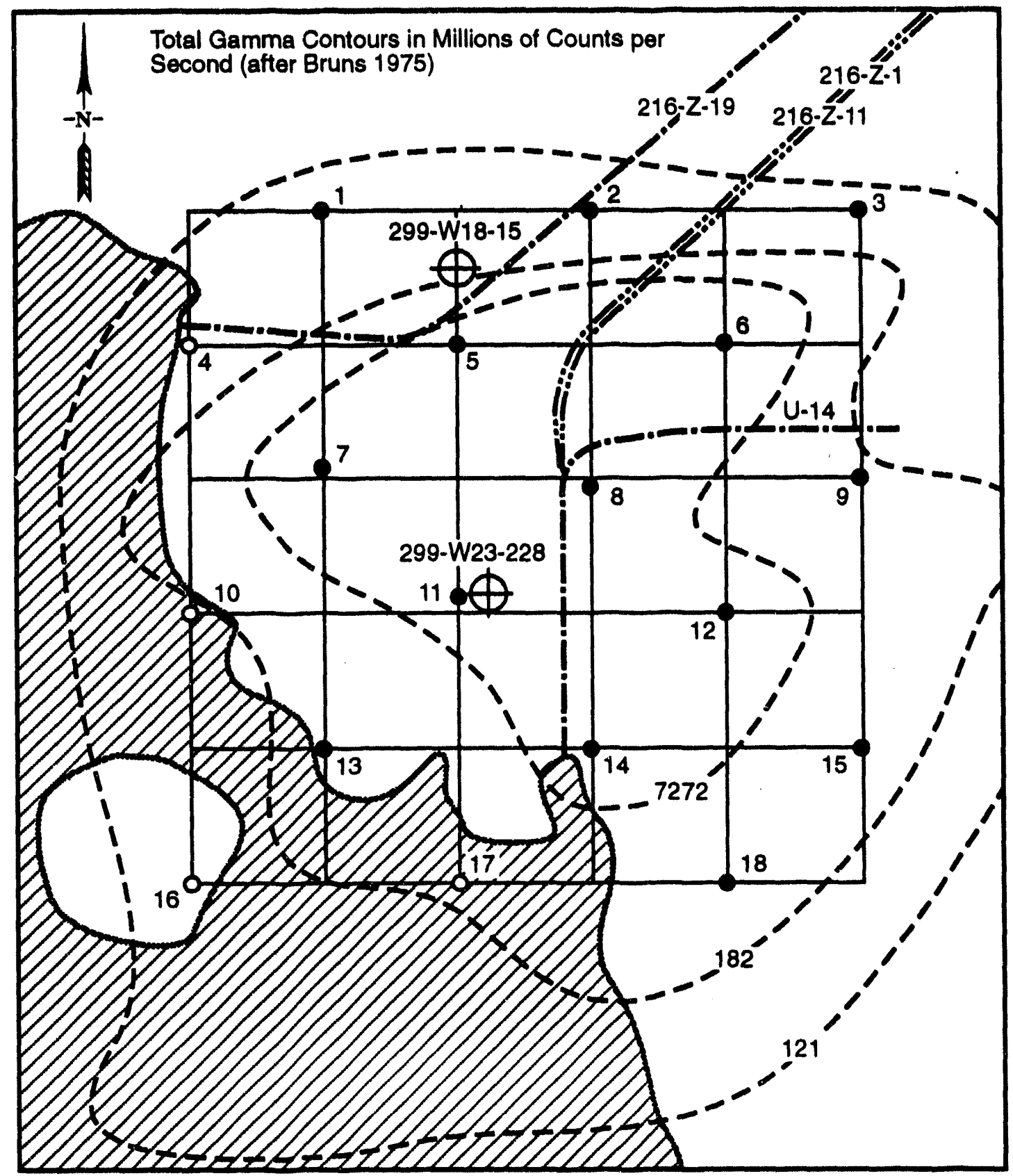

Pond Shoreline

-. Ditch Centerline (active)

-..- Ditch Centerline (backfilled)

- - - Total Gamma Isoexposure Contours
- U-Pond Delta Grid Points Sampled

- Not Sampled

$\bigoplus$ Wells

Figure 5.21. Establishment of the 216-U-10 Pond Delta Grid 


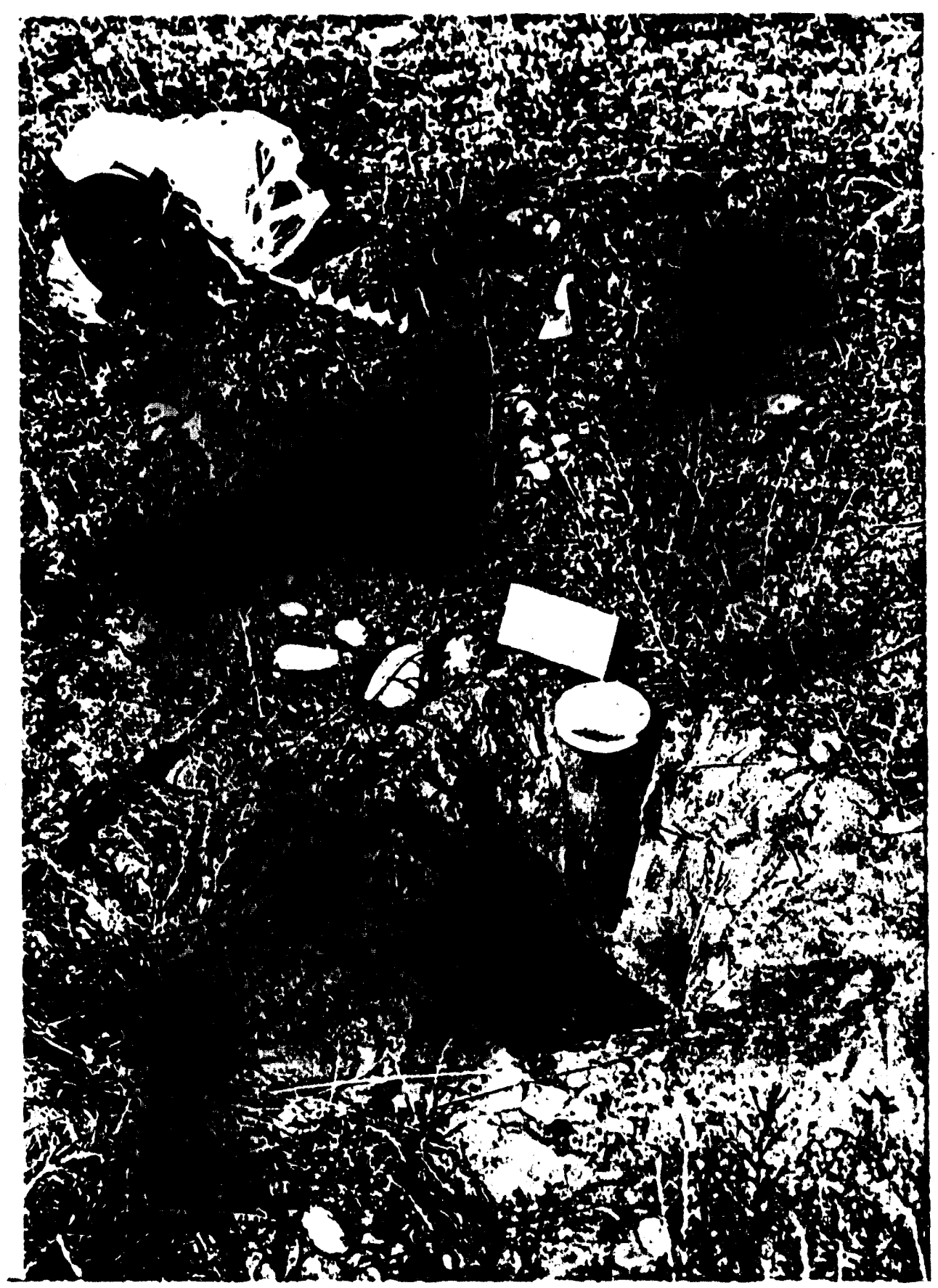

Figure 5.22. Core Sampling at $30-\mathrm{cm}$ Depth 
depths of 40 to 60 and 70 to $90 \mathrm{~cm}$ (Figure 5.23). In some cases, the geologic medium prevented the use of the hand auger, in which case, grab samples were collected with the aid of a shovel. All samples were placed in $65-\mathrm{cm}^{3}$ containers and qualitatively analyzed for sediment type. Eleven grid points were sampled, producing a total of 53 samples. Forty of these samples, representing 8 grid points, were analyzed using Dev Van $I A$ 's $\mathrm{Ge}(\mathrm{Li})$ detector and 39 using the $\mathrm{Si}(\mathrm{Li})$ detector. The Rockwell Laboratory analyzed 30 samples for fission products using GEA, six of the top core samples were then analyzed for plutonium and americium, and five for ${ }^{90} \mathrm{Sr}$. Eberline Instrument Corporation (Eberlino), Albuquerque, New Mexico, analyzed samples (from two grid points) for total uranium (2U) (refer to Appendix H).

In November and December 1979, 38 sediment samples were collected within and around U-Pond to quickly assess the contamination levels (Figure 5.24). Twenty-one of these samples were from the surface around the perimeter of $U$-Pond, where the sample locations were first prepared by carefully removing the decayed or living vegetation and placed in a plastic bags. Then, five surface samples were collected using a 2.45-cm-deep by 7.4-cm-diameter cookie cutter (Figure 5.25), placed in the same plastic bag, and further packaged for transport to the Rockwell Laboratory, where they were blended and subsampled. The remaining 17 samples were taken of the pond-bottom sediments. These samples were collected from floating dockways and boats, using the "Giant Syringe Mud Sampler" developed for taking undisturbed sediment samples through water. The giant syringe consists of a 9-cm-diameter, thick-wall Lexan tube, which was forced into the pond bottom to retrieve a core approximately $10 \mathrm{~cm}$ deep. The core is retained in the sampler by suction created by a rubber stopper attached to a stiff rod (Figure 5.26). Following retrieval of the core, the sediments were then forced out of the sample tube into a plastic bag and handled in a manner similar to the perimeter samples. All 38 samples were analyzed by the Rockwell Laboratory for gamma-emitting radionuclides, 20 were analyzed for plutonium and americium, and 20 for ${ }^{90} \mathrm{Sr}$.

The largest sampling effort was devoted to a $60-\times 60-\mathrm{m}$ square grid established over the entire U-Pond and 216-U-11 (U-11) Overflow Basin area, with the exception of the pond itself. During March and April 1980, the grid was established using a theodolite and steel tape, with survey markers placed at each grid point (Figure 5.27). This 95-point grid was established to be concordant with the Hanford Site coordinate system, so that, even after decommissioning of the area, these sampling sites could be reestablished. Prior to sample collection, each site was analyzed in situ, using Dev Van IA's downlooking $\mathrm{Ge}(\mathrm{Li})$ detector (Figure 5.28). Following in situ analyses, large twigs and other nuisance debris were removed and surface core samples were taken. The surface samples were collected by taking flve uniformally spread $(2.45-\mathrm{cm}$-deep by $7.35-\mathrm{cm}$-diameter) cookie cutter samples via a sampling template made to imitate the surface area seen by the downlooking $\mathrm{Ge}(\mathrm{Li})$ detector. These samples were then placed into a common plastic bag and mixed thoroughly. From this, a 500-mL aliquot was taken and placed in a plastic jar. The remaining sample was then bagged and taped for future reference. Of the 96 surface samples collected, the Rockwell Laboratory analyzed 32 for gamma-emitting radionuclides, 34 for plutonium and americium, and 34 for ${ }^{90} \mathrm{Sr}$. Fifty-one surface samples were analyzed by Eberline for $\Sigma U$. 
WHC-EP-0707, Rev. 0

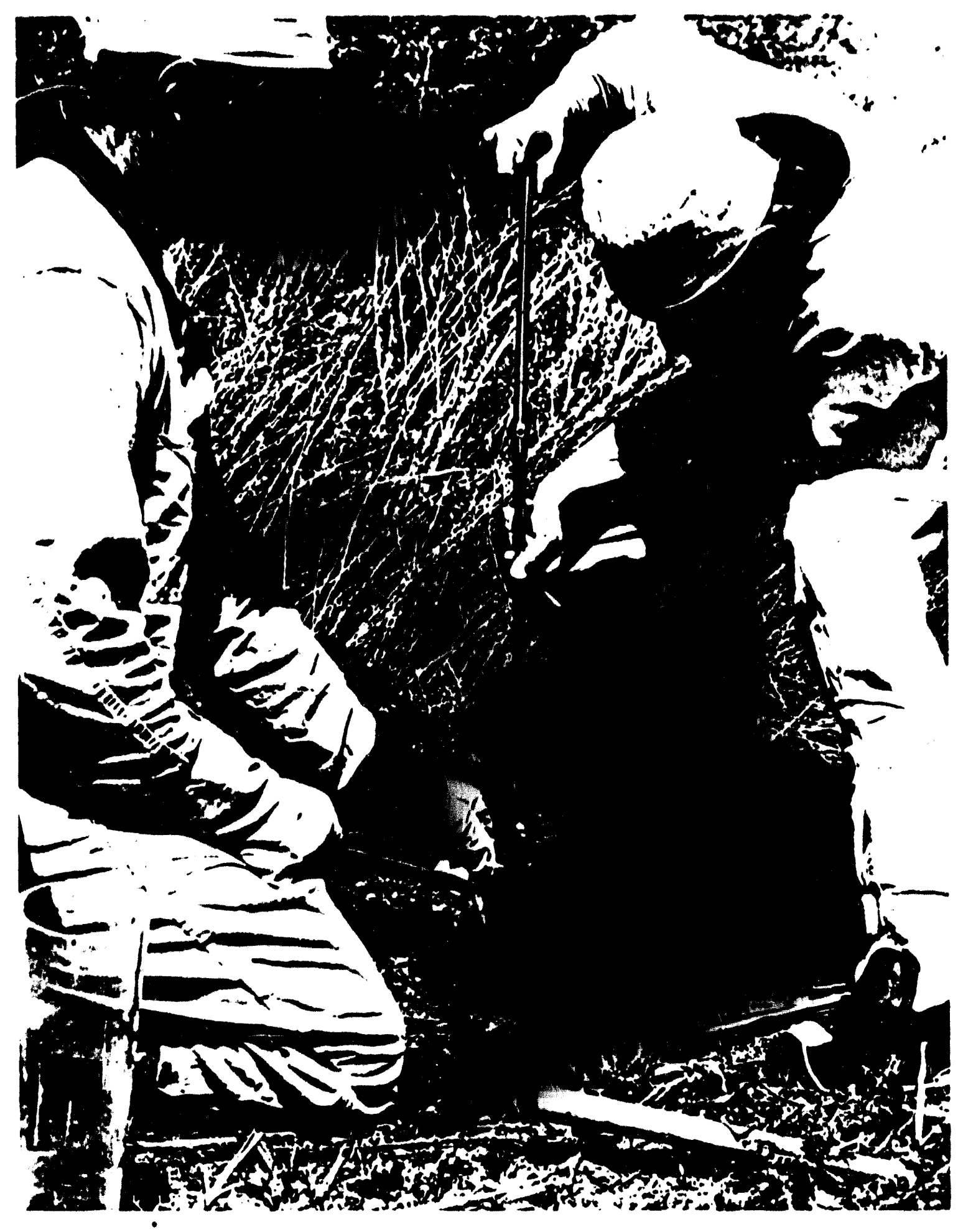

Figure 5.23. Hand Auger Sampling 


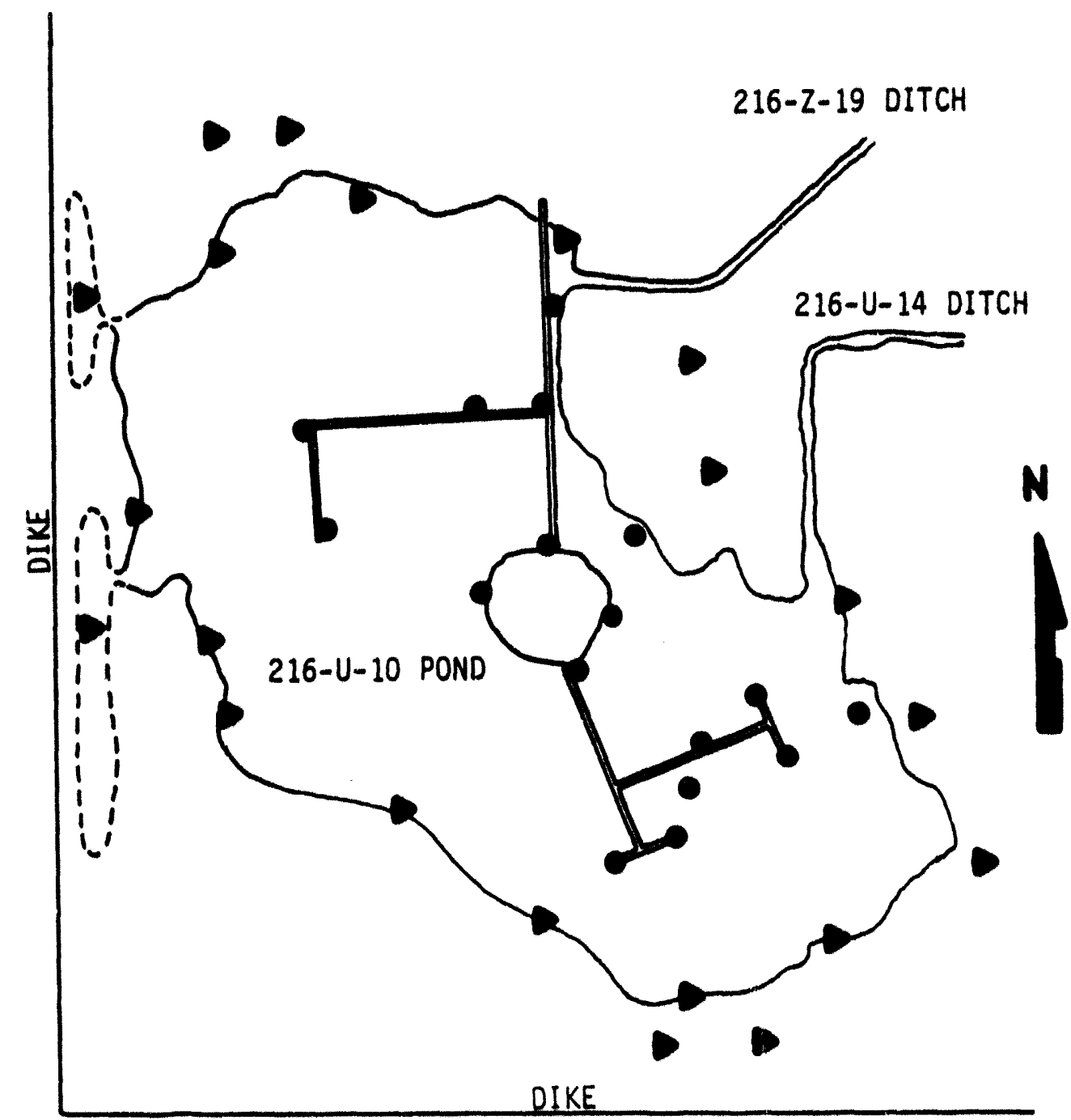

- PERIMETER SURFACE SAMPLES

- POND BOTTOM CORE SAMPLES

Figure 5.24. Location of Perimeter Surface Samples and Pond-Bottom Core Samples Taken in Late 1979 
WHC-EP-0707, Rev. 0

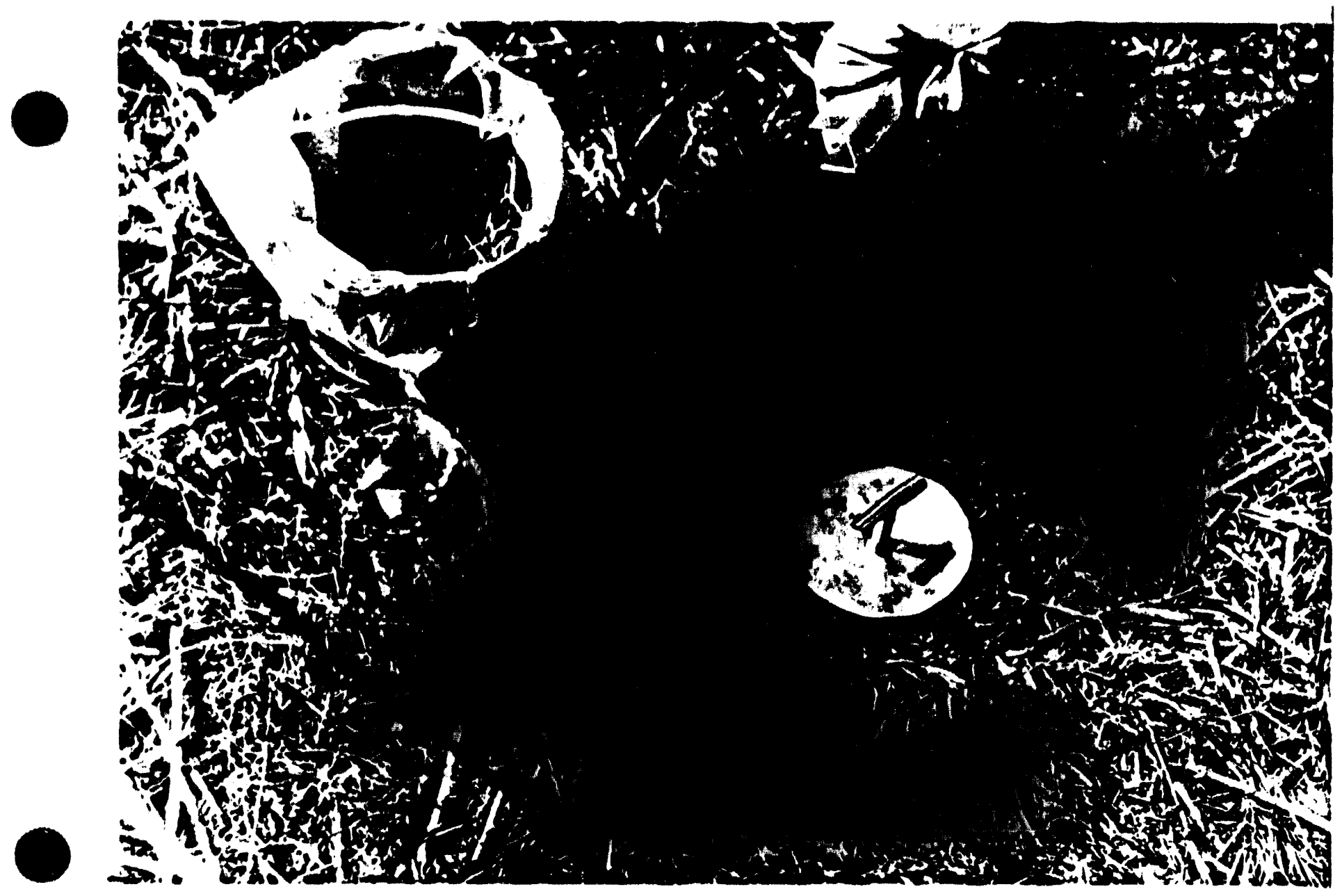

Figure 5.25. Cookie-Cutter-Type Surface Sampling

Following the surface sampling, a 30-cm-deep core sample was taken at each site around U-Pond, but only at selected sites in the U-11 Overflow Basin. These cores, taken from the center of the sampling template, were then divided into four subsamples by depth: 0 to 5,5 to 10,10 to 20 , and 20 to $30 \mathrm{~cm}$. The 0 - to $5-\mathrm{cm}$ samples may contain some disturbed material left over from surface sampling. The coring and subsampling techniques were similar to those used in the $30-\mathrm{x} 30-\mathrm{m}$ square grid core sampling of the delta area.

Complete cores (four subsamples each) from 11 grid points (a total of 44 samples) were analyzed by $\mathrm{Dev}$ Van IA's $\mathrm{Ge}(\mathrm{Li})$ detector, using the sample-to-detector technique. Fifteen of the 20 - to $30-\mathrm{cm}$ subsamples were analyzed by the Rockwell Laboratory for gamma emitters. Three each of the 0 - to 5and 20 - to $30-\mathrm{cm}$ subsamples were analyzed by Eberline for $\Sigma U$.

The intent of this sampling design was to place more emphasis on the relatively inexpensive Dev Van IA in situ analyses and to minimize the more expensive laboratory analyses. 


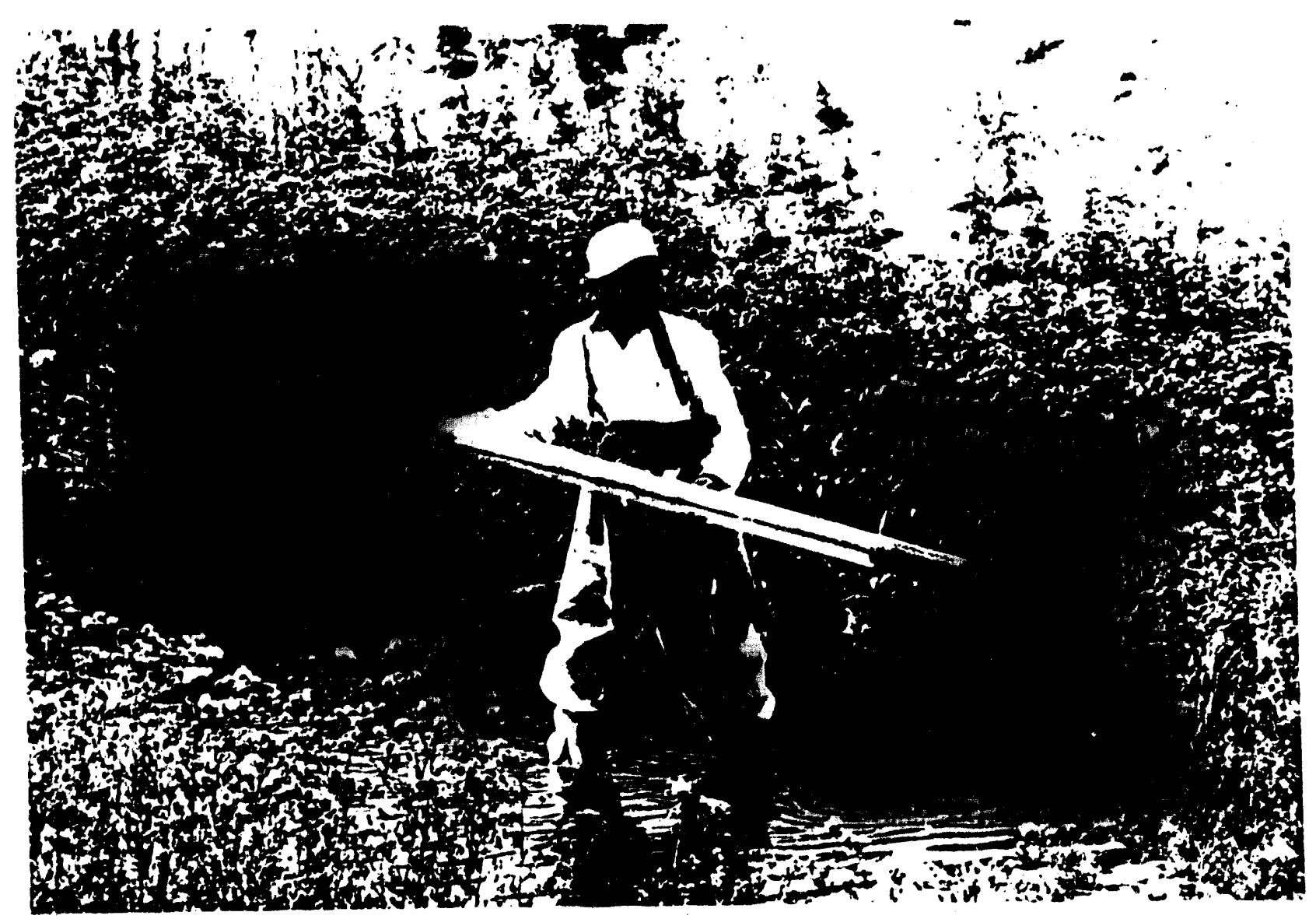

Figure 5.26. Giant Syringe Core Sampling of the 216-U-14 Ditch

Two other sampling activities were later implemented to make refinements of the preliminary results developed from the above analyses. The first, in August 1980, involved the Dev Van IA in situ analyses of 38 additional sites established to investigate areas of potential contamination missed by the 60- x 60-m grid. The second, in November 1980, was aimed at refining the contamination boundary at the 20 - to $30-\mathrm{cm}$-depth range. To accomplish this, six core-sampling sites were established, using a compass and steel tape, inside two of the leach trenches (three sites each at UN-216-W-15 and UN216-W-16). Samples were collected from depths of 0 to 10 and 20 to $30 \mathrm{~cm}$ by using the $30-\mathrm{cm}$ coring technique described earlier or, where necessary, by using a shovel to obtain grab samples from the desired depths. Another near-surface sample was obtained from one of the perimeter sites, surface sampled in November and December 1979. This sample was obtained from the 17.5- to $37.5-\mathrm{cm}$ depth by using a hand auger. All these samples, plus 11 additional core samples ( 5 from 10 to $20 \mathrm{~cm}$ and 6 from 20 to $30 \mathrm{~cm}$ ) from the 60- x 60-m grid sampling were analyzed at the Rockwell Laboratory for gamma-emitting radionuclides. 


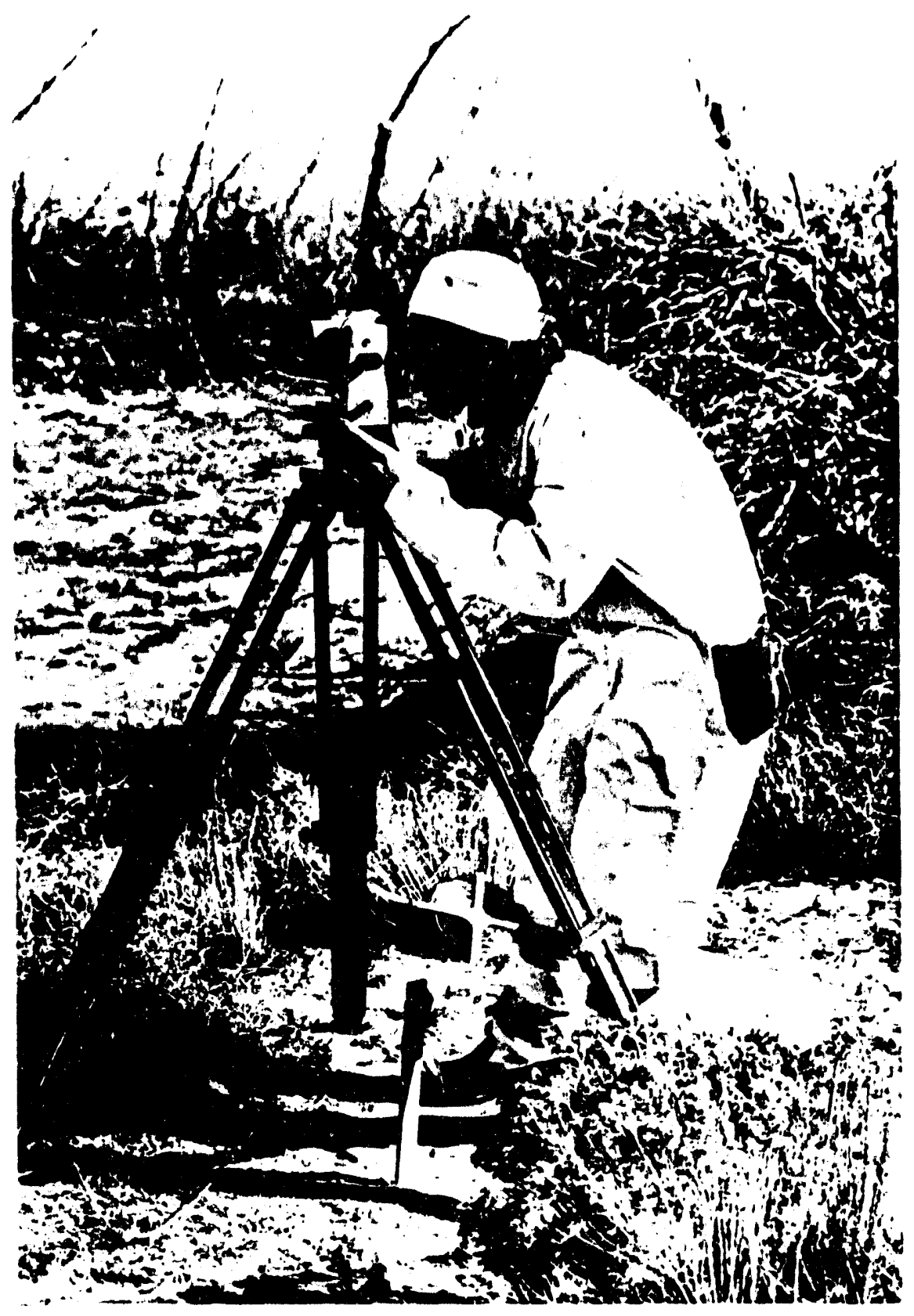

Figure 5.27. Establishment of Grid Points

216-Z-19 Ditch. In May and June 1979, a cooperative sampling program was initiated to support atmospheric transport, biological, and geologic studies of the Z-19 Ditch. Nine transects were established across the Z-19 Ditch (refer to Section 5.2.1 for details), with seven sampling stations along each transect. For simplification, each station is labeled by transect and station number (e.g., 1A is 


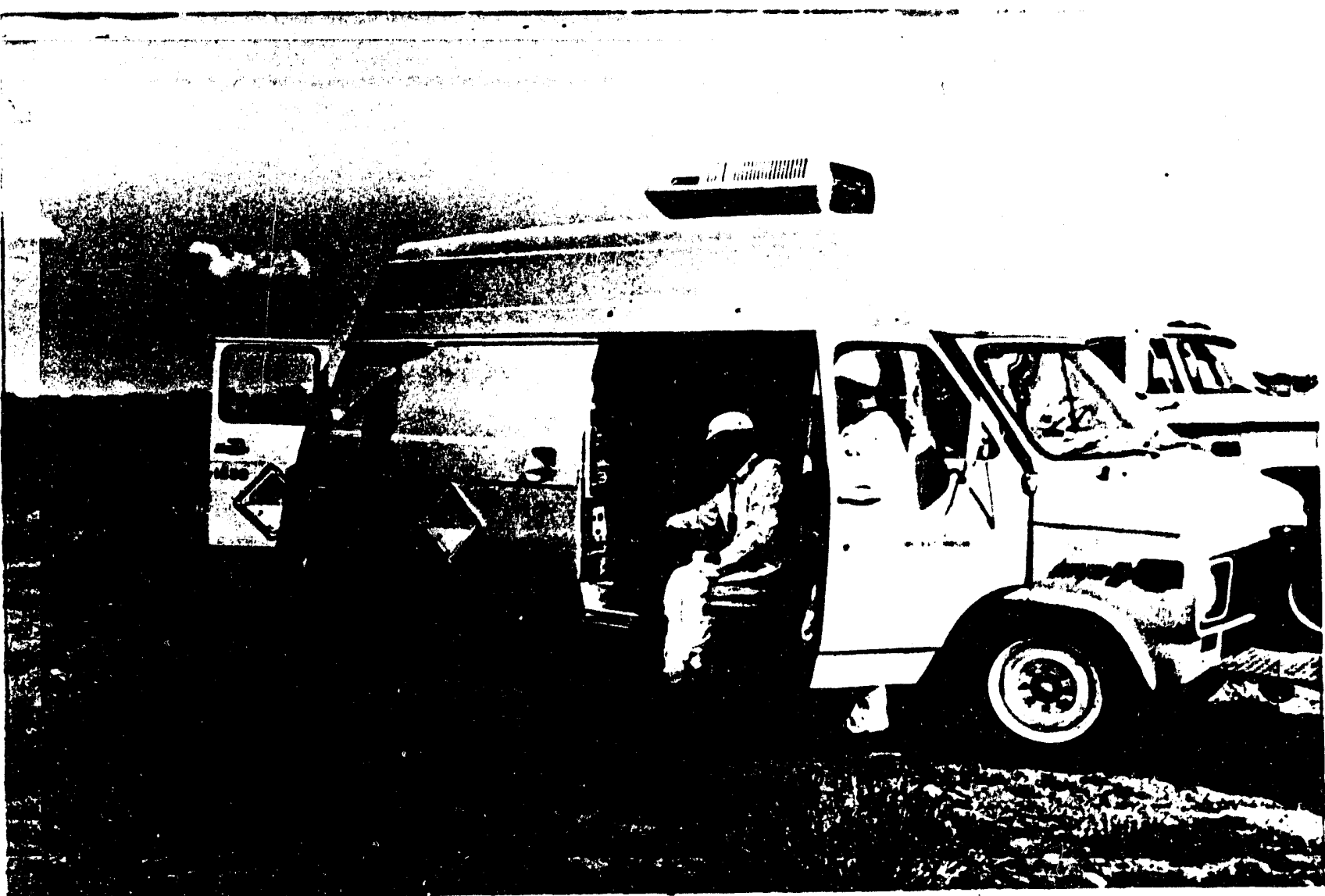

Figure 5.28. Dev Van IA in Situ Analysis of Grid Points

station A on transect 1; see Figure 5.3). A split-tube sampler was used to obtain 30-cm-deep cores from all stations but those in the ditch center. Each of these $30-\mathrm{cm}$ cores was divided into 0 - to 5-, 5- to $15-$ and 15- to ? $0-\mathrm{cm}$ subsamples and placed in $65-\mathrm{cm}^{3}$ containers. Samples from 40 to 60 and 70 to $90 \mathrm{~cm}$ were then collected using a hand auger.

The transect stations in the ditch center, north of 16th Street, were all under water and were sampled from temporary work platforms constructed across the ditch. To obtain undisturbed cores at these stations, a special underwater core sampler was developed to keep water out of the sampling tube and to provide a suction to retain the loose sediment during recovery. This sampler, similar to the giant syringe sampler, is constructed of Lexan tubing. The sampling tubes were $5.7 \mathrm{~cm}$ in diameter and $2.4 \mathrm{~m}$ in length. This sampling method worked well, with the cores averaging $76 \mathrm{~cm}$ (Figure 5.29). Each core was then broken into $10-\mathrm{cm}$ subsamples by cutting the plastic sampling tube with a hacksaw and carefully removing the center of the sediment core to prevent cross contamination from smear along the tube wall (Figure 5.30). 


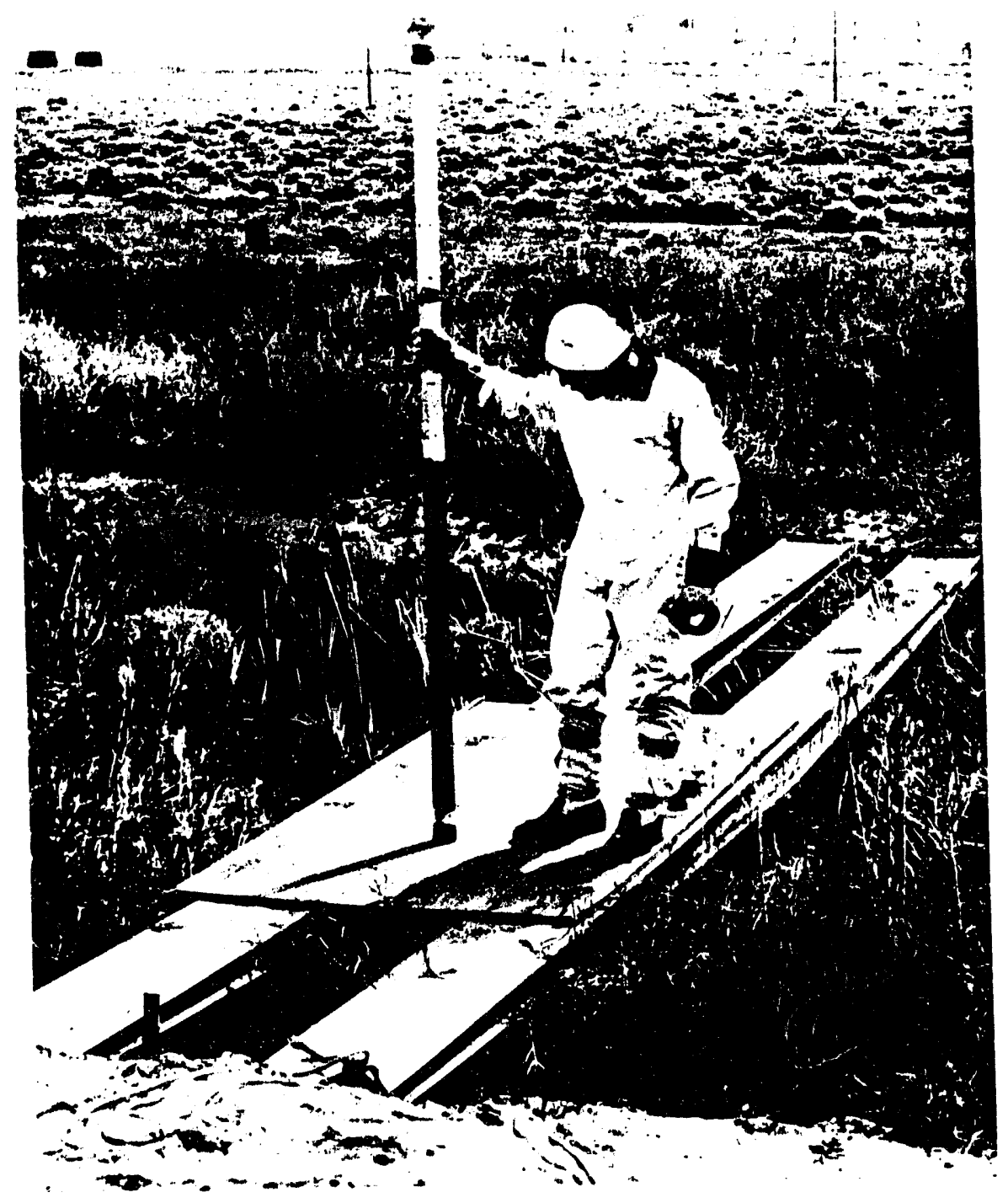

Figure 5.29. Core Sampling of the 216-Z-19 Ditch-Bottom Sediments

The two center ditch stations (1C and $2 \mathrm{C}$ ) below 16th street were dry and were sampled using the $30-\mathrm{cm}$ core sampler. Four subsamples were taken from each of these cores at 0 to 5,5 to 10,10 to 20 , and 20 to $30 \mathrm{~cm}$.

In all, 246 samples were collected from the 63 transect stations. The Rockwell Laboratory analyzed 172 samples for gamma-emitting radionuclides, 103 for plutonium and americium, and 8 for ${ }^{90} \mathrm{Sr}$. Eight samples were analyzed for plutonium and americium using Dev Van IA's $\mathrm{Si}(\mathrm{Li})$ detector. 


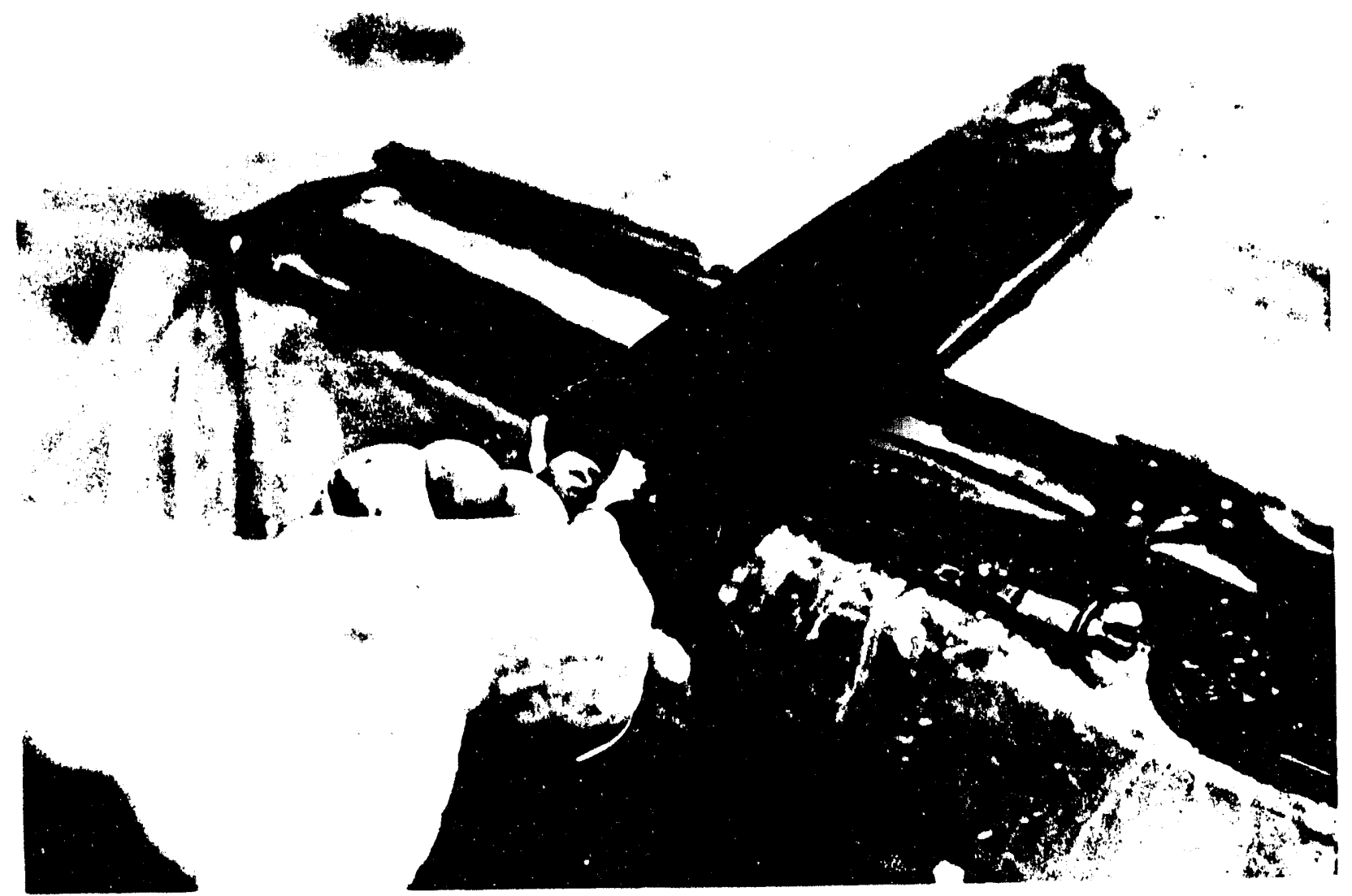

Figure 5.30. Subsampling of the 216-Z-19 Ditch-Bottom Cores

To further characterize the dry lower end of the ditch, surface samples were taken at 30-m intervals from 16th Street to the pond. These were collected by compositing five cookie cutter samples, taken in a transect across the ditch bottom (Figure 5.31), into a plastic bag. After thorough mixing, one $65-\mathrm{cm}^{3}$ and two $12.5-\mathrm{cm}^{3}$ aliquots were taken and the remaining sample bagged for future reference. These composited samples were taken to be representative of the average contamination levels across the ditch bottom. In the delta area where the ditch is not well defined, five cookie cutter samples were taken in an "X" pattern from a $90-\mathrm{cm}^{2}$ area. All 13 samples were analyzed at the Rockwell Laboratory for plutonium and americium concentrations.

216-U-14 Ditch. Following the sampling plan used for the Z-19 Ditch, 12 transects were established across the U-14 Ditch on the basis of the aerial gamma survey (Tipton 1973; Bruns 1975) (Figure 5.32). Two sampling stations were located on each ditch bank along each transect. At each station, core samples were taken using a split-tube core barrel. The cores were then subsampled into 0to 5-, 5- to 15-, and 15- to 30-cm depth intervals. A total of 144 samples were collected by the Biological Sciences Unit. The Rockwell Laboratory analyzed all the samples for gamma emitters only. 
WHC-EP-0707, Rev. 0
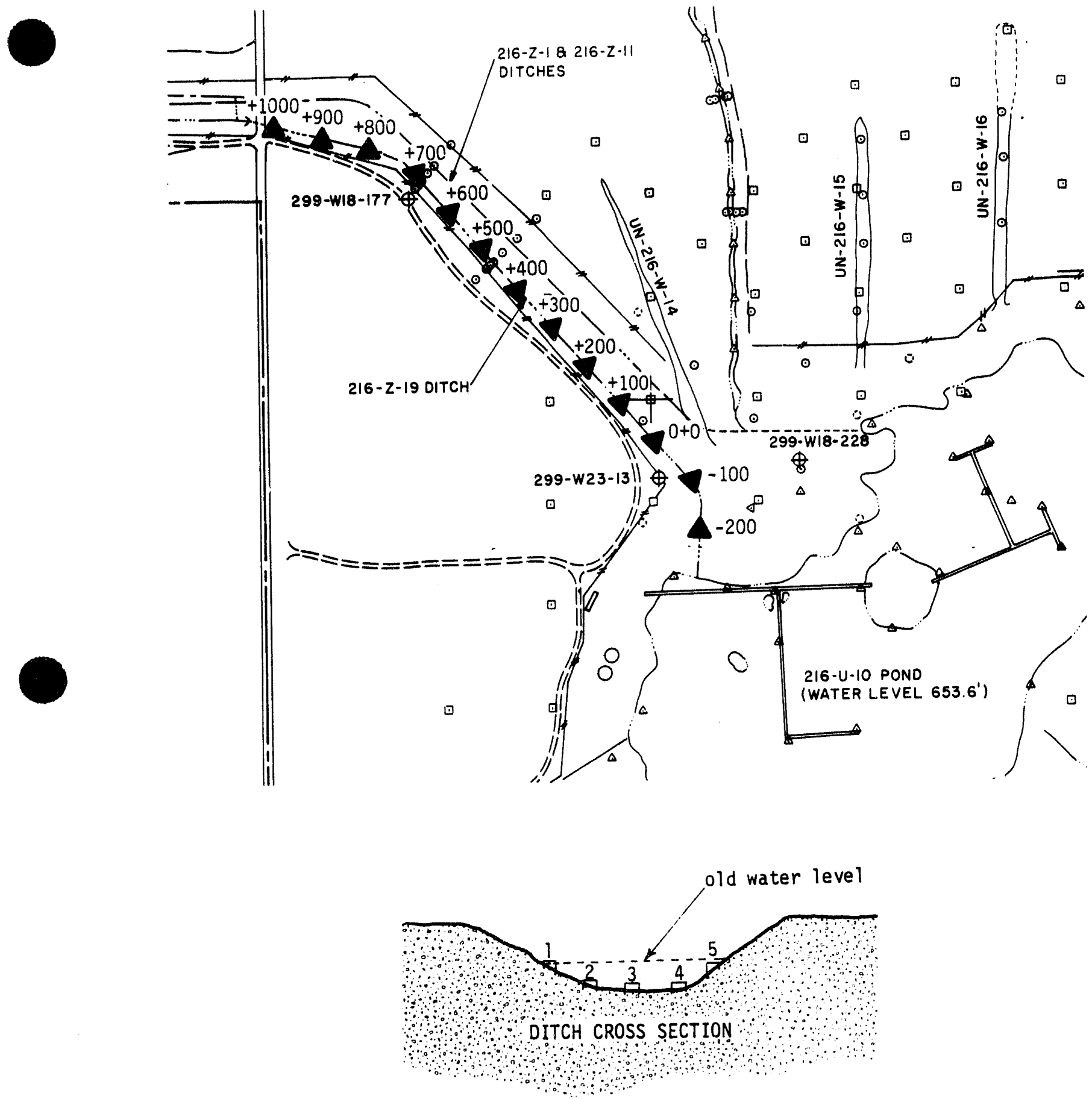

Figure 5.31. Location of the 216-Z-19 Ditch-Surface Samples 


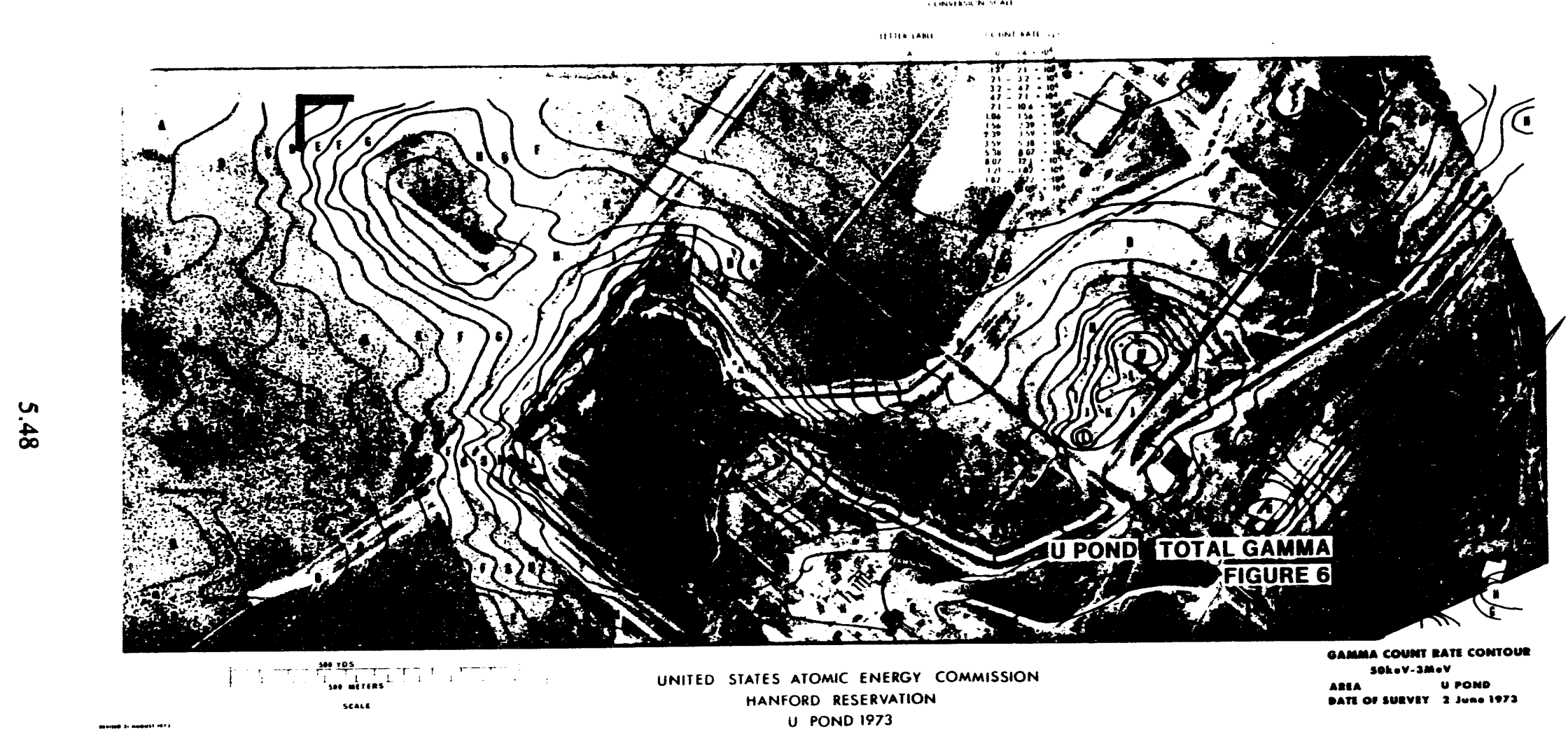

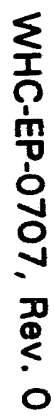

Figure 5.32. Establishment of the 216-U-14 Ditch-Sampling Transects 
The center of the ditch was core sampled at 30-m intervals from U-Pond to Cooper Avenue and $2 \mathrm{~m}$ downstream from each transect above Cooper Avenue. These core samples were collected using the giant syringe sampler that was manually carried into the ditch center. Once at the sampling location, the sampler was driven into the sediment using a 1.4-kg hammer. After the sampler was removed, the top $30 \mathrm{~cm}$ of core was pushed out of the sampler into a plastic bag. A total of 25 samples were collected. Each core sample was then mixed thoroughly and 500- and $12.5-\mathrm{mL}$ aliquots taken. Twenty-four of the 500-mL samples were analyzed by the Rockwell Laboratory for fission products and activation products. The $12.5-\mathrm{mL}$ aliquots (two for each station) were analyzed by Eberline for $\Sigma$ IU.

Several other cores were taken at the top end of the ditch, three at the head wall, and one each at distances of 15, 30, and $60 \mathrm{~m}$ downstream (Figure 5.33). These cores were taken in a manner similar to those in the center of the Z-19 Ditch, using temporary working platforms and the special underwater core sampler. Slight modifications were made to the sampler when sampling from the 4-m-high head wall (Figure 5.34). The cores, which averaged $75 \mathrm{~cm}$ long, were divided into $10-\mathrm{cm}$ incremental subsamples similar to those from the Z-19 Ditch. This resulted in 46 samples. The Rockwell Laboratory analyzed 45 for gamma-emitting radionuclides, 2 for plutonium and americium, and 22 for ${ }^{90} \mathrm{Sr}$.

\section{Subsurface Sampling}

Subsurface sediment sampling was accomplished in two phases: 1) the drilling of monitoring wells and 2) the drilling of shallow exploration wells (Table 5.8).

Monitoring Wells. Three monitoring wells were drilled during March and April 1980 (Figure 5.35). Two of these wells, 299-W18-177 and -178, were located alongside the Z-19 Ditch and were drilled to depths of 27 and $23 \mathrm{~m}$, respectively, never penetrating the water table. The third well, 299-W18-15, was located where the Z-19 Ditch enters the U-Pond delta area, approximately $53 \mathrm{~m}$ from the pond's edge. This well was drilled to a depth of $75 \mathrm{~m}$, penetrating the water table at approximately $53 \mathrm{~m}$. All three wells were constructed for permanent monitoring purposes.

The wells were drilled and sampled using standard cable-tool-drilling techniques and a drive-barrel sampler (Price et al. 1979) (Figures 5.36 and 5.37). Occasionally a split-barrel sampler was used to drill through cobble units, and when this proved inappropriate, the hard-tool (bit and bailer) method was used.

Sediment samples were collected throughout the entire length of each well. Those samples for moisture determinations were collected approximately every $0.3 \mathrm{~m}$ in the top $6 \mathrm{~m}$ of the well and every $0.8 \mathrm{~m}$ throughout the rest of the well. No moisture samples were taken when bit and bailer drilling techniques were used. Sediment samples for geologic and radiological analyses were collected approximately every $1.5 \mathrm{~m}$ or at notable changes in sediment type or moisture content. A total of 113 moisture samples and 100 geologic samples (two 500-mL samples) were collected. 


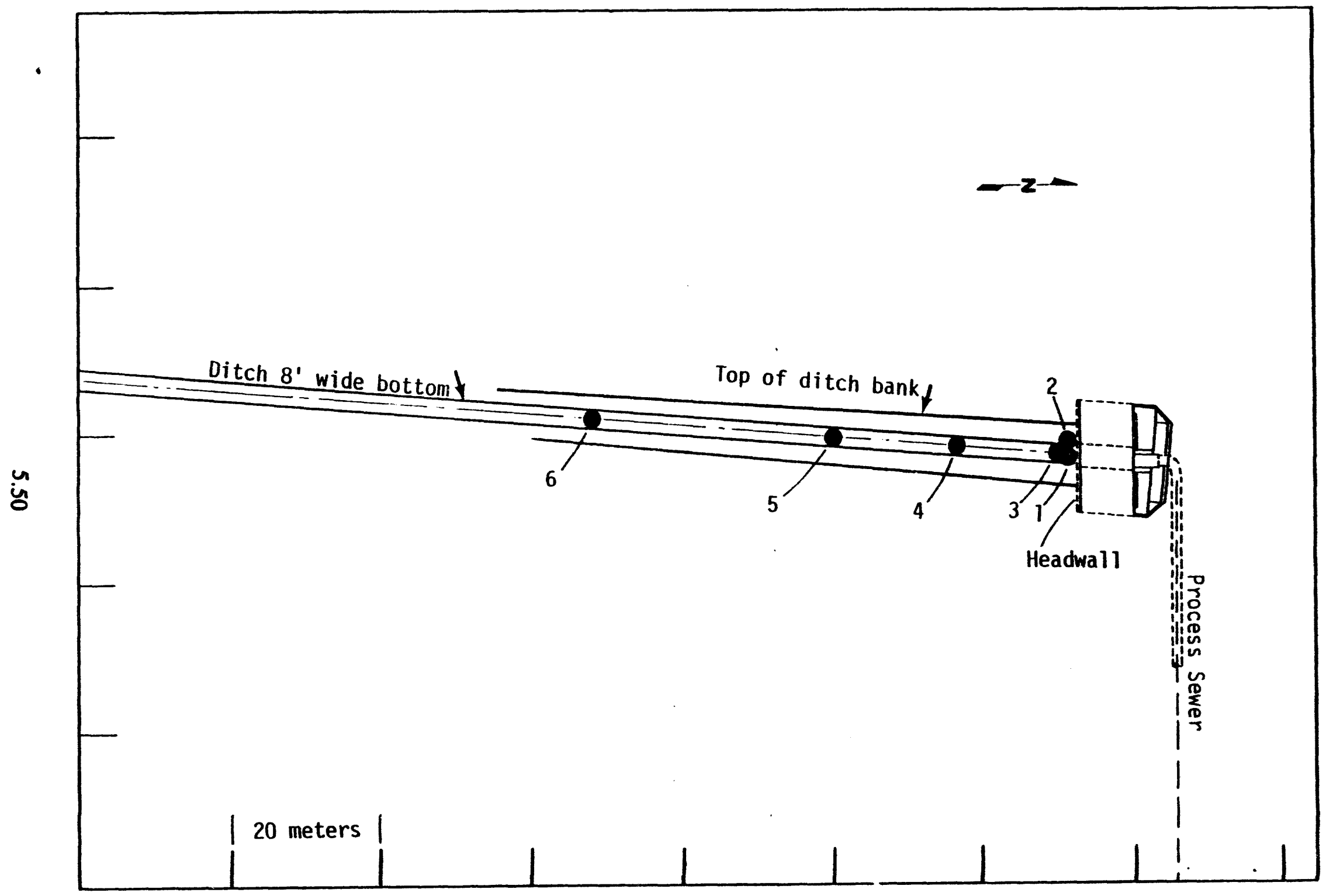

Figure 5.33. Head-End Core Sample Locations in the 216-U-14 Ditch 
WHC-EP-0707, Rev. 0

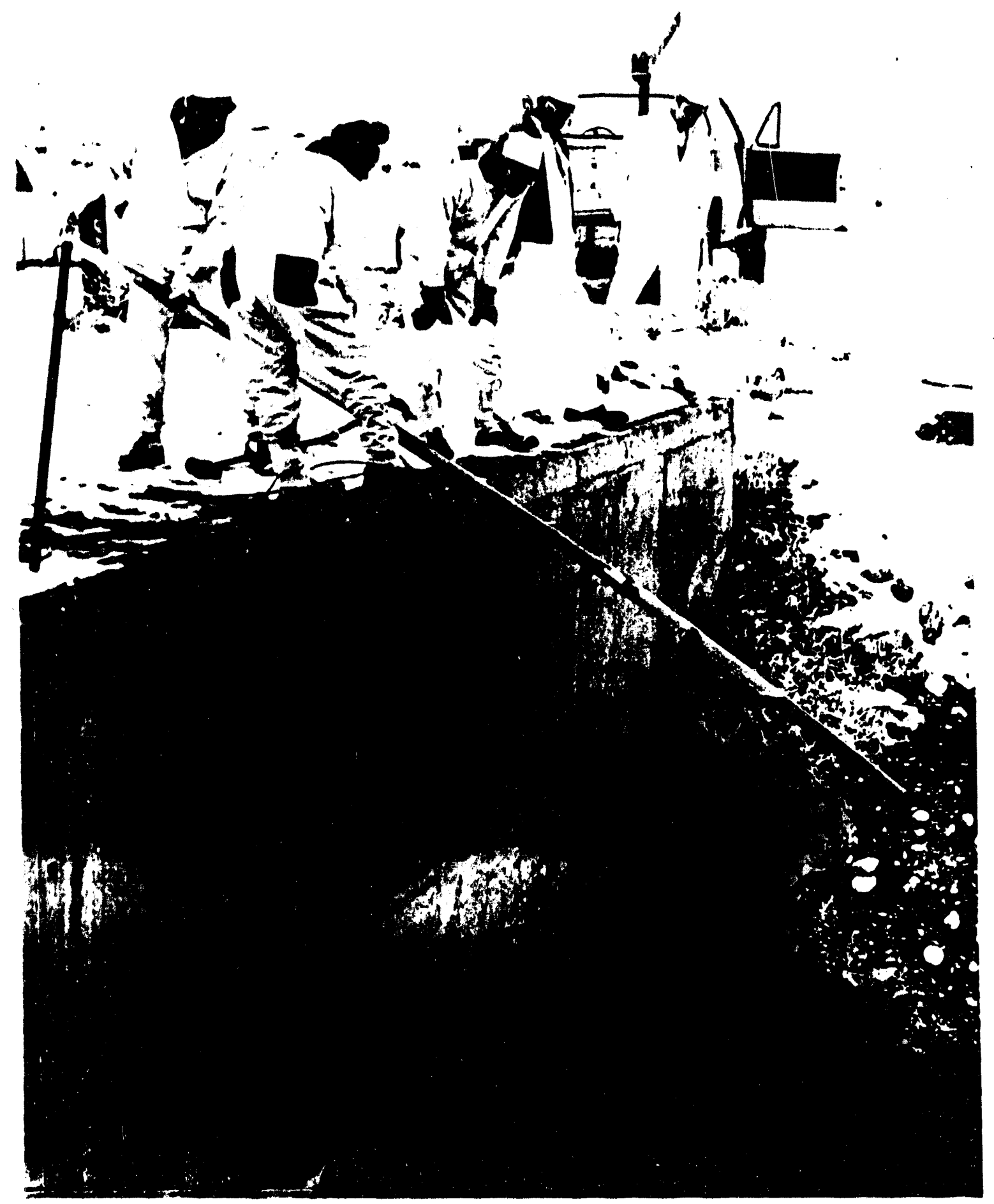

Figure 5.34. Core Sampling from the 4-m-High 216-U-14 Ditch Head Wall 
Table 5.8. Subsurface Samples and Analyses

\begin{tabular}{|c|c|c|c|c|c|c|c|}
\hline \multirow{3}{*}{ Sample } & \multirow{3}{*}{$\begin{array}{l}\text { Number of } \\
\text { Samples }\end{array}$} & \multirow{2}{*}{\multicolumn{4}{|c|}{ Laboratory Analyses }} & \multirow{2}{*}{\multicolumn{2}{|c|}{$\begin{array}{c}\text { Dev Van IA } \\
\begin{array}{c}\text { Sample-to-Detector } \\
\text { Analyses }\end{array}\end{array}$}} \\
\hline & & & & & & & \\
\hline & & GEA & $\mathrm{Pu} / \mathrm{Am}$ & ${ }^{90} \mathrm{Sr}$ & Total U & $\mathrm{Ge}(\mathrm{Li})$ & $\operatorname{Si}(\mathrm{Li})$ \\
\hline $\begin{array}{l}\text { Deep Monitoring Well } \\
\text { Samples }\end{array}$ & 100 & 37 & 30 & - & - & - & - \\
\hline $\begin{array}{l}\text { Shallow Exploration } \\
\text { Wells, U-Pond }\end{array}$ & 23 & 10 & 5 & 3 & - & - & - \\
\hline $\begin{array}{l}\text { Shallow Exploration } \\
\text { Wells, } 216-Z-1 \text { and } \\
\text { 216-Z-11 Ditches }\end{array}$ & 199 & - & 30 & - & - & - & 159 \\
\hline TOTAL & 322 & 47 & 65 & 3 & - & - & 159 \\
\hline
\end{tabular}




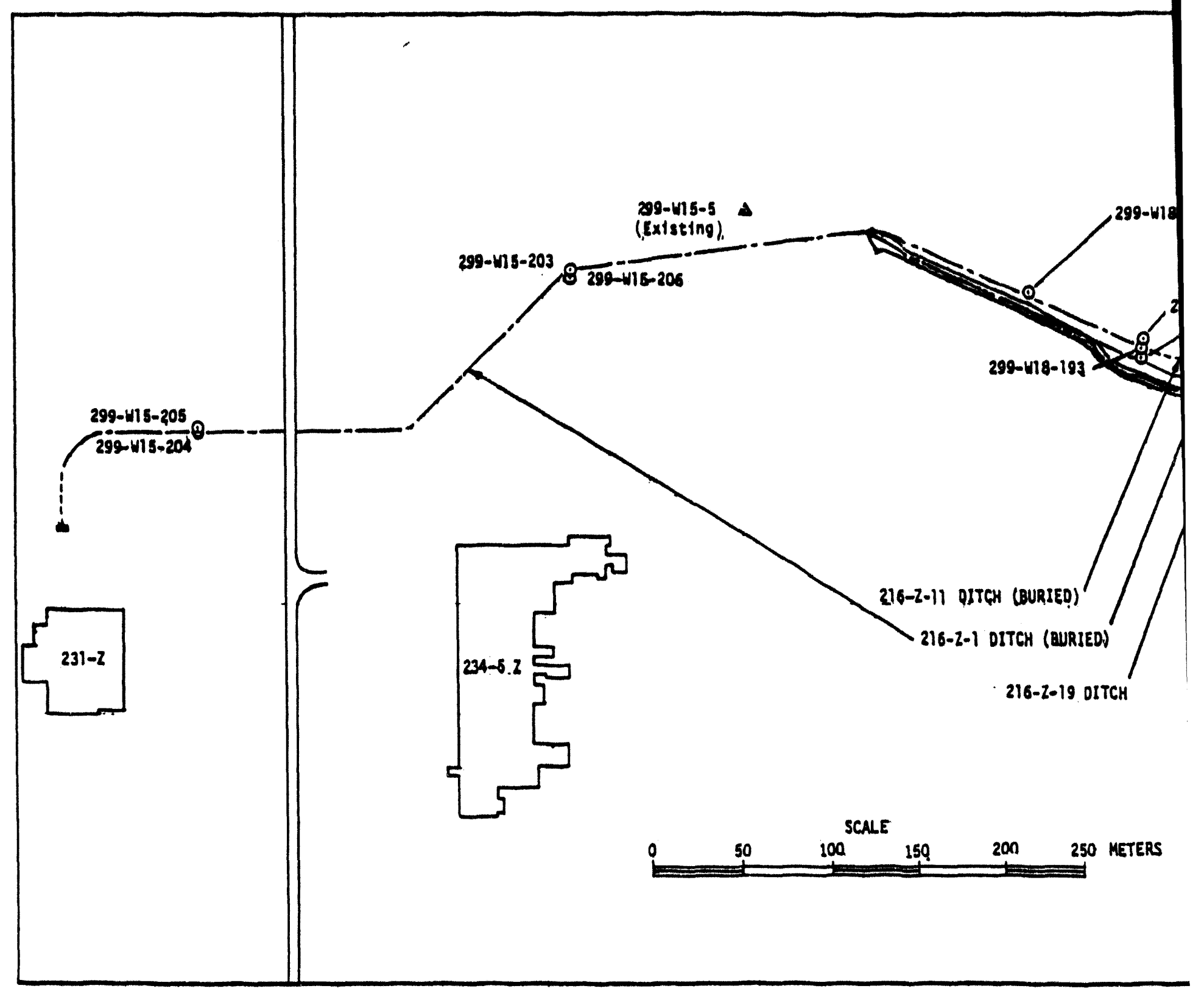

Figure 5.35. Location of Monitoring a 


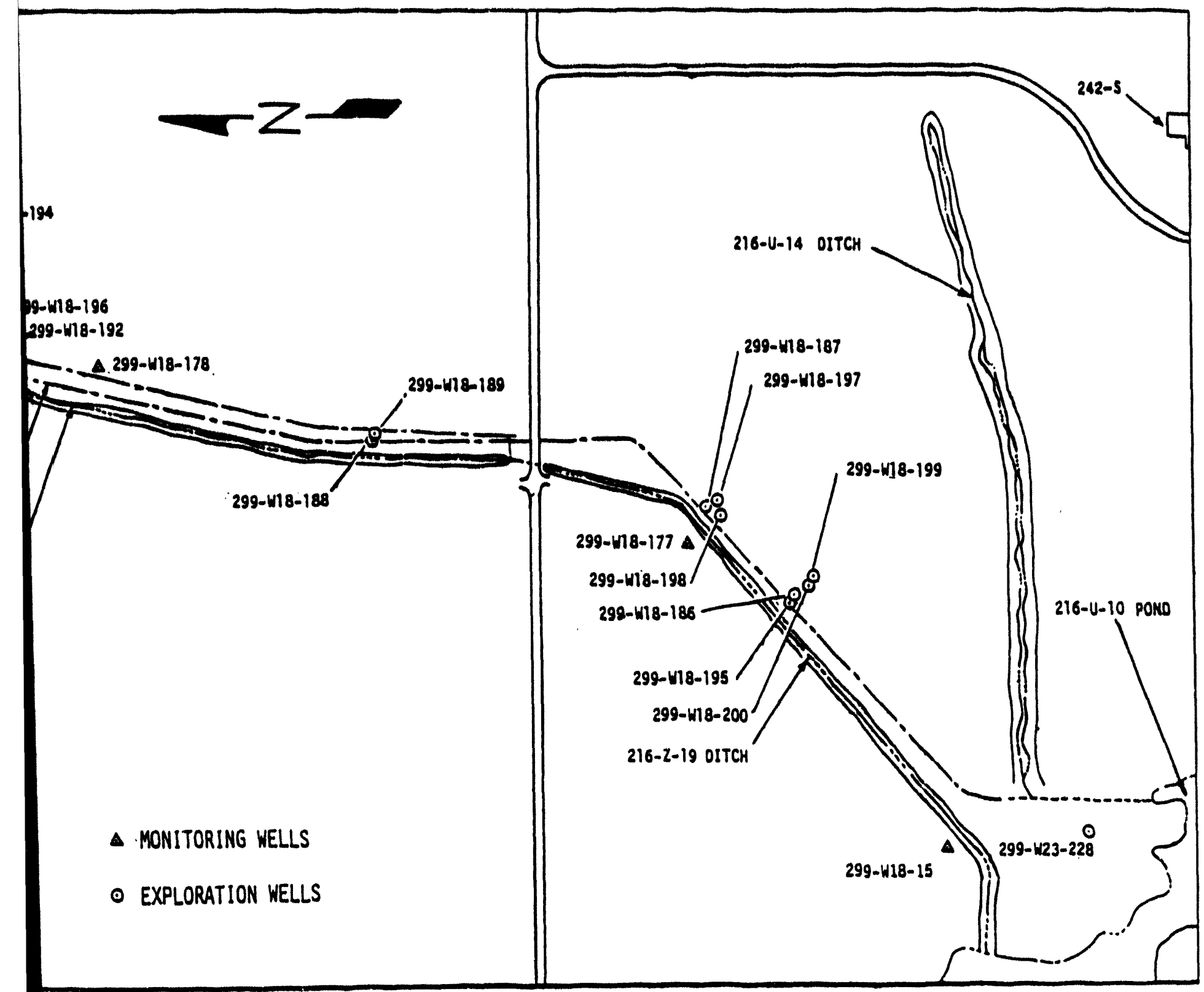

hd Exploration Wells 


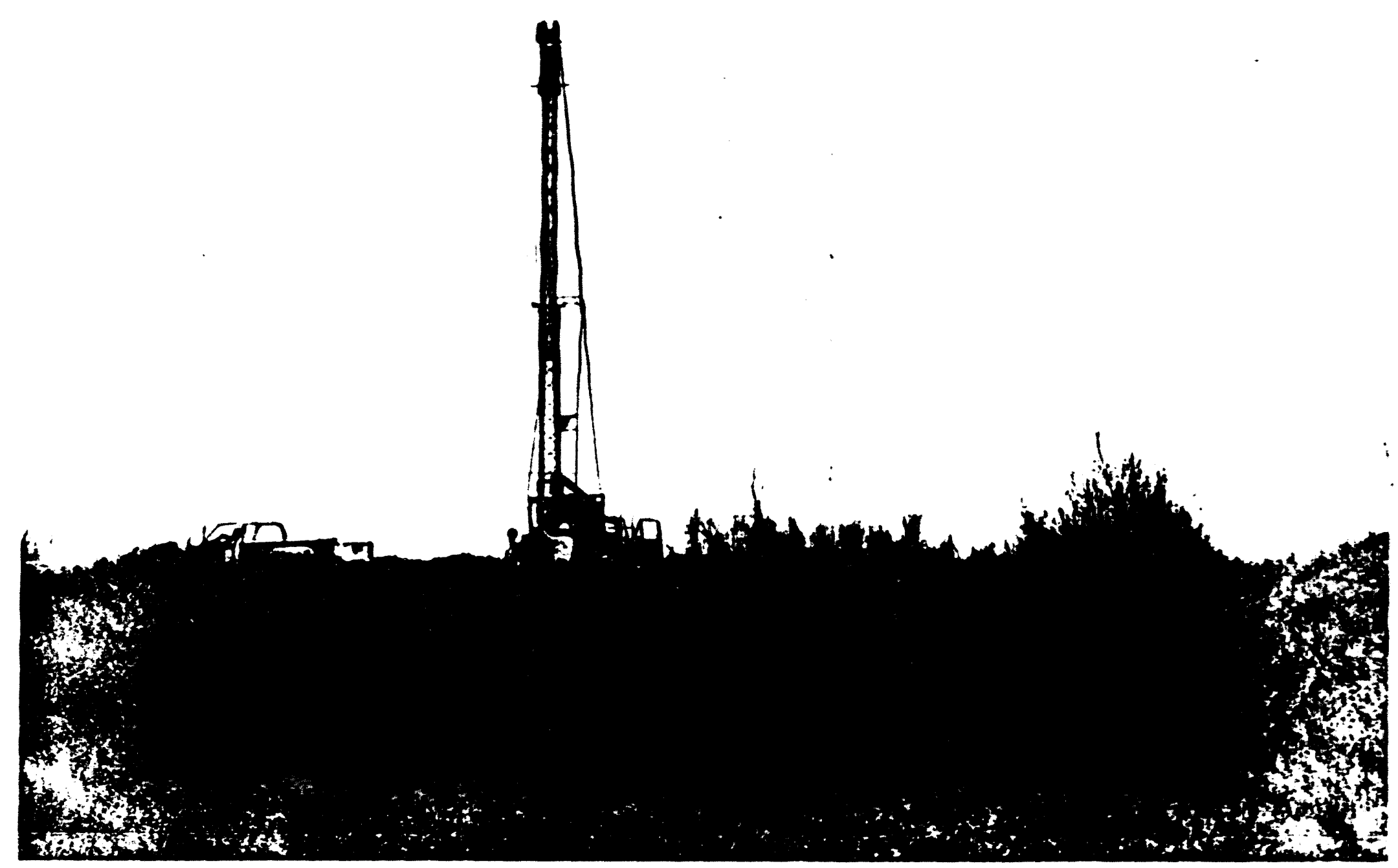

Figure 5.36. Cable-Tool-Drilling Rig 
WHC-EP-0707, Rev. 0

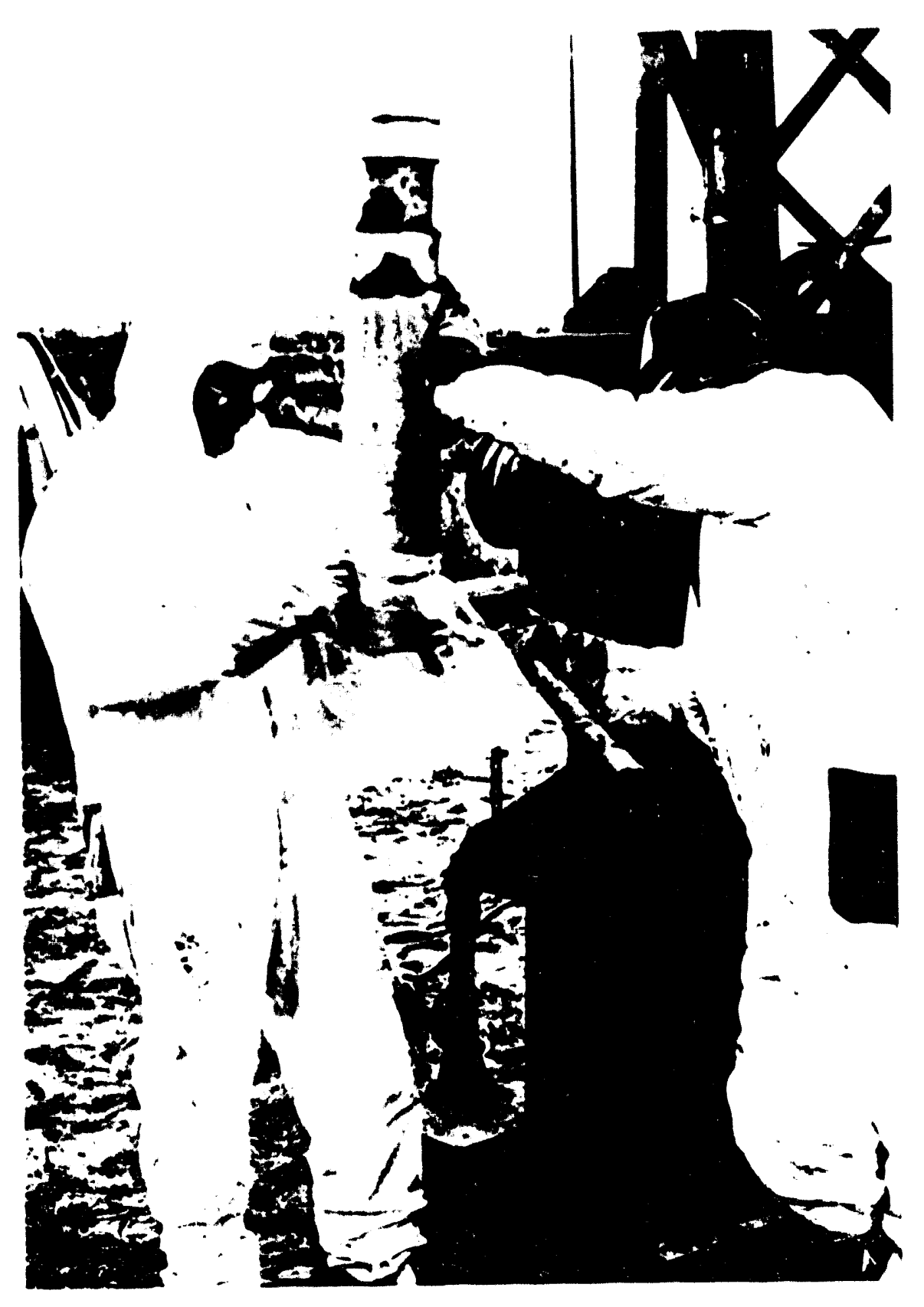

Figure 5.37. Drive-Barrel Sampling 
The Hydrogeology Sciences Unit performed gravimetric moisture analyses on all the moisture samples. The Rockwell Laboratory performed granulometric and $\mathrm{CaCO}^{3}$ analyses on all geologic samples from well 299-W 18-15 and the lower half of well 299-W18-177, and $\mathrm{CaCO}^{3}$ analyses on all geologic samples from well 299-W18-178. The Rockwell Laboratory also performed GEAs on 37 samples from the upper $46 \mathrm{~m}$ of well 299-W18-15. The LFE Laboratory (now Environmental Analysis Laboratories, Richmond, California) performed plutonium and americium analyses on 9 samples from the upper $12 \mathrm{~m}$ of this same well.

Plutonium and americium concentrations were also determined in samples from the top $12 \mathrm{~m}$ of wells 299-W 18-177 and -178. Eberline analyzed 15 of these samples and the LFE Laboratory analyzed 6 samples.

Exploration Wells. Eighteen shallow exploration wells were drilled to locate and sample areas of suspected or known subsurface contamination. The first well (299-W23-228) was drilled in February 1980 in the U-Pond delta (see Figure 5.35) to confirm the suspected existence of buried contamination in the U-Pond delta, inferred from the aerial gamma survey (Tipton 1973; Bruns 1975). This well was drilled by following standard tripod drilling procedures. A 7.3-m tripod was used in conjunction with a 64-kg hammer and threaded drill rods (Figure 5.38). The sampler was a 7.3-cm-diameter split-tube drive barrel; 7.6-cm-diameter threaded casing was installed. Well 299-W23-228 was drilled to a lepth of $7.3 \mathrm{~m}$. Fifteen moisture samples were collected at $30-$ to $60-\mathrm{cm}$ intervals and were gravimetrically analyzed by the Rockwell Laboratory. Radiological samples were collected at approximately 30-cm intervals or at changes in sediment type, resulting in 23 samples. The Rockwell Laboratory analyzed 10 of these samples for gamma-emitting radionuclides, 5 for plutonium and americium, and 3 for ${ }^{90} \mathrm{Sr}$ (Appendix I).

The remaining 17 shallow exploration wells were drilled to locate and sample the buried Z-1 and Z-11 ditches. Sixteen of these wells were drilled and sampled during February and March 1981 by cable-tool-drilling techniques. These wells were drilled using a $12.7-\mathrm{cm}$-diameter drive barrel and $15.2-\mathrm{cm}$ casing. When fleld-detectable contamination was encountered, the core barrel was decontaminated and/or the casing was kept close to the bottom of the hole to prevent cross contamination. Also as a cross-contamination precaution, the radiologic samples were collected from the bottom of the core barrel by removing sediment only from the center of the core. A total of 180 radiological samples were collected from approximately 30 - and $60-\mathrm{cm}$ intervals down the length of each well. These samples were then mixed thoroughly in a plastic bag and three subsamples taken: one $65-\mathrm{cm}^{3}$ sample and two $12.5-\mathrm{cm}^{3}$ samples. One-hundred fifty-nine samples were analyzed for plutonium and americium using Dev Van IA's $\mathrm{Si}(\mathrm{Li})$ detector, 26 by the Rockwell Laboratory, and 14 by the Environmental Analysis Laboratories. Following careful radiological sampling, the remaining core, excluding any slough, was emptied into large plastic bags, mixed thoroughly, and geologic (0.5-L) and moisture subsamples taken. One hundred ninety-three geologic samples (at $30-$ to $60-\mathrm{cm}$ intervals) and 77 moisture samples (at 60- to $120-\mathrm{cm}$ intervals) were collected. Rockwell's Hydrogeologic Sciences Unit analyzed all the uncontaminated moisture samples for gravimetric moisture content. The geologic samples were qualitatively classified as to their sediment type. 
WHC-EP-0707, Rev. 0

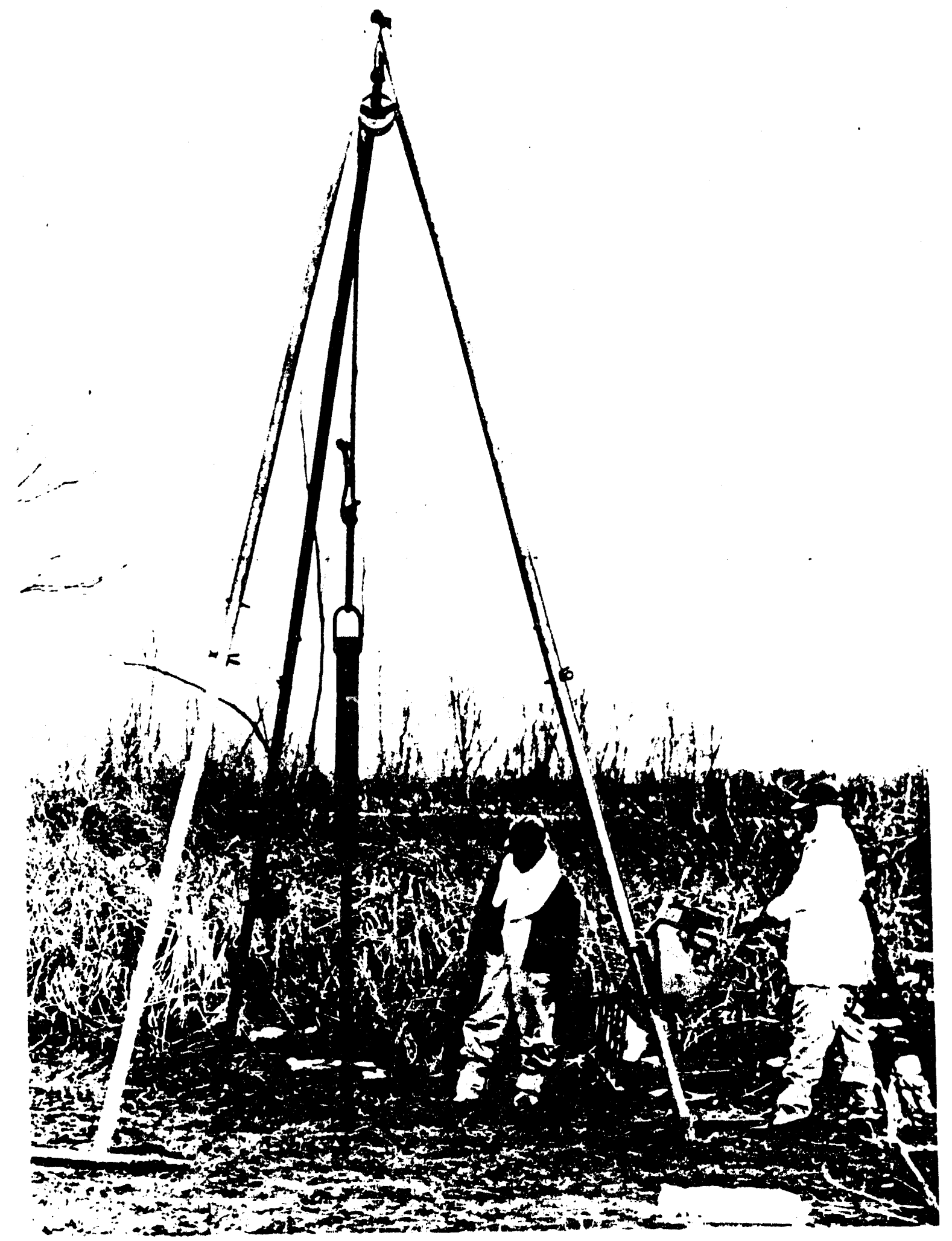

Figure 5.38. Tripod Drilling of Well 299-W23-228 
The seventeenth well (299-W18-195) was drilled in April 1981, using the tripod-drilling technique and split-tube sampler. Nine radiological samples were collected but have not been analyzed.

\section{Analytical Procedures}

Several types of analyses were performed on the samples taken from the U-Pond disposal system as outlined below.

Granulometric Analyses. Uncontaminated sediment samples collected from two of the deep wells (299-W18-15 and -178) were dry sieved using a rotap shaker (Fecht et al. 1978). The Rockwell Laboratory performed the analyses. In the procedure, a weighed aliquot of approximately $150 \mathrm{~g}$ is shaken for $15 \mathrm{~min}$ through a nest of nine $20.3-\mathrm{cm}$-diameter wire mesh sieves, and the disaggregate retained by each screen is weighed and recorded. The size fractions thus separated range from 0.037 to $4.0 \mathrm{~mm}$ and correspond with Wentworth grade-scale divisions (Figure 5.39). The relative proportions of these size fractions are used to categorize the sediment sample. These data were used in developing the geologic cross sections.

Plutonium and Americium Analyses. Three laboratories-Rockwell, Eberline, and LFE Laboratory-analyzed the sediment samples for ${ }^{238} \mathrm{Pu},{ }^{239.240} \mathrm{Pu}$, and ${ }^{241} \mathrm{Am}$. Chemical-extraction techniques were used to extract the plutonium and americium from the sediment. The plutonium was then separated from the americium, electroplated, and analyzed by alpha energy analysis (AEA). The americium was analyzed by AEA or GEA.

\begin{tabular}{|c|c|c|c|}
\hline & \multicolumn{2}{|c|}{ PAATICLE DESIGNATION } & $\begin{array}{l}\text { PARTICLE DIAMETER } \\
\text { (MM) }\end{array}$ \\
\hline \multirow{3}{*}{$\sum_{\frac{\pi}{0}}^{\frac{1}{0}}$} & \multicolumn{2}{|c|}{ BOULDER } & $>256$ \\
\hline & COBBLE & $\begin{array}{l}\text { LARGE } \\
\text { SMALL }\end{array}$ & $\begin{array}{c}256-128 \\
128-64\end{array}$ \\
\hline & PEBBLE & $\begin{array}{l}\text { VERY COARSE } \\
\text { COARSE } \\
\text { MEDIUM } \\
\text { FINE } \\
\text { VERY FINE }\end{array}$ & $\begin{array}{c}64-32 \\
32-16 \\
16-8 \\
8-4 \\
4-2\end{array}$ \\
\hline & SAND & $\begin{array}{l}\text { VERY COARSE } \\
\text { COARSE } \\
\text { MEDIUM } \\
\text { FINE } \\
\text { VERY FINE }\end{array}$ & $\begin{array}{c}2-1 \\
1-0.5 \\
0.5-0.25 \\
0.25-0.125 \\
0125-0.0625\end{array}$ \\
\hline & \multicolumn{2}{|c|}{ SILT \& CLAY } & $<0.0625$ \\
\hline
\end{tabular}

Figure 5.39. Grain-Size Nomenclature (Wentworth 1922) 
Uranium Analyses. Analyses for $\Sigma$ U content were preformed by the Eberline and LFE laboratories. Eberline used a fluorometric analysis technique, with a detection limit of $5 \mathrm{mg} / \mathrm{g}$ of sample ( $2 \mathrm{pCi} / \mathrm{g}$ of sample). The LFE Laboratory analyzed the samples isotopically via sediment digestion, chemical purification, and alpha spectrometry. The limit of detection was estimated at $0.005 \mathrm{pCi} / \mathrm{g}$ of sample.

Strontium Analyses. All ${ }^{90} \mathrm{Sr}$ analyses were performed by the Rockwell Laboratory using chemical-extraction methods. The ${ }^{0} \mathrm{Sr}$ was then beta assayed.

Gamma Energy Analyses. All analyses for gamma-emitting radionuclides were conducted by the Rockwell Laboratory using a system of three $\mathrm{Ge}(\mathrm{Li})$ detectors and 400 -channel analyzer.

In-Field Radionuclide Analyses. In-field soil surface analyses for $\gamma$ (gamma-emitting) and $X$-ray-emitting radionuclides were accomplished using a mobile data-gathering system (Kay 1980). This system, designated Dev Van IA, contained equipment necessary to support a $\mathrm{Si}(\mathrm{Li}) \mathrm{X}$-ray spectrometer for surface samples obtained in fixed-geometry sample containers and a downlooking $\mathrm{Ge}(\mathrm{Li})$ gamma ray spectrometer for in situ surface analysis. Spectral data were recorded on magnetic tapes as a transfer medium for later data reduction in the laboratory, using the computer-based gamma, X-ray reduction software program (Zimmer 1974).

Plutonium-americium analyses were accomplished using the X-ray spectrometer system. Soil samples in $65-\mathrm{cm}^{3}$ plastic containers were analyzed inside Dev Van IA. This mode of operation is referred to as "sample-to-detector" in-field analysis: Using this sample geometry with a low background, the minimum determinable level of plutonium for a $500-\mathrm{s}$ count is $1 \mu \mathrm{Ci} / \mathrm{g}$. The minimum determination level for ${ }^{241} \mathrm{Am}$ is $0.1 \mu \mathrm{Ci} / \mathrm{g}$.

Fission-product analyses were accomplished using the downlooking $\mathrm{Ge}(\mathrm{Li})$ spectrometer system. The primary radionuclide found was ${ }^{137} \mathrm{Cs}$. Using the in situ sample geometry with a low background, the minimum determinable amount of ${ }^{137} \mathrm{Cs}$ for a 500 -s count is $14,000 \mathrm{pCi} / \mathrm{g}$.

Neutron Logging. Neutron logs were taken at each shallow exploration well along the Z-19 Ditch to determine areas of higher neutron activity. This was accomplished by using a Campbell Pacific Nuclear Corporation hydroprobe with the neutron-emitting source removed. These data were of little value in locating the ditch or in aiding the selection of samples to be analyzed.

\subsubsection{Results}

A wide variety of data from previous investigations and the current study of the U-Pond disposal system is available for examination. This section details the assumptions and techniques involved in the presentation of the geologic data, followed by a discussion of the results by disposal-system component. An interpretation of these results is presented in Section 5.3.3. 
Interpretation of data from previous studies was often troublesome. For example, exact sampling locations, sampling methods, and analytical precisions generally were not given. Alternatively, a welldocumented study could not be directly correlated with surface or subsurface contamination at a given point (e.g., the aerial gamma survey; Tipton 1973; Bruns 1975). For the most part, the earlier studies were used to indicate trends in areal contamination or to corroborate findings of this study. In some cases, though, results were described in sufficient detail to be integrated directly. into the results of this study.

The results from the Dev Van IA in situ analyses required some special interpretation. The Dev Van IA in situ measurements were similar to laboratory-analyzed samples from the same location in areas of fairly uniform contamination. However, in "clean" areas adjacent to contaminated areas, Dev Van IA values are much higher than sample values (see, for example, ${ }^{137} \mathrm{Cs}$ values on the dike to the west of U-Pond, Plate 3). Evidently, the in situ counter "sees" some radiation (shine) from the nearby contaminated areas. In these situations, care was taken in interpreting Dev Van IA values.

Arriving at the overall methods of data synthesis involved several decisions. First, it was decided to present the data as a series of contour maps and cross sections of contamination levels. For that to happen, it was necessary to construct the contours by hand because several qualitative factors had to be taken into account. Specifically, on the surface and near-surface maps, it was necessary to individually interpret Dev Van IA in situ measurements as discussed in the previous paragraph. Also, knowledge of the operating history of the pond-ditch system indicated that the topography of the area had to be taken into account. For example, it was assumed that most of the contamination in the U-11 Overflow Basin would be in the ditches and low-lying areas because waste water never inundated the upper areas of the basin. Therefore, contours were drawn using linear interpolation with adjacent points and modified according to topography where necessary. Contour intervals start at a low of $10 \mathrm{pCi} / \mathrm{g}$ and increase in increments of factors of ten (i.e., 10,100, etc.). One additional isopleth at the average soil contamination limit for the radionuclide being plotted was added to reflect the boundary of the area requiring decontamination and decommissioning activity. Three types of surface soil contamination limits were developed for use by Rockwell: the average contamination limit, which assumes a general dispersion of contamination through the soil; the areal contamination limit, which assumes a concentration of activity in the uppermost centimeter or so of soil; and the spot activity limit, which assumes that all contamination is concentrated in less than $1 \mathrm{~cm}^{3}$ or is areal contamination less than $15 \mathrm{~cm}^{2}$ (Boothe 1979). All three limits for the radionuclides pertinent to this study are presented in Table 5.9. The average contamination limit is more appropriate for our sampling technique, so those values are used to delineate the contaminated area.

Plates 1 and 2 were prepared for use as a reference when examining the radionuclide distribution maps and cross sections: Plate 1 is a topographic map and legend of the entire disposal system and Plate 2 is a location map of all current sampling locations.

The discussion of each portion of the U-Pond disposal system is included under three major topics: surface contamination, near-surface contamination, and subsurface contamination. Surface contamination indicates which radionuclides are present, their concentrations, their distribution, and their 
Table 5.9. Surface Soil Contamination Limits (in $\mathrm{pCi} / \mathrm{g}$ )

\begin{tabular}{|c|c|c|c|}
\hline Isotope & $\begin{array}{c}\text { Average Soil } \\
\text { Contamination Limits }\end{array}$ & $\begin{array}{c}\text { Areal } \\
\text { Contamination Limits }\end{array}$ & $\begin{array}{c}\text { Spot Activity } \\
\text { Limits }\end{array}$ \\
\hline${ }^{211} \mathrm{Am}$ & 300 & 50 & 720 \\
${ }^{137} \mathrm{Cs}$ & 400 & 60 & 960 \\
${ }^{60} \mathrm{Co}$ & 300 & 50 & 720 \\
${ }^{154} \mathrm{Eu}$ & 200 & 30 & 480 \\
${ }^{155} \mathrm{Eu}$ & 200 & 30 & 480 \\
${ }^{208} \mathrm{Pu}$ & 60 & 10 & 150 \\
${ }^{209} \mathrm{Pu}$ & 60 & 10 & 150 \\
${ }^{200} \mathrm{Pu}$ & 60 & 10 & 150 \\
${ }^{90} \mathrm{Sr}$ & 400 & 60 & 960 \\
${ }^{208} \mathrm{U}$ & 300 & 50 & 750 \\
\hline
\end{tabular}

(After Boothe 1979.)

peripheral contamination boundary. Near-surface contamination describes the radionuclide concentrations and distribution at various near-surface depths and the boundary of significant contamination (based on the surface soil contamination limits) should the near surface be uncovered. This information can be used to estimate the potential for reduction of the contaminated area boundary. Subsurface contamination identifies the subsurface concentrations and describes their distribution.

Throughout the discussion, the concept of "index" radionuclides is used. An index radionuclide is defined here as the isotope whose distribution best estimates the maximum extent of contamination. The index radionuclide for a given area is of importance in determining the total area requiring decontamination or stabilization. The concentrations and distributions of the various radionuclides are graphically displayed in maps and cross sections, while the numerical results of sample analyses are presented in Appendix H.

\section{6-U-10 Pond and 216-U-11 Overflow Basin}

A wide variety of radionuclides have been detected in this component of the disposal system. Included are transuranics, fission products, and activation products. Table 5.10 lists the specific radionuclides identified at this site. Cesium-137 is the index radionuclide for the majority of the U-11 Overflow Basin. Other radionuclides of importance are plutonium, ${ }^{241} \mathrm{Am}$, uranium, and ${ }^{90} \mathrm{Sr}$, which all exceed the surface soil contamination limits. All other radionuclides are of minor occurrence and are not further discussed. The ${ }^{137} \mathrm{Cs}$ and ${ }^{90} \mathrm{Sr}$ entered the system via the U-14 Ditch and the 241-SX-402 Pipeline. Uranium entered the system via the U-14 Ditch, and plutonium and ${ }^{241} \mathrm{Am}$ entered via the $\mathrm{Z}$-ditches. Concentrations of the various radionuclides generally decrease away from their discharge points. 
WHC-EP-0707, Rev. 0

Table 5.10. Radionuclides Detected in the 216-U-10 Pond and 216-U-11 Basin

\begin{tabular}{|c|c|c|}
\hline Component & $\begin{array}{l}\text { Activation and } \\
\text { Fission Products }\end{array}$ & Uranium and Transuranics \\
\hline 216-U-Pond and 216-U-11 Overflow Basin & $\begin{array}{l}{ }^{125} \mathrm{Sb} \\
{ }^{144} \mathrm{Ce} \\
{ }^{134,137} \mathrm{Cs}^{(n)} \\
{ }^{60} \mathrm{Co} \\
{ }^{134,155} \mathrm{Eu} \\
{ }^{106} \mathrm{Ru} \\
{ }^{20} \mathrm{Na}(?) \\
{ }^{85,90} \mathrm{Sr}^{(n)}\end{array}$ & 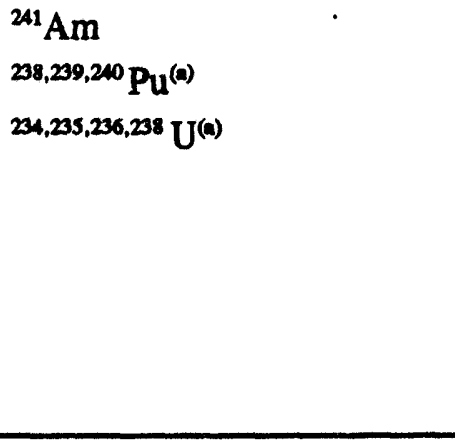 \\
\hline 216-Z-19 Ditch & ${ }^{137} \mathrm{Cs}$ & $\begin{array}{l}{ }^{288,239,240} \mathrm{Pu}^{(n)} \\
{ }^{241} \mathrm{Am}^{(n)}\end{array}$ \\
\hline 216-U-14 Ditch & $\begin{array}{l}{ }^{141,144} \mathrm{Ce} \\
{ }^{137} \mathrm{Cs} \\
{ }^{57,60} \mathrm{Co} \\
{ }^{152,154,155} \mathrm{Eu} \\
{ }^{59} \mathrm{Fe} \\
{ }^{54} \mathrm{Mn} \\
{ }^{95} \mathrm{Nb} \\
{ }^{106} \mathrm{Ru} \\
{ }^{22} \mathrm{Na}(?) \\
{ }^{85,90} \mathrm{Sr} \\
{ }^{65} \mathrm{Zn} \\
{ }^{95} \mathrm{Zr}\end{array}$ & $\begin{array}{l}239,240 \mathrm{Pu} \\
234,235,236,238 \mathrm{U}^{(1)}\end{array}$ \\
\hline
\end{tabular}

(a) Exceeds average surface soil contamination limits.

Surface Contamination. The surface distribution of the important radionuclides is illustrated in Plates 3 through 7. Discussion of individual radionuclide distributions follows.

- Cesium-137-The most obvious feature about the distribution of ${ }^{137} \mathrm{Cs}$, shown on Plate 3 , is the extent of contamination. In fact, the distribution exceeds that of any other radionuclide and is considered to represent the maximum extent of waste water from the pond. The average soil contamination limit of $400 \mathrm{pCi} / \mathrm{g}$ (see Table 5.9) is provided for defining the periphery of the contaminated area. There are areas on the map where some reported values seem anomalous. For example, the alternating Dev Van IA and laboratory values on the dike areas are obviously artifacts of the different analysis techniques. Some anomalously low values from the pond bottom remain unexplained, but because they are surrounded by high values, the whole area can be considered contaminated. 
- Plutonium-238,239,240-Emery and Garland (1974) found a wide range of ${ }^{228} \mathrm{Pu}$ to ${ }^{239.240} \mathrm{Pu}$ ratios in the pond-bottom sediments. The mean of the ratios was reported as $0.85: 1$, indicating that $\Sigma P u$ concentrations are probably significantly higher than those reported for ${ }^{239.240} \mathrm{Pu}$ on Plate 4.

- Americium-241 data, shown on Plate 5, are limited, particularly along the U-14 Ditch. Peripheral contamination levels are shown where possible, as well as the $300-\mathrm{pCi} / \mathrm{g}$ average soil contamination limit (see Table 5.9).

Note: The high concentrations of plutonium and americium are identifled along the lower portions of the Z-19 Ditch and the delta area. For reference purposes, a value exceeding $10 \mathrm{nCi} / \mathrm{g}$ is considered high. Areas exceeding this value are delineated by a dotted isopleth. Further investigations of the delta area have shown an association of the high concentrations with a thin (approximately $2.5-\mathrm{cm}$ ) organic layer composed of decaying vegetation below which the activity decreases rapidly. It should be noted, however, that the highest value recorded, $12,500 \mathrm{nCi} / \mathrm{g}$ ${ }^{239.200} \mathrm{Pu}$, was from a sample that was not predominantly organic.

- $\Sigma U$ values were reported in parts per million rather than picoCuries because ratios of the isotopes 234,235,236,238 $\mathrm{U}$ were not known. Specific activity calculations are necessarily rough estimates because the different isotopes have different activities. Plate 6 is, therefore, a map of $\Sigma U$ in parts per million. Concentrations increase up the U-14 Ditch to Cooper Avenue, the influent source of uranium to the system. The Z-19 Ditch can be assumed to be relatively free of uranium. The average soil contamination standard of $300 \mathrm{pCi} / \mathrm{g}$ for ${ }^{238} \mathrm{U}$ can be converted to parts per million by assuming the isotopic ratio of natural uranium $\left(0.7 \%{ }^{235} \mathrm{U}\right.$ and $\left.99.3 \%{ }^{238} \mathrm{U}\right)$. The result of the calculation is a limit of approximately $850 \mathrm{ppm}$, which should be considered an estimate of the applicable limit.

- Strontium-90 data are very limited. Those values that are available are shown on Plate 7, along with the average soil contamination limit of $400 \mathrm{pCi} / \mathrm{g}$. Notice that only one value exceeds the 400-pCi/g limit.

Near-Surface Contamination. The characterization of the near-surface contamination (Plates 8 and 9) allows estimates of the potential reduction of the U-Pond contamination boundary. For example, it may be possible to remove an upper layer of contaminated soil, leaving a new surface that is below surface soil contamination limits. For this reason, the near-surface characterization is discussed in terms of the surface soil limits.

Very few data are available for the near surface. A limited number of radionuclides have been detected, mostly owing to the limited numbers of analyses that have been received. The largest number of analyses exists for ${ }^{137} \mathrm{Cs}$, and because of its extent at the surface, it is considered an index radionuclide for the near surface also. There are adequate data for plutonium and americium only in the delta area where the Z-19 Ditch enters U-Pond. These data will be discussed under the Z-19 Ditch section. All other radionuclide analyses are too scarce to be of use in characterization. 
- Cesium-137-A large number of core samples were taken, but constraints in budget and laboratory capacity allowed only a small fraction of those to be analyzed. As a supplement to these values, Dev Van IA in situ measurements were used for guidance in drawing contours. Specifically, where no core data are available (as in the present pond) the near-surface values are generally assumed to be the same as the Dev Van IA concentrations. This is justified as a conservatively high value for two reasons. First, most radionuclides sorb onto soil particles and their concentration tends to decrease away from the source. In a pond bottom, the radionuclides would be expected to decrease with depth. Second, experience with actual cores in the U-Pond area shows the expected decrease in activity with depth almost exclusively. Contoured interpretations of ${ }^{137} \mathrm{Cs}$ levels are shown on Plate 8 for the $10-$ to $20-\mathrm{cm}$ depths and Plate 9 for the 20- to $30-\mathrm{cm}$ depths. The approximate area, which if uncovered, would exceed the surface soil contamination limit as shown by the dashed contours. Compared with the surface contamination map (see Plate 3), a significant reduction in contaminated area is indicated.

Comparison of activity concentrations at the various near-surface depths shows rapidly decreasing activity. This is because of the high sorption capacity of Hanford Site sediments, resulting in the accumulation of contamination on the surficia sediments.

Subsurface Characterization. The characterization of the subsurface provides information on the concentrations and distributions of the radionuclides with depth.

Very few data are available for the subsurface because only two wells (299-W18-15 and 299-W23-228) were drilled in this area (both at the U-Pond delta). A limited number of radionuclides were detected in the sediment samples collected during the drilling of these wells. The largest number of positive analyses exist for ${ }^{137} \mathrm{Cs}$ and, thus, it is used as an index radionuclide to define the maximum distribution of contamination in the subsurface. However, there is some indication in well $299-\mathrm{W} 23-228$ that ${ }^{90} \mathrm{Sr}$ may be a better index radionuclide, at the deeper depths, because of its higher concentration than ${ }^{137} \mathrm{Cs}$ in one sample, at the 7-m depth. This can be supported by experimental data on the relative sorption and migration of ${ }^{90} \mathrm{Sr}$ and ${ }^{137} \mathrm{Cs}$ derived using a similar waste type (Routson et al. 1981). The relative concentrations of the more significant radionuclides with depth and sediment type in wells 299-W18-15 and 299-W23-228 are given in Appendix J. Three general correlations can be made from these data: 1) activity generally decreases with depth, 2) activity peaks occur in the finer sediments, and 3) activity peaks occur in zones of higher moisture content, particularly saturated zones. Both the chemical properties controlling the waste sediment reactions and the physical properties that control water movement through unsaturated, stratified sediments are responsible for the waste distribution observed in these wells.

Figure 5.40 illustrates the subsurface distribution of ${ }^{137} \mathrm{Cs}$ in the U-Pond delta, as interpreted from the limited data described above.

\section{6-Z-19 Ditch}

Only four radioactive contaminants were detected in the ditch: ${ }^{137} \mathrm{Cs},{ }^{239.240} \mathrm{Pu}$, and ${ }^{241} \mathrm{Am}$ (see Table 5.10). Of these, ${ }^{239.240} \mathrm{Pu}$ and ${ }^{241} \mathrm{Am}$ are most important because of their concentration and 
WHC-EP-0707, Rev. 0

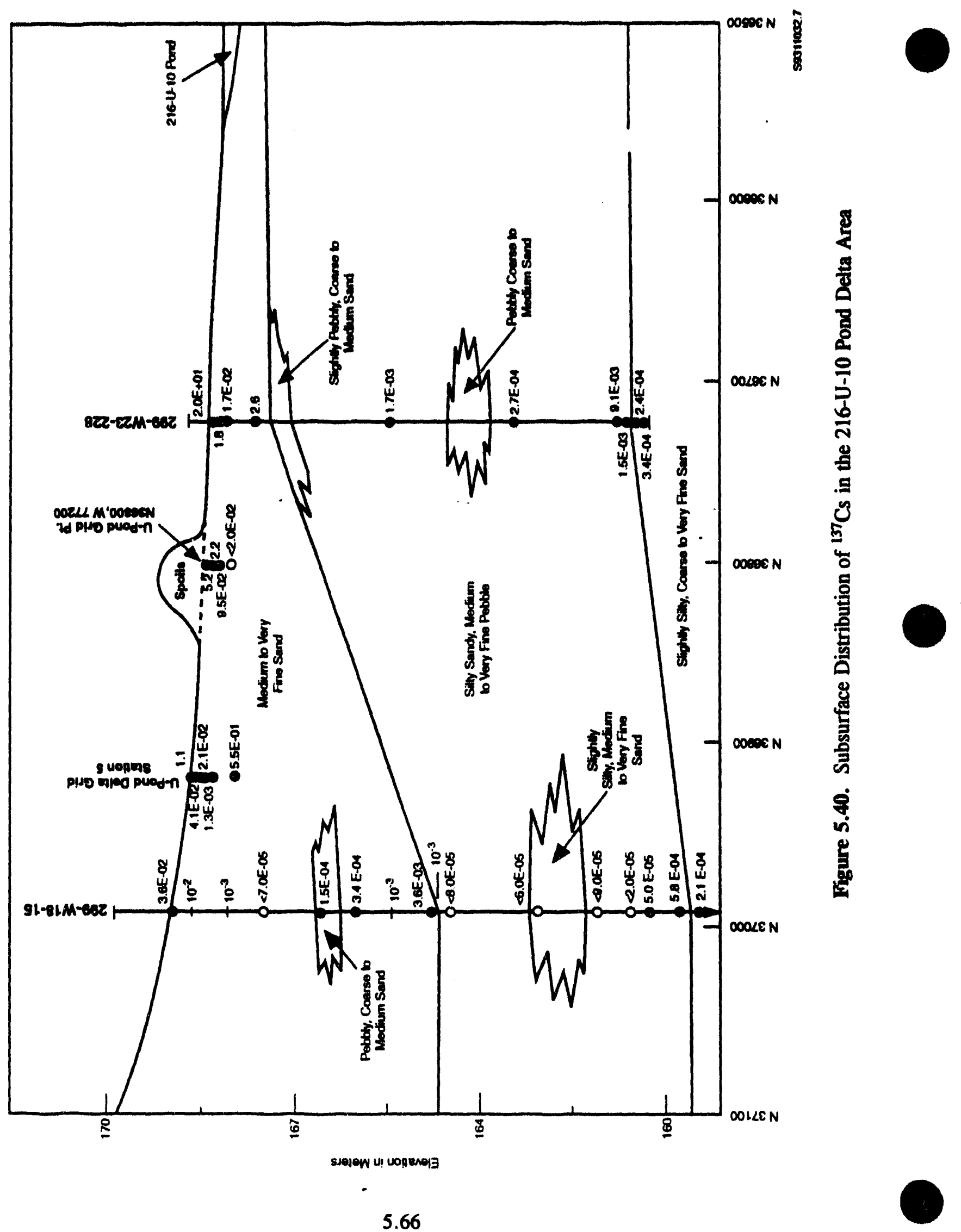


distribution. Plutonium-238 is important, but only limited data exist to characterize its distribution. Cesium-137 concentrations are generally below detection limits and always below surface soil contamination limits. No further discussion of ${ }^{137} \mathrm{Cs}$ is offered.

Plutonium and americium entered the ditch intermittently from two process sewer discharge pipes at the north end of the ditch. One pipe carried waste from the 231-Z Building (Laboratory) and the other was from 234-5Z Building. Distributions of the plutonium and americium are not always correlative, but the relative concentrations of plutonium to americium are usually much higher. Therefore, plutonium is used as the index radionuclide for this component of the disposal system.

\section{Surface Contamination.}

- Plutonium-239,240-Surface distribution of ${ }^{209.200} \mathrm{Pu}$ is defined on Plate 4 and schematically in Figure 5.41. The dashed contour represents the surface soil contamination limit for ${ }^{20.200 \mathrm{Pu}}$ $(60 \mathrm{pCi} / \mathrm{g})$. Three areas outside the ditch were found to exceed this limit. The southernmost area (northeast of U-Pond) remains unexplained at this time; however, it is rumored that heavy equipment was decontaminated in this vicinity in the past. The contaminated area west of the head end is probably the result of contamination spread when the backfilled Z-1 Ditch was mistakenly uncovered. The third area, east of the head end, is probably associated with the backfllled Z-11 Ditch. All the concentrations found on the ditch bottom exceed the surficial soil contamination limit, with most approaching or exceeding $10 \mathrm{nCi} / \mathrm{g}$.

- Americium-241-Surface distribution of ${ }^{211} \mathrm{Am}$ is shown an Plate 5. Figure 5.42 shows a schomatic representation of this distribution. The ${ }^{211} \mathrm{Am}$ data closely resemble the plutonium distribution, with a few minor exceptions. The ${ }^{241} \mathrm{Am}$ concentrations are generally an order of magnitude lower than the ${ }^{209,200} \mathrm{Pu}$ values. Comparison of the plutonium and americium distributions indicates fairly good correlation between the two, except on the east side of the ditch's head end. Here, the americium concentrations are too low to delineate the same hot spot as does the plutonium.

Near-Surface Contamination. Plutonium and americium are the most significant radionuclides present in the near surface also and are the only ones discussed further. Core samples taken across the ditch at nine different locations provide analyses at various depths.

- Plutonium-238,239,240-Plate 10 illustrates the actual distribution of ${ }^{239,220} \mathrm{Pu}$ at the $15-$ to $30-\mathrm{cm}$ depth range, while Figure 5.43 shows a schematic representation of the same data. Figure 5.44 schematically illustrates the depth profile of ${ }^{239.200} \mathrm{Pu}$ contamination down the length of the ditch. Figure 5.45 schematically illustrates some of the few ${ }^{238} \mathrm{Pu}$ concentrations down the ditch center.

- Americium-241-The near-surface (15- to 30-cm) distribution of ${ }^{241} \mathrm{Am}$ is shown in Plate 11 and schematically illustrated in Figure 5.46. Figure 5.47 is a schematic cross section showing the depth profile of contamination down the length of the ditch. 


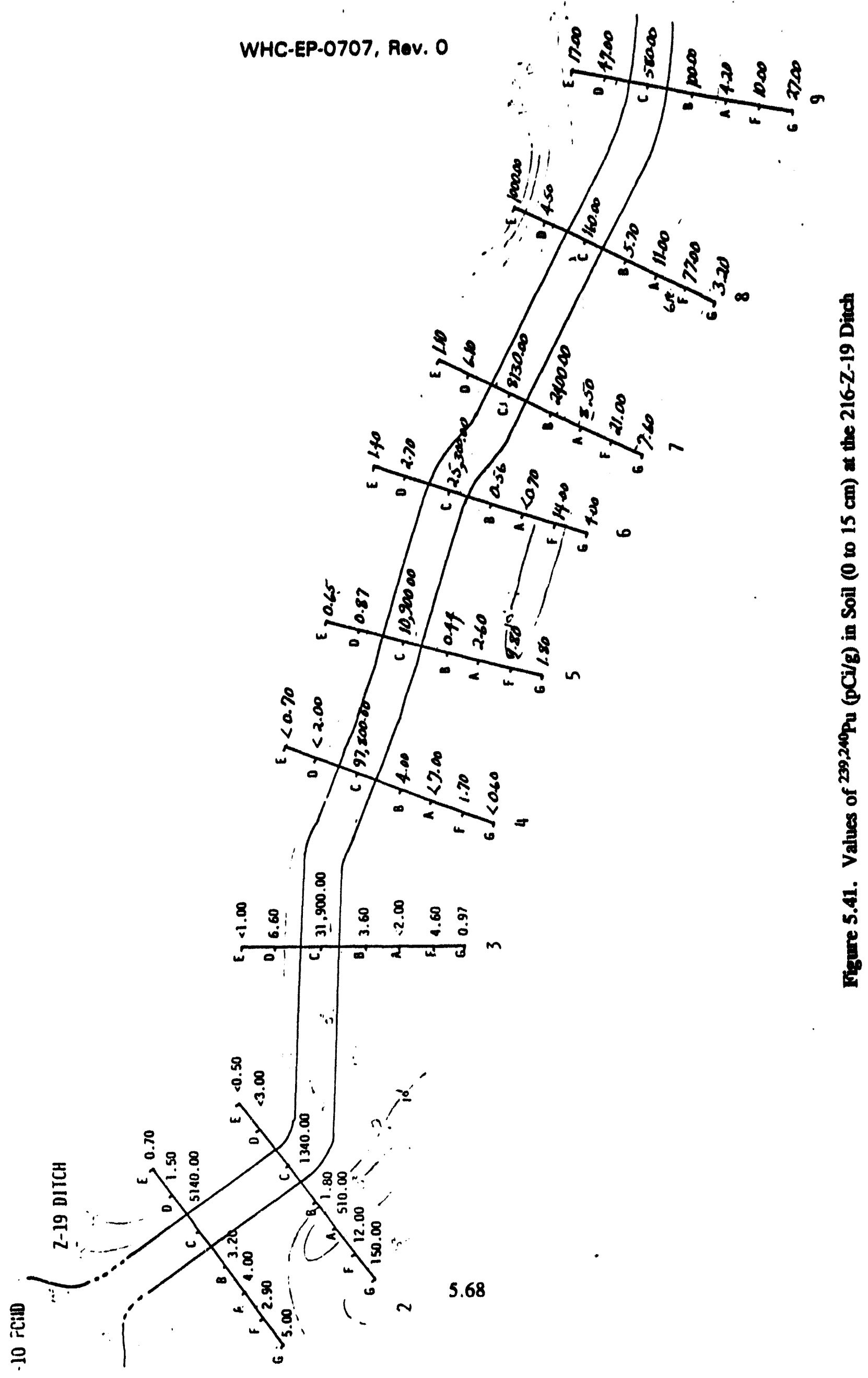

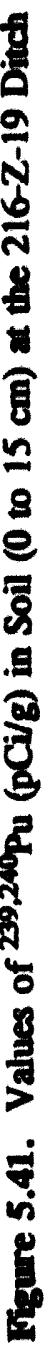




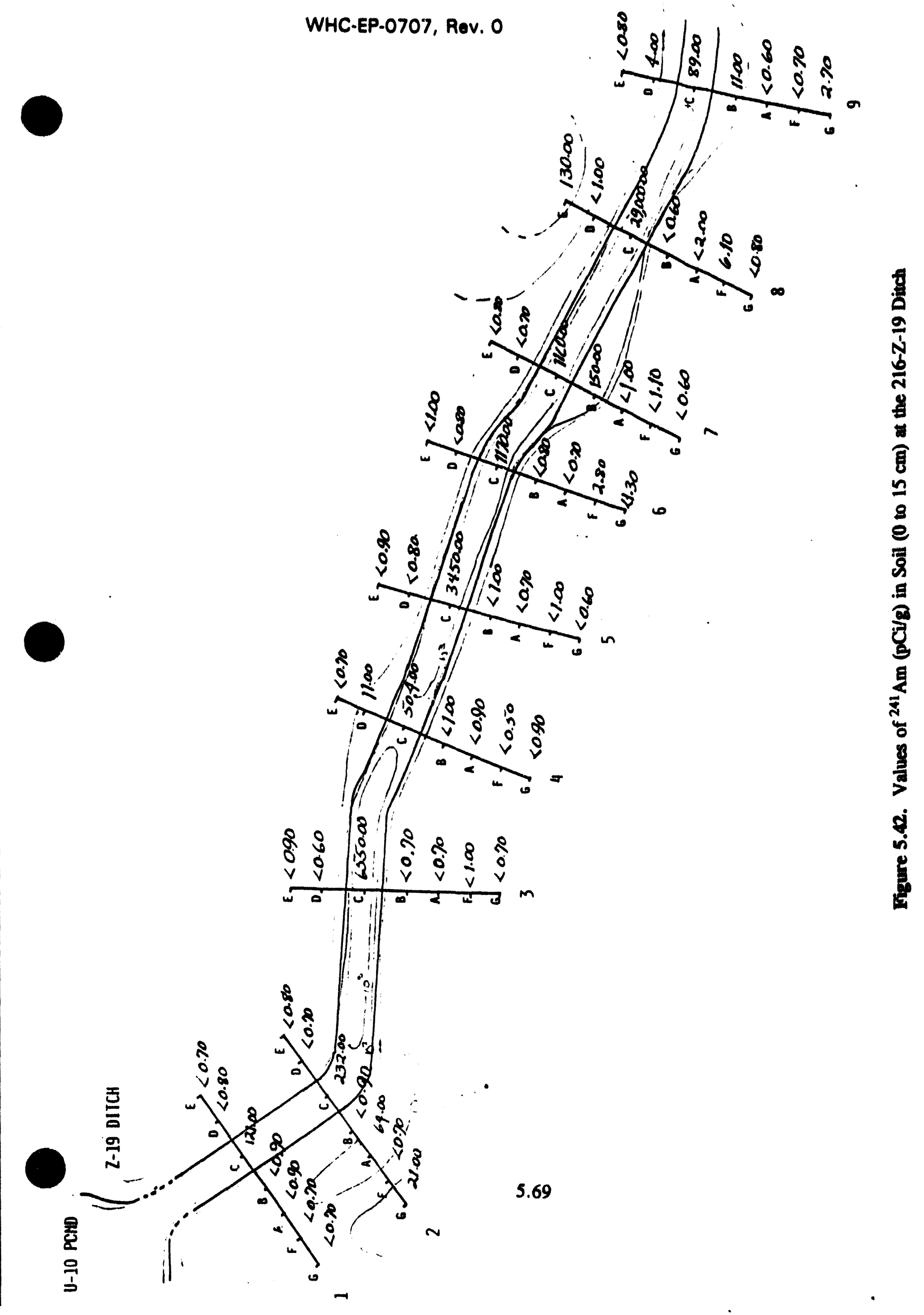




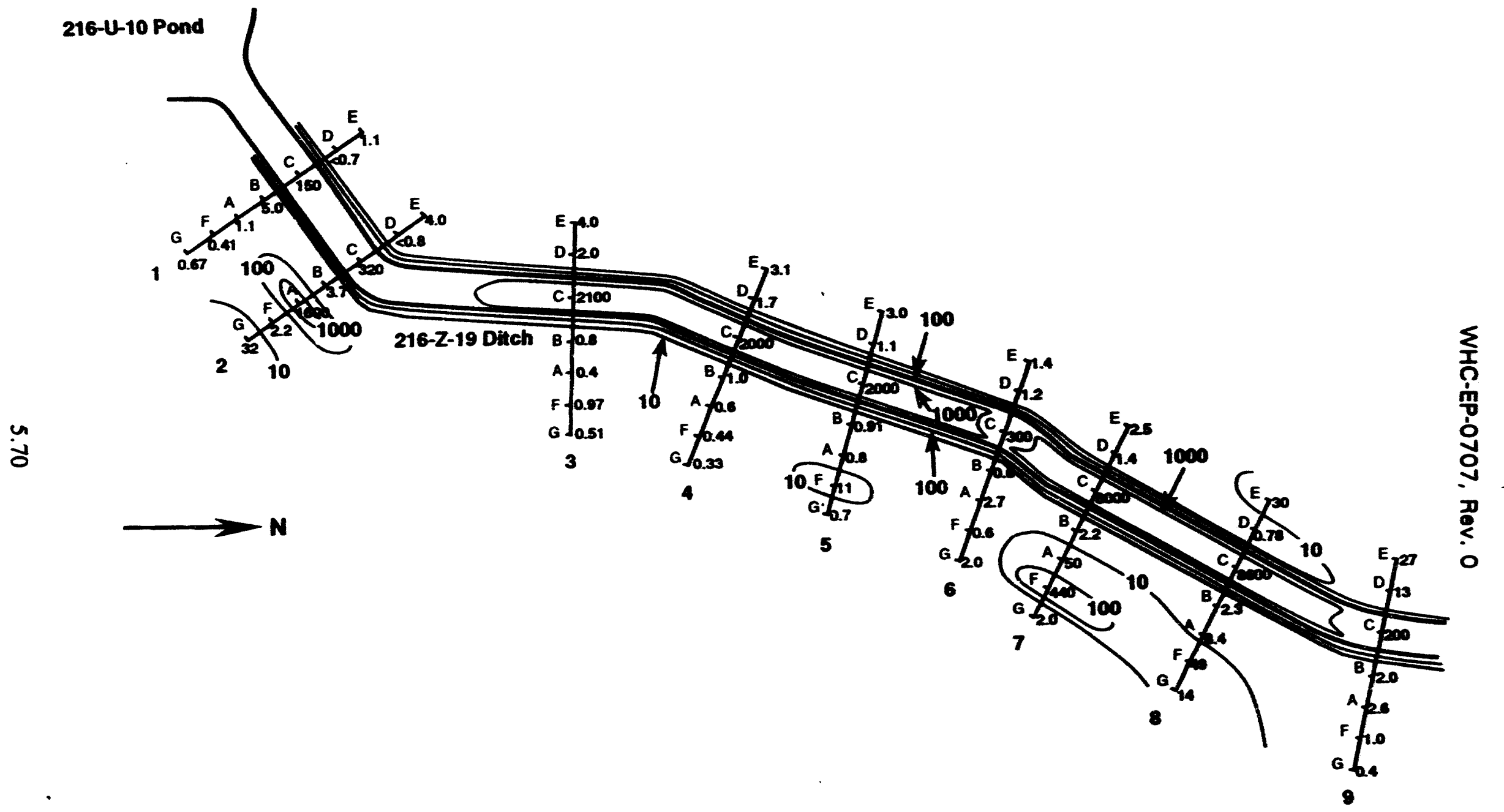

Figure 5.43. Values of ${ }^{28,209,200} \mathrm{Pu}(\mathrm{pCi} / \mathrm{g})$ in Soil $(15$ to $30 \mathrm{~cm})$ at the 216-Z-19 Ditch 


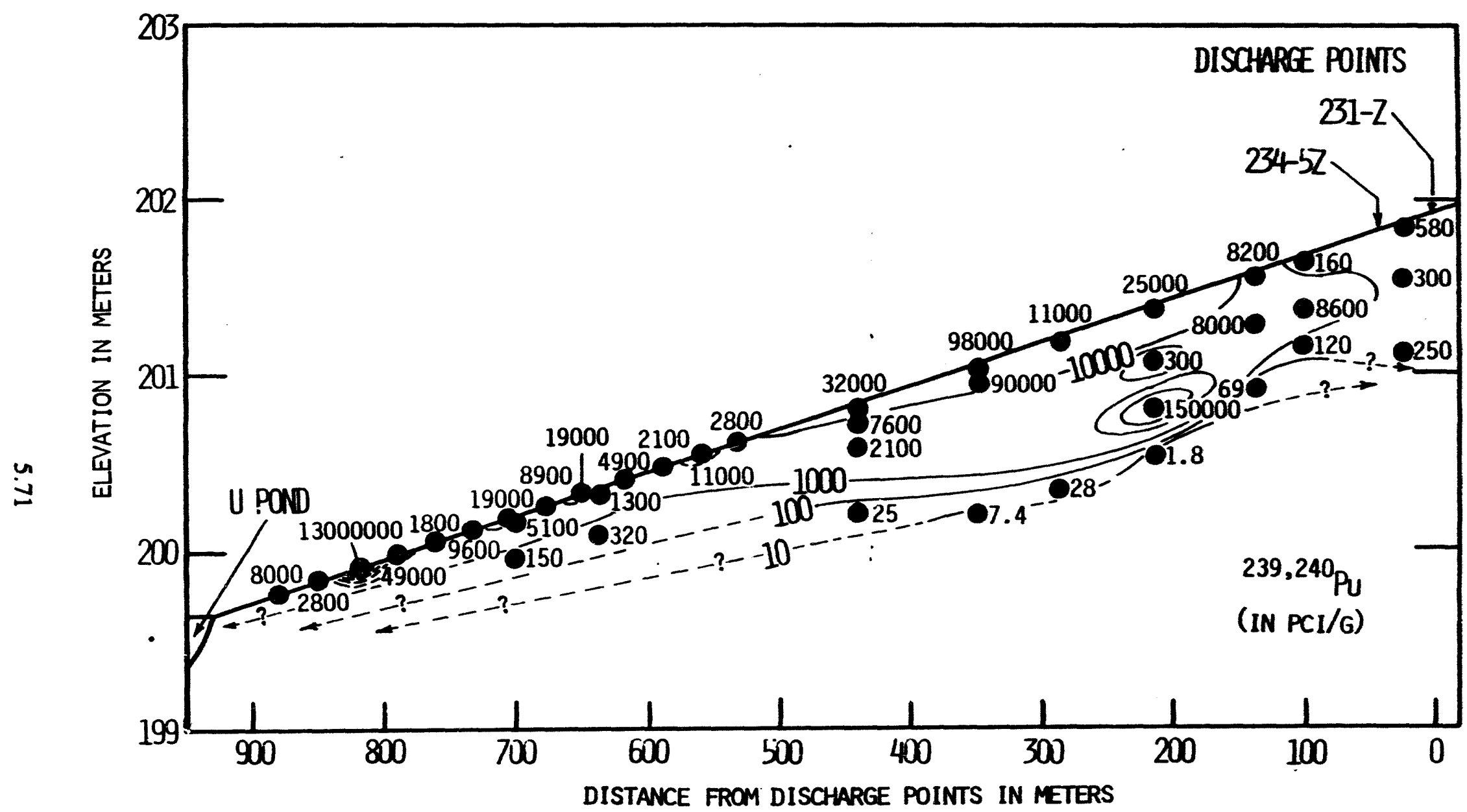

Figure 5.44. Schematic Cross Section Along the 216-Z-19 Ditch, Showing ${ }^{209200} \mathrm{Pu}$ Concentrations (pCi/g) 


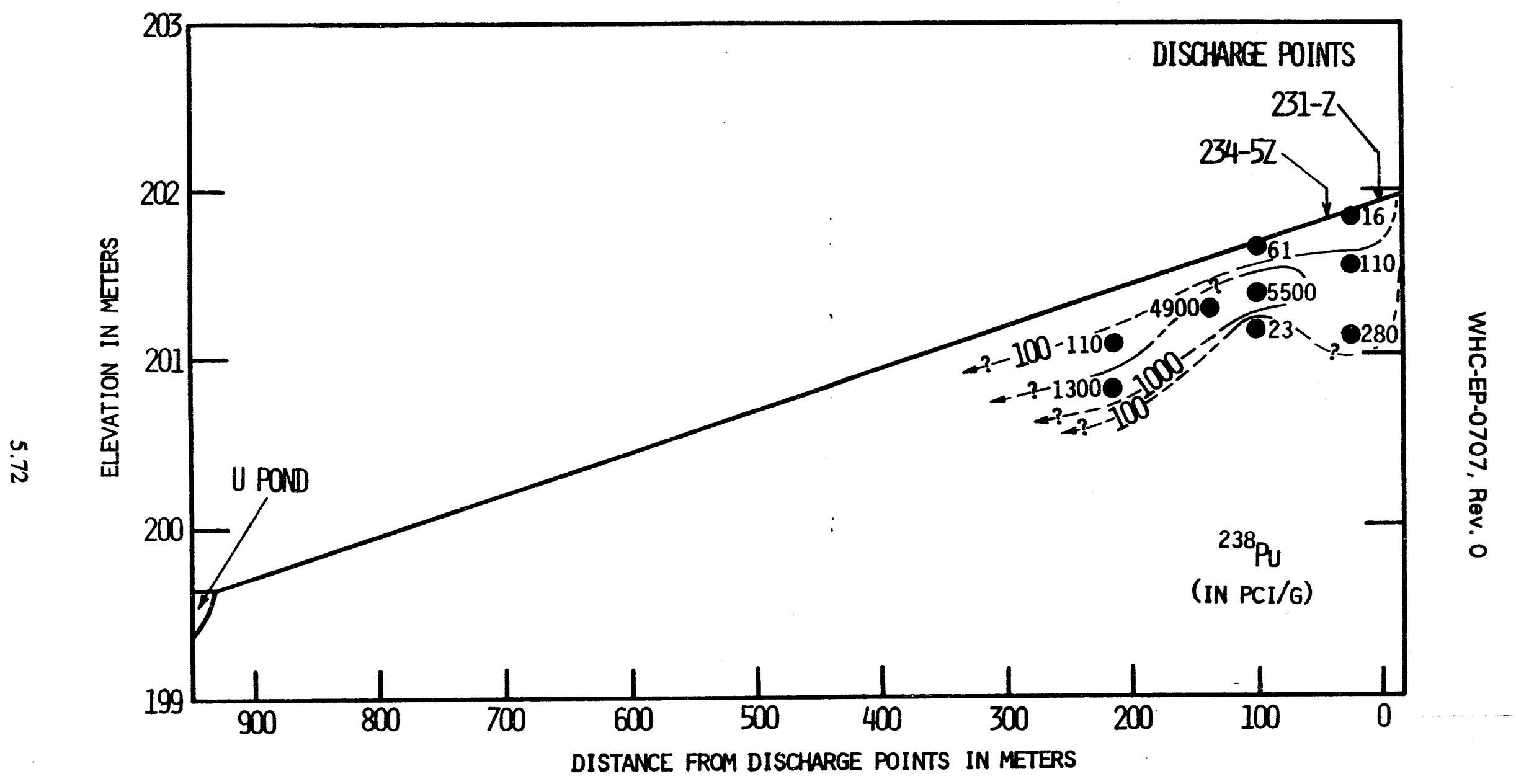

Figure 5.45. Schematic Cross Section Along the 216-Z-19. Ditch, Showing ${ }^{208} \mathrm{Pu}$ Concentrations (pCi/g) 


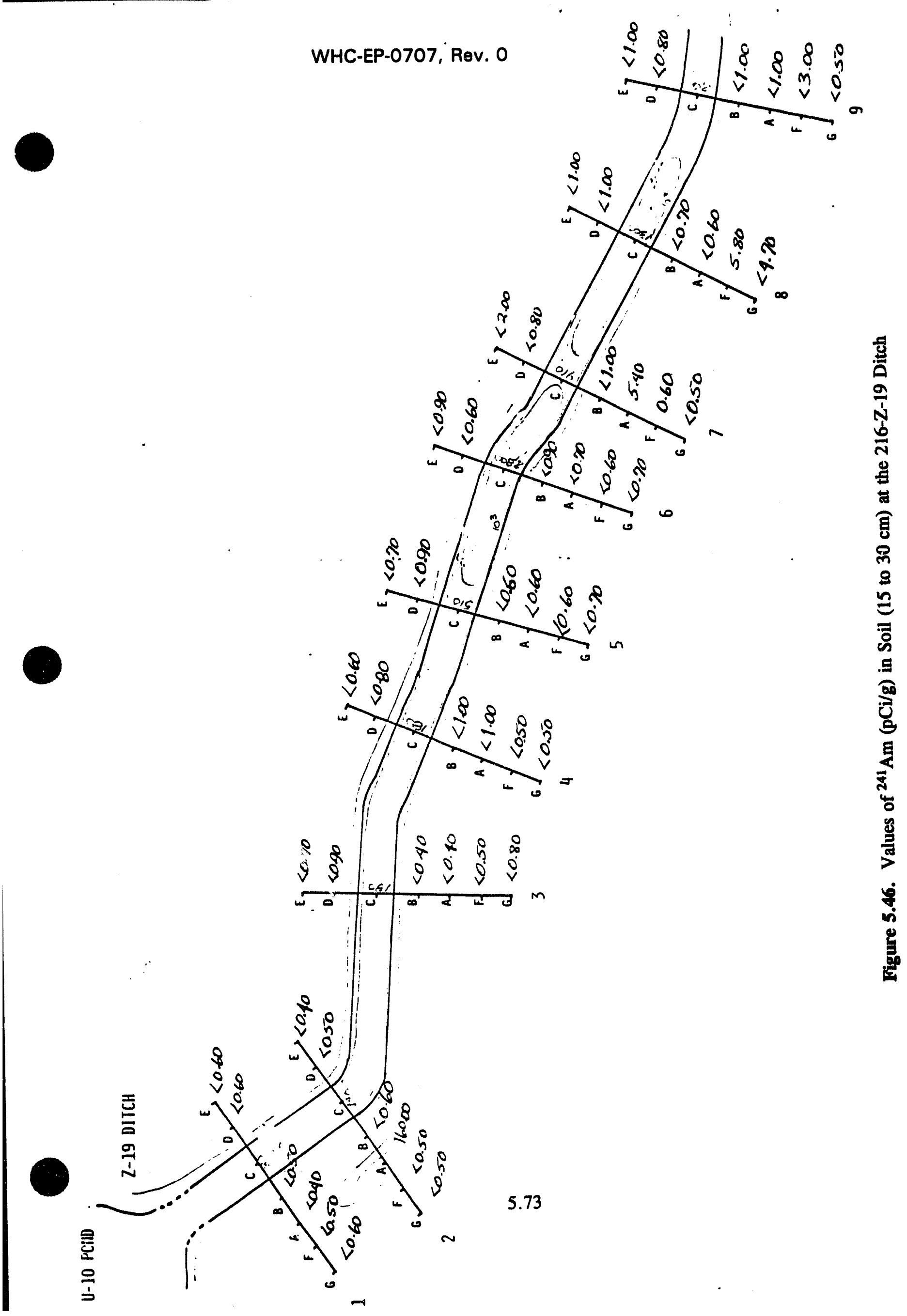




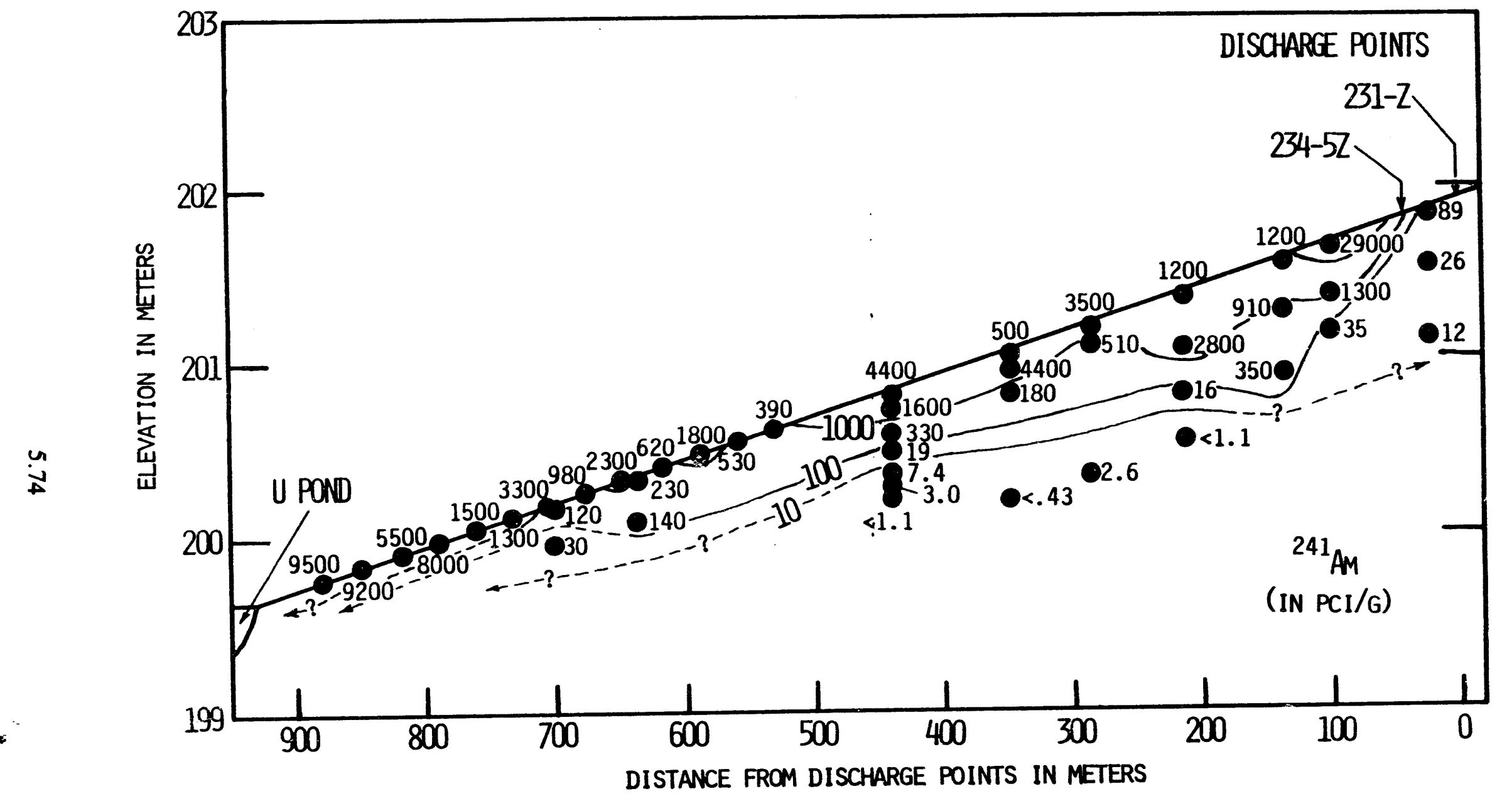

Figure 5.47. Schematic Cross Section Along the 216-Z-19 Ditch, Showing ${ }^{241}$ Am Concentrations (pCi/g) 
These data interpretations indicate that the plutonium and americium sorb onto the ditch-bottom sediments very quickly, with concentrations decreasing rapidly both vertically through the sediments and down the length of the ditch. Anomalously high concentrations outside the ditch at the head end are associated with the Z-1 mistake on the west side of the ditch and with the backfilled Z-11 Ditch on the east side. Those at the lower end of the ditch are not fully understood at this time.

Subsurface Contamination. Two deep monitoring wells and 17 shallow exploration wells were drilled along the Z-19 Ditch and its predecessors, the Z-1 and Z-11 ditches (see Figure 5.35). Contamination profiles and lithologic logs of each well are provided in Appendix J. Numerical values of each analysis are included in Appendix I. These data indicate that ${ }^{239.200} \mathrm{Pu}$ is always found in higher concentrations than any other detected radionuclide; it is, thus, considered the index radionuclide for defining the maximum subsurface waste plume.

The two deep monitoring wells found detectable contamination only in zones of high moisture content, and even these values were so low as to be considered inconsequential.

The shallow exploration wells were drilled to locate and sample the backfilled Z-1 and Z-11 ditches (predecessors to the Z-19 Ditch). The wells that were successful in locating the buried ditches were shown in Figure 5.35. Only limited analytical data exist for these wells. Therefore, interpretation of the ditch locations and their associated contamination plumes are considered to be only rough approximations.

- Plutonium-239,240-Figures 5.48 and 5.49 schematically illustrate the cross-sectional distributions of ${ }^{239,210} \mathrm{Pu}$ associated with the $\mathrm{Z}-1$ and $\mathrm{Z}-11$ ditches, respectively. These cross sections correspond to the sampling transects and incorporate the surface and near-surface data.

- Americium-241-The ${ }^{241} \mathrm{Am}$ distributions are illustrated in Figures 5.50 and 5.51 for the Z-1 and Z-11 ditches, respectively.

These data have indicated the presence of contaminant plumes associated with the buried ditches; however, the ditches have not been adequately located nor sampled to the extent that volumes and inventories of contamination could be addressed at this time.

\section{6-U-14 Ditch}

Several different waste streams enter the U-14 Ditch at various locations. Included are fission products, activation products, and depleted uranium $\left.{ }^{238} \mathrm{U}\right)$. Table 5.10 listed the isotopes detected in the ditch. The activation products and minor amounts of fission products were discharged at the head end of the ditch. Larger amounts of fission products and the uranium entered the ditch just south of 16th Street. The most data exist for ${ }^{137} \mathrm{Cs}$, so it is used in delineating the extent of the peripheral contamination. Cobalt-60, ${ }^{54} \mathrm{Mn},{ }^{154,155} \mathrm{Eu}$, and uranium analytical results are available in sufficient quantities for characterization of the ditch center only. All other radionuclides are of comparatively minor importance. 


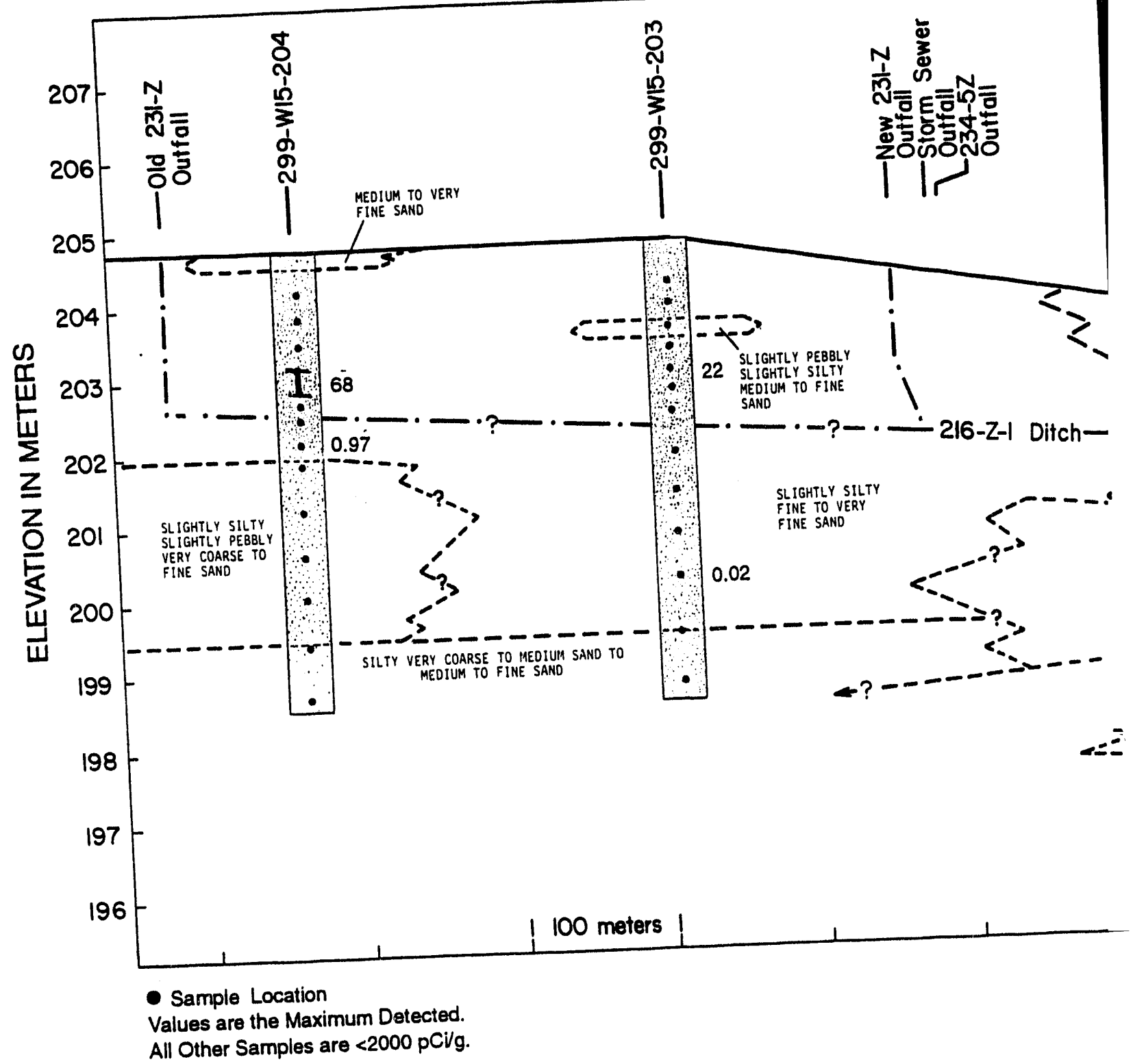

Figure 5.48. Schematic Cross Se 

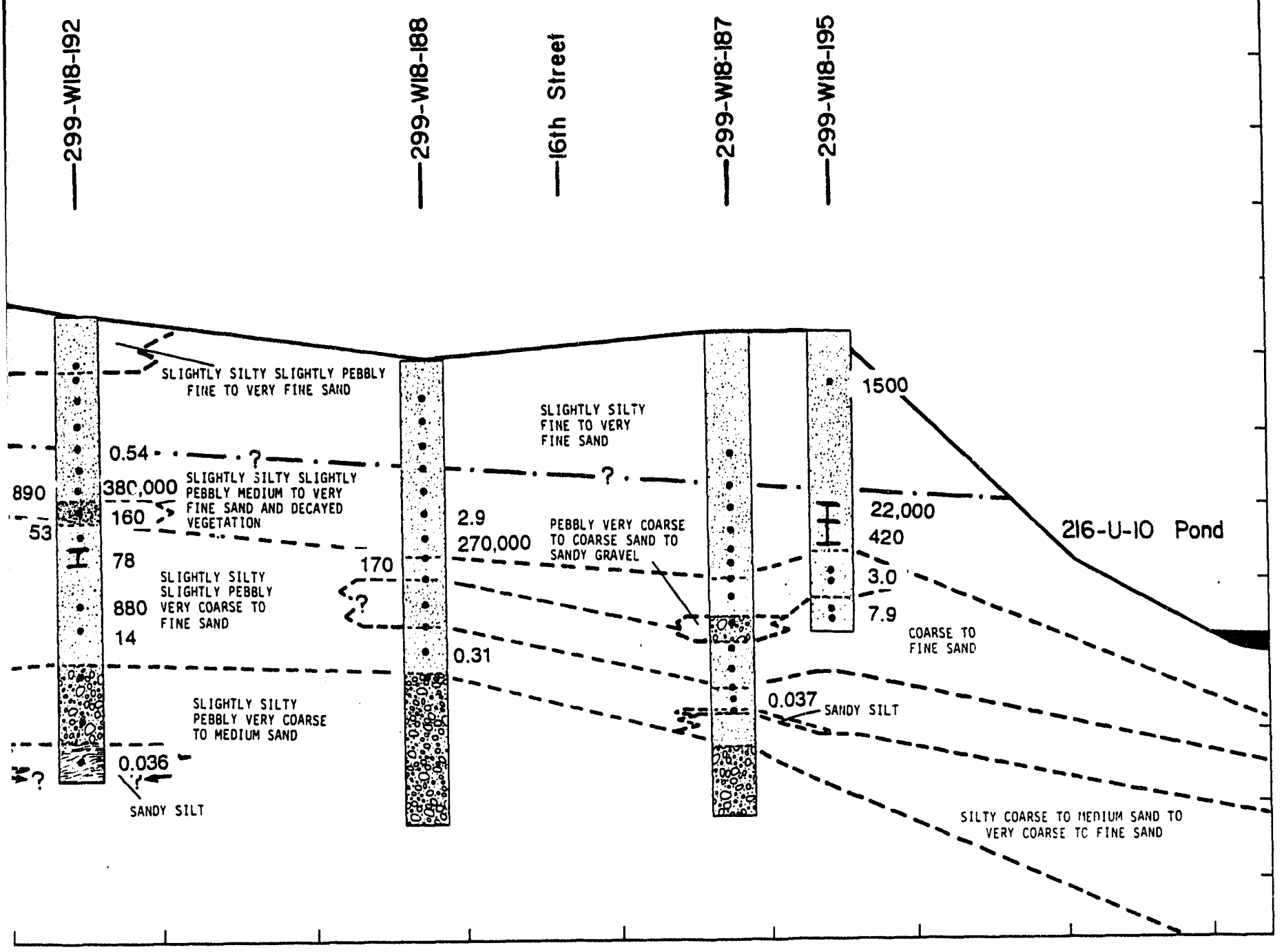

tion of ${ }^{239,240} \mathrm{Pu}$ Contamination Associated with the 216-Z-1 Ditch 


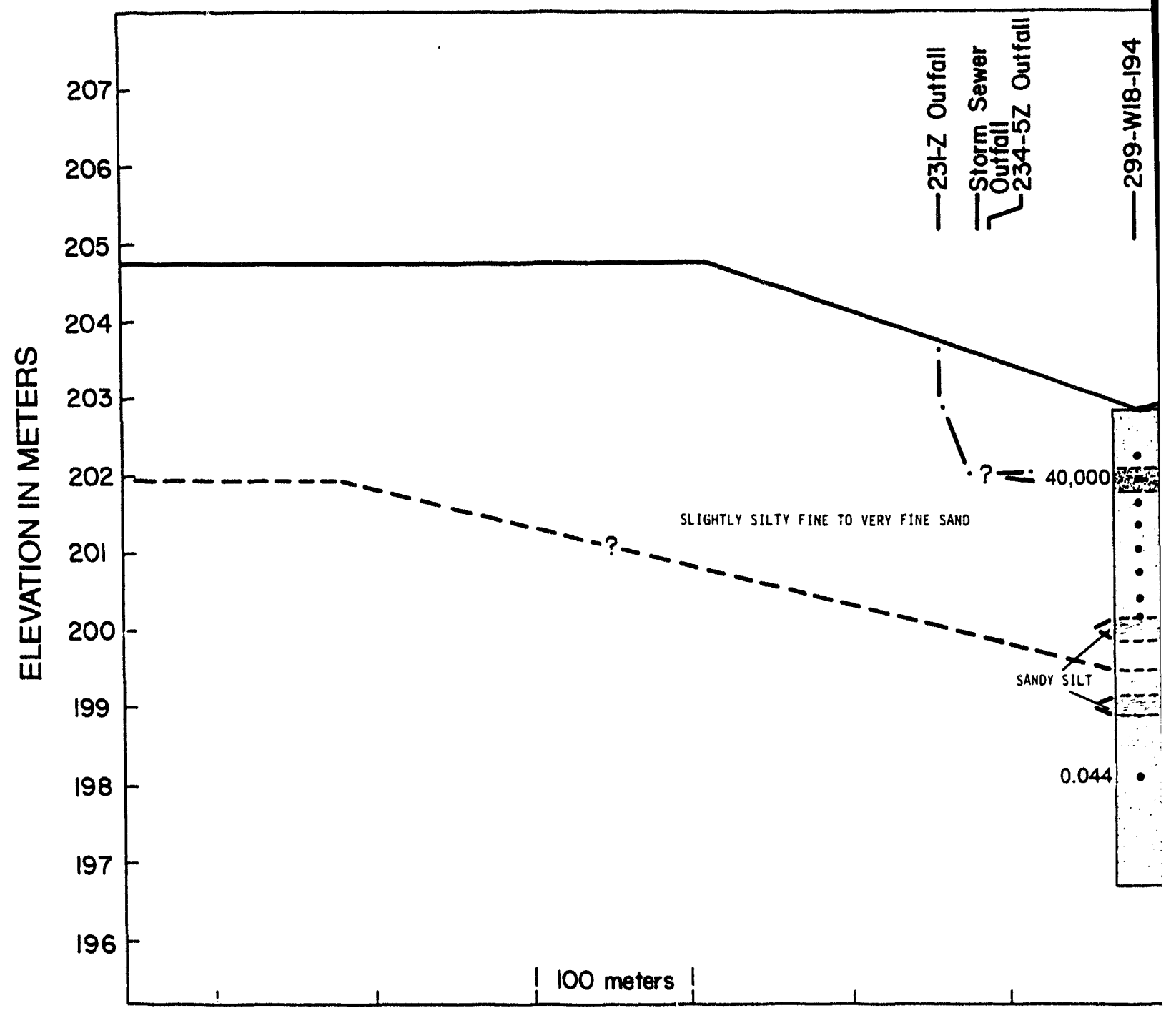

- Sample Location

Values are the Maximum Detected.

All Other Samples are $<2000$ pCVg.

Figure 5.49. Schematic Cross Sec 


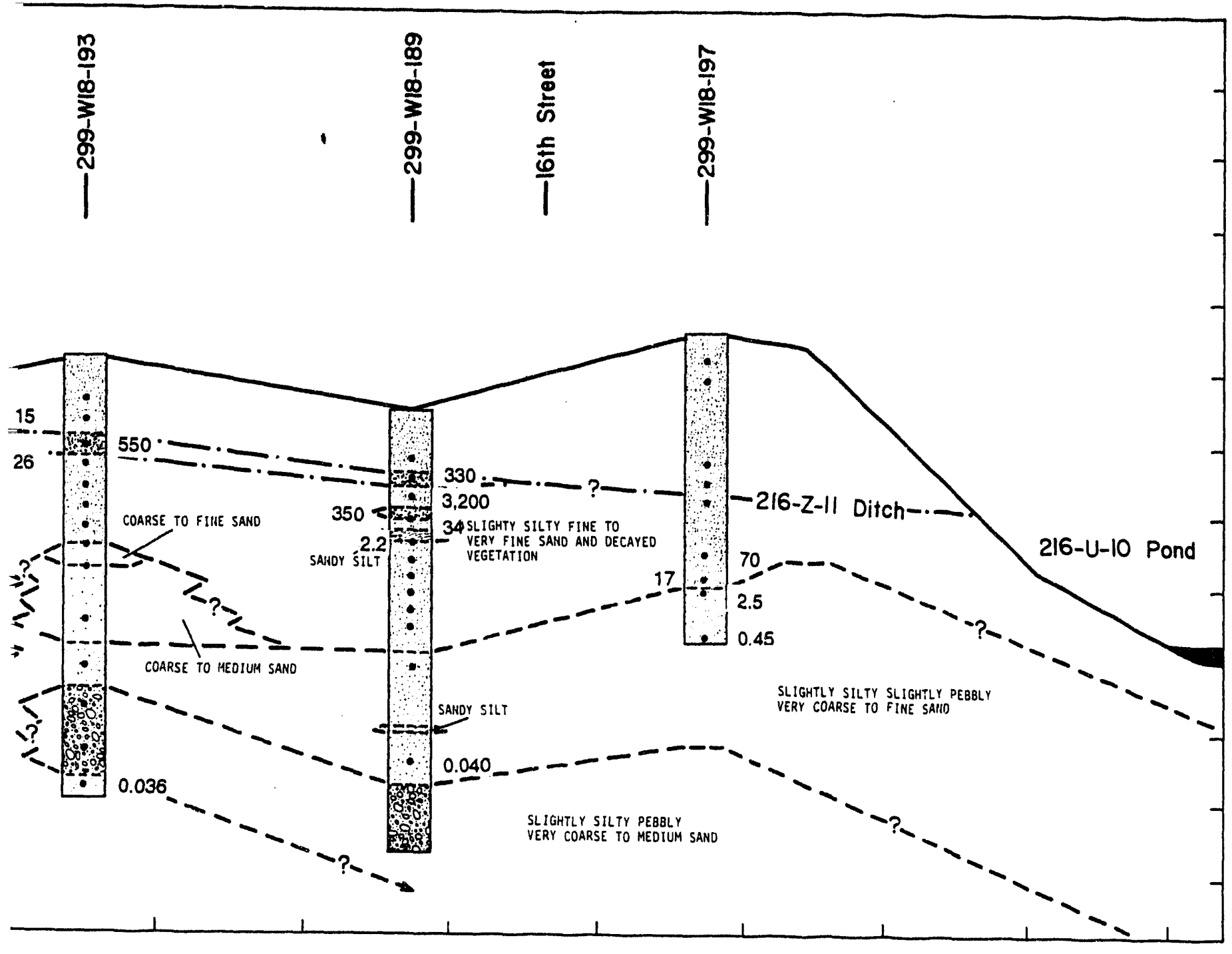

Fion of ${ }^{239,240} \mathrm{Pu}$ Contamination Associated with the 216-Z-11 Ditch 


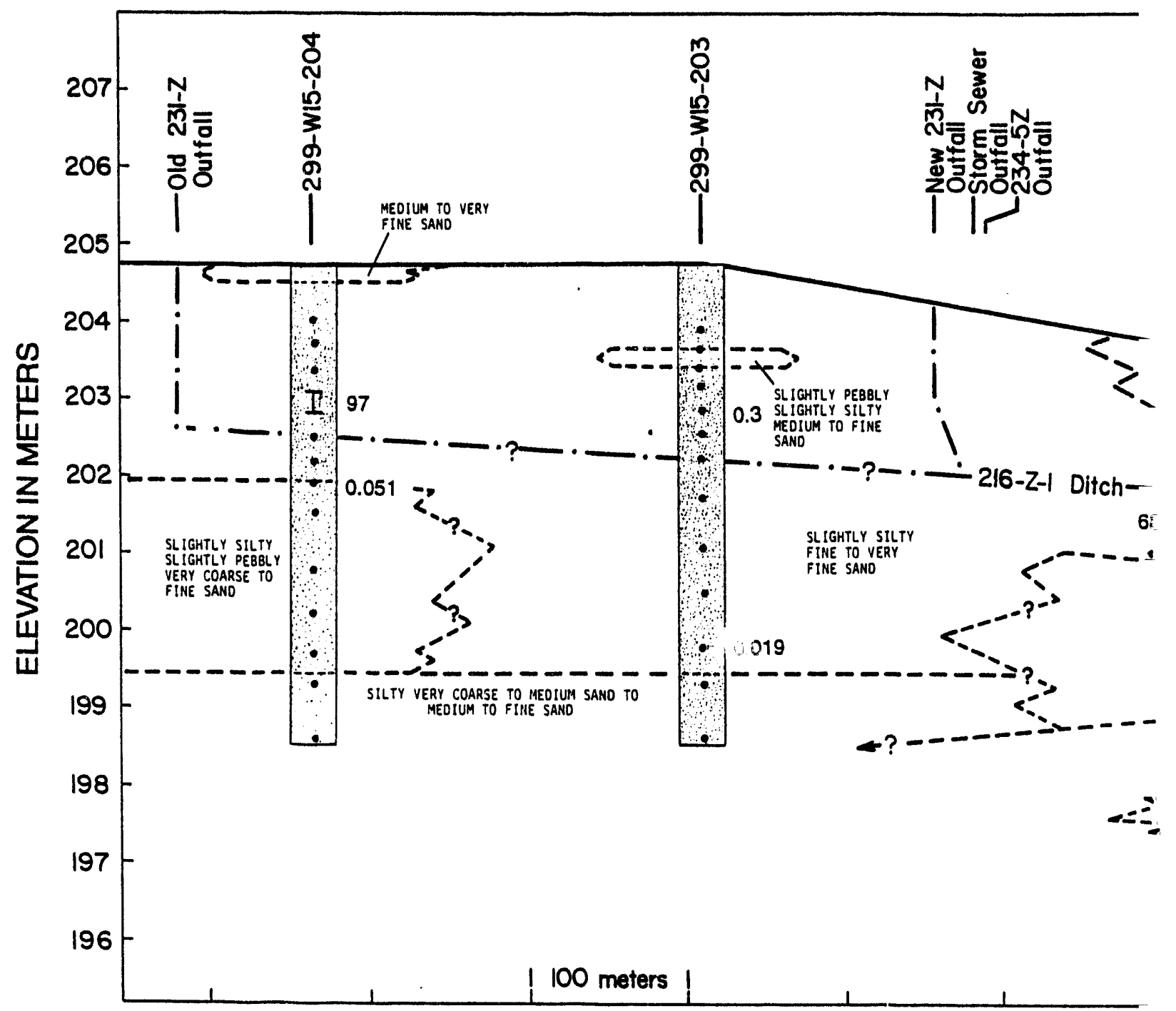

- Sample Location

Values are the Maximum Detected.

All Other Samples are $<200 \mathrm{pCV} g$.

Figure 5.50. Schematic Cross Secî 


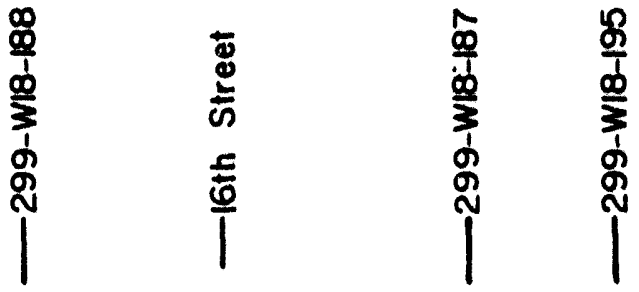

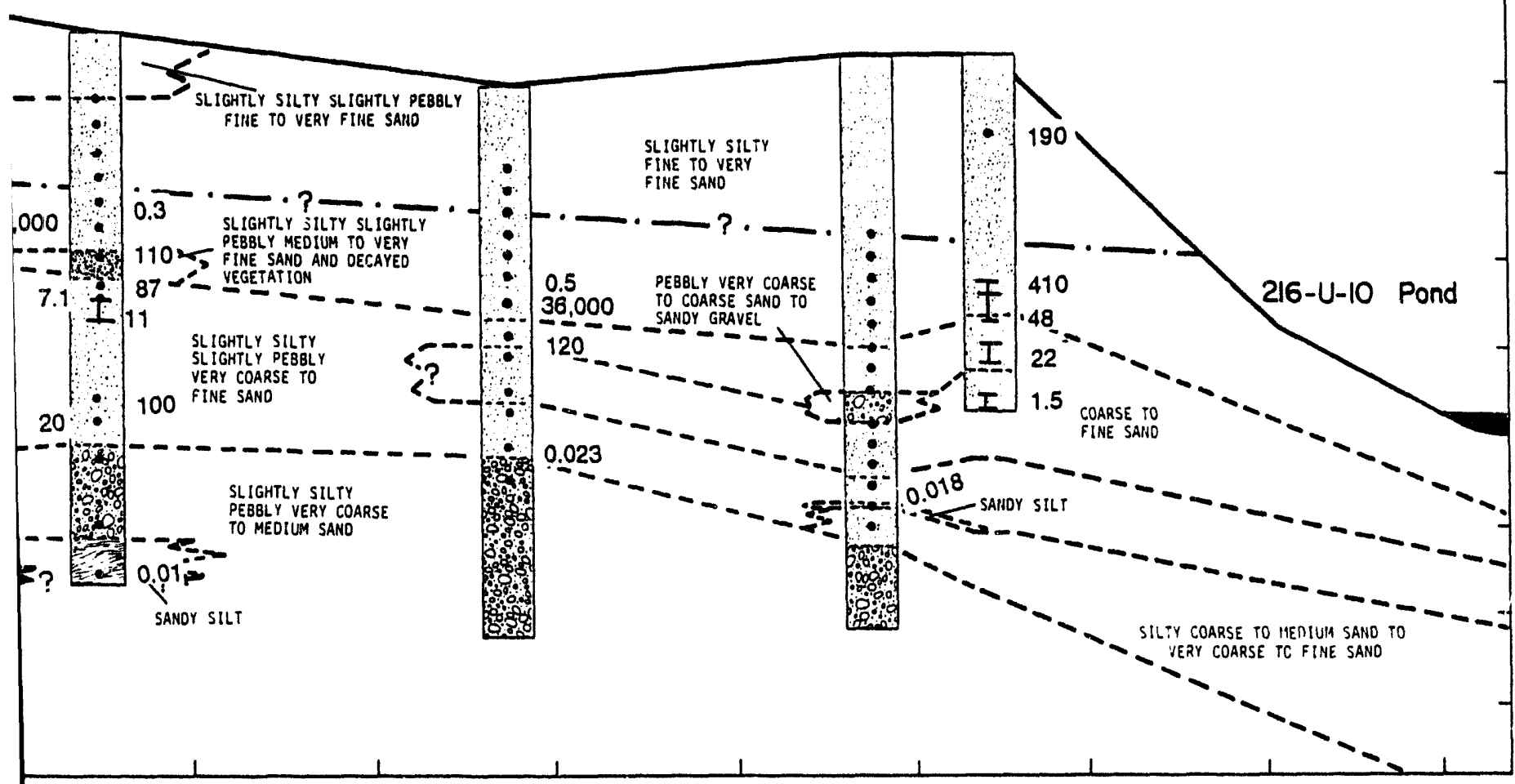

on of ${ }^{241} \mathrm{Am}$ Contamination Associated with the 216-Z-1 Ditch 


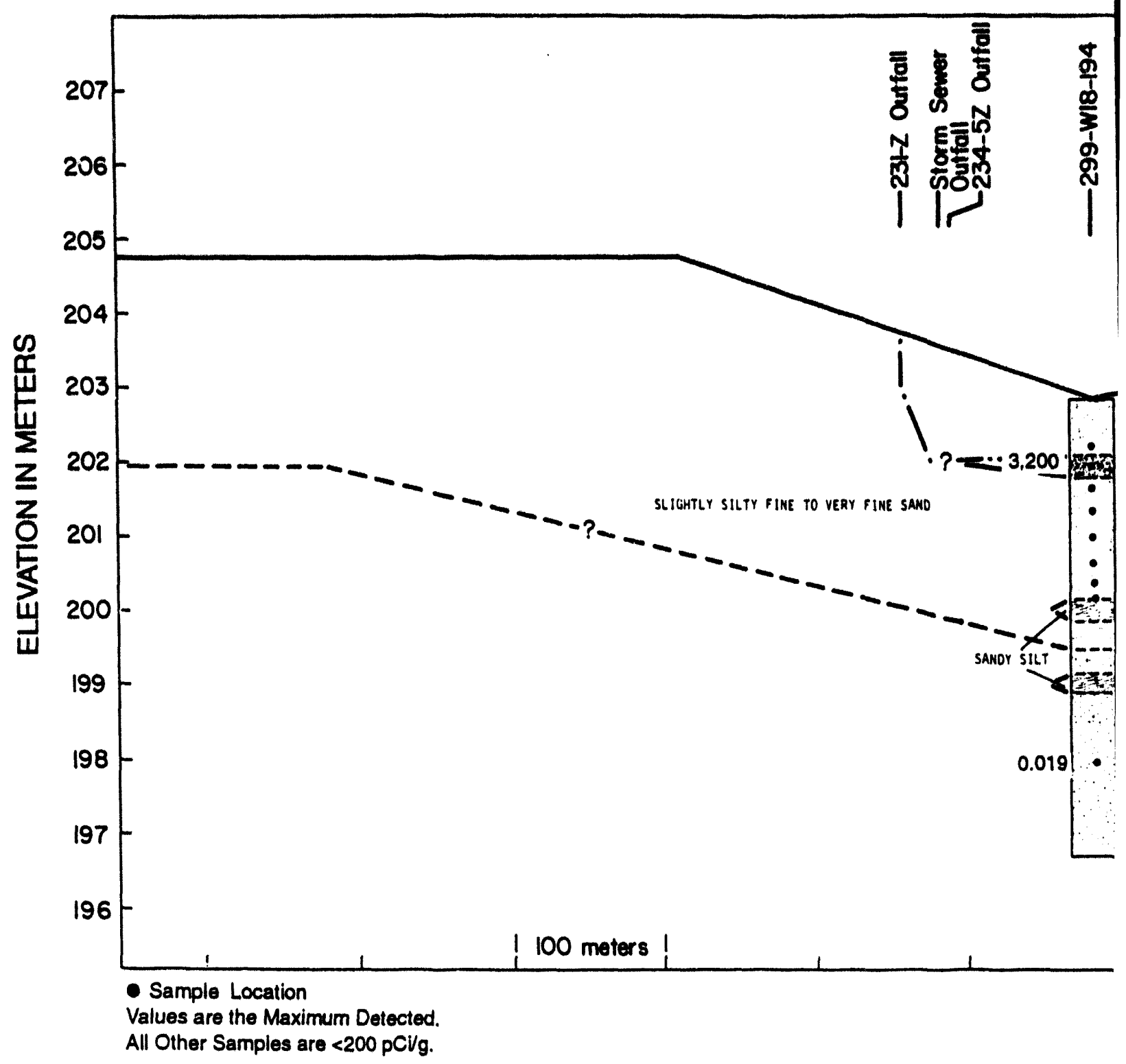

Figure 5.51. Schematic Cross Se 


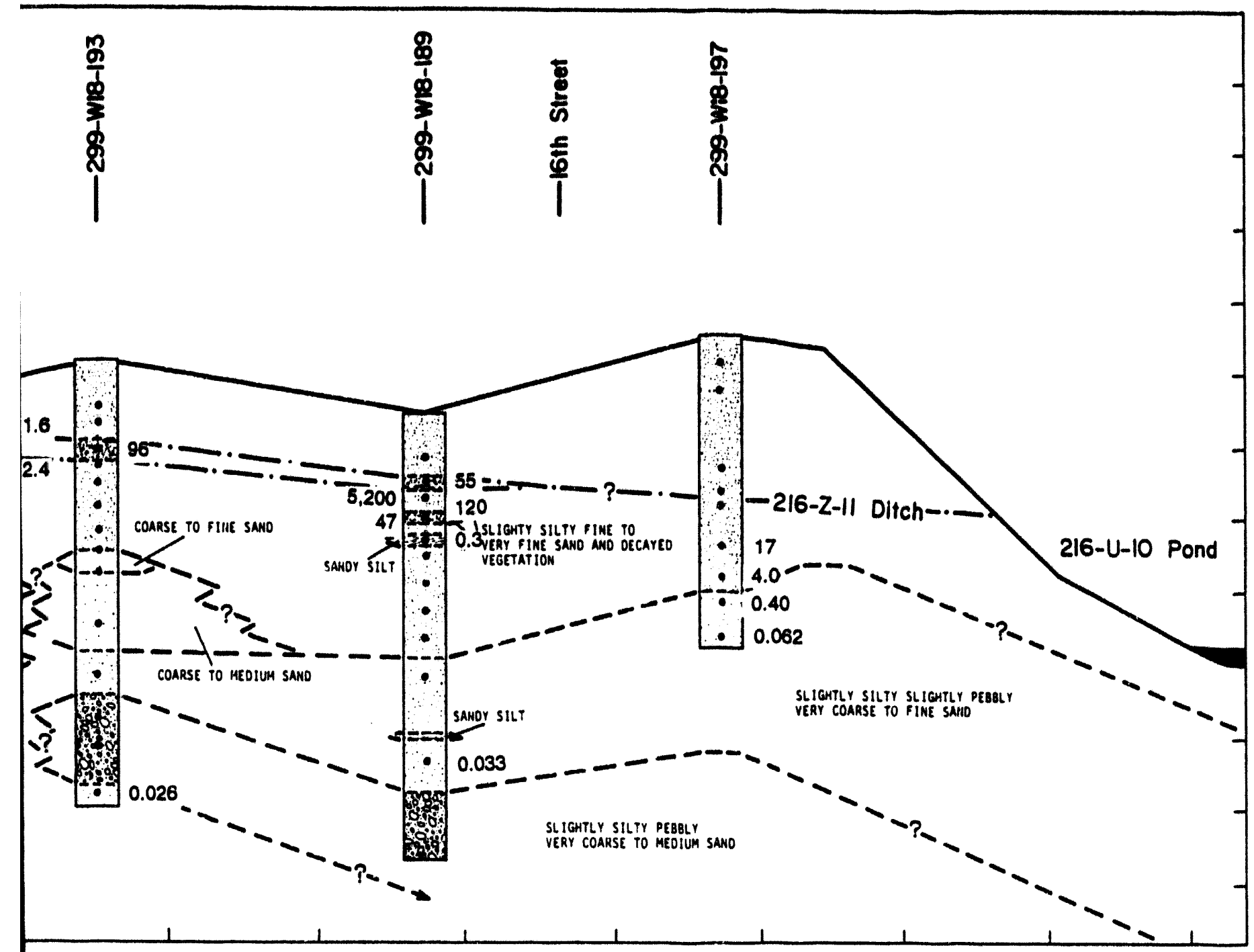

tion of ${ }^{241} \mathrm{Am}$ Contamination Associated with the 216-Z-11 Ditch 


\section{Surface Contamination.}

- Cesium-137-The ${ }^{137} \mathrm{Cs}$ data are available for both sides of the ditch, but do not extend far enough on the west side to characterize the lateral extent of contamination. The distribution, with incomplete contours to the west, was shown on Plate 3. In addition to the lateral asymmetry of contamination, note the abrupt decrease in ${ }^{137} \mathrm{Cs}$ concentrations north of 16 th Street. Above 16th Streat, ${ }^{17} \mathrm{Cs}$ does not appear to be a serious contamination problem. The dashed isopleth indicates the estimated location of the surface soil contamination limit for ${ }^{137} \mathrm{Cs}$.

- Cobalt-60, ${ }^{4} \mathrm{Mn}$, and ${ }^{13,135} \mathrm{Eu}-D a t a$ for these four isotopes are available only for the center of the ditch at the surface; therefore, no peripheral contamination levels can be drawn nor can crosssectional profiles be constructed. The data are presented in raw form for the four radionuclides on Plate 12, with no interpretation of distributions.

- Uranium (Total)-Data for EU exist only for the ditch center (see Plate 6). No contamination contours can be interpreted from these limited data.

Near-8urface Contamination. Cesium data are available to estimate near-surface contamination levels near the U-14 Ditch. Again, sampling was not extensive enough to the west of the ditch, so estimates of peripheral contamination boundaries are incomplete. Plate 9 showed the deep near-surface data $(30 \mathrm{~cm})$ for ${ }^{137} \mathrm{Cs}$. As was the case with the surface contamination map (see Plate 3), contamination is unbounded to the west and increases signiflcantly below 16th Street. The surface soil contamination limit is shown as a dashed contour. Plates 13 shows the near-surface concentrations for $\mathbf{L U}$.

Subsurface Contamination. No subsurface information exists for this component of the U-Pond disposal system.

\subsubsection{Discussion}

The geologic distribution of radionuclides throughout the U-Pond disposal system demonstrates that the system has distributed low-level wastes over a very large area. The radionuclides are usually more concentrated toward their individual discharge sources and in the topographically low areas of the system but are generally well distributed throughout the pond area.

The most signiflcant radionuclides in this disposal system are uranium, ${ }^{90} \mathrm{Sr},{ }^{137} \mathrm{Cs},{ }^{209.200} \mathrm{Pu}$, and ${ }^{211} \mathrm{Am}$. The uranium, ${ }^{90} \mathrm{Sr}$, and ${ }^{137} \mathrm{Cs}$, were mostly distributed via the U-14 Ditch, while ${ }^{209,200} \mathrm{Pu}$ and ${ }^{2 a}$ Am were distributed via the three $Z$-ditches.

The distribution of ${ }^{137} \mathrm{Cs}$ exceeds that of any other radionuclide through most of the U-Pond disposal system. The only components of the system not affected by ${ }^{137} \mathrm{Cs}$ are the three Z-ditches. Its greatest distribution occurs at the surface throughout U-Pond and its immediate perimeter. The higher ${ }^{137} \mathrm{Cs}$ concentrations were found in the lower areas of the pond, with lower concentrations extending radially away from the pond at higher elevations (Figure 5.52). This general correlation between activity and elevation reflects the different lengths of time available for the contaminants to accumulate 


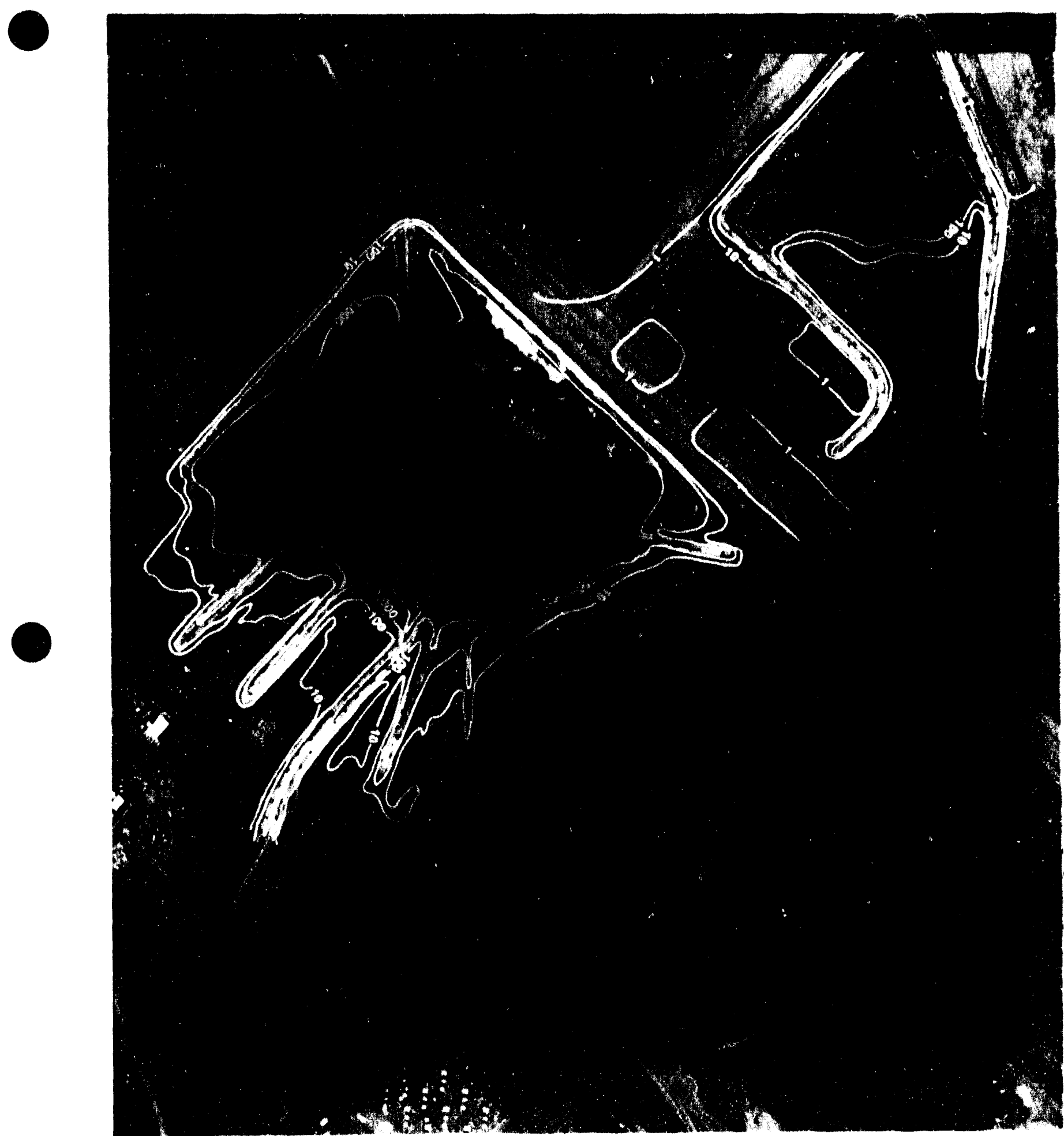

Figure 5.52. Distribution of ${ }^{137} \mathrm{Cs}$ (yellow; $\mathrm{pCi} / \mathrm{g}$ ) Relative to Elevation ( $\mathrm{ft}$ above mean sea level). Green contour is surface soil contamination limit (Boothe 1979). To convert picoCuries to nanoCuries, divide by 1000 . 
(owing to pond-level changes). Two areas with highest observed ${ }^{137} \mathrm{Cs}$ concentrations $(>10 \mathrm{nCi} / \mathrm{g}$ ) have been identified. The area in the delta is attributed to the accumulation of fluvially deposited contaminants where past discharges from the U-14 Ditch entered U-Pond. The area inside U-Pond lies at the lowest elevation of the disposal system, in the deepest part of the pond. Thus, it not only had the greatest accumulation time, but the deeper water provided a quieter depositional environment. Contaminated sediments remobilized by wave action in the shallow areas would tend to accumulate there. Some areas of lower contamination have also been delineated inside U-Pond. The most significant of these is located near the present mouth of the U-14 Ditch. The low concentrations here are attributed to the flushing away of contaminated sediments by the high volumes of relatively clean waste waters from the 242-S Evaporator and the clean makeup water now being added to the U-14 Ditch.

The primary source of the ${ }^{137} \mathrm{Cs}$ contamination appears to have been the discharge points just south of 16th Street in the U-14 Ditch. The most likely source comes from the 241-U-104 and -110 tanks via the 216-U-3 Crib, which was only in service for a short period in the mid 1950s. An alternate source is the process sewer from the 224-U Building, which has been in service much longer but is not known to have discharged significant amounts of fission products. Another potential source of the high cesium concentrations is the $241-\mathrm{SK}-401$ and -402 pipelines, which enter the southeast corner of U-Pond.

The high concentrations of ${ }^{137} \mathrm{Cs}$ found on the north and west banks of the U-14 Ditch, south of 16th Street, are from contaminated spoils piles from past dredging activities.

Depth of the cesium contamination is not known, except around the perimeter of U-Pond, and is best known in the delta area. Near-surface data indicate that ${ }^{137} \mathrm{Cs}$ is generally concentrated in the top $10 \mathrm{~cm}$ of soil around U-Pond. However, subsurface data in the delta area indicate significant concentrations ( $>400 \mathrm{pCi} / \mathrm{g}$ ) down to a depth of $15 \mathrm{~m}$ and much lesser concentrations down to $30 \mathrm{~m}$.

The distribution of ${ }^{90} \mathrm{Sr}$ is not nearly as widespread nor as well known as that for ${ }^{137} \mathrm{Cs}$. Its observed concentrations are consistently much lower than those of ${ }^{137} \mathrm{Cs}$, with only one area, located in the deep part of U-Pond, exceeding surface soil contamination limits.

The only subsurface data on ${ }^{90} \mathrm{Sr}$ are from the delta area, where there is some indication that the ${ }^{90} \mathrm{Sr}$ concentrations may be higher at depth than those of ${ }^{137} \mathrm{Cs}$. This suggests that the ${ }^{90} \mathrm{Sr}$ did not sorb on the sediments as readily as the ${ }^{137} \mathrm{Cs}$.

Uranium was also distributed via the U-14 Ditch and is dispersed throughout the U-Pond area. Its highest concentrations exceed surface soil contamination limits in the deep part of U-Pond, with the concentrations decreasing away from the pond.

The primary source of uranium has historically been attributed to the U-Plant facilities, which discharge to the U-14 Ditch just south of 16 th Street. However, the $\Sigma U$ concentrations upstream of this discharge point are comparable to those downstream. Therefore, an additional source of uranium was indicated that must discharge to the head end of the U-14 Ditch. An examination of the activity ratios of ${ }^{235} \mathrm{U}$ to ${ }^{238} \mathrm{U}$ indicate that downstream of the $\mathrm{U}$-Plant discharges the uranium is depleted, while 
upstream the uranium is undepleted (natural ratio). This confirms an additional discharge source for the uranium. That additional source is now believed to be from the fly ash, released during backflushing of filters from the coal-fired powerplant.

The depth of uranium contamination is unknown but near-surface data around U-Pond indicate the uranium is concentrated on the surface, decreasing rapidly with depth.

Plutonium-239,240 was distributed via the three Z-ditches, and though it is found throughout U-Pond in concentrations exceeding surface soil contamination limits, it is not very extensively distributed compared to ${ }^{137} \mathrm{Cs}$ or uranium. Most of the ${ }^{239,200} \mathrm{Pu}$ contamination is localized in the Z-ditches (Figure 5.53). The ${ }^{239,200} \mathrm{Pu}$ that did reach U-Pond was well distributed, with the entire pond having concentrations between 0.1 and $1.0 \mathrm{nCi} / \mathrm{g}$. Several areas are identified with higher or lower concentrations from individual sample analyses and are considered to reflect the particulate (PuO) nature of ${ }^{239,200} \mathrm{Pu}$ contamination (Emery and Garland 1974). One of these higher concentrations on the southwest side of U-Pond is fairly significant, in that it approaches $10 \mathrm{nCi} / \mathrm{g}$. The only other concentrations approaching that level are in the Z-ditches and delta area. In the Z-19-Ditch, ${ }^{239,200} \mathrm{Pu}$ is concentrated in the top $50 \mathrm{~cm}$ of sediment, where levels exceed $10 \mathrm{nCi} / \mathrm{g}$. The variability of the concentrations in the upper $50 \mathrm{~cm}$ is attributed to both the intermittent releases of ${ }^{239,200} \mathrm{Pu}$ and its particulate nature (PuO). Below this upper $50 \mathrm{~cm}$, the concentrations show a fairly uniform decrease with depth, with picoCurie-per-gram levels found at approximately 1-m depths.

The high ${ }^{239,200 \mathrm{Pu}}$ levels in the delta area are often found in decayed organic material forming a crust on the soil near the entrance of the Z-19-Ditch to U-Pond. At this time, this association is not clearly understood; though one plausible cause is the filtering of contamination solutions through the already existing organic layer, much as with any other surface soil.

The source of the ${ }^{239,200} \mathrm{Pu}$ contamination is the head end of the Z-19-Ditch. Comparison of concentrations above and below the 234-5Z Outfall suggests that the 234-5Z Building is the primary source, with the $231-Z$ Laboratory playing a secondary role.

The depth of ${ }^{239,200} \mathrm{Pu}$ contamination extends to $14 \mathrm{~m}$ beneath the Z-19 Ditch, though at much reduced levels. Higher concentrations of ${ }^{239.240} \mathrm{Pu}$ in subsurface sediments were found at the sites of the buried Z-1 and Z-11 ditches. The highest concentrations associated with either ditch were considered to represent the location of the ditch bottom, and the lower levels to represent the ditch banks or the edge of the contamination plume. The highest concentrations associated with the Z-1 Ditch are in the $100-\mathrm{nCi} / \mathrm{g}$ range and were found at two locations in the middle portion of the ditch. Although the data are very limited (i.e., two samples of the ditch bottom), these high concentrations do compare very well with values found in 1959 (set Appendix A) for these same areas, thus supporting the 1959 results. The highest concentration associated with the Z-11 Ditch is an order of magnitude lower (in the $10-\mathrm{nCi} / \mathrm{g}$ range), found at only one location near the head end of the ditch. This datum is very limited and can only sugg wit that the Z-11 Ditch contains lower concentrations of ${ }^{239,200} \mathrm{Pu}$ than the Z-1 Ditch. Beneath the e buried ditches, the ${ }^{239.240} \mathrm{Pu}$ contamination extends at least $6 \mathrm{~m}$, though at very low levels. 
WHC-EP-0707, Rev. 0

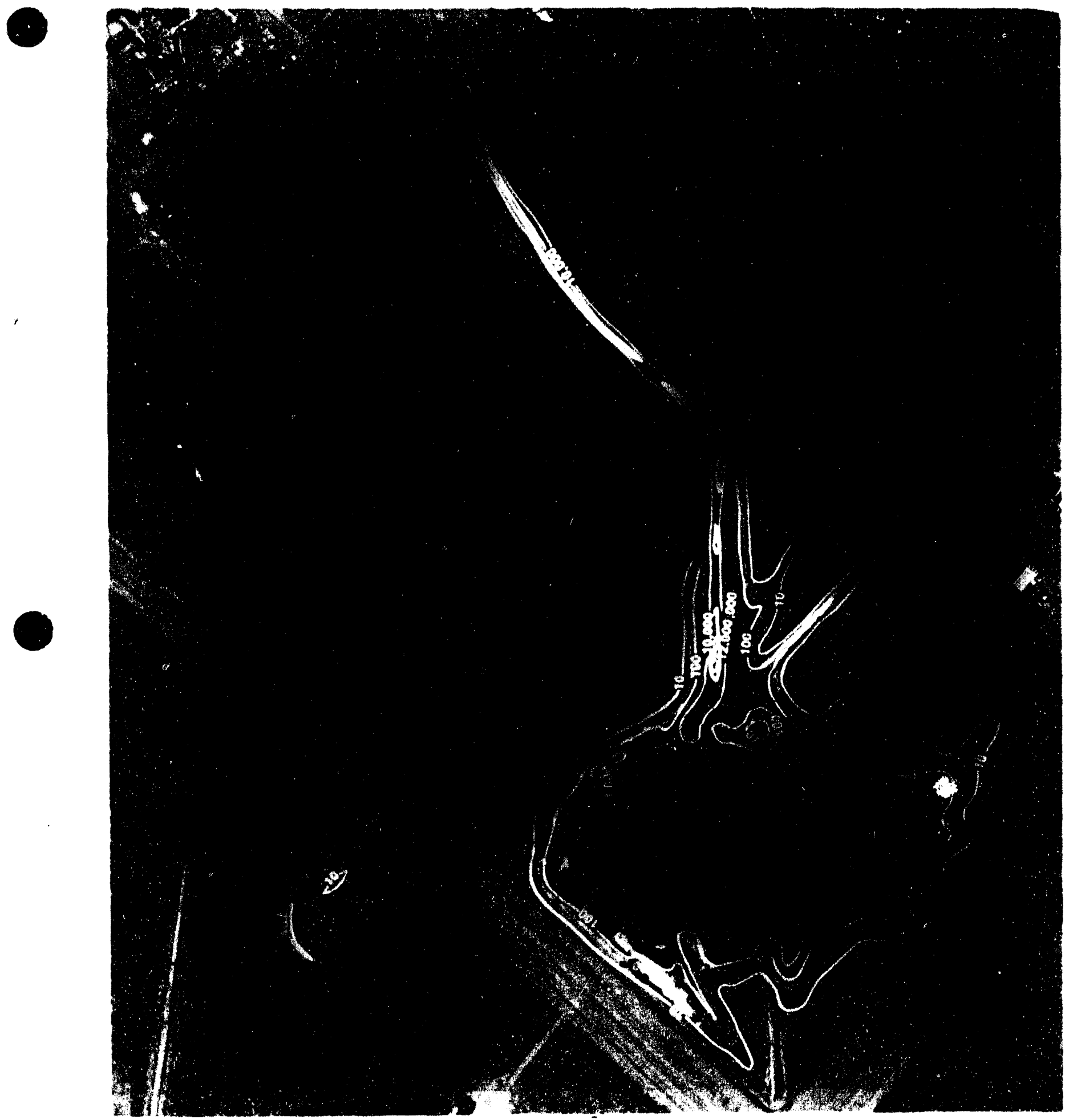

Figure 5.53. Distribution of ${ }^{239,240} \mathrm{Pu}$ in Z-Ditches (yellow, white; $\mathrm{pCi} / \mathrm{g}$ ) Relative to Elevation (ft above mean sea level). Green contour is the surface soil contamination limit (Boothe 1979). To convert picoCuries to nanoCuries, divide by 1000 . 
Plutonium-238 was also observed in the Z-19-ditch samples; however, the amount of data is very limited. These data do suggest some correlations with the ${ }^{239.240} \mathrm{Pu}$ data. The ${ }^{238} \mathrm{Pu}$ concentrations in the upper portion of Z-1Y-Ditch are generally comparable to those of ${ }^{239.240} \mathrm{Pu}$, except for one sample toward the middle portion of the ditch, where the concentrations are two orders of magnitude lower. Concentrations above the 234-5Z Outfall increase slightly with depth, showing an inverse correlation with the ${ }^{239,240} \mathrm{Pu}$. Data associated with the buried $\mathrm{Z}-1$ and $\mathrm{Z}-11$ ditches show ${ }^{238} \mathrm{Pu}$ concentrations generally two orders of magnitude lower than ${ }^{239,210} \mathrm{Pu}$, except at the one location where the bottom of the Z-11 Ditch was sampled. Here, the concentrations were only one order of magnitude lower. At depth, the ${ }^{200} \mathrm{Pu}$ concentrations were observed to increase relative to the ${ }^{239,200} \mathrm{Pu}$, possibly indicating greater mobility.

The distribution of ${ }^{241} \mathrm{Am}$ is similar to that of the plutonium, mostly because of its common 1 distribution components, the Z-ditches. In U-Pond, the ${ }^{241} \mathrm{Am}$ concentrations are much lower than plutonium, exceeding surface soil contamination limits only in the northeastern portion of the pond, with one exceptional hot spot on the southwest.

The concentrations of ${ }^{241} \mathrm{Am}$ are generally two orders of magnitude lower than plutonium in the decayed organic material on the U-Pond delta area, but occur in higher concentrations in other surface samples from this same area. The concentrations in the lower portion of the Z-19-Ditch were always found to be at lower levels than plutonium; at the upper end of the ditch, ${ }^{241} \mathrm{Am}$ was again found to be higher in some samples than plutonium. The ${ }^{241} \mathrm{Am}$ does not appear to have migrated as deep beneath $\mathrm{Z}$-19-Ditch as the ${ }^{239,200} \mathrm{Pu}$, except in one sample toward the upper end of the ditch.

The primary discharge source of the ${ }^{241} \mathrm{Am}$ is considered to be the same as that for plutonium, the 234-5Z Outfall. However, there clearly seems to be different source terms occasionally discharging ${ }^{261} \mathrm{Am}$ contamination in higher concentrations than ${ }^{239,240} \mathrm{Pu}$. Subsurface data beneath the Z-19-Ditch show low levels $\left(<1 \mathrm{pCi} / \mathrm{g}\right.$ ) of ${ }^{241} \mathrm{Am}$ at least $11 \mathrm{~m}$ deep. Americium-241 concentrations associated with the buried Z-1 Ditch were in the tens of nanoCurie-per-gram range, while those associated with the Z-11 Ditch were in the nanoCurie-per-gram range. All these data show good correlations between the ${ }^{241} \mathrm{Am}$ to ${ }^{239.240} \mathrm{Pu}$ ratios.

Earlier studies have reported an inventory of $22 \mathrm{~g}$ of plutonium in the U-Pond bottom sediments (Emery and Klopfer 1974; Emery and Garland 1974). A 1959 study (see Appendix A) of the Z-1 Ditch estimated an inventory between 3 and $10 \mathrm{~kg}$ of plutonium. These studies are considered to represent good inventory estimates. Because current sampling was limited in these areas, no further estimates of these components were attempted.

Sufficient data were gathered from the Z-19-Ditch to allow a rough inventory estimate to be made. To do this, the ditch was divided in half, with the lower half examined first. Here, five surface samples were collected across the ditch bottom every $30 \mathrm{~m}$, producing an average concentration of $12.837 \mathrm{nCi} / \mathrm{g}$ in the top $2.5 \mathrm{~cm}$ of ditch bottom in the first $305 \mathrm{~m}$ of the 1.2 -m-wide ditch below 16th Street and assuming a soil density of $1.4 \mathrm{~g} / \mathrm{cm}$ (because it is disturbed surface material). This results in an inventory of $0.17 \mathrm{Ci}$ in the top $2.5 \mathrm{~cm}$ of sediment. Assuming a concentration of $1.0 \mathrm{nCi} / \mathrm{g}$ down to 
a depth of $30 \mathrm{~cm}$, excluding the top $2.5 \mathrm{~cm}$ of this same area, and assuming a density of $1.7 \mathrm{~g} / \mathrm{cm}^{3}$, an inventory of $0.14 \mathrm{Ci}$ results, for a total of $0.31 \mathrm{Ci}$ for the lower part of the ditch. In the upper part of the ditch, a concentration of $10 \mathrm{nCi} / \mathrm{g}$ is assumed to a depth of $30 \mathrm{~cm}$ down the $500-\mathrm{m}$ length, with density of $1.7 \mathrm{~g} / \mathrm{cm}^{3}$, which results in an inventory of $3.1 \mathrm{Ci}$. Add to that $1.0 \mathrm{nCi} / \mathrm{g}$ to a depth of $75 \mathrm{~cm}$, which equals $0.46 \mathrm{Ci}$ for a total of $3.56 \mathrm{Ci}$ for the upper portion. The ditch total is now $3.87 \mathrm{Ci}$ or $63 \mathrm{~g}$ of ${ }^{239} \mathrm{Pu}$ value. This estimated inventory is very rough and is considered to represent a minimum compared to an estimated $<208 \mathrm{~g}$ from discharge records.

No inventories were estimated for the $216-Z-11$ Ditch because only very limited data exist.

\subsection{Hydrologic Studies}

U-Pond has affected the ground-water-flow system and contamination distribution in the unconfined aquifer. The purpose of this section is to present the results of hydrologic modeling of the groundwater-flow system in the U-Pond area. The section presents the following:

- relevant hydrogeologic information needed for a proper understanding of the 200 West Area unconfined aquifer flow system.

- historical simulation of the unconfined aquifer in the 200 West Area between 1944 and 1981

- predictive simulation of the decline of the 200 West Area ground-water mound between 1982 and 1989 in response to the proposed decomrnissioning of U-Pond.

The approach used in studying the U-Pond hydrologic system (Figure 5.54) was a conceptualnumerical model. First, a conceptual model for surface-water infiltration was developed and then incorporated into a mathematical analytical model. This analytical model describing infiltration from a surface pond was compared with a numerical (computer) simulation of liquid waste-water infiltration from a pond.

It was found that the computer simulation closely models liquid waste infiltration from a surface infiltration site. After the conceptual model was found to adequately describe a general case, the computer model was altered to model the liquid waste disposal system for the 200 West Area. Aquifer properties of the unconfined aquifer in the 200 West Area were selected to be included into the computer model; this selection was based on pump test field data (Table 5.11), geometric modeling studies (Newcomb et al. 1972), and pump tisst modeling studies for the unconfined aquifer in the 200 West Area. Discharge histories of various disposal sites, including U-Pond, were input into the computer model, along with various boundary conditions describing the areal extent of the unconfined aquifer. 


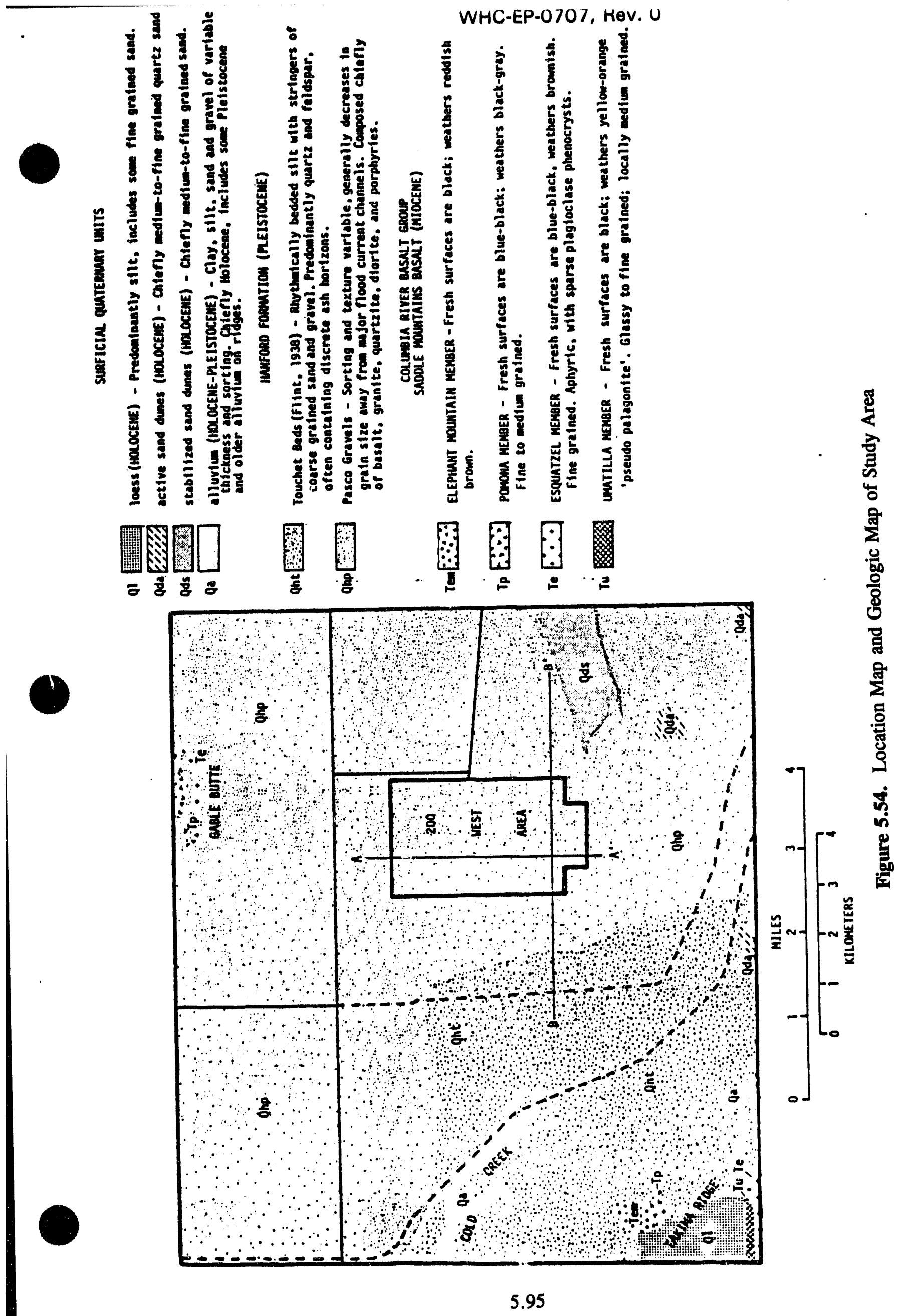


Table 5.11. Summary of Pump Test Results in the Unconfined Aquifer in the 200 East and 200 West Areas Between 1969 and $1980^{(a)}$

\begin{tabular}{|c|c|c|c|c|c|c|c|c|c|c|c|}
\hline \multirow[b]{2}{*}{$\begin{array}{c}\text { Data } \\
\text { Source }\end{array}$} & \multirow[b]{2}{*}{$\begin{array}{l}\text { Tesi } \\
\text { Year }\end{array}$} & \multirow[b]{2}{*}{ Well Location } & \multirow[b]{2}{*}{$\begin{array}{l}\text { Interval } \\
\text { Tested }^{(c)} \\
\end{array}$} & \multicolumn{2}{|c|}{ Hydraulic Conductivity } & \multicolumn{2}{|c|}{ Transmissivity } & \multirow[b]{2}{*}{$\begin{array}{l}\text { Coefficient } \\
\text { of Storage }\end{array}$} & \multirow[b]{2}{*}{$\begin{array}{c}\text { Test } \\
\text { Type }^{(d)}\end{array}$} & \multirow[b]{2}{*}{ Durntion } & \multirow{2}{*}{$\begin{array}{c}\text { Analysis } \\
\text { Technique }\end{array}$} \\
\hline & & & & m/day & ft/day & $\mathrm{m}^{2} /$ day & $\mathrm{ft}^{2} /$ day & & & & \\
\hline 1 & 1969 & 299-W21-1 & MR & 8.2 & 27 & 502 & 5400 & - & $\mathrm{CD}, \mathbf{R}$ & 4 & T,RA \\
\hline 1 & 1969 & $699-32-77$ & MR & 6.4 & 21 & 420 & 4500 & - & CE,R & 6 & T,RA \\
\hline 2 & 1969 & $699-36-61$ & MR & 13 & 43 & 260 & 2800 & 0.05 & CD, R & 8 & CJ,RA \\
\hline 1 & 1969 & $699-43-88$ & MR & 2.7 & 9 & 186 & 2000 & 0.016 & CD & 24 & CJ \\
\hline 1 & 1969 & $699-47-60$ & MR & 7.6 & 25 & 93 & 1000 & - & CD & 7 & CJ \\
\hline 3 & 1979 & $699-37-82$ & LR & 2.7 & 9 & 25 & 270 & 0.018 & CD & 48 & MCJ,B \\
\hline 3 & 1979 & $699-43-88$ & LR & 3 & 10 & 90 & 970 & 0.05 & CD & 21 & $\mathbf{T}$ \\
\hline 3 & 1980 & $699-43-88$ & LR & 2.4 & 8 & 74 & 800 & 0.04 & $C D$ & 24 & T,CJ \\
\hline
\end{tabular}

(a) Revised from Graham et al. (1981).

(b) Data source: 1 = Kipp and Mudd (1973)

$$
2 \text { = Deju (1974) }
$$

$3=$ Graham et al. (1981).

(c) Interval tested: $\mathbf{H}=$ Hanford formation

MR = Middle Ringold Formation

$L R=$ Lower Ringold Formation.

(d) Test type: $\mathrm{CD}=$ Constart Discharge

$\mathbf{R}=$ Recovery

(e) Analysis technique: $T=$ Theis Analysis (1935)

CJ = Cooper-Jacob Analysis (1946)

RA = Recovery (Jacob) Analysis (1950)

MCJ = Modified Cooper-Jacob Analysis (1946) 
After calibrating the computer model, it was used to simulate the historical period of liquid waste disposal from 1944 to 1980 . The water-table elevation described by the model was then compared with historical field data. The model was then placed in a predictive mode to evaluate the impact of U-Pond decommissioning on the unconfined aquifer flow system.

It was hoped that the model would closely describe the water-table elevation history for the 200 West Area. However, there were many uncertainties that contributed to possible error in the analysis, such as unknown boundary conditions, uncertain inflow rates into various waste disposal sites, and unknown aquifer parameters. It was expected that the model would be limited in its utility only by these unknowns.

\subsubsection{Methods and Material}

To determine the ability of a computer model to describe an infiltration system such as the 200 West Area liquid waste disposal system, the computer model must be compared with a general analytical model that describes an idealized infiltration system. If, after given the same input parameters, the computer model and the analytical model closely agree, the computer model is capable of describing a more corritex system.

The test case involves the infiltration of liquid effluents from a surface disposal pond $t$ an unconfined aquifer. This test case simulates a pond $127 \mathrm{~m}$ in diameter that infiltrates $3.8 \mathrm{E}+05 \mathrm{~L} /$ day of waste water directly into an unconfined aquifer. The Hantush (1967) analytical solution was used to describe the idealized system and was compared with the Prickett and Lonnquist (1971) numerical computer solution. The numerical solution agrees well with the analytical solution; water levels in the aquifer increase over time as the pond discharges liquid effluents to the unconfined aquifer (Figure 5.55).

The basic abilities of the numerical methods to simulate nonsteady-state inflow into an unconfined aquifer have been verified by comparing numerical solutions to various test cases with an idealized analytical solution. The computer model accurately describes infiltration from a surface pond into an unconfined aquifer.

To use a computer-numerical model to simulate a hydrologic system, the model must be calibrated or assigned values estimating the properties of the natural system. Needed in the simulation of the 200 West Area unconfined aquifer were hydrologic properties of the aquifer, discharge histories of liquid waste disposal sites, initial pre-Hanford Site conditions of the water-table surface, and boundary conditions used to delineate the model's areal extent.

Hydrologic properties at points (wells) located in the unconfined aquifer were listed in Table 5.11. Various test cases were executed using parameters calculated from pump test data for input into the numerical model. Figure 5.56 shows a comparison between fleld test data and the computer-predicted response to the aquifer; this comparison indicates a newly confined aquifer in the lower Ringold at this well. 


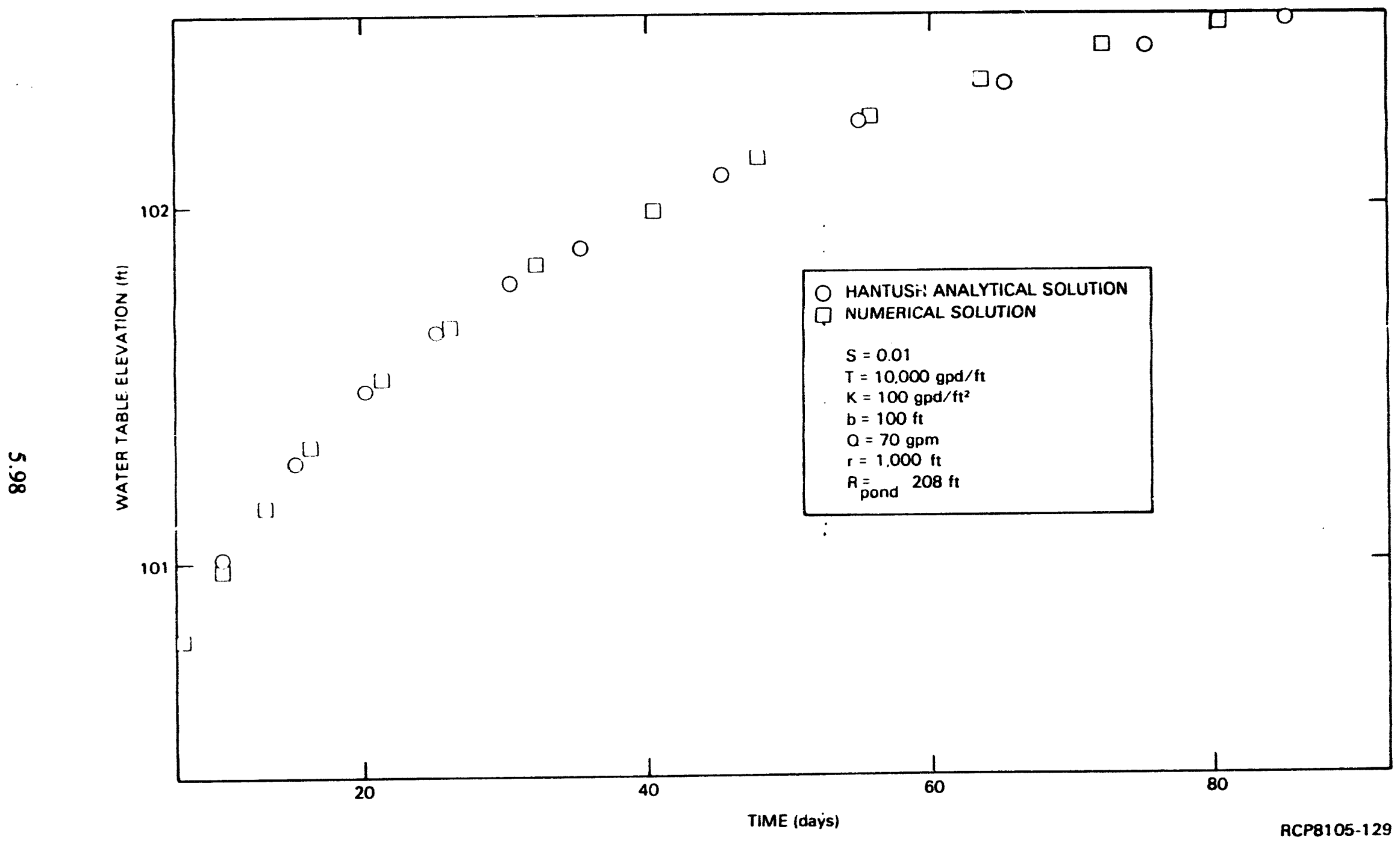

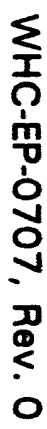

Figure 5.55. Comparison of Hantush (1967) Analytical and Numerical Solution 


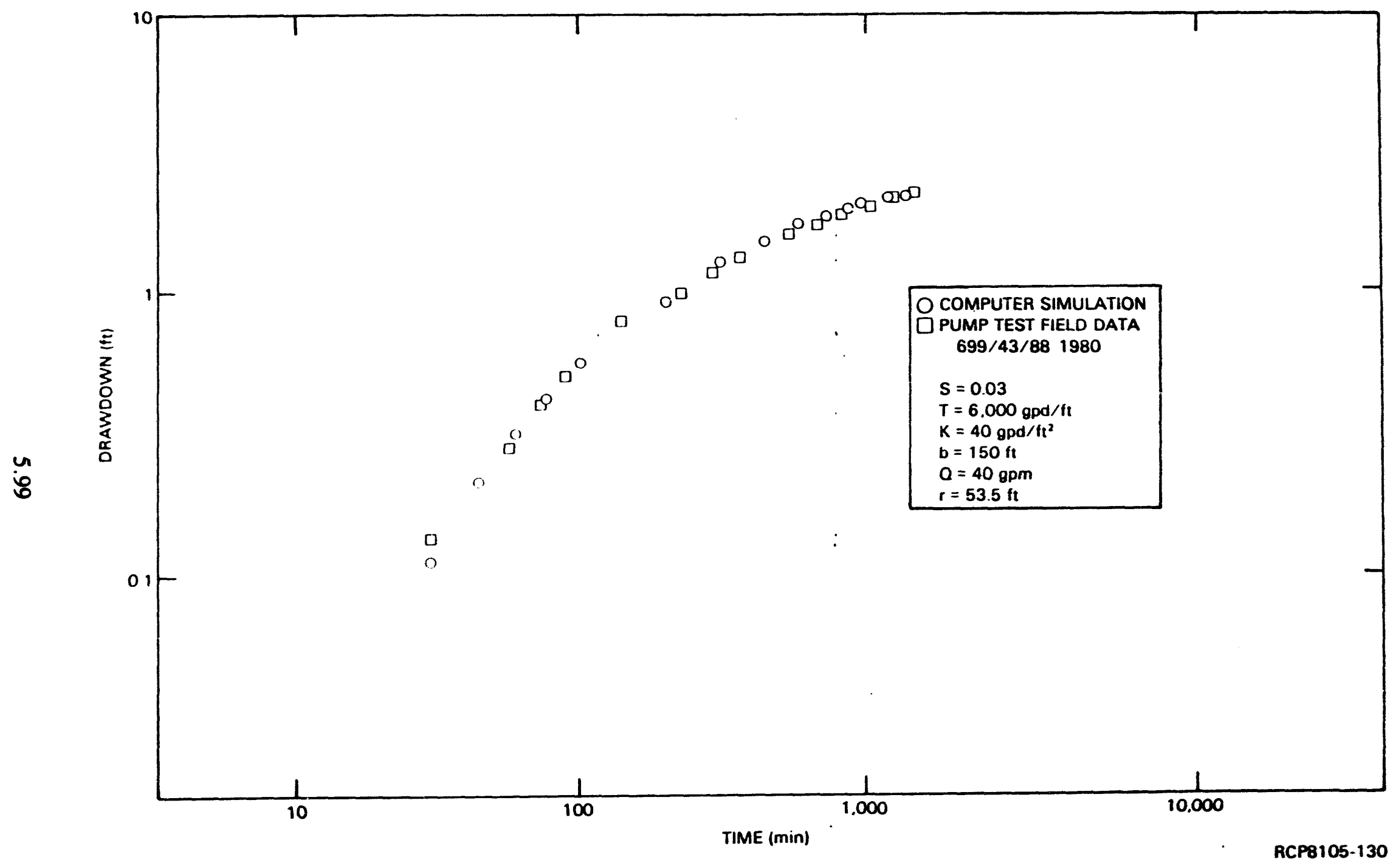

Figure 5.56. Comparison of Pump Test Data at Well 699-43-88 with Computer-Generated Data 
At well 699-37-82, the calculated aquifer parameters were again input into the computer model. The storage coefficient (S) was alluwed to change at 100 min into the pump test simulation; this change simulates the delayed yield (Sy) of the unconfined aquifer observed at this location (Figure 5.57).

After various trial computer runs with distributed and nondistributed aquifer parameters, it was found that a nondistributed value for hydraulic conductivity of $7 \mathrm{~m} /$ day and a value of 0.085 for the storage coefficient of the aquifer would best simulate the water-level trends observed in the unconfined aquifer (see Table 5.11). The high value for storativity actually represents the specific yield for the aquifer. Transmissivity within the aquifer was distributed based on the default hydraulic conductivity and the saturated thickness of sediments within the aquifer.

Volumes of liquid wastes released to the ground have been tabulated for the various waste disposal sites in the 200 East and 200 West areas. Input values of waste volumes into the various sites from 1944 to 1971 are given in Hanson et al. (1978). Subsequent discharge summaries are based on this document.

For this current hydrologic study, 11 liquid waste disposal sites in the 200 West Area were examined to determine input volumes to the unconfined aquifer. Any site in the study area that received more than $303 \mathrm{~L} / \mathrm{min}$ of liquid effluents at any one time was assumed to have a direct impact on the unconfined aquifer.

Initial heads used for the 1944 to 1989 model simulation are shown in Figure 5.58. Lateral boundaries for the computer simulations can be seen in Figure 5.54: Umtanum Ridge-Gable Butte, Yakima Ridge, and subcrop of Yakima Ridge. A no-flow boundary is assumed to exist if the water table within the unconfined aquifer intersects the confining bed.

A constant head boundary was used along the eastern edge of the study area. Over time, the heads in the unconfined aquifer along the eastern and northeastern margins of the study area have not changed appreciably. This constant head distribution can be attributed to the presence of the unconfined aquifer within the Hanford formation. Pump tests completed within this formation indicate hydraulic conductivities an order of magnitude higher than in the Ringold Formation (Graham et al. 1981).

\subsubsection{Results and Discussion}

Simulation of the unconfined flow system around the 200 West Area and U-Pond area was done after the model had been assigned the properties of the 200 West Area liquid waste disposal system. The simulation of the system began with 1944 input data and continued through 1989. To determine the model's capability of simulating the 200 West Area hydrologic system, model results throughout the historical period of calibration (1944 to 1980) were compared with field data for the same period. If the computer model is able to reproduce field measurements within a certain margin of error thriughout the historical period of simulation, then the model results are acceptable. 


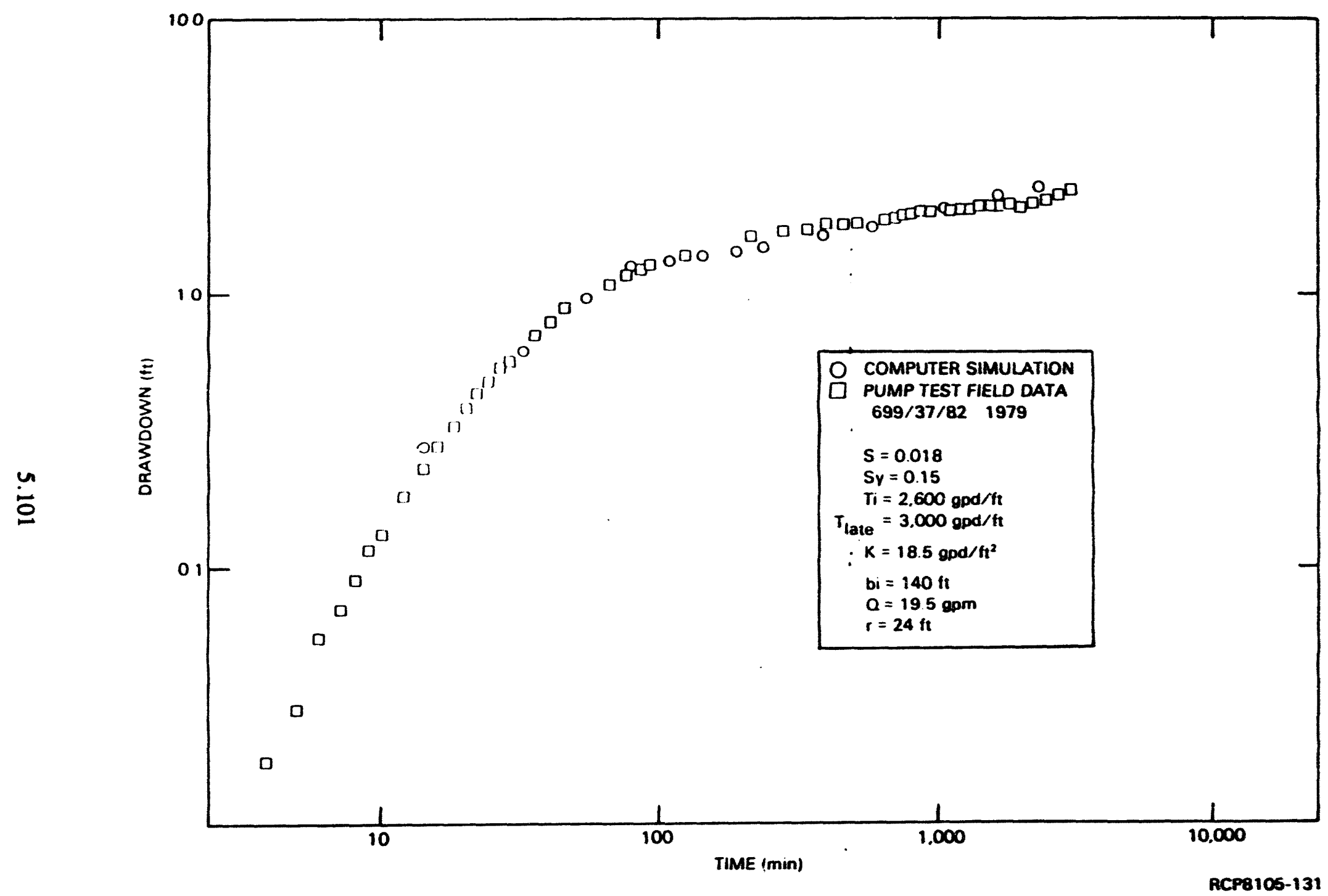

Figure 5.57. Comparison of Pump Test Data at Well 699-37-82 with Computer-Generated Data 


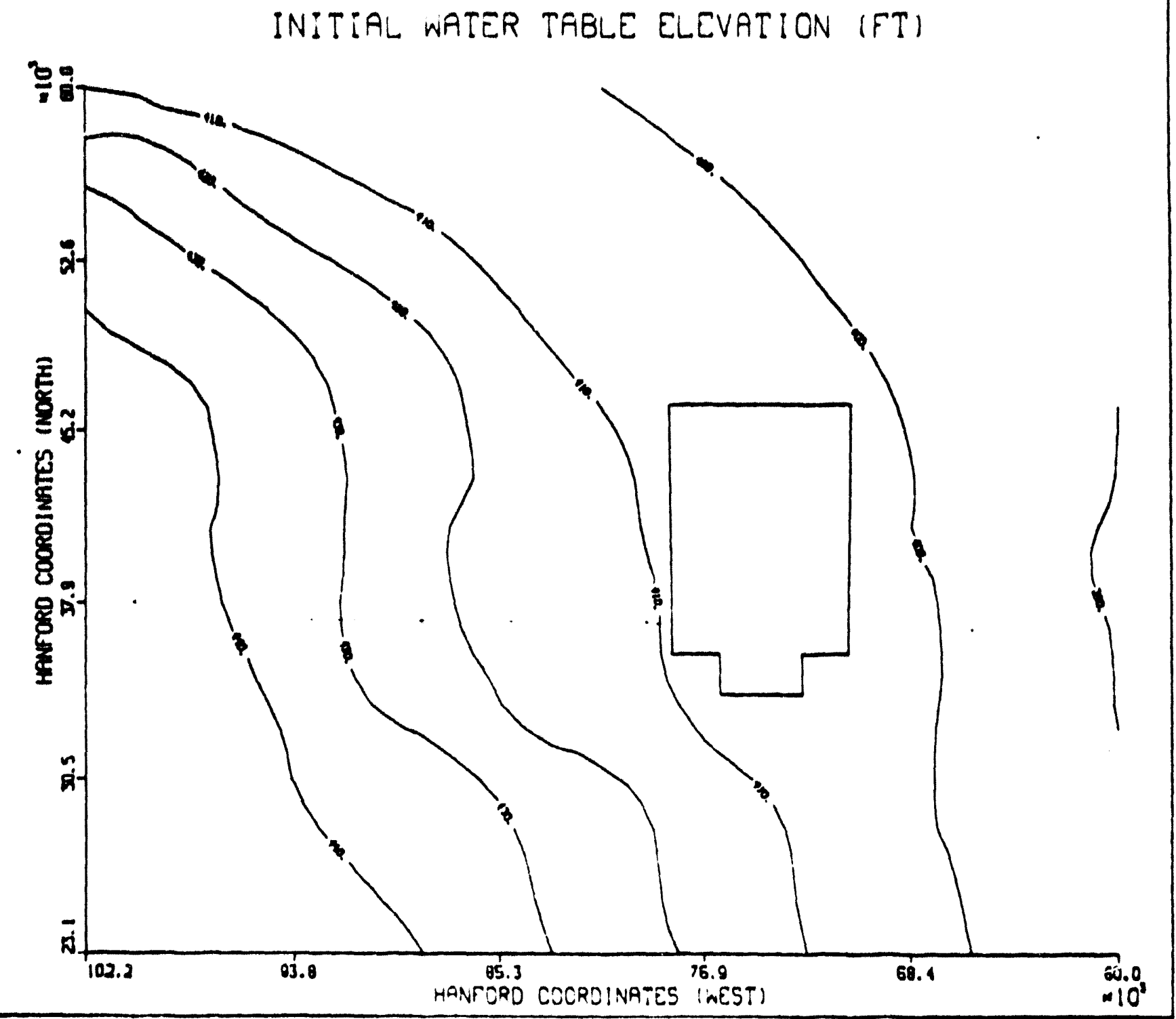

Figure 5.58. Pre-Hanford Site Water-Table Elevation

To calculate a meaningful interpolated distribution of heads throughout the study area, a relatively uniform initial distribution of water-level measurements is necessary. Prior to 1956, few wells existed in the study area; those that did were concentrated within the 200 West Area. Therefore, meaningful verification of the model results prior to 1956 is not possible because a distribution of field measurements cannot be readily inferred.

Figure 5.59 is a comp: tter-interpolated distribution of water levels in the unconfined aquifer for 1956. When compared with the model simulation of the aquifer system of the same year (Figure 5.60), a determination of the model's ability to describe the unconfined aquifer can be made. A residual error 


\section{WATER TABLE. ELEVATION (FT)}

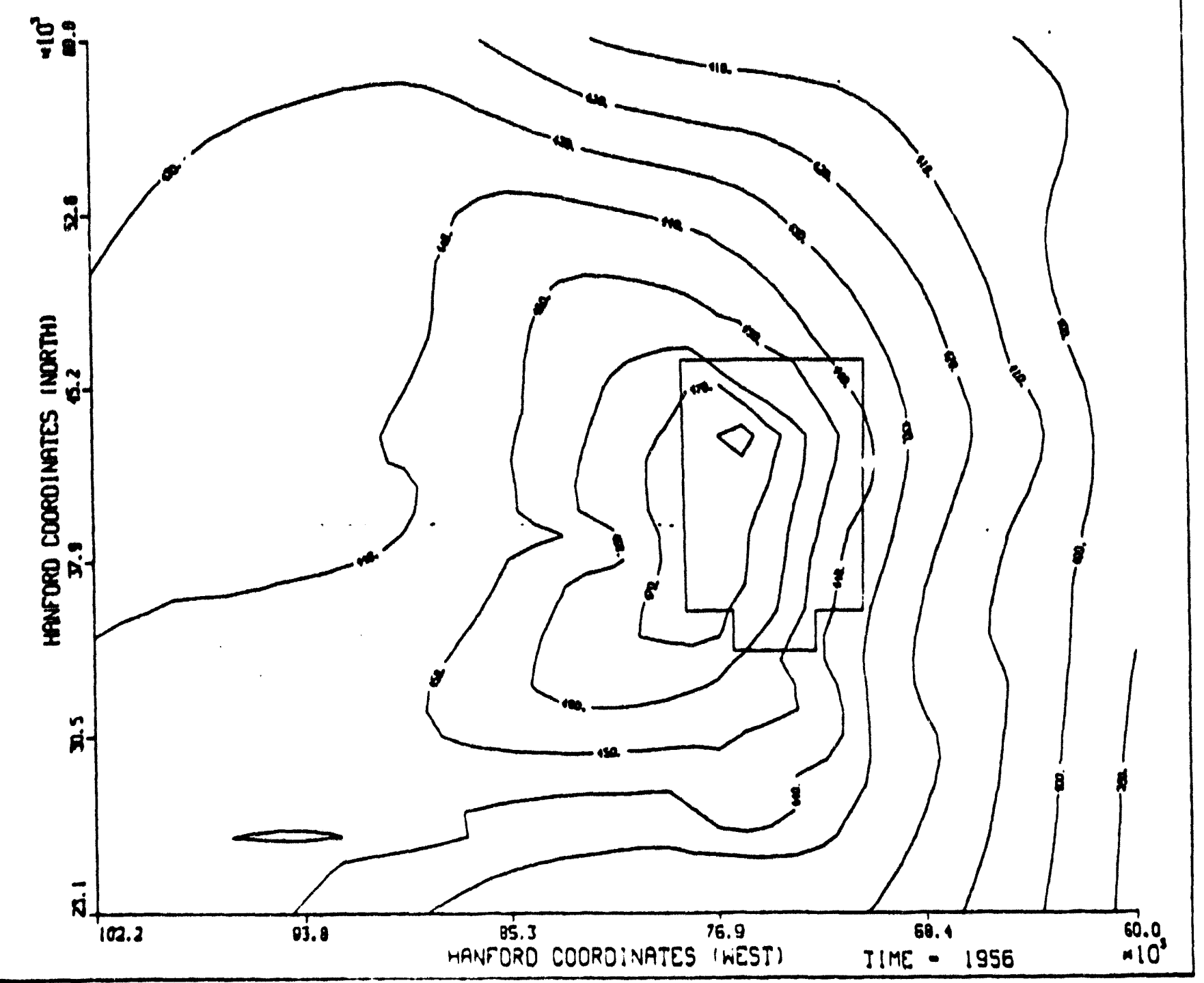

Figure 5.59. Water-Table Elevation, 1956 (Field)

map was created that shows the numerical difference between the model results and the interpolated field results (Figure 5.61). The model does a reasonable job of predicting the water-table elevations for this year, as evidenced by the low residual error, though the model overpredicts heads toward the southern portion of the study area. The maximum error in the 200 West Area represents approximately $30 \%$ of the range of the dependent variable (water-table elevation) at this particular time. 

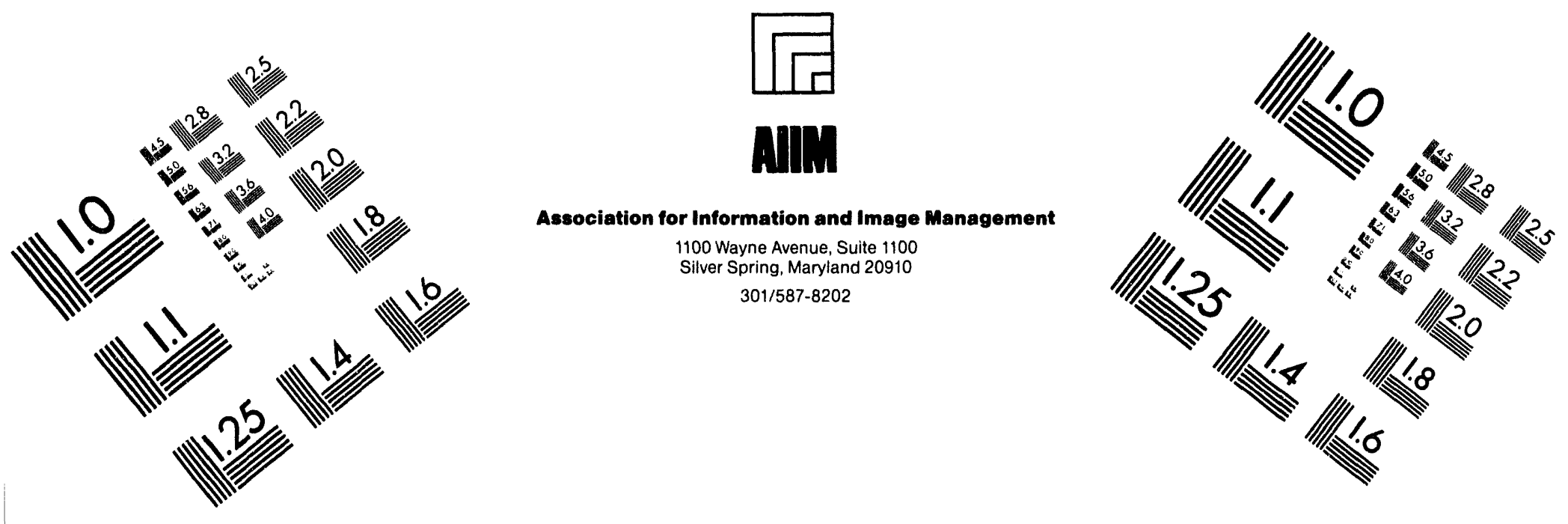

Centimeter

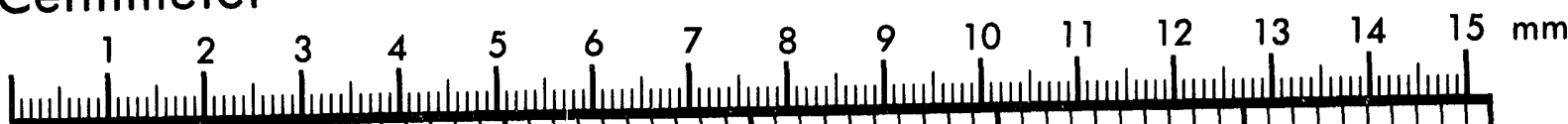

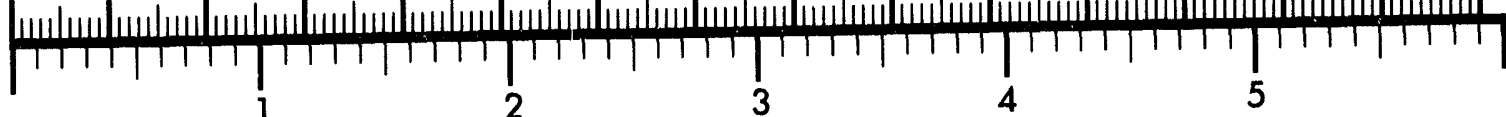
Inches
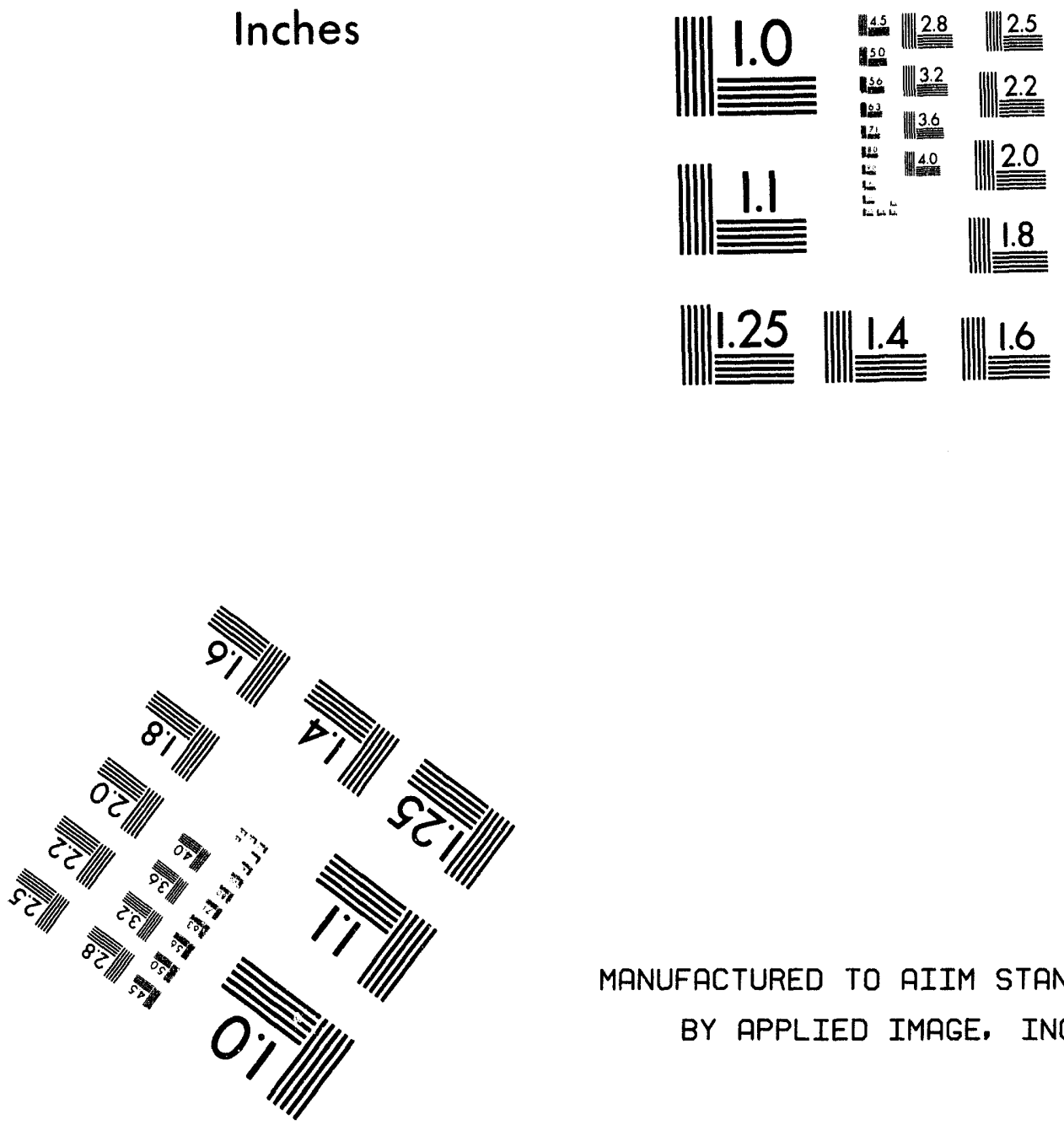

MANUFACTURED TO AIIM STANDARDS

BY APPLIED IMAGE, INC.

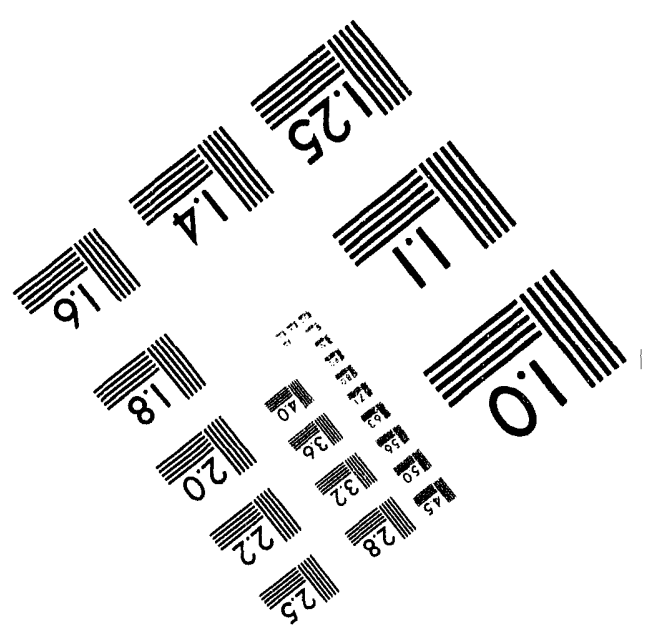



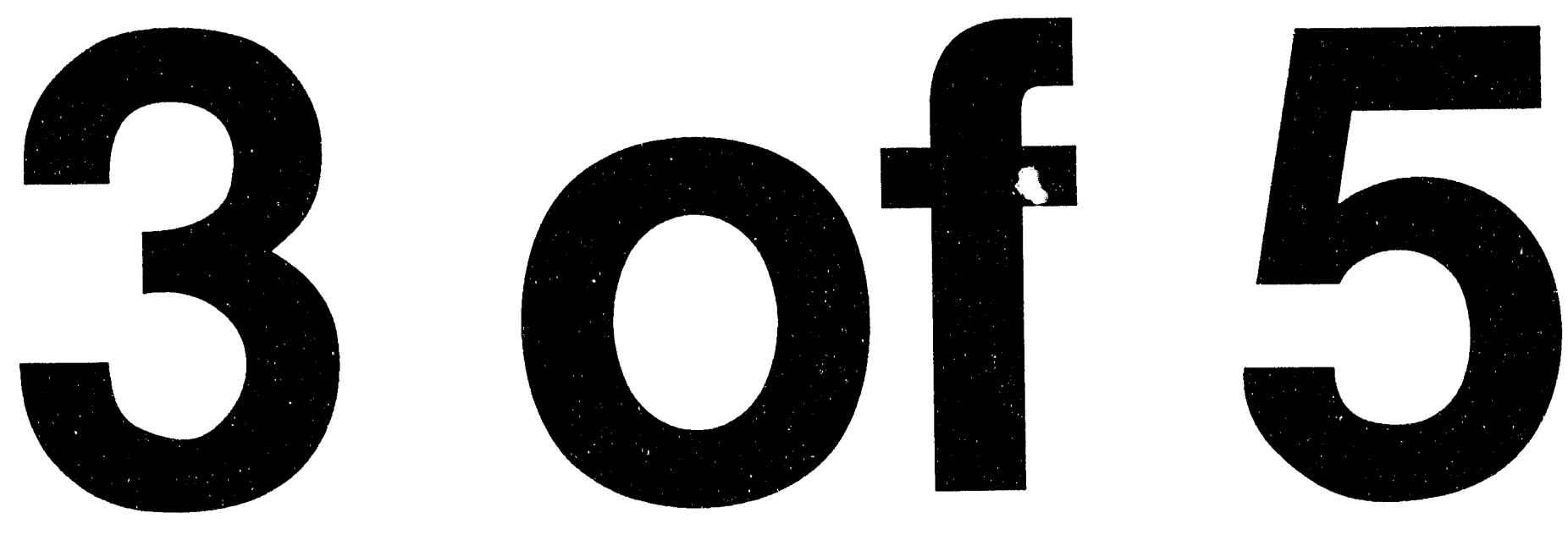


\section{WATER TABLE ELEVATION (FT)}

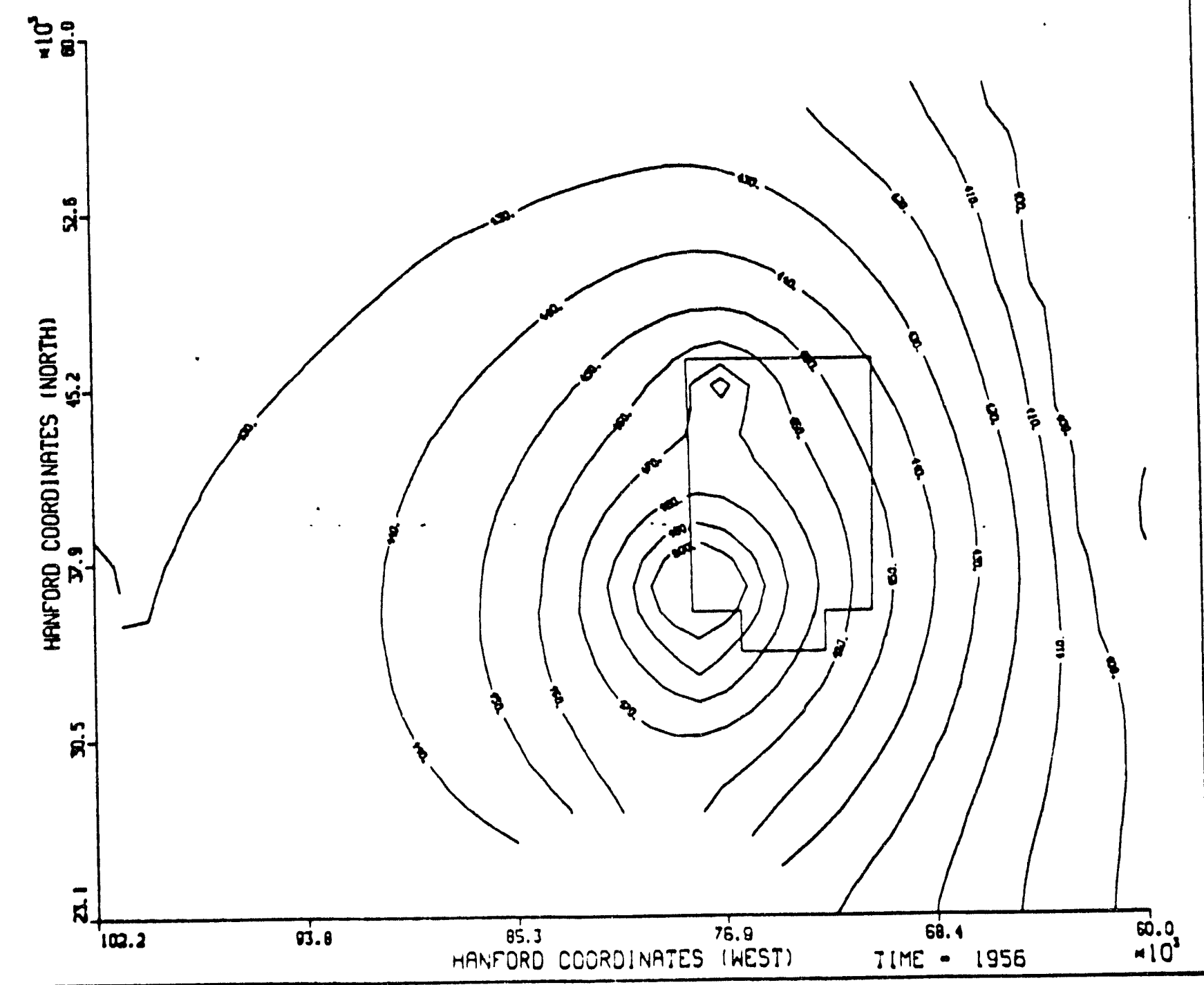

Figure 5.60. 1956 Water-Table Elevation, 1944 to 1989 Simulation

The error analysis was also completed for 1968 and 1980 with comparable results. The maximum error of the model results in the 200 West Area represents approximately $20 \%$ to $30 \%$ of the range of the dependent variable.

Although $20 \%$ to $30 \%$ residual error throughout the historical model simulation appears relatively high, this error represents the maximum error that could occur at any one point and not the average expected error over the entire model. The average error is generally less than $6 \%$ of the range of the 


\section{RESIOUAL ERROR (FT)}

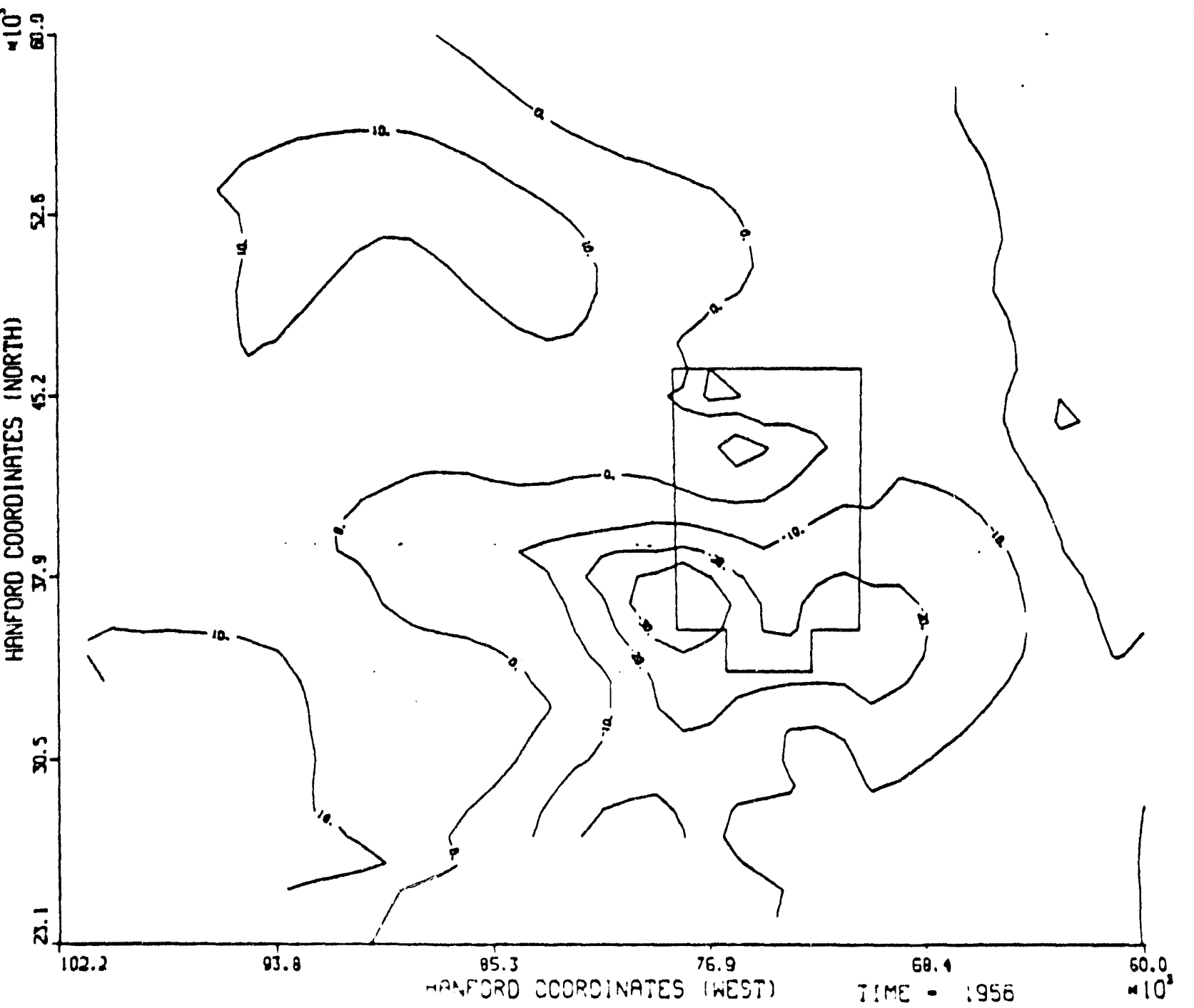

Figure 5.61. Residual Error Map, 1956

dependent variable in the 200 West Area during the historical simulation. A value of residual error, averaging less than $10 \%$ throughout the history-matching simulation in the 200 West Area, verifies the ability of the computer model to simulate the unconfined aquifer.

A more elegant procedure than that outlined above for estimating water-level declines in the unconfined aquifer is to restart the computer simulation at 1980 with 1980 field data. This would 
remove uncertainty associated with the 1944 water-level elevations used as initial conditions and eliminate random inflow and parameter estimation errors that are cumulative throughout the model simulation.

Figure 5.62 shows the predicted water-level decline in the unconfined aquifer in relation to 1980 field data. In 1989, 7 years after the proposed shutdown, declines of over $11 \mathrm{~m}$ are expected in the vicinity of U-Pond.

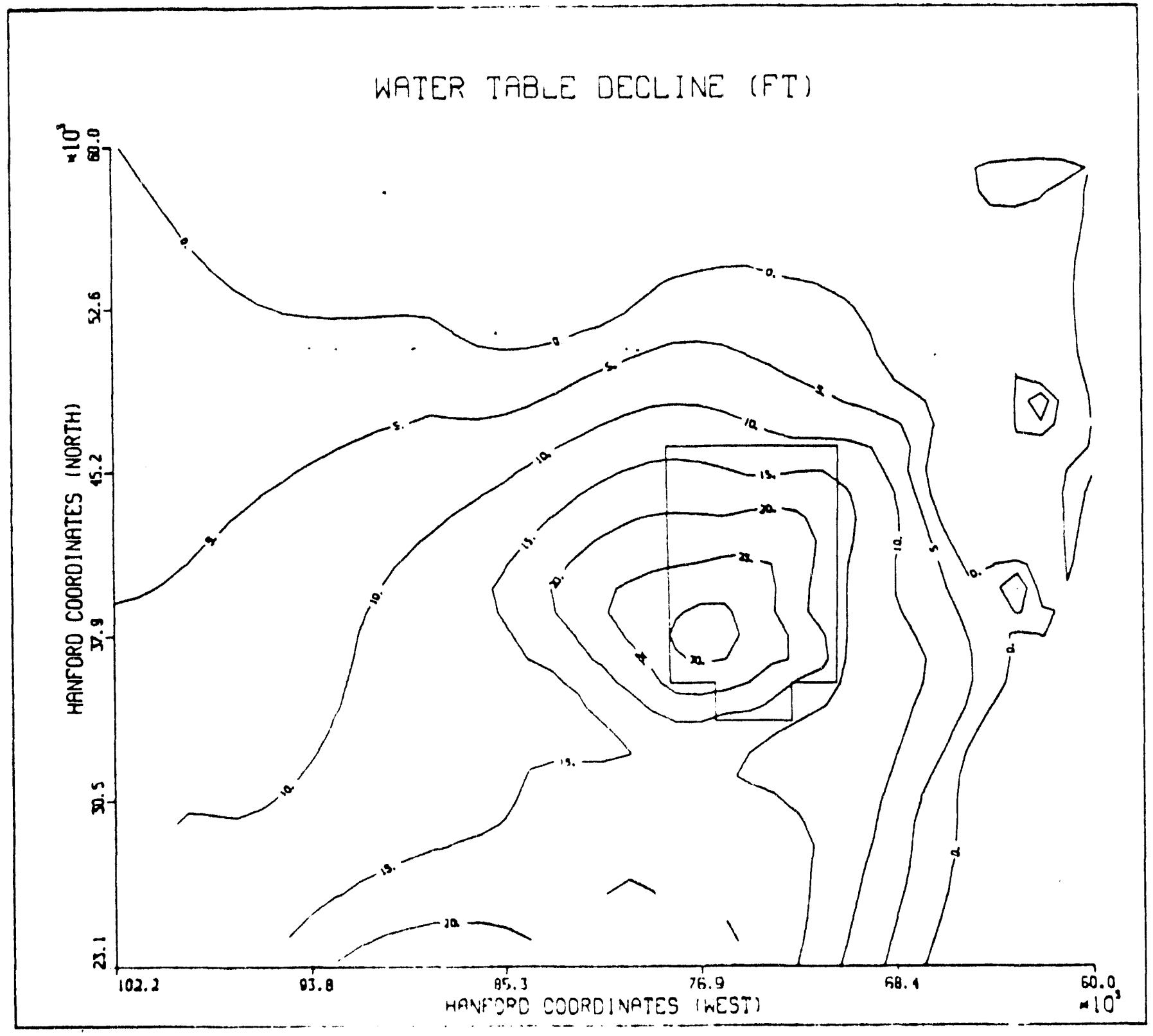

Figure 5.62. Predicted Water-Table Decline, 1989 
Much of the water discharged to U-Pond eventually becomes incorporated into the unconfined ground-water system. Flow directly below the pond appears to be essentially vertical, though there is some evidence that silt and clay layers below the infiltration area cause lateral saturated movement. Intiltration of liquids through to the unconfined aquifer has caused the formation of a large, mounded water-table surface. Water levels in the unconfined aquifer have risen over $26 \mathrm{~m}$ since startup. of operations at the Hanford Site. Saturated flow is both radial and vertical within this mound. U-Pond is recharging the deeper part of the unconfined aquifer, though vertical gradients near the pond are essentially not known.

The U-Pond waste disposal system has caused a water-table rise in over $154 \mathrm{~km}^{2}$ of the aquifer. The indirect impact of U-Pond liquid discharges on the rest of the Hanford Site is not as well known; the 200 East and 200 West areas' liquid waste disposal systems have impacted each other over time.

Decommissioning of the U-Pond system will have a pronounced effect on the 200 West Area unconfined aquifer flow system. If all inflow into the pond is eliminated, the 200 West Area flow system will begin to revert to pre-Hanford Site flow conditions (i.e., ground water will flow primarily from west to east toward the 200 East Area). Water levels in the unconfined aquifer will drop over $11 \mathrm{~m}$ in the vicinity of the pond just 7 years after U-Pond shutdown.

\subsubsection{Ground-Water Contamination}

U-Pond and its associated ditches have received low-level liquid waste, with the exception of unplanned releases of high-level wastes (Emery and Garland 1974). As stated earlier, these contaminants were largely adsorbed on the sediment and, therefore, did not reach the water table in appreciable concentrations. An analysis of the present distribution of radionuclide and nitrate contamination in the unconfined aquifer indicates that U-Pond is not a significant contributor to contamination of the aquifer. An analysis of selected radionuclide concentrations in a sample collected in April 1981 from well 299-W18-15, which monitors U-Pond (Figure 5.63), is presented in Table 5.12. Analysis of a sample of perched water encountered in well 299-W23-228 (SHD-1) (see Figure 5.63) at $6.4 \mathrm{~m}$ is also given in Table 5.12. The concentration guides for water in an uncontrolled area are also listed in the table for comparison. The concentrations of radionuclides in the ground-water sample are well below the standard of $10 \%$ of concentration guides for active disposal facilities.

Well 299-W18-15 was again sampled on May 18, 1981. This sample was analyzed for the 19 primary and secondary inorganics as specified in the Safe Drizking Water Act of 1974 (Table 5.13); sodium was added to the list in 1981. Again, the concentrations are well below allowable limits, also given in the table. 
WHC-EP-0707, Rev. 0

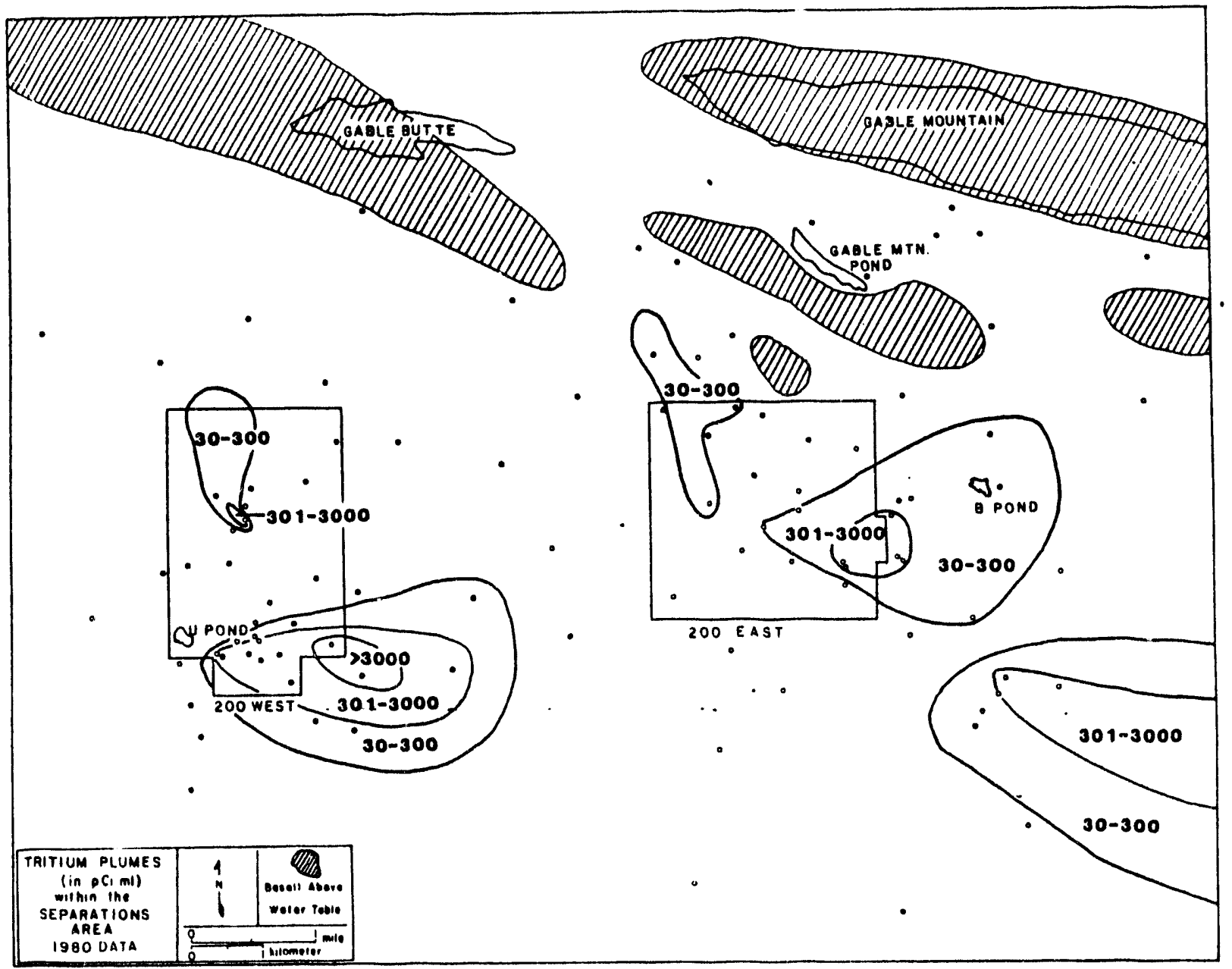

Figure 5.63. Tritium Plumes Within the 200 East and 200 West Areas, 1980

Although U-Pond is not a major source of ground-water contamination, it does provide a driving force to move contaminants in the aquifer resulting from other disposal facilities. For example, the tritium contamination plumes resulting from the $216-\mathrm{S},-\mathrm{U}$, and $-\mathrm{T}$ cribs are aligned along the flow paths from the U-Pond ground-water mound (see Figure 5.63). Thus, the largest impact of U-Pond on the hydrology has been on the flow system and less so on water quality. 
Table 5.12. Concentrations of Radionuclides in Well 299-W18-15, Perched Water in Well 299-W23-228, and Concentration Guides for Water in an Uncontrolled Area (in $\mathrm{pCi} / \mathrm{mL}$ )

\begin{tabular}{|l|c|c|c|}
\hline & $\begin{array}{c}\text { Well 299-W18-15 } \\
4 / 28 / 80^{(a)}\end{array}$ & $\begin{array}{c}\text { ERDA (1977) Concentration } \\
\text { Guides, Uncontrolled Area }\end{array}$ & $\begin{array}{c}\text { Perched Water; } \\
\text { Well 299-W23-228 } \\
4 / 28 / 81^{(a)}\end{array}$ \\
\hline \hline Total alpha & $3.2 \mathrm{E}-2$ & $(\mathrm{~b})$ & - \\
Total beta & $2.4 \mathrm{E}-3$ & $(\mathrm{~b})$ & - \\
${ }^{90} \mathrm{Sr}$ & -- & $3.0 \mathrm{E}-1$ & $3.4 \mathrm{E}-2$ \\
${ }^{137} \mathrm{Cs}$ & $<4.3 \mathrm{E}-3$ & $2.0 \mathrm{E}+1$ & $1.94 \mathrm{E}-1$ \\
${ }^{60} \mathrm{Co}$ & $<3.0 \mathrm{E}-2$ & $1.0 \mathrm{E}+1$ & - \\
${ }^{3} \mathrm{H}$ & $5.4 \mathrm{E}-1$ & $3.0 \mathrm{E}+3$ & - \\
${ }^{\text {Uranium }}$ & $4.1 \mathrm{E}-2$ & $2.0 \mathrm{E}+1$ & - \\
${ }^{239} \mathrm{Pu}$ & -- & $5.0 \mathrm{E}+1$ & $7.0 \mathrm{E}-3$ \\
\hline
\end{tabular}

(a) Sample date.

(b) Not applicable; significance of contamination determined by specific radionuclide analysis. 
Table 5.13. May 15, 1981 Inorganic Chemical Analysis of Water Sample from Well 299-W18-15 (mg/L)

\begin{tabular}{|l|c|c|}
\hline \multicolumn{1}{|c|}{ Contaminant } & Sample & Maximum Allowed \\
\hline \hline Arsenic & 0.016 & 0.05 \\
Barium & 0.5 & 1 \\
Cadmium & $<0.001$ & 0.01 \\
Chromium & $<0.02$ & 0.05 \\
Lead & $<0.005$ & 0.05 \\
Mercury & $<0.0005$ & 0.002 \\
Selenium & $<0.001$ & 0.01 \\
Silver & $<0.01$ & 0.05 \\
Iron & 0.24 & 0.3 \\
Manganese & 0.01 & 0.05 \\
Copper & $<0.01$ & 1 \\
Zinc & $<0.05$ & 5 \\
Sodium & 14.5 & 20 (goal) \\
Color & $<5$ & 15 \\
Total Dissolved Solids & 109 & 500 \\
Fluoride & 0.28 & 250 \\
Nitrate-N & 0.50 & 10 \\
Chloride & 22.4 & 250 \\
Sulfate & 12.5 & 2.0 \\
\hline & & \\
\hline
\end{tabular}




\subsection{Summary and Conclusions}

This document represents the accumulation of existing information on the $216-\mathrm{U}-10$ (U-) Pond and its associated 216-Z-19 (Z-19) Ditch. The most significant findings from this information are summarized below.

- The continued disposal of low-level wastes to this disposal system has resulted in the surface accumulation of transuranics and fission products in concentrations exceeding surface soil contamination limits. A total of approximately 19 ha exceed these limits.

- The large volumes of waste water discharged have locally raised the water table approximately $26 \mathrm{~m}$ and produced numerous perched water zones. This has impacted the hydrologic flow patterns beneath the 200 East and West areas but has not adversely impacted the quality of the ground water.

- The fission products and uranium are well distributed throughout most of the disposal system, while the transuranics (plutonium and americium) are localized more closely to the points of discharge. Most of the estimated $8.22 \mathrm{~kg}$ of plutonium listed on discharge records appears to be located in the backfilled 216-Z-1 (Z-1) Ditch, with an estimated sampling inventory of 3 to $10 \mathrm{~kg}$. The backfilled 216-Z-11 (Z-11) and the active Z-19 ditches are considered to have about similar concentrations (which are an order of magnitude lower than the Z-1 Ditch). U-Pond has the lowest concentrations and has an estimated $22 \mathrm{~g}$ of plutonium in the top $10 \mathrm{~cm}$ of the pond bottom.

- The contamination around U-Pond and the Z-19 Ditch is primarily located in the top 10 to $15 \mathrm{~cm}$ of soil. However, deeper contamination was found in the U-Pond delta, where significant concentrations of ${ }^{137} \mathrm{Cs}$ were observed $1.5 \mathrm{~m}$ beneath the surface.

- The index radionuclides (for decommissioning purposes) are ${ }^{137} \mathrm{Cs}$ for U-Pond, 216-U-11 (U-11) Overflow Basin, and the lower portion of the U-14 Ditch and ${ }^{239.240} \mathrm{Pu}$ for the Z-19 Ditch.

- Past decreases in the pond-water level have resulted in the exposure and drying out of the surface contamination around U-Pond. This has provided the source from which the atmospheric resuspension of ${ }^{90} \mathrm{Sr},{ }^{137} \mathrm{Cs},{ }^{239,240} \mathrm{Pu}$, and ${ }^{241} \mathrm{Am}$ has occurred. The resuspension levels of these contaminants are considered to be low, but surface concentrations of ${ }^{137} \mathrm{Cs}$ away from U-Pond have indicated a potential redistribution of the contaminants down wind.

- U-Pond has developed a unique ecological system that maintains a varied community of plants and animals. These plants and animals can assimilate the radionuclides and can provide biological transport away from the site. Algal flocs are the major biological concentrator of plutonium and americium in U-Pond. Cattails have assimilated higher concentrations of plutonium and americium than any other aquatic plants in the Z-19-Ditch. The trees around U-Pond are known to assimilate ${ }^{90} \mathrm{Sr}$ and ${ }^{137} \mathrm{Cs}$, with detectable levels found throughout their various parts. Strontium-90, ${ }^{137} \mathrm{Cs}$, 
${ }^{239,240} \mathrm{Pu}$, and ${ }^{241} \mathrm{Am}$ were all found in the small mammals inhabiting the U-Pond and Z-19-Ditch environs. Deer mice and house mice were found to have the highest concentrations, and both these species live in close association with humans. Avifauna at U-Pond are also considered a transport pathway, with the American coot noted as the most significant species.

- Human intrusion has occurred at this site when workers unknowingly excavated into the decommissioned Z-1 Ditch, exposing the high levels of transuranics to the atmospheric and biological environs for a short period.

In conclusion, this study has shown that the surface disposal of large volumes of low-level wastes at U-Pond has impacted all aspects of the environment. The most significant radiological impacts are associated with the biological uptake of contaminants and with the accumulation of contaminants over a large surface area. However, no significant impacts to humans have ever been associated with this disposal system over its 37-year history. 


\subsection{References}

Aldrich, R. C. and G. J. Slicer. 1981. Radioactive Liquid Wastes Discharged to Ground in the 200 Areas During 1980. RHO-CD-80-34-4Q, Rockwell Hanford Operations, Richland, Washington.

Anderson, J. D. 1973. Radioactive Liquid Wastes Discharged to Ground in the 200 Areas During 1972. ARH-2757 Part 3, Atlantic Richfield Hanford Company, Richland, Washington.

Anderson, J. D, 1974. Radioactive Liquid Wastes Discharged to Ground in the 200 Areas During 1973. ARH-2806-4Q REV, Atlantic Richfield Hanford Company, Richland, Washington.

Anderson, J. D. 1975. Radioactive Liquid Wastes Discharged to Ground in the 200 Areas During 1974. ARH-3093-4Q, Atlantic Richfield Hanford Company, Richland, Washington.

Anderson, J. D. 1976a. Radioactive Liquid Wastes Discharged to Ground in the 200 Areas During 1975. ARH-CD-371-4Q, Atlantic Richfield Hanford Company, Richland, Washington.

Anderson, J. D. 1976b. Input and Decayed Values of Radioactive Liquid Wastes Discharged to the Ground in the 200 Areas Through 1975. ARH-CD-745, Atlantic Richfield Hanford Company, Richland, Washington.

Anderson, J. D. and B. E. Poremba. 1978. Radioactive Liquid Wastes Discharged to Ground in the 200 Areas During 1977. RHO-CD-34-4Q, Rockwell Hanford Operations, Richland, Washington.

Anderson, J. D. and B. E. Poremba. 1979. Radioactive Liquid Wastes Discharged to Ground in the 200 Areas During 1978. RHO-CD-78-34-4Q, Rockwell Hanford Operations, Richland, Washington.

Bates, J. A. 1981. Environmental Report Relating to the Decommissioning of the 216-U-10 (U Pond) System. RHO-LD-154, Rockwell Hanford Operations, Richland, Washington.

Bierschenk, W. H. 1957a. Hydraulic Characteristics of Hanford Aquifers. HW-48916, General Electric Company, Richland, Washington.

Bierschenk, W. H. 1957b. The Effect of Ground-Water Mounds on the PUREX Operation. HW-47128, General Electric Company, Richland, Washington.

Bierschenk, W. H. 1957c. Fluctuations of Hanford Water Levels. HW-53599, General Electric Company, Richland, Washington.

Bierschenk, W. H. 1959a. Aquifer Characteristics and Ground-Water Movement at Hanford. HW-60601, General Electric Company, Richland, Washington. 
Bierschenk, W. H. 1959b. Observational and Field Aspects of Ground-Water Flow at Hanford. HW-SA-41, General Electric Company, Richland, Washington.

Bierschenk, W. H. and M. W. McConiga. 1957. Changes in the Hanford Water Table 1944 to 1957. HW-51277, General Electric Company, Richland, Washington.

Boothe, G. F. 1979. Surface Soil Contamination Standards. RHO-CD-782, Rockwell Hanford Operations, Richland, Washington.

Brown, D. J. and R. E. Isaacson. 1977. The Hanford Environment as Related to Radioactive Waste Burial Grounds and Transuranium Storage Facilities. ARH-ST-155, Atlantic Richfield Hanford Company, Richland, Washington.

Brown, R. E. and H. G. Ruppert. 1948. Underground Waste Disposal at Hanford Works, An Interim . Report Covering the 200 West Area. HW-9671, General Electric Company, Richland, Washington.

Brown, R. E. and H. G. Ruppert. 1950. The Underground Disposal of Liquid Wastes at the Hanford Works, Washington. HW-17088, General Electric Company, Richland, Washington.

Brown, D. J., R. C. Routson, W. H. Price, and K. R. Fecht. 1979. Status of Liquid Waste Leaked from the 241-T-106 Tank. RHO-ST-1, Rockwell Hanford Operations, Richland, Washington.

Bruns, L. E. 1975. Aerial Gamma Survey by Helicopter to Measure Surficial Contamination. ARH-SA-226, Atlantic Richfield Hanford Company, Richland, Washington.

Cadwell, L. L., R. G. Schreckhise, and R. E. Fitzner. 1979. Cesium-137 in Coots (Fulica americana) on Hanford Waste Ponds: Contribution to Population Dose and Offsite Transport Estimates. PNL-SA-7167, Pacific Northwest Laboratory, Richland, Washington.

Chambers, F. S. 1944. H.E.W. Class and Waste Disposal. DUH-4904, DuPont Hanford, Richland, Washington.

Compton, R. R. 1962. Manual of Field Geology. John Wiley and Sons, Inc., New York.

Cooper, H. H. and C. E. Jacob. 1946. "A Generalized Graphical Method for Evaluating Formation Constants and Summarizing Well-Field History," Transactions of the American Geophysical Union 17(IV):526-534.

Cottam, G. and J. T. Curtis. 1956. "The Use of Distance Measures in Phytosociological Sampling," Ecology 37:451-460.

Cushing, C. E. and D. G. Watson. 1974. Aquatic Studies of Gable Mountain Pond. BNWL-1884, Pacific Northwest Laboratory, Richland, Washington. 
Daubenmire, R. 1959. "A Canopy-Covered Method of Vegetation Analysis," Northwest Science 33:43-64.

Daubenmire, R. 1970. Steppe Vegetation of Washington. Technical Bulletin 62, Washington Agricultural Experiment Station, Washington State University, Pullman, Washington.

Deju, R. A. 1974. The Hanford Field Testing Program. ARH-C-004, Atlantic Richfield Hanford Company, Richland, Washington.

Denham, D. H. 1970. Radiological Status of Ground Water Beneath the Hanford Project, July to December, 1969. BNWL-1392, Pacific Northwest Laboratory, Richland, Washington.

Eddy, P. A. and J. S. Wilbur. 1980. Radiological Status of the Groundwater Beneath the Hanford Project, January to December, 1979. PNL-3346, Pacific Northwest Laboratory, Richland, Washington.

Emery, R. M. and T. R. Garland. 1974. The Ecological Behavior of Plutonium and Americium in a Freshwater Ecosystem: Phase II, Implications of Differences in Transuranic Isotopic Ratios.

BNWL-1879, Pacific Northwest Labọratory, Richland, Wạshington.

Emery, R. M. and D. C. Klopfer. 1974. The Ecological Behavior of Plutonium and Americium in a Freshwater Ecosystem: Phase I, Limnological Characterization and Isotopic Distribution.

BNWL-1867, Pacific Northwest Laboratory, Richland, Washington.

Emery, R. M. and M. C. McShane. 1978. Comparative Ecology of Nuclear Waste Ponds and Streams on the Hanford Site. PNL-2499, Pacific Northwest Laboratory, Richland, Washington.

ERDA. 1975. Final Environmental Impact Statement, Waste Management Operations, Hanford Reservation, Richland, Washington. ERDA-1538, U.S. Energy Research and Development Administration, Richland, Washington.

ERDA. 1977. Standards for Radiation Protection with Appendix, Manual Chapter 0524. U.S. Energy Research and Development Administration, Washington, D.C.

Fecht, K. R., G. V. Last, and M. C. Marratt. 1978. Granulometric Data, 216-S Crib Facilities Monitoring Well Sediments. RHO-LD-70, Rockwell Hanford Operations, Richland, Washington.

Fitzner, R. E. and K. R. Price. 1973. The Use of Hanford Waste Ponds by Waterfowl and Other Birds. BNWL-1738, Pacific Northwest Laboratory, Richland, Washington.

Fitzner, R. E. and W. H. Rickard. 1975. Avifauna of Waste Ponds, ERDA Hanford Reservation, Benton County, Washington. BNWL-1885, Pacific Northwest Laboratory, Richland, Washington. 
Fitzner, R. E. and R. G. Schreckhise. 1979. The American Coot (Fulica americana) on the Hanford Site, Part I: Nesting Biology. PNL-2462, Pacific Northwest Laboratory, Richland, Washington.

Fix, J. J. and P. G. Blumer. 1977. Radiochemical Analysis of Game Birds Collected from the Hanford Environs 1971 to 1975. BNWL-2089, Pacific Northwest Laboratory, Richland, Washington.

Flint, R. F. 1938. Origin of the Cheney-Palouse Scabland Tract. Geological Society of America Bulletin 49, pp. 461-524.

Gano, K. A. 1979. Analysis of Small Mammal Populations Inhabiting the Environs of a Low-Level Radioactive Waste Pond. PNL-2479, Pacific Northwest Laboratory, Richland, Washington.

Gdrten, Jr., C. T. 1980. "Comparative Uptake of ${ }^{234} \mathrm{U},{ }^{238} \mathrm{U},{ }^{239} \mathrm{Pu},{ }^{241} \mathrm{Am}$, and ${ }^{244} \mathrm{Cm}$ by Boxelder Trees (Acer negundo) Inhabiting a Contaminated Tennessee Floodplain," Health Physics 39:332-334.

Gephart, R. E., P. A. Eddy, R. C. Arnett, and G. A. Robinson. 1976. Geohydrologic Study of the West Lake Basin. ARH-CD-775, Atlantic Richfield Hanford Company, Richland, Washington.

Gephart, R. E., R. C. Arnett, R. G. Baca, L. S. Leonhart, F. A. Spane, Jr., D. J. Palumbo, and S. R. Strait. 1979. Hydrologic Studies Within the Columbia Platecu, Washington: An Integration of Current Knowledge. RHO-BWI-ST-5, Rockwell Hanford Operations, Richland, Washington.

Gholz, H. L., C. C. Grier, A. G. Campbell, and A. T. Brown. 1979. Equations for Estimating Biomass and Leaf Area of Plants in the Pacific Northwest. Research Paper 41, Forest Research Laboratory, Oregon State University, Corvallis, Oregon.

Graham, M. J., M. D. Hall, S. R. Strait, and W. R. Brown. 1981. Hydrology of the Separations Area. RHO-ST-42, Rockwell Hanford Operations, Richland, Washington.

Greigh-Smith, P. 1964. Quantitative Plant Ecology, 2nd Edition. Academic, New York.

Grier C. C. and R. H. Waring. 1974. "Conifer Foliage Mass Related to Sapwood Area," Forest Science 20(3):205-206.

Hanson, G. L., J. D. Anderson, G. R. Kiel, B. T. McMurray, and N. P. Nisick. 1978. Input and Decayed Values of Radioactive Fluid Wastes Discharged to the Ground in the 200 Areas Through 1971. ARH-2761, Atlantic Richfield Hanford Company, Richland, Washington.

Hantush, M. S. 1967. "Growth and Decay of Groundwater-Mounds in Response to Uniform Percolation," Water Resources Research 3(1).

Horst, T. W. 1976. The Estimation of Air Concentrations Due to the Suspension of Surface Contamination by the Wind. BNWL-2047, Pacific Northwest Laboratory, Richland, Washington. 
Houston, J. R. and P. J. Blumer. 1980. Environmental Surveillance at Hanford for CY-1979. PNL-3283, Pacific Northwest Laboratory, Richland, Washington.

Jacob, C. E. 1950. "Flow of Ground Waters." In Engineering Hydraulics, ed. H. Rouse, John Wiley and Sons, Inc., New York, pp. 321-386.

Jacobs, M. C. and J. D. Anderson. 1972. Radioactive Liquid Wastes Discharged to Ground in the 200 Areas During 1971. ARH-2353 Part 3, Atlantic Richfield Hanford Company, Richland, Washington.

Jacobs, M. C. and D. L. Uebelacker. 1969. Radioactive Contamination in Liquid Wastes Discharged to Ground Within the Chemical Separations Area Control Zone Through 1968. ARH-1159, Atlantic Richfield Hanford Company, Richland, Washington.

Jacobs, M. C. and D. L. Uebelacker. 1970. Radioactive Contamination in Liquid Wastes Discharged to Ground Within the Chemical Separations Area Control Zone Through 1969. ARH-1608, Atlantic Richfield Hanford Company, Richland, Washington.

Jacobs, M. C. and D. L. Uebelacker. 1971. Radioactive Liquid Wastes Discharged to Ground in the 200 Areas During 1970. ARH-2015 Part 3, Atlantic Richfield Hanford Company, Richland, Washington.

Kasper, R. B. 1982. 216-Z-12 Transuranic Crib Characterization: Operational History and Distribution of Plutonium and Americium. RHO-ST-44, Rockwell Hanford Operations, Richland, Washington.

Kay, M. A. 1980. In Situ Determination of Transuranic and Fission Product Radionuclides. RHO-SA-156, Rockwell Hanford Operations, Richland, Washington.

Kipp, K. L. and R. D. Mudd. 1973. Collection and Analysis of Pump Test Data for Transmissivity Values. BNWL-1709, Pacific Northwest Laboratory, Richland, Washington.

Ledgerwood, R. K., C. W. Myers, and R. W. Cross. 1978. Pasco Basin Stratigraphic Nomenclature. RHO-BWI-LD-1, Rockwell Hanford Operations, Richland, Washington.

Lundgren, L. L. 1971. Radioactive Liquid Waste Disposal Facilities 200 West Area. ARH-2155, Atlantic Richfield Hanford Company, Richland, Washington.

Marratt, M. C., A. F. Van Luik, and R. B. Kasper. 1985. 216-Z-8 French Drain Characterization Study. RHO-RE-EV-46 P, Rockwell Hanford Operations, Richland, Washington.

McConiga, M. W. 1955. Changes in the Hanford Ground Water Table 1944 to 1955. HW-40469, General Electric Company, Richland, Washington. 
Mirabella, J. E. 1977. Radioactive Liquid Wastes Discharged to Ground in the 200 Areas During 1976. ARH-CD-743-4Q, Atlantic Richfield Hanford Company, Richland, Washington.

Newcomb, R. C., J. R. Strand, and F. J. Frank. 1972. Geology and Ground-Water Characteristics of the Hanford Reservation of the U.S. Atomic Energy Commission, Washington. Geological Survey Professional Paper 717.

Owens, K. 1979. Existing Data on the 216-Z Liquid Waste Sites. RHO-LD-114, Rockwell Hanford Operations, Richland, Washington.

Panesko, J. V., R. L. Dirkes, K. Kover, and R. E. Wheeler. 1978. Environmental Protection Annual Report - CY 1977. RHO-LD-78-75, Rockwell Hanford Operations, Richland, Washington.

Panesko, J. V., D. E. Bihl, G. F. Boothe, R. L. Dirkes, K. Kover, and R. E. Wheeler. 1980. Environmental Protection Annual Report - CY 1978. RHO-LD-79-75, Rockwell Hanford Operations, Richland, Washington.

Prickett, T. A. and C. G. Lonnquist. 1971. "Selected Digital Computer Techniques for Groundwater Resource Evaluation," Illinois State Water Survey Report. Urbana, Illinois.

Price, S. M., R. B. Kasper, M. K. Additon, R. M. Smith, and G. V. Last. 1979. Distribution of Plutonium and Americium Beneath the 216-Z-1A Crib: A Status Report. RHO-ST-17, Rockwell Hanford Operations, Richland, Washington.

Rogers, L. E. and W. H. Rickard. 1977. Ecology of the 200 Area Plateau Waste Management Environs: A Status Report. PNL-2253, Pacific Northwest Laboratory, Richland, Washington.

Routson, R. C., W. H. Price, D. J. Brown, and K. R. Fecht. 1979. High-Level Waste Leakage from the 241-ST-106 Tank at Hanford. RHO-ST-14, Rockwell Hanford Operations, Richland, Washington.

Routson, R. C., G. S. Barney, R. M. Smith, C. N. Delegard, and L. Jensen. 1981. Fission Product Sorption Parameters for the Hanford 200 Area Sediment Types. RHO-ST-35, Rockwell Hanford Operations, Richland, Washington.

Safe Drinking Water Act of 1974, as amended, Public Law 93-523, 88 Stat. 1660, 42 USC 300f et seq.

Sehmel, G. A. 1977. Radioactive Particle Resuspension Research Experiments on the Hanford Reservation. BNWL-2081, Pacific Northwest Laboratory, Richland, Washington.

Sehmel, G. A. and F. D. Lloyd. 1977. "Wind-Caused Particle Resuspension Rates," in Pacific Northwest Laboratory Annual Report for 1976. BNWL-2100-3-BPNL, Pacific Northwest Laboratory, Richland, Washington. 
Slicer, G. J. 1980. Radioactive Liquid Wastes Discharged to Ground in the 200 Areas During 1979. RHO-CD-79-34-4Q, Rockwell Hanford Operations, Richland, Washington.

Smith, R. M. 1980. 216-B-5 Reverse Well Characterization Study. RHO-ST-37, Rockwell Hanford Operations, Richland, Washington.

Stone, W. A., D. E. Jenne, and J. M. Thorp. 1972. Climatology of the Hanford Area. BNWL-1605, Pacific Northwest Laboratory, Richland, Washington.

Tallman, A. M., K. R. Fecht, M. C. Marratt, and G. V. Last. 1979. Geology of the Separations Areas, Hanford Site, South-Central Washington. RHO-ST-23, Rockwell Hanford Operations, Richland, Washington.

Theis, C. V. 1935. "The Relation Between the Lowering of the Piezometric Surface and the Rate and Duration of Discharge of a Well Using Ground-Water Storage." Transactions of the American Geophysical Union 2:519-524.

Tipton, W. J. 1973. An Aerial Radiological Survey of the U.S. Energy Research and Development Administration's Hanford Reservation. EG\&G, Las Vegas, Nevada.

Tomlinson, R. E., R. E. Isaacson, D. T. Brown, and M. D. Veatch. 1970. Management of the Hanford Water Table and Waste Management Implications. ARH-1837, Atlantic Richfield Hanford Company, Richland, Washington.

Van Luik, A. E. and R. M. Smith. 1982. 216-S-1 and S-2 Mixed Fission Product Crib Characterization Study. RHO-ST-39, Rockwell Hanford Operations, Richland, Washington.

Veatch, M. D. 1971. Anticipated Effect of Discharging 242-S Evaporator Cooling Water to the Ground. ARH-2214, Atlantic Richfield Hanford Company, Richland, Washington.

Waring, R. H., H. L. Gholz, C. C. Grier, and M. L. Plummer. 1977. "Evaluating Stem Conducting Tissue as an Estimator of Leaf Area in Four Woody Angiosperms, " Canadian Journal of Botany 55(11):1474-1477.

Wentworth, C. K. 1922. "A Grade Scale and Class Terms for Clastic Sediments," Journal of Geology 30:377-392.

Wheeler, R. E. and A. G. Law. 1980. Rockwell Hanford Operations Environmental Surveillance Report for Calendar Year 1979. RHO-LD-132, Rockwell Haniord Operations, Richland, Washington. 
WHC-EP-0707, Rev. 0

Witkamp, M. and M. L. Frank. 1964. "First Year of Movement, Distribution and Availability of ${ }^{137} \mathrm{Cs}$ in the Forest Floor Under Tagged Tulip Populars," Radiation Botany 4:485-495.

Zimmer, W. H. 1974. Gamma, X-ray Data Reduction System, 1-Gamma. ARH-ST-114-1, Atlantic Richfield Hanford Company, Richland, Washington. 


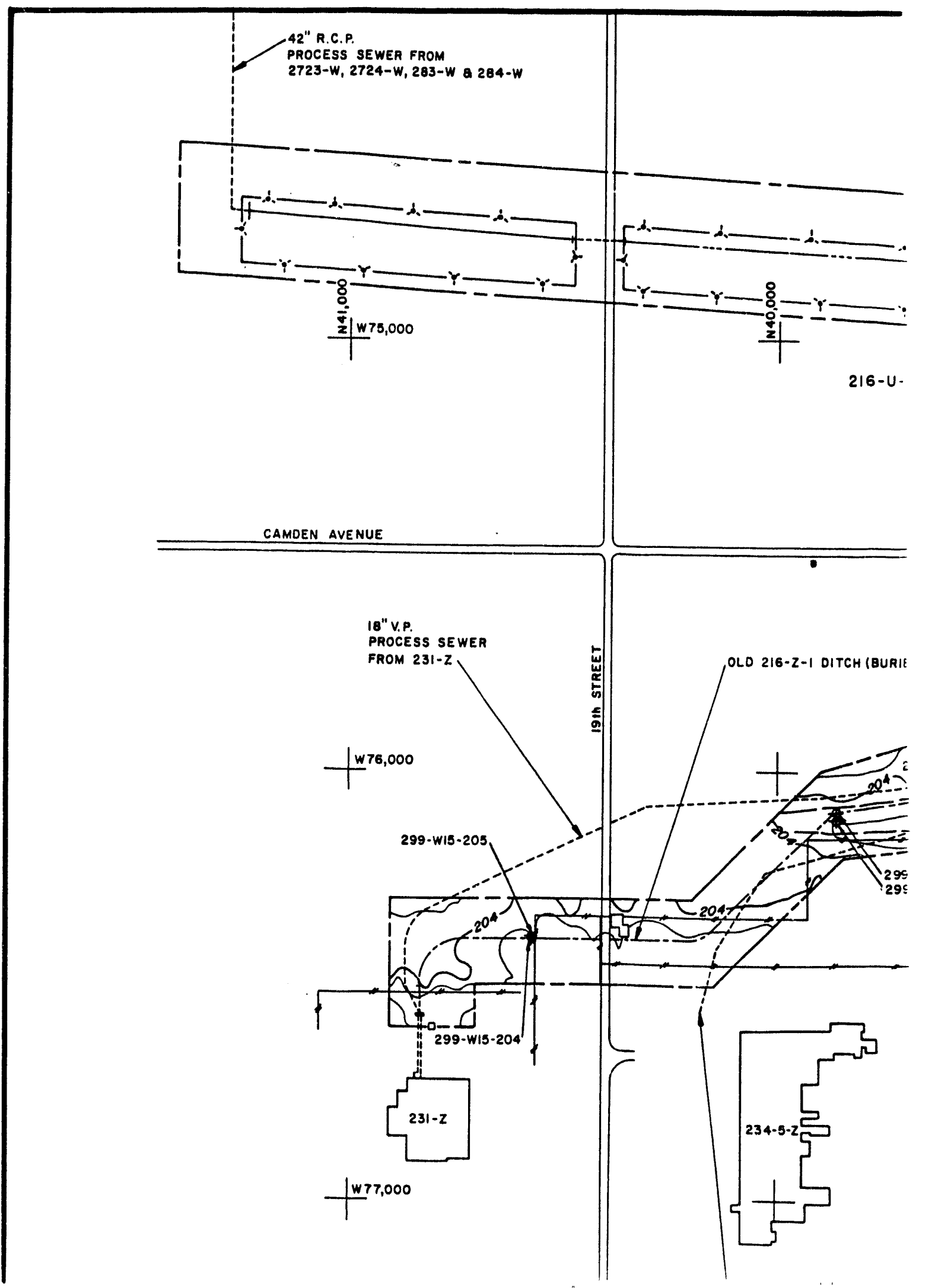




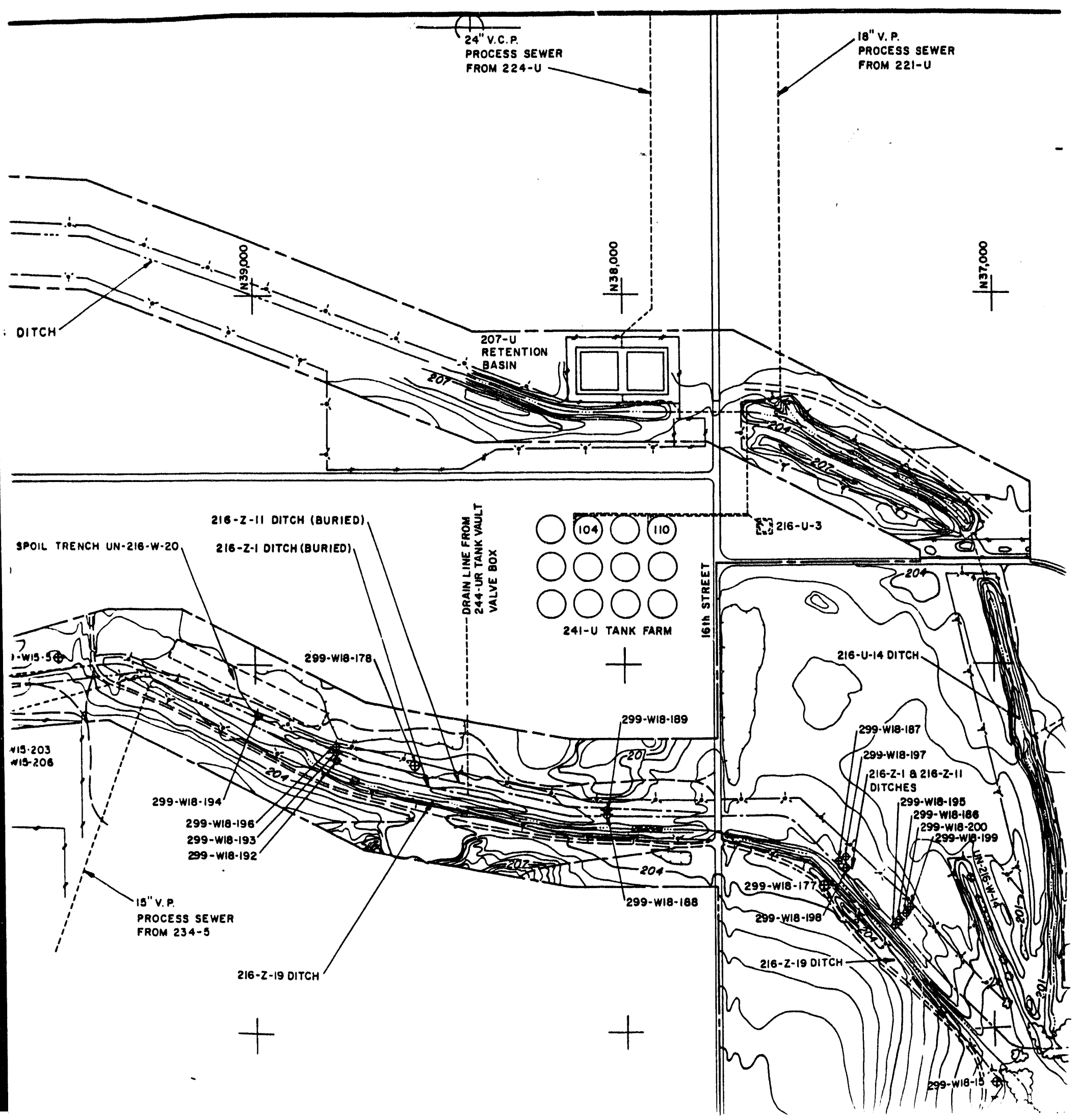


g"V.P.

'ROCESS SEWER

ROM $221-U$
WHC.EP.D707, Rov, 0

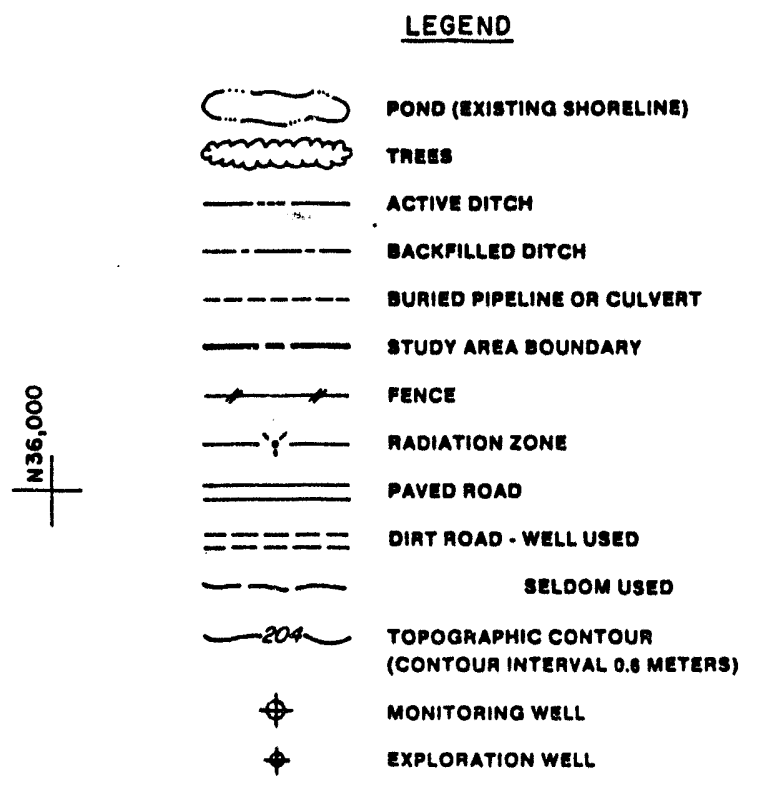

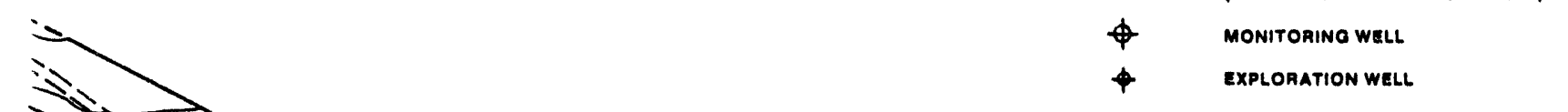


ROCESS SEWER

ROM 234-5

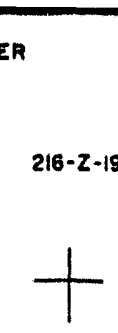

C. $299-m 18 \cdot 16$
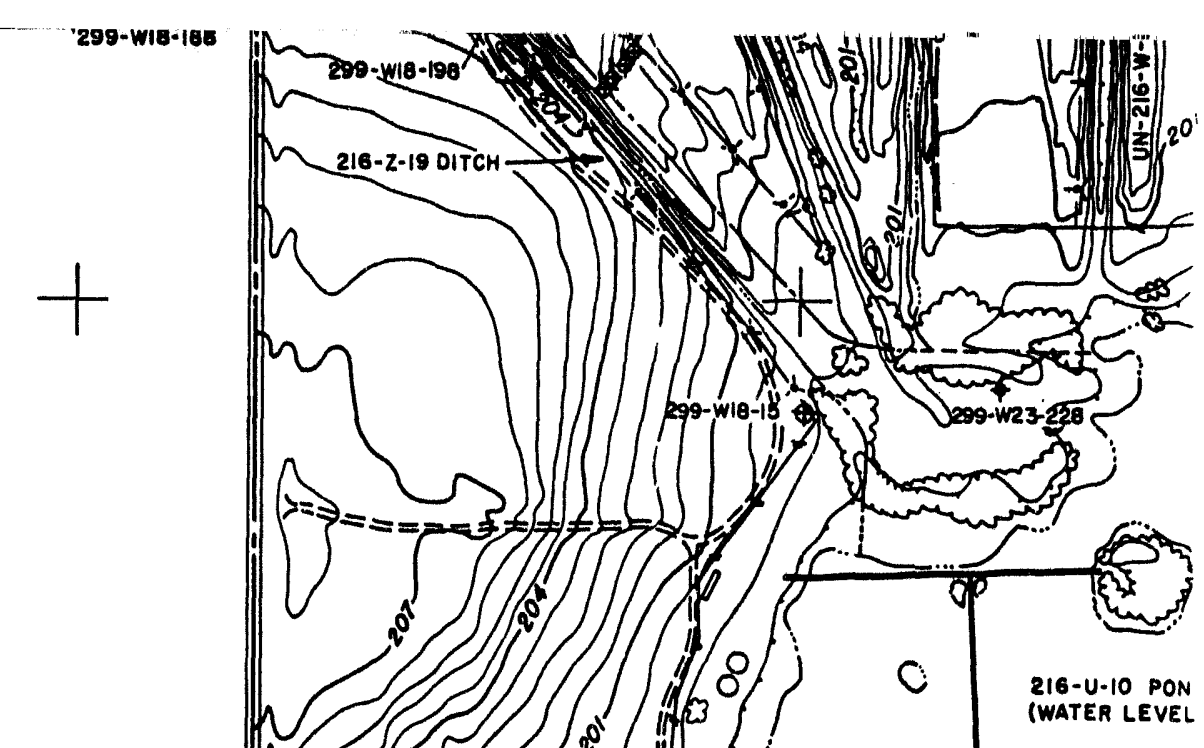

$0 \quad 30 \quad 100^{\text {SCALAE }} 150 \quad 200 \quad 250$ METERS 


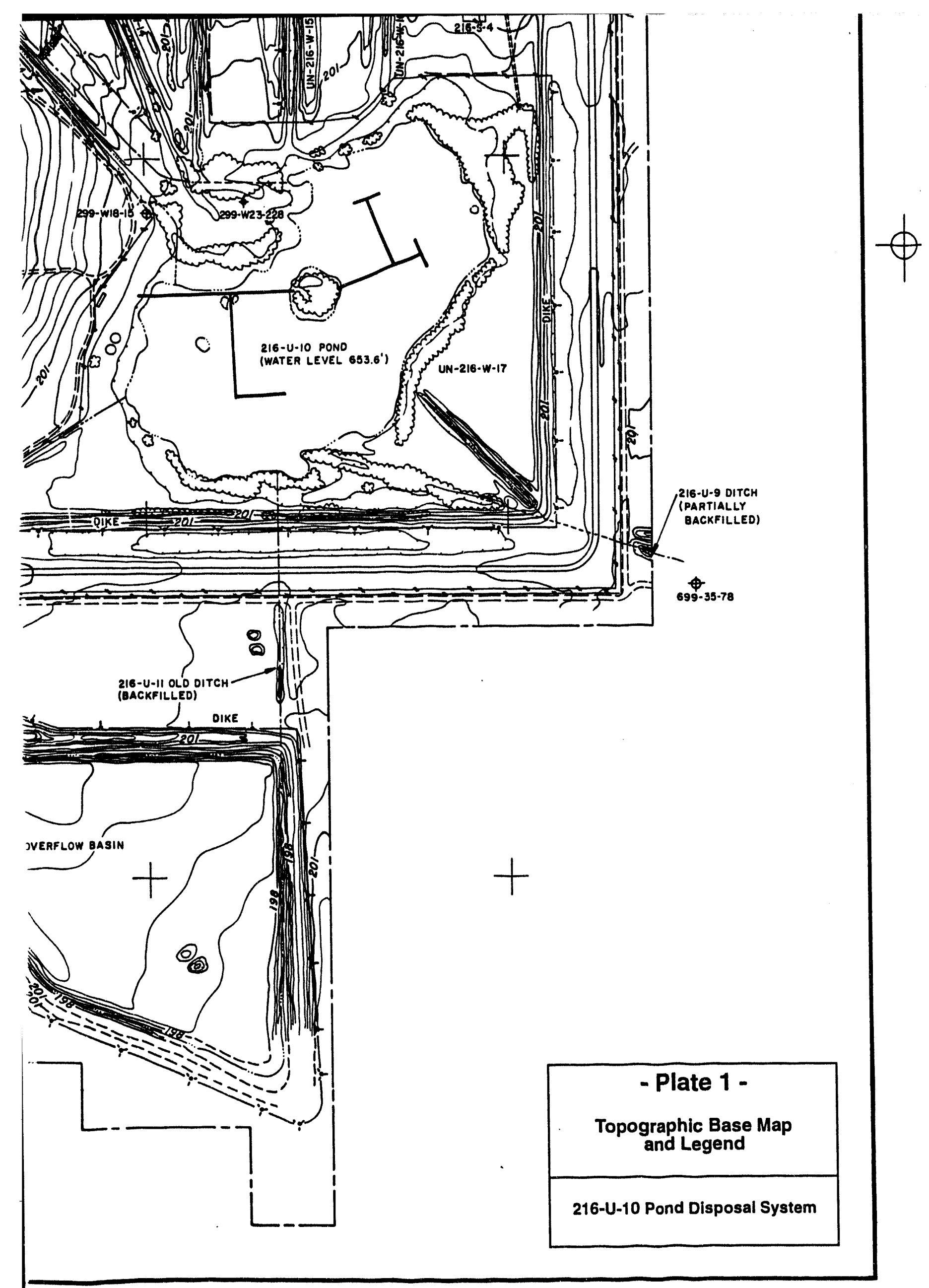




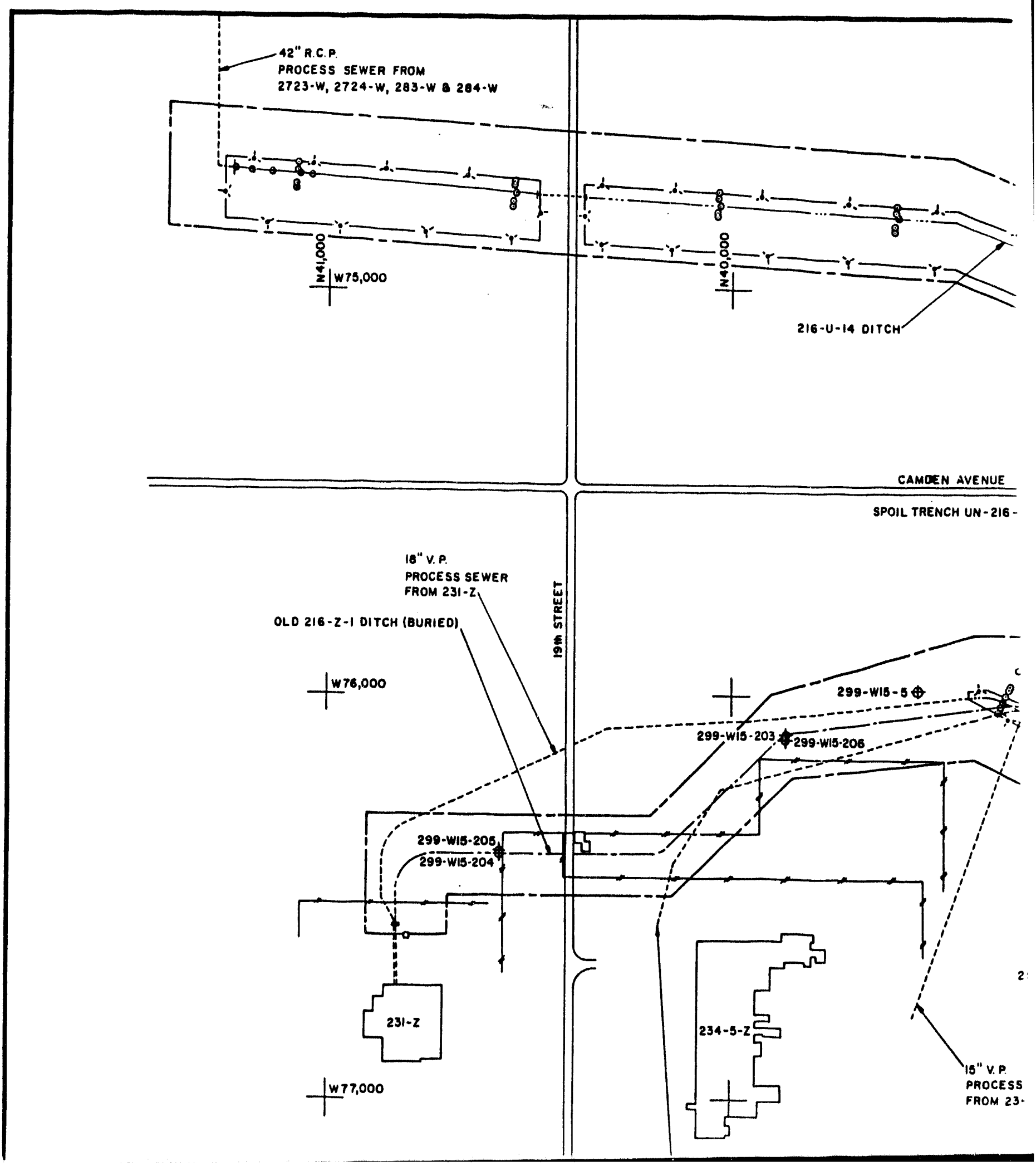




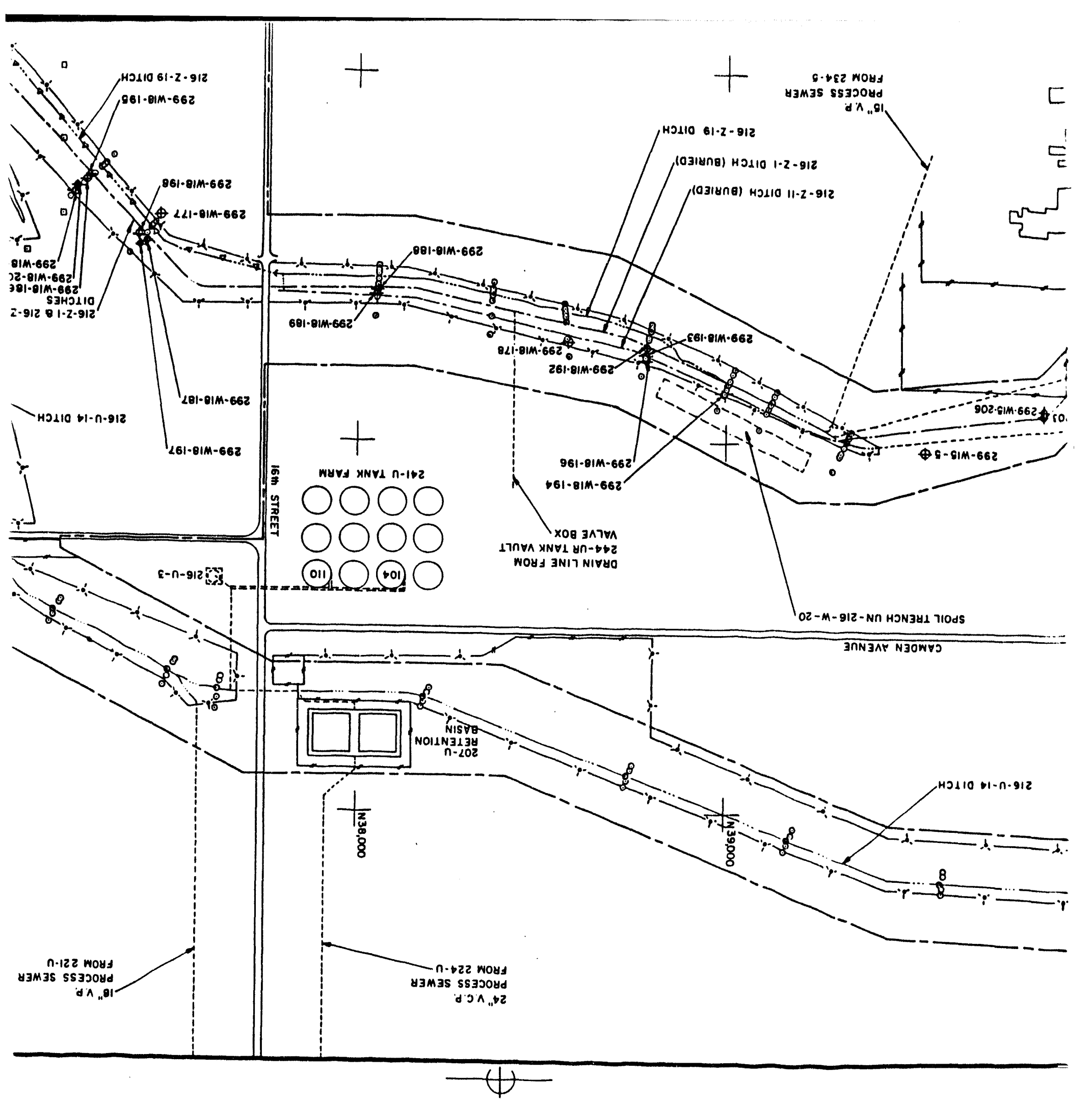




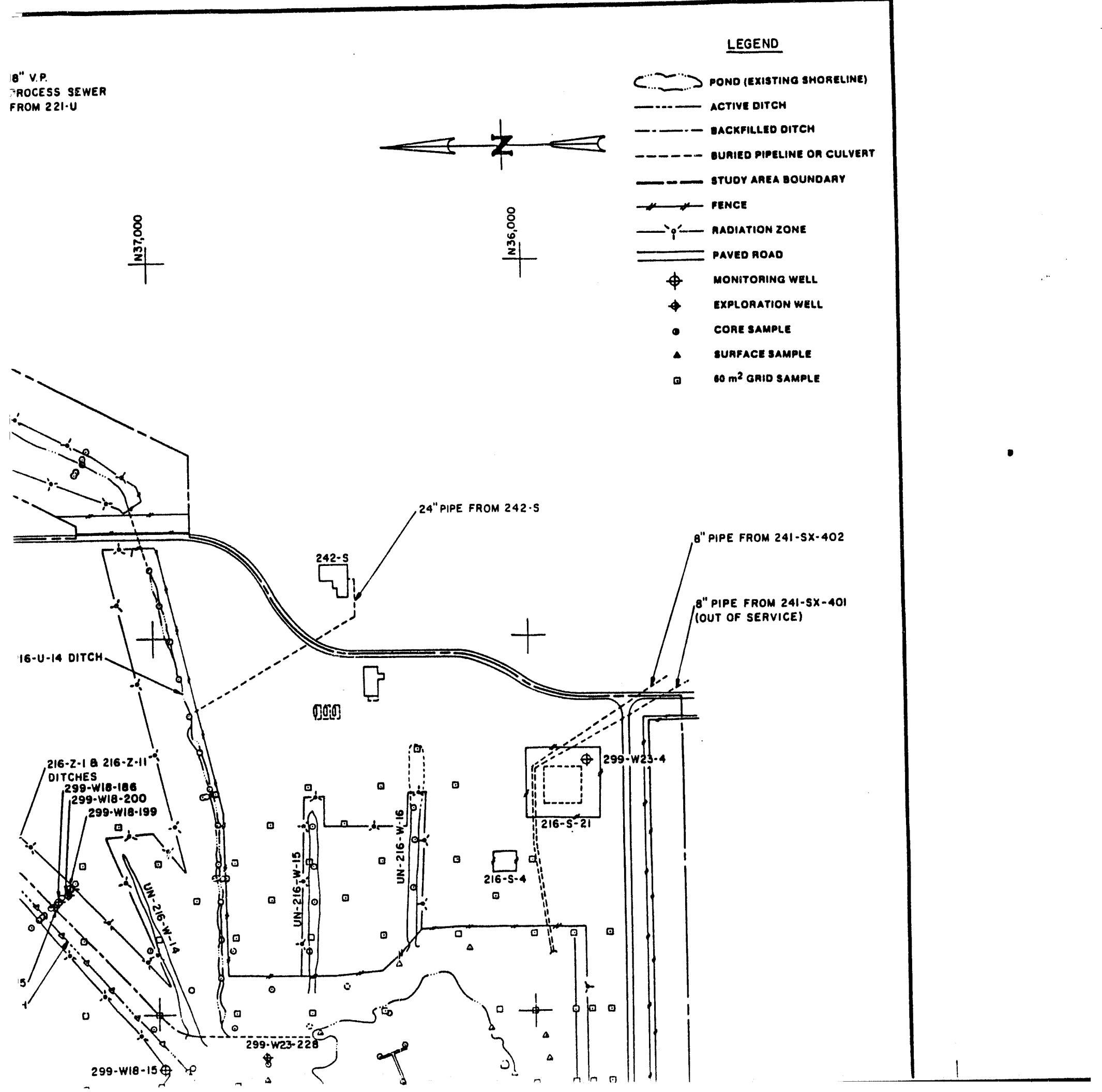



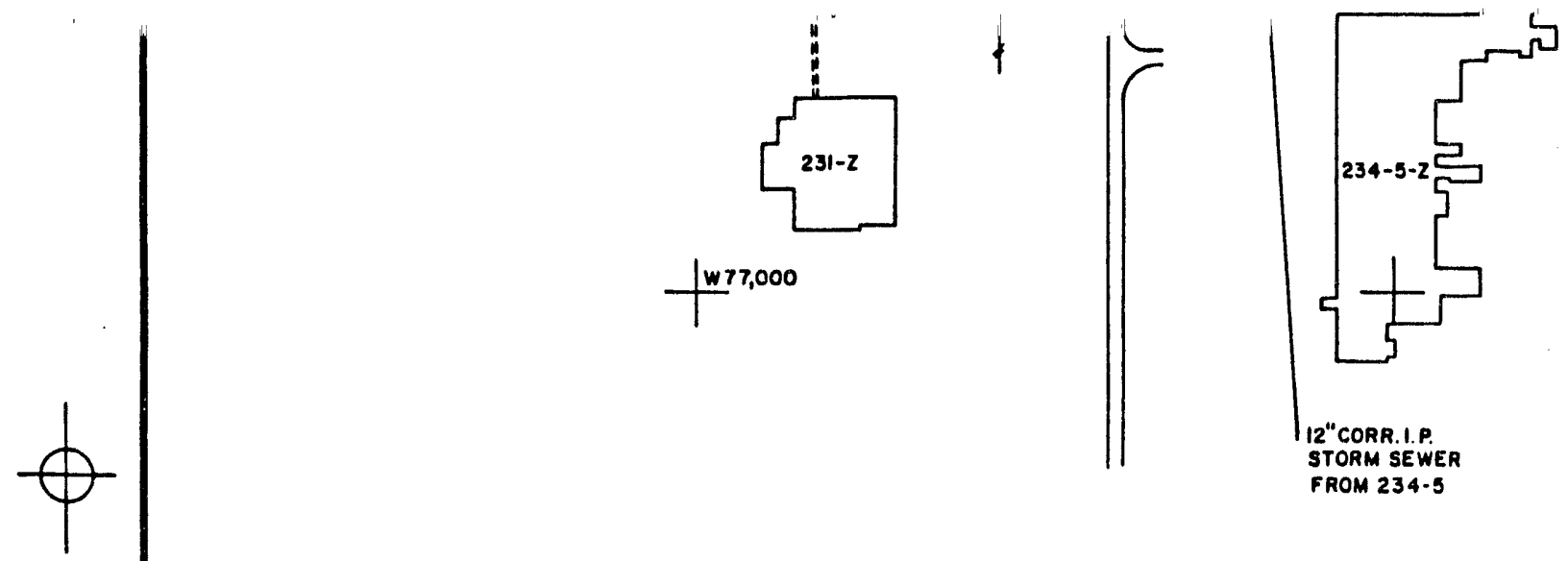
$\searrow_{15 " v . ?}$

PROCESS SEWER FROM 234.5

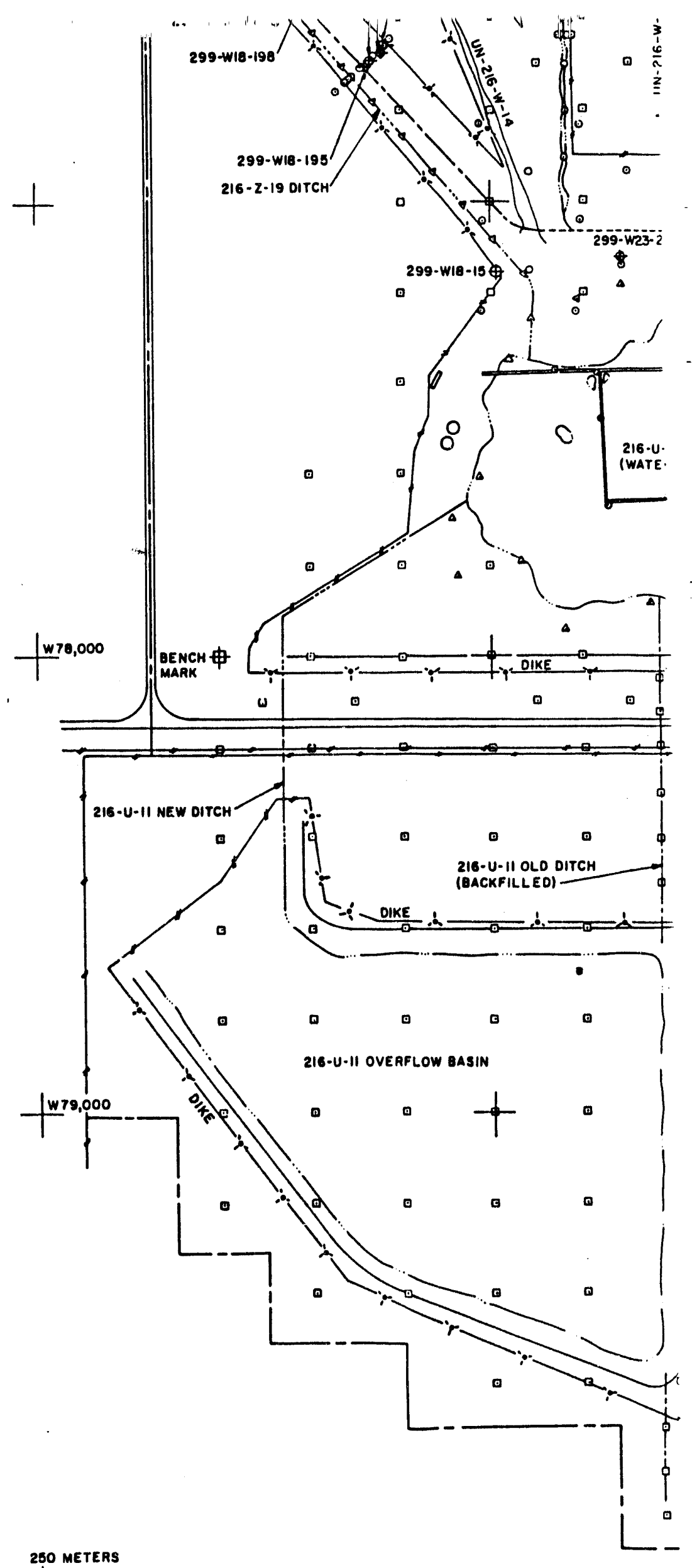




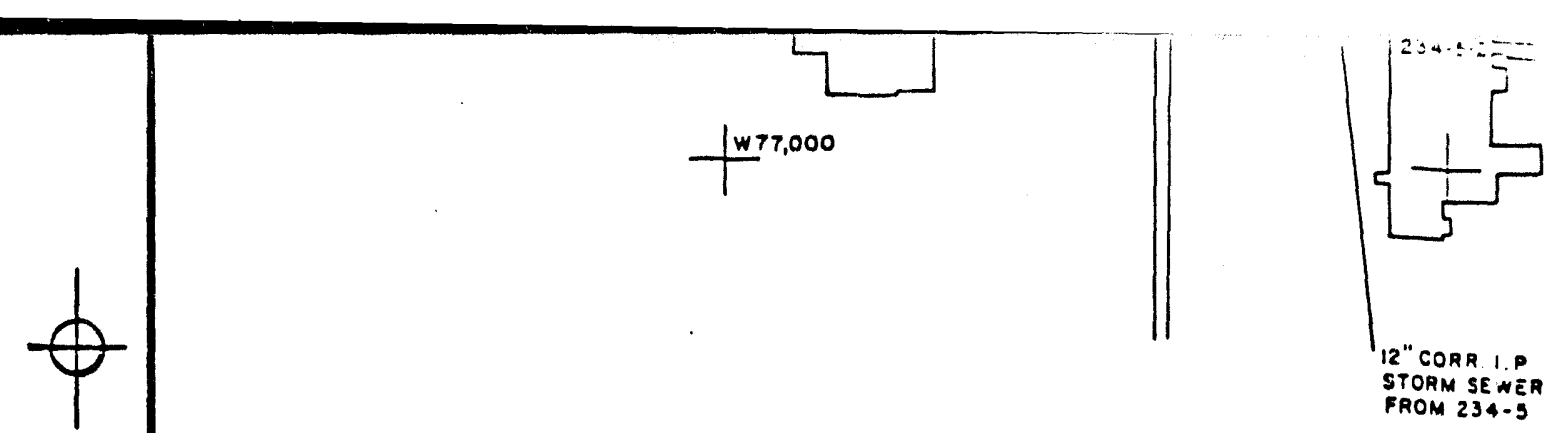




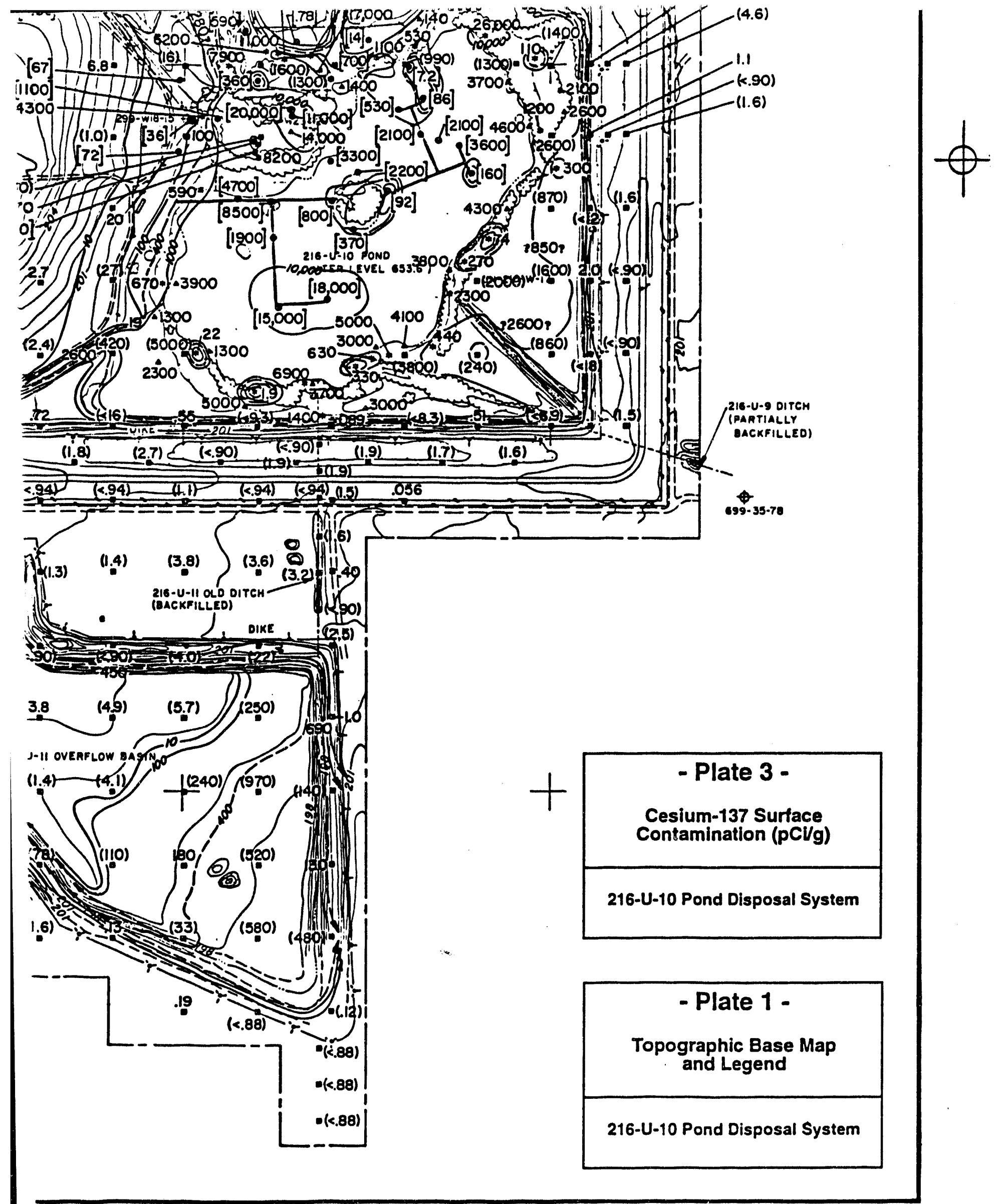




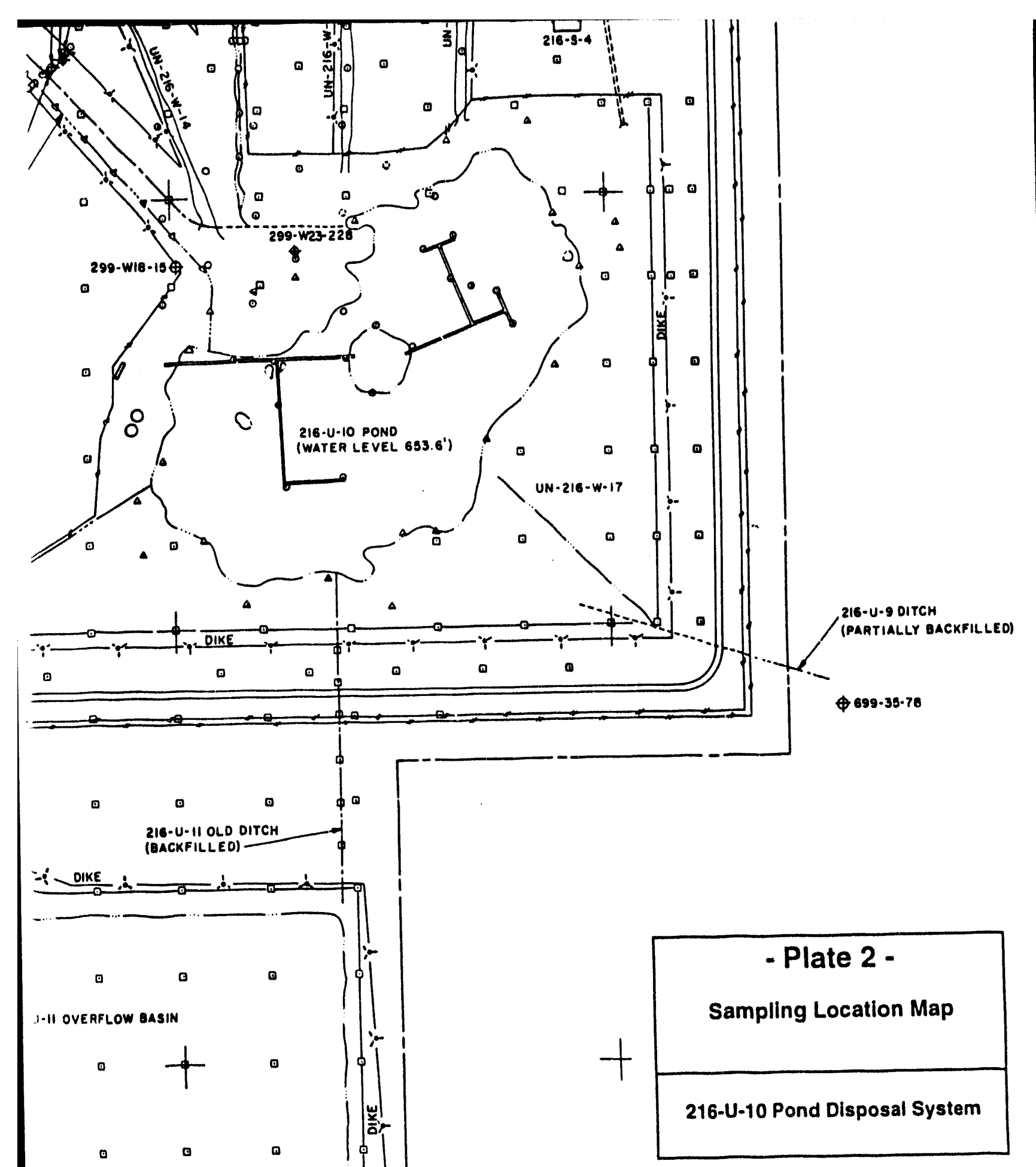




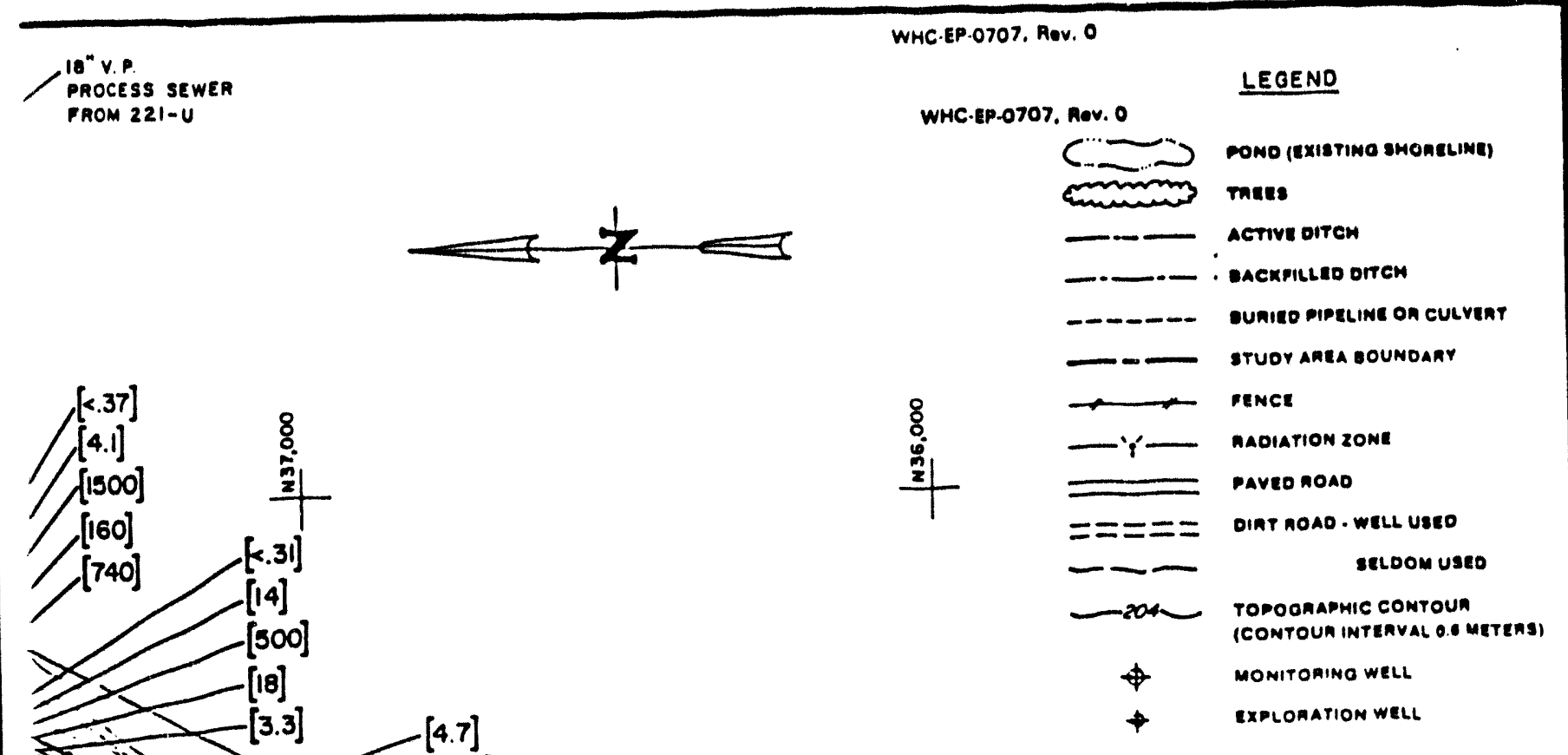




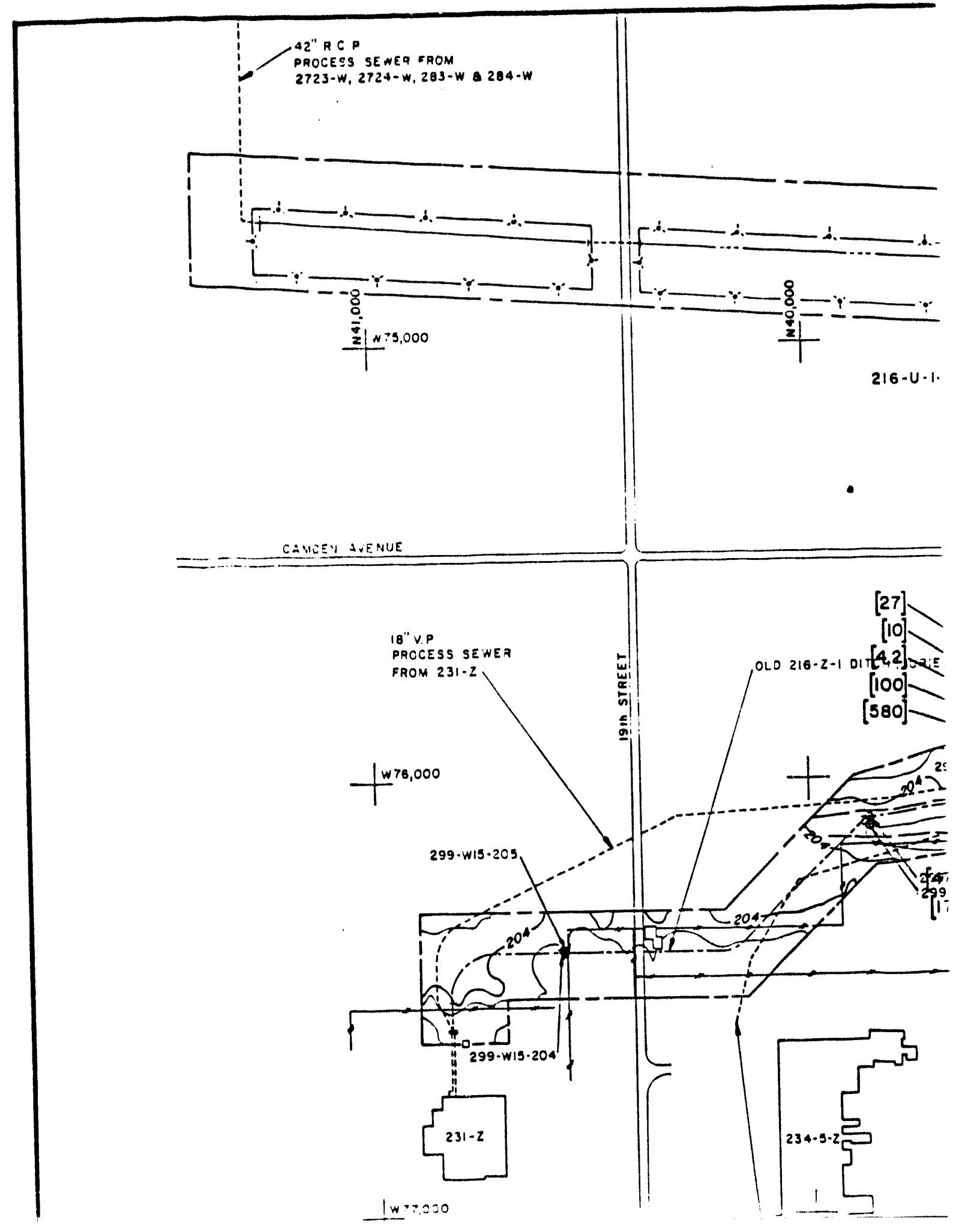




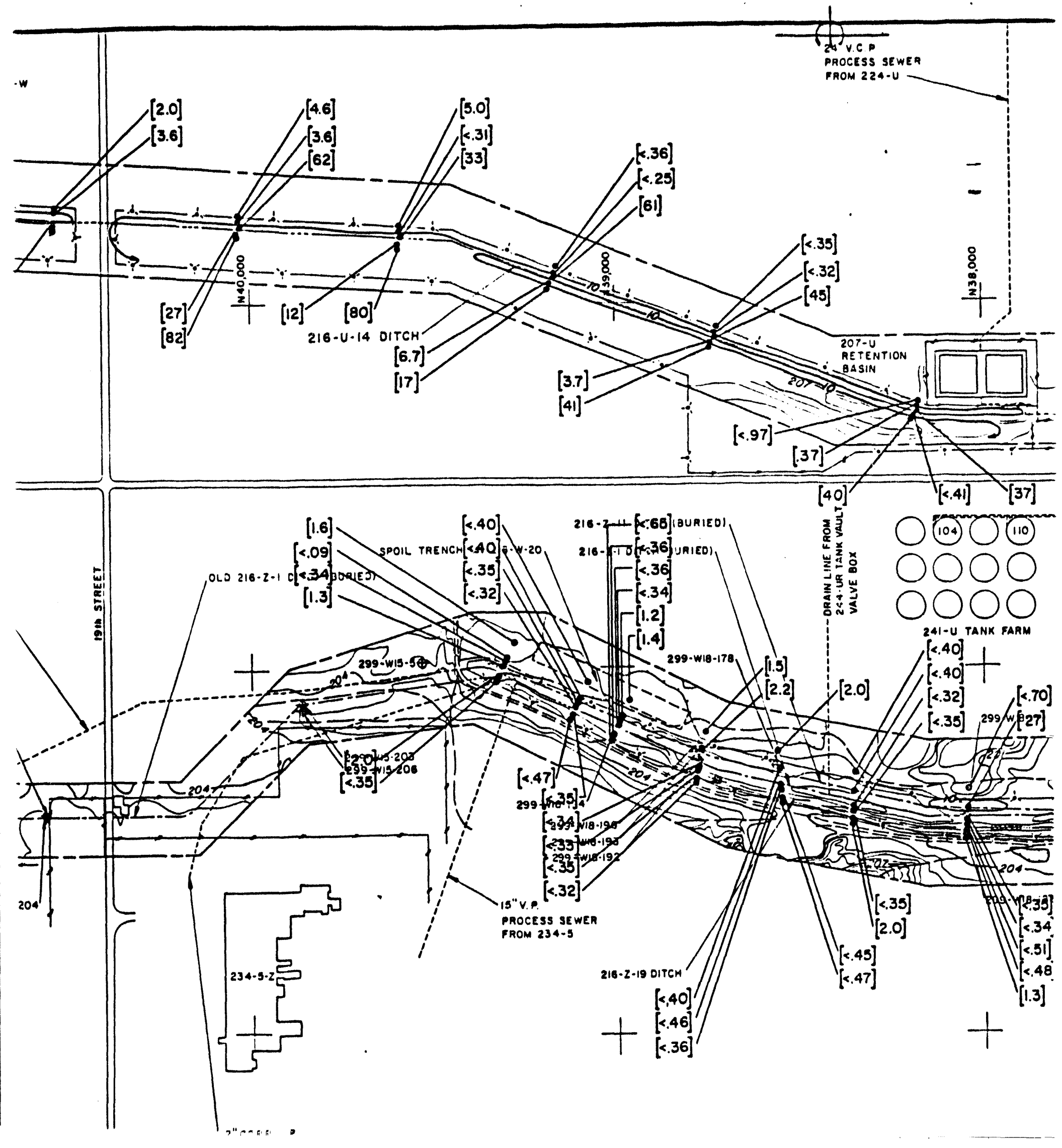




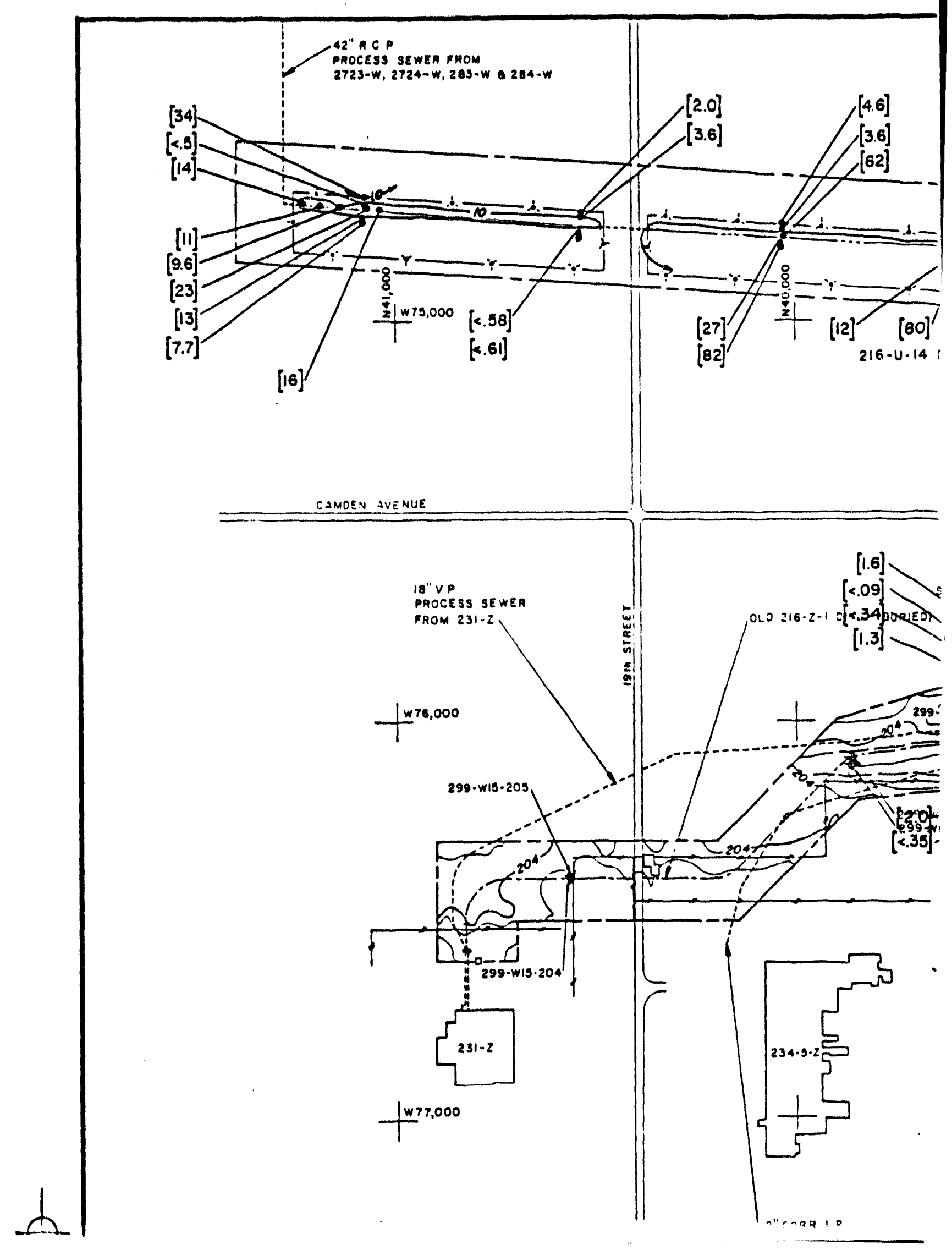




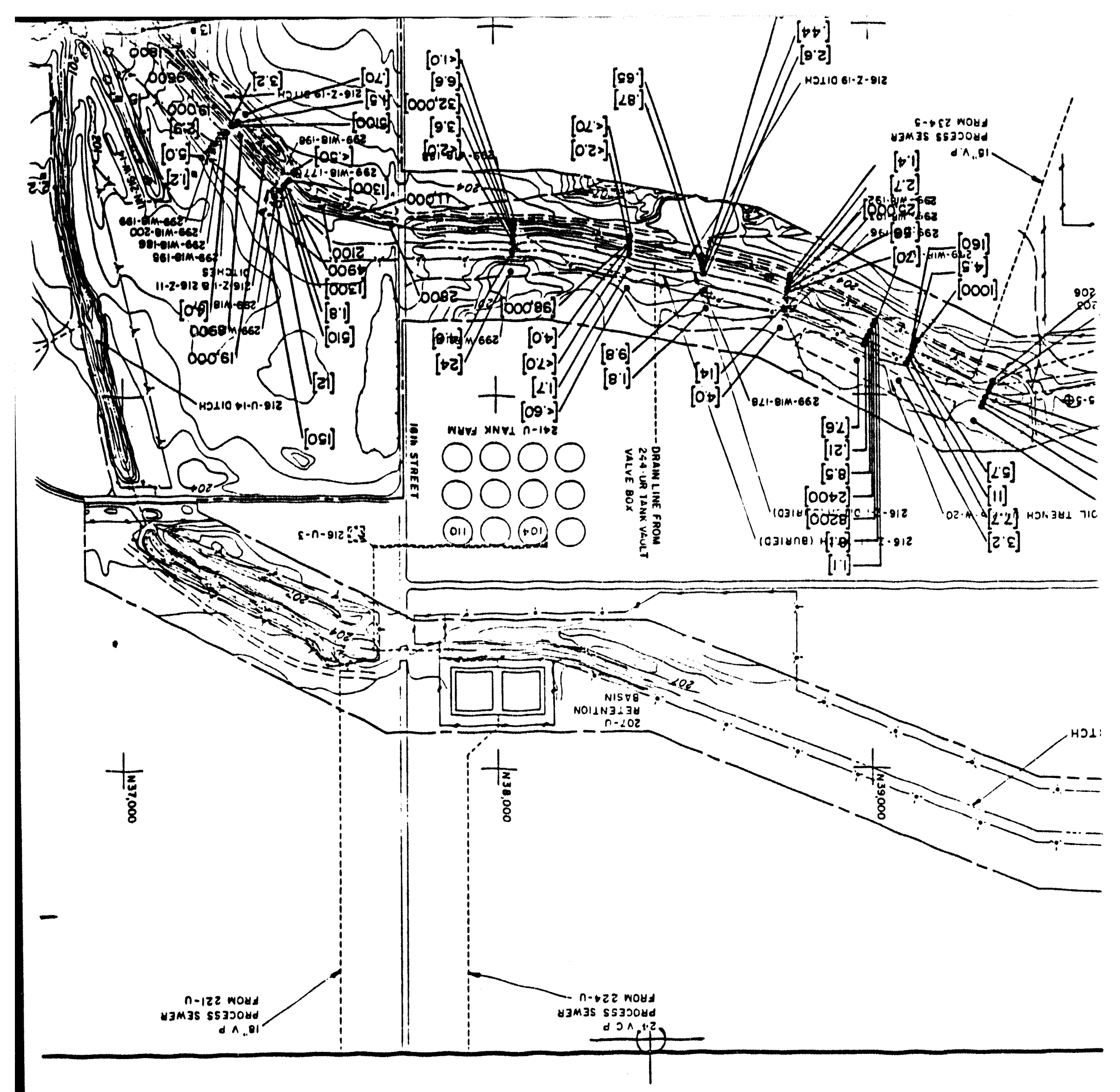




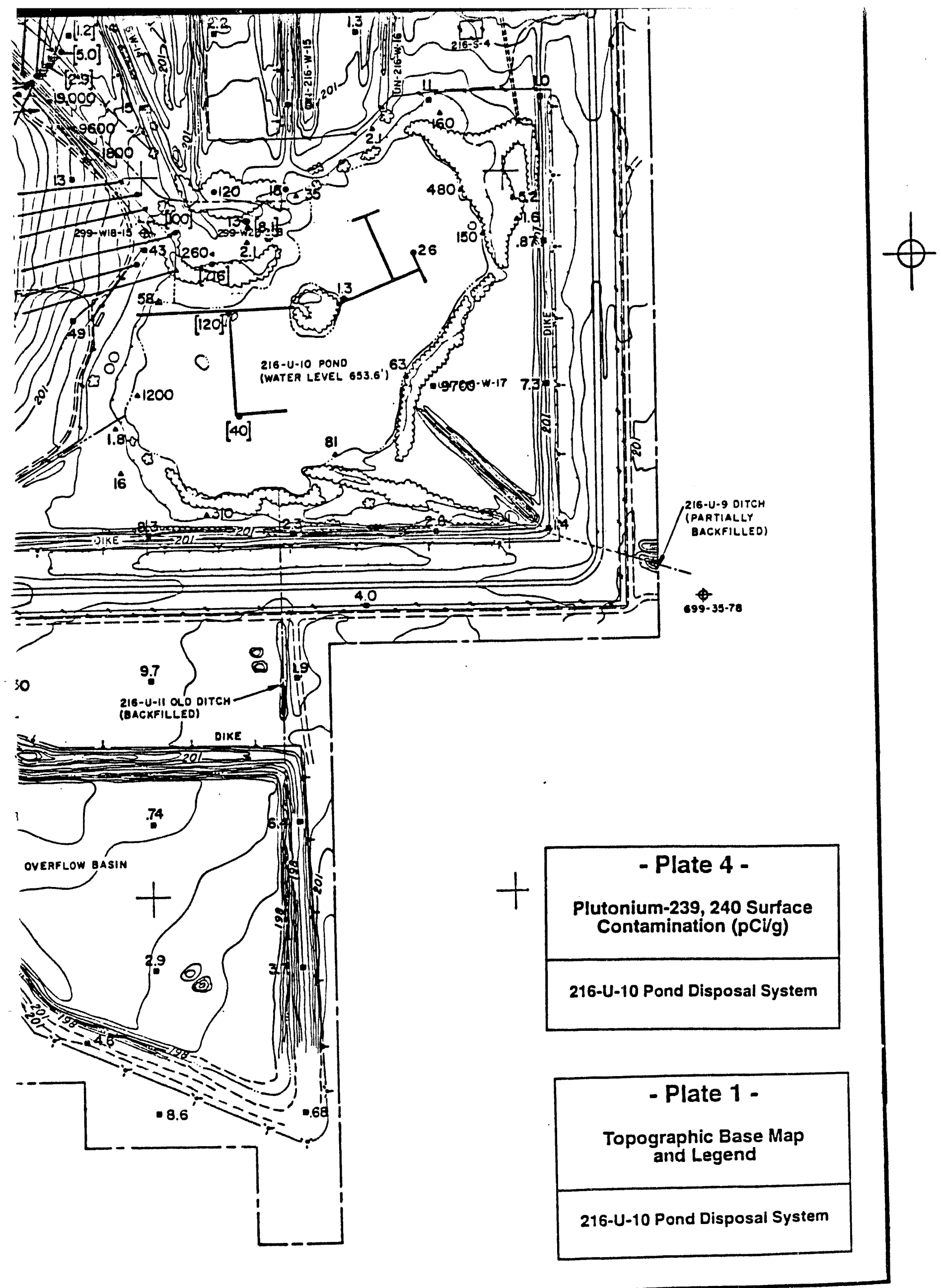




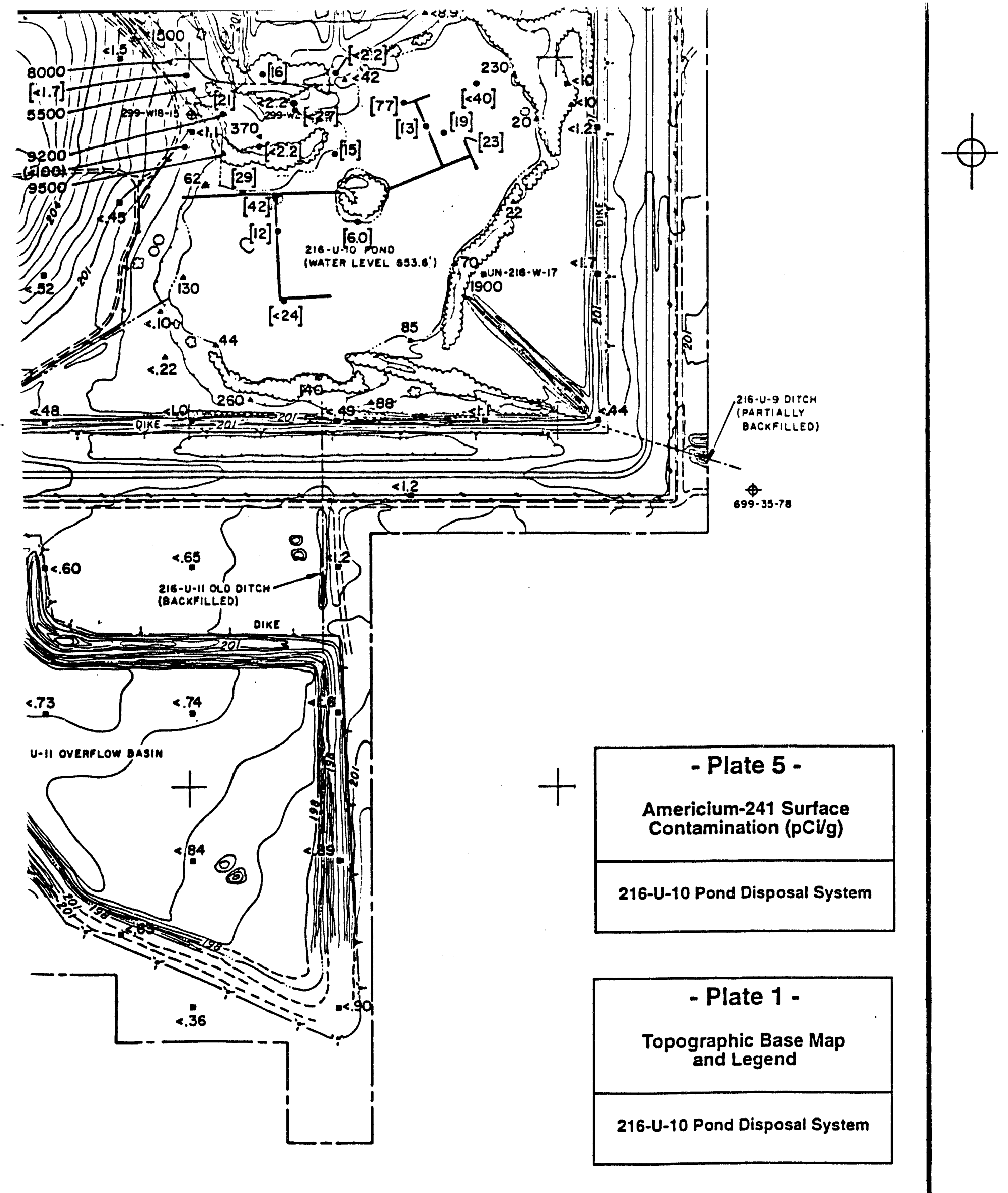




$$
1
$$



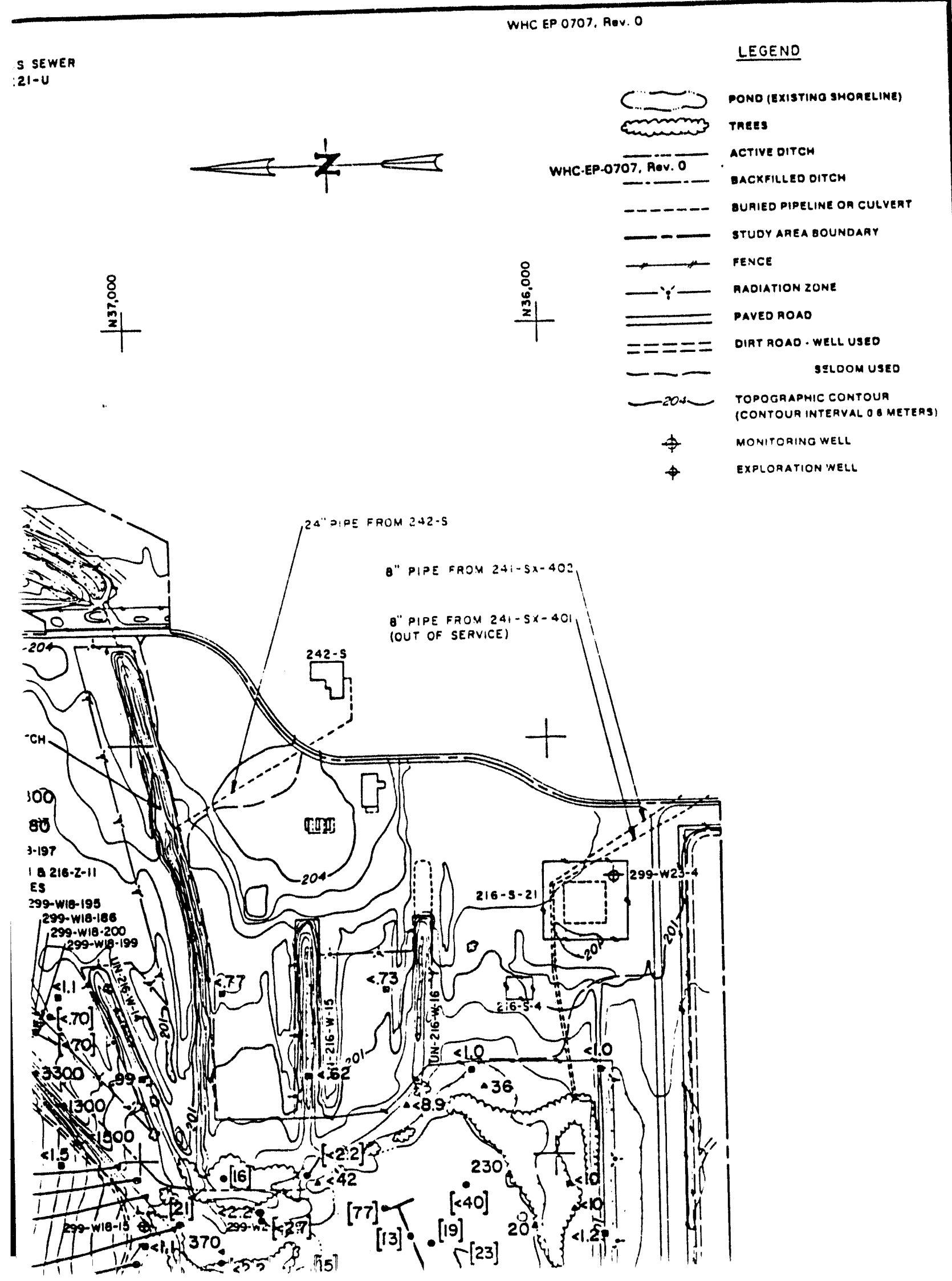


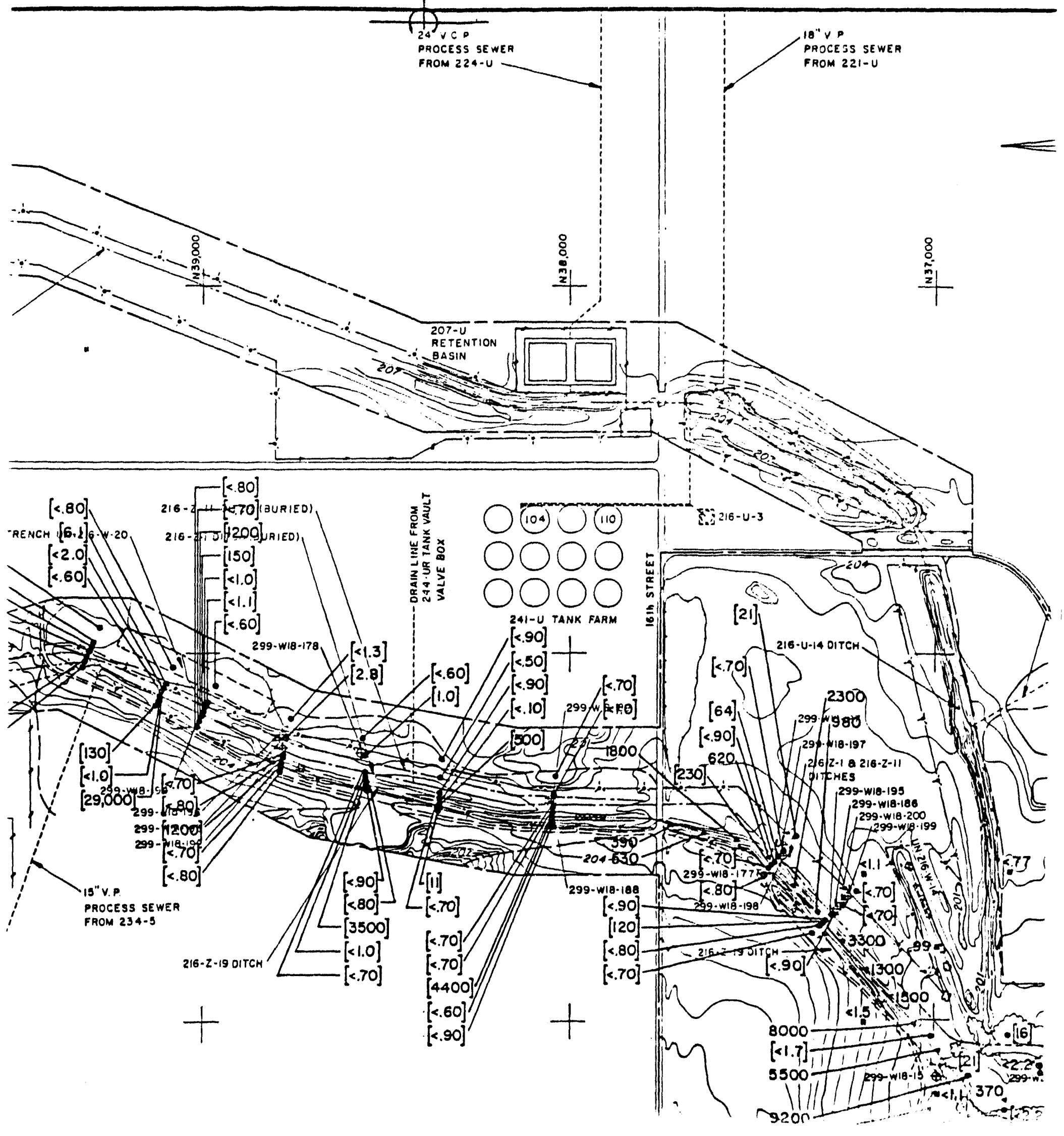




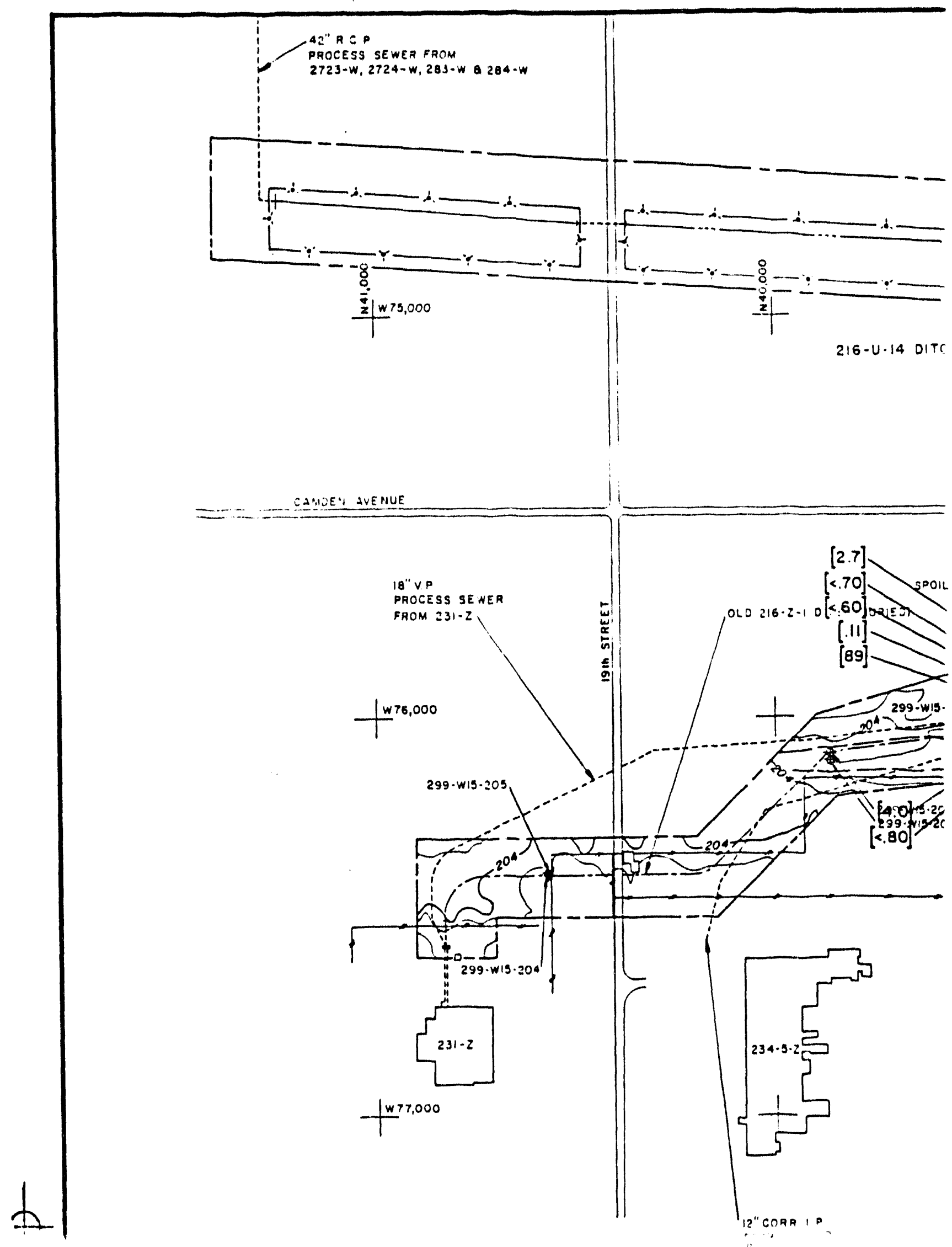




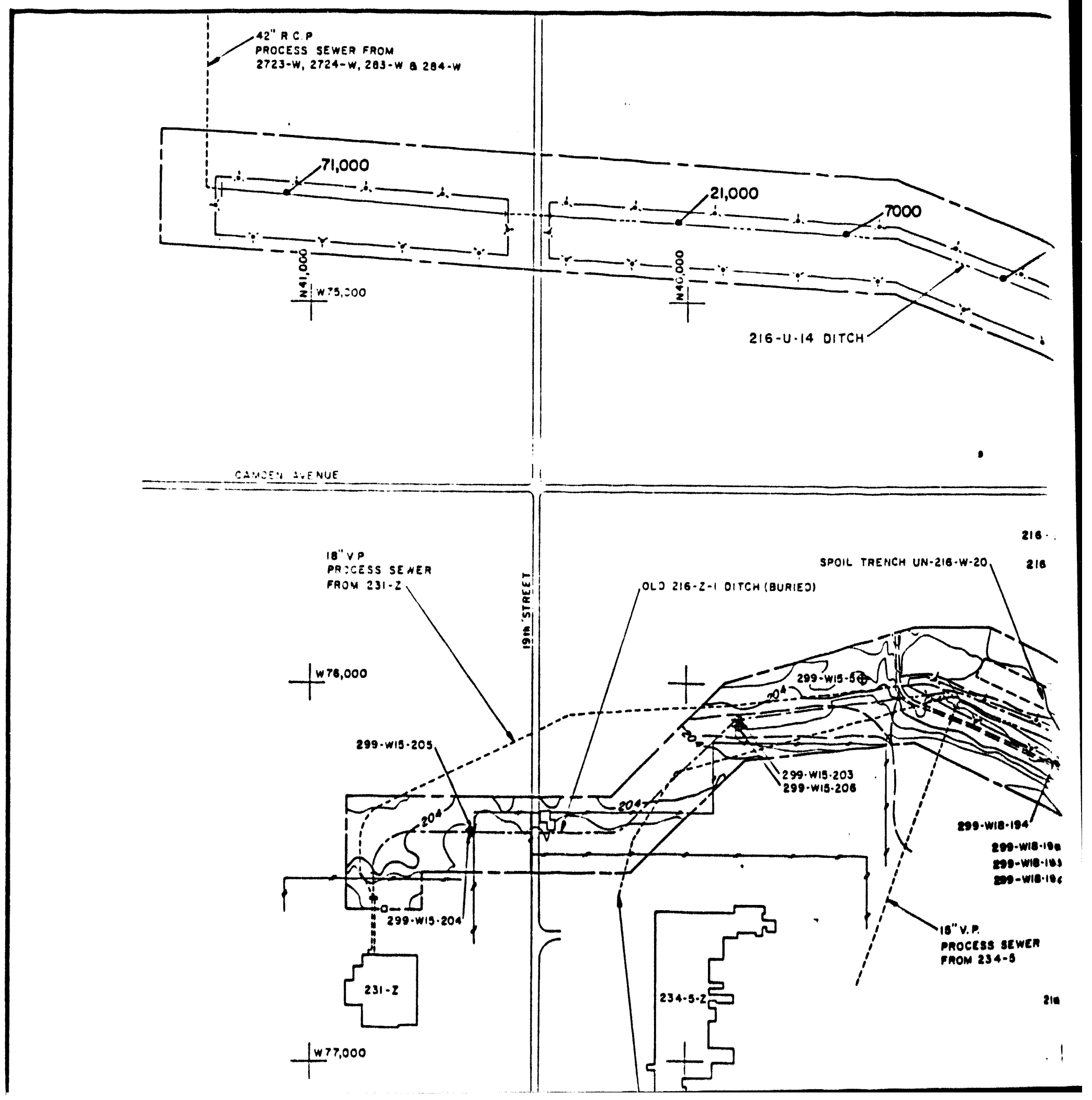




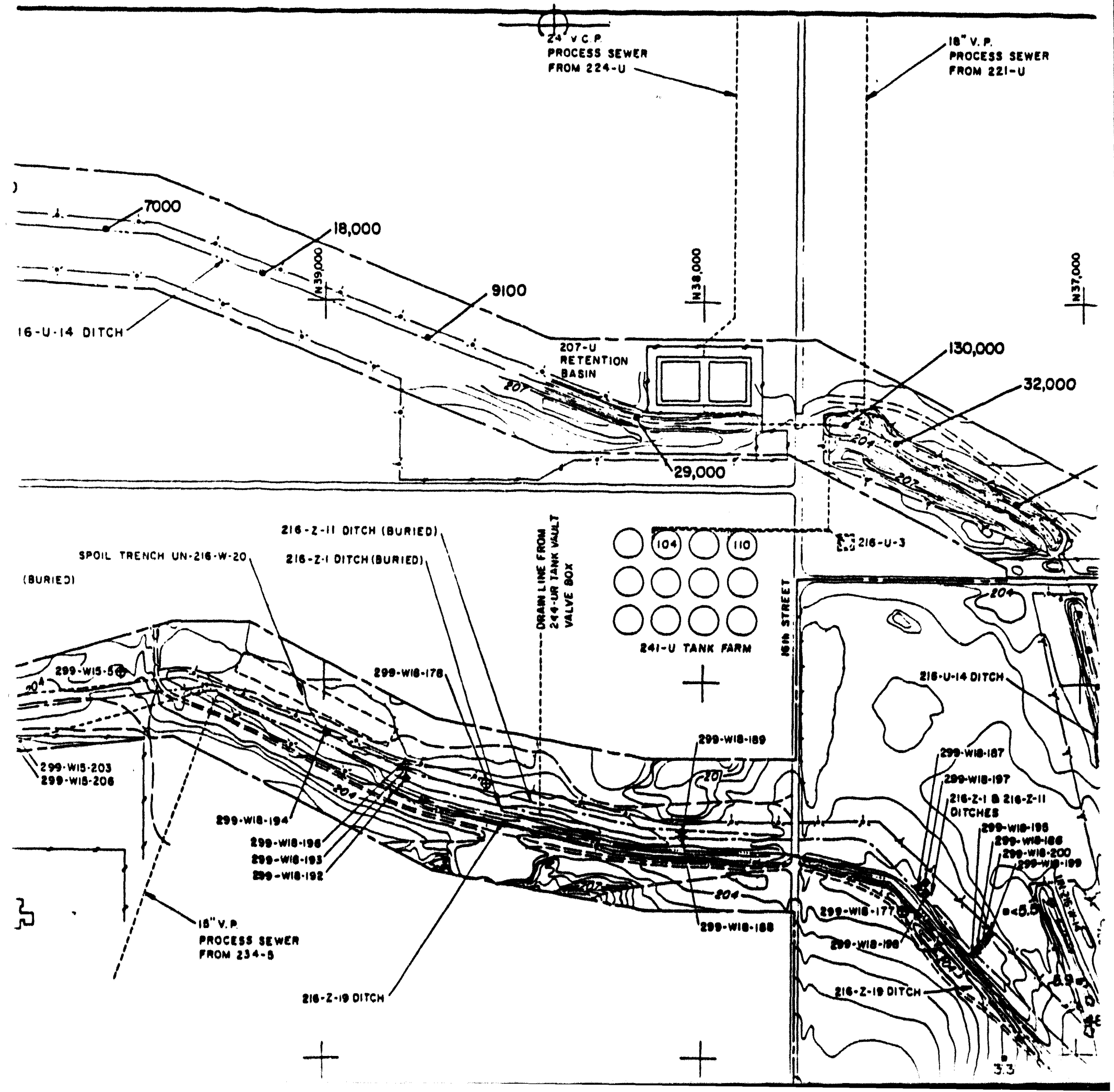




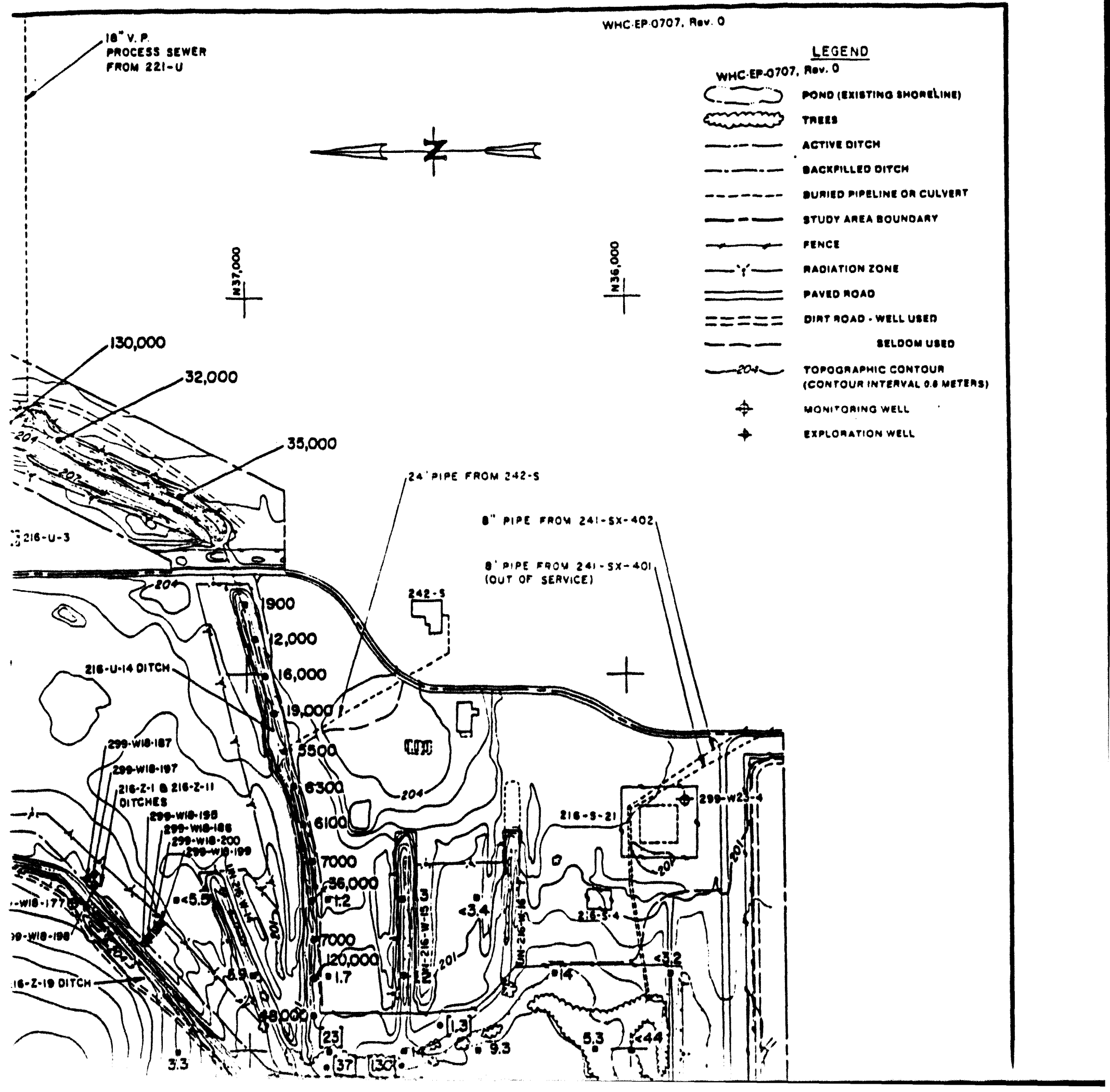




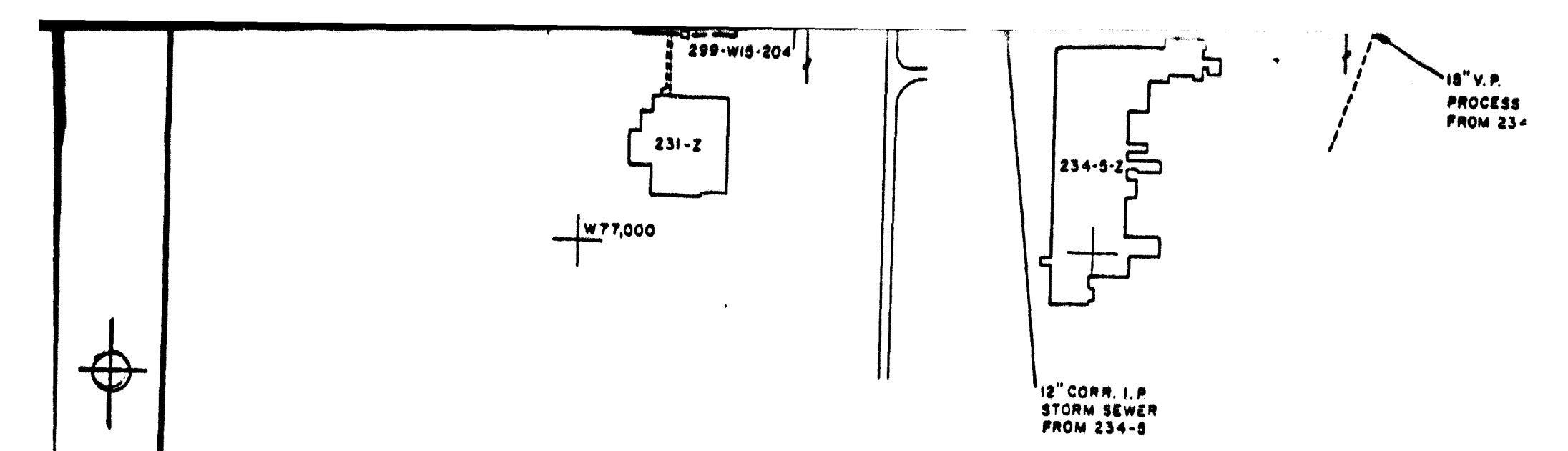




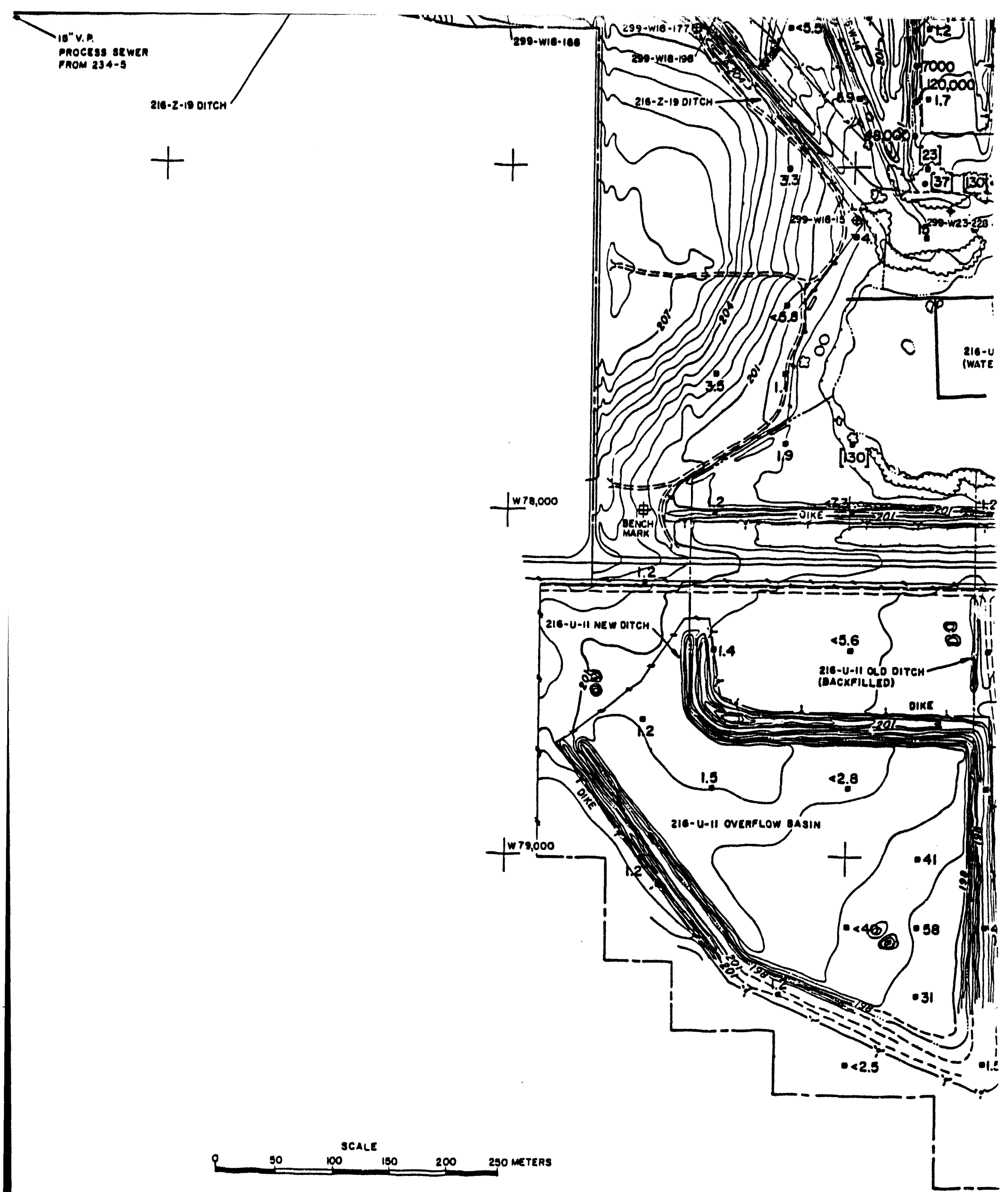




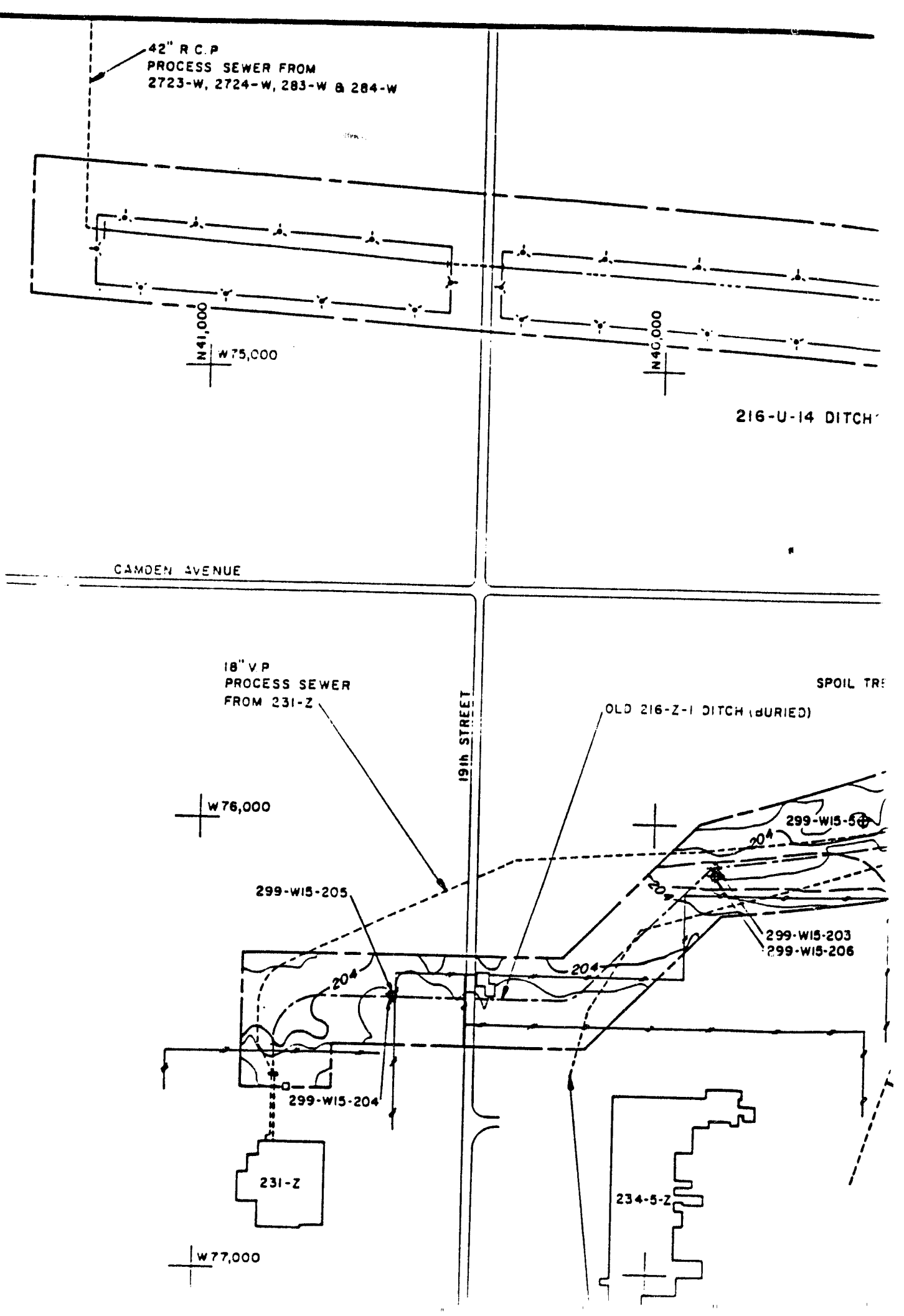




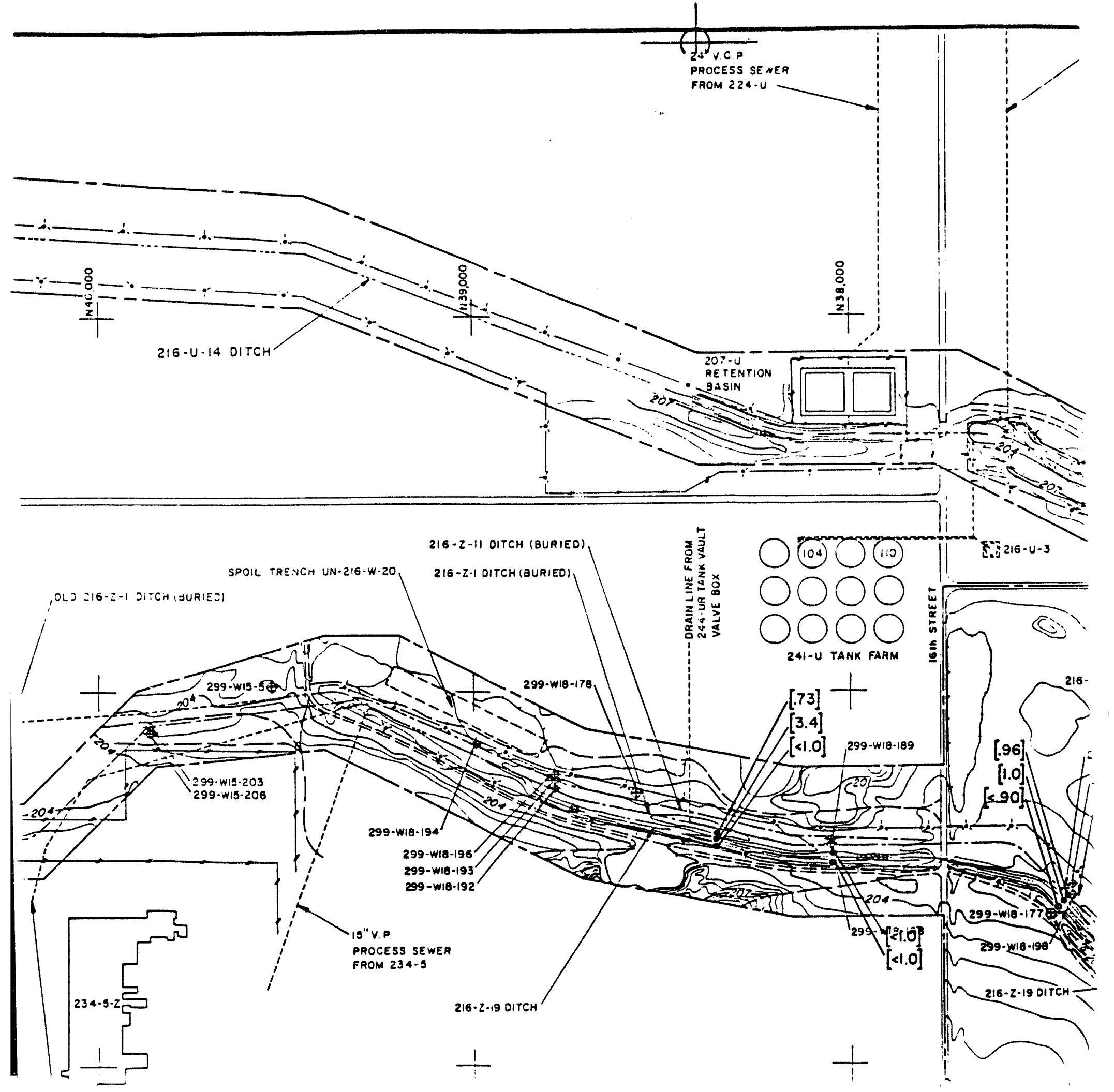


WHC EP.0707, Aev. 0

$180 \vee P$

PROCESS SEWER

FROM $221-U$
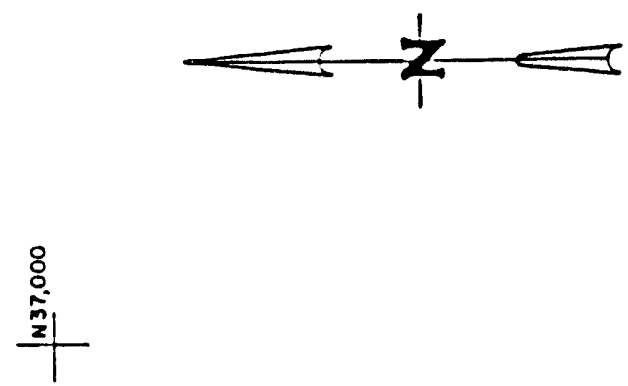

$=$
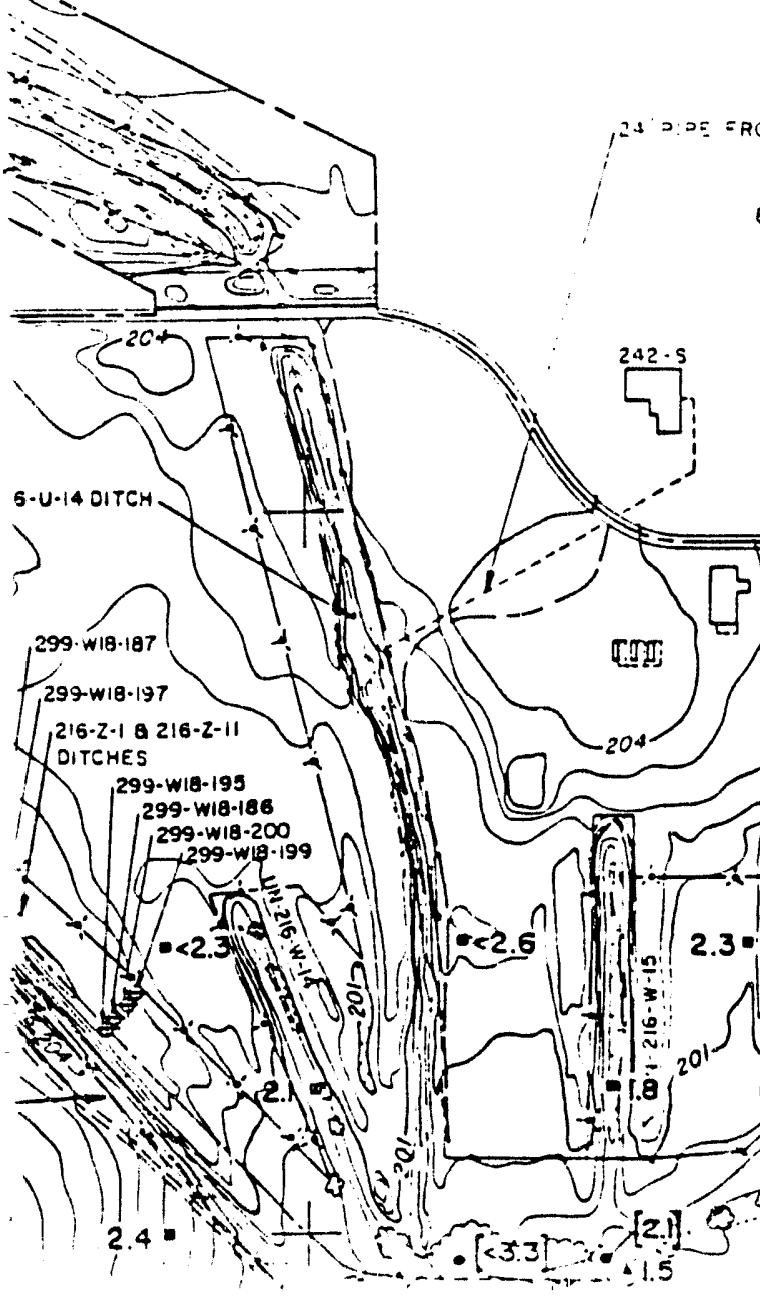

\section{LEGENO}

WHC-EP-Q702 RovPONO (EXISTINO SMONELINE) Taees

-

AACKPILLEO OITCH

DUNiEd PIPELINE ON CuLVEAT

STUOY AREA BOUNOARY

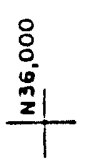

FENCE

L : - MADIATIONZONE

= PAVEDAOAO

ニニニニニ DIRTAOAD. WELL USEO

$-\longrightarrow$

SELDOM USEO

TOPOGAAPHIC CONTOUN (CONTOUA INTEAYAL O. METERS)

$\stackrel{t}{t}$ MONITOAING WELL

+ exploration well 


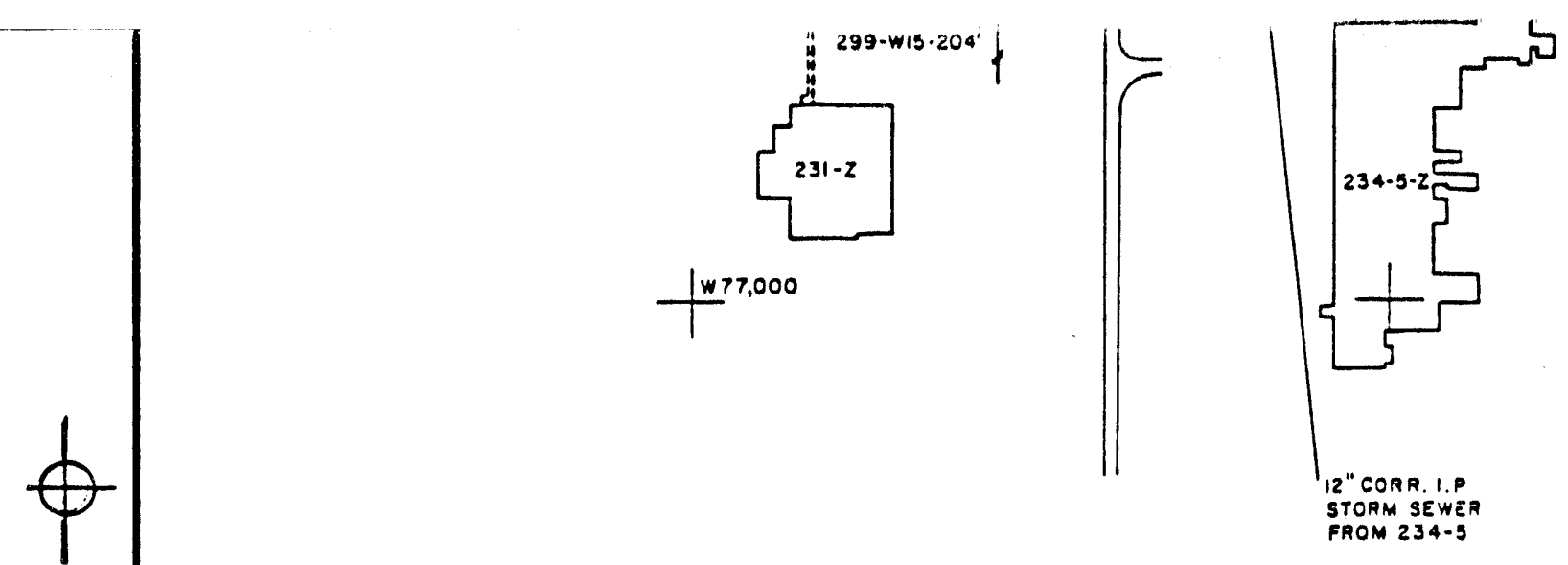
STORM SEWER 


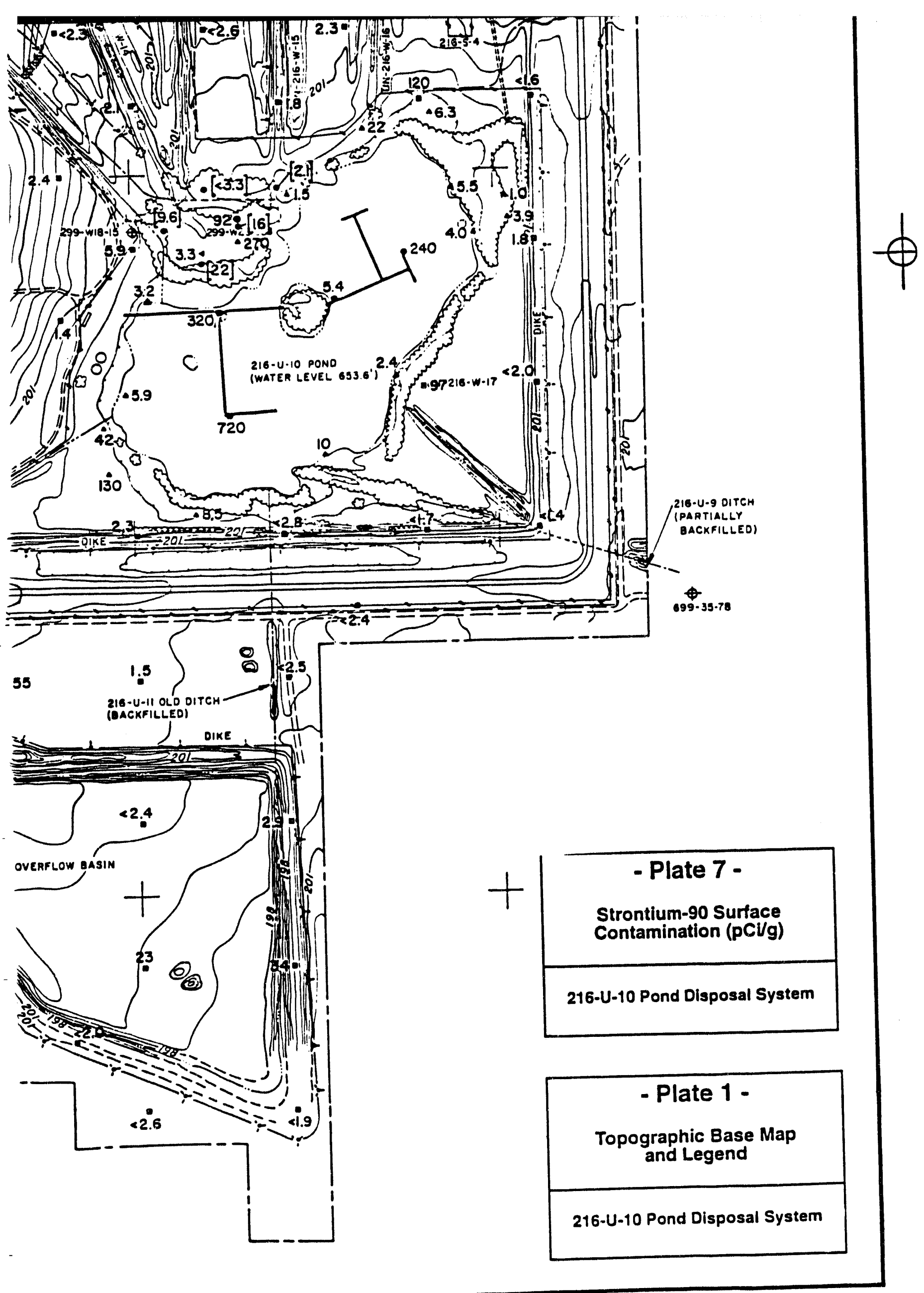




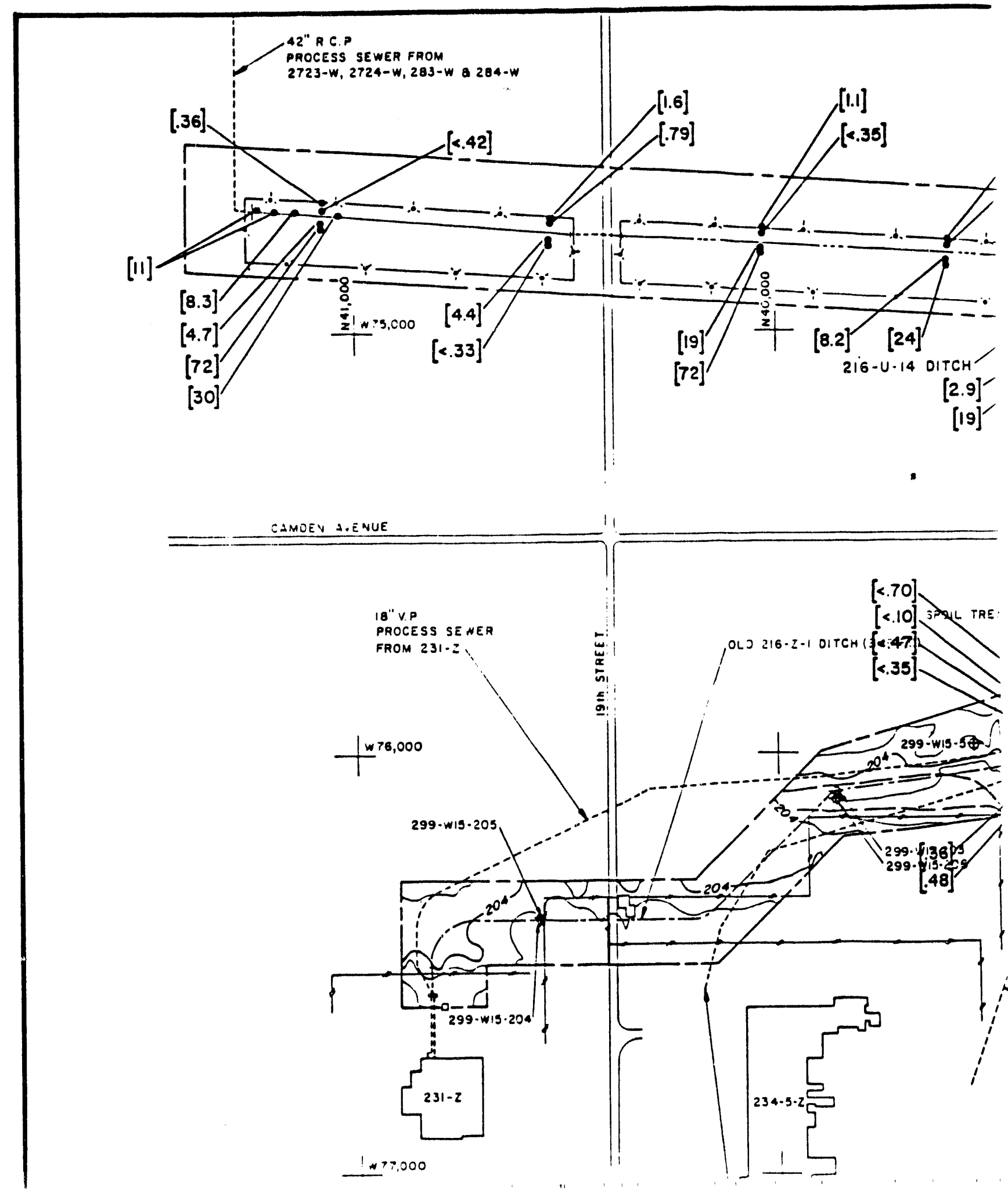




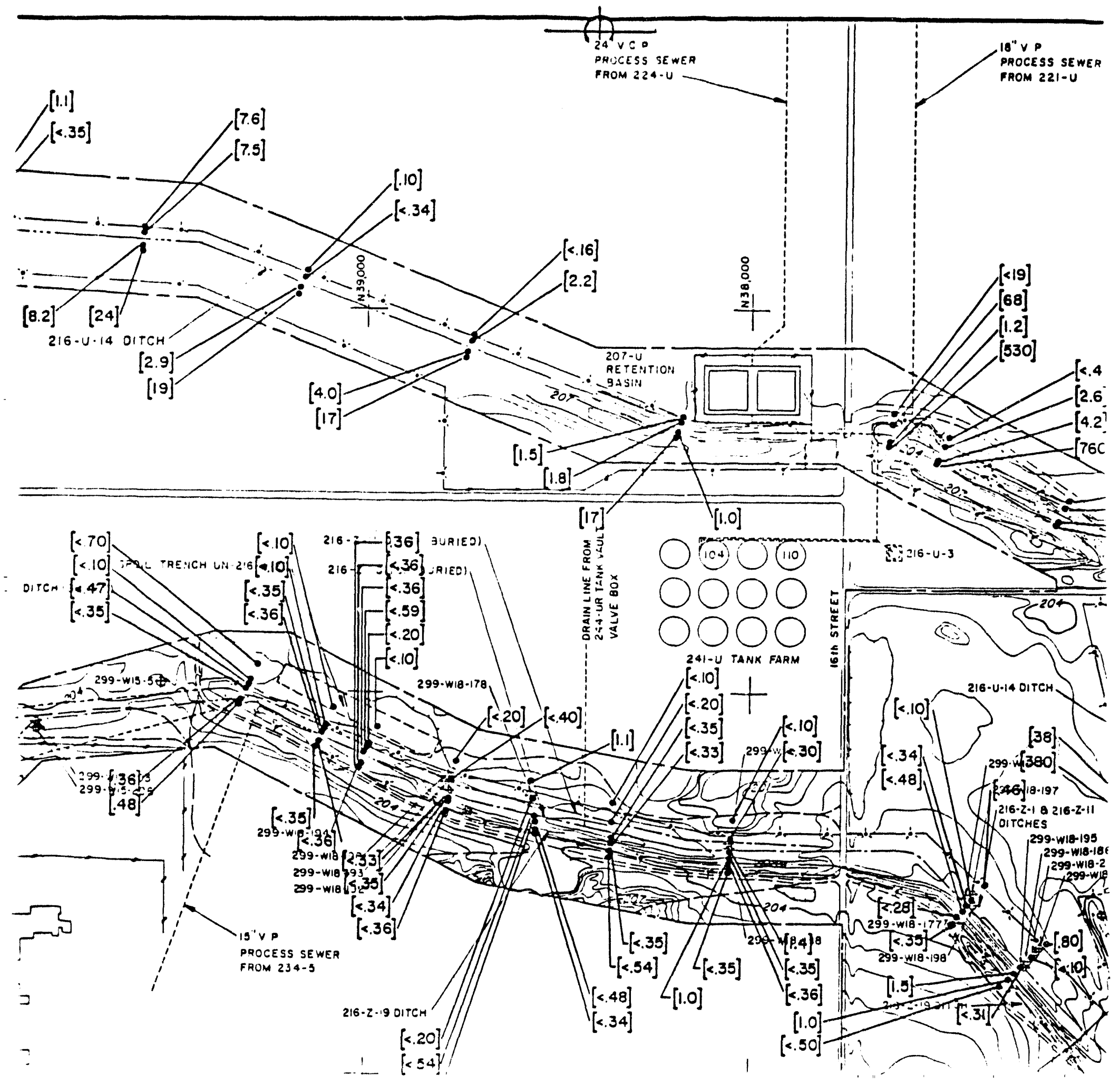




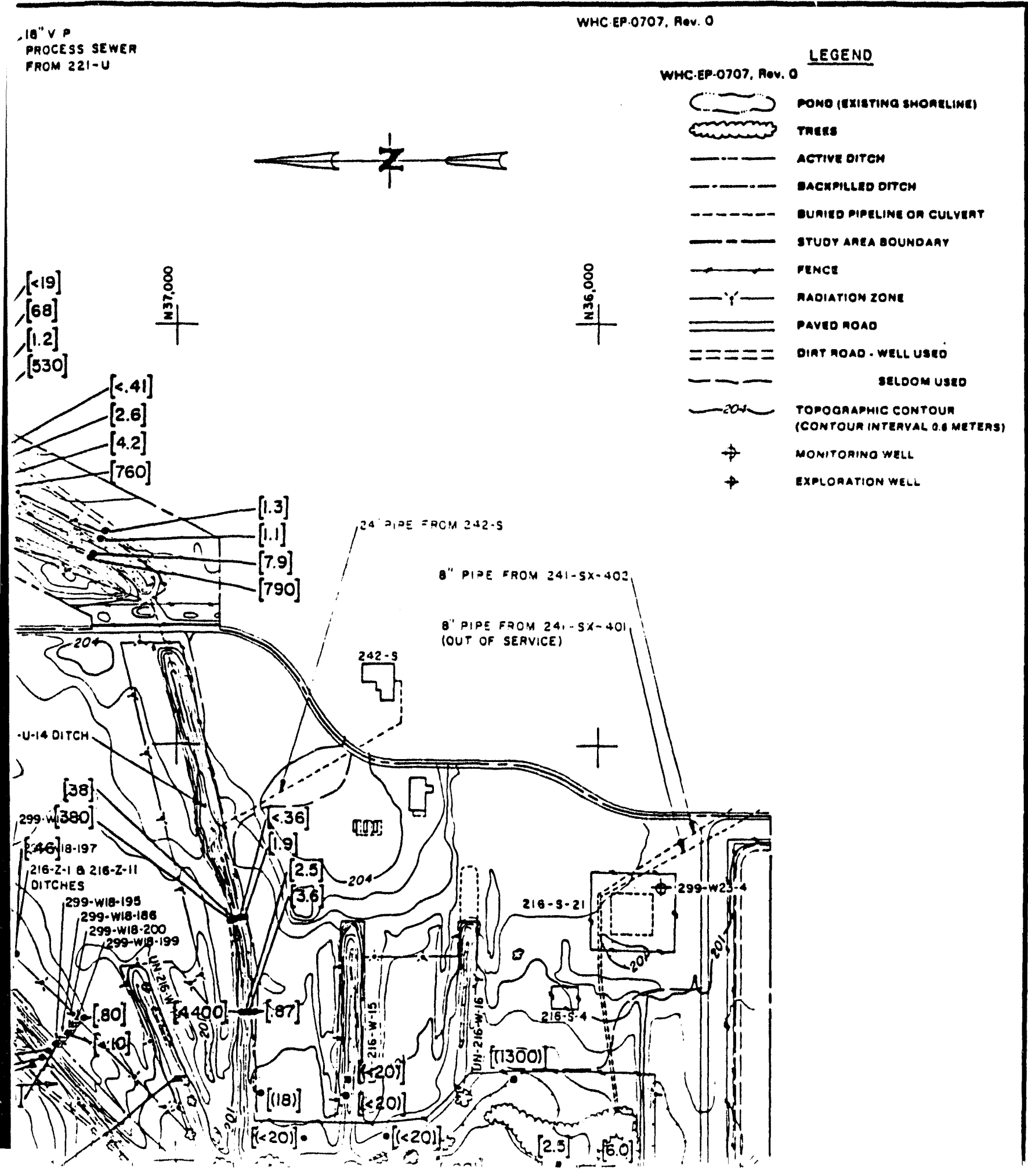




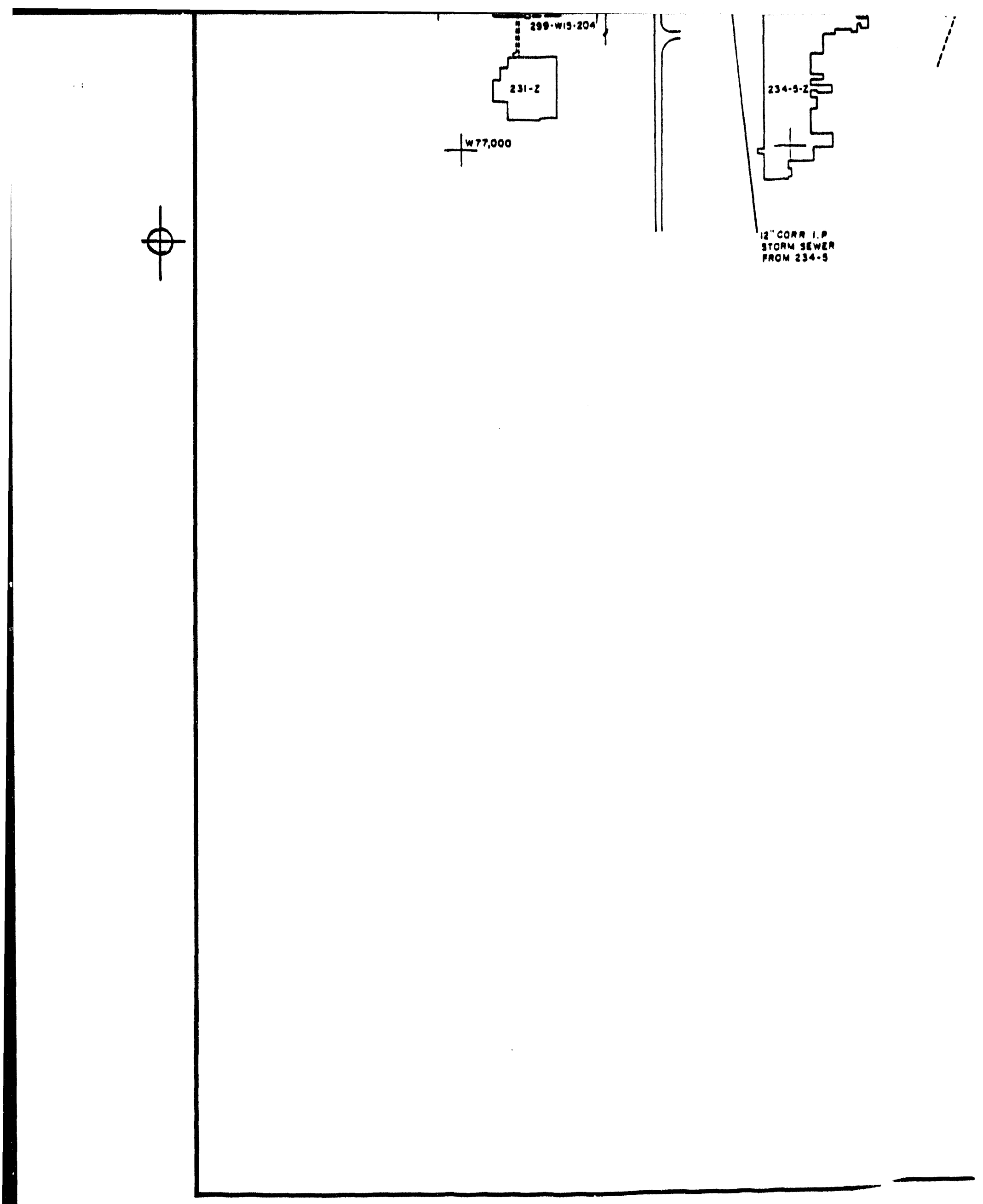




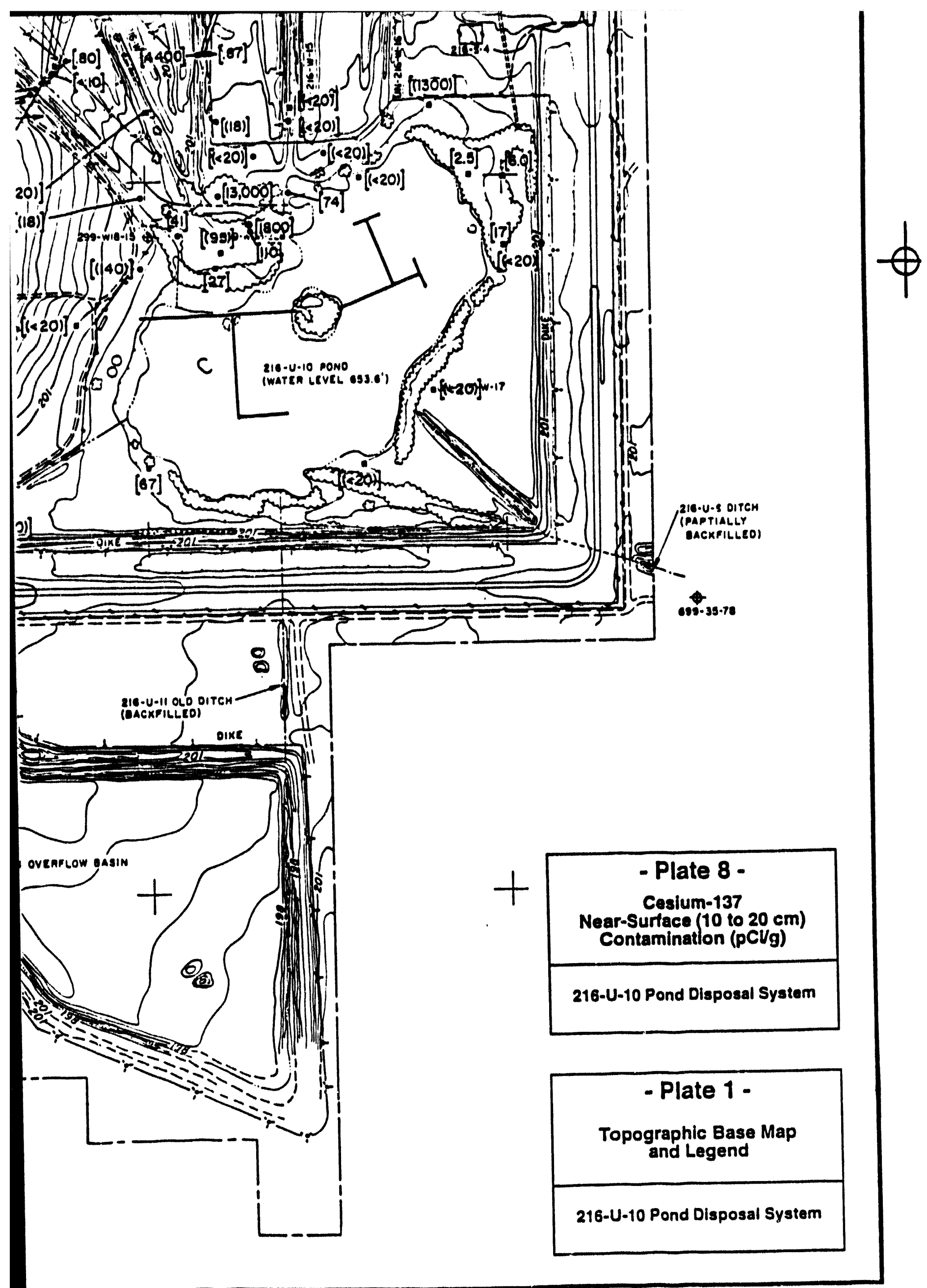




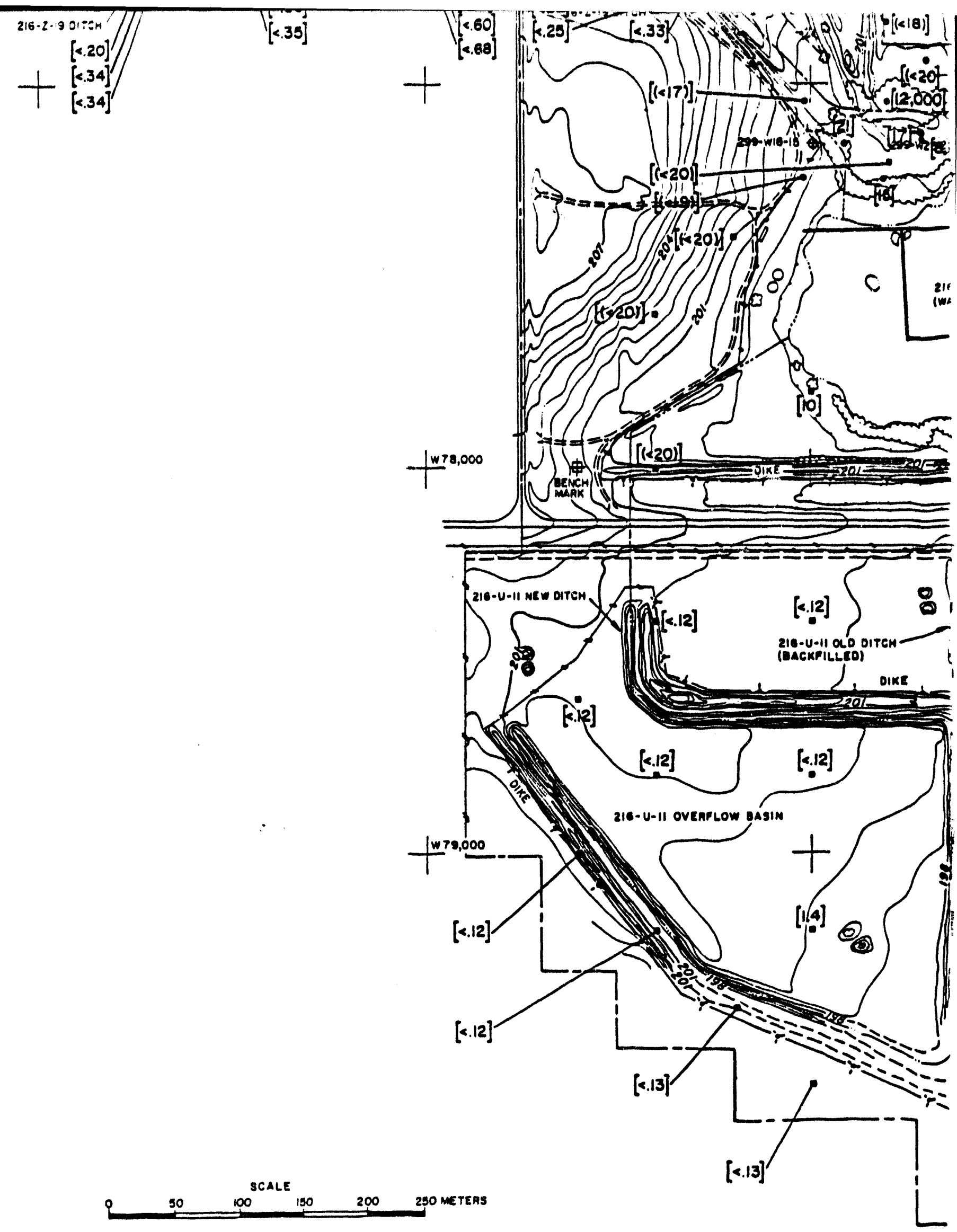




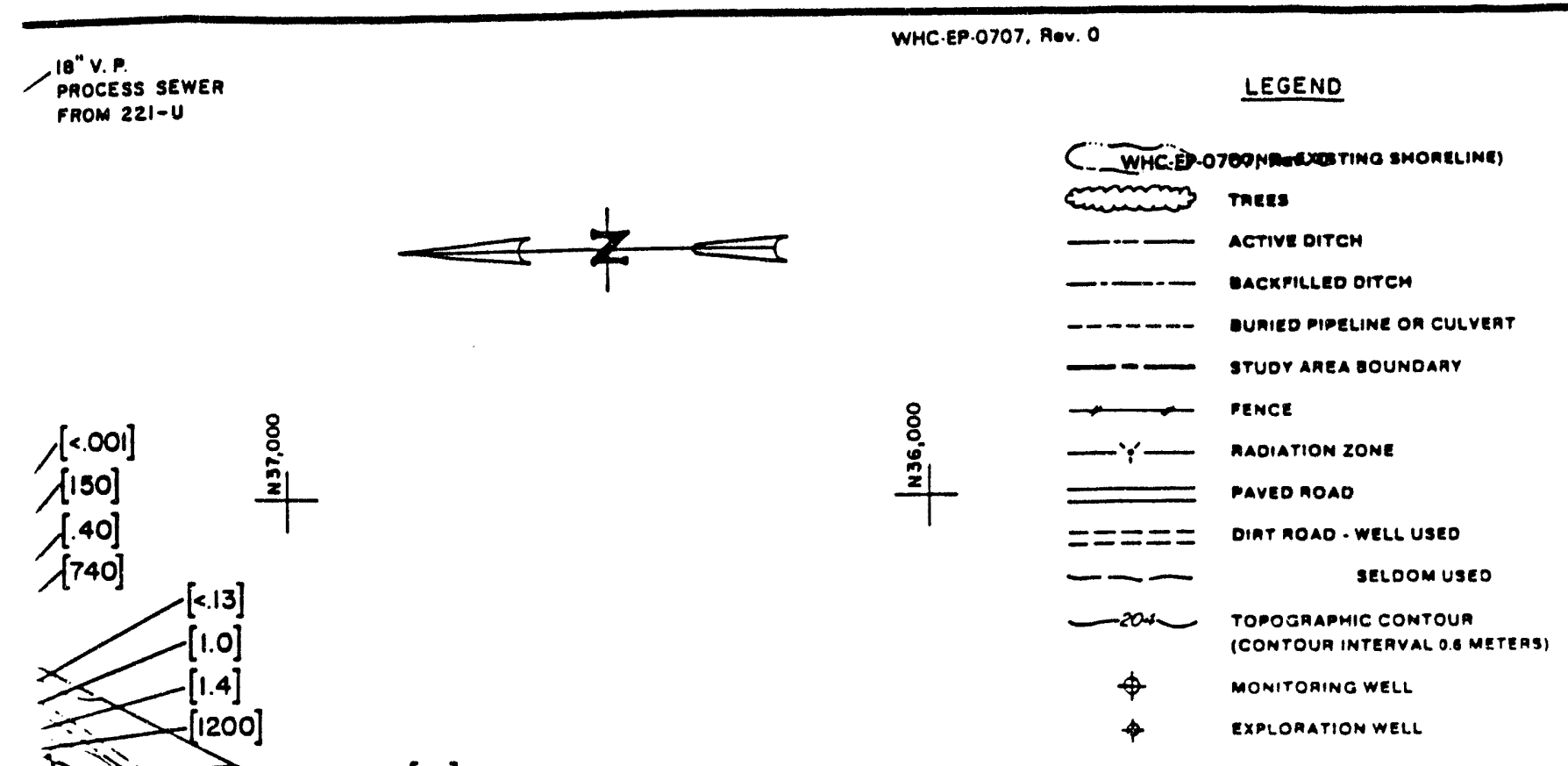




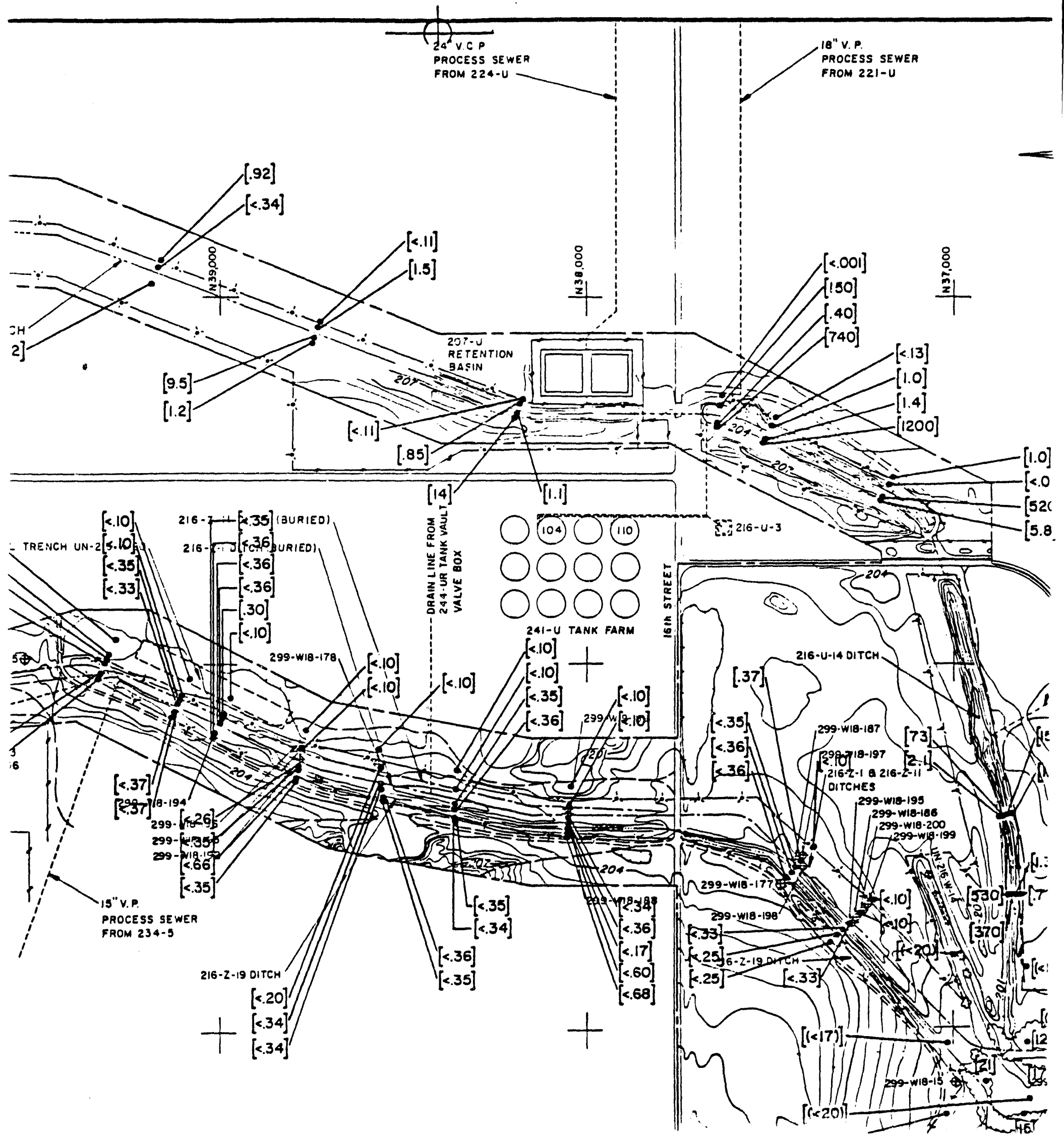




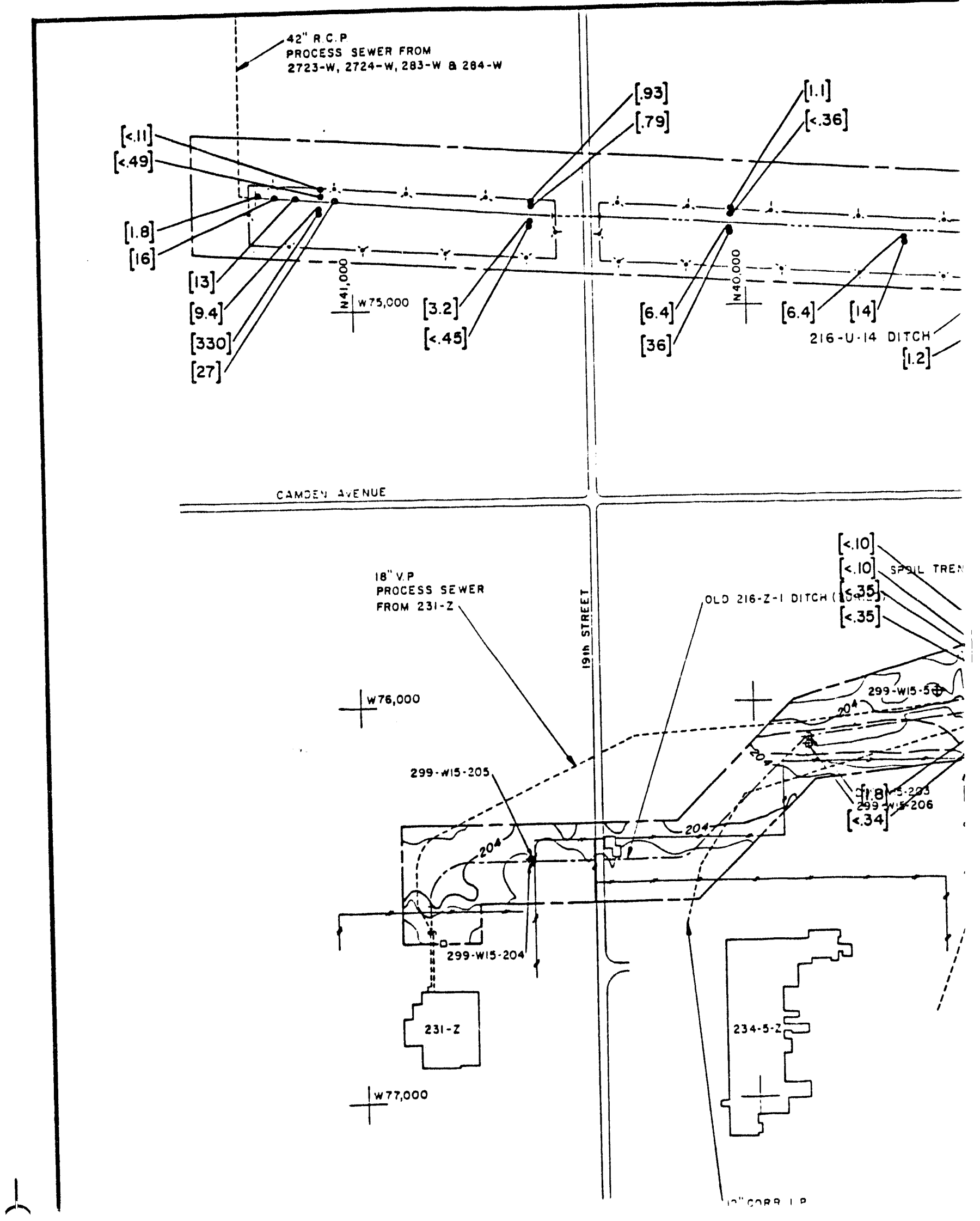




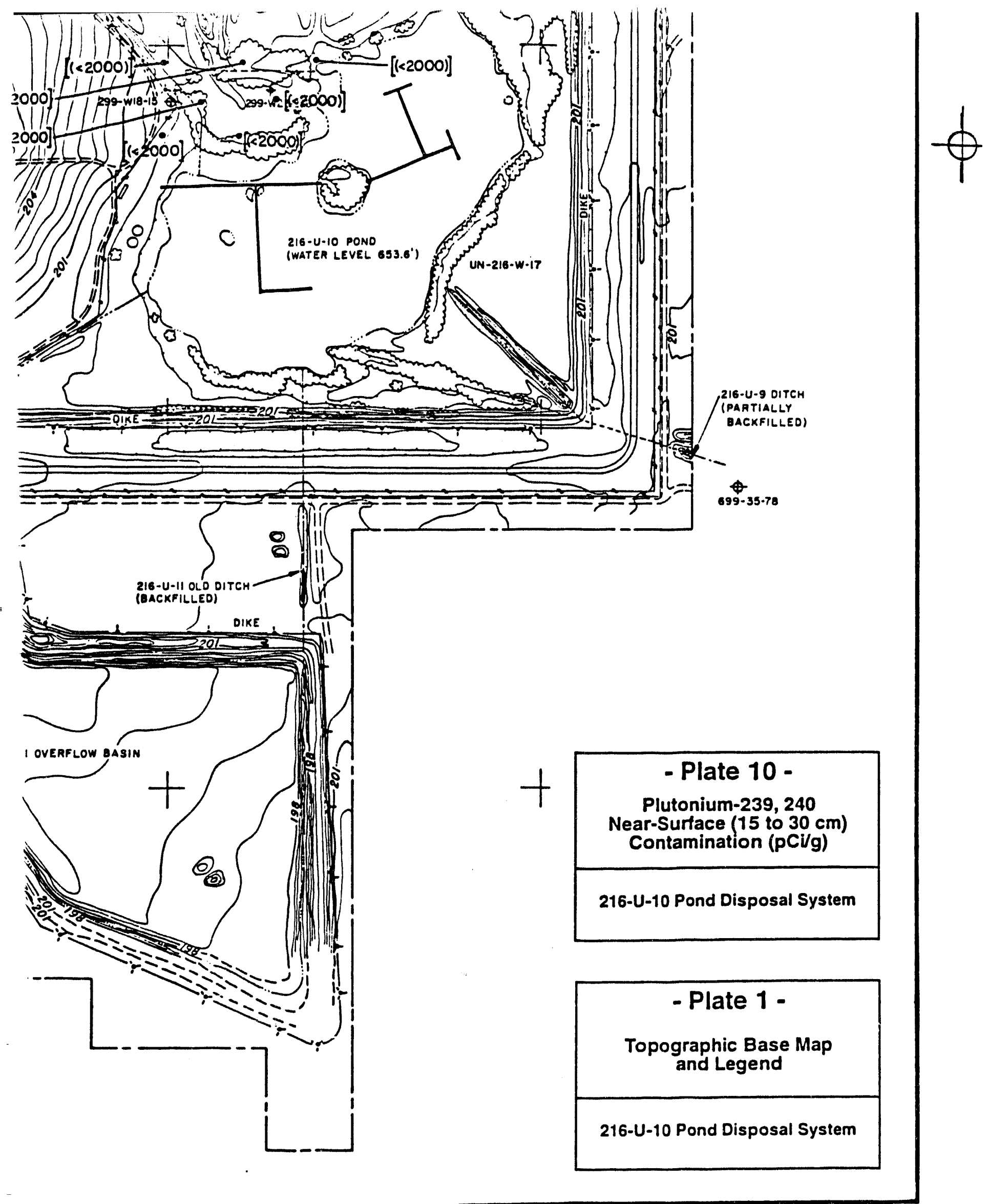




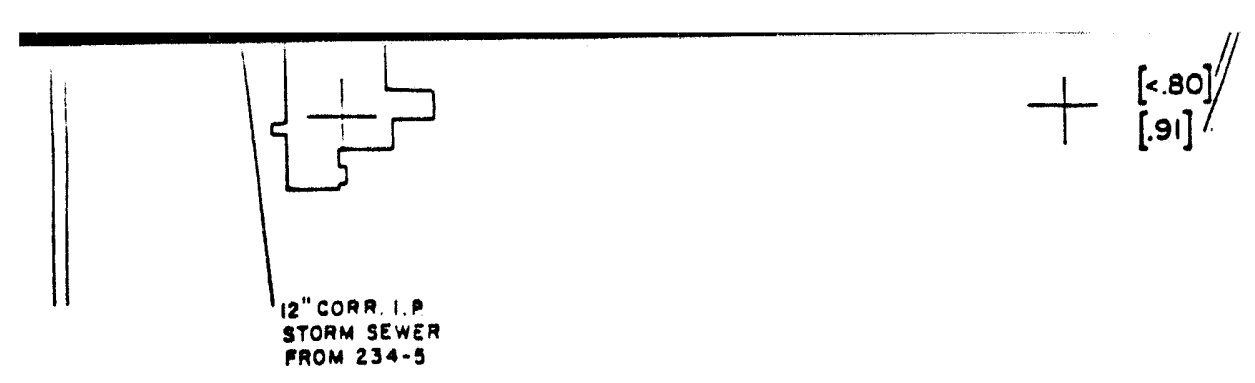

$[0.0]$
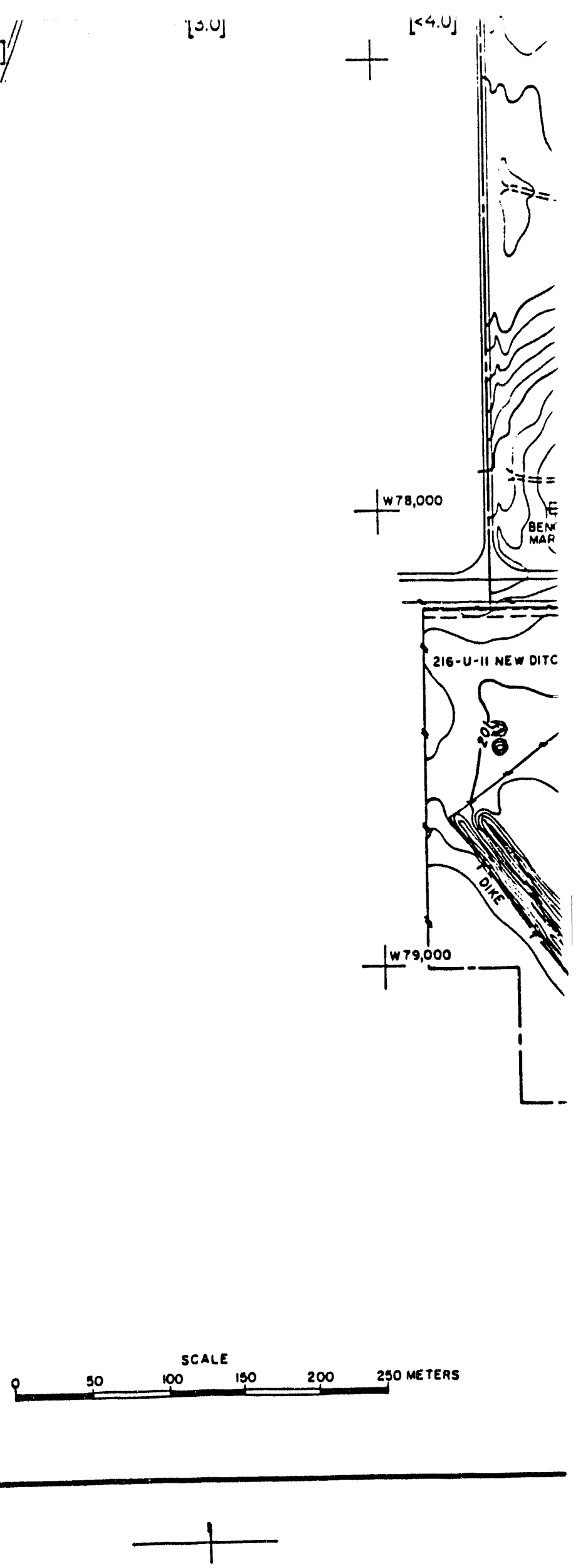


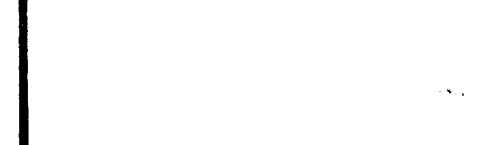

Pिल $234-9$ 


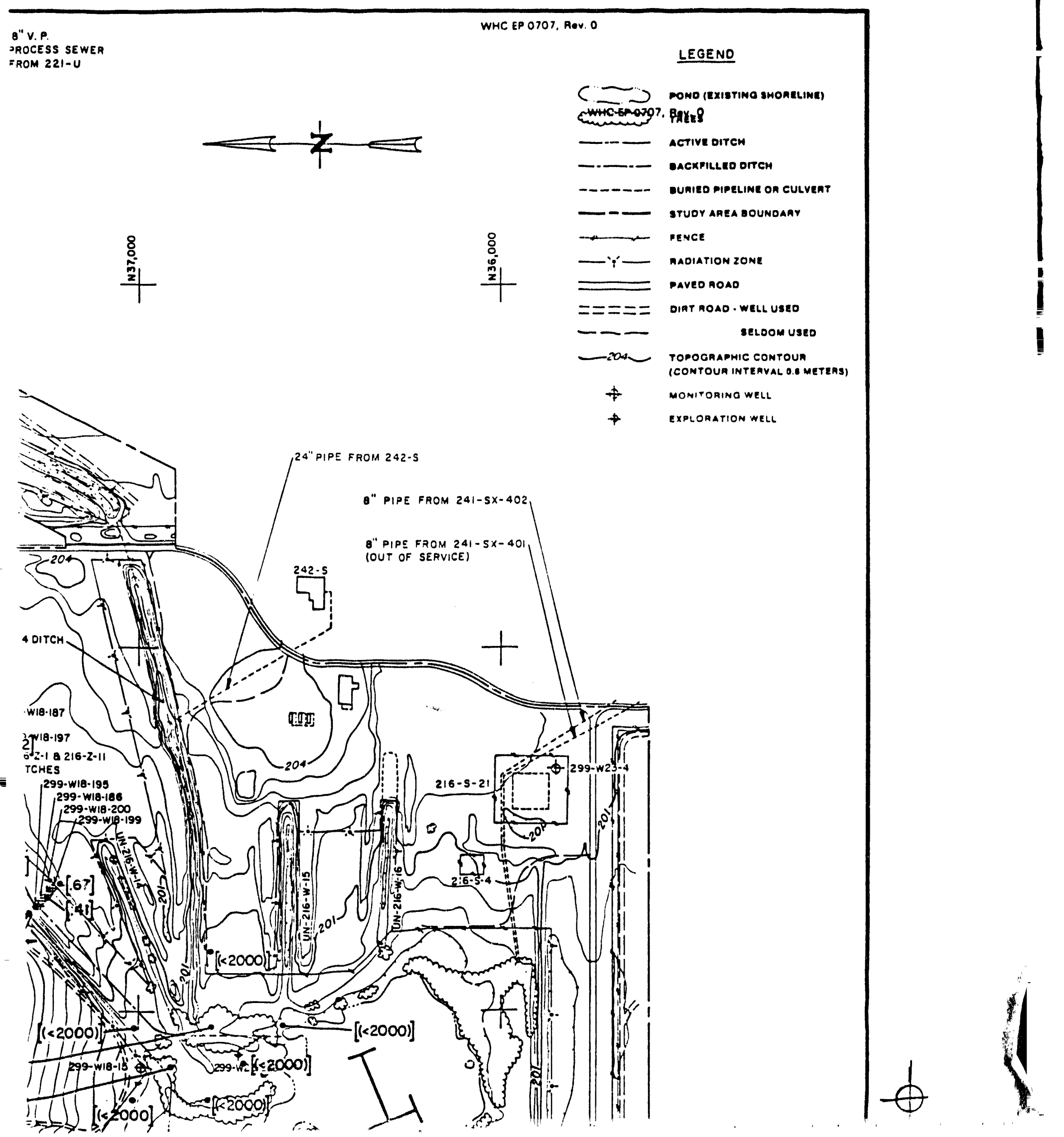




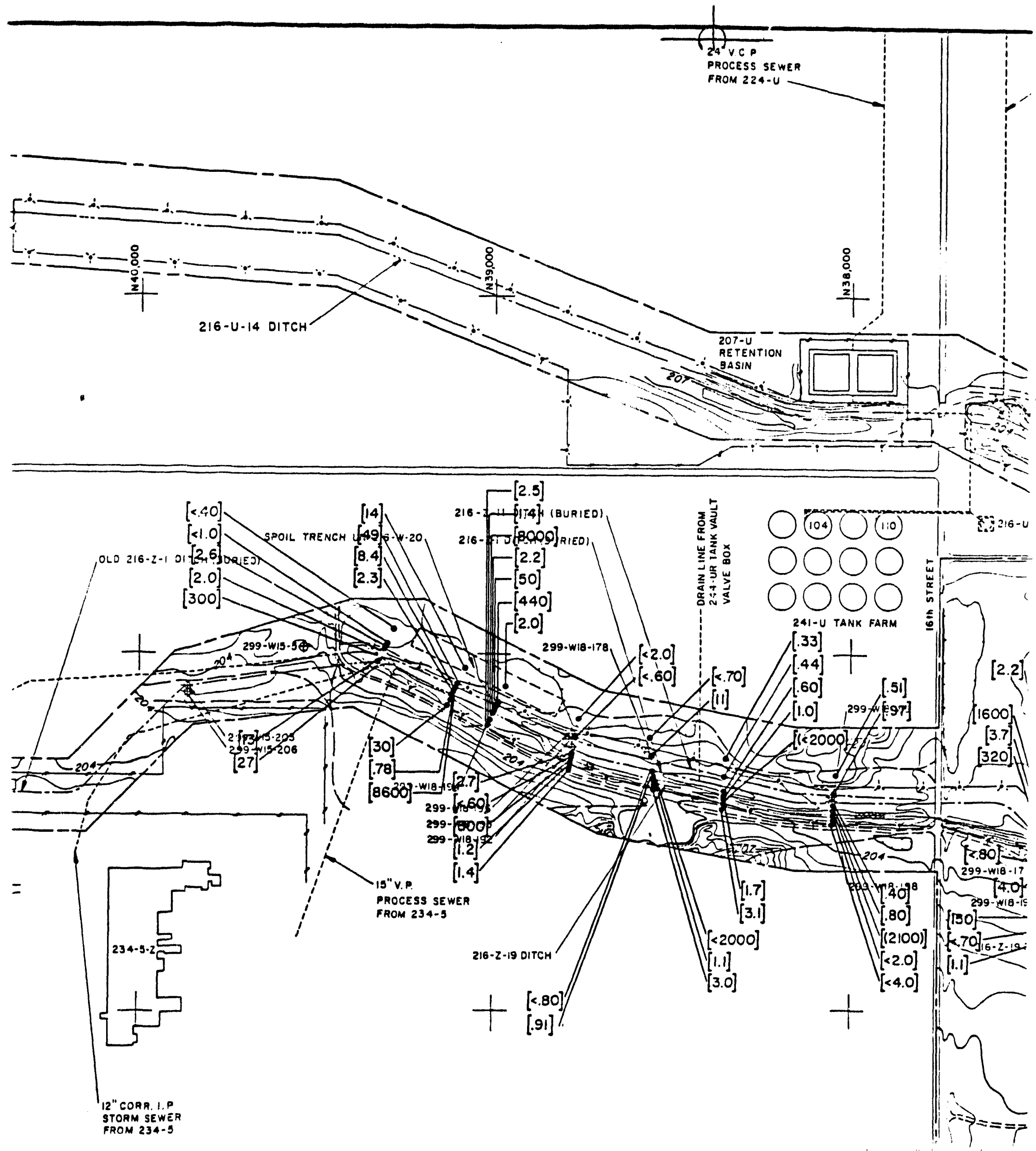




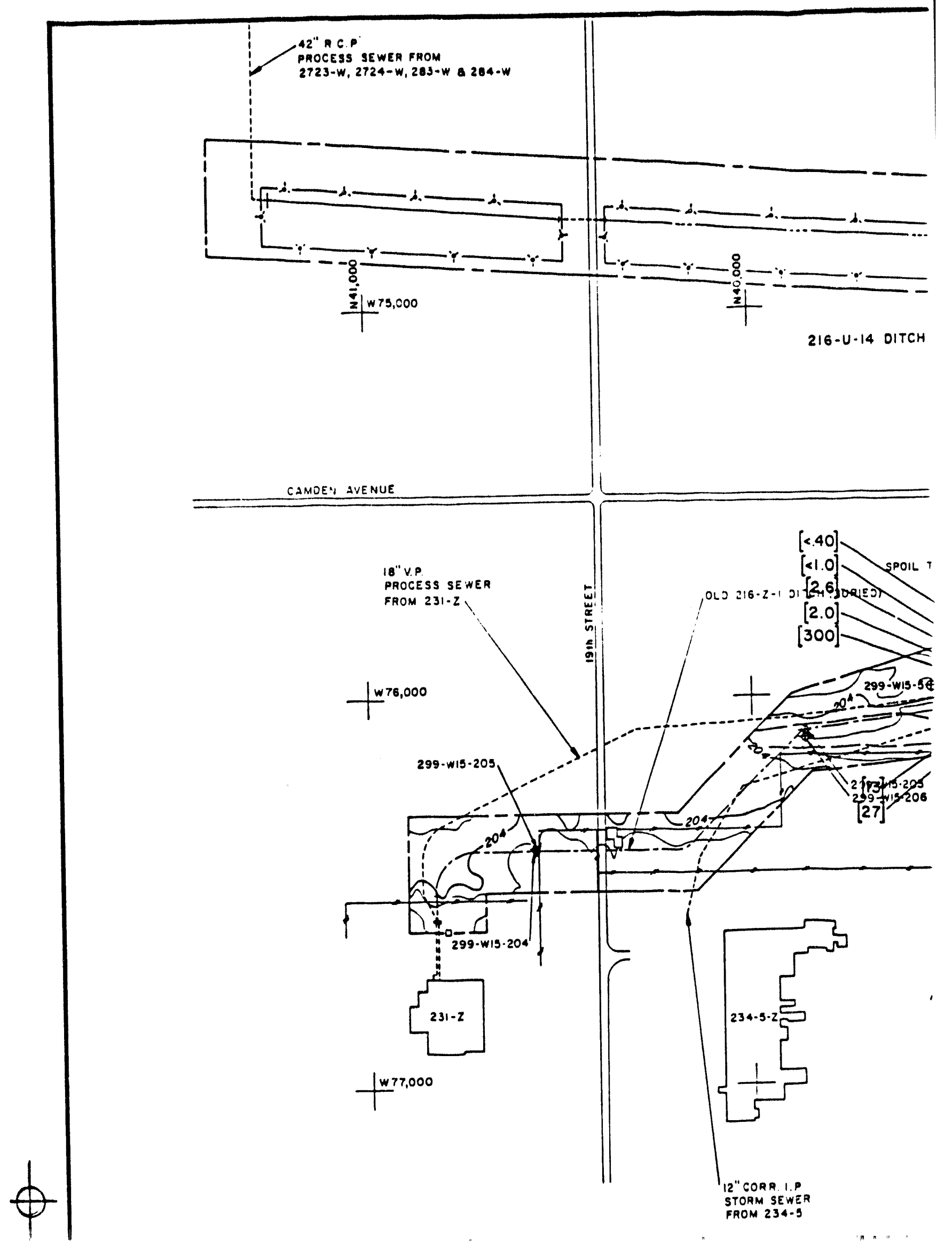




$$
L
$$




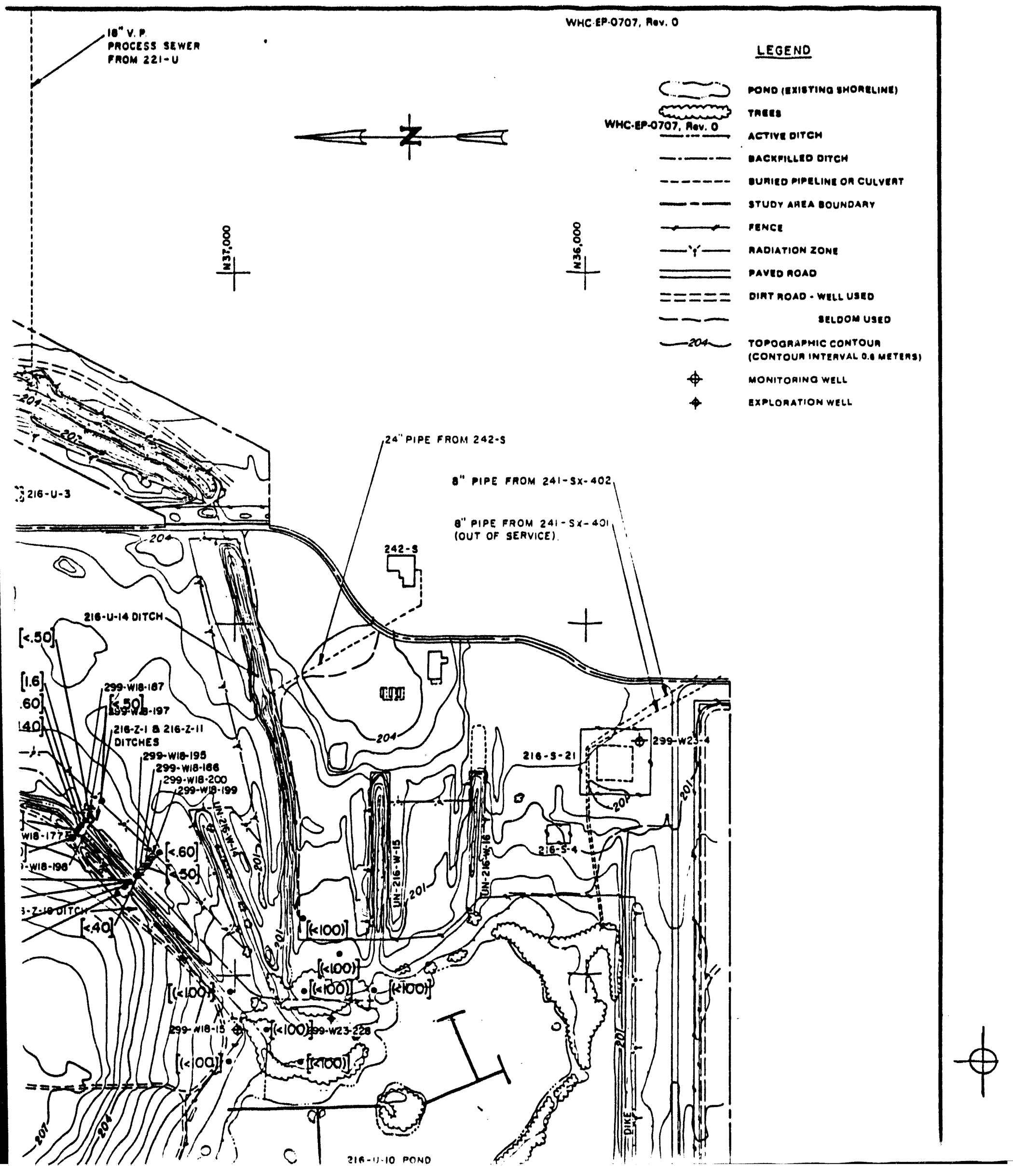




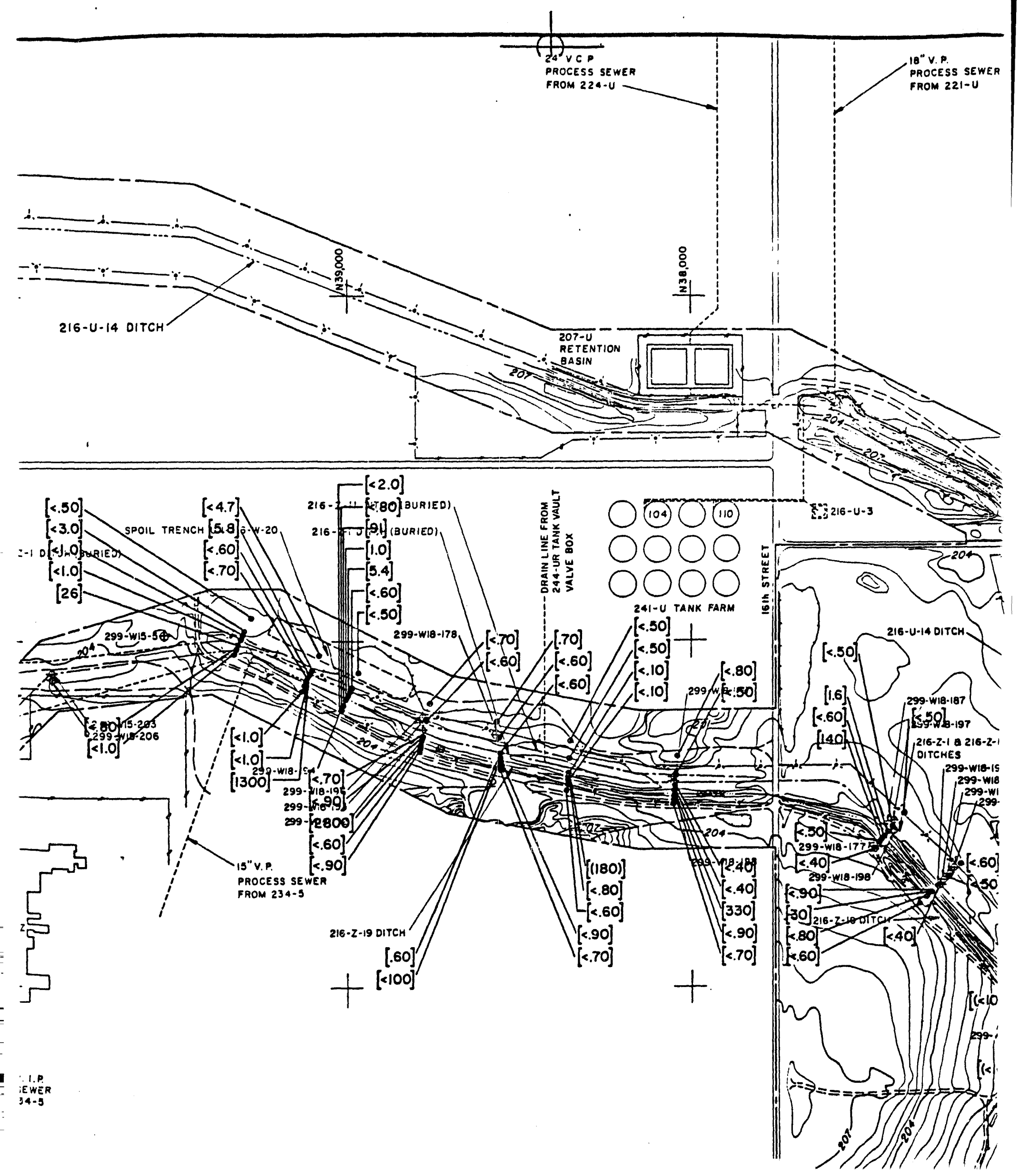




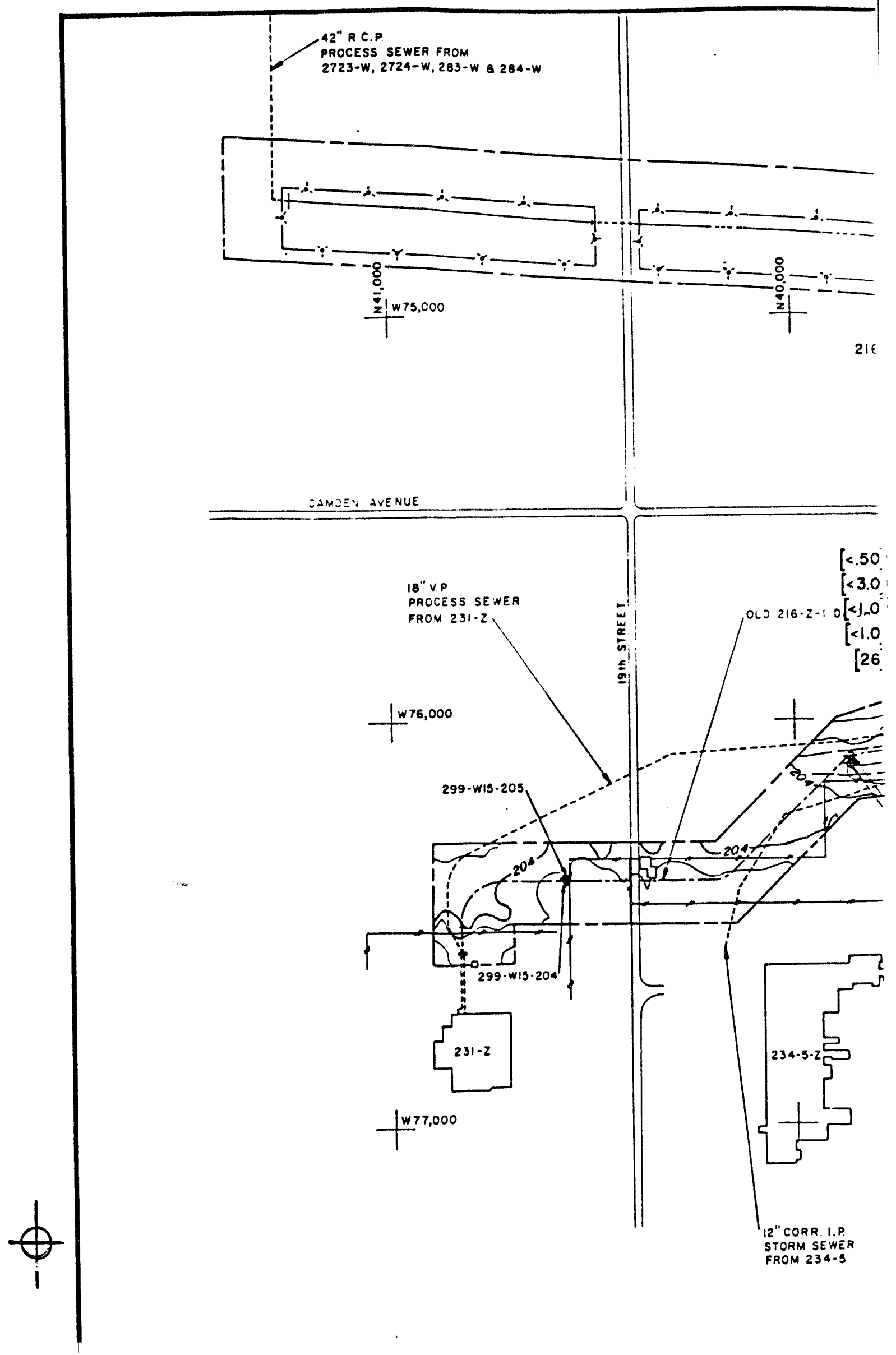




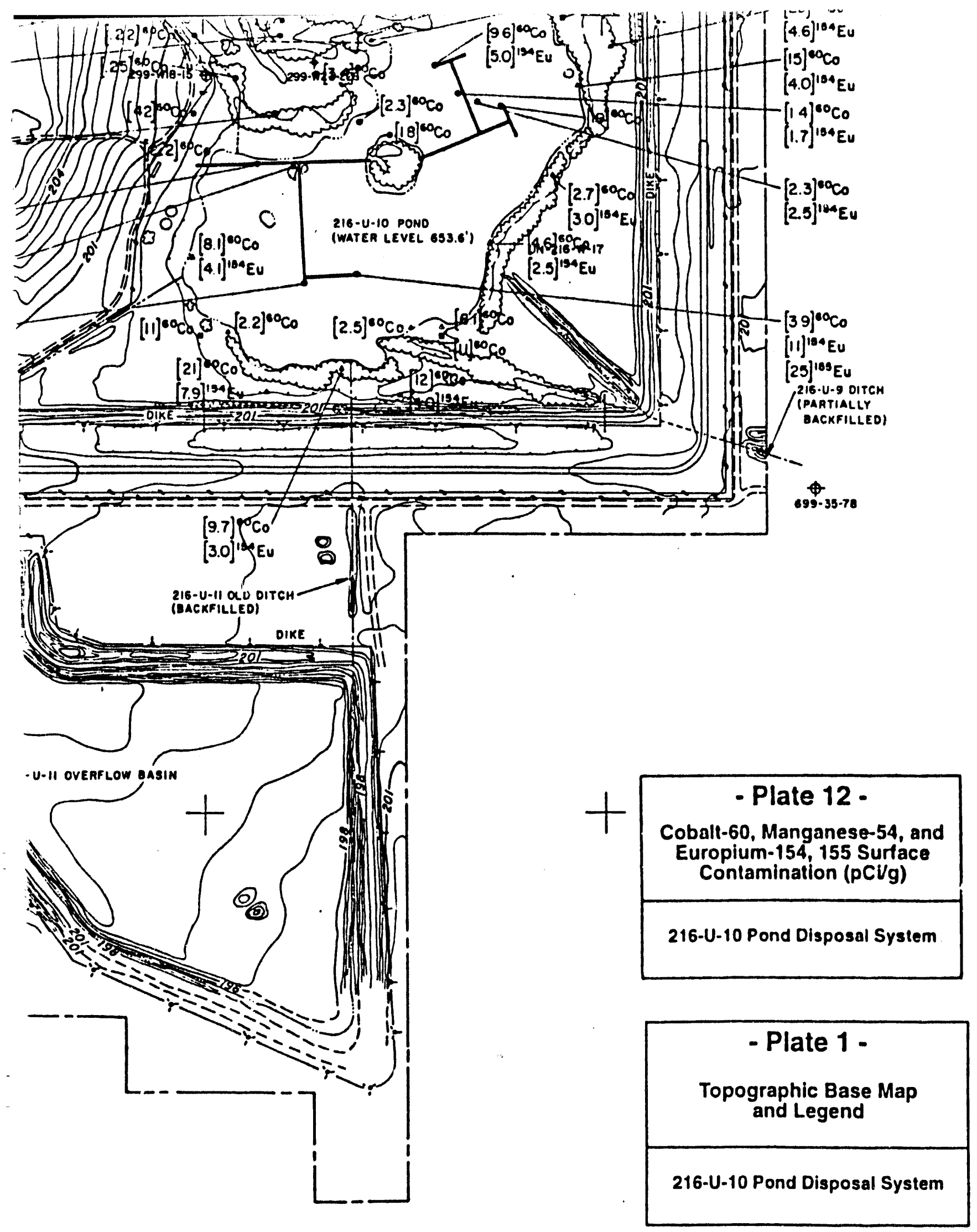


[27] ${ }^{199} \mathrm{Eu}$ $[228]^{90} \mathrm{Co}$ $[77]^{190} \mathrm{Eu}$
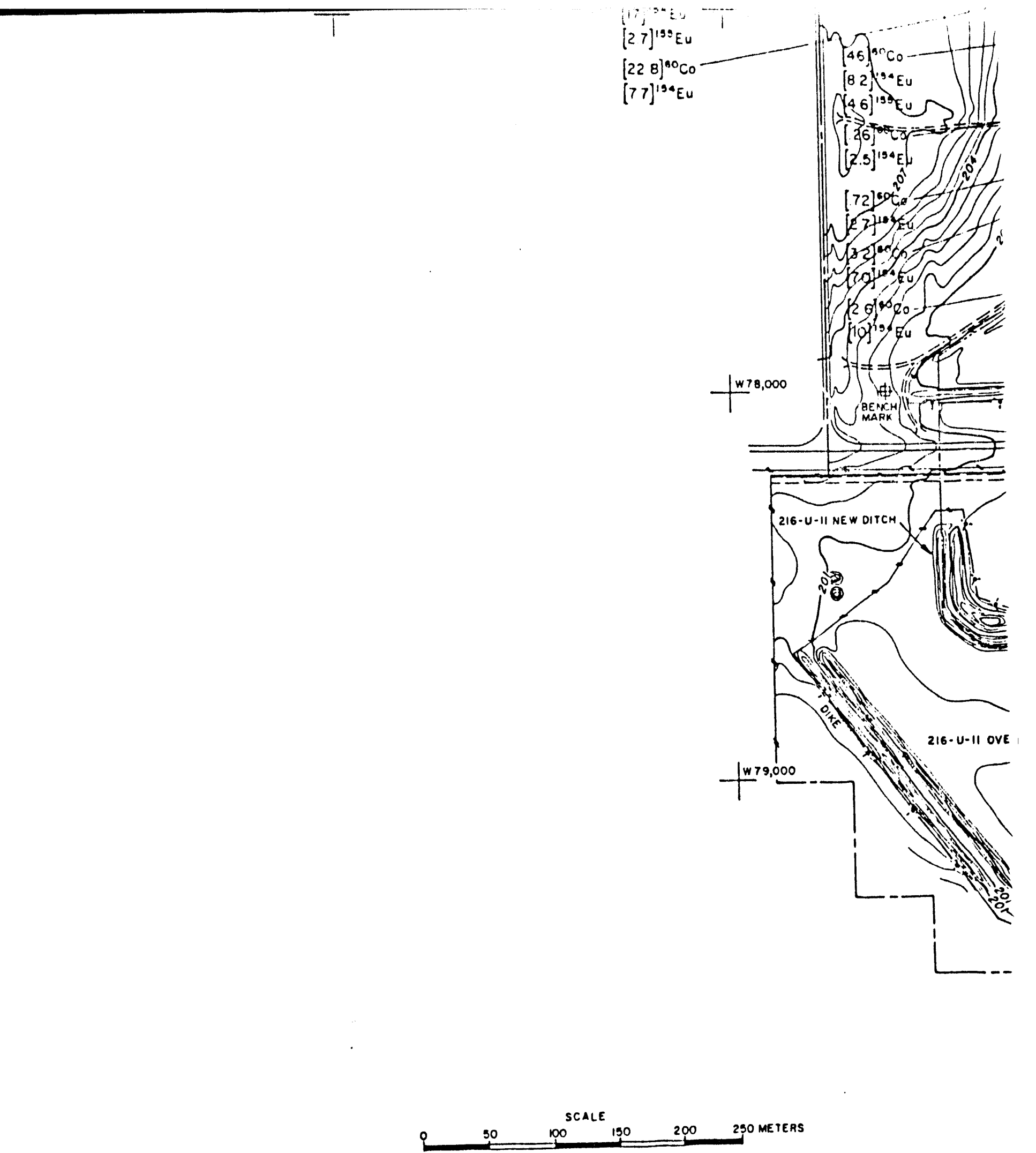


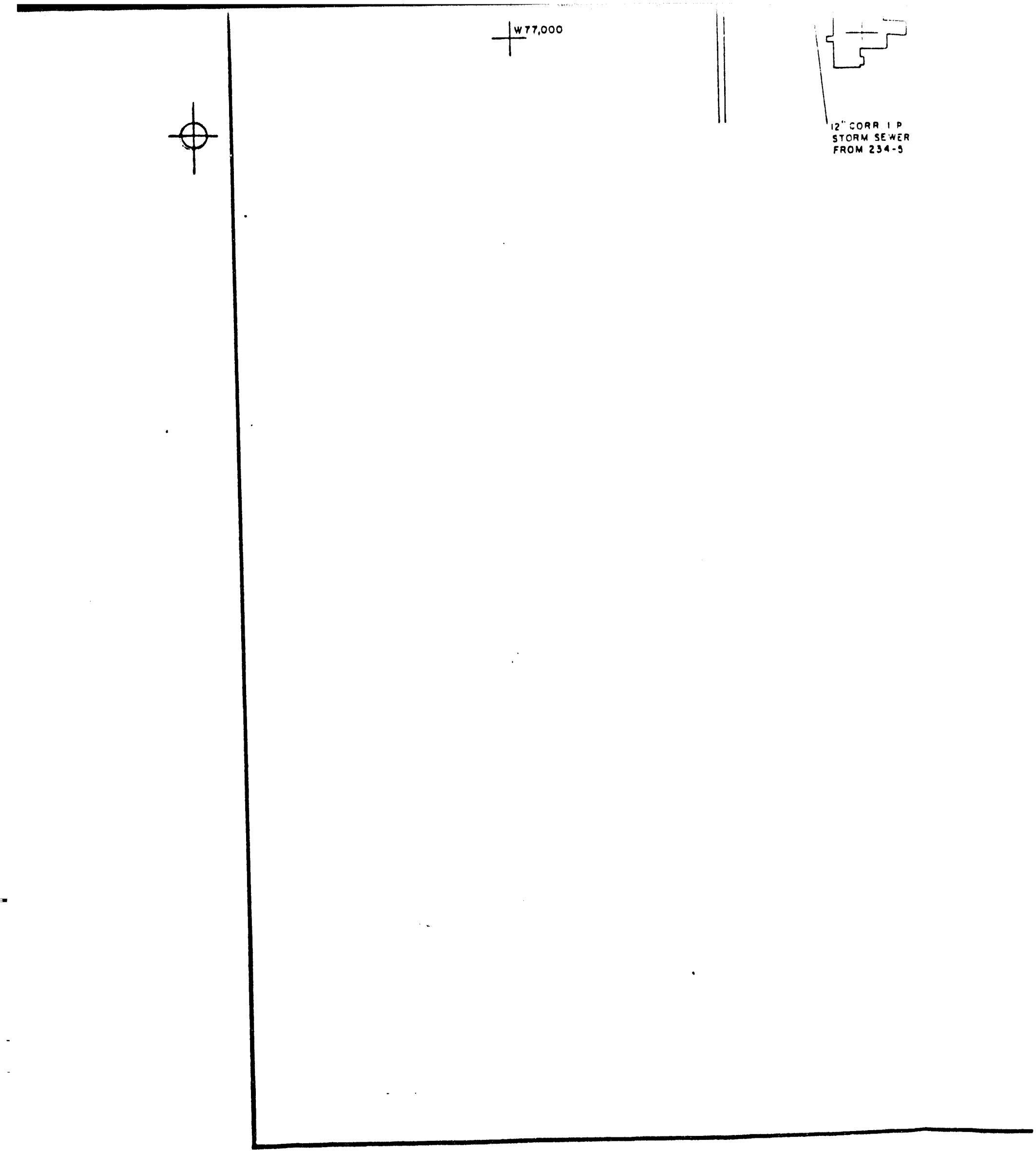


10" V.P.

PROCESS SEWER

FROM 221-U
WHC.EP.0707, Aov. 0

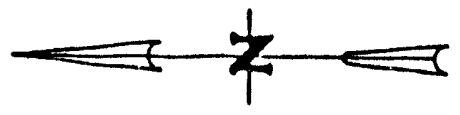

$16.5]^{80} \mathrm{Co}$

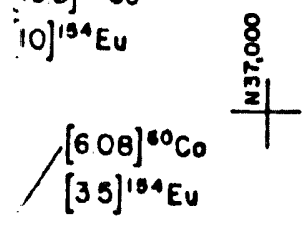

$[25]^{\circ 0} \mathrm{Co}$

$[12]^{104} \mathrm{Eu}$

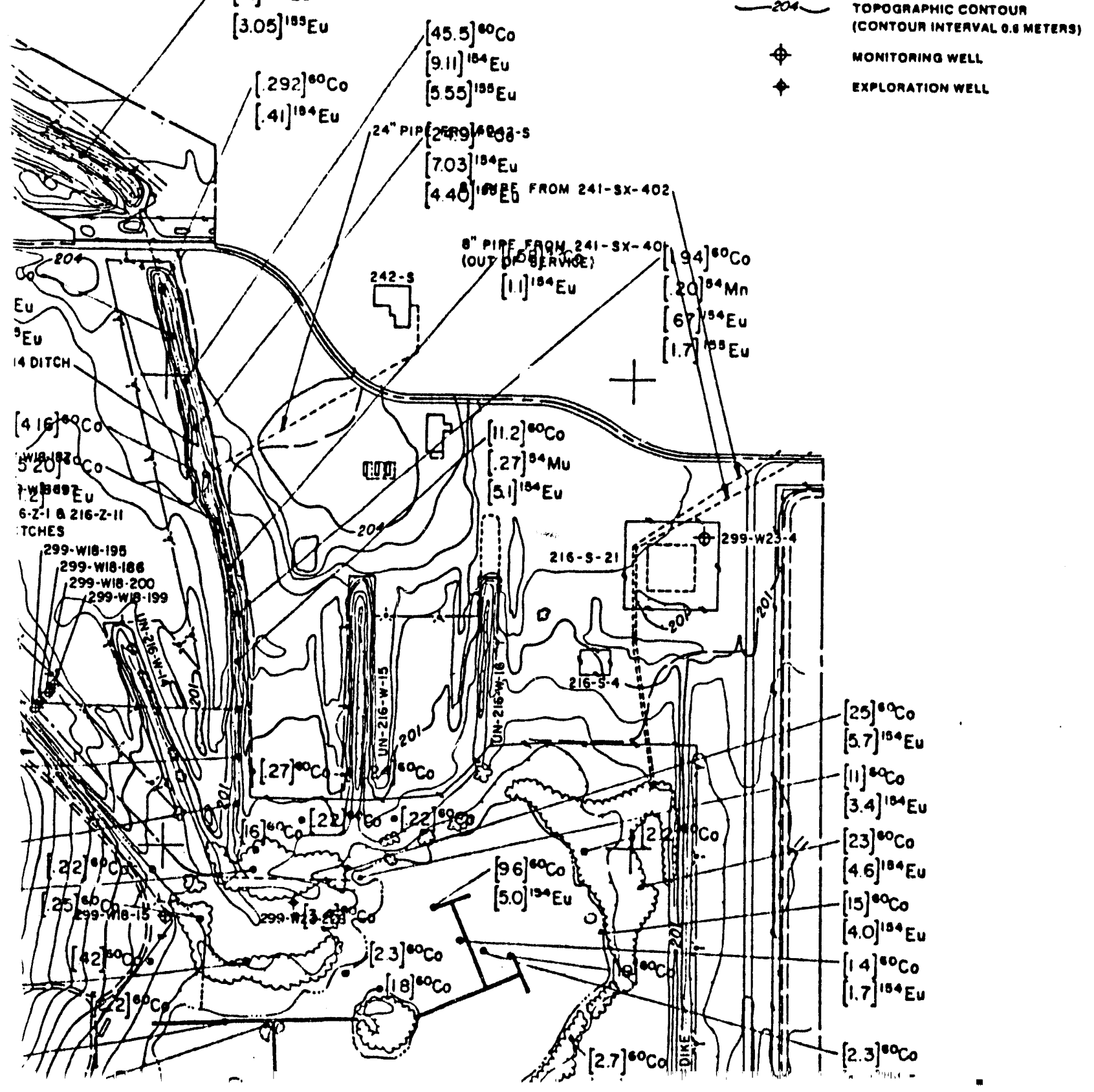

LEGEND

(…ㄱ) РОNo (ExIstine shoneLINE)

cmoms rmets

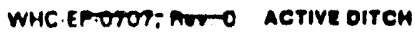

---- DACKFILLLO OTTCH

Dunied PIPELINe on culvent

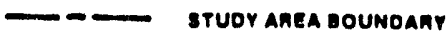

- ' $:$ - MADIATION ZONE

= PAVEDROAO

$==ニ=ニ$ OIRT ROAD - WELL USEO

- SELDOM USEO

TOPOQRAPHIC CONTOUA

$\$$ monitonime well.
8
8
0
01
3

rence 


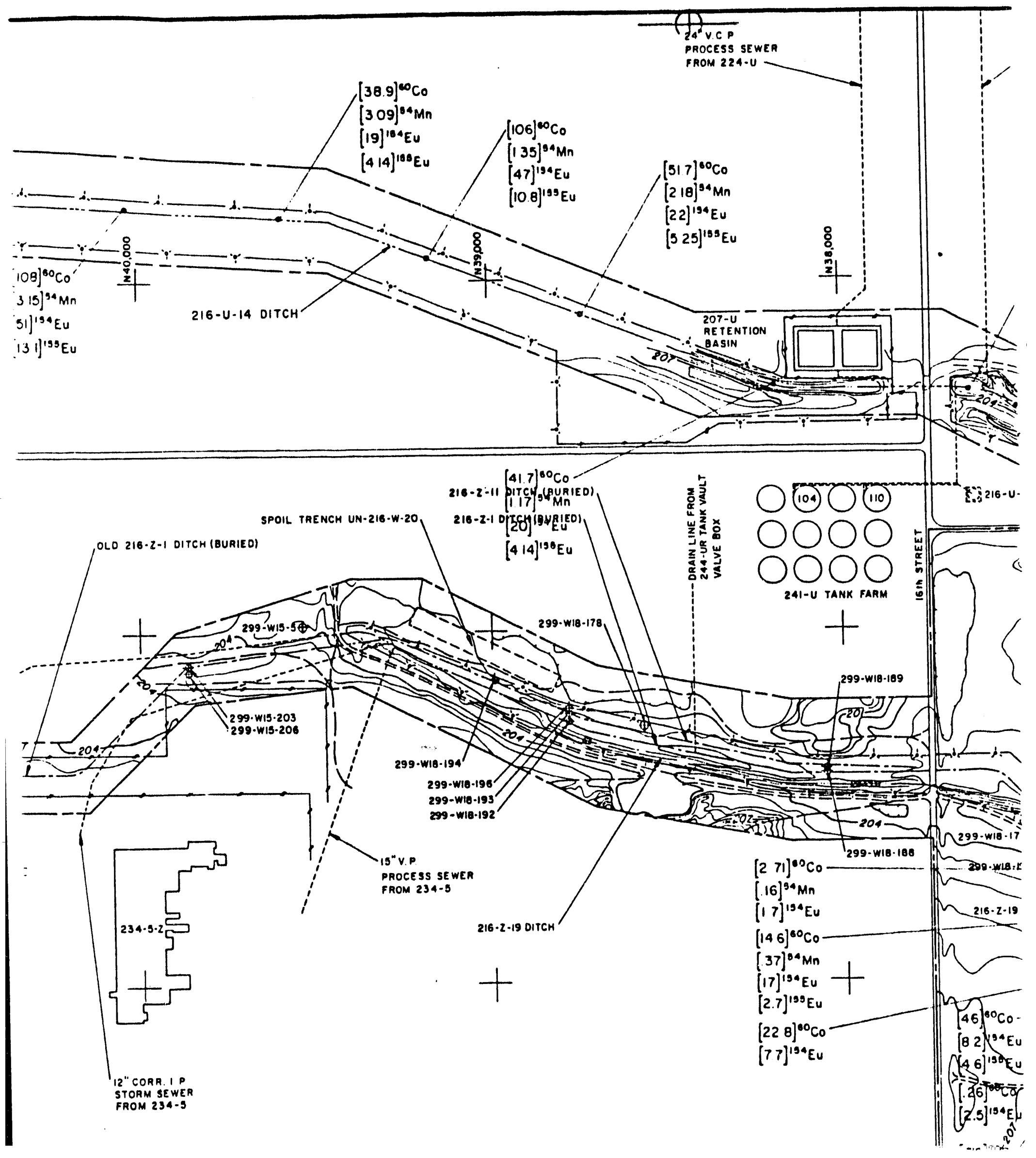




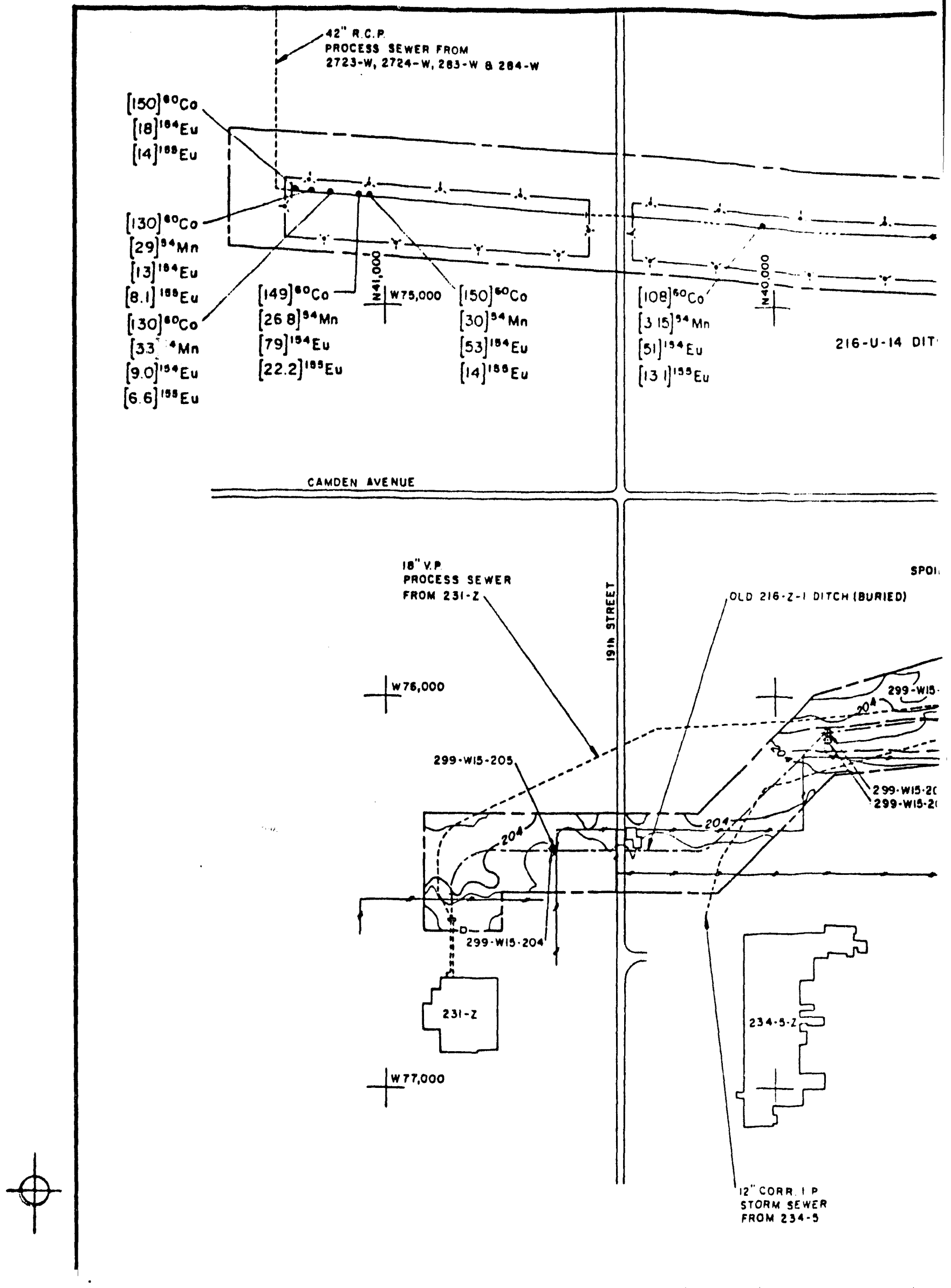




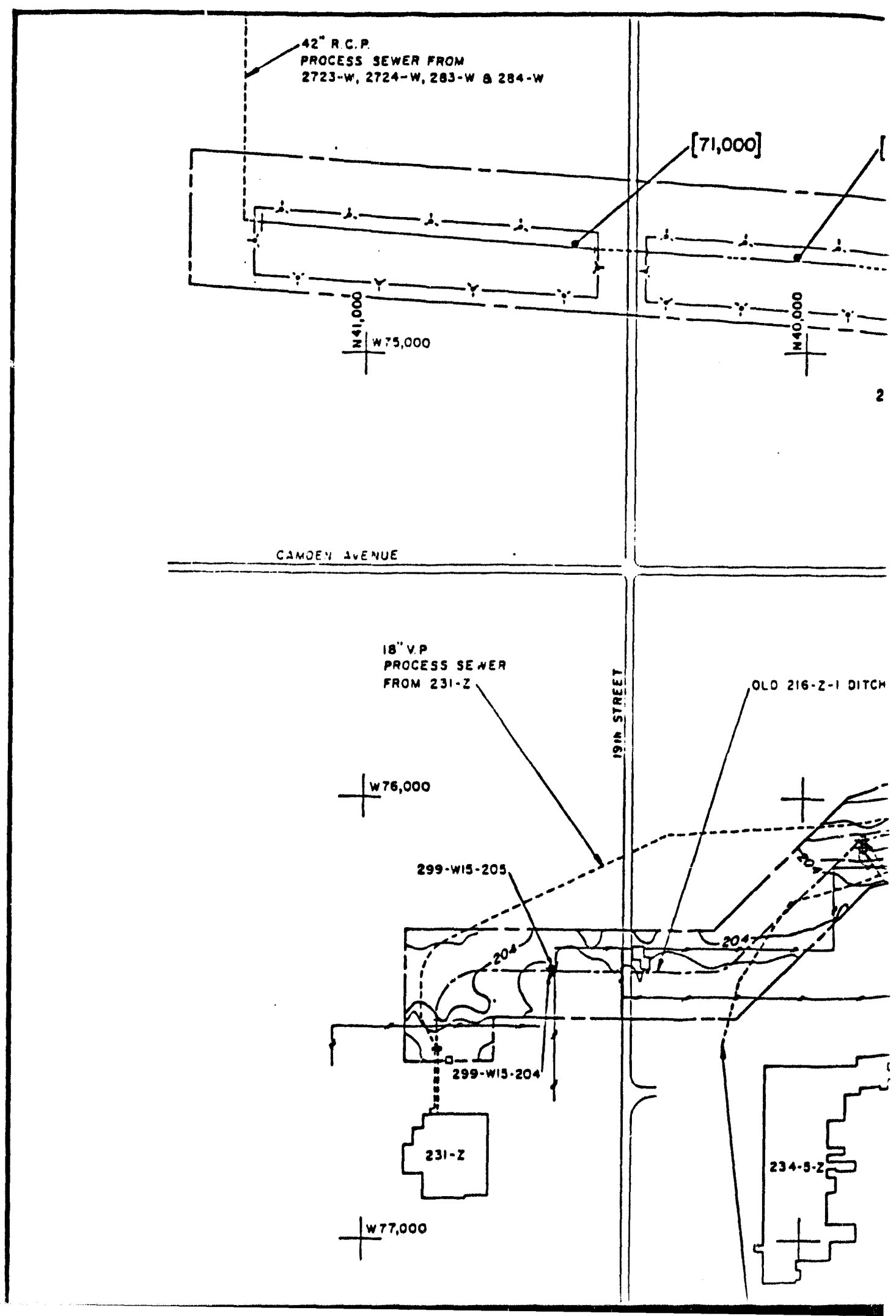




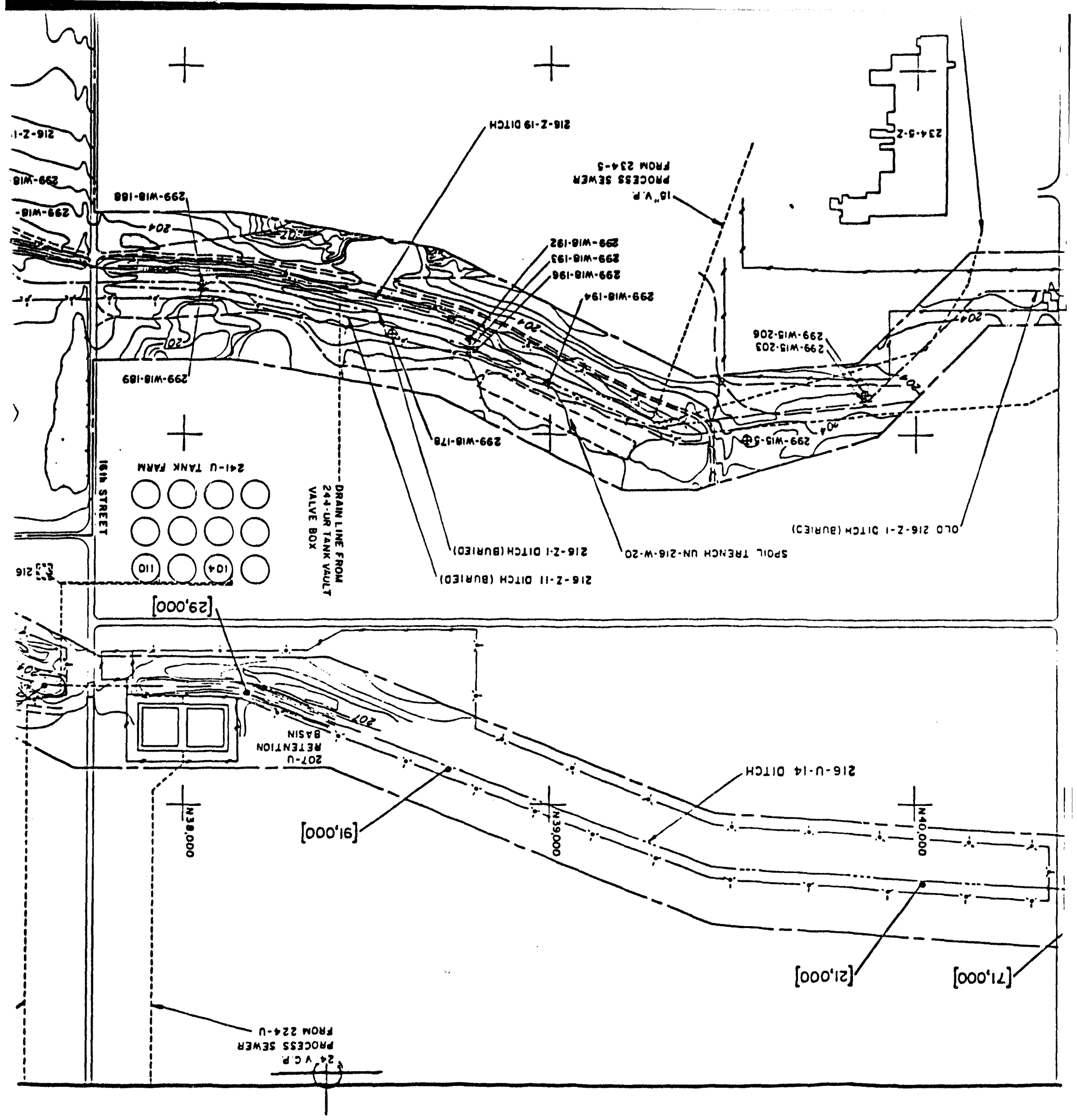




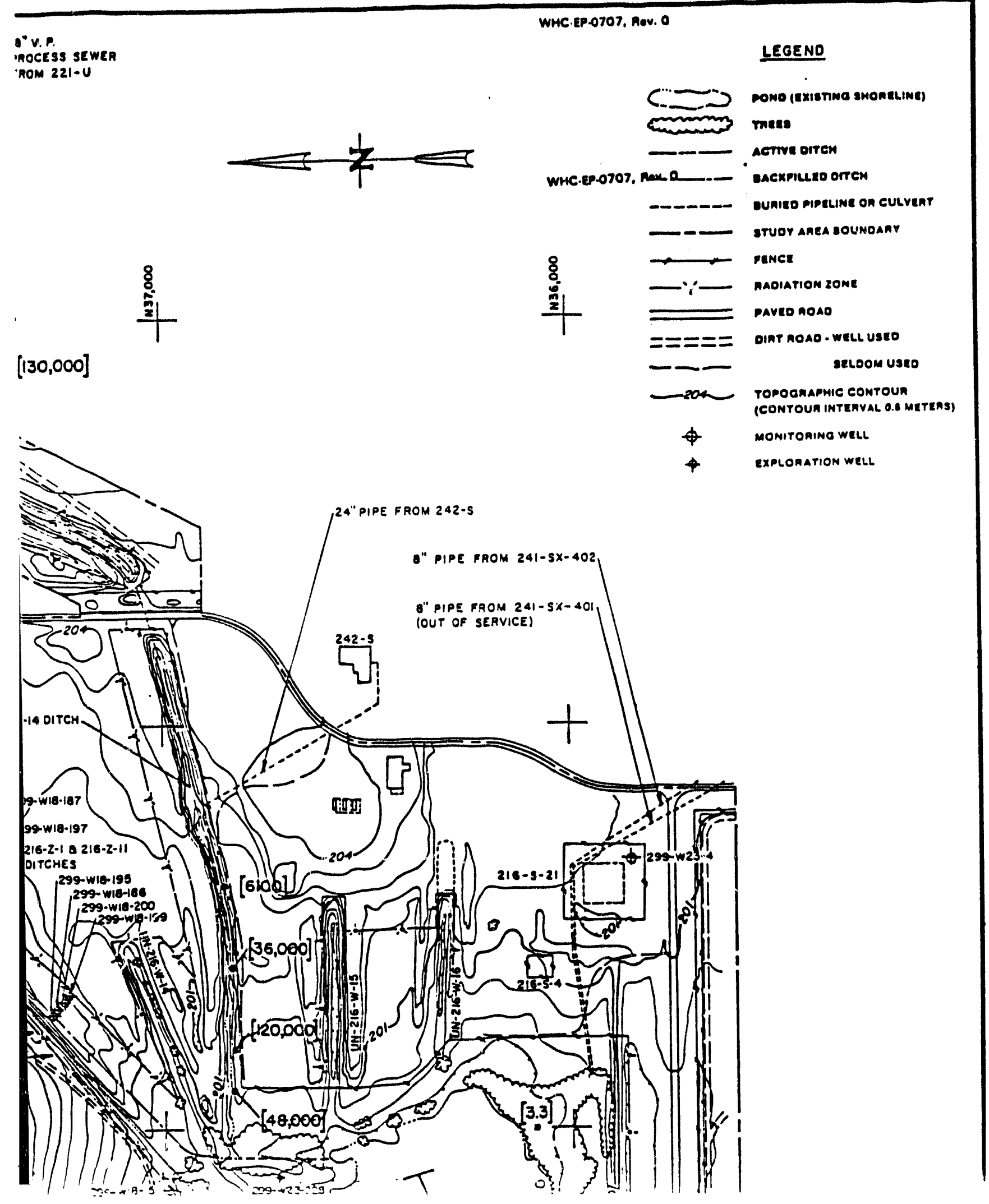




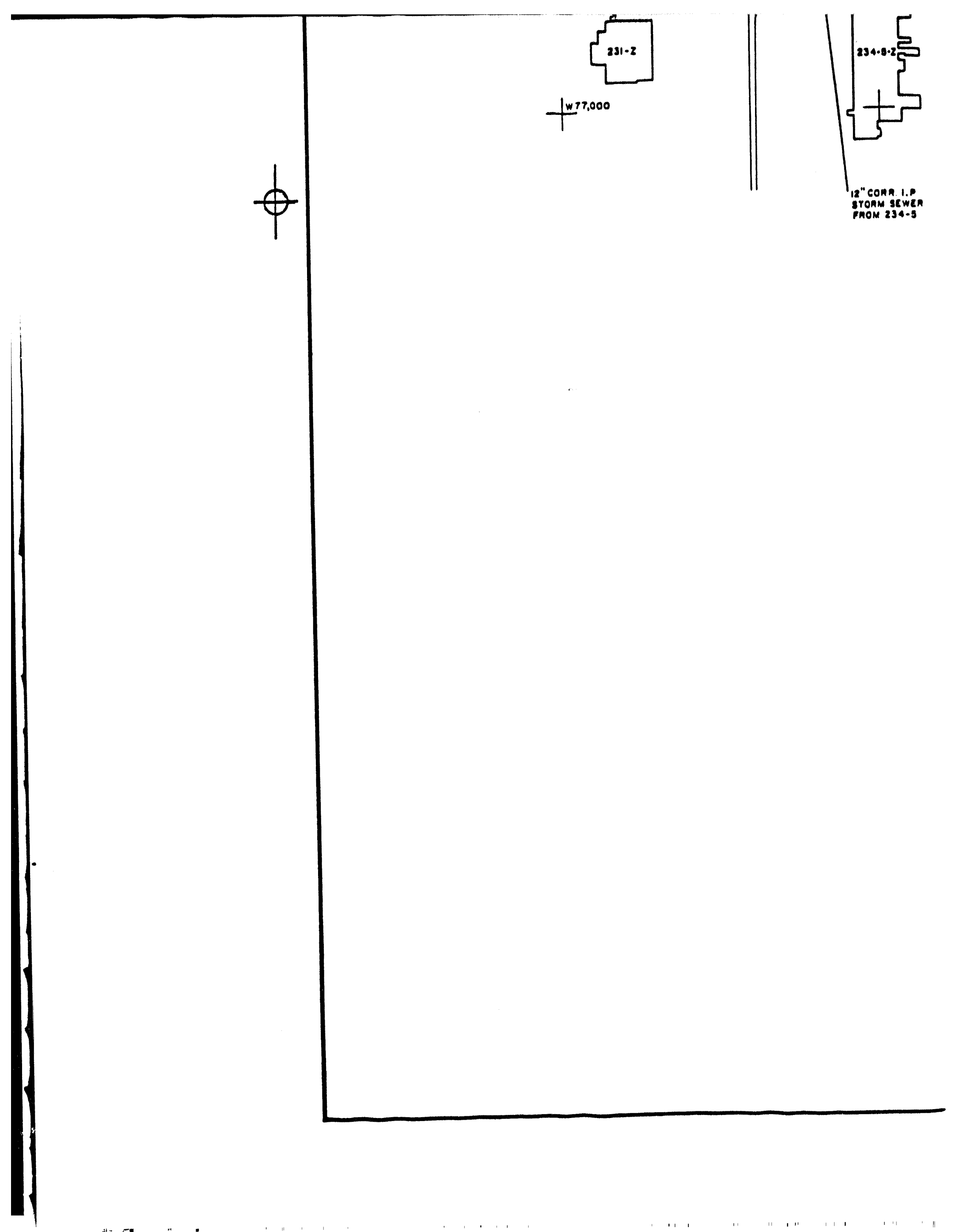



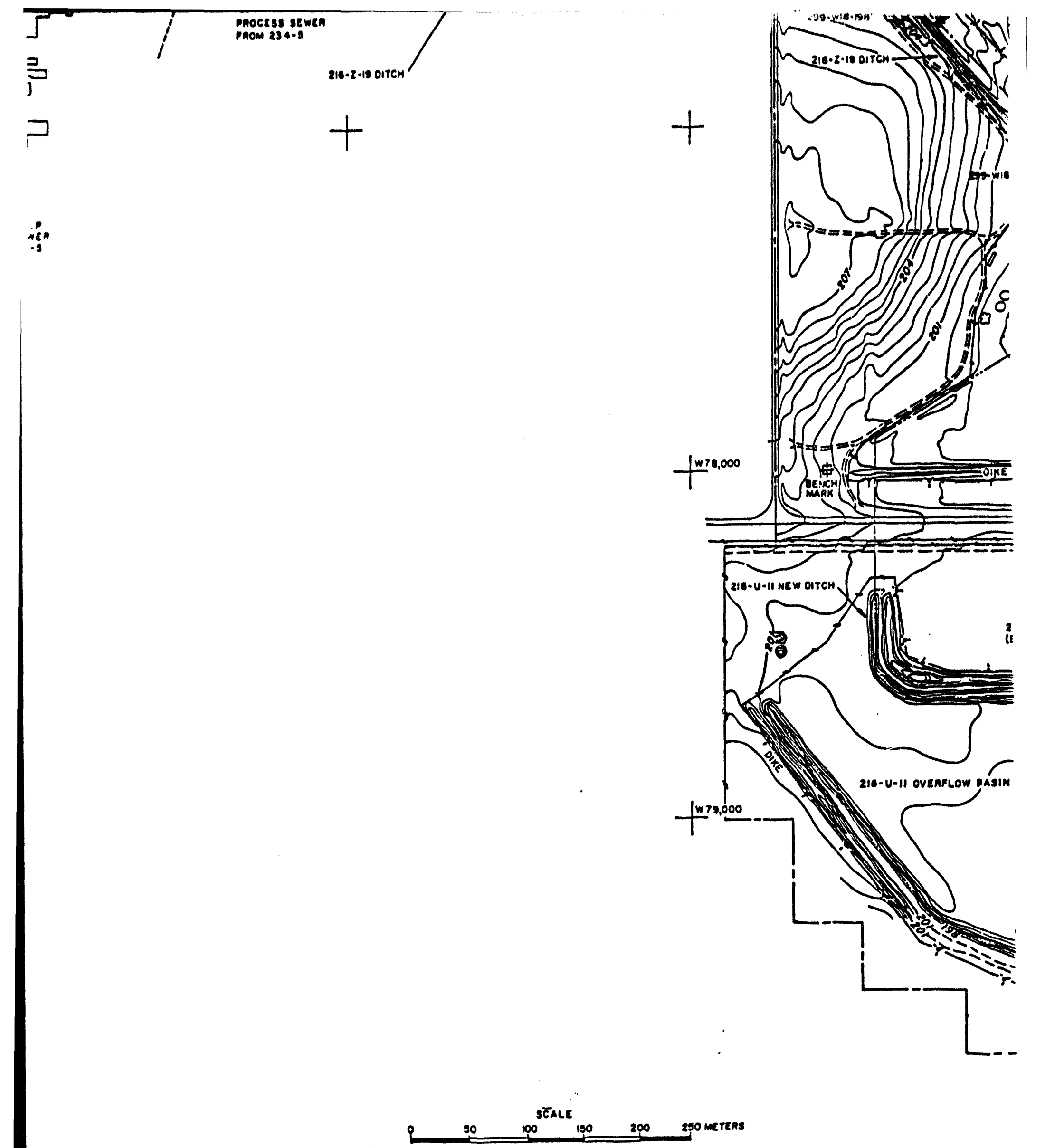


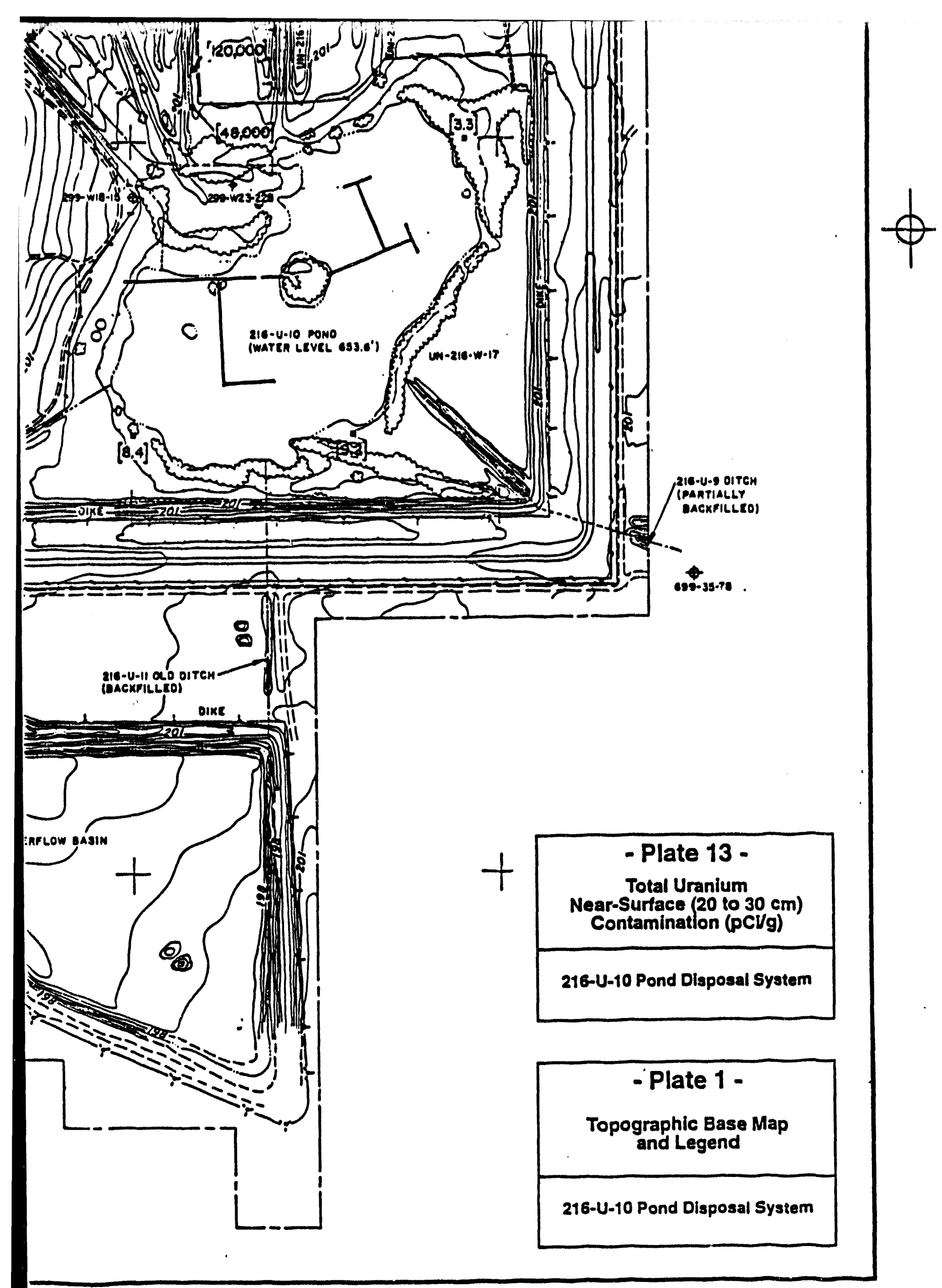



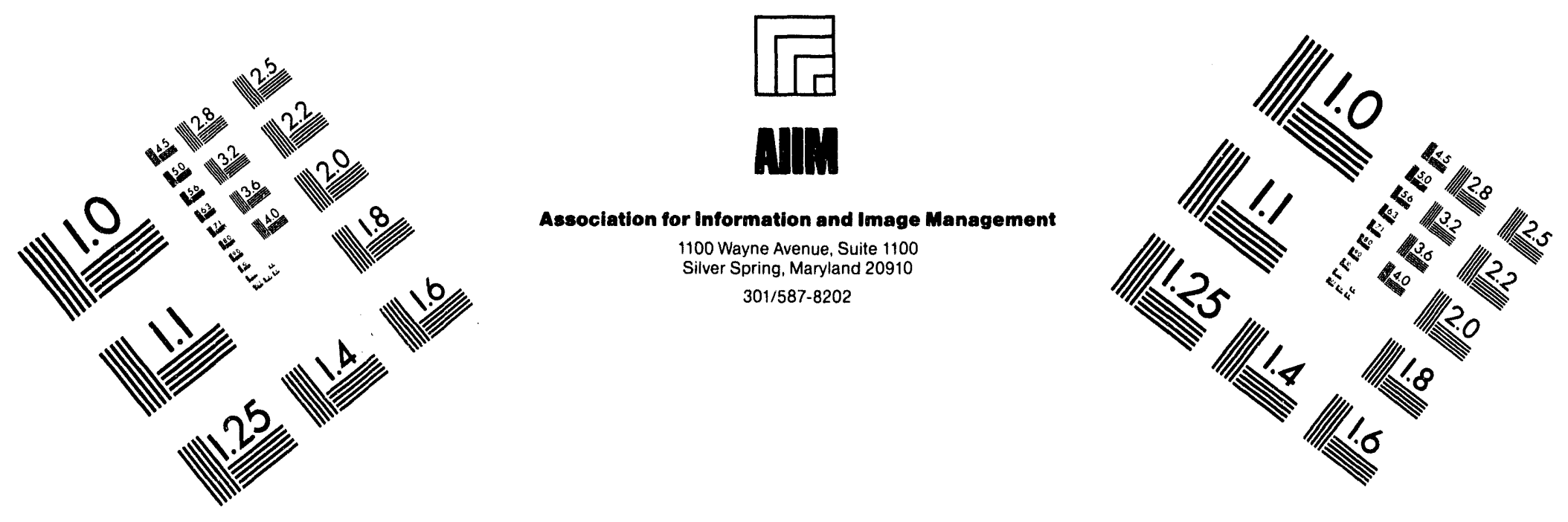

\section{Centimeter}

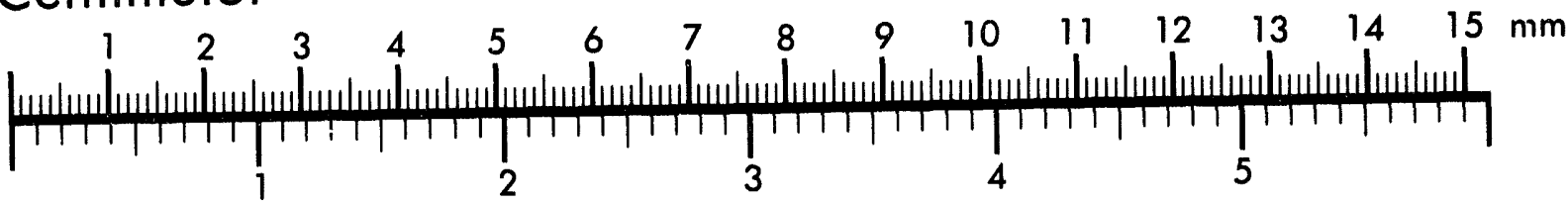
Inches
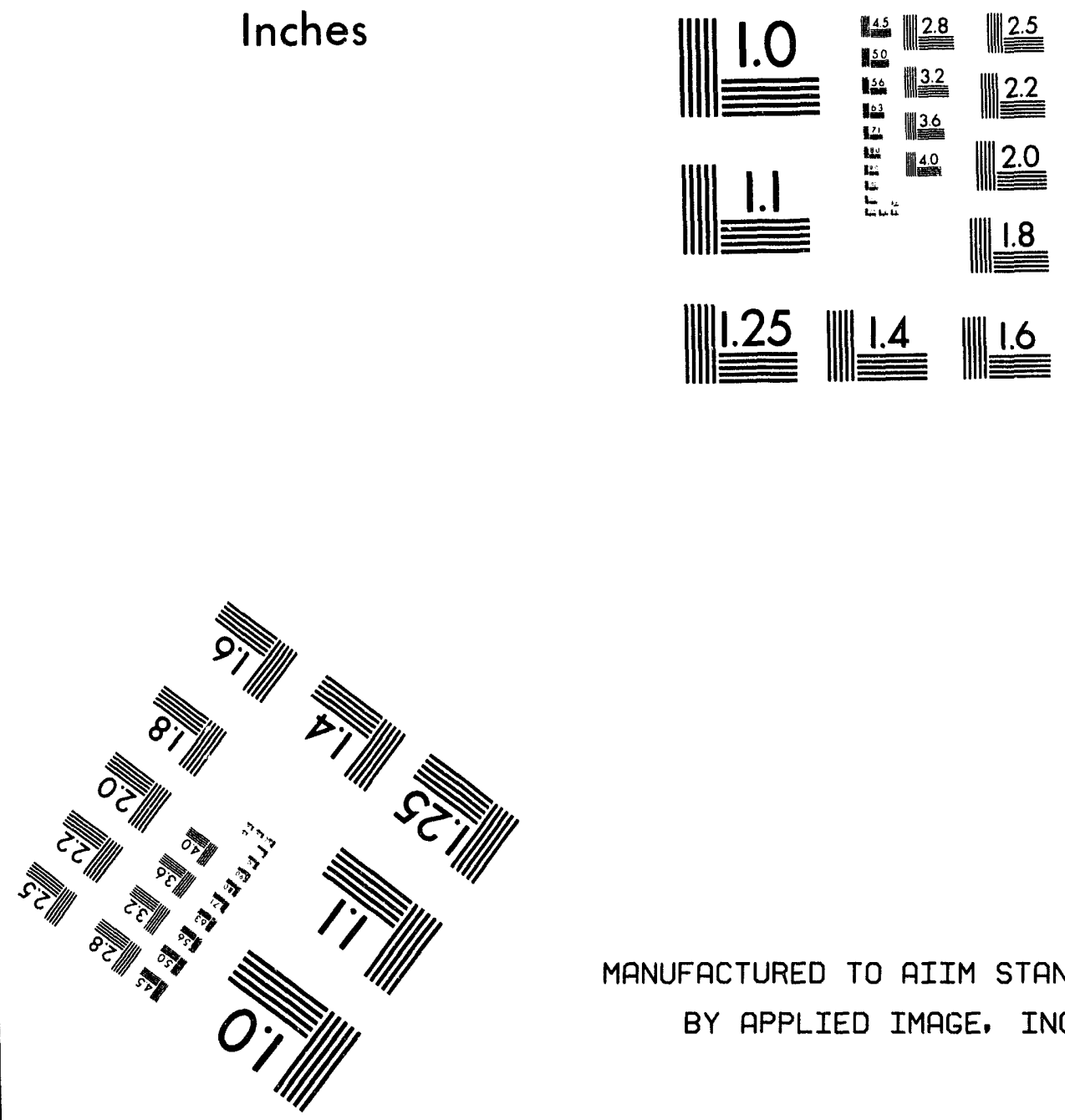

MANUFACTURED TO AIIM STANDARDS BY APPLIED IMAGE, INC.

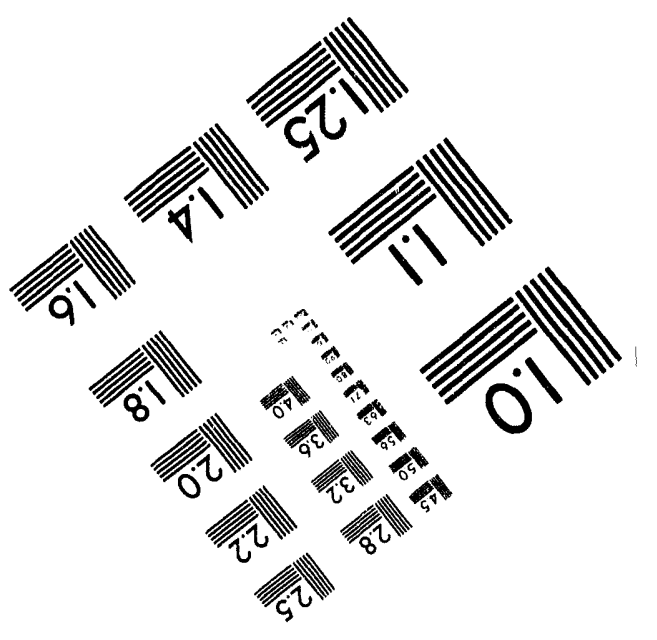



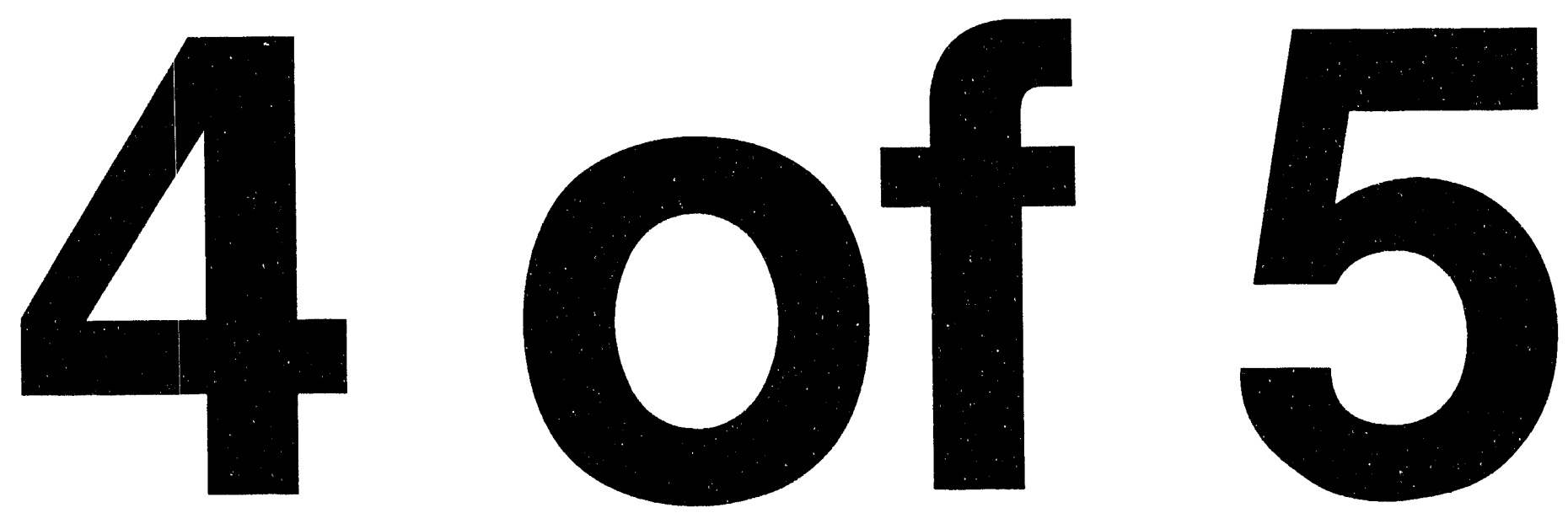
WHC-EP-0707, Rev. 0

Appendix A

Sediment Analyses from U-Swamp and 234-5 Ditch 
○

○

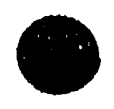


L. H. Kaleints

lionater, control operetlons

Flalabed Products Operatiaz

234-5 Distlitag, 200-Wect

KOD AULYES IRX: U-CHR:D ND 234-5 DIMCH

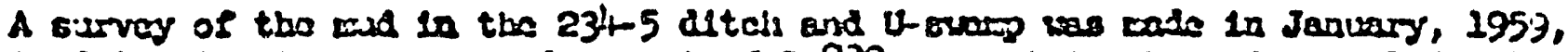
to deterwine the extent and wownt of Pu230 present in thece dioposal facillties.

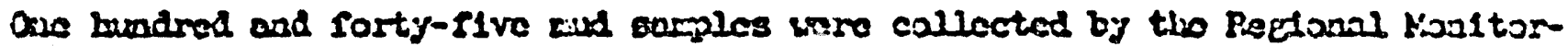

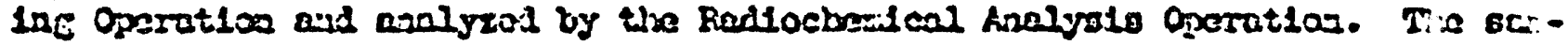

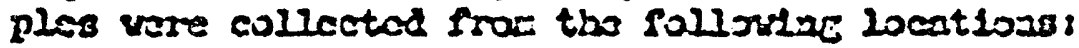

1. 23't-5 Ditch pipe outlet

2. Turee casples at 100 - foot laterrale along the eatlre lezith of tho diteh

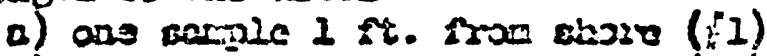

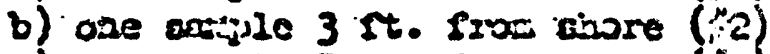

c) ons ansle 5 ft. Irom share (i 3 )

3. U-susto Inlet

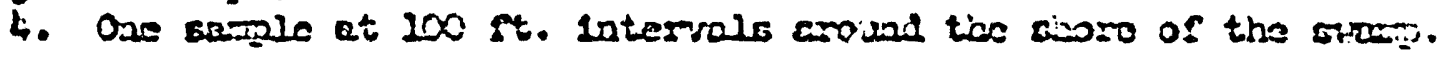

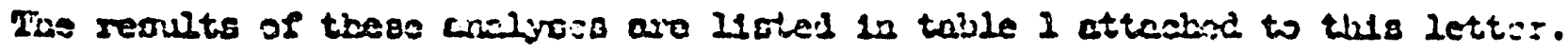

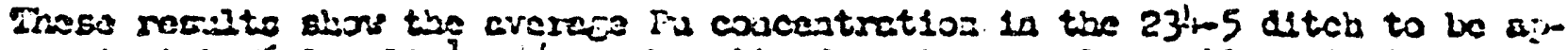

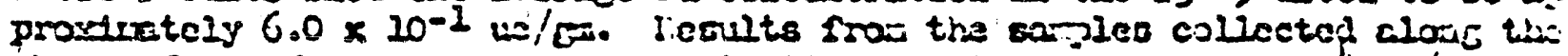

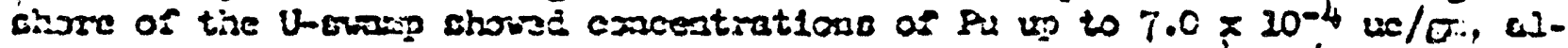

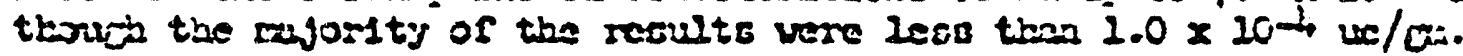

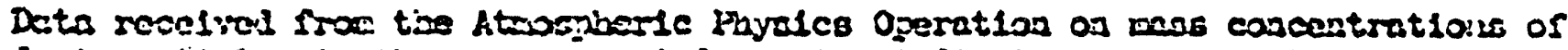

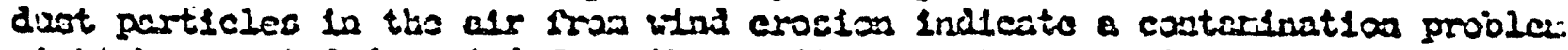

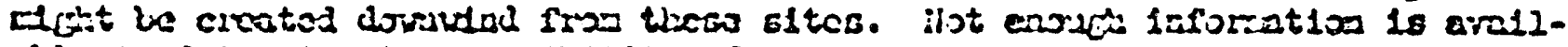
able to detcrisina tbe poariblitity of ouch an ocourresen.

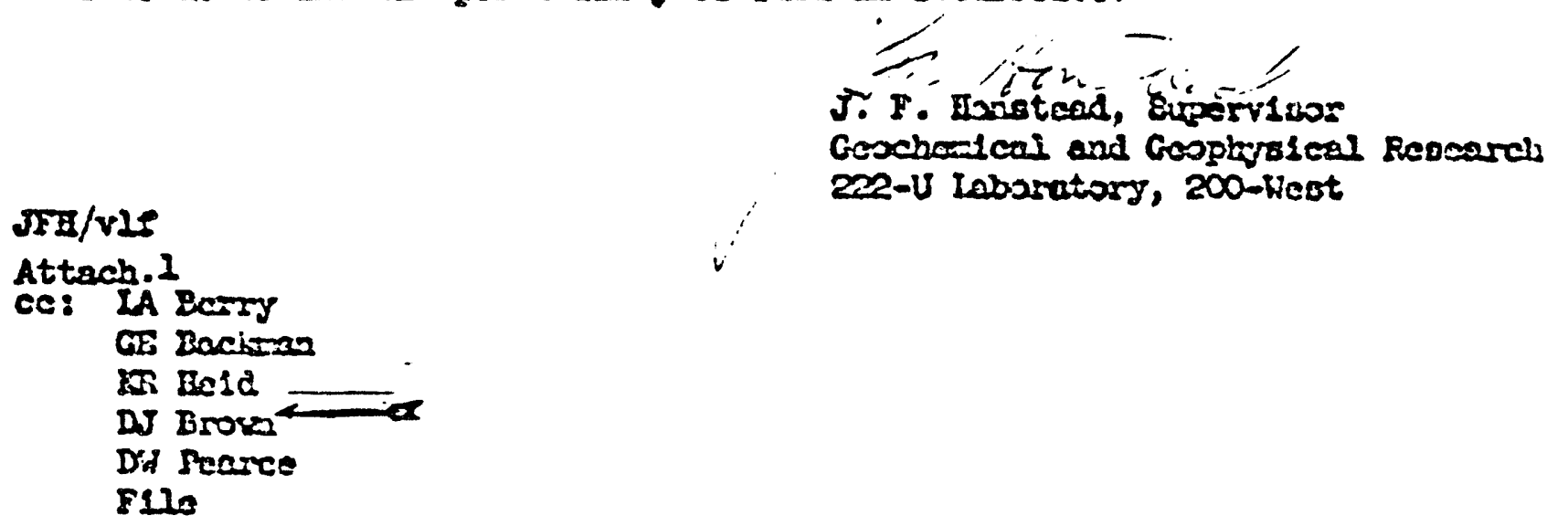


ANALYTICAL REPORT

HLO ANALYTICAL LAEOAATORIES OPERATION

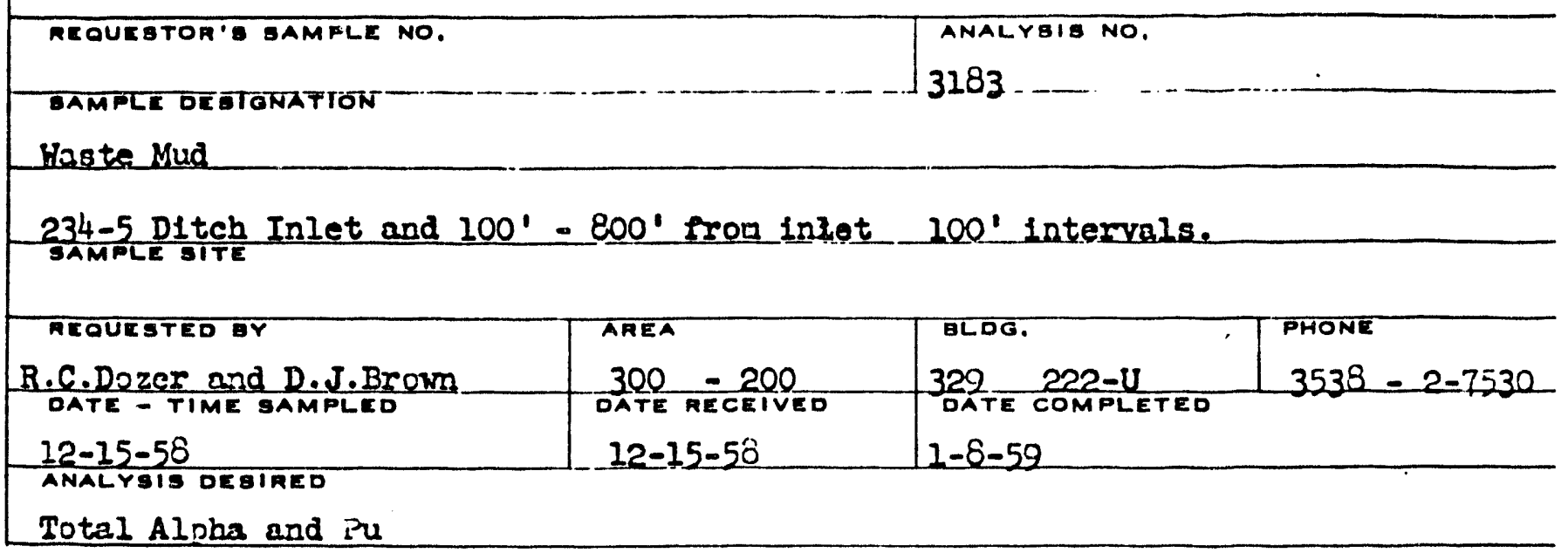

uc/era=

Sample Ho.

$1700234-5$ DITCH INLET

Total Alpha.

$8.6 \times 10^{-1}$

1301100 FEET FROM. INLET

$1902200 " 1.1 \times 10^{-1}$

$1903300 " 11 " 11.5 \times 10^{-2}$

1904400 " " $" 2.6 \times 10^{-2}$

$1305500 "$ " " $3.3 \times 10^{-2}$

$1906600 "$ " $" 3.9 \times 10^{-1}$

$1907700 "$ " " $5.9 \times 10^{-2}$

$1908800 "$ " $" 5.4 \times 10^{-1}$
Pu

$75 \times 10^{-1}$

$3.4 \times 10^{-2}$

$8.9 \times 10^{-2}$

$4.6 \times 10^{-2}$

$2.4 \times 10^{-2}$

$3.3 \times 10^{-2}$

$3.1 \times 10^{-1}$

$3.8 \times 10^{-2}$

$7.6 \times 10^{-1}$

cc: D.J.Brow

AP B1nder

File

WIM 2-8-59

wepes

A. 2 


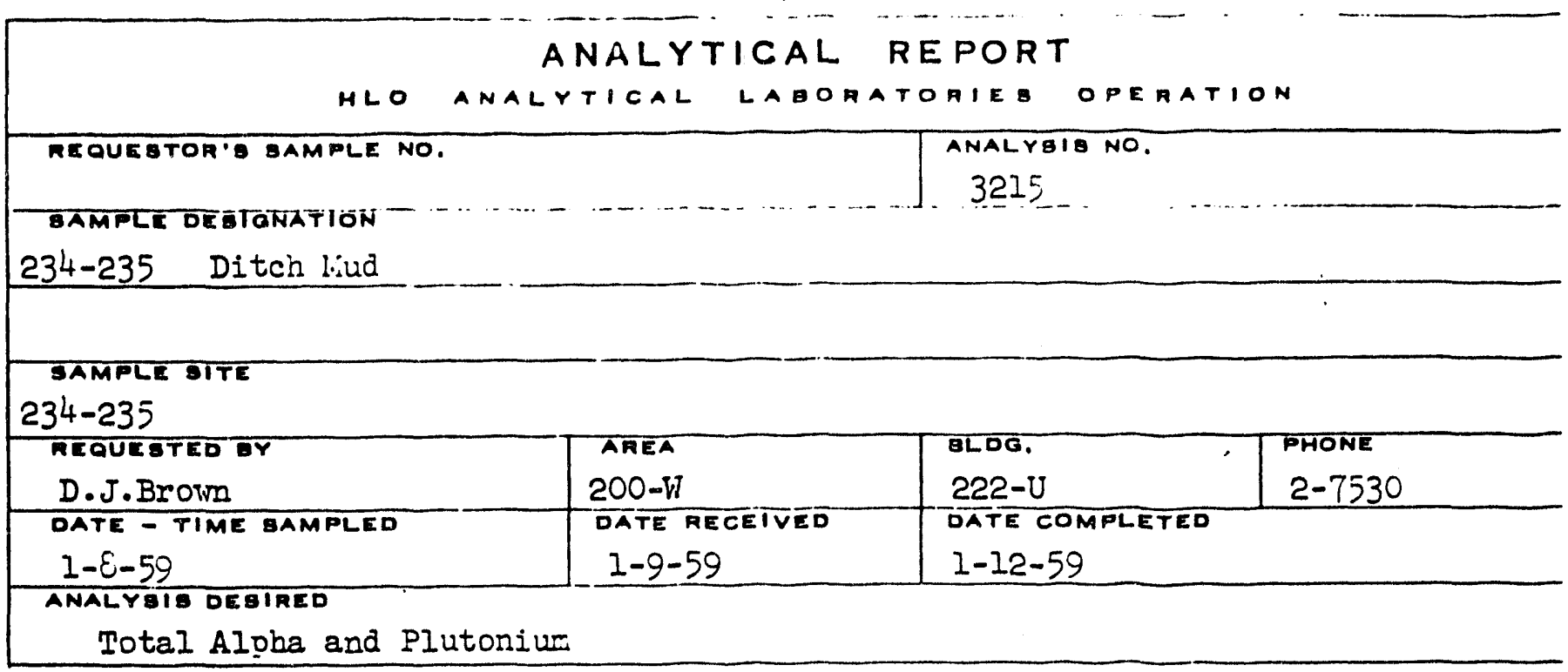

Samole INo.

234-235 Ditch

Inlet $\frac{\| 1}{\pi}$

Inlet $\pi$

Inlet

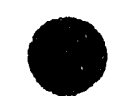

234-235 Ditch $100^{\prime}$

from Inlet

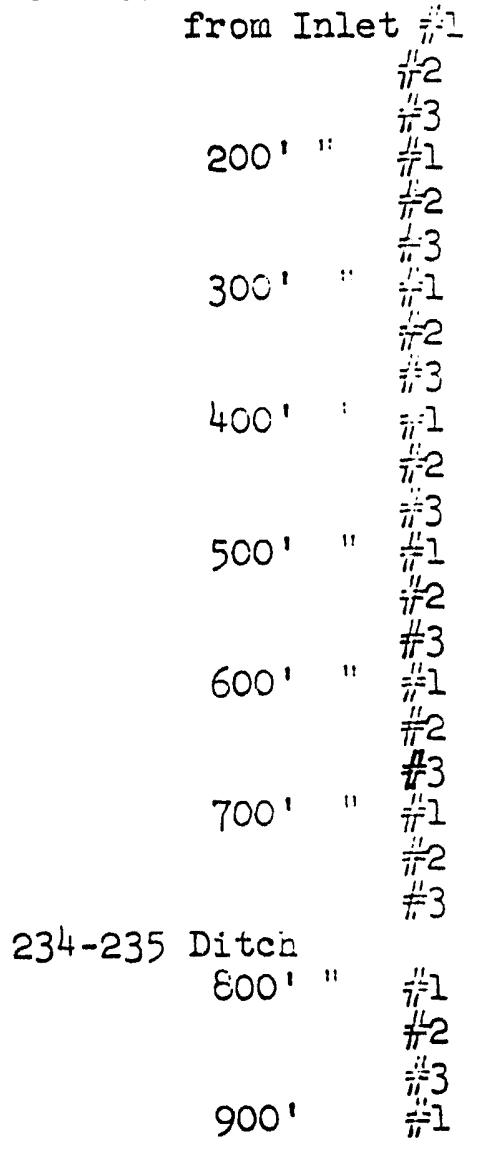

uc/gram

Total Aloha

$P_{u}^{239(1)}$

$8.6 \times 10^{-1}$

$3.1 \times 10^{-2}$

$4.6 \times 10^{0}$

$7.5 \times 10^{-1}$

$2.3 \times 10^{c}$

$4.2 \times 10^{-1}$

$96 \cdot 9 ;$

$97 \cdot 0 \%$

$3.6 \times 1 C^{-i}$

$1.3 \times 10-2$

$6.6 \times 10^{-2}$

$4.7 \times 10^{-1}$

$1.3 \times 10^{0}$

5. $0 \times 10^{-3}$

$1.5 \times 10^{0}$

$1.7 \times 10^{-1}$

$1.5 \times 10^{-2}$

$2.0 \times 10^{-3}$

$2.3 \times 10^{-2}$

$5.0 \times 10^{-3}$

$2.9 \times 10^{-2}$

$4.1 \times 10^{-2}$

$2.5 \times 10^{-2}$

$1.3 \times 10^{\mathrm{C}}$

$1.9 \times 10^{-2}$

$7.3 \times 10^{-3}$

$3.9 \times 10^{-1}$

$5.6 \times 10^{-3}$

$3.4 \div 10^{-1}$

$97 \cdot 5 \%$

qú.3\%

$5.0 \times 10^{-2}$

$4.2 \times 10^{-1}$

$27.1 \times 10^{0}$

$4.3 \times 10^{-2}$ 
ANALYTICAL REPORT

HLO ANALVTICAL LABOAATOAIEB OPERATION

REQUEBTOR'B BAMPLE NO.

BAMFLE DE BTOAATTON ANALYBIB NO.

$32] .5$

GAMPLE STTE

\begin{tabular}{l|l|l|l}
$\begin{array}{l}\text { REOUESTED GY } \\
\text { D.J.BYOWM }\end{array}$ & BLOG. & PHONE \\
\hline OATE - TIME GAMPLED & DATE RECEIVED & DATE COMPLETED & \\
\hline
\end{tabular}

ANALYSIB DEGIAEO

uc / sram

Sample rio.

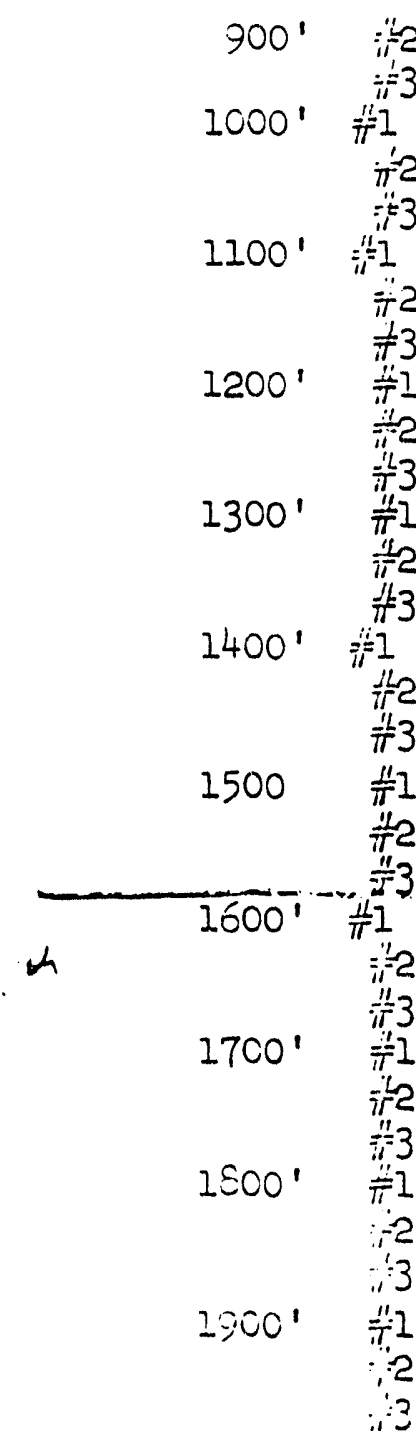

Total Alpha

$z^{239(1)}$

$7.5 \times 10^{-2}$

$1.6 \times 10^{-1}$

$4.4 \times 10^{-1}$

$4.0 \times 10^{-2}$

$7.0 \times 10^{-2}$

$2.9 \times 10^{-3}$

$1.5 \times 10^{-1}$

$3.4 \times 10^{-1}$

$0.5 \times 10^{-2}$

$2.2 \times 10^{-1}$

$1.2 \times 10^{-1}$

$4.5 \times 10^{-2}$

$1.1 \times 10^{-2}$

$7.8 \times 10^{-3}$

$1.5 \times 10^{-1}$

1. $气 \times 10^{-2}$

$5.2 \times 10^{-2}$

$4.6 \times 10^{-2}$

$9.0 \times 10^{-2}$

$6.9 \times 10^{-2}$

* $1.7 \times 10^{\circ}$

$\times 1.4 \times 10^{-1}$

$1.2 \times 10^{-2}$

$8.7 \times 10^{-2}$

$9.8 \times 10^{-3}$

$2.7 \times 10^{-2}$

. $1.8 \times 10^{-1}$

$5.3 \times 10^{-3}$

$3.3 \times 10^{-2}$

I.2 $\because 10^{-1}$

$\because 2: 1010-3$

A.4 $2.3 \times 10^{-3}$ 
ANALYTICAL REPORT

HLO ANALYTICAL LABORATORIEB OPERATION

\begin{tabular}{l|l} 
REQUEBTOR'D BAMPLE NO. & ANALYBIS NO. \\
BAMPLE OEETONATTON- & 32I \\
\hline
\end{tabular}

\begin{tabular}{|c|c|c|c|}
\hline SAMPLE STTE & & & \\
\hline $\begin{array}{l}\text { AEOUEGTED BY } \\
\text { D.J.BroWm }\end{array}$ & AREA & ELDG. & PHONE \\
\hline DATE - TIME SAMPLED & DATE RECEIVED & DATE COMPLETED & \\
\hline
\end{tabular}

ANALYSIS DEBIRED

גa/ Ira:

Sar...jle :io.

Total Aljina

$23 \div-235$ Ditch $2000^{\prime}$ from

Inlet

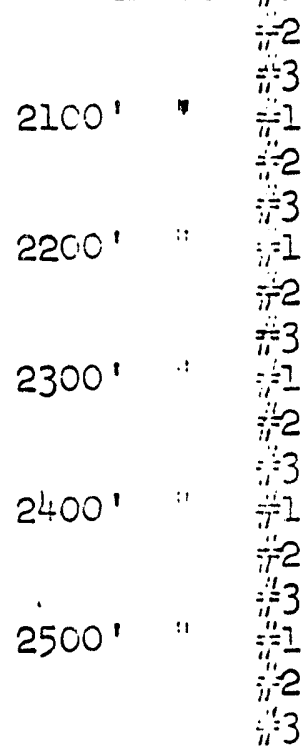

$1.6 \times 10^{-2}$

$+5.0 \times 10^{-1}$

$1.5 \times 10^{-2}$

$2.5 \times 10^{-2}$

$1.4 \times 10^{-2}$

$2.7 \times 10^{-2}$

$7.0 \times 10^{-3}$

$7.4 \times 10^{-3}$

$+1.5 \times 10^{-1}$

$5.5 \times 10^{-2}$

$4.3 \times 10^{-2}$

$3.6 \times 10^{-2}$

$3.5 \times 10^{-2}$

$7.0 \times 10^{-3}$

$2.4 \times 10^{-3}$

$2.6 \times 10^{-3}$

$1.5 \times 10^{-2}$

$1.6 \times 10^{-3}$

(1) Percent $\mathrm{Pu}^{239}$ determined by alpha ener $\because$ analysis.

:ote: Residue reraining from the original extraction of eicht of the samples ras re-extracted for tctal al ina determination. An averare of $1.3 \%$ of the orginally extracted alpia activity ias obtained on re-extraction. This would indicate that $>95^{\circ}$, of the activity was extracted in the original extract. 
ANALYTICAL REPORT

HLO ANALYTICAL LABOAATORIEB OPERATION

\begin{tabular}{l|l} 
REOUEBTOA' BAMPLE NO. & ANALYBIB NO.
\end{tabular}

BATM TLE OETERATTON

3230

Pare I:-

"U" Stramp Inlet and arounà edie, erery 100 feet.

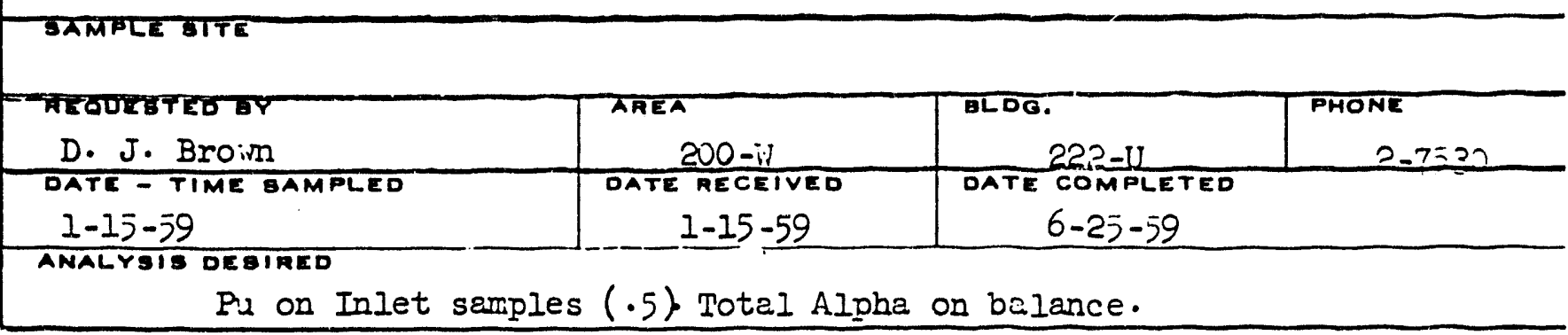

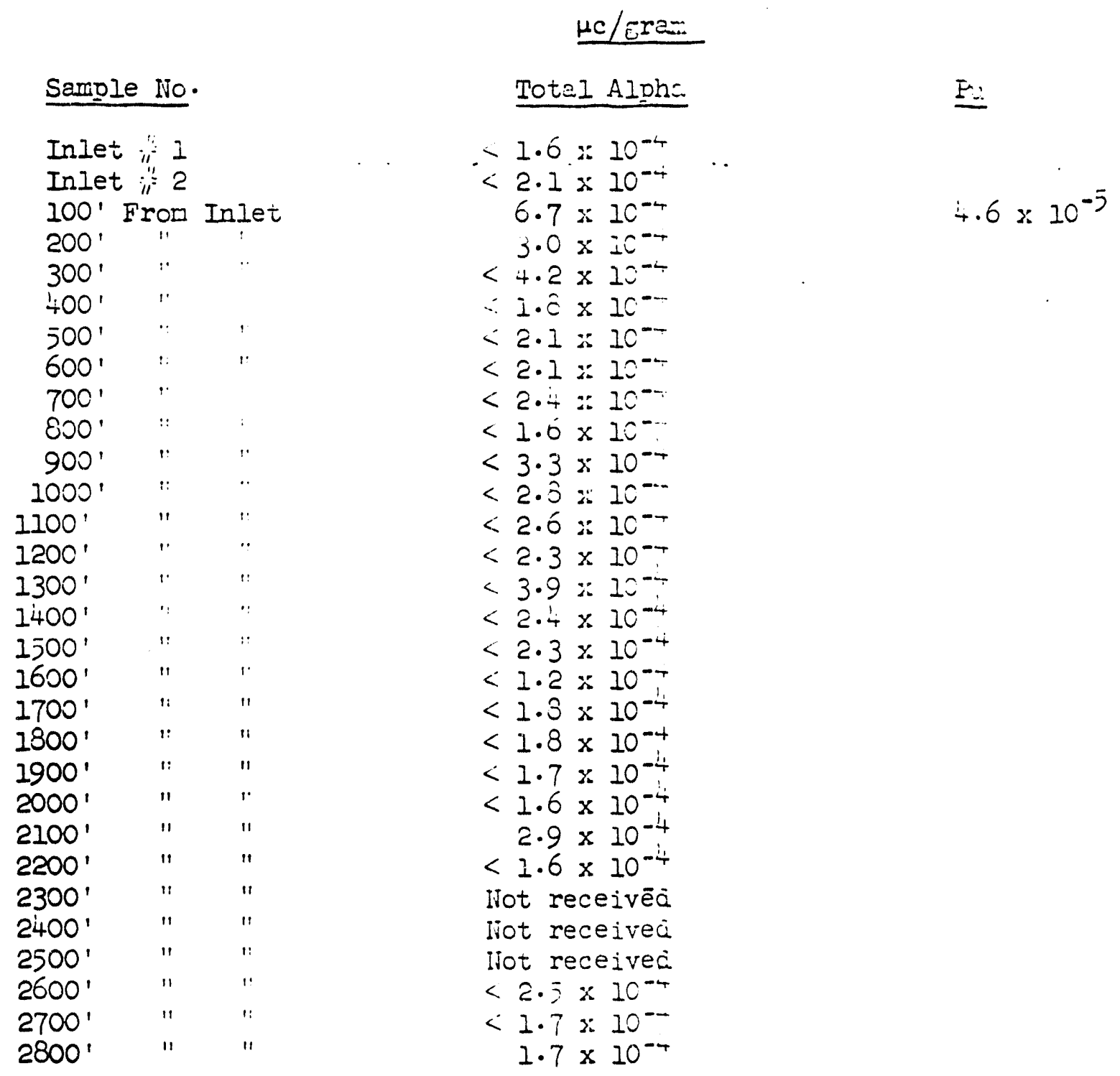

A. 6 
WHC-EP-0707, Rev. 0

ANALYTICAL REPORT

HLO ANALYTICAL LAEOAATORIE OPERATION

\begin{tabular}{|c|c|c|}
\hline NEOUEBTOR'S SAMPLE NO. & & $\begin{aligned} \text { ANALYBIB NO. } & \\
3230 & \text { Page }\end{aligned}$ \\
\hline \multicolumn{3}{|l|}{ BAMTFCE OESTINATIOA } \\
\hline \multicolumn{3}{|l|}{ SAMTLE STTE } \\
\hline RTOULSTEOTY & ATEA & PHONE \\
\hline DATE - TIME BAMPLED & DATE RECEIVED & DATE COMPLETED \\
\hline ANALYSIS DESIRED & & \\
\hline
\end{tabular}

\section{$\mu \mathrm{c} / \mathrm{Tram}$}

汪品le No.

Total Alpha

2900' From Inlet

$2.4 \times 10^{-4}$

$3000^{\prime}: 1:$

$<1.3 \times 10^{-4}$

3100

$<1.7 \times 10^{-1}$

3200

$<1.3 \times 10^{-4}$

$3300^{\prime}$

$<1.0 \times 10^{-}$

$3 \div 00$

$<1.6 \times 10^{-4}$

$3500^{\prime}$

$1.9 \times 10^{-4}$

3600

$<2.0 \times 10^{-7}$

$3700^{\prime}$

$<1.7 \times 10^{-}$

$3500^{\circ}$

$<1.3 \times 10^{-4}$

$3900^{\prime}$

$<1.4 \times 10^{-4}$

$-000^{\circ}$

$+100^{\prime}$

$<2.0 \times 10^{-4}$

$<2.2 \times 10^{-4}$

$1.45 \times 10^{-4}$

$\div 200$

$1.4 \times 10^{-4}$

$\div 300^{\prime}$

4400 '

$4500^{\prime}$

$4600^{\prime}$

$4700^{\prime}$

$4300^{\prime}$

$4900^{\prime}$

;000'

$<1.3 \times 10^{-1}$

$<1.6 \times 10^{-4}$

$<1.3 \times 10^{-4}$

$2.0 \times 10^{-4}$

$<1.6 \times 10^{-4}$

$<1.4 \times 10^{-4}$

INot received

iote: These samples :ere held for severil reeks for aditional analyses but vere accidently discarded before the analyses rere run.

zC: RC Dozer

inn: $6-25-59$

$\therefore$ P Binder

File

A.7

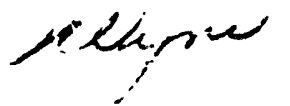




\section{$8^{\circ} \mathrm{V}$}

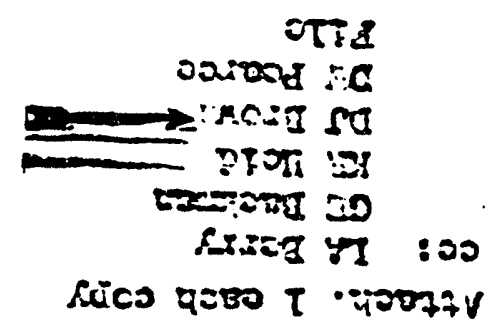

$\operatorname{TA,H}$

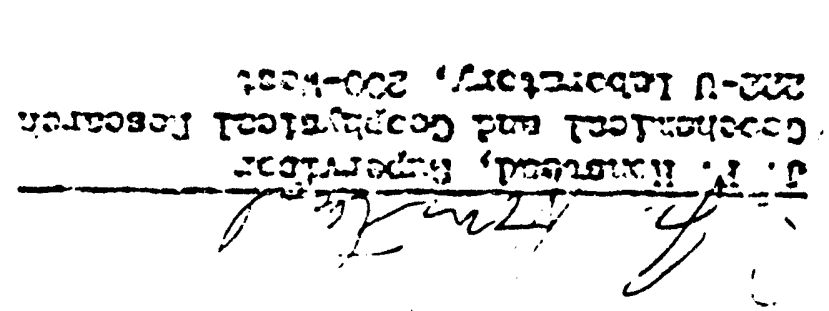

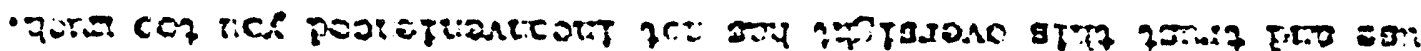

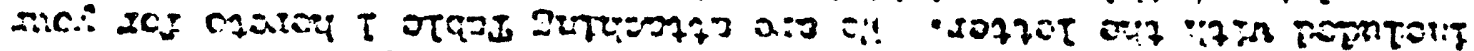
icli aisa

$$
\begin{aligned}
& \text { एक. } \\
& \text { Tinisa }
\end{aligned}
$$

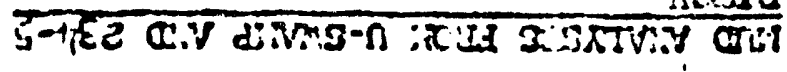


Date Sampled 1-15-59

\begin{tabular}{|c|c|c|c|c|c|c|c|c|c|c|c|c|c|}
\hline & $\begin{array}{l}\text { Samplin } \\
\text { Locatio }\end{array}$ & & & & $\begin{array}{l}\text { Total Alpha } \\
\left(10^{-4} \mathrm{uc} / \mathrm{gm}\right)\end{array}$ & $\underline{\mathrm{Pu}}$ & $\begin{array}{l}\text { Sampl } \\
\text { Locat }\end{array}$ & $\begin{array}{l}\text { ling } \\
\text { tion }\end{array}$ & & & $\begin{array}{l}\text { Tot: } \\
(10 \\
\end{array}$ & $\begin{array}{l}\text { al Alpha } \\
-4 \mathrm{uc} / \mathrm{gm})\end{array}$ & Pu \\
\hline $\begin{array}{r}U-s \\
U-s \\
100 \\
200 \\
300 \\
400 \\
500 \\
600 \\
700 \\
800 \\
900 \\
1000 \\
1100 \\
1200 \\
120 \\
10 \\
1500 \\
1600 \\
1700 \\
1800 \\
1900 \\
2000 \\
2100 \\
2200 \\
2600 \\
2700 \\
2800\end{array}$ & 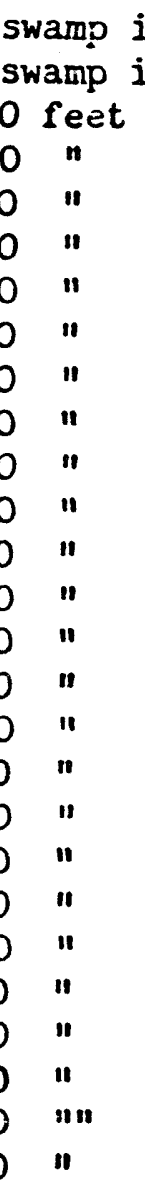 & $\begin{array}{c}\text { inlet } \\
\text { inlet } \\
\text { from } \\
\text { " } \\
\text { " } \\
\text { " } \\
\text { " } \\
\text { " } \\
\text { " } \\
\text { " } \\
\text { " } \\
\text { " } \\
\text { " } \\
\text { " } \\
\text { " } \\
\text { " } \\
\text { " } \\
\text { " }\end{array}$ & $\begin{array}{l}\# 1 \\
\dot{t 2} \\
\text { inlet } \\
" 1 \\
" 1 \\
" \\
" \\
" \\
" \\
" \\
" \\
" \\
" \\
" \\
" \\
" \\
" \\
" \\
" \\
" \\
" \\
" \\
" \\
"\end{array}$ & $\begin{array}{l}\text { (west)* } \\
" \\
" \\
" \\
" \\
" \\
" \\
" \\
" \\
" \\
" \\
" \\
" \\
\text { " } \\
\text { (south) } \\
" \\
" \\
" \\
" \\
\text { " } \\
\text { " } \\
\text { " }\end{array}$ & $\begin{array}{l}1.0 \\
1.0 \\
6.7 \\
3.0 \\
1.0 \\
1.0 \\
1.0 \\
1.0 \\
1.0 \\
1.0 \\
1.0 \\
1.0 \\
1.0 \\
1.0 \\
1.0 \\
1.0 \\
1.0 \\
1.0 \\
1.0 \\
1.0 \\
1.0 \\
1.0 \\
2.9 \\
1.0 \\
1.0 \\
1.0 \\
1.7\end{array}$ & $30.0 \%$ & $\begin{array}{l}2900 \\
3000 \\
3100 \\
3200 \\
3300 \\
3400 \\
3500 \\
3600 \\
3700 \\
3800 \\
3900 \\
4000 \\
4100 \\
4200 \\
4300 \\
4400 \\
4500 \\
4600 \\
4700 \\
4800 \\
4900\end{array}$ & $\begin{array}{l}\text { feet } \\
n \\
n \\
n \\
n \\
n \\
n \\
n \\
n \\
n \\
n \\
n \\
n \\
n \\
n \\
n\end{array}$ & 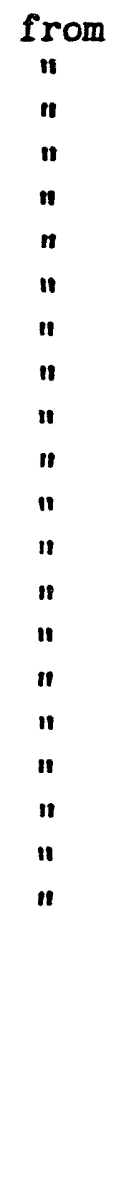 & $\begin{array}{c}\text { inlet } \\
\text { " } \\
n \\
n \\
n \\
" \\
n \\
n \\
n \\
" \\
" \\
n \\
" \\
" \\
" \\
"\end{array}$ & $\begin{array}{l}\text { (east) } \\
" \\
" \\
" \\
" \\
" \\
" \\
" \\
" \\
" \\
" \\
\text { (north) } \\
n \\
n \\
" \\
" \\
" \\
\text { " }\end{array}$ & $\begin{array}{l}1.0 \\
1.0 \\
1.0 \\
1.0 \\
1.0 \\
1.0 \\
1.9 \\
1.0 \\
1.0 \\
1.0 \\
1.0 \\
1.0 \\
1.0 \\
1.5 \\
1.0 \\
1.0 \\
1.0 \\
1.0 \\
2.0 \\
1.0 \\
1.0\end{array}$ & \\
\hline
\end{tabular}

Results from Radiological Chemical Analysis Operation. 


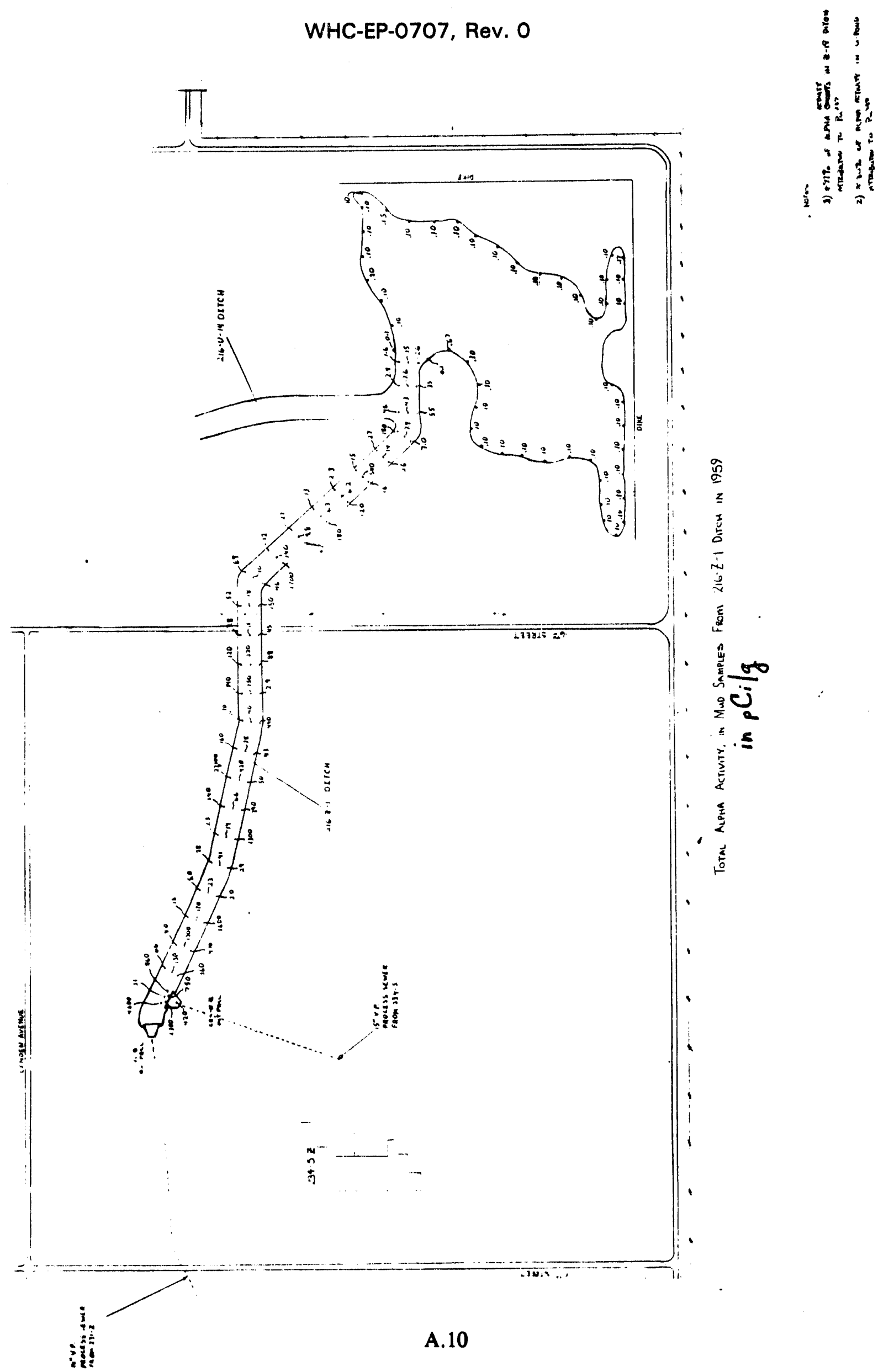




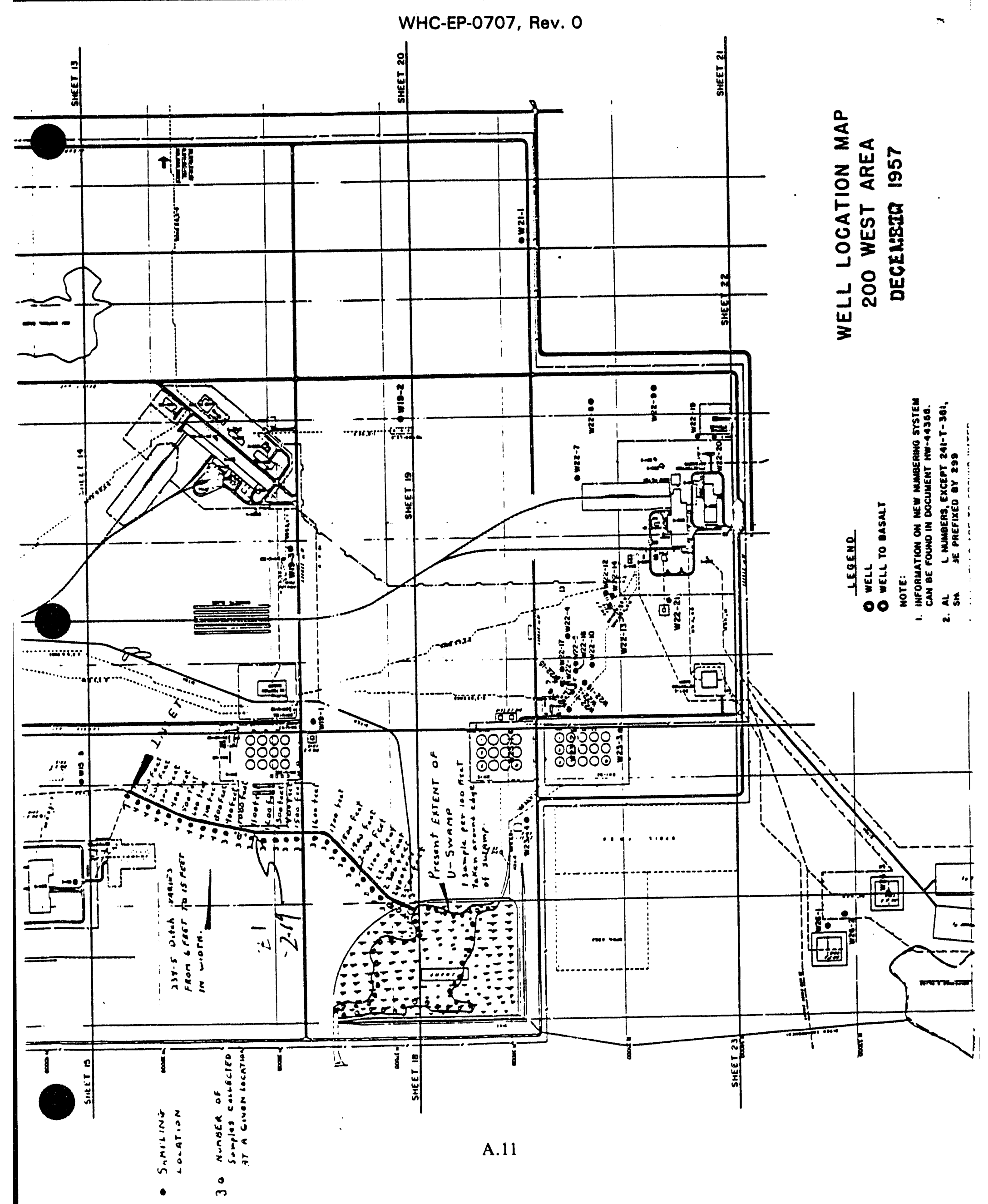


WHC-EP-0707, Rev. 0

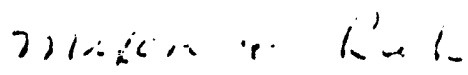

234-5 Diteh samples

$$
1 / 8 / 59 \quad P N
$$

milet - (N) $35^{2}{ }_{4}$ (s)

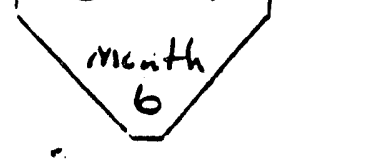

Ditich a iaces from $w \rightarrow E \quad 3$ sumples ciery lat'

$100^{\prime}$

$140 \mathrm{c}$

2001

(iinderpass) 15 ive'

Tatal samples $=81$

;is.

160

$400^{\prime}$

170

sien

180.

bo

$1900^{\circ}$

$70{ }^{\prime}$

zot

sze'

2102

ice

2300

100

I3'

1100 '

$24 \mathrm{cr}$

1200

2501

$130^{\circ}$

A. 12 
WHC-EP-0707, Rev. 0

:o; :- Lindoroth

From: U. J. lrown

Subject: CHRONOLOSICAL STZUEIICE OF EVEITS RELAT LIG IU TIE SA:PLIMG OF TIE 23ओ-5 DITCH A:D U-S .AIIP.

$22-10-53$

Esily in Docemter, 1953, we received information relating to the hiph frons alpha concentration in tho wasto water in the 234-5 ditch from $\%$. A. lianey and tine Reilonal :Iont.toring Operation. At. this t,ime 222-l! personnel were investicating the plutondun uptake by 200-llest solls and the movomont of Pu voirine wastes in tho ground beneath dj.sposal sitcs in tho vicinity of the z-plant. It was felt that mud sampies from. tinis aitch would provirie useful data.

$12-15-53$

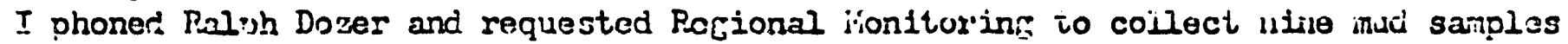
from the 234-5 ditch. These samples vere analyzed bj tive Raiioloidical Ciemical

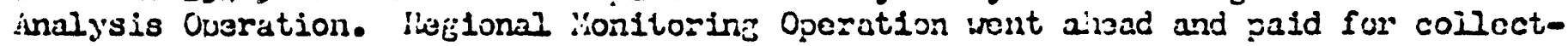
int and andlyzing these saroles vithout asking for a C.E.T. bork srcior.

$2-3-59$

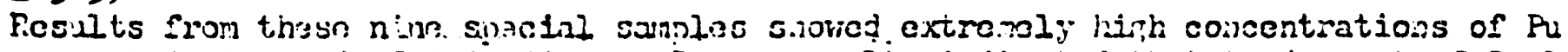
present in the mid of this citch. Insse resilts incicated tilat tise anoust of Pu lost may $b=0$ of ocjonic sirnificance and possibly vortin recoverini: fron tia ditch. This infor:ation was resorted in a hishlir,ht.

Join i:onstsad rude a phone call to Ho i. Finpoert, fiadiation frotoction cperation, 200-ijest irea, to inform hin the ditch was not posted as a containaition zuro. This

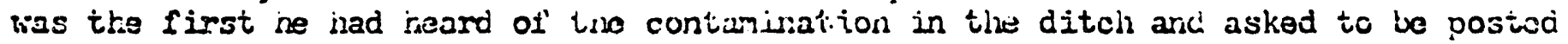
on any additional information we mi-int collect on tino diteh or tino j-Etamp.

$1-4-59$

To cigtermine the approxinate dinount of in in tise mud of the 234-5 ditch iurtiar spceial samoles vere reziuested. This requost called for il samples to ve collected along the entire leneth of tiw ditch. Ken ioid phoned and said ic hal been assienod to follow the ditch contamination proglem and asked for a copy of tho results.

$1-3-50$

Eiphitij one samples wore collectod from tho $234-5$ ditch.

$1-12-59$

in a telephone conversition, J.F. Honstead and 3. V. Anderson decided that Regtonal lonitoring Operation woil' ay for coliectins and Analyzirs; thoso samplos.

\section{1-13-59}

Ken liad phoned and asked if we intended to sample the U-swano. I said we wero blanning to take sone samnlcs. is reguestad a cony of the results.

$1-14-59$

Fesults from the sil mud analyses siloird sirrificant ps contamination alcar, tra entire lenfth of the ditch. From this data tixe amount of Pu in the ditch was estinated to be betreen 3 and 10 kilograns. These data were roported in a hirilifini and a cop; of the revults $x$ was sent to Ken Heid. A.13 
WHC-EP-0707, Rev. 0

$$
-2-
$$

$1-15-59$

ken reid stopnod by tho 222-j bulldinf erior to attonding a neetine witis personnol of tiro Finisined Products veration to discuss the U-gramp and 234-5 ditch. All of tixe avallable data wo sad was showa to him. ifter his meoting witis F.P.O. he phoned to rojuest mud samplos bo collected from tho delta in the U-swamp. These samplos roro to be collocted at tise same time Eogional ionitorini were taking sanplos for our group.

I pi.oned Falph Do:er and regausted tho delta and shore-line of tho U-swamp be sampled.

$1-1 ;-23-59$

‥ E. Dackman, Firiched Prodicts Oecration, sant in is rork ord3r to corer tho cost of collectini and analyzin those samplos. This actionx was takan foilowir:s tele-

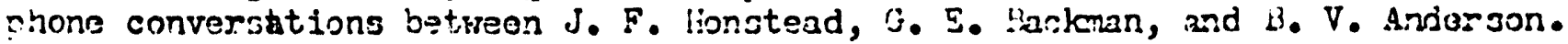

\section{2-13-5?}

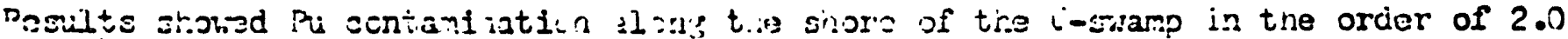

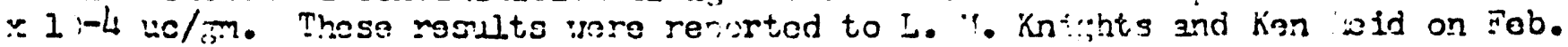
$27,1959$. 
WHC-EP-0707, Rev. 0

Appendix B

216-U-10 Pond Sampling 
WHC-EP-0707, Rev. 0

Atlantic Richficld Hanford Company

Date: $\quad$ September 26, 1973

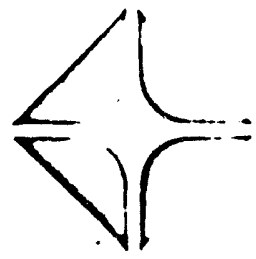

To: R. E. Isaacson

From: $\quad$ L. E. Bruns

Subject: U POND SAMPLING

Sampling results recently received are from samples sent to laboratories in the spring. Many more samples have been taken, however, due to lack of personnel and space, over 500 samples are awaiting processing. We need an improved capability of sample preparation. If samples can be prepared (for example, ground, dried, mixed, etc.), then we can send samples to various qualified environmental laboratories throughout the United Sta.tes.

Initial results come from samples away from the shore where a three-inch vegetation layer, mostly decayed vegetation, has built up over the years. A square meter was staked off, the vegetation was removed and packaged, two cores 30 centimeters deep were taken, and the remaining top soil was taken about five centimeters deep. The disintegrations per minute (dpm) on the vegetation was less than 500 . When the vegetation was removed, the dpm attained 3,000. Results of the vegetation, top soil and cores are indicated on the attached table. The point of sampling is shown on the attached photograph which is dated March, 1973. The results show cesium-137 varying from 1.0 to $6.0 \times 10^{-3}$ microcuries per gram of soil for top soil, zero to five for bulk top soil, and zero to 10 centimeters for the top core sample. Agreement between laboratories (Atlantic Richfield Hanford Company. and Battelle-Northwest) is excellent considering the low magnitude. Not shown on the table are results received from LFE Environmental Laboratory. Their cesium-137 was $3.8 \times 10^{-3}$ microcuries per gram. Many other correlations were made to corroborate results; for example, measurement of four different aliquots within one soil sample and $G e(L i)$ determinations versus wet chemistry.

The strontium-90/cesium-137 curie ratis varied from 4.5 to $1.0 \times 10^{-3}$, most of the results being in the $10^{-3}$ area. Another significant result was the $239+240 \mathrm{Pu}$ values which were in the $10^{-8}$ grams of plutonium per gram of soil magnitude (about 10 to 20 grams of plutonium per arra. 
Allantic Richfield Hanford Company

R. E. Isaacson

Page 2

September 26, 1973

A neutron survey of the exposed pond area showed significant neutron count. Initial checks calibrated against point source standards indicate values as high as 400 grams of plutonium per acre of shore area adjacent to the ditch inlets. A complete sur ay of the exposed area (see map) indicated plutonium though no values can be attached to these latest results since the helium probe was picking up gamma. A recheck of the area is planned with the gamma minimized.

Over 500 filter samples from resuspension towers have been taken. Results from Intelcom show plutonium-239 and uranium-235 to be less than 0.02 micrograms. Even if this were all plutonium, the concentration in air is far below the MPC for air value.

Many ring type samples have been taken from the exposed pond bottom area, along with other top soil samples. These have not been processed as yet.

LEB: jmh

Att.

cc: GE Backman, w/att.

CW Malody, w/att.

BJ McMurray, w/att.

HP Shaw, w/att.

AE Smith, w/att.

PW Smith, w/att.

JH Warren, w/att. 
WHC-EP-0707, Rev. 0

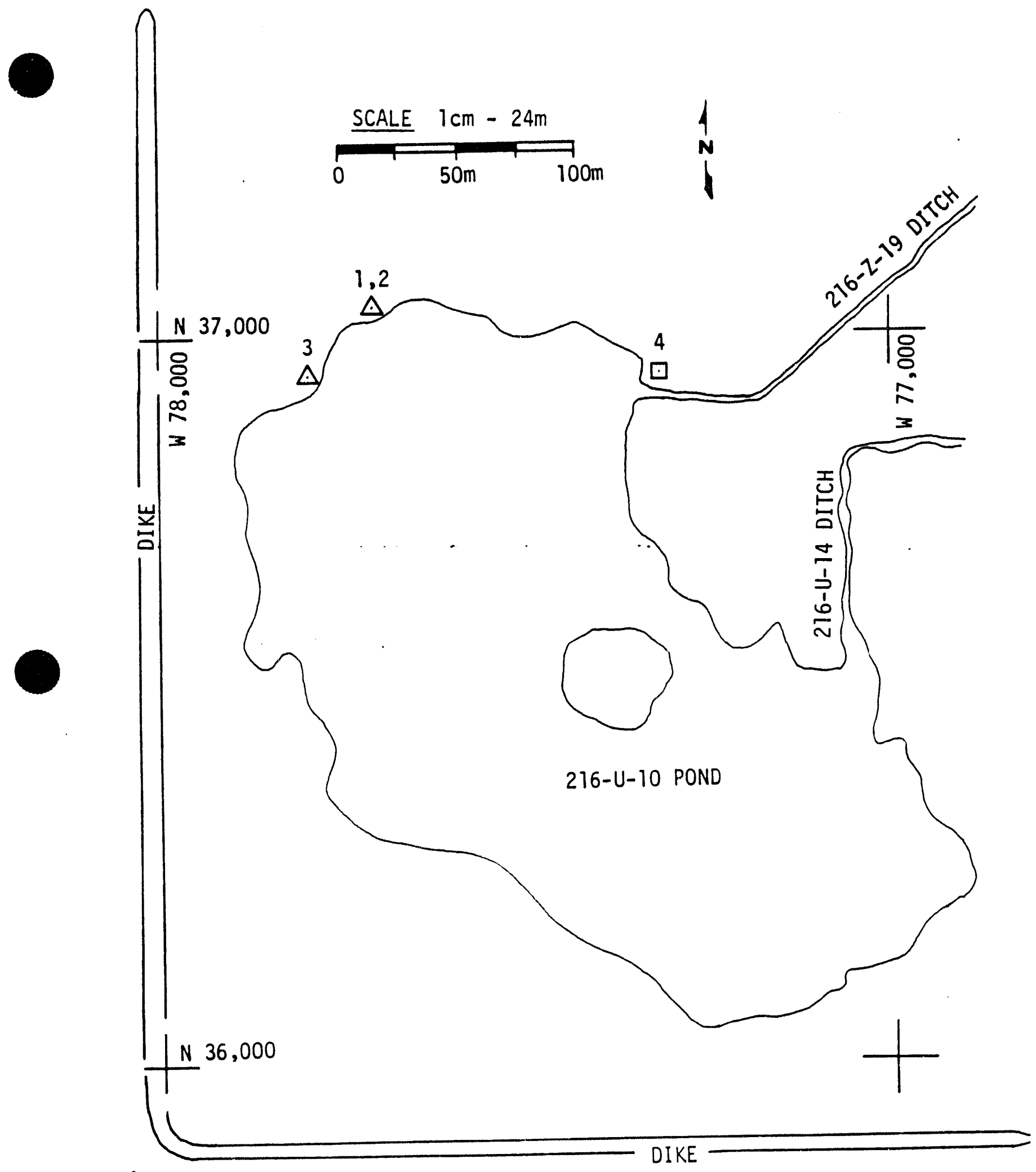


WHC-EP-0707, Rev. 0

Appendix C

Determination of Flow Patterns in the 216-U-10 Pond 
WHC-EP-0707, Rev. 0

\section{DETERMINATION OF FLOW PATTERNS IN THE \\ 216-U-10 POND}

by

S. B. Ailes

J. R. Eliason

H. P. Foote

to

\section{ATLANTIC RICHFIELD HANFORD COMPANY}

August 1974

BATTELLE

PACIFIC NORTHWEST LABORATORIES

Richland, Washington

C. 1 
WHC-EP-0707, Rev. 0

DETERMINATION OF FLOW PATTERNS IN

THE 216-U-10 POND

INTRODUCTION

The $\vec{U}-10$ pond is a cooling water discharge pond located in 200 West Area. Several facilities discharge potentially contaminated liquid wastes to this pond through three main discharge canals or trenches. Discharges from these canals vary significantly, causing discharge velocity to fluctuate. This velocity, along with waste mass and volume and ambient or induced currents in the pond, determines where waste material will settle.

The purpose of this study was to investigate flow patterns in the pond during normal operations in order to gain qualitative information on settling locations of the majority of the waste materials. Due to the unknown and complex flow patterns which could result from three effluents with differing geometries and outfall velocities, an aerial scanner system capable of tracing an injected dye continuously over a large area was used to analyze the flow patterns in the pond. A description of the system is appended.

\section{SUMMARY AND CONCLUSIONS}

Battelle-Northwest conducted a tracer dye test of the U-10 Pond on December 4, 1973. Weather conditions improved long enough to allow one test to be conducted before discharge to the pond was increased significantly by waste water discharge from the evaporators.

Computer analysis of visible and infrared data showed clockwase circulation in the pond. It was obvious from the data that the 216-U-14 ditch was the dominant flow entering the pond during the test; however, another major factor affecting pond flow patterns was wind. Due to the short time schedule, no other tests were performed. Thus, the role of wind in determining the circulation and deposition of waste in the bottom sediments cannot be determined from this data. Surface flow patterns were affected by the wind during the survey and suggest that, due to 
WHC-EP-0707, Rev. 0

the shallowness of the pond, analysis of the average yearly wind direction would determine the best locations for sampling sites.

Additional aerial surveys under varying wind conditions woula be necessary to accurately define the magnitude of the wind's effect on flow pattern. The present data suggest that the majority of the waste material deposition on the pond floor occurs along the east and south banks since prevailing winds over most of the year are from the northwest (Figure 1).

\section{SURVEY TECHNIQUES}

The 216-U-10 Pond is located in the 200-W Area of the Atomic Energy Commission Hanford Reservation. Figure 2 is a map of the area showing the pond in relation to discharge trenches, access roads, and processing plants. Figure 3 is a recent aerial photograph of the pond (the catwalks were installed for other research after this aerial survey was completed). The tracer dye release points are indicated by the arrows.

Aerial surveys of dye tracer techniques were conducted over the test site to determine surface temperature patterns and discharge movement rates. Each survey flight was made at a predetermined altitude (between 1,000 and 1,500 feet above pond level) and at a constant heading and air speed. The headings were selected to minimize direct sun reflection with the system.

Dye was released at the 216-U-14 ditch because initial float tests showed its surface velocity at the discharge to be the highest by far of the three effluents, with possibly the largest effect on the ambient currents. Due to biological tests being conducted on the pond, low concentrations of Rhodamine $B$ dye were used; this limited surveillance time to approximately 4 hours. Prearranged hand signals and aircraft manuevers were used to indicate the start of each survey. 
WHC-EP-0707, Rev. 0
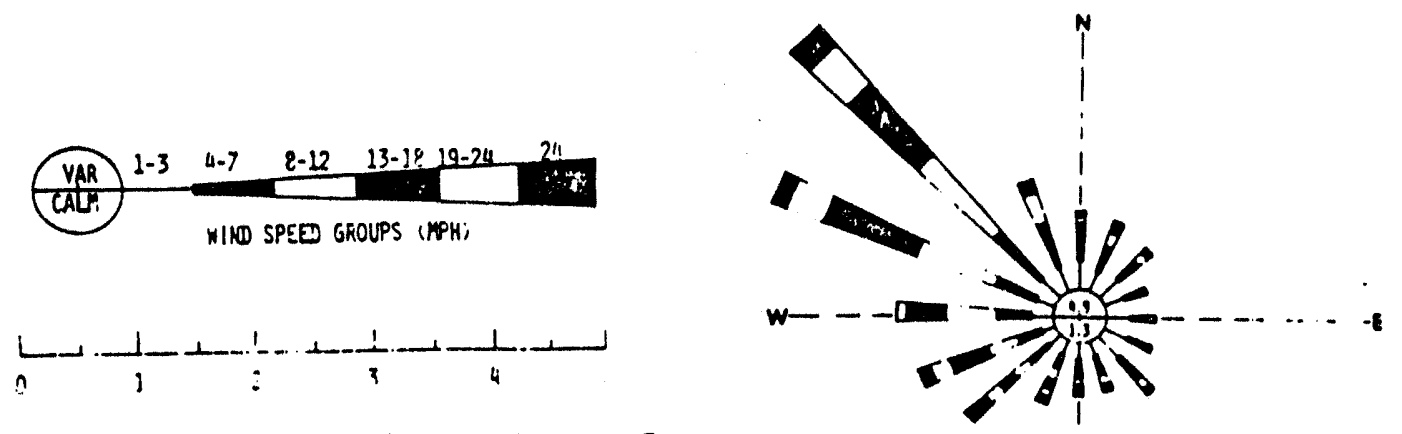

Magnitude and Direction of Wind over 15 Years' Period, 1955-1970

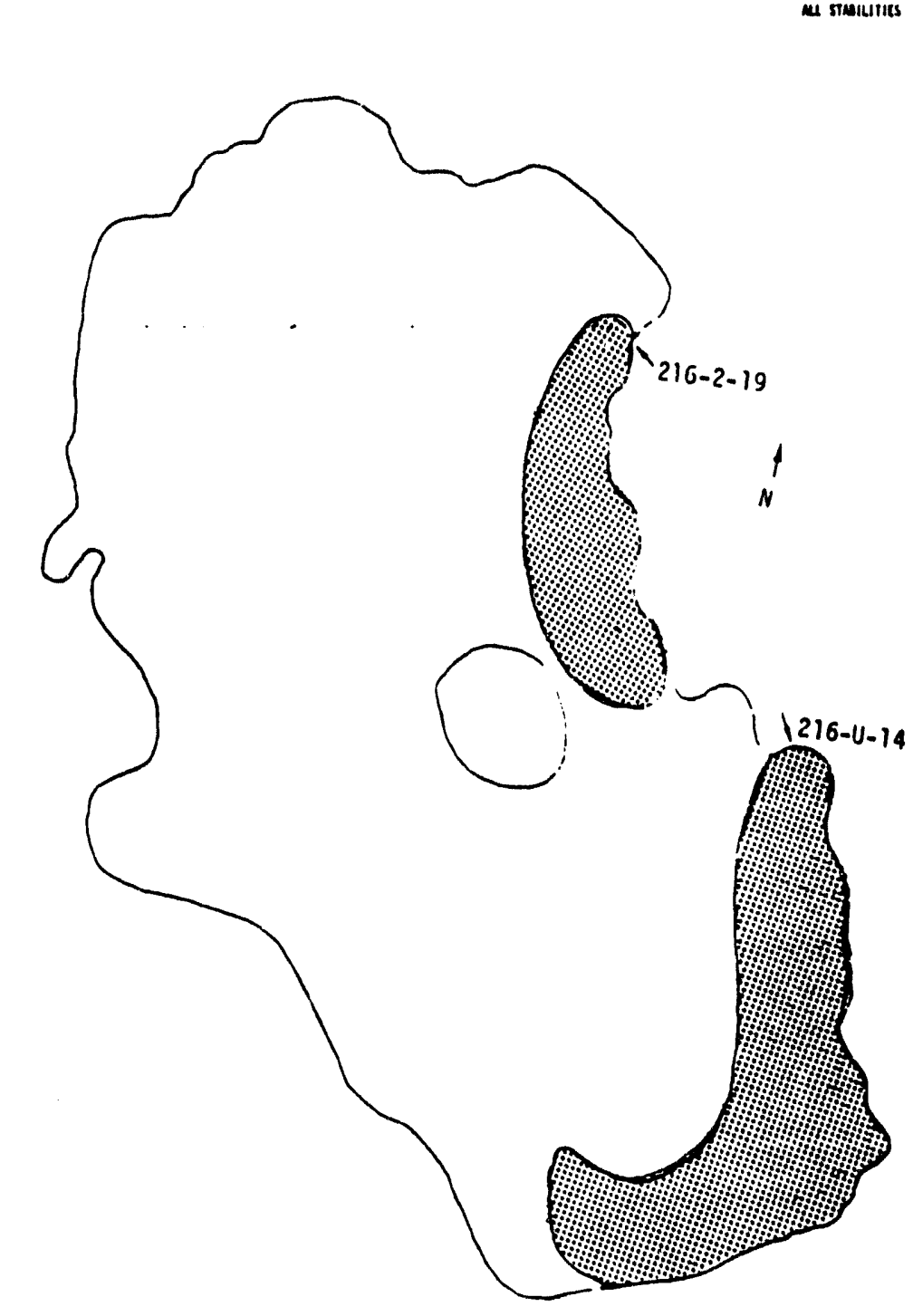

FIGURE 1. Areas of Likely Waste Deposition in 216-U Pond

C. 4 


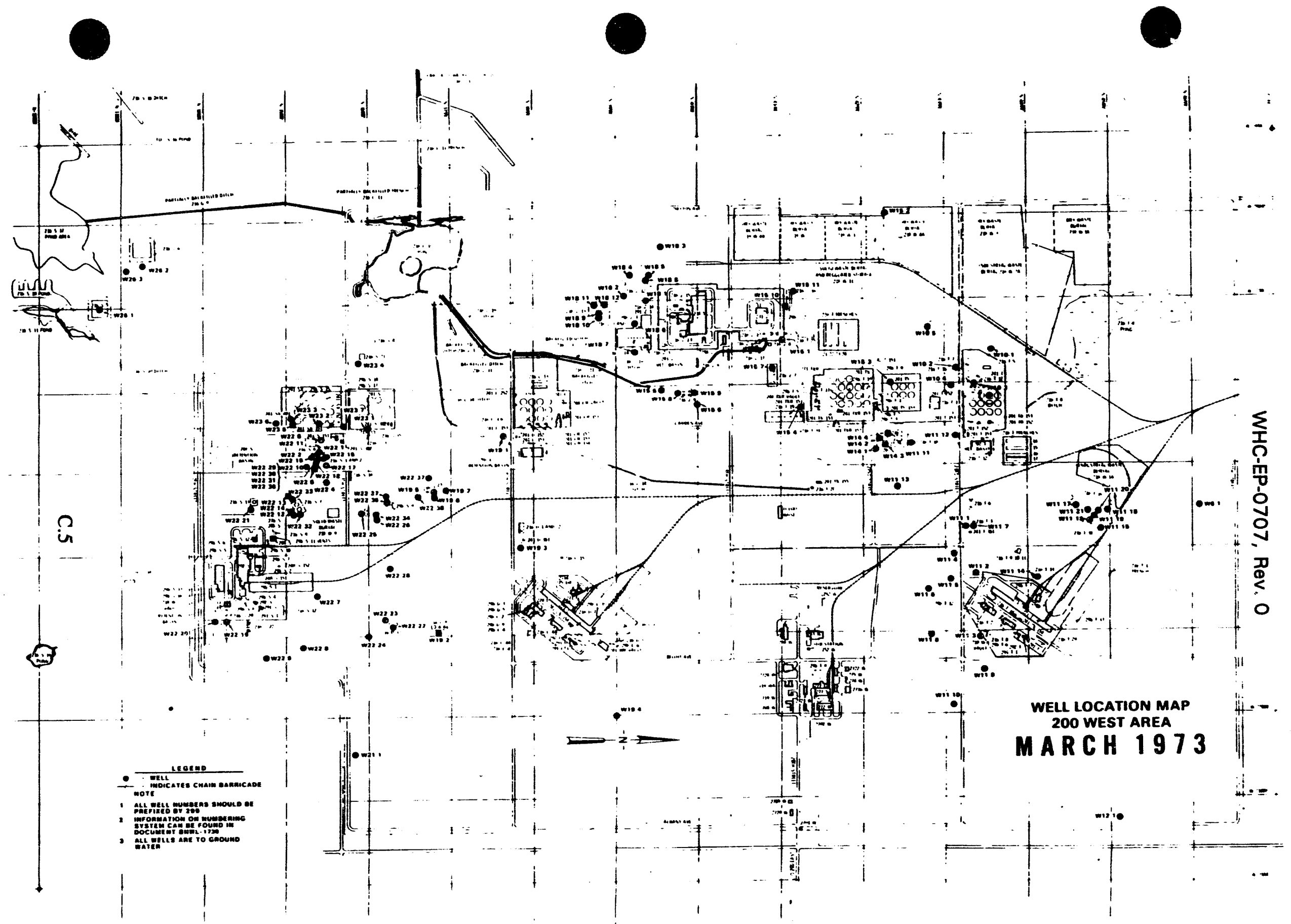

FIGURE 2. Map of 200-West Area Showing Pond and Discharge Canals 


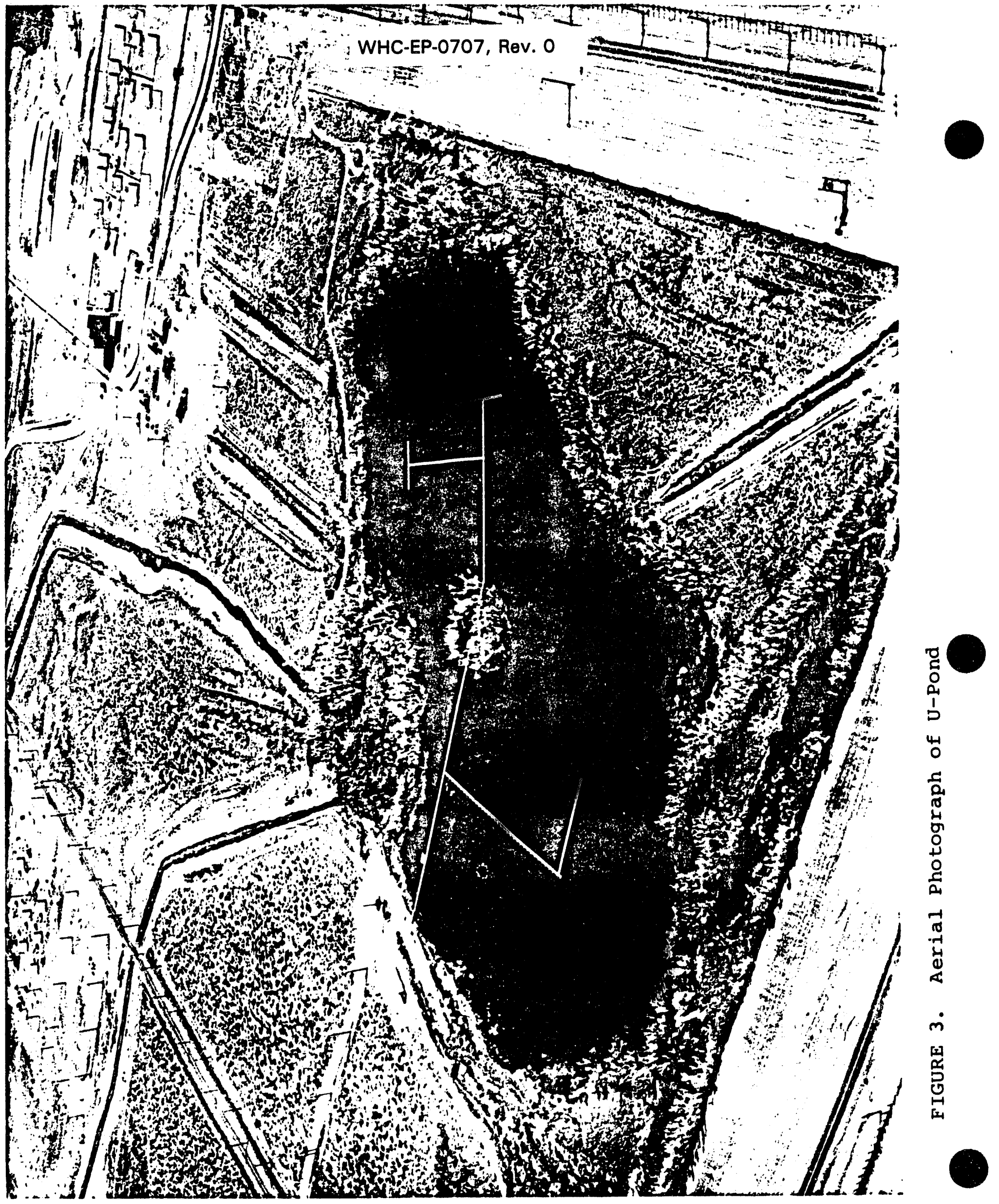


Five liters of dye solution were discharged at a constant rate for 30 minutes beginning at 10:47 hours PST on December 4, 1973. Surveys were made at 3 minute intervals until changes became less rapid, after which the intervals were increased to 15 minutes. Aerial surveillance was continued until 14:35 hours, at which time low sun angle and dye dispersion reduced the visual signal to a minimum and the survey was concluded.

\section{RESULTS}

Initial computer analysis of the visual and thermal data resulted in the photograph form in Figures 4-8. Only the best data depicting a particular flow stage were processed, eliminating repetition in output format. Figures 4-7 represent 11 different surveys conducted during the tracer study. Figure 8 represents three infrared data runs showing changes in surface temperature distribution during the test. The dark areas near the borders of the pond are caused by a thin sheet of ice, too transparent to show in the visual data but quite evident in the thermal.

Also noticeable in both infrared and tracer dye data is a slight shift in flows. These shifts occurred nearly concurrently with changes in wind velocity. During tracer release at 10:45 hours, winds were calm; however, both ground crew and aircraft logs noted a slight breeze building up at 11:02 hours. The pond thermal distribution seems to have responded most quickly since only surface temperatures are measured. Figure 8 a shows initial conditions during the survey, with the thermal plume building up along the east shore. By 11:11 hours (Figure 8b) mixing of the plume is observed, especially at 216-U-14 ditch discharge, signifying the presence of some other flow. By 12:34 hours (Figure 8c) another established flow is evident.

The dye responded less quickly to wind than the thermal distribution, probably because it was released several inches below the surface. This would explain why the tracer, after 

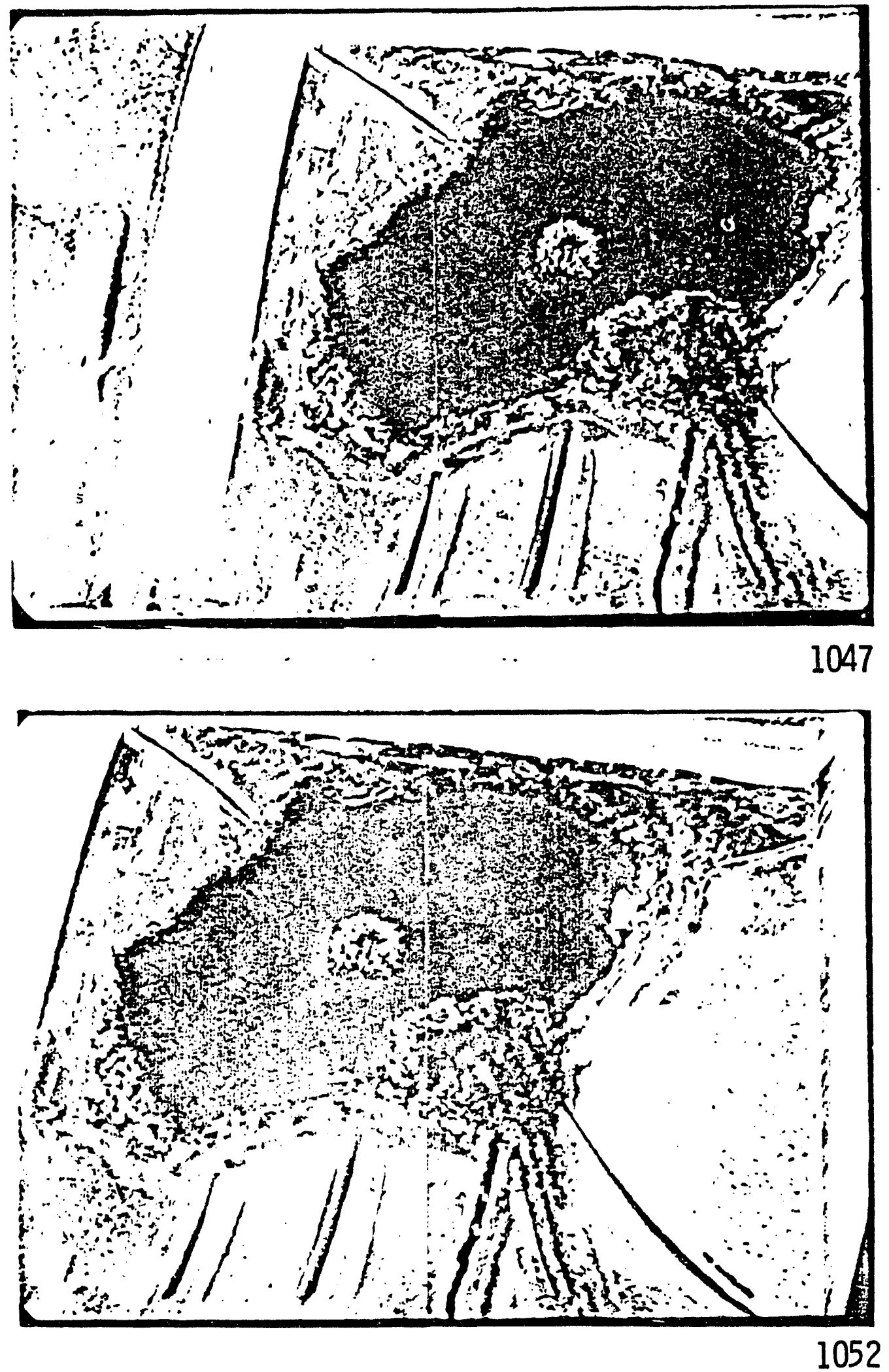

U POND DYE TEST

$12-4-73$

FIGURE 4. Images of Dye Tracer Movement in U-Pond at 1047 and 1052 on December 4, 1973 


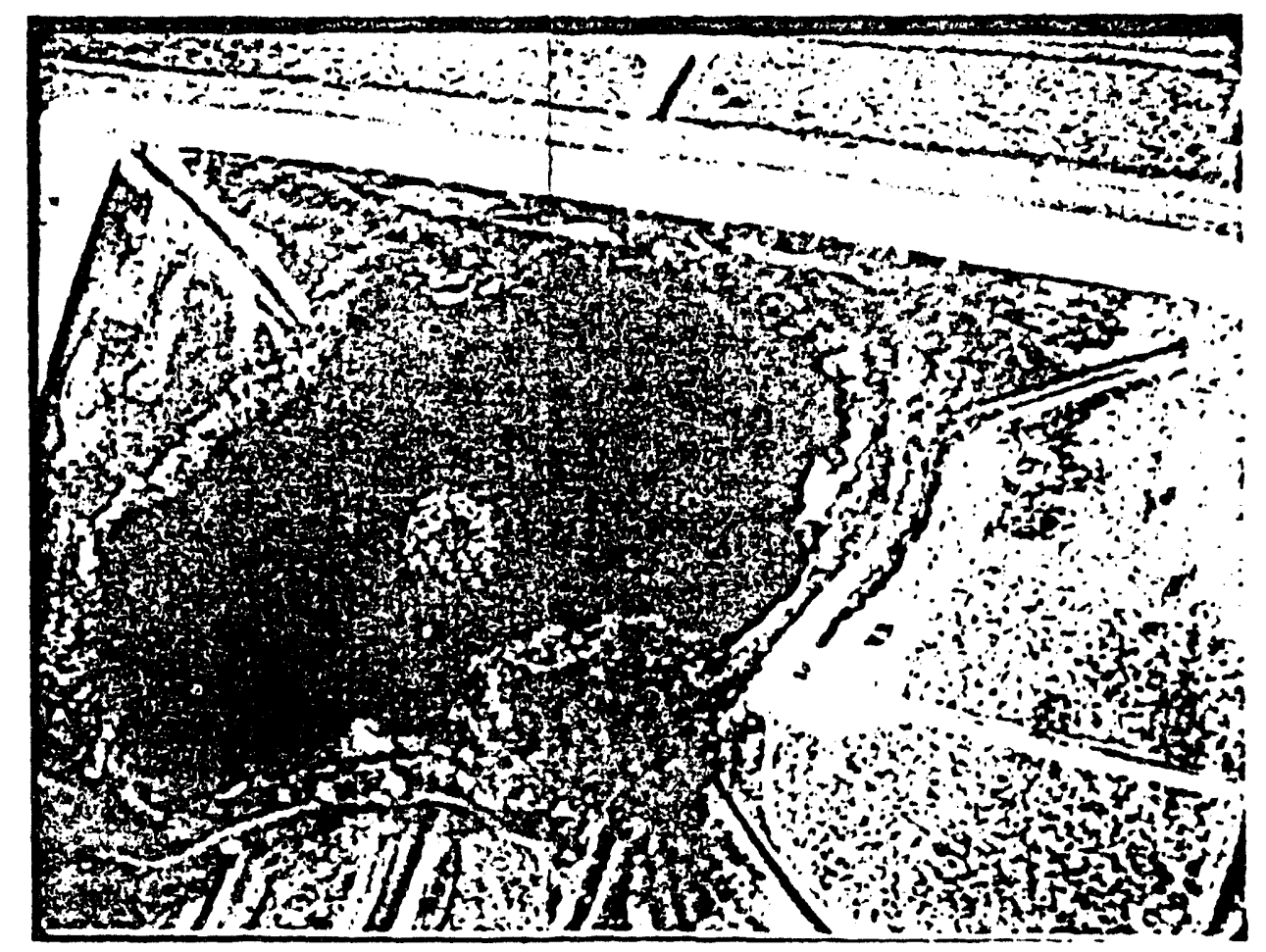

1134

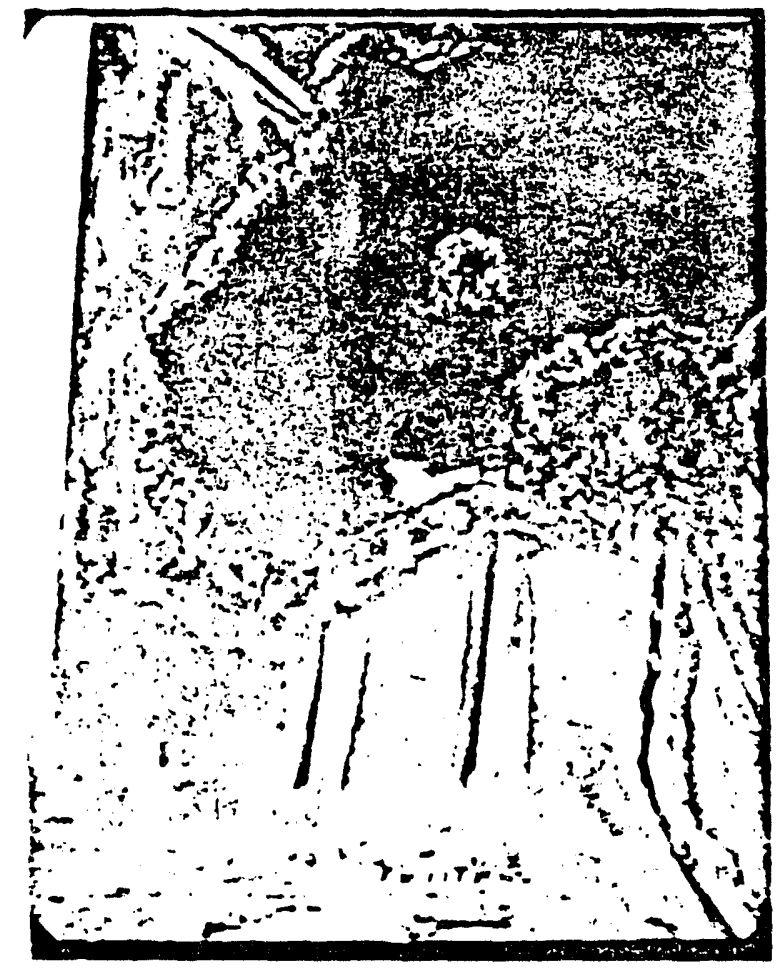

1147

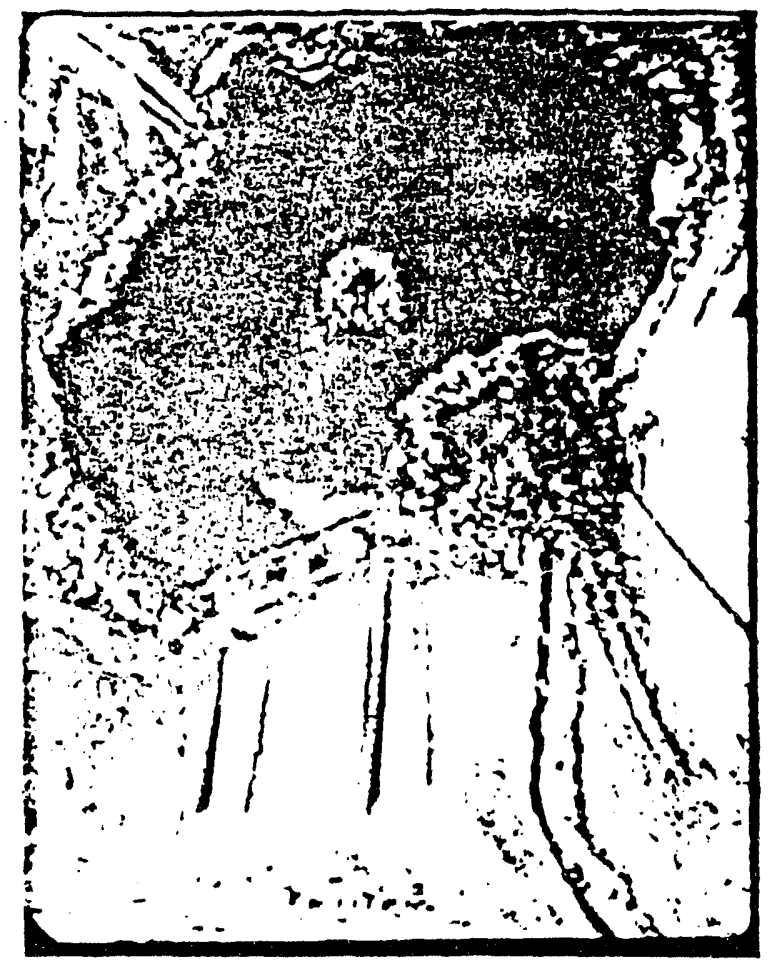

1158

\section{U POND DYE TEST}

$12-4-73$

FIGURE 6. Images of Dye Tracer Movement in U-Pond at 1134, 1147, and on December 4, 1973 


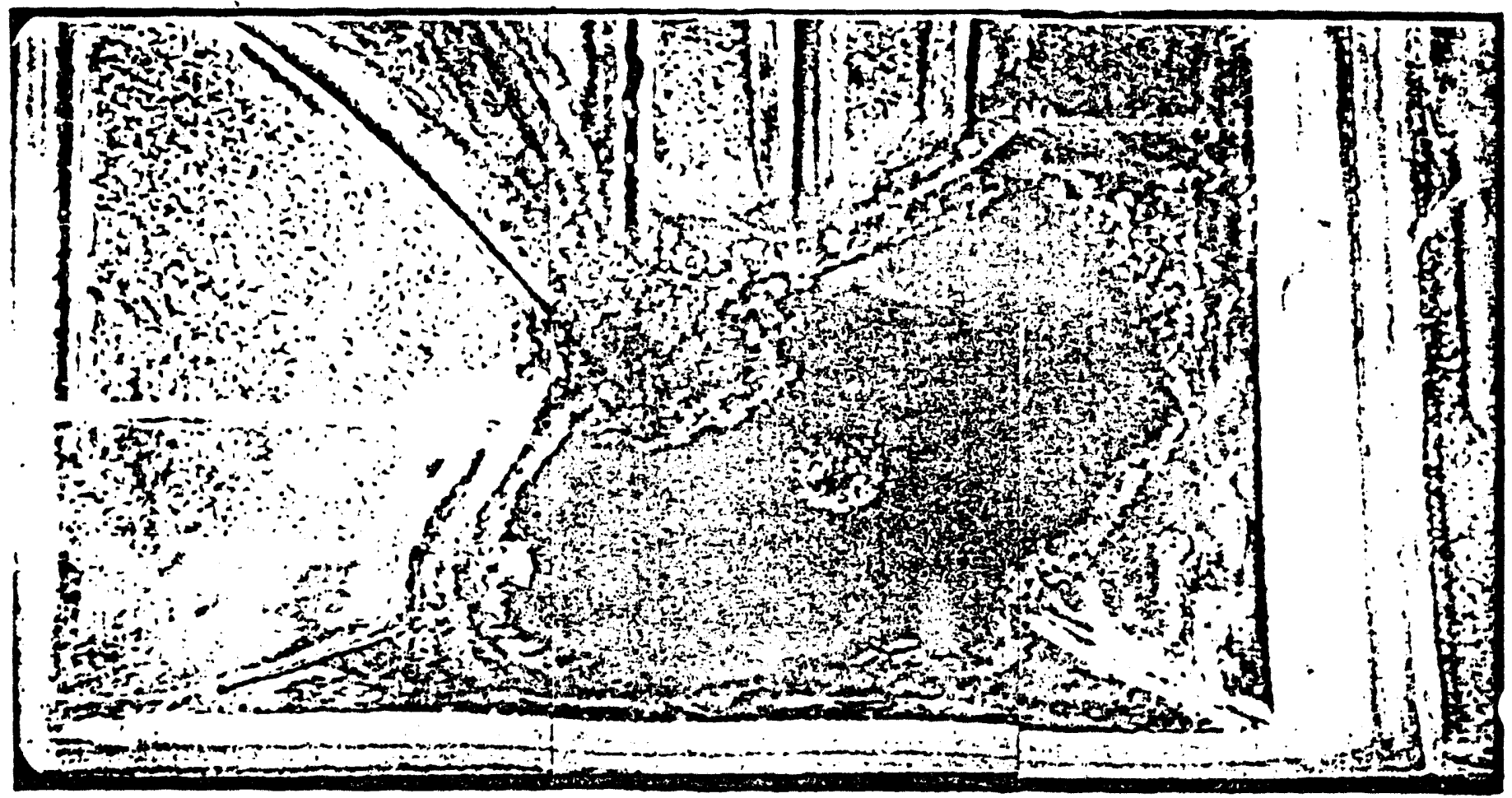

घZI

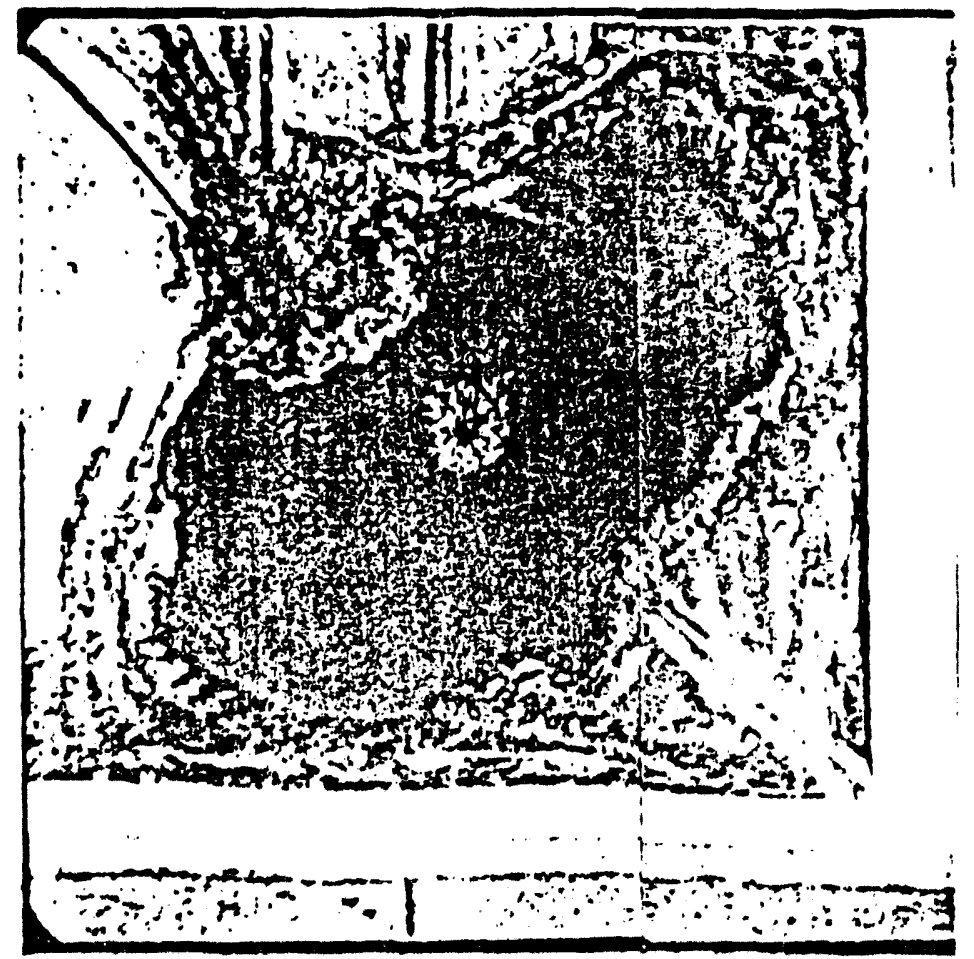

OIZI

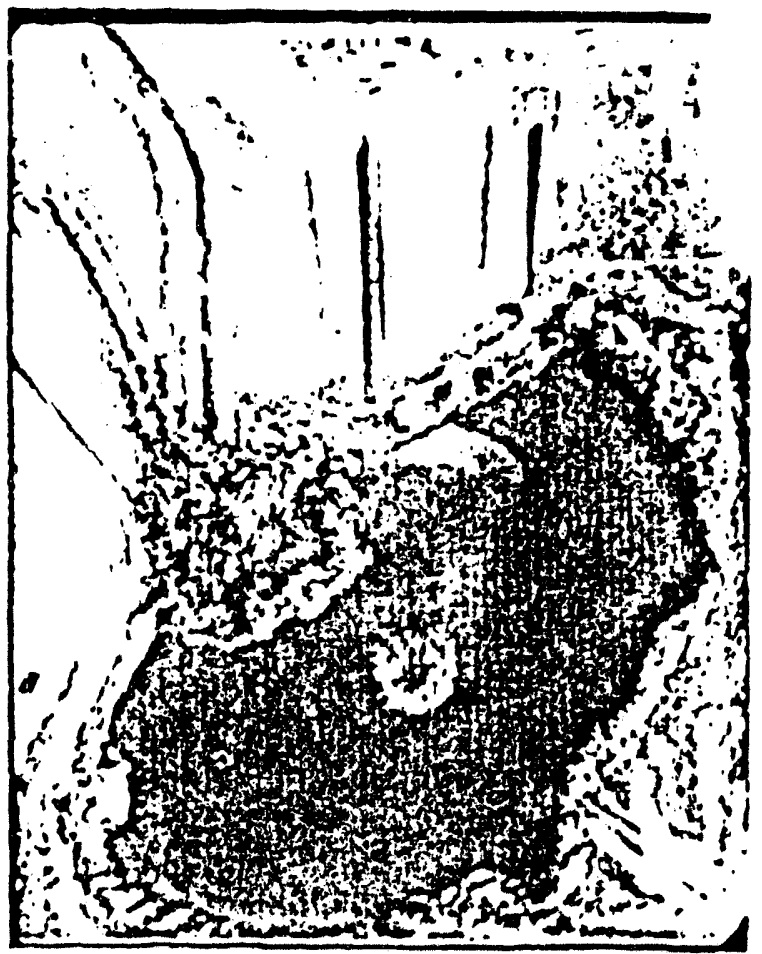



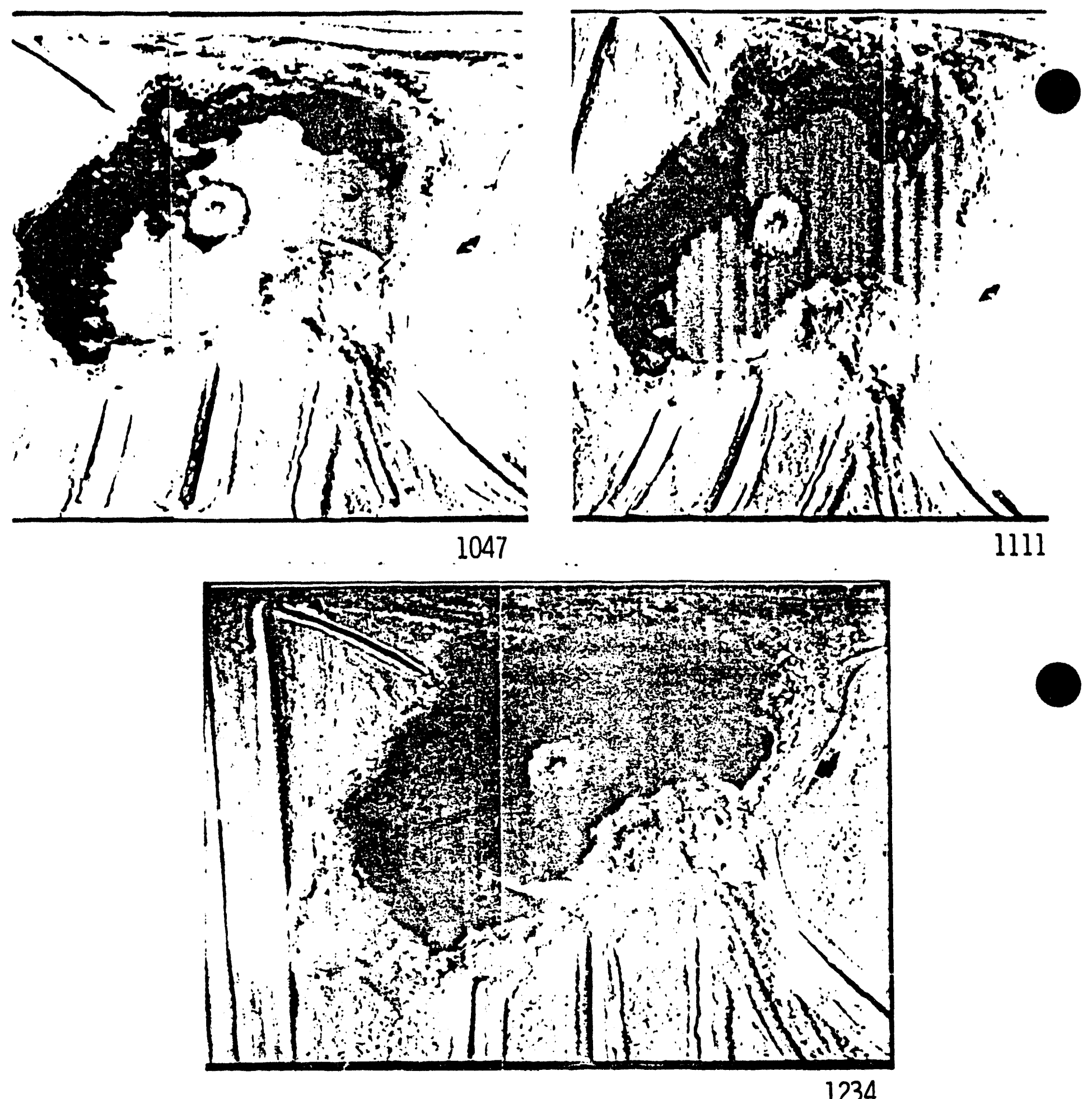

U POND INFRARED TEST

$$
12-4-73
$$

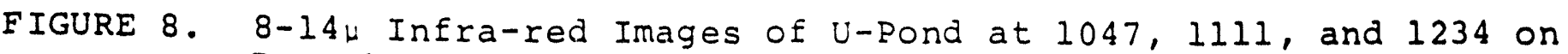
December 4, 1973 
flowing in a direction similar to that of the thermal plume, abruptly began flowing south, as shown in Figures $7 b$ and $c$ and Figure 8a. This took place from 11:11 hours to 11:47 hours. Meteorological data obtained from the Battelle weather station (shown in Figure 9) confirms that a calm wind prevalled at 10:10 hours and increased to approximately 5 knots from the northeast at 13:00 hours.

Although the photographic display is visually descriptive, no quantitative comparison of temperature ranges or dye dispersion rates can be made from this information. Therefore, character coded temperature and dye concentration maps were computed for several test periods from 10:47 hours to 14:20 hours. Figures 10 and 11 are a wide angle and enlargement of the tracer dye survey conducted at 10:52 hours on December 4. Figure 12 is an enlargement at $12: 23$ hours.. Figure 13 is a wide angle temperature map also conducted at 12:34 hours. The calibration temperatures used were estimated from data collected by BattelleBiology on November $27,1973$.

Because the bulk and expense of editing and preparing 22 such maps ( 11 wide angle and 11 enlargements of tracer dye) are beyond the scope of this project, overlays of each computer calculated dye concentration versus time were made on one wide angle map, Figure 14. Figure 15 is a plot of tracer centerline movement versus time and Figure 16 is a corresponding tracer map of $U$-Pond dye movement and centerline velocity patterns. 


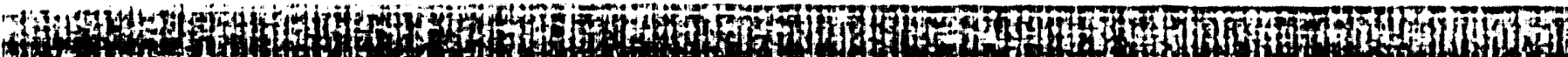

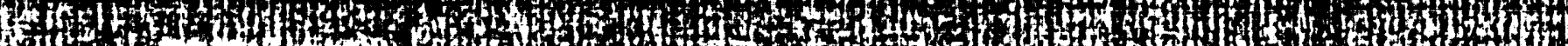

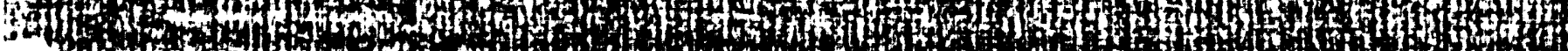

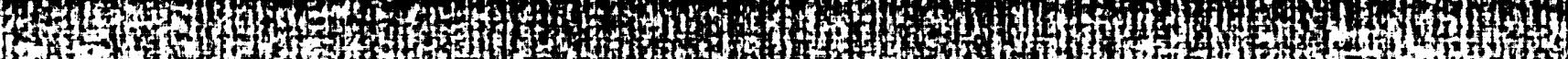

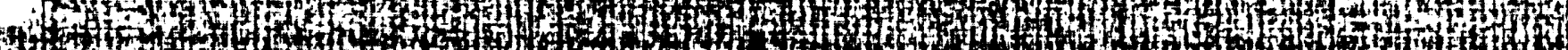

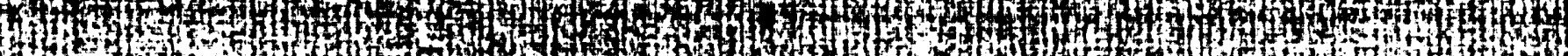
Got

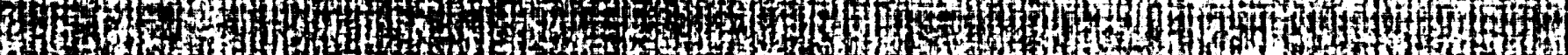
H.2.

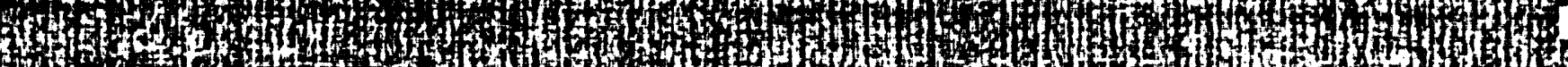

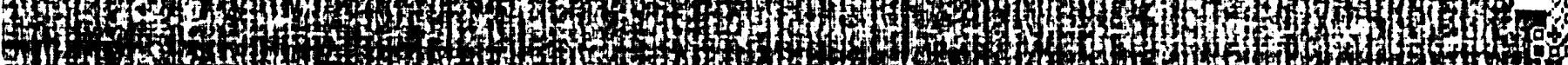

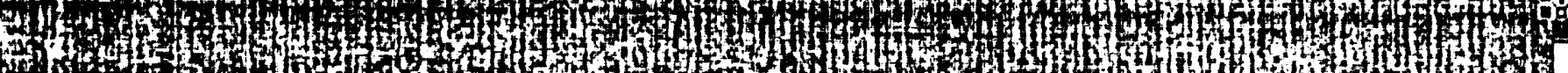

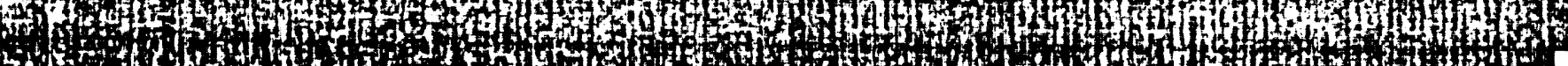
s.

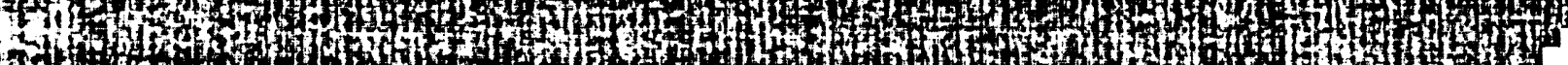

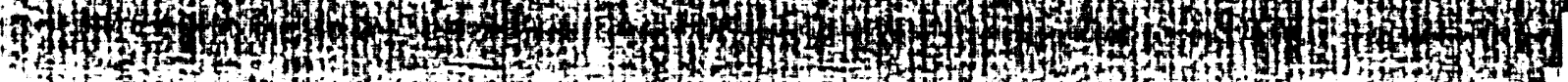

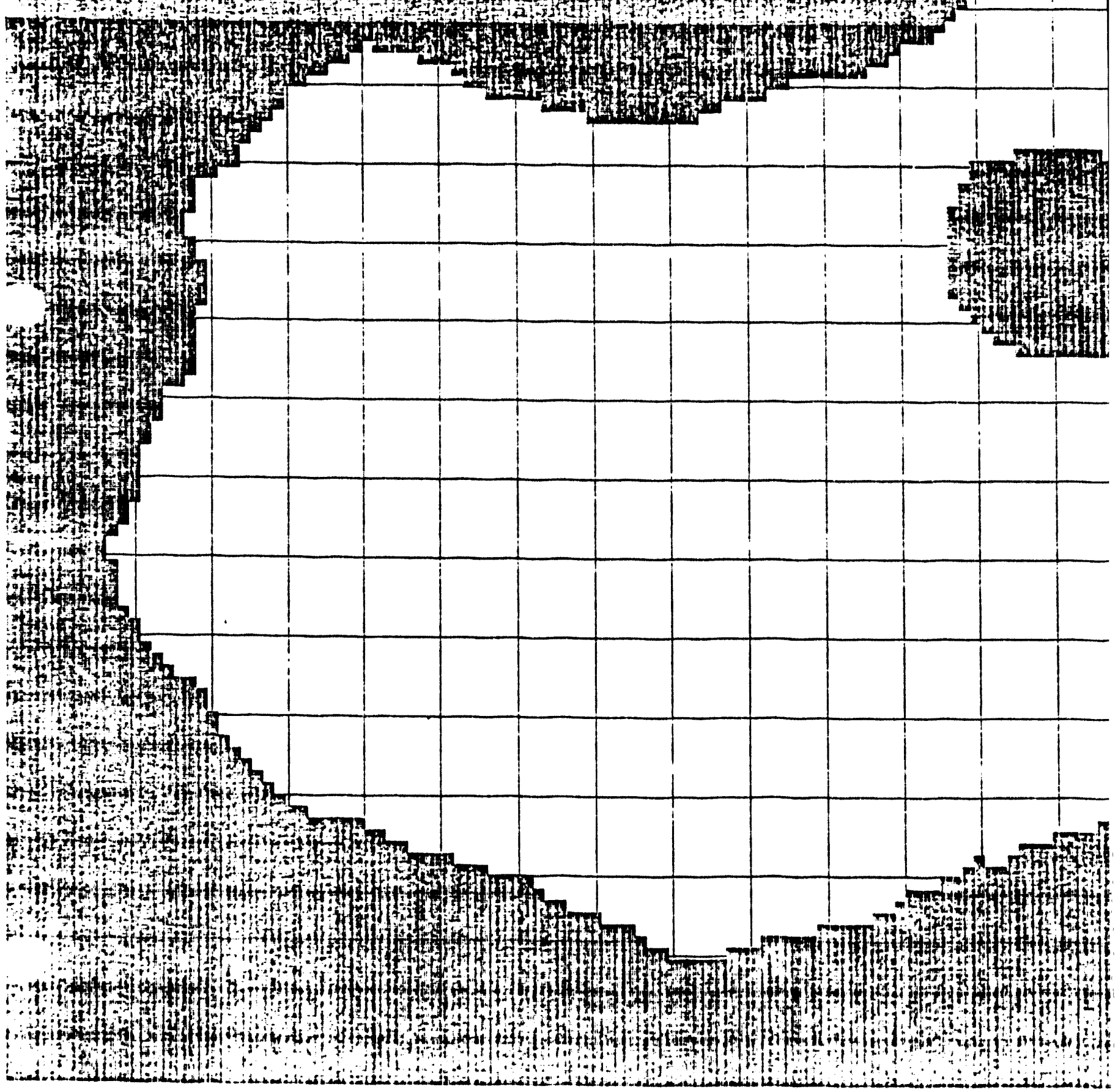




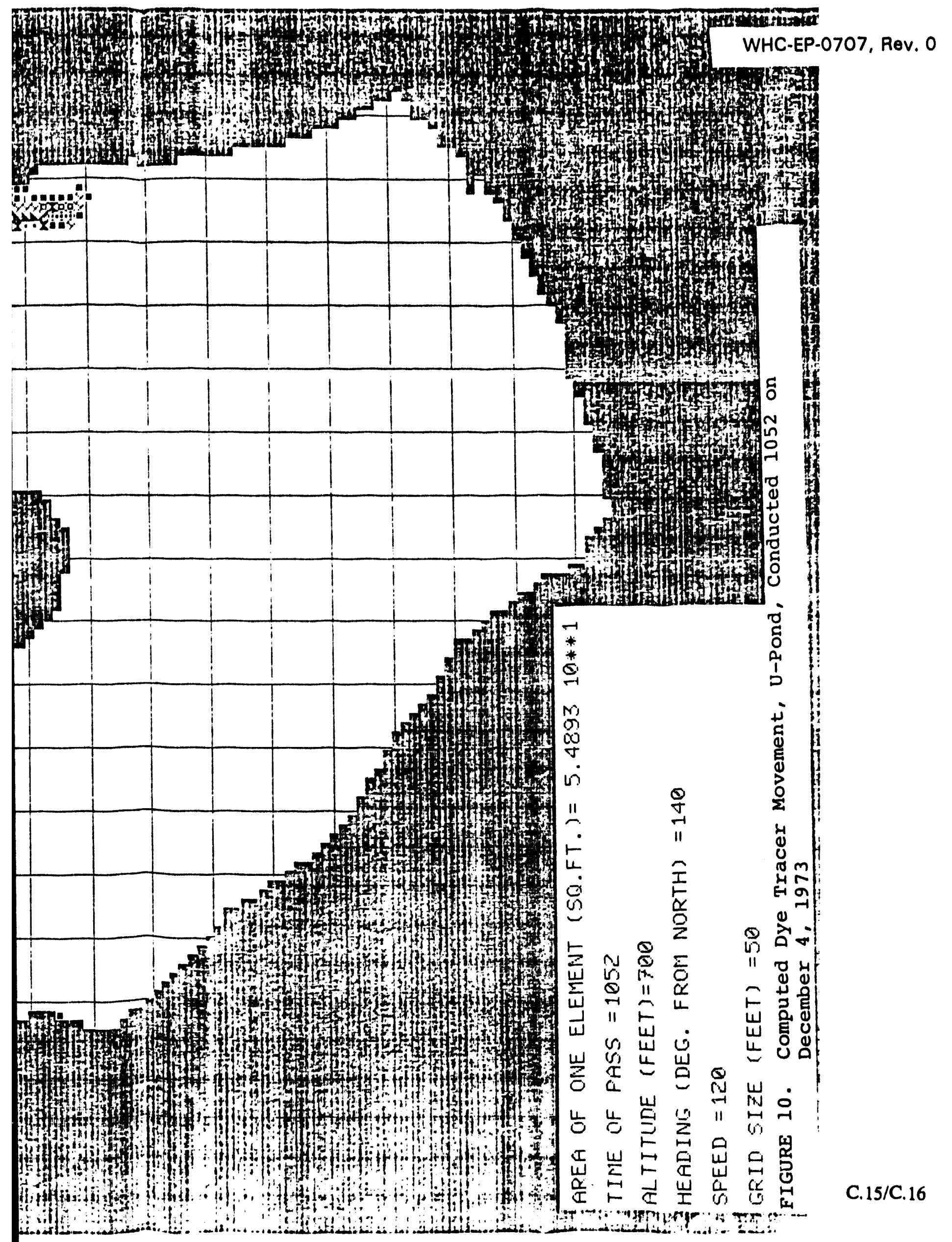


?

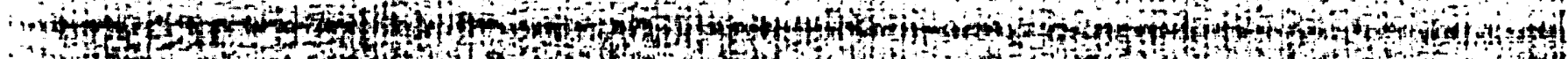

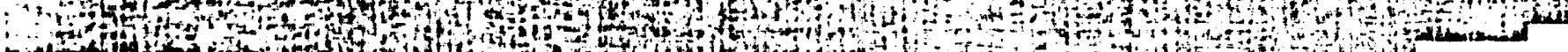

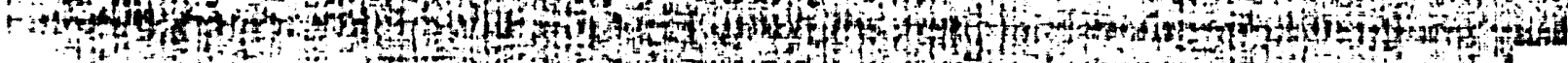

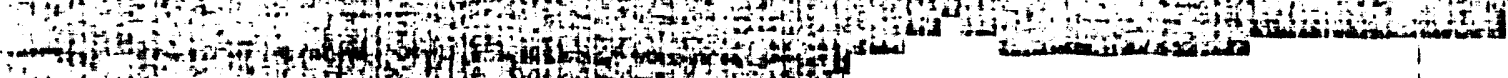

a

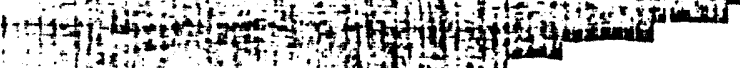

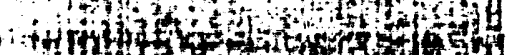

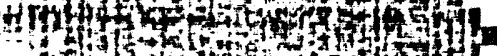

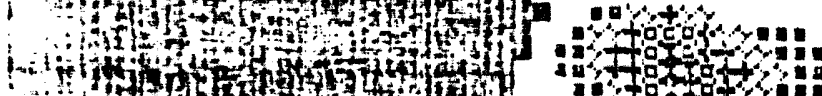

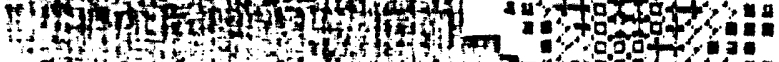

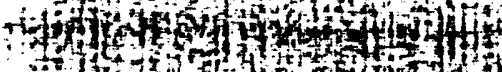

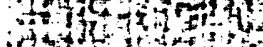

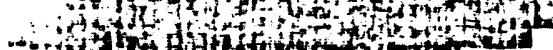

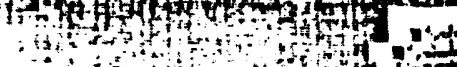

a

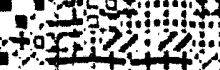

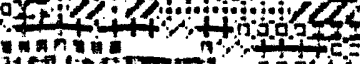

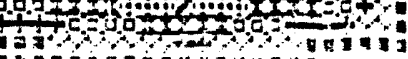

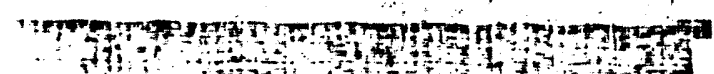

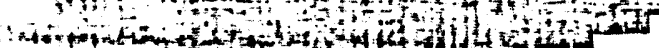

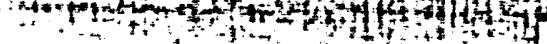

.

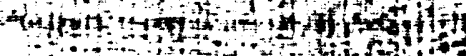

:

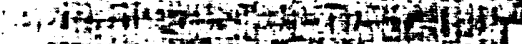

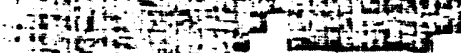

$\therefore$ :

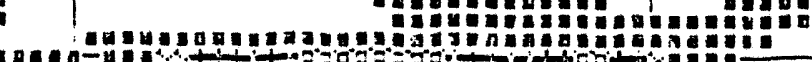
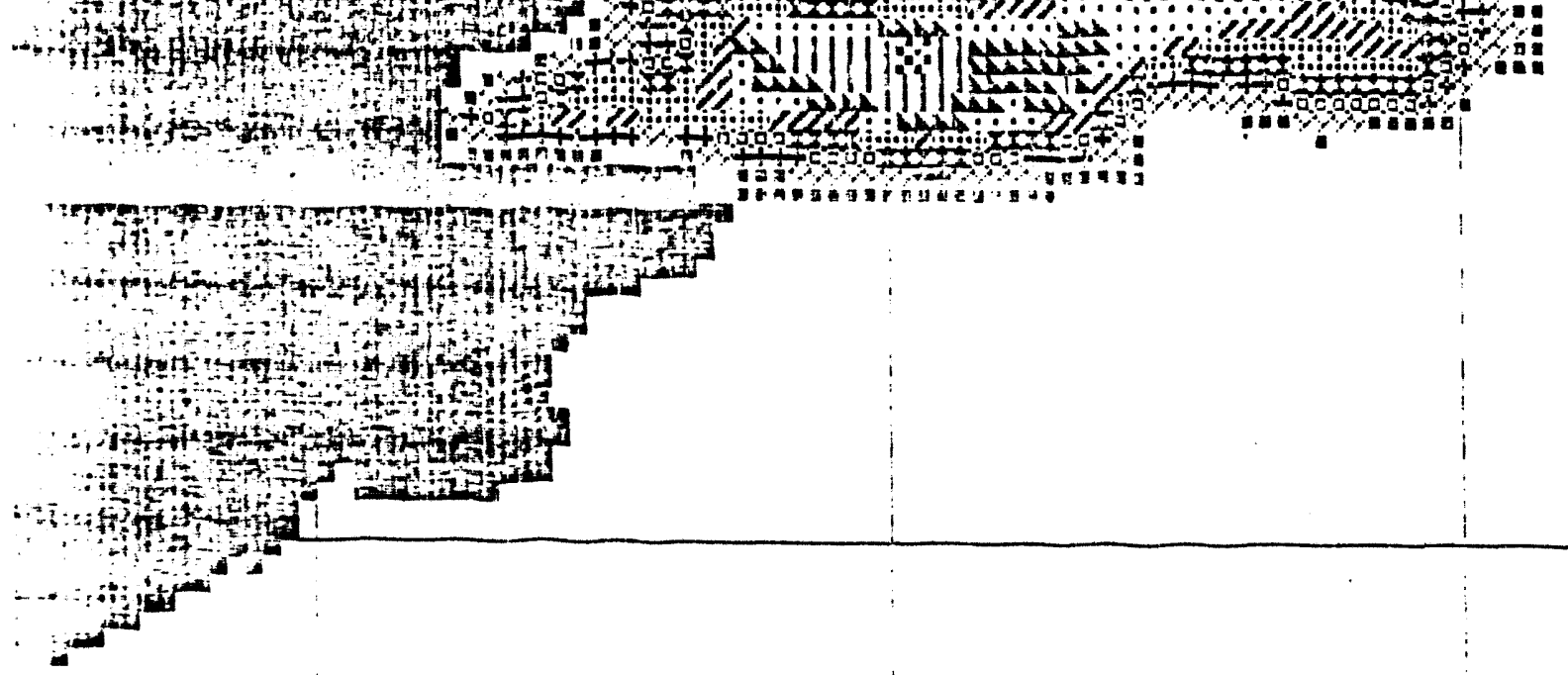


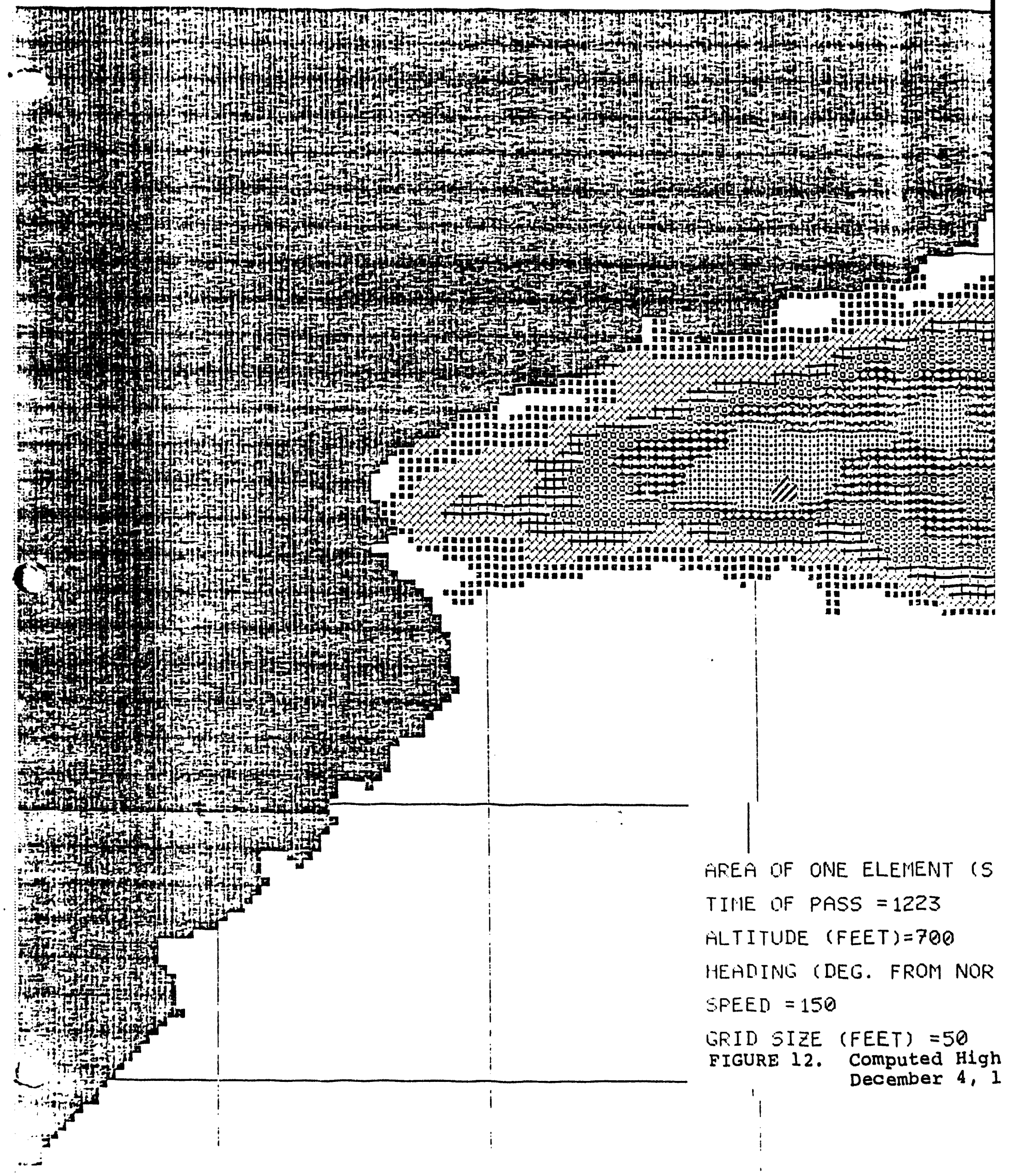




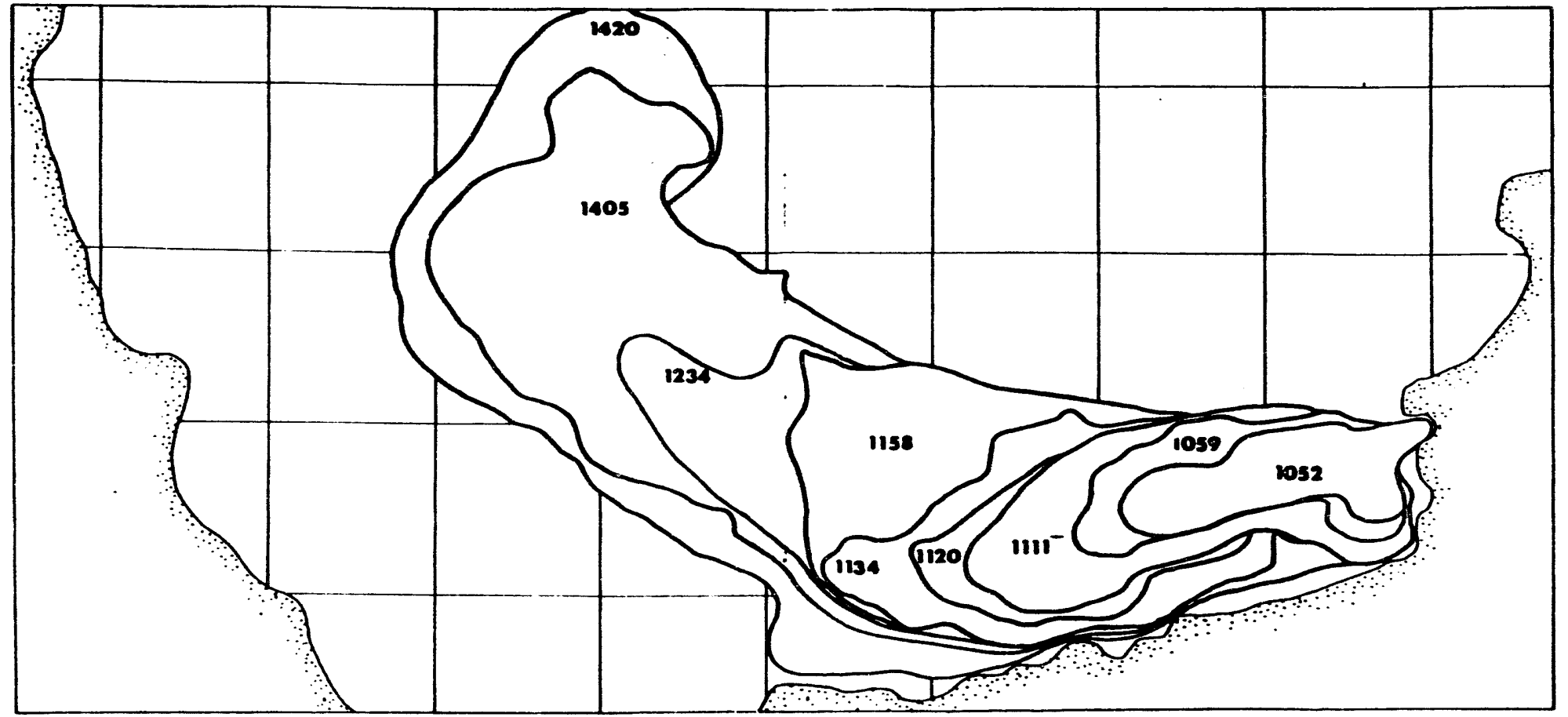

FIGURE 14. Map of Dye Tracer Movement in U-Pond with Time 
WHC-EP-0707, Rev. 0

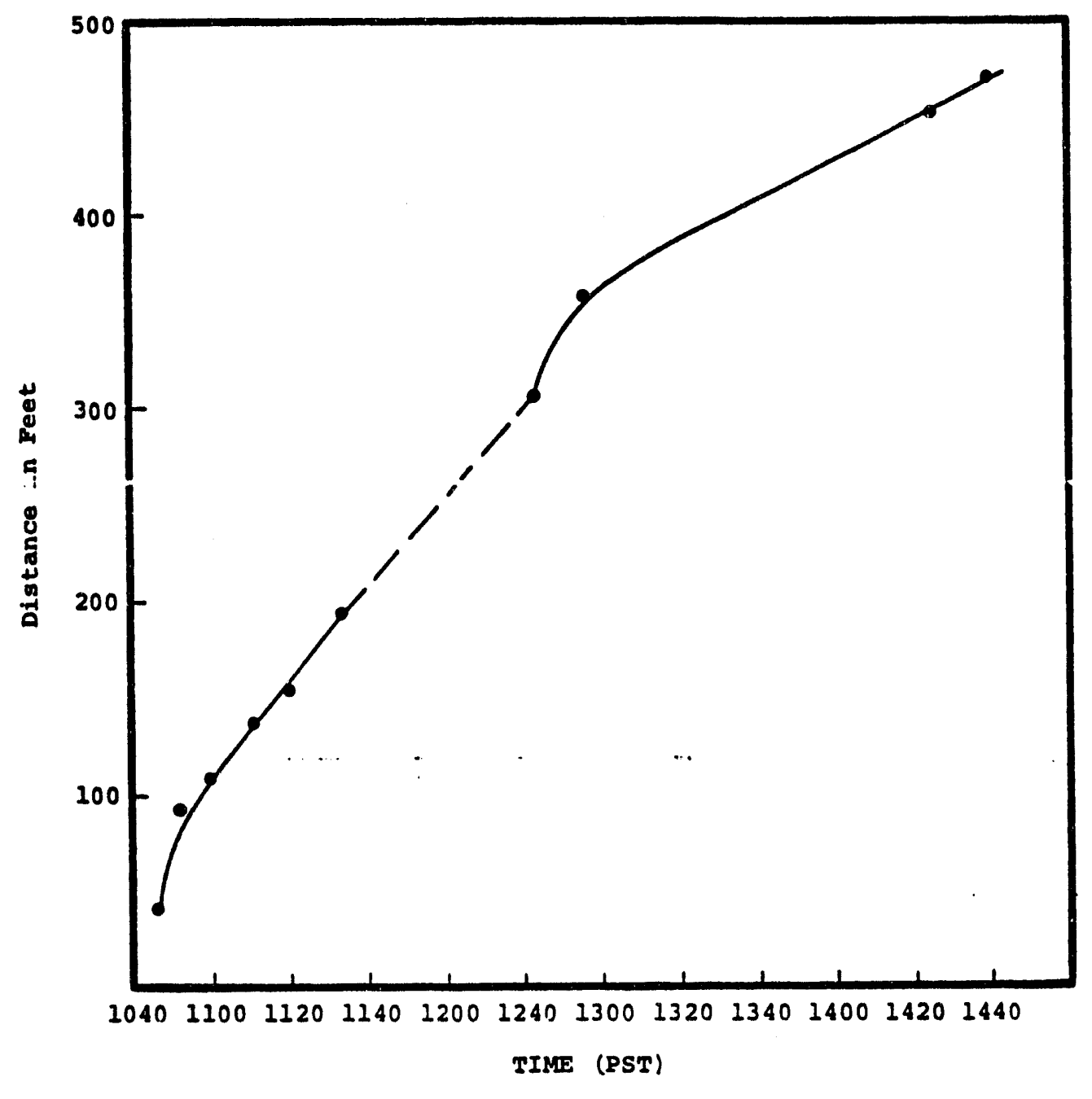

December 4, 1973

FIGURE 15. Plot of Tracer Centerline Distance Versus Time 


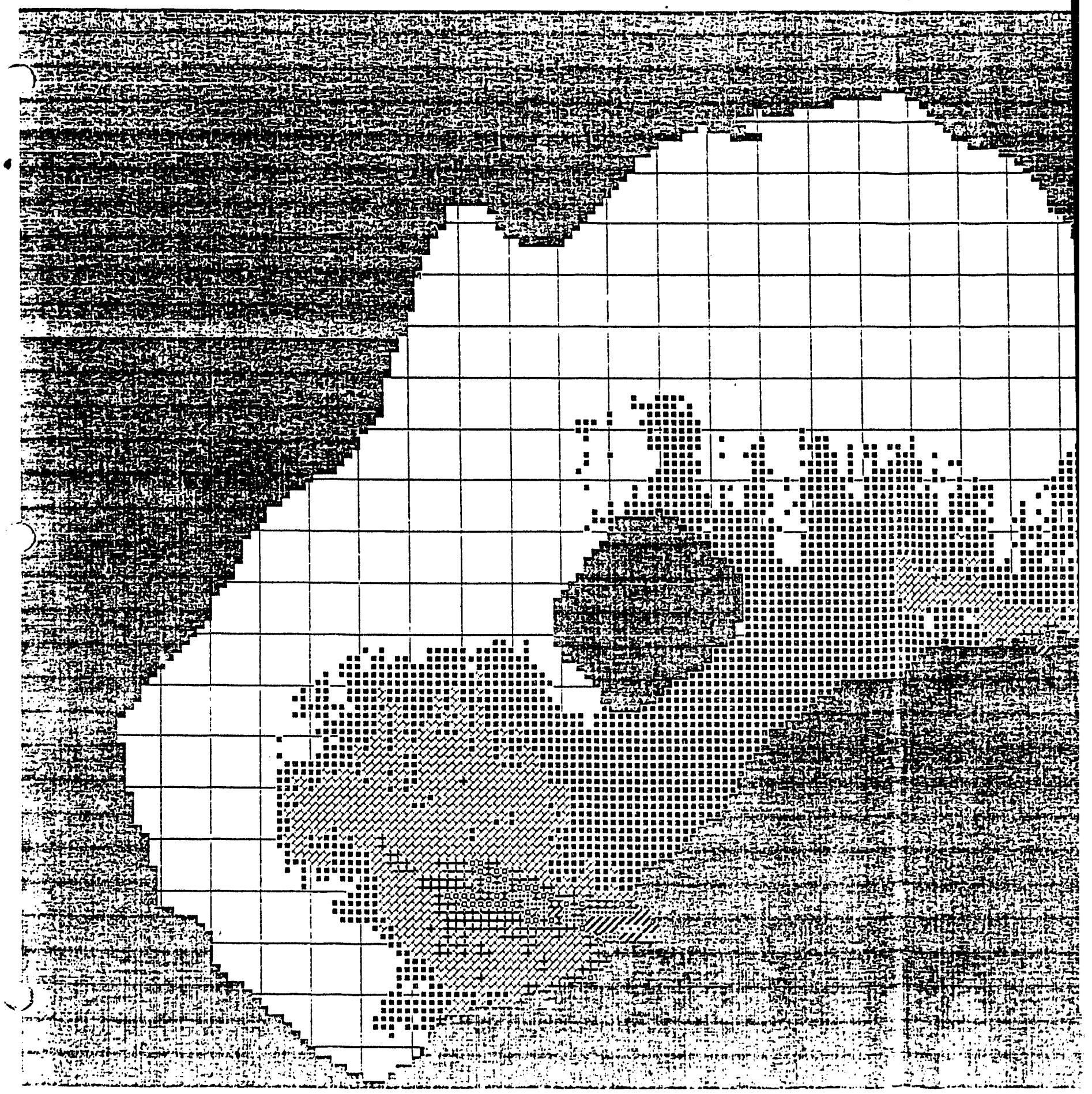




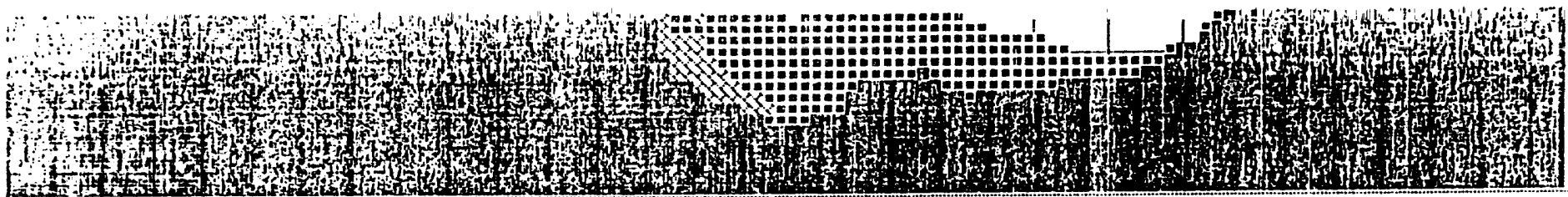

FYEL TEMP. RARISE (DES.F)

1 ::::

- 1 is

갈

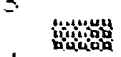

+ Lijist

आm

ज्ञास

$:::::$

Bifif

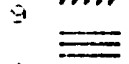

(1)

init

$1 \%$ :

singos

$1+\frac{1}{2000}$

15. PIII,

15. IIIII

17. 该

10 낸ㅊ

1.

$\therefore 4$

$39.27-48.74$

$40.74-42.20$

$42.20-43.67$

$43.67-45.13$

$45.13-40.60$

$46.60-48.06$

$48 . \theta E-49.53$

49.53 - 50.99

$50.99-52.45$

$53.92-55.38$

$55.38-56.85$

$56.55-58.31$

$58.31-59.78$

$59.78-61.24$

$61.24-62.71$

$62.71-04.17$

$64.17-65.64$

$65.04-67.10$

$67.10-68.57$
$52.45-53.92$

ELEMENT (SQ.FT.) $=6 .+2.1110 *+$

IIIIE CIF PASS $=123.1$

ril. $11111 U \mathrm{ULE}$ (FEET) $=700$

iE AIIIN' (DEG. FROH NURTH) $=340$

¿FEE[ $=1 \ddot{C} \dot{E}$

$\therefore$ I1 5 IZE (FEET) $=50$

$\because$ FHID IR TEST $12: 4,73$
MUMGER OF FREA ELEMENTS

2259
765
142
36
21
23
23
5
0
0
0
0
0
0
0
0
0
0
0

AREF(SO.FT.)

$1.4511 \quad 16 *+5$

$4.9143 \quad 10 * * 4$

9. $1221 \quad 10 * * 3$

$2.3126,16 * * 3$

$1.3 .490 \quad 10 * * 3$

$1.477510 * * 3$

1. $4775 \quad 10 * * 5$

$3.2120 \quad 10 *+2$

c. 5000 $10 *+4$

$0.000016 *+1$

$0.6000 \quad 10+* 4$

$0.006010 * 44$

$0.0000 \quad 10 * * 1$

$0.006010 * * 4$

$6.000010 * 4$

$0.000410 * * 4$

6.0000 $10 * * 4$

(1). $000010+4.1$

$0.000010+4.7$

$0.0000 \quad 10 * 44$ 


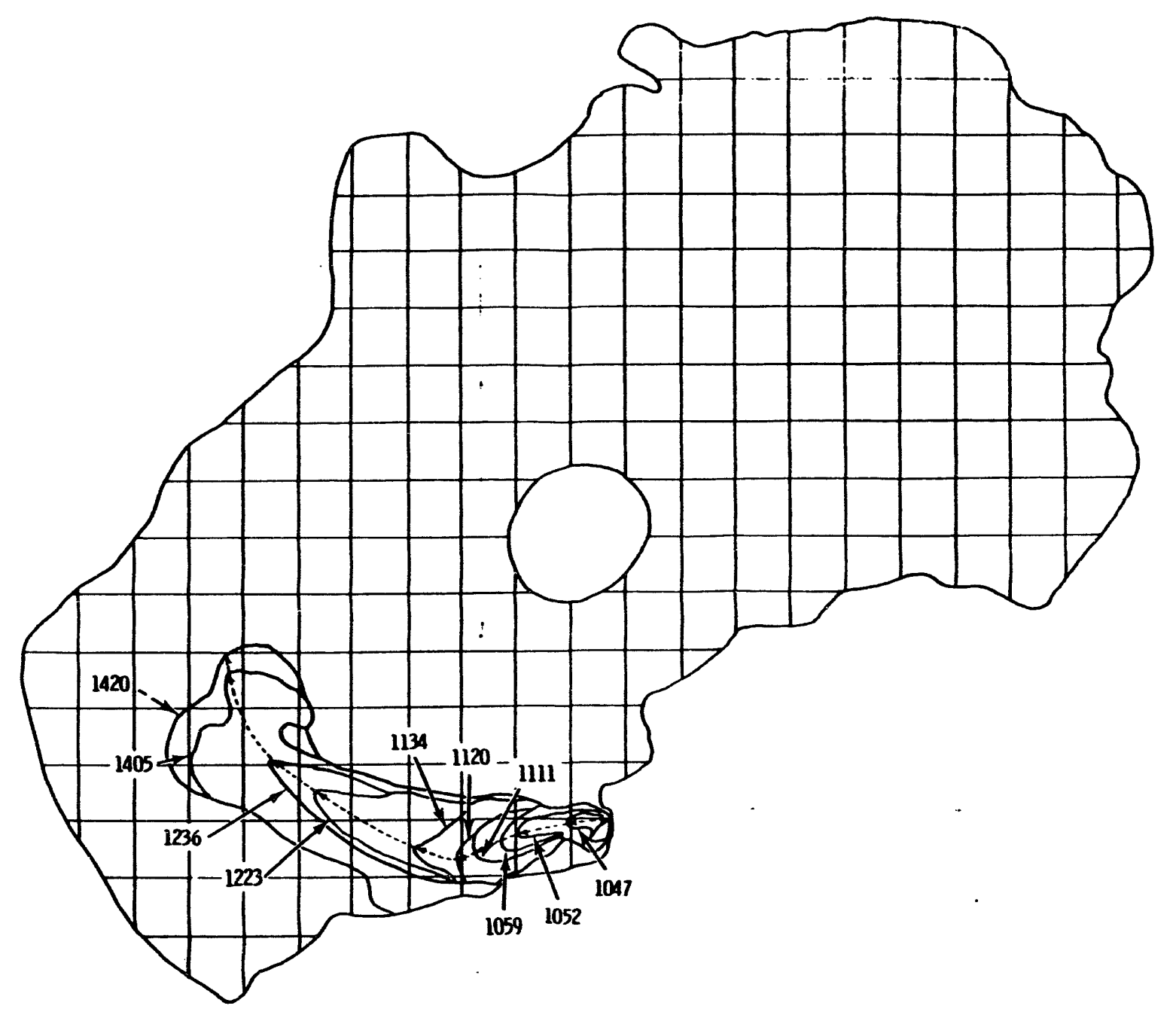


WHC-EP-0707, Rev. 0

APPENDIX A

DATA COLLECTION AND ANALYSIS SYSTEM

C. 27 
WHC-EP-0707, ReV. 0

APPENDIX

\section{DATA COLLECTION AND ANALYSIS SYSTEM}

A remote sensing system developed by Battelle-Northwest was used to conduct the surface temperature and tracer dye test survey described in this report. The basic data collection system shown in Figures $A-1$ and $A-2$ is an optical mechanical scanner which is operated from a Cessna 310. Data is recorded directly on magnetic tape which can be input to a computer system for analysis. Output can be obtained as isothermal or isoconcentration plots produced directly by the computer or on digital tape, paper tape, or computer cards for subsequent computer analysis.

The optical mechanical imaging system scans an area normal to the aircraft flight path and 60 degrees either side of nadir. Figure A-3 shows a typical scanner sweep path and the instantaneous field of view of the scanner, illustrating the relationship of the scanning system to the ground. Figure A-4 shows 2 generalized diagram of the optical mechanical imaging system and the signals produced in the system. The scanning unit consists of a rotating mirror system that scans a segment of the surface normal to the flight path and optic systems that collect and focus the incoming radiation on the detectors.

The dye tracer system collects electromagnetic radiation emitted by fluorescent dye due to solar pumping, while the infrared thermal system collects long wavelength electromagnetic energy emitted by objects according to their temperatures. Both systems are combined into one scanner. The dye system utilizes photomultipliers for the detectors and the thermal system has a photoconductive long wavelength, mercury-cadmium-telluride detector sensitive to $8-14 \mu$ infrared radiation. 

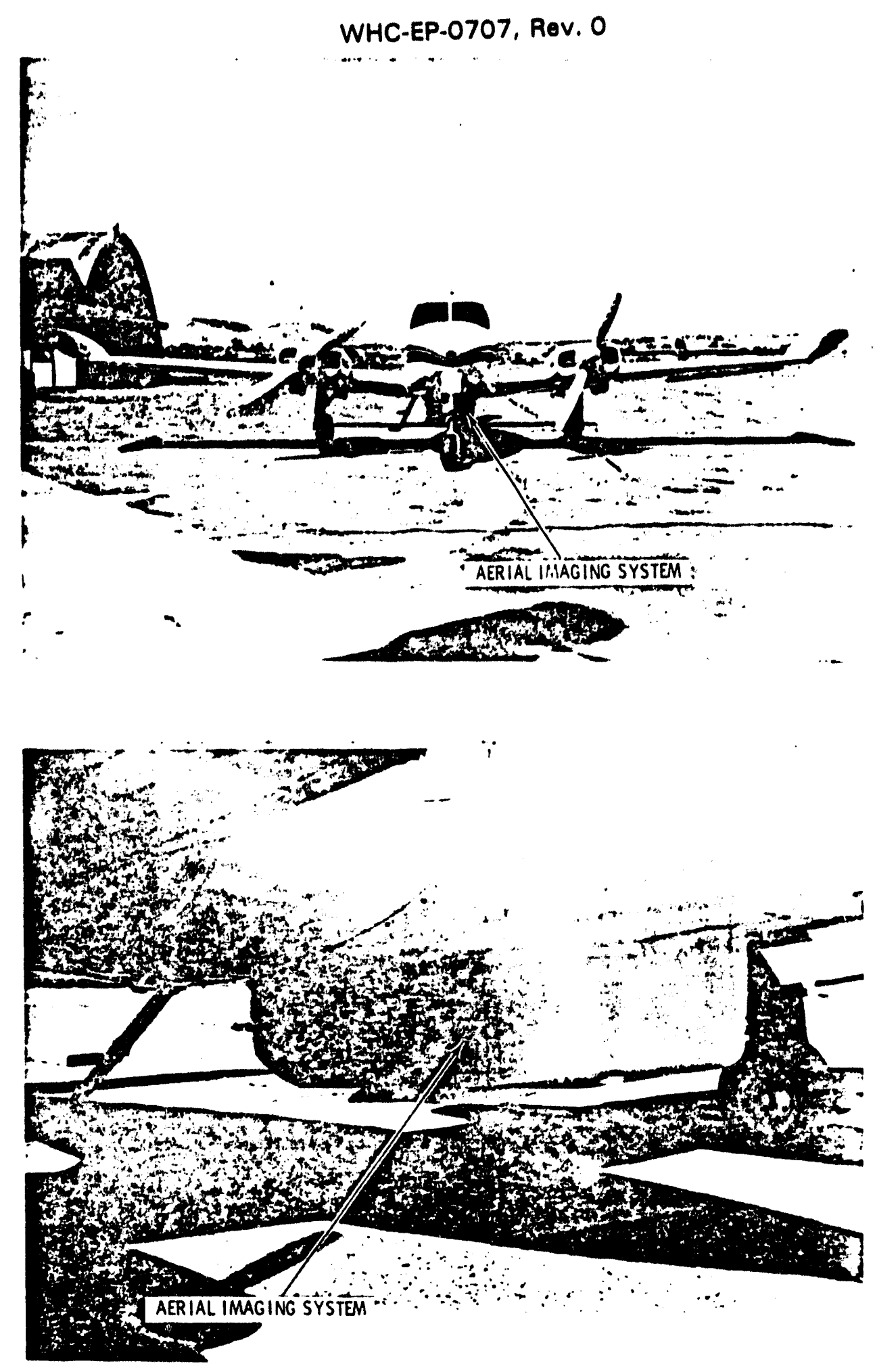

FIGURE A-1. Aerial Imaging System Mounted on the Survey Aircraft 


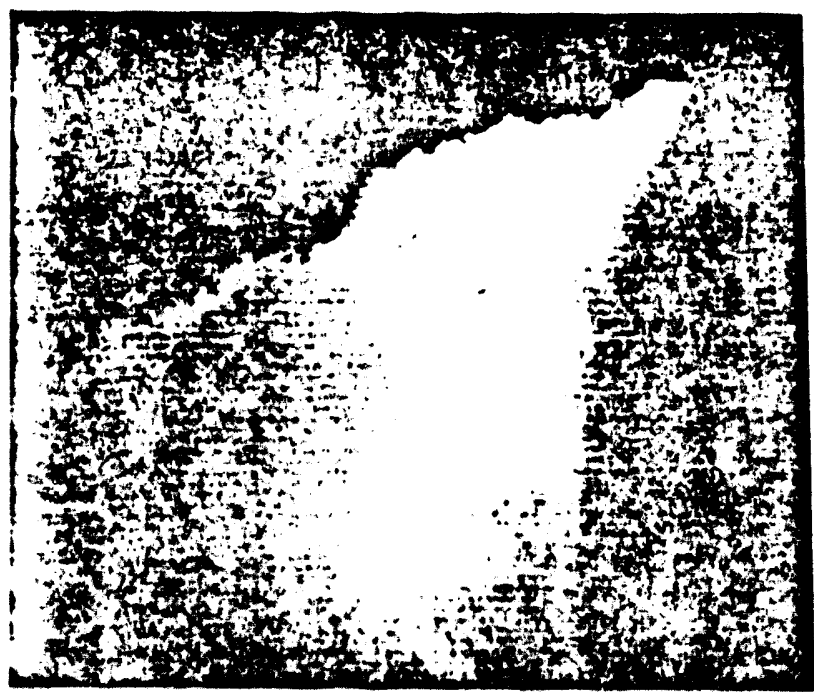

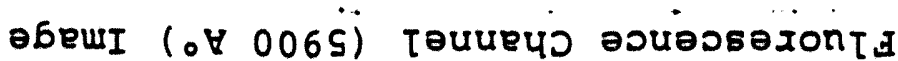

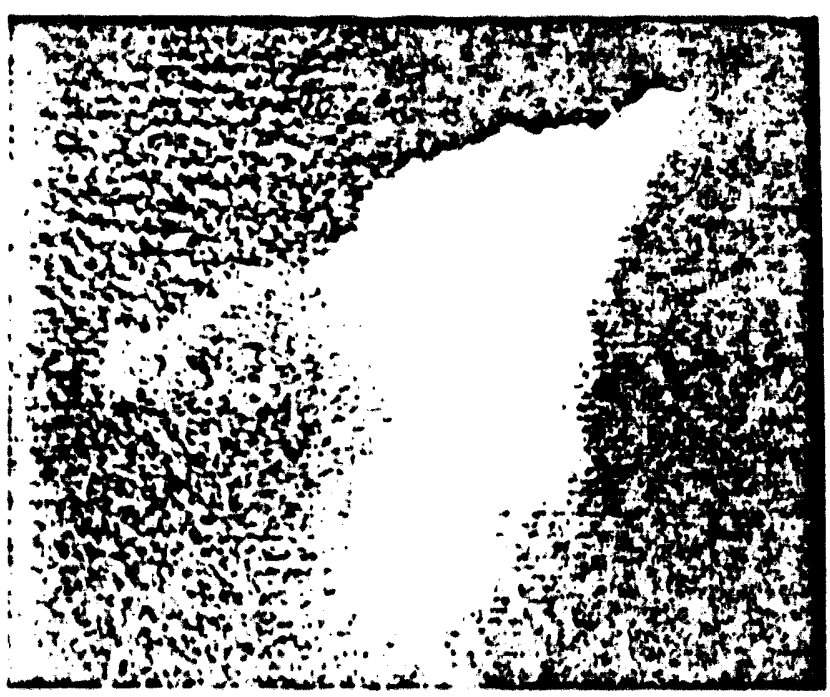


WHC.EP-0707, Rev. 0

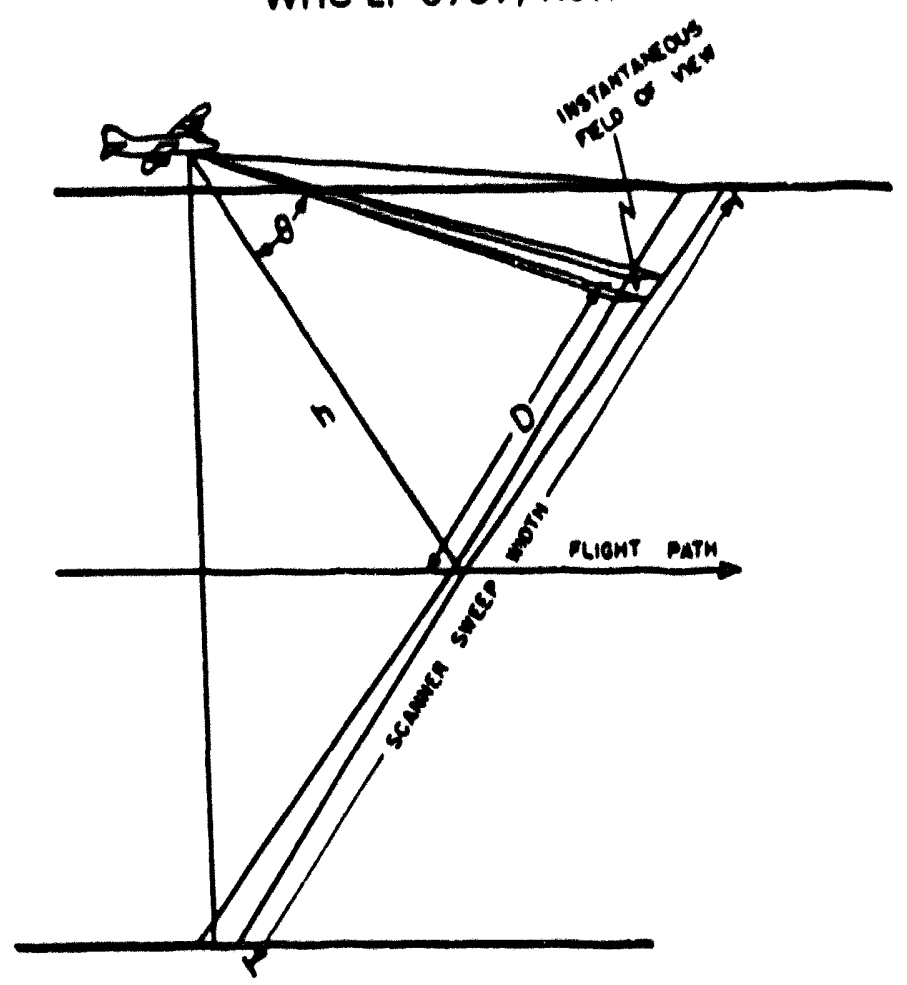

FIGURE A-2. Imaging system Relationship to the Ground

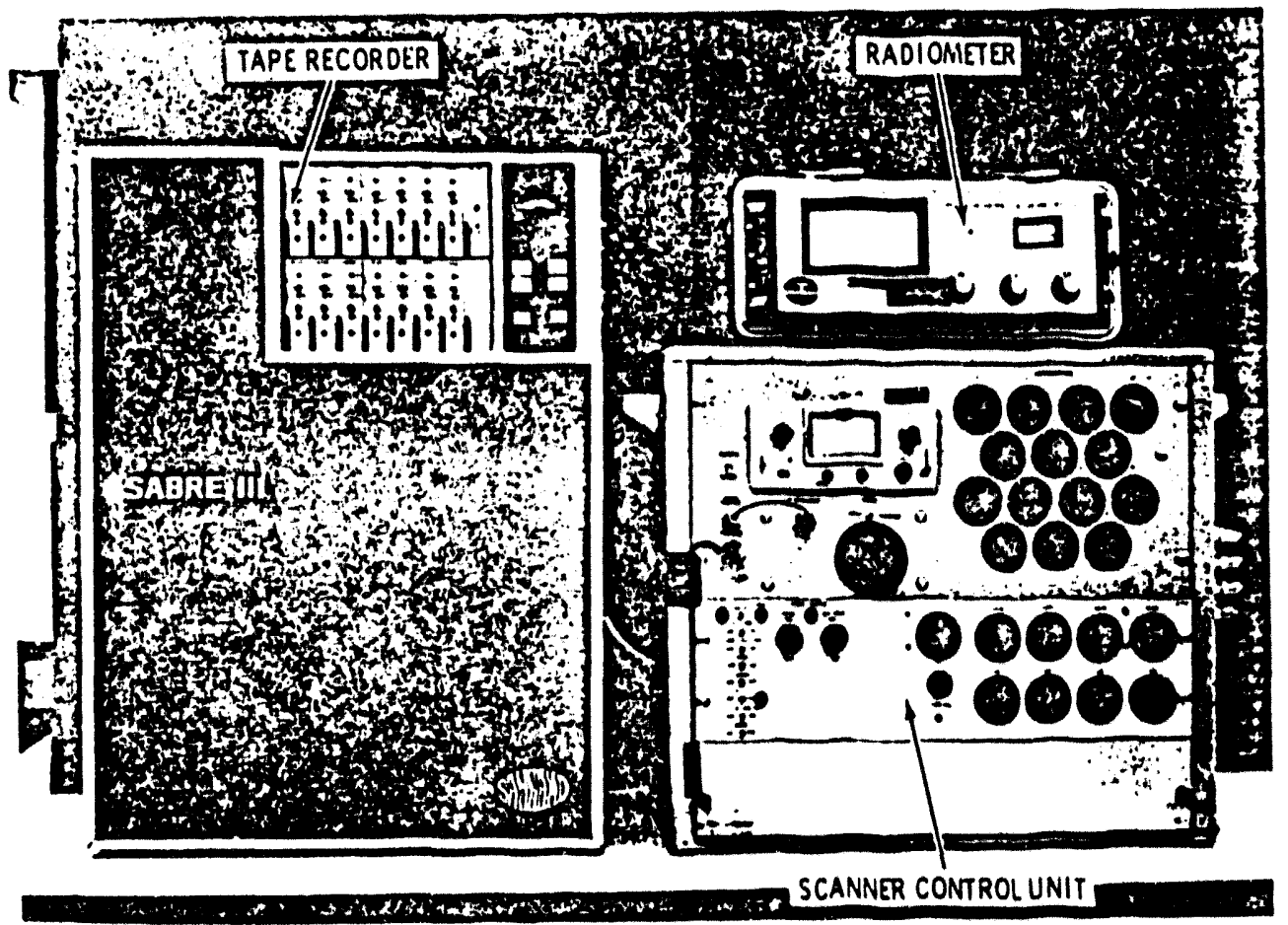

FIGURE A-3. Recording and Control Units for the Aerial Imaging System 
WHC-EP-0707, Rev. 0

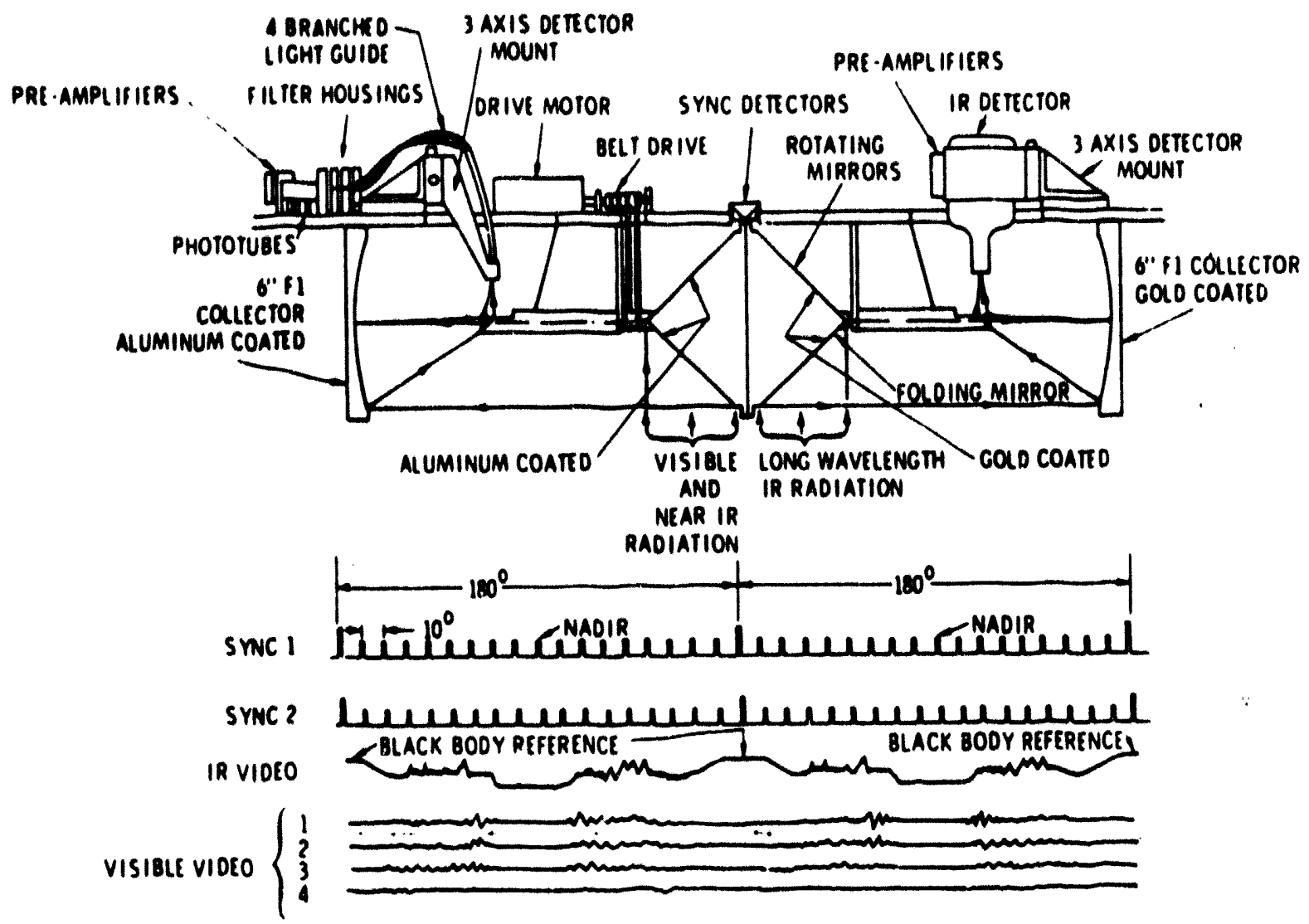

FIGURE A-4. Optical Mechanical Imaging system and Signals Produced from the Detectors

The thermal imaging system used in these surveys consists of the optical mechanical imaging system equipped with a long wavelength mercury-cadmium-telluride detector which provides a temperature sensitivity to $<0.5^{\circ} \mathrm{C}$, a magnetic tape recording system, and computer data analysis programs. Data collected with this system is representative of the near-surface $(<0.1 \mathrm{~mm})$ temperatures. A complete two-dimensional pattern is collected as the aircraft traverses the target area. The optical resolution depends on aircraft altitude; the system divergence is less than 2 milliradians, which limits the instantaneous field of 
view to an area of approximately 2 feet in diameter at 1,000 foot altitude. In order to quantitatively evaluate the imagery, it is necessary to collect surface temperature measurements during each survey.

For this survey only a relative measurement of temperature distribution over the pond surface was necessary. Temperature data recorded by Battelle-Blology on November 27, 1974, under ARHCO contract were reviewed and estimates were made to process the infrared data.

- The aerial tracer dye system utilizes two of the visible channels in the optical mechanical imaging system, a magnetic tape recording system, and a computer data analysis program. Narrow band pass filters in the imaging system are centered at the fluorescence emission maximum of the tracer dye $\left(5,900 \mathrm{~A}^{\circ}\right)$ for the fluorescence channel and at longer wavelengths beyond the fluorescence emission of the dye $\left(7,000 \mathrm{~A}^{\circ}\right)$ for the reference channel. Data from the fluorescence channel is corrected for reflectance variation using the longer wavelength reference channel. Figure A-5 shows intensity modulated tracer dye images produced with and without the reflectance correction, illustrating the significance of this correction. Magnetic tape recordings of the data are collected and processed by a computer program which produces a display of individually coded selected dye concentration ranges, The computer generated displays are rectified to correct for aircraft roll and scanner distortion and superimposed on a reference grid after which the integrated areas for each concentration range are printed out. Since it was beyond the scope of this project to determine rates of dispersion, appropriate dye concentration values for analyzing the tracer dye data were estimated. This procedure gives approximate flow rates which are sufficient for this project.

Battelle-Northwest has developed computer programs which simplify the analysis of recorded infrared and tracer dye data and facilitate presentation of the information in an under- 
standable, quantified format. These programs apply the necessary geometric and temperature corrections, calibrate the signals, and produce the final output.

The analysis programs are now running on a small hybrid computer system which consists of a Beckman analog and a small digital computer (Figure A-6). The digital computer is a DEC PDP-7 with 18 bit word, 1.75 microsecond cycle time and a $500 \mathrm{~K}$ word disc. The two machines are linked by 24 channels of digitalto-analog and analog-to-digital converters. The analog-todigital conversion rate is $100 \mathrm{KHz}$. Peripheral devices include a storage scope which allows the operator to view input and calibration data and to display the output plots for editing and review and an analog control box consisting of various switches, buttons, potentiometers and multiposition switches which through the $A-t O-D$ converters allow the operator to perform many program control functions swiftiy and efficiently that would be somewhat cumbersome to communicate through a teletype. Output is plotted on an electrostatic printer.

Data required for the quantitative analysis of the aerial survey data are recorded on magnetic tape in the aircraft (viden, sync radiometer and roll signals); in notebooks in the aircraft (run identification, time, magnetic tape, footage and identification number, altitude, air speed, and other observations of the crew); and in notebooks of ground crews (discharge location, velocity of discharge, time log at dye release and approximation of movement with time, etc.). The processing sequence is shown in block form in Figure $A-7$,

The first step in the analysis sequence is input of the video, roll and sync signals to the digital computer through analog amplifiers and the $A$ to $D$ converters. Altitude and air speed are input at this time through the teletype. Scan lines are digitized over the full $120^{\circ}$ field of view of the scanner. Each scan line is converted to $448-13$ bit binary numbers. Several successive scan lines are averaged and the resulting 448

$$
\text { A-: }
$$


WHC-EP-0707, Rev. 0
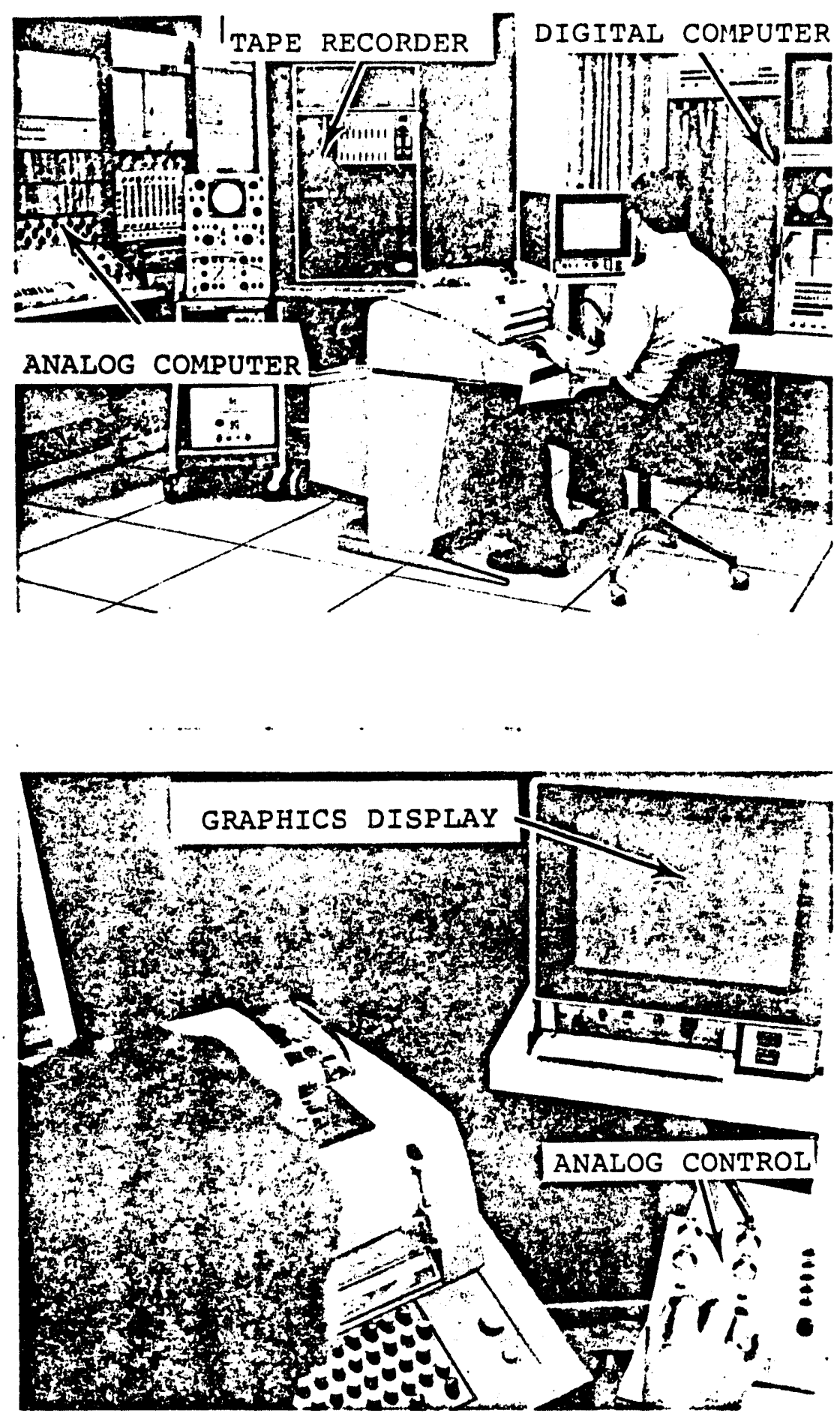

FIGURE A-6. Data Processing Hybrid Computer System 


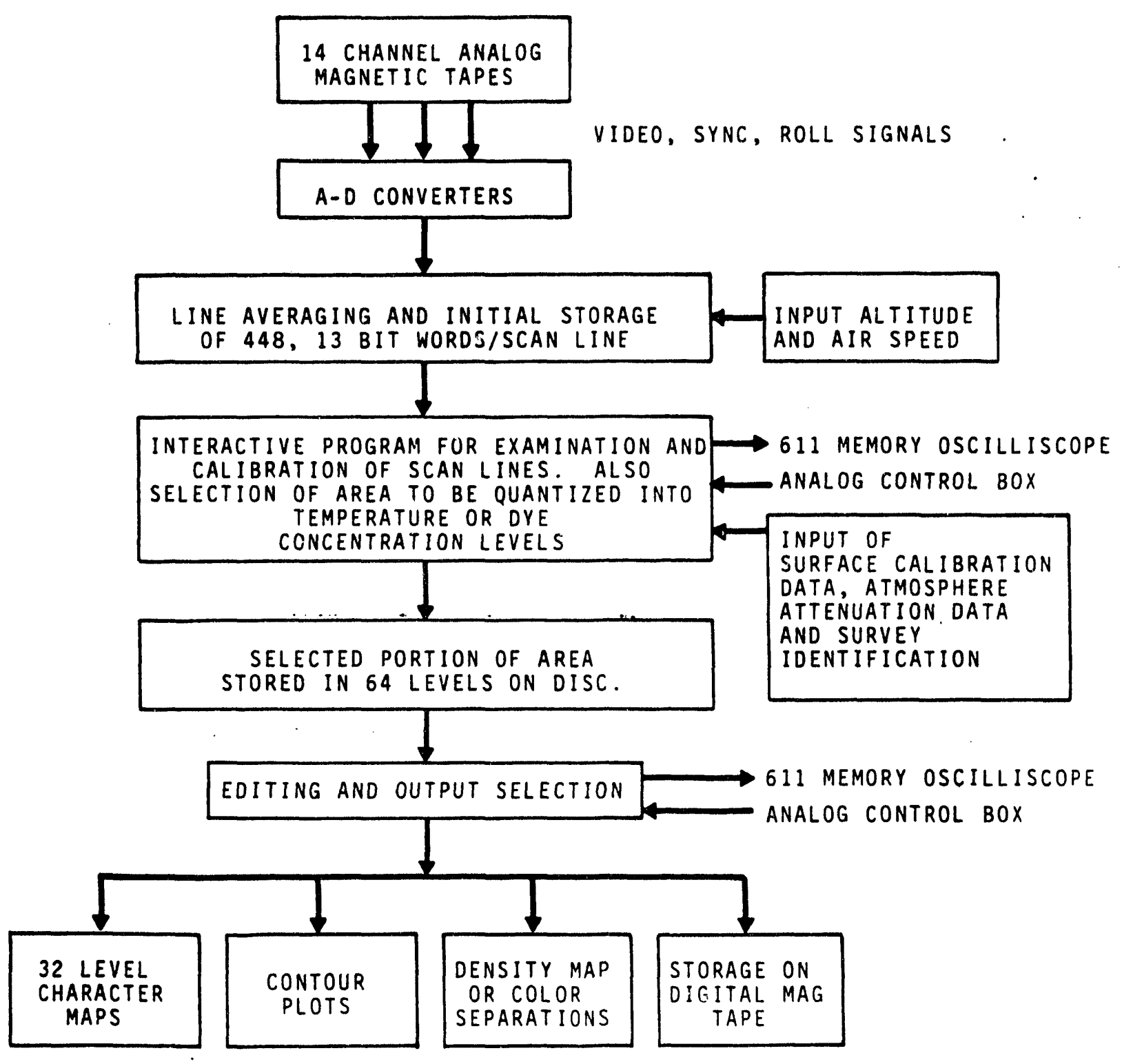

FIGURE A-7. Block Diagram of Processing Program 
numbers are stored on the disc. The number averaged is directly proportional to altitude, typically varying from 2 to 50 , and can be modified by the operator if desired. The process continues until the area of interest has been transferred to the disc. At this point, the operator may recall and examine any of the stored scan lines.

The second step in the analysis sequence is calibration of the digitized scan lines. Atmospheric absorption corrections are made from direct measurement of signal attenuation over areas of known temperature near the survey site. Ground truth temperature or dye concentration data are input to the program by the computer operator at station locations identified on the stored scan lines. At this time the program enables the computer operator to scale distances along scan lines or along the flight path to obtain accurate locations of ground truth stations from identifiable landmarks in the imagery, thus insuring accurate calibration data input. The temperature calibration for a survey is determined from the input ground truth data by computing a straight line least squares fit of the data.

The third step in the analysis sequence is selection of the area to be plotted, temperature or dye concentration contour interval, and application of the roll and tangent scan angle correction. The length and width of the area to be analyzed is selected by the operator from the calibrated data on disc. Temperature or dye concentration scales are then chosen to provide the desired output. Typical temperature plots are produced at $1^{\circ} \mathrm{F}$ or $2^{\circ} \mathrm{F}$ level spacing, although if adequate calibration data are available accurate plots of temperature levels down to $0.5^{\circ} \mathrm{F}$ can be produced by the system. The operitor specifies the spacing of temperature levels and the characters which represent each absolute temperature range. The same characters are normally used for the temperature ranges in all output plots for a survey so that subsequent runs can be compared without confusion. Typically, the lowest temperature level assigned a character is the lowest absolute temperature 
level which occurs in the survey area. However, in these thermal plots some areas show no characters, only the background grid. The temperature in these areas (without characters) is less than one level below the lowest temperature range represented by the characters. Once the desired temperature level spacing is chosen, the program applies two more corrections and proceeds to generate the quantitized output on another protion of the disc. The last two corrections are roll and a tangent scan angle correction. If the scan angle is $\theta$ and the roll angle is a then the true ground position relative to a point beneath the plane is given by the equation

$$
\mathrm{x}=\mathrm{h} \operatorname{Tan}(\theta+\alpha)
$$

where $h$ is the altitude above the ground. This equation is used to convert the angular data into an undistorted ground map.

The final step in the analysis sequence is editing and selection of the output. form. To obtain accurate estimates of water areas in the various temperature or dye concentration ranges, it is necessary to remove data collected over land. Because this process cannot yet be executed automatically with the required precision by the machine, the operator must remove any existing land area from the picture with an editing program which has been developud. The output plots, which are continuous strips, are broken up into overlapping pages to be displayed on the scope for editing. The analog control box allows the operator to recall and edit these pages. The editing process consists of drawing a contour on the memory scope around the area to be deleted, after which the program deletes this data from the disc. At any stage along the way printouts of the temperature map are easily produced on the electrostatic printer.

When editing is complete the temperature map may be output in a number of forms:

1. characters that form distinctive patterns for each temperature level

2. numbers or letters representing particular levels on each element of the map 
WHC-EP-0707, Rev. 0

Appendix D

216-U-10 Pond-Bottom Sediments from BNW's Grid Sampling 


\section{Appendix D}

\section{U-Pond Bottom Sediments from BNW's Grid Sampling ${ }^{(a)}$}

\begin{tabular}{|c|c|c|c|c|c|c|}
\hline $\begin{array}{c}\text { Sample } \\
\text { Date }\end{array}$ & Location & $\begin{array}{c}{ }^{137} \mathrm{Cs} \\
(\mathrm{pCi} / \mathrm{g})\end{array}$ & $\begin{array}{c}{ }^{238} \mathrm{Pu} \\
(\mathrm{pCi} / \mathrm{g})\end{array}$ & $\begin{array}{c}239,240 \mathrm{Pu} \\
(\mathrm{pCi} / \mathrm{g})\end{array}$ & $\begin{array}{l}{ }_{(\mathrm{pCi} / \mathrm{gm}} \mathrm{Am} \\
\end{array}$ & $\begin{array}{c}\text { Total U } \\
\text { (ppm) }\end{array}$ \\
\hline $10 / 17 / 73$ & $\begin{array}{l}\text { Grid 1 } \\
\text { Grid 2 } \\
\text { Grid } 3 \\
\text { Grid } 4 \\
\text { Grid 5 } \\
\text { Grid } 6 \\
\text { Grid } 7 \\
\text { Grid } 8 \\
\text { Grid 9 } \\
\text { Grid 10 } \\
\text { Grid 11 } \\
\text { Grid 12 } \\
\text { Grid 13 } \\
\text { Grid 14 } \\
\text { Grid } 15 \\
\end{array}$ & $\begin{array}{l}- \\
- \\
- \\
- \\
- \\
- \\
- \\
- \\
- \\
- \\
- \\
- \\
- \\
- \\
-\end{array}$ & $\begin{array}{l}- \\
- \\
- \\
- \\
- \\
- \\
- \\
- \\
- \\
- \\
- \\
- \\
- \\
- \\
-\end{array}$ & $\begin{array}{l}- \\
- \\
- \\
- \\
- \\
- \\
- \\
- \\
- \\
- \\
- \\
- \\
- \\
-\end{array}$ & $\begin{array}{l}- \\
- \\
- \\
. \\
. \\
. \\
- \\
- \\
- \\
- \\
- \\
- \\
- \\
. \\
-\end{array}$ & $\begin{array}{r}2.3 \mathrm{E}+02 \\
4.0 \mathrm{E}+02 \\
7.0 \mathrm{E}+02 \\
1.4 \mathrm{E}+02 \\
1.4 \mathrm{E}+02 \\
1.0 \mathrm{E}+03 \\
1.0 \mathrm{E}+03 \\
6.2 \mathrm{E}+02 \\
396.6 \\
719.0 \\
1074.0 \\
84.7 \\
337.0 \\
439.0 \\
362.0\end{array}$ \\
\hline $11 / 28 / 73$ & $\begin{array}{l}\text { Grid 1A } \\
\text { Grid 1B } \\
\text { Grid 2A } \\
\text { Grid 2B } \\
\text { Grid 3 } \\
\text { Grid 4 } \\
\text { Grid 5A } \\
\text { Grid 5B } \\
\text { Grid 6 } \\
\text { Grid 7 } \\
\text { Grid 8A } \\
\text { Grid 8B }\end{array}$ & $\begin{array}{l}- \\
- \\
- \\
- \\
- \\
- \\
- \\
- \\
- \\
- \\
- \\
-\end{array}$ & $\begin{array}{l}- \\
- \\
- \\
- \\
- \\
- \\
- \\
- \\
- \\
- \\
- \\
-\end{array}$ & $\begin{array}{l}- \\
- \\
- \\
- \\
- \\
- \\
- \\
- \\
- \\
- \\
-\end{array}$ & $\begin{array}{l}- \\
. \\
- \\
- \\
- \\
- \\
- \\
- \\
- \\
- \\
- \\
-\end{array}$ & $\begin{array}{r}295.6 \\
295.6 \\
422.4 \\
422.4 \\
255.1 \\
1710.0 \\
357.0 \\
357.0 \\
1109.0 \\
1189.0 \\
672.0 \\
672.0\end{array}$ \\
\hline
\end{tabular}

(a) Provided by D. C. Klopfer (Battelle, Pacific Northwest Laboratories [BNW]) and L. E. Bruns (Rockwell Hanford Operations).

D.1 
WHC-EP-0707, Rev. 0

Table D.1. Continued

\begin{tabular}{|c|c|c|c|c|c|c|}
\hline $\begin{array}{c}\text { Sample } \\
\text { Date }\end{array}$ & Location & $\begin{array}{c}{ }^{137} \mathrm{Cs} \\
(\mathrm{pCi} / \mathrm{g})\end{array}$ & $\begin{array}{c}{ }^{208} \mathrm{Pu} \\
(\mathrm{pCi} / \mathrm{g})\end{array}$ & $\begin{array}{l}239,240 \mathrm{Pu} \\
(\mathrm{pCi} / \mathrm{g})\end{array}$ & $\begin{array}{l}{ }_{(\mathrm{p}}^{241} \mathrm{Am} \\
(\mathrm{Ci} / \mathrm{g})\end{array}$ & $\begin{array}{c}\text { Total U } \\
\text { (ppm) }\end{array}$ \\
\hline $\begin{array}{l}11 / 28 / 73 \\
\text { (contd) }\end{array}$ & $\begin{array}{l}\text { Grid } 9 \\
\text { Grid } 10 \\
\text { Grid 11A } \\
\text { Grid 11B } \\
\text { Grid } 12 \\
\text { Grid } 13 \\
\text { Grid 14 } \\
\text { Grid 15A } \\
\text { Grid 15B }\end{array}$ & $\begin{array}{l}- \\
- \\
- \\
- \\
- \\
- \\
- \\
- \\
-\end{array}$ & $\begin{array}{l}- \\
- \\
- \\
- \\
- \\
- \\
- \\
- \\
-\end{array}$ & $\begin{array}{l}- \\
- \\
- \\
- \\
- \\
- \\
- \\
- \\
-\end{array}$ & $\begin{array}{l}- \\
- \\
- \\
- \\
- \\
- \\
- \\
- \\
-\end{array}$ & $\begin{array}{r}419.0 \\
1176.0 \\
555.0 \\
\\
293.2 \\
337.0 \\
626.0 \\
484.0\end{array}$ \\
\hline $12 / 28 / 73$ & $\begin{array}{l}\text { Grid } 1 \\
\text { Grid } 2 \\
\text { Grid } 3 \\
\text { Grid } 4 \\
\text { Grid } 5 \\
\text { Grid } 10 \\
\text { Grid } 11 \\
\text { Grid } 12 \\
\text { Grid } 13 \\
\text { Grid } 14 \\
\text { Grid } 15\end{array}$ & $\begin{array}{l}- \\
- \\
- \\
- \\
= \\
- \\
- \\
- \\
- \\
- \\
-\end{array}$ & $\begin{array}{l}- \\
- \\
- \\
- \\
- \\
- \\
- \\
- \\
- \\
-\end{array}$ & $\begin{array}{l}- \\
- \\
- \\
- \\
- \\
- \\
- \\
- \\
- \\
- \\
-\end{array}$ & $\begin{array}{l}- \\
- \\
- \\
- \\
- \\
- \\
- \\
- \\
- \\
- \\
-\end{array}$ & $\begin{array}{r}257.9 \\
375.3 \\
635.0 \\
554.0 \\
1176.0 \\
1037.0 \\
70.6 \\
125.0 \\
778.0 \\
403.0\end{array}$ \\
\hline $1 / 22 / 74$ & $\begin{array}{l}\text { Grid } 1 \\
\text { Grid } 2 \\
\text { Grid } 3 \\
\text { Grid } 4 \\
\text { Grid } 5 \\
\text { Grid } 6 \\
\text { Grid } 7 \\
\text { Grid } 8 \\
\text { Grid } 9 \\
\text { Grid } 10 \\
\text { Grid } 11 \\
\text { Grid } 12 \\
\text { Grid } 14 \\
\text { Grid } 15\end{array}$ & $\begin{array}{l}- \\
- \\
- \\
- \\
- \\
- \\
- \\
- \\
- \\
- \\
- \\
- \\
- \\
- \\
\end{array}$ & $\begin{array}{l}- \\
- \\
- \\
- \\
- \\
- \\
- \\
- \\
- \\
- \\
- \\
- \\
- \\
\end{array}$ & $\begin{array}{l}- \\
- \\
- \\
- \\
- \\
- \\
- \\
- \\
- \\
- \\
- \\
- \\
- \\
-\end{array}$ & $\begin{array}{l}- \\
- \\
- \\
- \\
- \\
- \\
- \\
- \\
- \\
- \\
- \\
- \\
- \\
-\end{array}$ & $\begin{array}{r}183.4 \\
367.0 \\
926.0 \\
635.0 \\
212.9 \\
466.0 \\
1521.0 \\
143.2 \\
354.0 \\
744.0 \\
988.0 \\
326.0 \\
1478.0 \\
455.0 \\
\end{array}$ \\
\hline $2 / 22 / 74$ & Grid 13 & - & - & - & - & 1.9 \\
\hline
\end{tabular}


WHC-EP-0707, Rev. 0

Table D.1. Continued

\begin{tabular}{|c|c|c|c|c|c|c|}
\hline $\begin{array}{c}\text { Sample } \\
\text { Date }\end{array}$ & Location & $\begin{array}{c}{ }^{137} \mathrm{Cs} \\
(\mathrm{pCi} / \mathrm{g})\end{array}$ & $\begin{array}{l}{ }_{(\mathrm{pCi} / \mathrm{g}}{ }^{20} \mathrm{Pu} \\
\text { (n) }\end{array}$ & $\begin{array}{l}239,240 \mathrm{Pu} \\
(\mathrm{pCi} / \mathrm{g})\end{array}$ & $\begin{array}{l}{ }_{(\mathrm{pCl} / \mathrm{g})} \mathrm{Am} \\
\end{array}$ & $\begin{array}{c}\text { Total U } \\
\text { (ppm) }\end{array}$ \\
\hline $3 / 21 / 74$ & $\begin{array}{l}\text { Grid } 13 \\
\text { Grid } 13\end{array}$ & $\begin{array}{l}36.0 \\
19.0 \\
\end{array}$ & $\cdot$ & - & - & $\begin{array}{l}1.4 \\
1.6\end{array}$ \\
\hline $4 / 17 / 74$ & $\begin{array}{l}\text { Grid } 7 \\
\text { Grid } 9 \\
\text { Grid } 10 \\
\text { Grid } 14\end{array}$ & $\begin{array}{c}1.0 \mathrm{E}+01 \\
1.2 \mathrm{E}+04 \\
2.6 \mathrm{E}+02 \\
- \\
\end{array}$ & $\begin{array}{c}- \\
4.6 \mathrm{E}+01 \\
4.6 \mathrm{E}+02 \\
5.0 \mathrm{E}+01\end{array}$ & $\begin{array}{c}- \\
1.6 \mathrm{E}+02 \\
3.7 \mathrm{E}+02 \\
3.7 \mathrm{E}+02 \\
\end{array}$ & $\begin{array}{c}- \\
1.1 \mathrm{E}+01 \\
3.2 \mathrm{E}+02 \\
6.7 \mathrm{E}+01 \\
\end{array}$ & - \\
\hline $5 / 17 / 74$ & $\begin{array}{l}\text { Grid } 1 \\
\text { Grid } 3 \\
\text { Grid } 4 \\
\text { Grid } 5 \\
\text { Grid } 6 \\
\text { Grid } 7 \\
\text { Grid } 8 \\
\text { Grid } 9 \\
\text { Grid } 10 \\
\text { Grid } 12 \\
\text { Grid } 13 \\
\text { Grid } 15\end{array}$ & $\begin{array}{c}- \\
\text { N.D. } \\
- \\
\text { 5.6E+03 } \\
\text { N.D. } \\
- \\
- \\
= \\
- \\
- \\
6.3 \mathrm{E}+03 \\
9.9 \mathrm{E}+01 \\
\end{array}$ & $\begin{array}{c}7.8 \mathrm{E}+01 \\
- \\
2.9 \mathrm{E}+02 \\
2.8 \mathrm{E}+02 \\
<6.4 \mathrm{E}-01 \\
4.3 \mathrm{E}+01 \\
1.2 \mathrm{E}+02 \\
2.4 \mathrm{E}+00 \\
5.2 \mathrm{E}+01 \\
2.9 \mathrm{E}+02 \\
2.2 \mathrm{E}+02 \\
<5.9 \mathrm{E}-01\end{array}$ & $\begin{array}{c}1.6 \mathrm{E}+02 \\
- \\
3.0 \mathrm{E}+02 \\
2.0 \mathrm{E}+02 \\
<6.4 \mathrm{E}-01 \\
7.9 \mathrm{E}+01 \\
1.3 \mathrm{E}+02 \\
2.7 \mathrm{E}+00 \\
6.3 \mathrm{E}+01 \\
2.2 \mathrm{E}+02 \\
1.0 \mathrm{E}+02 \\
1.7 \mathrm{E}+01 \\
\end{array}$ & $\begin{array}{c}7.6 \mathrm{E}+01 \\
- \\
1.9 \mathrm{E}+02 \\
1.1 \mathrm{E}+02 \\
\text { N.D. } \\
2.6 \mathrm{E}+01 \\
7.3 \mathrm{E}+01 \\
1.9 \mathrm{E}+00 \\
1.4 \mathrm{E}+01 \\
2.1 \mathrm{E}+02 \\
1.7 \mathrm{E}+01 \\
\text { N.D. }\end{array}$ & $\begin{array}{c}- \\
1.5 \mathrm{E}+\infty \\
- \\
- \\
1.4 \mathrm{E}+\infty \\
- \\
- \\
- \\
- \\
- \\
- \\
1.2 \mathrm{E}+01 \\
\end{array}$ \\
\hline $6 / 21 / 74$ & $\begin{array}{l}\text { Grid } 1 \\
\text { Grid } 2 \\
\text { Grid } 3 \\
\text { Grid } 4 \\
\text { Grid } 5 \\
\text { Grid } 6 \\
\text { Grid } 7 \\
\text { Grid } 8 \\
\text { Grid } 9 \\
\text { Grid } 10 \\
\text { Grid } 12 \\
\text { Grid } 13 \\
\text { Grid } 14\end{array}$ & $\begin{array}{c}- \\
- \\
2.8 \mathrm{E}+02 \\
\text { N.D. } \\
- \\
- \\
- \\
\text { N.D. } \\
- \\
- \\
\text { 3.8E+02 } \\
\text { N.D. } \\
\text { N.D. }\end{array}$ & $\begin{array}{c}8.3 \mathrm{E}+00 \\
8.6 \mathrm{E}-01 \\
<1.4 \mathrm{E}+\infty 0 \\
<1.1 \mathrm{E}+\infty 0 \\
1.6 \mathrm{E}+01 \\
7.2 \mathrm{E}+01 \\
3.9 \mathrm{E}+01 \\
<7.7 \mathrm{E}-01 \\
4.5 \mathrm{E}+01 \\
9.5 \mathrm{E}+01 \\
<6.4 \mathrm{E}-01 \\
<6.8 \mathrm{E}-01 \\
<1.1 \mathrm{E}+\infty\end{array}$ & $\begin{array}{c}7.2 \mathrm{E}+00 \\
6.6 \mathrm{E}-01 \\
3.1 \mathrm{E}+01 \\
<2.9 \mathrm{E}+00 \\
1.5 \mathrm{E}+01 \\
6.9 \mathrm{E}+01 \\
3.6 \mathrm{E}+01 \\
6.7 \mathrm{E}+01 \\
4.2 \mathrm{E}+01 \\
9.2 \mathrm{E}+01 \\
1.7 \mathrm{E}+\infty 0 \\
<6.8 \mathrm{E}-01 \\
<6.4 \mathrm{E}-01\end{array}$ & $\begin{array}{c}5.7 \mathrm{E}+00 \\
5.0 \mathrm{E}-01 \\
2.1 \mathrm{E}+01 \\
7.0 \mathrm{E}+00 \\
1.1 \mathrm{E}+01 \\
5.8 \mathrm{E}+01 \\
3.0 \mathrm{E}+01 \\
\text { N.D. } \\
3.5 \mathrm{E}+01 \\
7.7 \mathrm{E}+01 \\
\text { N.D. } \\
\text { N.D. } \\
-\end{array}$ & $\begin{array}{c}- \\
- \\
2.5 \mathrm{E}+\infty 0 \\
1.4 \mathrm{E}+\infty 0 \\
- \\
- \\
- \\
2.0 \mathrm{E}+\infty \\
- \\
- \\
1.2 \mathrm{E}+\infty \\
1.1 \mathrm{E}+\infty\end{array}$ \\
\hline
\end{tabular}

D.3 
WHC-EP-0707, Rov. 0

Appendix E

1974 Analyses of the 216-U-10 Pond Shoreline Samples 


\section{Appendix E}

\section{Analyses of the 216-U-10 Pond Shoreline Samples}

This appendix presents the analytical results of soil samples collected from the shoreline of the 216-U-10 Pond. These samples were collected by Atlantic Richfleld Hanford Company in 1974 but never reported. The sample locations are presented in Figure E.1, and the analytical results are presented in Table E.1. 
WHC-EP-0707, Rev. 0

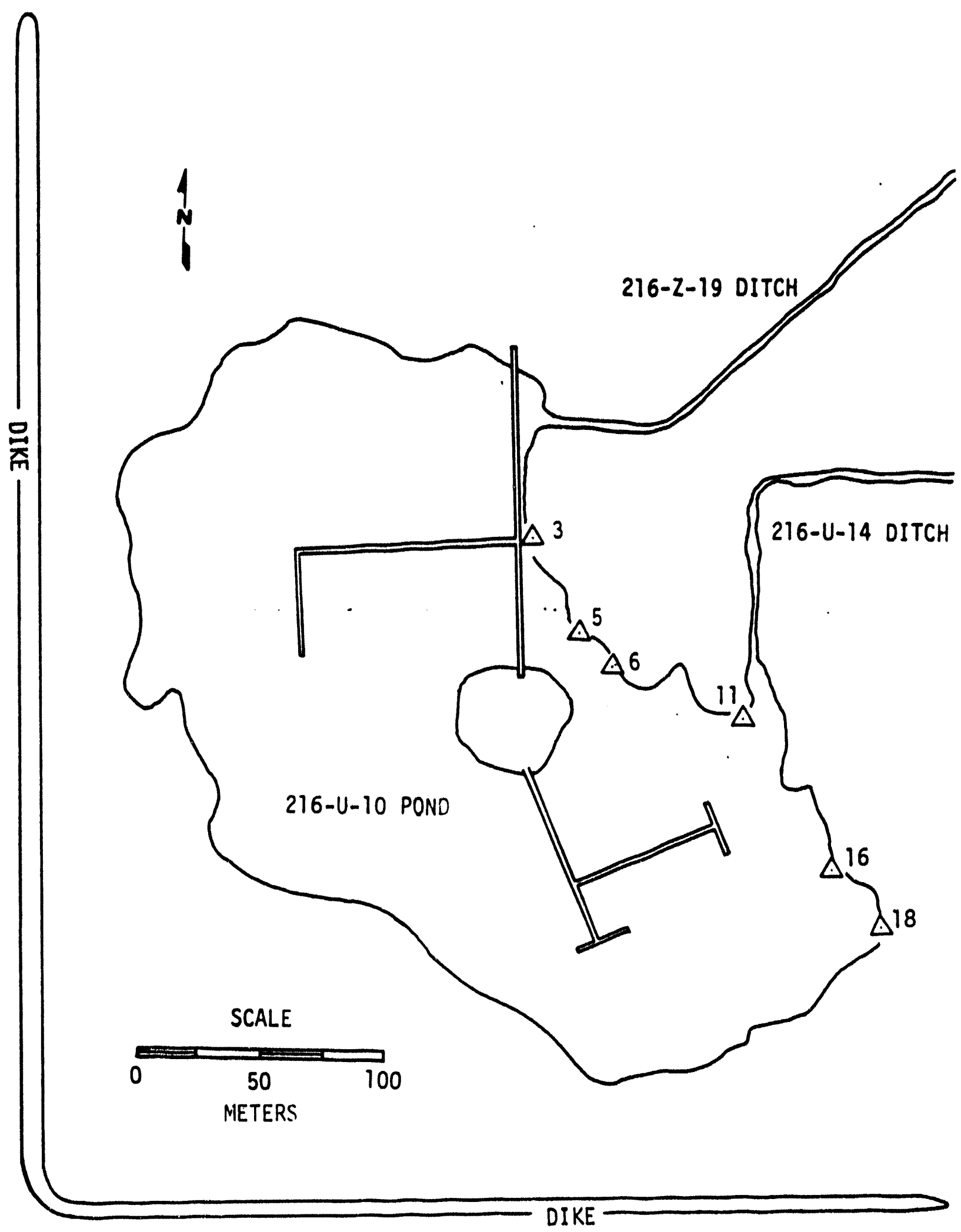

Figure E.1. 216-U-10 Pond Shoreline Sampling Locations 
Table E.1. 1974 Analyses of U-Pond Shoreline Samples

\begin{tabular}{|c|c|c|c|c|c|c|}
\hline $\begin{array}{c}\text { Original } \\
\text { Sample }\end{array}$ & $\begin{array}{c}\text { Sample } \\
\text { Depth }(\mathrm{cm})\end{array}$ & $\begin{array}{l}\text { Sample } \\
\text { Mass }(\mathrm{cm})\end{array}$ & ${ }^{241} \mathrm{Am}(\mathrm{pCi} / \mathrm{g})$ & ${ }^{226} \mathrm{Ra}(\mathrm{pCi} / \mathrm{g})$ & ${ }^{137} \mathrm{Cs}(\mathrm{pCt} / \mathrm{g})$ & ${ }^{40} K(p C I / g)$ \\
\hline $3 C$ & 20.0 to 30.0 & 120.25 & $<1.4$ & $<1.0$ & $18.7 \pm 0.54+01 \%$ & $16.5 \pm 0.24+02 \%$ \\
\hline $5 C$ & 20.0 to 30.0 & 131.65 & $<4.5$ & $<3.7$ & $813.5 \pm 0.79+00 \%$ & $13.7 \pm 0.25+02 \%$ \\
\hline $6 C$ & 20.0 to 30.0 & 125.62 & $<1.7$ & $<1.40$ & $80.56 \pm 0.26+01 \%$ & $13.46 \pm 0.26+02 \%$ \\
\hline $16 B$ & 12.5 to 25.0 & 112.36 & $3.357 \pm 0.28+02 \%$ & $:<2.0$ & $152.9 \pm 0.20+01 \%$ & $16.36 \pm 0.25+02 \%$ \\
\hline $18 B$ & 10.0 to 20.0 & 125.33 & $<0.85$ & $0.9033 \pm 0.28+02 \%$ & $2.7 \pm 0.14+02 \%$ & $11.59 \pm 0.28+02 \%$ \\
\hline 170 & 20.0 to 30.0 & 119.32 & $<2.7$ & $<2.2$ & $251.2 \pm 0.15+01 \%$ & $16.15 \pm 0.24+02 \%$ \\
\hline
\end{tabular}


WHC-EP-0707, Rev. 0

\section{Appendix F}

Estimates of Plutonium to the 216-Z-19 Ditch (March 25, 1976) 
WHC-EP-0707, Rev. 0

Atlantic Richllold Hanford Company

DUR

Date: April 7, 1976

To: D. L. Vebelacker

From: $\quad$ D. T. Crawley, 2-2545

Subject: ESTIMATES OF PLUTONIUM TO 216-2-19 DITCH ON MARCH 25, 1976

\section{SUMMARY}

This letter contains the calculations made to obtain estimates of the plutonium in the effluent stream to the subject ditch, in the U-Pond and in the soil in the subject ditch as a result of the high alpha activity samples obtained on March 25, 1976 . The quantities obtained in these calculations have been quoted to several persons during inquiries made relative to the incident. Some assumptions had to be made and are being made available to you to aid you in your contacts relative to the incident.

There is a flow rate recorder and a fiow integrator at the 2904-2A sampling station. The flow rate is not a steady rate because the pump out from the 291-2 pumps operate intermittantly at rates up to $200 \mathrm{gpm}$. The $300 \mathrm{gpm}$ rate was used as an upper limit of the flow based on the estimated supply of water to Z-Plant. The 2904-ZA integrator does not agree with the supply volume. It is consistently lower. The pipeline between the Z-Plant buildings and 2904-ZA sampling station could be leaking the volume difference.

\section{A. Estimate by Sample Concentration and Flow Estimate}

1. 0030 to 0830 Sample ( 8 hours)

Sample result: filtrate $1.35 \mathrm{uCi} / 1$

solids $\frac{.50 \mathrm{uCi} / 1}{T .85 \mathrm{uCi} /}$
Total

ESTIMATED maximum flow 300 gals per min.

$300 \mathrm{gpm} \times 60 \mathrm{~min} . / \mathrm{hr} .=18,000 \mathrm{gals} . / \mathrm{hr}$.

$18,000 \mathrm{gals} . / \mathrm{hr} . \times 8 \mathrm{hrs} .=144,000 \mathrm{gals}$.

$144,000 \mathrm{gals} \times 4 \mathrm{l} / \mathrm{gal}=576,000$ liters

$.576 \times 10^{6}$ liters $\times 1.85 \times 10^{-6} \mathrm{Cj} / 1=1.07$ curies

1.07 curies $\times 16$ grams $\mathrm{Pu} /$ curie $=17$ grams $\mathrm{Pu}$. 
Atlantic Richficld Hanford Company

D. L. Lebelacker

Page 2

Acril 7. 1976

2. 0830 to 1300 . Sample (4 1/2 hrs.)

236-Z shutdown at 1330, flow 5 hrs.

Sample result: filtrate $5.18 \mathrm{uCi} / 1$

solids $\quad 2.74 \mathrm{uCi} / 1$

Total $7.92 \mathrm{uCi} / \mathrm{T}$

Estimated maximum flow 300 gals. per min.

$300 \mathrm{gpm} \times 60 \mathrm{~min} / \mathrm{hr} .=18,000 \mathrm{gals} . / \mathrm{hr}$.

$18,000 \mathrm{gals} . / \mathrm{hr} . \times 5 \mathrm{hrs} .=90,000 \mathrm{gals}$.

90.000 gals. $\times 4$ liters/gal. $=360,000$ liters

$.36 \times 10^{6}$ liters $\times 7.9 \times 10^{-6} \mathrm{Ci} / 1=2.84$ curies

2.84 curiés $\times 16$ grams Pu/curies $=45$ grams

3. Total (maximum flow)

0030 to $0830 \quad 17$ grams $\mathrm{Pu}$

0830 to 133045 grams $\mathrm{Pu}$

Total

62

Estimated plutonium $30-60$ grams

to ditch

B. Estimate of Plutonium in U-Pond

Estimated area of pond 10 acres

Estimated depth of pond $30 \mathrm{~cm}$

$30 \mathrm{~cm}=11.9$ inches $\Xi 1$ foot

1 (U.S.) acre $=43,560$ sq. ft.

10 acres $\times 44,000 \mathrm{ft}^{2}=440,000 \mathrm{ft}^{2}$

$$
\cong .5 \times 10^{6} \mathrm{ft}^{3}
$$

1 cubic foot $=28$ liters $=7.5 \mathrm{gals}$.

$.5 \times 10^{6} \mathrm{ft}^{3} \times 281 / \mathrm{ft3}=14 \times 10^{6}$ 1iters 
Atlantic Richficld Hanford Company

D. L. Uebelacker

Aprit 3 , 1976

Pond sample results:

$$
\begin{aligned}
& \text { East } 2.6 \times 10^{-4} \mathrm{uCi} / 1 \\
& \text { West } \frac{17 . \times 10^{-4} \mathrm{uCi} / 1}{19.6 \times 10^{-4} \mathrm{uCi} / 1}
\end{aligned}
$$

Average concentration $1 \times 10^{-3} \mathrm{UCi} / 1$

$14 \times 10^{6} 1 \times 1 \times 10^{-3} \mathrm{uCi} / 1=14 \times 10^{3} \mathrm{uCi}=0.014$ curies

0.014 curies $\times 16 \mathrm{gs}$ Pu/curies $=\frac{0.22 \text { grams } P u}{\text { in } U \text {-Pond }}$

C. Estimate of Plutonium in 216-2-19 Ditch Soil

Mud samples (dried in laboratory and then weighed samples analyzed)

Location

\section{Aloha activity, nanocuries/gram}

Outfall

25.9

$1 / 3$ Way

9.6

Near 16th St.

2.8

South of 16 th St.

4.7

Just before ditch enters U-Pond

Average

10.2

As sumed:

$\begin{array}{ll}\text { Ditch bottom width } & 6 \text { feet } \\ \text { Ditch side width } & 6 \text { inches each side } \\ \text { Total ditch soil width } & 7 \text { feet } \\ \text { Ditch length } & 2000 \text { feet } \\ \text { Ditch soil depth } & 1 \text { centimeter } \\ \text { Soil density } & 2 \text { grams } / \mathrm{cm}^{3}\end{array}$


Atlantic Richficld Hanford Company

D. L. Uebelacker

Page 4

April 7, 1976

$7 \mathrm{ft} \times 2000 \mathrm{ft}=14,000$ sq. ft.

I sq $\mathrm{ft}=929 \mathrm{~cm}^{2} \equiv 1 \times 10^{3} \mathrm{~cm}^{2}$

- Ditch soil depth 1 centimeter

14, 000 sq. $\mathrm{ft} \times 1 \times 10^{3} \mathrm{~cm}^{2} / \mathrm{sq} \mathrm{ft} .=14 \times 10^{6} \mathrm{~cm}^{2}$

$14 \times 10^{6} \mathrm{~cm}^{2} \times 1 \mathrm{~cm}=14 \times 10^{6} \mathrm{~cm}^{3}$

Soil density $=2 \mathrm{~g} / \mathrm{cm}^{3}$

$14 \times 10^{6} \mathrm{~cm}^{3} \times 2 \mathrm{~g} / \mathrm{cm}^{3}=28 \times 10^{6}$ grams of

Soil samples average about 10 nanocuries/gram

$=10 \times 10^{-3} \mathrm{uCi} / \mathrm{g}$

$10 \times 10^{-3} \times 28 \times 10^{6}=280 \times 10^{3}$ u curies

$280 \times 10^{3}$ u curies $=0.28$ curies

0.28 curies $\times 16 \mathrm{gs}$ Pu/curie $=4.5 \mathrm{gs} \mathrm{Pu}_{\mathrm{u}}$ in ditch soit

OTC : amr

ce: DJ Brown «

PC Doto

DG Harlow

HL Maxfield

JV Panesko

BJ Saueressig 
Atlantic Richficld Hanford Cornonny

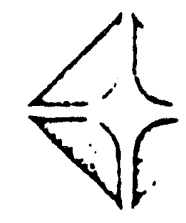

Date: June 30,1976

To:

D. L. Uebelacker

From:

D. T. Crawley, 2-2545

Subject: ESTIMATES OF PLUTONIUM TO 216-Z-19 DITCH ON MARCH 25, 1976

Reference: Letter, D. T. Crawley to D. L. Uebelacker, April 7, 1976, same subject

The reference letter provided estimates and their calculations for your use in communications relative to the incident of March 25, 1976. To make the caiculations an assumption had to be made on the flow rate to the 216-z-19 (z-19) ditch. The maximum flow was assumed to be 300 gallons per minute.

The estimated flow of liquid to ground from Z-Plant nas since been reported as $13.4 \times 10^{\circ}$ gallons for the month of March, 1976. This averages out to be 300 gallions per minute over the entire month. Since the flows were reduced for the last $51 / 2$ days of the month as a resul: of the incident, the actual average flowrate out of $2-P$ lant was areater than 300 gallons per minute at the time of the incident. However, there are comolicating factors ir. estimating the actual plutonium discarded to the 216-2-19 ditch.

Some of the complicating factors in estimating the plutonium unintentionally discarded are:

1. The flow out of Z-Plant is based on the estimated supply of water. There are no working water meters measuring the supply.

2. The vitreous clay pipe drain line leaks. Consequently, the flow does not all reach the $2-19$ ditch. This probably affects the concentration measured at the 2904-ZA sampling station.

3. The 2904-ZA flowrate recorder drifts considerably. This flowrate measurement controls the sampling rate.

4. The sampling of solids is not necessarily representative. 
WHC-EP-0707, Rev. 0

Allinlic Rochlicld Hanford Combiny

D. L. Uebelacker

Page 2

June 30,1976

The calculation in the reference letter gave 62 grams of plutonium unintentionally discarded from Z-Plant. Because of uncertainties, I would round this to 60 grams. Because of pipeline leaks I estimate a maximum of 45 grams of plutonium discarded to the $216-z-19$ ditch.

OTC: amr

cc: DJ Brown

PC Doto

OG Harlow

HL Maxfield

JV Panesko

BJ Saueressig 


\section{Internal Leiter}

D.1. S Septeniber 8, 1977

TO

$$
\text { - J. V. Panesko }
$$

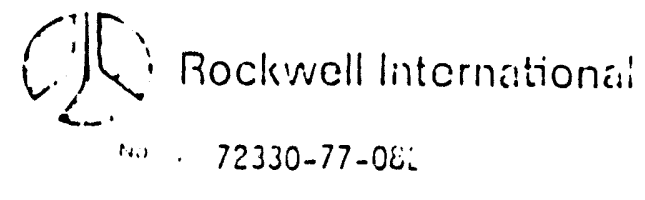

FROM - R. E. Wheeler

$2-2928$

Subiect: Assessment of 216-Z-19 Ditch

The attached report is my assessment of the radioactivity in the 216-2-19 ditch.

The assessment is based on recent surveys of the Z-19 ditch, Environmental Surveillance data, personal interviews with Radiation Monitoring and Laboratory personnel, Battelle-Northwest and Rockwell Hanford Operations documents on special environmental studies, and Environmental Protection annual reports. Af ter reviewing and evaluating this information, conclusions were made with respect to:

1. Quantity of Pu discharged to the environment by way of $Z-19$.

2. Location of the higner contamination levels in the ditch.

3. Resuspension potential for the Plutonium and Americium in the ditich.

4. The level of plutonium reaching the water table.

Although not included as part of the report, the following recommendations are made:

1. Animal species tnat are resident around the $2-19$ ditch be sampie: to determine if radionuclides are being transported by the fauna.

2. The Radiation Monitoring Environmental Surveillance group performis more routine radiation surveys of $z-19$ ditch to track contaminatior.

3. The Environmental Surveillance Program should include more extensive sampling of the water and sediment in the ditch.

4. Additional testwells should be drilled closer to the $2-19$ ditch tc provide the means for more intensive groundwater surveillance around the ditch.

5. Additional ambient air sample station should be established arounc the $z-19$ ditch to nonitor resuspension of radionuclides from the diteh.

6. Additional evaluation de performed to determine the distribution of contamination in the ditch with respect to depth. 
J. V. Panesixo

Page 2

September 8,1977

I have plans to include recommendations $1,2,3$, and 5 as part of the Environmental Suryeillance Program. The Research Department will be consulted on recommendation 4. I have been advised that information that can aid in the evaluation mentioned in recommendation 6 may be available within the company.

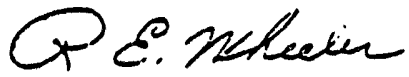

R. E. Wheeler

REW/KkC

Att.

CG:

G. C. Owens

EPS Stafi 
WHC-EP-0707, Rev. 0

\section{INTRODUCTION}

The 216-z-19 ditch in the 200-West area receives low level radioactive liquid waste from the $231-2$ and $234-52$ complex. Although Low level, the conclnuous flow of radioactive liquid from the pluconium processing plant over the years and the several upsets in the plant have delivered multigram quantities of pluconium to the environment by way of the 2-19 ditch.

Because of the coxicity of the radioisotopic concaminants in the ditch, questions have been raised as to the impact the 216-2-19 ditch has on 1 ts surrounding environment. How much pluconium has been discharged to the environment by way of z-19 ditch? Whare is the contamination accumulating in the 2-19 ditch? What is the resuspension potential for plutoniur and Americium in the $z-19$ dicch? Is plutonium reaching the warer table and if so to what levels? 


\section{OBSERVATIONS}

\section{Phys1cal Descriprion}

a) Dimensions - 2,763 ft. by $4 \mathrm{ft}$. (Includes $665 \mathrm{ft}$. of the old 216-2-1 ditch and $235 \mathrm{ft}$. of the old 216-z-11 d1tch.)

b) Location - Stares $760 \mathrm{ft}$. southeast of the 234-5 Bullding, $450 \mathrm{ft}$. West of Camden Avenue and runs in a southwesterly direction to the 216-U-10 Pond.

c) Elevations - Ground: $673 \mathrm{ft}$. above sea leval Water Table: $475 \mathrm{ft}$. above sea level (1973)

d) Estimated flow into ditch $-1 \times 10^{7}$ gallons/month

2. Function

a) Service Dares - S/71 to Present.

b) neceives and transporcs low level liquid radloactive wase to 216-1J-10 Ponds from the following:

1) Process cooling wacer, steam condensace, to and sink drain wacer, and vacuun pump seal and compressor cooling water from the 234-52 Plant complex.

2) Cooling water from Battelle laboratury operations in the 231-2 Bu1lding.

3. Plutonium D1scharges to the 216-2-19 Ditch (Based on 2-Planc and 231-2 D1scharge Daca)

Year Pu (grams)

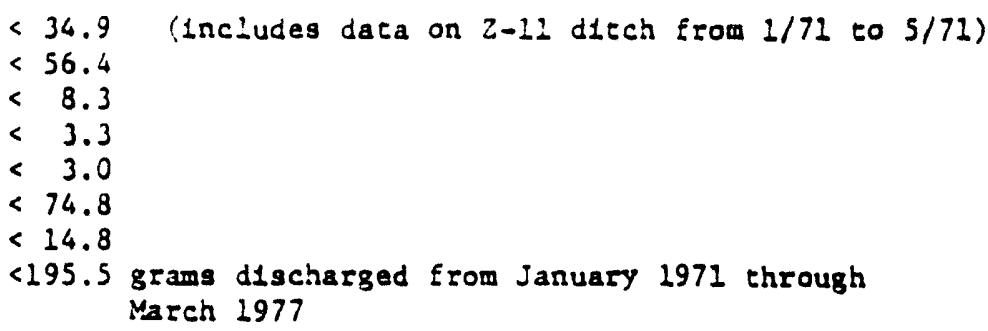




\section{WHC-EP-0707, Rev. 0}

4. Radsoisolonic Analyses of linvironnental Suratilincs

Samplas trum 216-z-19 DIEci1

a) Mud, water and aquatic vegetacion samples from head enc of dicch. (Table A)

b) Special soll and vegecacton samples from specific locations around the ditch. (Table B)

c) Various vegetacion samples from inside the ditch. (Iable C)

d) Aerial Radiation Survey of U-Pand and 2-19 Ditch showing 241 Am Concentration (F1gure I).

TABLE A

Mud, Wacer and Aquaric Vegecation Samples from the Head End of the Z-19 Ditch

Unics Are pCl/gram Dry Weight unless ocherwise noted

Year $241_{\mathrm{Am}} \quad 239 \mathrm{Pu}$

1974 Wacer Mud $\quad 4,230$

Vegetation $\quad 10,200$

1975 Wate:

Muc

Vegecarion

1976 Wace:

Mud

Vegeracion

1977 Wacer

Mud
610

< $0.1 \mathrm{pCi} / \mathrm{ml}$ (Annual Average by $2-19$ grao sal=

$$
7.2 \mathrm{pCi} / \mathrm{ml} \text { (Annual Average }
$$
by 2-19 grab sam:

780 1300 370

$84 \mathrm{pCl} / \mathrm{ml}$ (First Quarter Ave: by 2904-Z A sampie. 
MIBLE B

SHECLAL SOLL Dill VEGETATIUN SAHHLS FKUH

2-19 UITCll IN MAKCH AND APKIL 1976

\begin{tabular}{|c|c|c|c|c|c|c|c|c|c|}
\hline \multirow{2}{*}{ 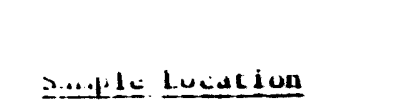 } & \multirow[b]{2}{*}{ AlluterideI } & \multirow[b]{2}{*}{ Buste } & \multirow[b]{2}{*}{$241.4 \mathrm{n}$} & \multirow[b]{2}{*}{$21 y_{1}$} & \multicolumn{3}{|c|}{ All Units are pCi/gran } & \multicolumn{2}{|c|}{ Dry Weight } \\
\hline & & & & & $9990 \mathrm{sr}$ & $137 \mathrm{Cs}$ & $226_{R_{a}}$ & $40_{K}$ & 13yce \\
\hline$\therefore \rightarrow$ t buak head end & $\begin{array}{l}\text { Sull } \\
\text { veb. dry }\end{array}$ & $3 / 24 / 70$ & $\begin{array}{r}770 \\
1,800\end{array}$ & $\begin{array}{r}21,000 \\
153\end{array}$ & 198 & $3^{1.6}$ & $\begin{array}{l}.43 \\
.91\end{array}$ & $\begin{array}{l}11.1 \\
12.4\end{array}$ & $\begin{array}{l}.12 \\
.42\end{array}$ \\
\hline $\begin{array}{l}\text { 1.:sc Bank } 500 \mathrm{ft} \text {. } \\
\text { Duwlustrcam }\end{array}$ & $\begin{array}{l}\text { Sull } \\
\text { Vez. diy }\end{array}$ & $\begin{array}{c}3 / 24 / 76 \\
11\end{array}$ & $\begin{array}{l}2,300 \\
1,100\end{array}$ & $\begin{array}{r}5,200 \\
26.2\end{array}$ & 402 & $\begin{array}{l}1.1 \\
1.3\end{array}$ & $\begin{array}{l}.47 \\
.79\end{array}$ & $\begin{array}{l}12.1 \\
11.6\end{array}$ & \\
\hline $\begin{array}{l}\text { bist Bank } 100 \mathrm{ft} \text {. Huthh } \\
\text { of } 16 \mathrm{ch} \text { Sc. }\end{array}$ & $\begin{array}{l}\text { Sull } \\
\text { vis d dry }\end{array}$ & $\begin{array}{c}3 / 24 / 76 \\
1 /\end{array}$ & $\begin{array}{l}898 \\
880\end{array}$ & 27 & & $\begin{array}{l}1 \\
1.6\end{array}$ & $\begin{array}{l}.42 \\
.72\end{array}$ & $\begin{array}{l}12.3 \\
12.1\end{array}$ & .1 \\
\hline $\begin{array}{l}\text { Luit Bank } 200 \mathrm{ft} \text {. Suchth } \\
\text { of } 16 \mathrm{ch} \mathrm{St} \text {. }\end{array}$ & $\begin{array}{l}\text { Sull } \\
\text { Veg. dry }\end{array}$ & $3 / 24 / 76$ & $\begin{array}{l}260 \\
720\end{array}$ & $\begin{array}{r}4,900 \\
32\end{array}$ & 56 & $\begin{array}{l}1.1 \\
1.1\end{array}$ & $\begin{array}{l}.53 \\
.71\end{array}$ & $\begin{array}{l}13 \\
9.2\end{array}$ & .11 \\
\hline C. li. Bank at U-10 Inlet & $\begin{array}{l}\text { Sull } \\
\text { Veb. dry }\end{array}$ & $\begin{array}{c}3 / 24 / 76 \\
11\end{array}$ & $\begin{array}{l}844 \\
170\end{array}$ & 71.6 & 114 & $\begin{array}{r}19.1 \\
2.6\end{array}$ & $\begin{array}{l}.52 \\
1.3\end{array}$ & $\begin{array}{l}11.5 \\
10.6\end{array}$ & .33 \\
\hline Frois Ditch at Outfall & Sull & $4 / 21 / 76$ & 563 & 33,000 & & .7 & .4 & 11 & .4 \\
\hline $\begin{array}{l}\text { Ficu Diteh Near } \\
\text { loch it. }\end{array}$ & Suil & $4 / 21 / 76$ & 630,000 & 8.8 & & 3,800 & 5,200 & 130,000 & 1.500 \\
\hline ham becolt ac Encrance & soil & $4 / 21 / 70$ & .200 .000 & & & 120,000 & 5,000 & 130,000 & \\
\hline
\end{tabular}

* The dry vegecation samples were separated frow

che soil samples by sieving and andyzed us a separate pladse.

isim Diccition 


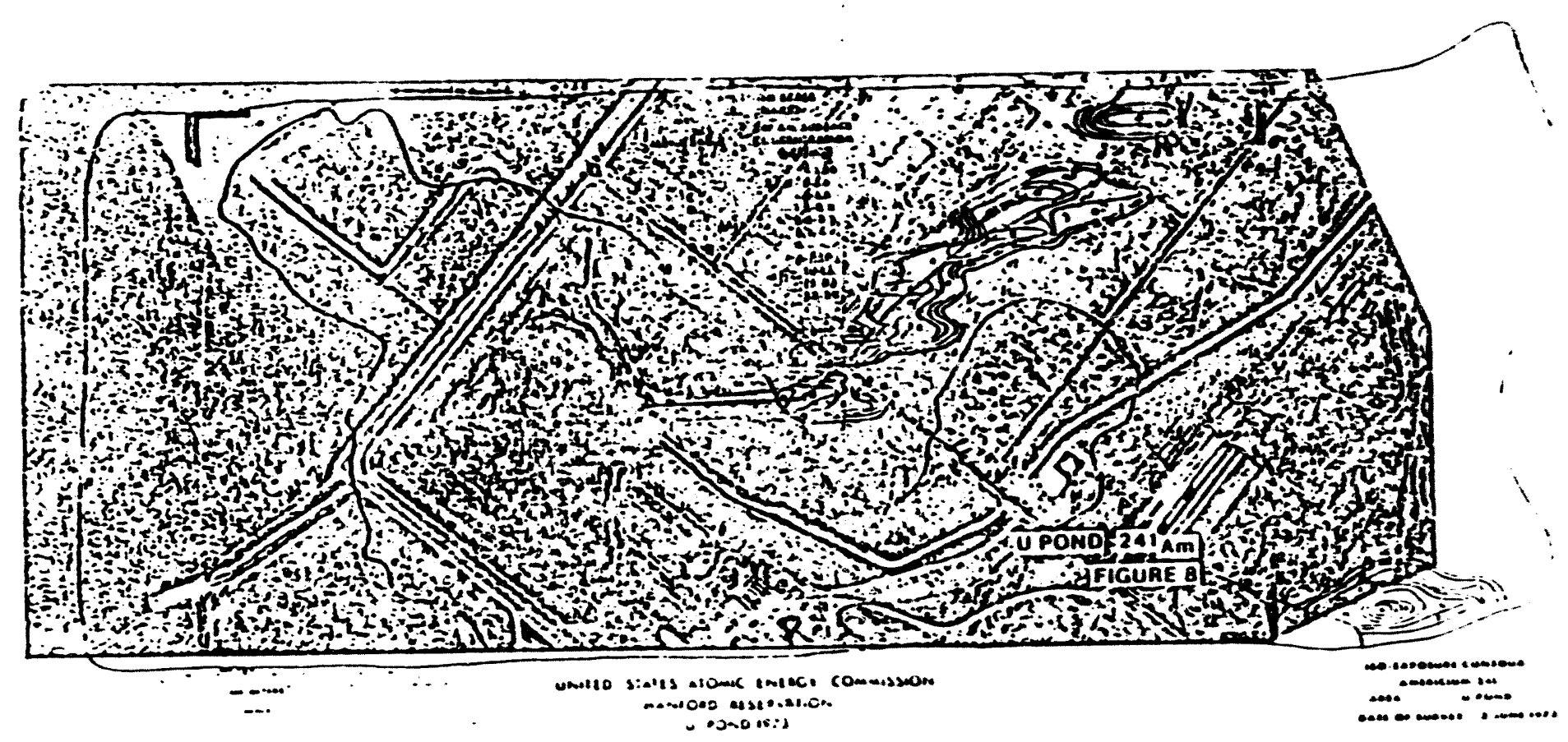


VARIOUS VEGETATION SAMPLES FROM 216-2-19 DITCH

Al1 Unies are pC1/gram Dry Walghe

\begin{tabular}{|c|c|c|c|c|c|c|c|}
\hline Common Name & Dace Sampled & $241_{\mathrm{Am}}$ & $137 \mathrm{cs}$ & ${ }^{40} \mathrm{~K}_{\mathrm{K}}$ & ${ }^{141} \mathrm{Ce}$ & $228 \mathrm{Th}$ & No Pu Analuges \\
\hline Algee & $11 / 10 / 76$ & 1400 & & & & 4.5 & \\
\hline Catcall & $11 / 19 / 76$ & 4.4 & 5.4 & 11.6 & & & \\
\hline Asparagus & $11 / 19 / 76$ & 1.5 & 20.4 & 26.1 & 3.2 & & \\
\hline $\begin{array}{l}\text { Peach Leat } \\
\text { W11low }\end{array}$ & $11 / 19 / 76$ & 4.1 & 8.2 & 8 & & & \\
\hline Bullbrush & $11 / 19 / 76$ & 53.6. & 16.3 & $\cdots$ & & & \\
\hline Thisele & $11 / 19 / 77$ & 2.3 & 9 & 25.8 & 4 & & \\
\hline Smare Heed & $11 / 19 / 77$ & 5.8 & 8.6 & 18.3 & & & \\
\hline
\end{tabular}


5. Groundwacur scudies

Groundwater samples caken since 1971 from cuscwells $1299 \mathrm{~h}-1 \mathrm{j}-\mathrm{s}$ which is locaced approximately $100 \mathrm{fc}$. north of the $2-19$ dicch head and and A299W-18-7 which is locacad approximacely 400 fe. west of the ditch hasd end show gross alpha activicy $<.017 \mathrm{pCl} / \mathrm{ml}$. EROA Manual Chapter 0524 Table II limits are $5 \mathrm{pCI} / \mathrm{ml}$ for $2{ }^{39} \mathrm{Pu}$ and $4 \mathrm{pCL} / \mathrm{ml}$ for $24 \mathrm{I}_{\mathrm{Am}}$.

\section{Radiacion Survers}

A radiacion survey by RM on June 29, 1977 revealed an open area, 25 to $50 \mathrm{tC.} .^{2}$, in the $2-19$ ditch about 75 yards upseream tron the entrance co U-10 Pond chat had a maximum reading of 18,000 dp an with a portable alpha meter.

\section{Procective Bargiers}

a) In March, 1976, a series of three dams were placed in the 2-19 ditch to backup water in the upper end of the ditch to cover contamination along the banks. The dams also creaced ponds in the ditch in which contaminants could precipicace out and settle to the botcom racher chan be carried to the U-10 Pond.

b) A chick growth of vegecation has developed in and along cht banks of the 2-19 ditch over the years. This vegetation torms a protective barrier which prevents sediments form blowing out of the dicch.

c) There are no barriers to prevent local animals from eacing and drinking irom the $z-19$ ditch.

\section{Resuspension Scudy}

Batcelle Nortinesc conducted experiments from 1972 to 1975 at the $2-19 \mathrm{~d} f \mathrm{cch}$ and ocher sites to decermine whether radioaceive particles from the sites were resuspended and transported by wind. During the course of the study, the maximum observed air concentration for $23{ }^{3} \mathrm{pu}$ was $8 \times 10^{-15} \mathrm{\mu Cl} / \mathrm{cm}^{3}$ and $3 \times 10^{-15} \mathrm{\mu Cl} / \mathrm{cm}^{3}$ for $241 \mathrm{Am}$. The maximum permissible airborne concencraciors (NPC 40hr) ior $239 \mathrm{pu}$ and $24 \mathrm{Am}$ are $2 \times 10^{-12} \mathrm{uCi} / \mathrm{cm}^{3}$ and $6 \times 10^{-12} \mathrm{uCi} / \mathrm{cm}^{3}$ respectively. Fallouc devel in the air for Pluconium in this area is approximaceiv $1 \times 10^{-17} \mathrm{HCl} / \mathrm{cm}^{3}$. 
WHC-EP-0707, Rev. 0

8

\section{DATA EVALUATION}

1. Table A of Observacion 4 ind1caces that the average ${ }^{23}{ }^{9} \mathrm{Pu}$ concentration of the water in the $7-19$ ditch is below ERDA Manual Chapter 0524 Table I lim1ts of $100 \mathrm{pCl} / \mathrm{ml}$.

2. Table A, B, and C, 1ndicaces appreclable amounts of $239^{\mathrm{Pu}}$ and $241 \mathrm{Am}$ in sediments and so1 in the $z-19 \mathrm{dicch}$.

3. Table B shows that the highest concentration of $23{ }^{9} \mathrm{Pu}$ in the soil is at the head end of the 2-19 ditch while the highest concentrations of $24 \mathrm{Am}$ and ocher oucstanding radiolsotopes are further downstream, near the ditch inlet to the U-10 Pond.

4. Flgure 1 indicetes that the higher concentrations of $241 \mathrm{Am}$ in the $z-19$ ditch are near the U-10 Pond inlet. Unfortunately, the ${ }^{241} \mathrm{Am}$ information $1 \mathrm{~s}$ masked by high $137 \mathrm{Cs}$ count race from U-10 Pond as the 2-19 dicch crosses 16ch Street and approaches the pond.

5. Table $C$ shows algae as being the vegetation sample from the ditch with the highest concentracton of $241 \mathrm{Am}$ ( $1400 \mathrm{pC1} / \mathrm{gram}$ ) which 18 morie chan $20^{-}$times higher than any other identified vegacation suinple.

6. Analysis of groundwater samples from testwells near the $2-19$ dicch Indicates that the ratios of alpha concentration in the water to 0524 Table II limits are 0.003 for $239 \mathrm{Pu}$ and .004 for ${ }^{24} \mathrm{Am}$.

7. The Batcelle Nortiwest resuspension study shows maximum observed airborne concentration to IPC $40 \mathrm{hr}$ ratios of 0.004 for ${ }^{239} \mathrm{Pu}$ and .0005 for $24 ! \mathrm{Am}$.

\section{CONCLUSION}

1. The estimate maximum amount of Plutonium discharged to the environment v1a the 2-19 diech is 196 grams for the perlod January, 1271, ehrough March, 1977.

2. Based on soil and sediment analyses, the majorlty of the plutonium contamination discharged to the $2-19$ ditch is accumulacing around the head end of the ditch while the Americtum contamination is migrating toward the dicch inlet to U-Pond. 
WHC-EP-0707, Rev. 0

9

3. There is nu significant levels of liulunium or Nmericium contamination reaciling the groundwater. The concencracion of alpha emteting isotopes in testwell samples indicate the lovel to be less thin .003 and .004 of the EWUA Manual Chapeer $052411 \mathrm{mits}$ for water in an unconcrolled area for $239 \mathrm{Pu}$ and $24 \mathrm{I}_{\mathrm{Am}}$ respectively.

4. Based on Battelle Northwest resuspension studies, atrborne concentration for ${ }^{239} \mathrm{Pu}$ and $241 \mathrm{Nm}$ are substancially less chan the maximum permissible concencracions $\left(0.004\right.$ of MPC $40 \mathrm{hr}$ for $23 \mathrm{SPu}^{\mathrm{Pu}}$ and 0.0005 of MPC $40 \mathrm{hr}$ for $241 \mathrm{Am}$ ) but greater than fallout levels. The series of dams and the thick growth of vegetation in the 216-2-19 ditch have contributed to the reduction of airoorne contamination. 
WHC-EP-0707, Rev. 0

10

REFERENCES :

1. Anderson, J. D., Jacobs, M. C., and Mirabella, J. E., 1972-1977, Radioactive Liquid Wasces Discharged to The Ground in the 200 Areas During 1971 chrough 1977 ARH-2353 Pare 3, ARH-2757 Part 3, ARH-2806 4Q, ARH-3093 4Q, ARH-CD-371 4Q, ARH-CD-743 4Q, and RHO-CD-34 $1 Q$.

2. Bruns, L. E., 1974, Aerlal Gamma Survey by Helicopter to Measure Surficial Contamination: ARH-SA-176.

3. Emery, R. M., 1976, The Ecological Behavior of Plutonium and Americtum in Freshwater Ecosyscem: Phase I and II, BNWL 1867 and 1879.

4. Maxfield, H. L., Price, K. R., 1976, Environmental Protection and Concrol Annual Report - CY 1975: ARH-LD-125.

5. Panesko, J. V. and ec.al. 1977, Environmental Protection Annual Report CY-1976: ARH-LD-154.

6. Personal communication with 222-5 laboracory supervision, Rockwell Analytical Laboracories, January through February 1977.

7. Sehmei, G. A., February 1977, Radioactive Particle Resuspension Research Experimencs on the Hanford Reservacion, BNWL-2081. 
WHC-EP-0707, Rev. 0

Appendix G

Minutes of Team Meeting

Decommissioning of the 216-U-10 Pond 


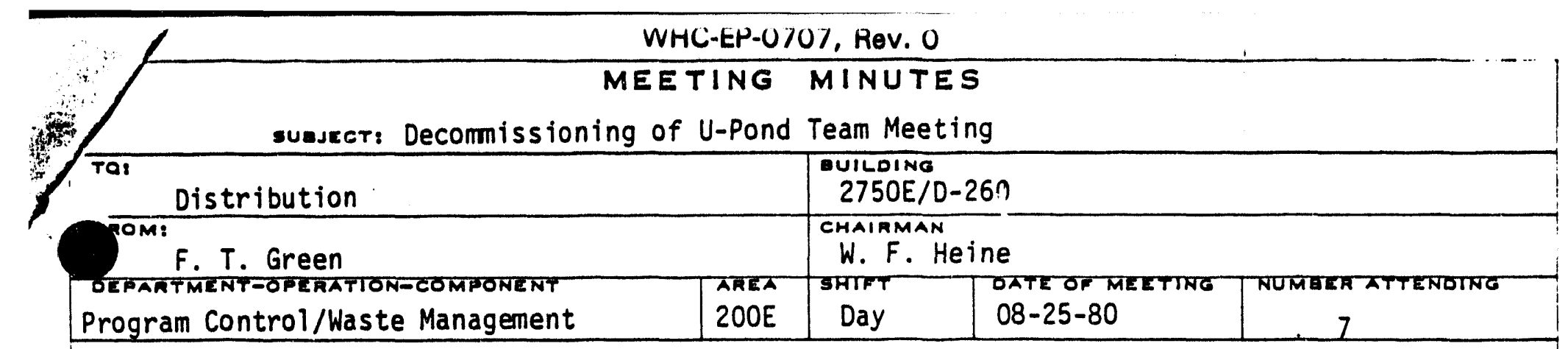

\section{Discussion:}

1) George Last reported that he had distributed an interim letter report outlining U-Pond characterization work as of August 1, 1980. This report includes results of previous studies, current sampling status, and preliminary surface contamination contour maps of the U-Pond area. Last said he would hold a meeting of all parties who have been collecting sample data to develop a plan and format for the final characterization report which he expects to issue in the first quarter of FY 1981.

Sample analysis have yet to be received from Eberline and LFE. The 50 'additional spot measurements around the U-Pond area have been taken with Devan I, however the data reduction has not been completed yet. Additional samples will be taken at depths of up to 1 meter in the U-14 ditch.

2) Engineering is waiting information on analysis of vegetation samples. When this information is available a plan will be developed for vegetation removal.

3) Lloyd Kusler reported that Research and Engineering has begun work on the activity plan to decommission U-Pond. With the shutdown of 242-S (01-01-81) and completion of th? laundry crib (4th quarter, FY 81) the only effluent stream to U-14 dtich/U-Pond will be the power house and water treatment facility. Bill Heine asked R\&E to begin addressing the planning for a new power house waste pond, as the completion of this pond will be a key element in the decommissioning of U-Pond and the U-14 ditch.

4) Ron. Wheeler reported on the results of the Radon tests for the U-Pond area. Analysis results were less than $.037 \%$ of Table I and less than $1.2 \%$ of Table II. . . The data results indicate that the radon levels are wold withis guidetines for-controlled areas, and that there is no

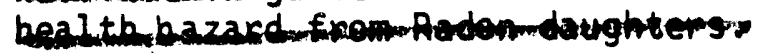

5) The engineering report, "Disposal Alternatives for 216-U-10 Pond Influents," was released.

6) Some preliminary planning has been done on the Environmental Analysis report on the effects of decommissioning of U-Pond. This report, to be done in FY 1981, will take about $61 / 2$ man-months to complete.

Note: The next meeting will be Monday, September 22, 1980, 1:00 p.m.; $2750 E / D-221$. 
Distribution

Page 2

08-25-80
WHC-EP-0707, Rev. 0

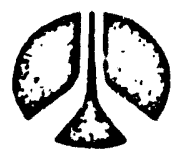

Rockwell

International

Completed Action I tems:

Responsibility

Action Item

Comment

1) G. V. Last Issue letter report with completed U-Pond area contamination level maps.

2) J. F. Geiger Review R\&E needs for additional sampling data.

3) J:' C. Frostenson Issue final report on

$U$-Pond influents

a) ternatives study.

4) R. D. Fox/

Eva] uate Racion Test

R. E. Wheeler

results and determine what/

if further actions should

be taken.

5) W. L. Nees

Expedite extension of LFE contract to include U-Pond Uranium analysis.

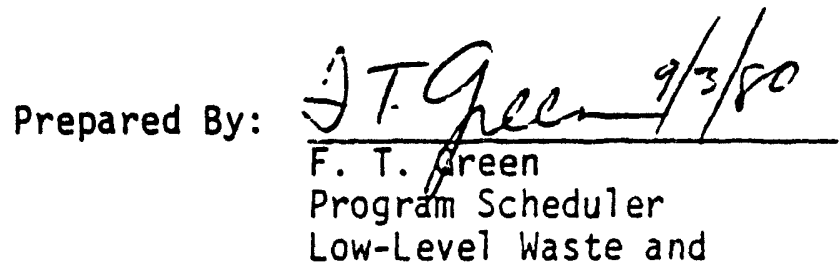

Surveillance and Maintenance

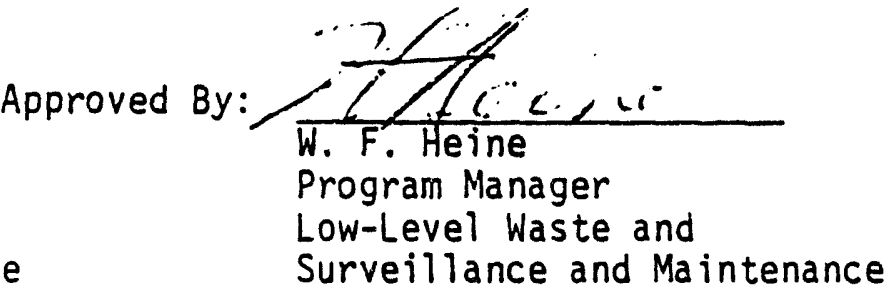

WFH/FTG/Idd 
WHC-EP-0707, Rev. 0

\section{Apperıdix H}

\section{Analytical Data from Surface and Near-Surface Sediment Samples}


DEV VAN I ANALYSES OF SPECIAL SURFACE SAMPLES

FROM THE U-POND DELTA

November $19 ? 8$

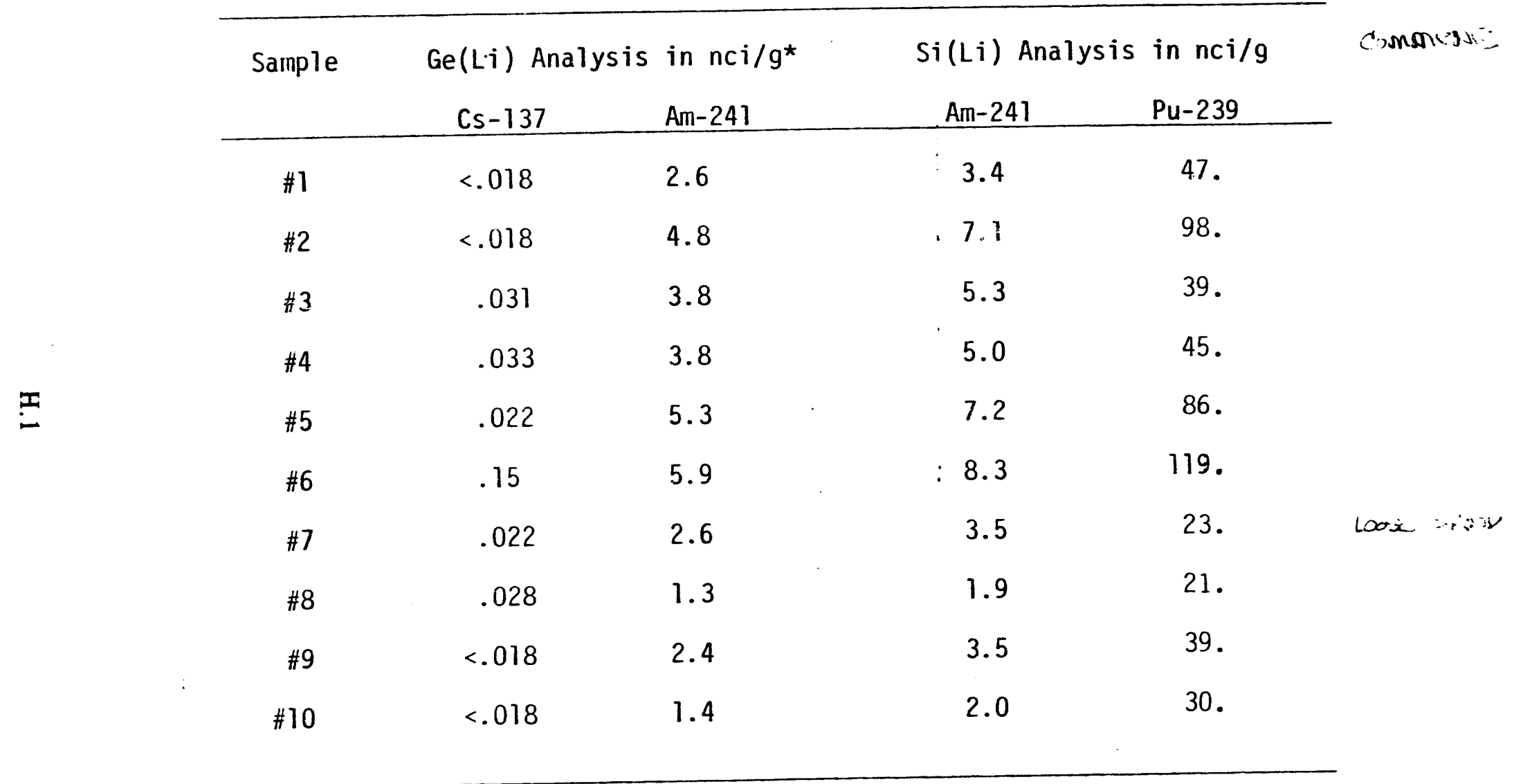

*Assuming a soil density of $1.7 \mathrm{~g} / \mathrm{cc}$.

NOTE: Samples were collected in November 1978 but analyses were not performed until November 1979. 


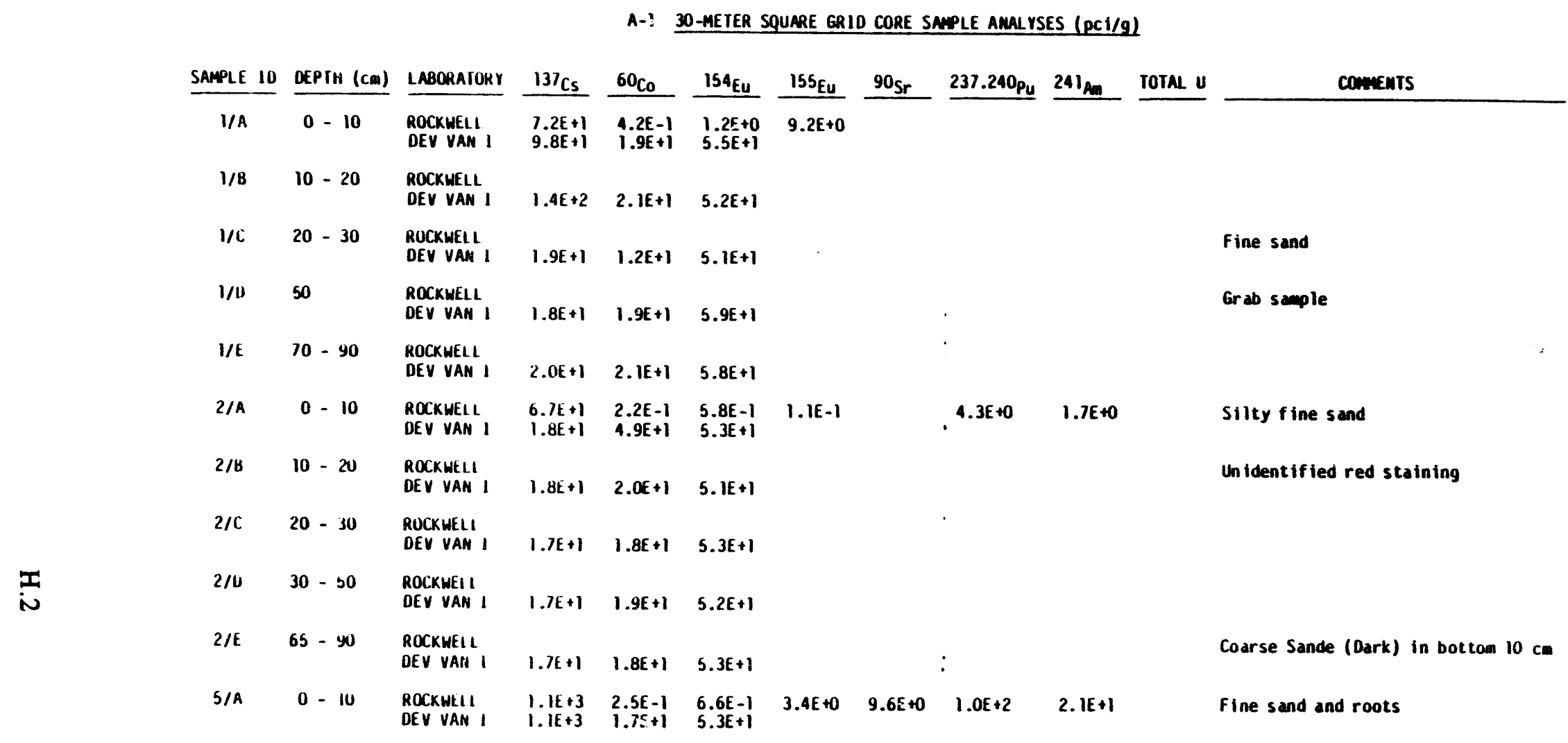


A-1 30-METER SQUARE GRID CORE SAPLL AMALYSES (PC1/g)

\begin{tabular}{|c|c|c|c|c|c|c|c|c|c|c|c|}
\hline SAMPLE ID & DEPTH $(\mathrm{cm})$ & LABORATORY & $137 \mathrm{Cs}$ & $60 c_{0}$ & $154 \mathrm{Eu}$ & 155 Eu & $90 s r$ & $237.240 \mathrm{pu}_{\mathrm{u}}$ & $241_{\mathrm{Am}}$ & TOTAL U & coments \\
\hline $5 / 8$ & $10-20$ & $\begin{array}{l}\text { ROCKWELL } \\
\text { DEV VAN I }\end{array}$ & $\begin{array}{l}\text { 4. } 1 E+1 \\
5.9 E+1\end{array}$ & $\begin{array}{l}2.5 E-1 \\
1.8 E+1\end{array}$ & $\begin{array}{l}6.5 E-1 \\
5.2 E+1\end{array}$ & $1.1 E-1$ & & & & & \\
\hline $5 / C$ & $20-30$ & $\begin{array}{l}\text { ROCKHELL } \\
\text { DEV VAN I }\end{array}$ & $\begin{array}{l}2.1 E+1 \\
1.8 E+1\end{array}$ & $\begin{array}{l}1.0 E-2 \\
1.8 E+1\end{array}$ & $\begin{array}{l}2.7 E+0 \\
5.5 E+1\end{array}$ & 9. IE-I & & & & & \\
\hline $5 / 0$ & $30-30$ & $\begin{array}{l}\text { ROCKHELL } \\
\text { DEV VAN I }\end{array}$ & $\begin{array}{l}1.3 E+0 \\
1.8 E+1\end{array}$ & $\begin{array}{l}2.3 E-1 \\
1.9 E+1\end{array}$ & $\begin{array}{l}6.0 E-1 \\
5.6 E+1\end{array}$ & $1.1 E-1$ & & & & & \\
\hline $5 / E$ & $65-85$ & $\begin{array}{l}\text { ROCKWELL } \\
\text { DEV VAN } 1\end{array}$ & $\begin{array}{l}5.5 E+2 \\
4.7 E+2\end{array}$ & $\begin{array}{l}2.8 E-1 \\
1.7 E+1\end{array}$ & $\begin{array}{l}7.3 E-1 \\
5.2 E+1\end{array}$ & $2.1 E+0$ & & . & & & Sample aaybe cross contaminated \\
\hline $7 / A$ & $0-10$ & $\begin{array}{l}\text { ROCKWELI } \\
\text { DEV VAN I }\end{array}$ & $\begin{array}{l}4.2 E+3 \\
3.5 E+3\end{array}$ & $\begin{array}{l}2.6 E-1 \\
2.1 E+1\end{array}$ & $\begin{array}{l}2.5 E+0 \\
5.8 E+1\end{array}$ & $6.8 E+0$ & $2.2 E+1$ & $7.6 E+0$ & $2.2 E+0$ & & $\begin{array}{l}\text { Top } 2.5 \mathrm{~cm} \text { is organics } \\
\text { fine sand some } 5 \mathrm{~cm} \text { dia GRAVE }\end{array}$ \\
\hline $7 / 8$ & $10-20$ & $\begin{array}{l}\text { ROCKWELL } \\
\text { UEV VAN I }\end{array}$ & $\begin{array}{l}2.7 E+1 \\
3.5 E+1\end{array}$ & $\begin{array}{l}2.2 E-1 \\
1.8 E+1\end{array}$ & $\begin{array}{l}5.9 E-1 \\
5.6 E+1\end{array}$ & $1.1 E-1$ & & • & & & (B) $[F]$ \\
\hline$\pi / C$ & $20-30$ & $\begin{array}{l}\text { ROCKWELL } \\
\text { OEV VAN I }\end{array}$ & $\begin{array}{l}1.5 E+1 \\
2.5 E+1\end{array}$ & $\begin{array}{l}2.2 E-1 \\
1.1 E+1\end{array}$ & $\begin{array}{l}5.7 E-1 \\
5.5 E+1\end{array}$ & $1.1 E-1$ & & & & & Hit gravel at $30 \mathrm{~cm}$ \\
\hline $7 / 0$ & 45 & $\begin{array}{l}\text { ROCKWELL } \\
\text { DEV VAN I }\end{array}$ & $\begin{array}{l}1.4 E+1 \\
3.2 E+1\end{array}$ & $\begin{array}{l}2.2 E-1 \\
1.9 E+1\end{array}$ & $\begin{array}{l}5.8 E-1 \\
5.2 E+1\end{array}$ & $1.1 E-1$ & & ' & & & Grab sample \\
\hline $8 / A$ & $0-10$ & $\begin{array}{l}\text { ROCKWEII } \\
\text { DEV VAN I }\end{array}$ & $\begin{array}{l}3.6 E+2 \\
2.9 E+2\end{array}$ & $\begin{array}{l}4.6 E+1 \\
3.4 E+1\end{array}$ & $\begin{array}{l}8.2 E+0 \\
5.5 E+1\end{array}$ & $4.6 E+0$ & $3.3 E+0$ & $1.2 \mathrm{E}+2$ & $1.6 E+1$ & $3.7 E+1$ & High in organics \\
\hline $8 / 8$ & $10-20$ & $\begin{array}{l}\text { ROCKWFII } \\
\text { DEV VAN I }\end{array}$ & $\begin{array}{l}1.3 E+4 \\
1.2 E+4\end{array}$ & $\begin{array}{l}9.0 \mathrm{E}+0 \\
1.8 \mathrm{E}+1\end{array}$ & $\begin{array}{l}1.4 E+1 \\
5.8 E+1\end{array}$ & $3.7 E+1$ & & & & & Organic layer ends sand \\
\hline $8 / \mathrm{C}$ & $20-30$ & $\begin{array}{l}\text { ROCKWE IL } \\
\text { DEV VAN I }\end{array}$ & $\begin{array}{l}1.2 E+4 \\
1.3 E+4\end{array}$ & $\begin{array}{l}2.2 E-1 \\
1.9 E+1\end{array}$ & $\begin{array}{l}2.3 E+0 \\
5.4 E+1\end{array}$ & $1.2 \mathrm{E}+1$ & & & & & Sand \\
\hline
\end{tabular}


A-1 30-METER SQUARE GRID CORE SAMPLE AMULYSES (pCi/g)

\begin{tabular}{|c|c|c|c|c|c|c|c|c|c|c|c|c|}
\hline & SAMPLE 10 & DEPIH $(\mathrm{cm})$ & LABORATOKY & $137 C_{s}$ & ${ }^{60} \mathrm{Co}$ & $154_{\mathrm{Eu}}$ & $155_{\mathrm{Eu}}$ & ${ }^{90} \mathrm{Sr}$ & $237.240 \mathrm{pu}$ & $241_{\mathrm{B}}$ & IOTAL U & coments \\
\hline & $8 / 0$ & $40-60$ & $\begin{array}{l}\text { ROCKMELL } \\
\text { DEV VAN I }\end{array}$ & $\begin{array}{l}4.5 E+2 \\
6.0 E+2\end{array}$ & $\begin{array}{l}2.0 E-1 \\
2.0 E+1\end{array}$ & $\begin{array}{l}5.2 E-1 \\
5.5 E+1\end{array}$ & $2.1 E+0$ & & & & & \\
\hline & $8 / E$ & $65-85$ & $\begin{array}{l}\text { ROCKUELL } \\
\text { DEY VAM I }\end{array}$ & $\begin{array}{l}1.4 E+2 \\
8.5 E+1\end{array}$ & $\begin{array}{l}1.9 \mathrm{E}-1 \\
1.9 \mathrm{E}+1\end{array}$ & $\begin{array}{l}4.9 E-1 \\
5.5 E+1\end{array}$ & & & & & $1.4 E+1$ & Hit rocks - saturated \\
\hline & $9 / A$ & $0-10$ & $\begin{array}{l}\text { ROCKUELL } \\
\text { DEV VAN I }\end{array}$ & $\begin{array}{l}1.5 E-1 \\
1.7 E+1\end{array}$ & $\begin{array}{l}2.7 E-1 \\
1.8 E+1\end{array}$ & $\begin{array}{l}7.1 E-1 \\
5.5 E+1\end{array}$ & $1.3 \mathrm{E}-1$ & & & & & \\
\hline & $9 / 8$ & $10-20$ & $\begin{array}{l}\text { ROCKUELL } \\
\text { DCY VAN I }\end{array}$ & $1.8 E+1$ & $1.9 E+1$ & $5.6 E+1$ & & & . & & & \\
\hline & $9 / C$ & $20-30$ & $\begin{array}{l}\text { ROCKWELL } \\
\text { DEV VAM I }\end{array}$ & $1.8 t+1$ & $2.0 E+1$ & $5.2 E+1$ & & & . & & & \\
\hline & $9 / 0$ & $40-60$ & $\begin{array}{l}\text { ROCKUELLL } \\
\text { DEV VAN I }\end{array}$ & $1.7 E+1$ & $1.9 E+1$ & $5.5 E+1$ & & & • & & & \\
\hline & 9/E & $70-85$ & $\begin{array}{l}\text { RUCKULLLL } \\
\text { DEV VAN I }\end{array}$ & $1.8 E+1$ & $1.9 \mathrm{E}+1$ & $5.3 E+1$ & . & & & & & \\
\hline & $11 / A$ & $0-10$ & $\begin{array}{l}\text { ROCKUELL } \\
\text { DEV VAN I }\end{array}$ & $\begin{array}{l}1.1 E+4 \\
8.9 E+3\end{array}$ & $\begin{array}{l}3.4 E+0 \\
1.9 E+1\end{array}$ & $\begin{array}{l}9.9 E+0 \\
5.6 E+1\end{array}$ & $2.7 \mathrm{E}+1$ & $1.6 E+1$ & 8. IE +0 & $2.7 E+0$ & & $\begin{array}{l}\text { Sety fine - medium sand with } 5-7 \mathrm{~cm} \\
\text { organics }\end{array}$ \\
\hline I & $11 / 8$ & $10-20$ & $\begin{array}{l}\text { ROCKWELL } \\
\text { DEV VAN I }\end{array}$ & $\begin{array}{l}1.1 \mathrm{E}+2 \\
3.9 \mathrm{E}+1\end{array}$ & $\begin{array}{l}2.4 E-1 \\
1.7 E+1\end{array}$ & $\begin{array}{l}6.3 E-1 \\
4.6 E+1\end{array}$ & $1.1 \mathrm{E}-1$ & & & & & \\
\hline & $11 / c$ & $20-30$ & $\begin{array}{l}\text { ROCKWEILL } \\
\text { DEV VAN I }\end{array}$ & $\begin{array}{l}8.1 E+0 \\
2.6 E+1\end{array}$ & $\begin{array}{l}2.4 E-1 \\
2.0 E+1\end{array}$ & $\begin{array}{l}6.2 E-1 \\
5.5 E+1\end{array}$ & $1.1 E-1$ & & : & & & \\
\hline & $11 / 0$ & 52.5 & $\begin{array}{l}\text { ROCKHULL } \\
\text { DEV YAM I }\end{array}$ & $\begin{array}{l}3.1 E+1 \\
4.4 E+1\end{array}$ & $\begin{array}{l}2.3 E-1 \\
1.9 E+1\end{array}$ & $\begin{array}{l}5.9 \mathrm{E}-1 \\
5.2 \mathrm{E}+1\end{array}$ & $1.1 E-1$ & & & & & Grab sample \\
\hline
\end{tabular}


A-1 30-METER SQUARE GRID CORE SAMLE AMULYSES (PCi/g)

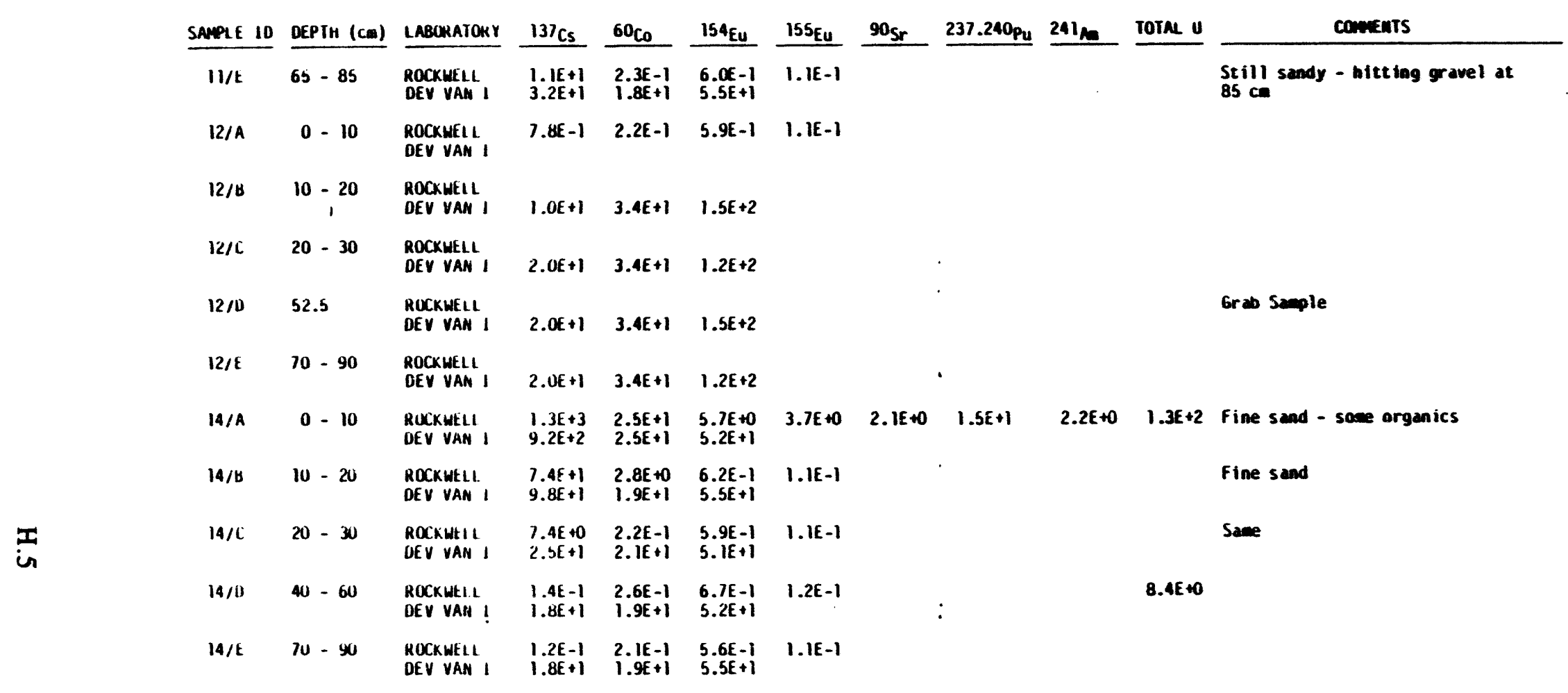




\section{A-1 30-METER SQUARE GRID CORE SAMPLE AMAYSES (pCi/g)}

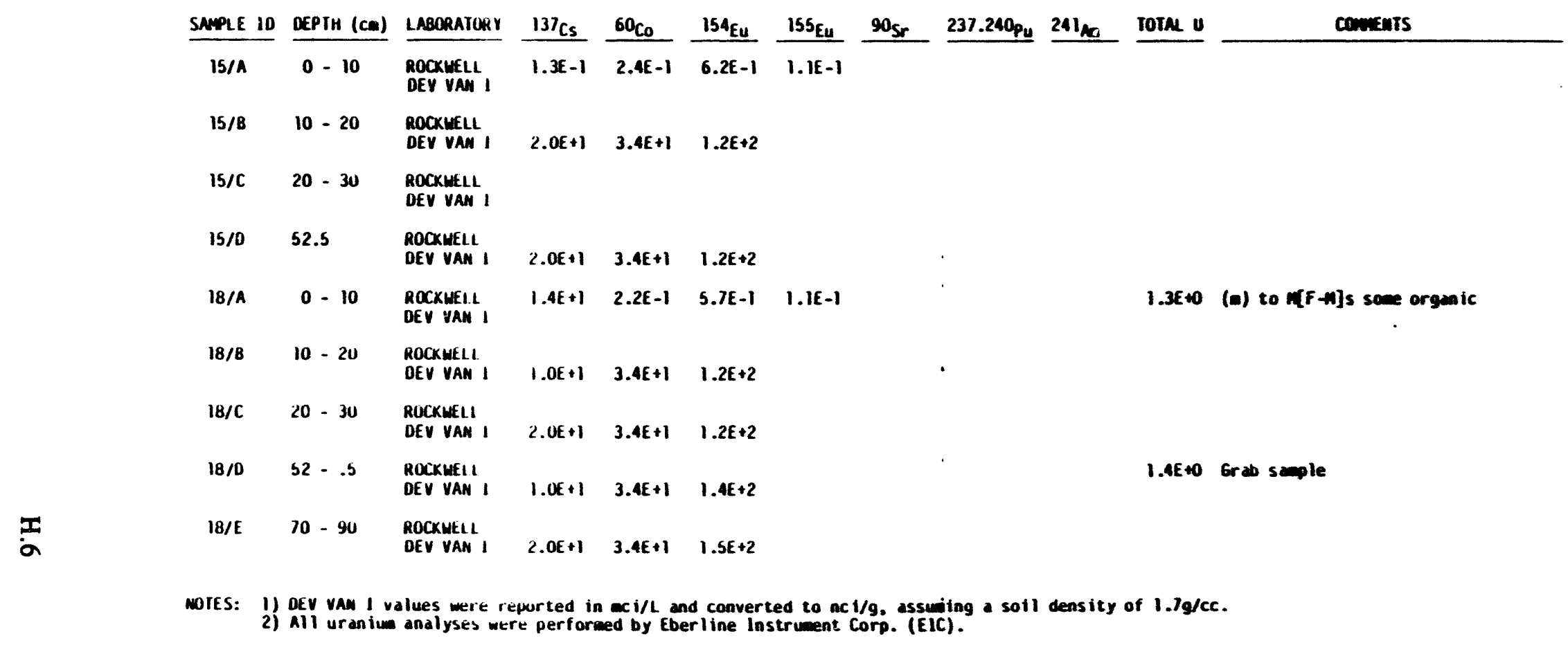


A-2 POND BOTTOM COAE SAMPLES

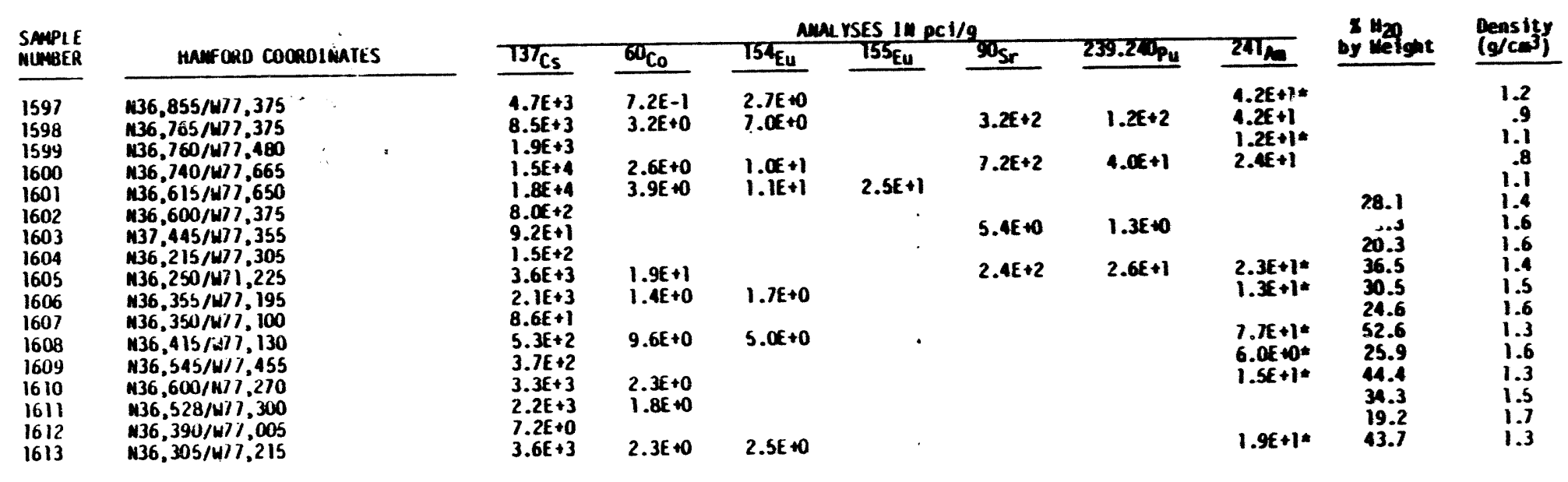

- Anericium Analysis performed by GEA. 

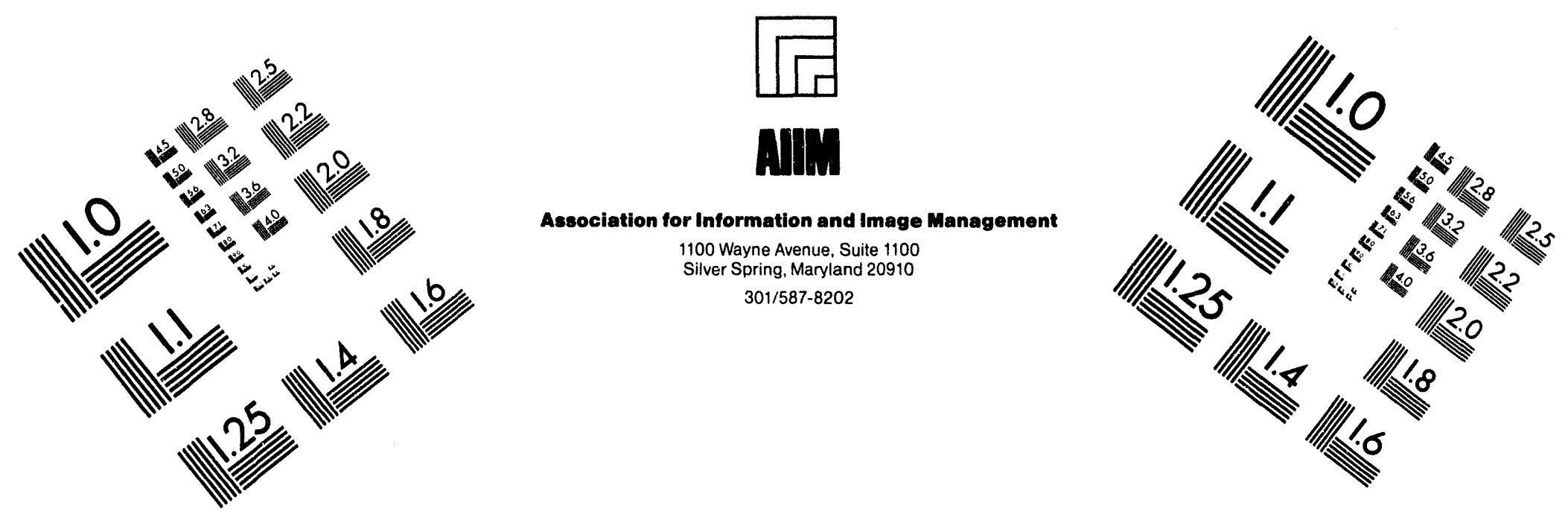

\section{Centimeter}

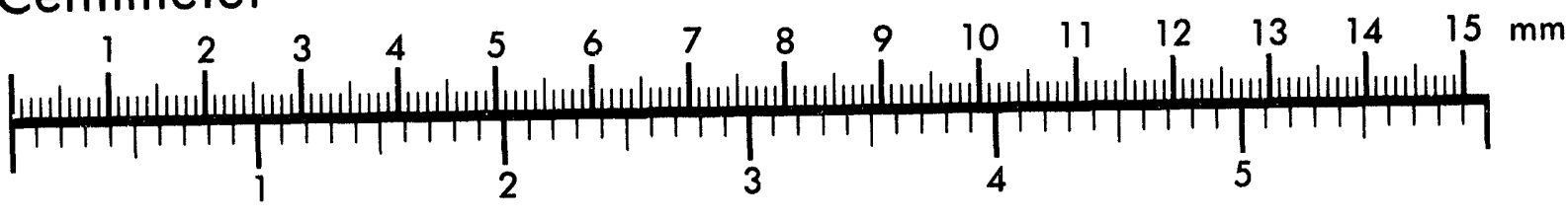
Inches
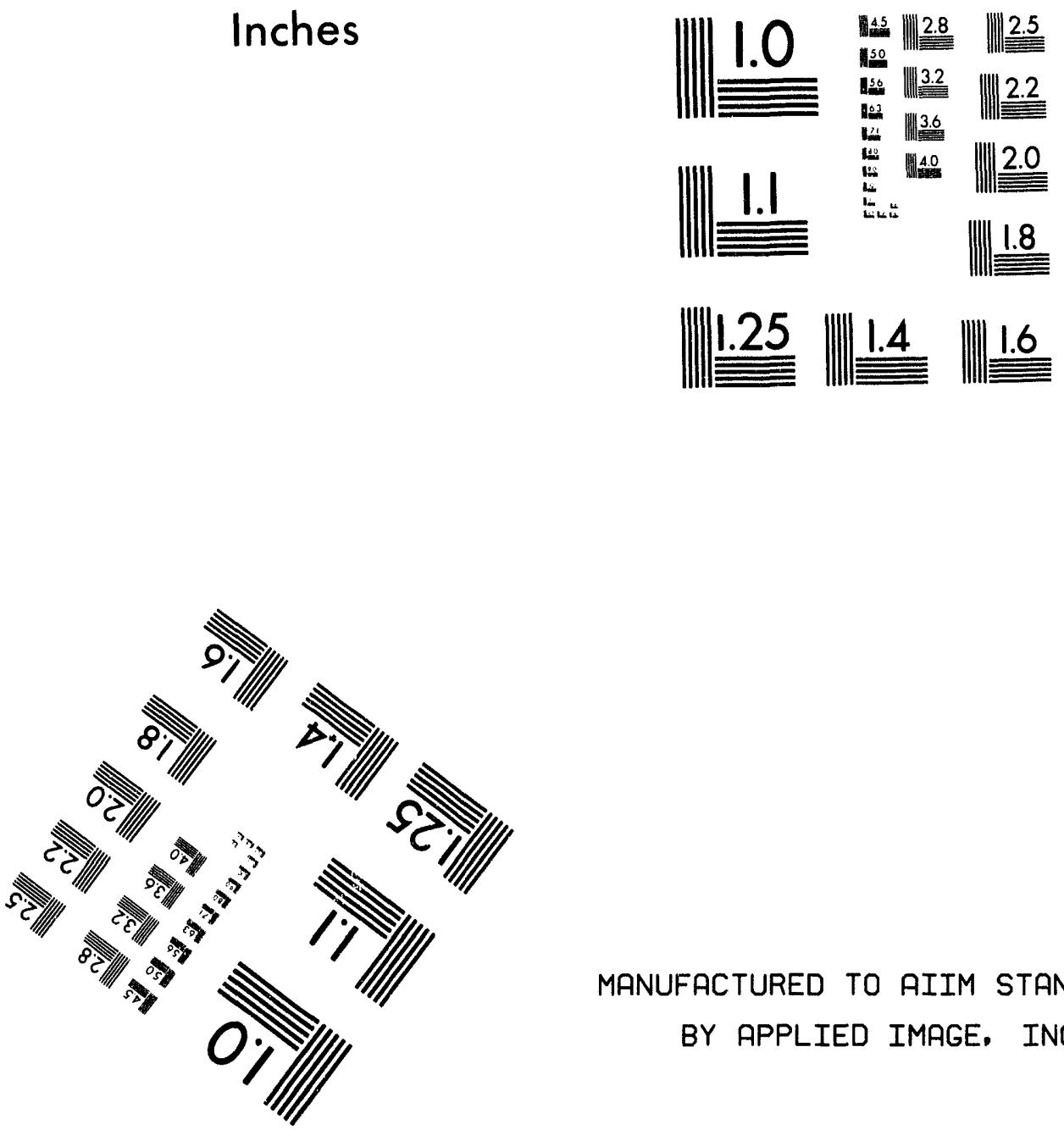

MANUFACTURED TO AIIM STANDARDS

BY APPLIED IMAGE. INC.

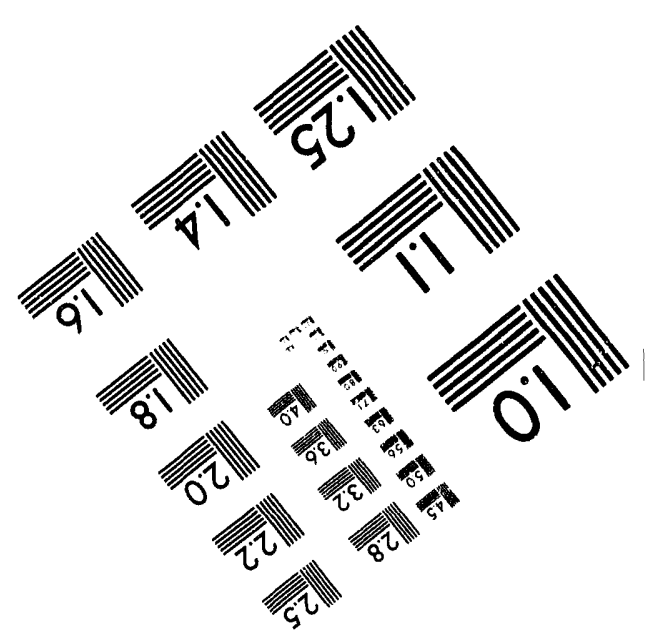



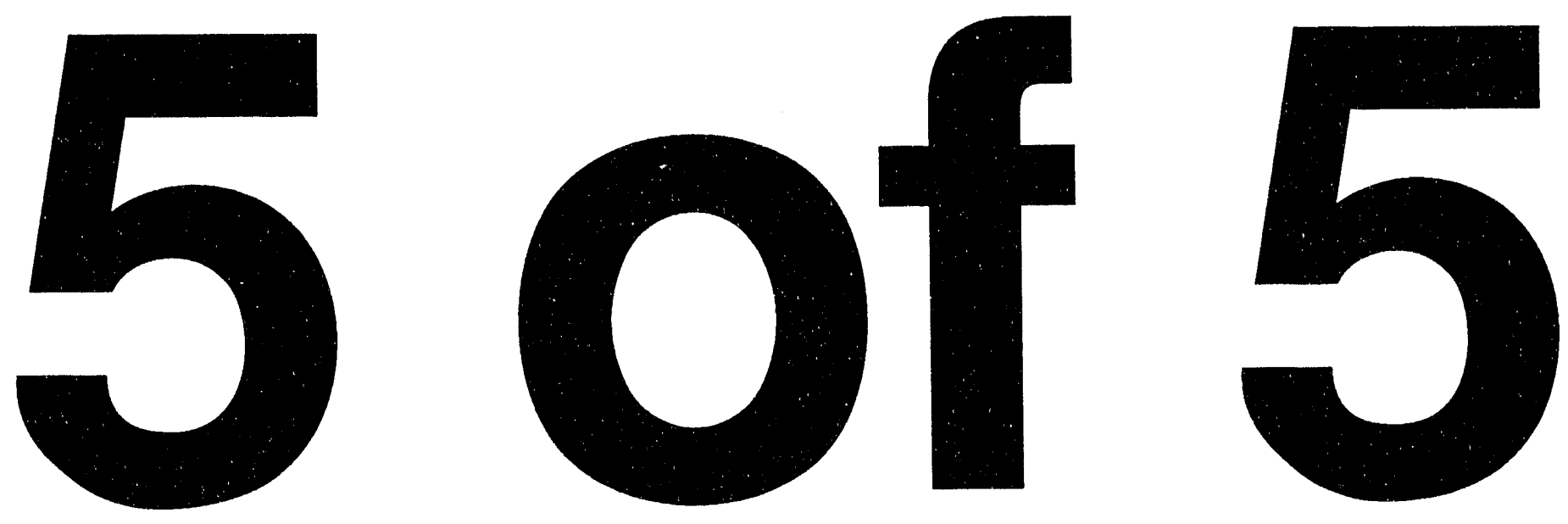


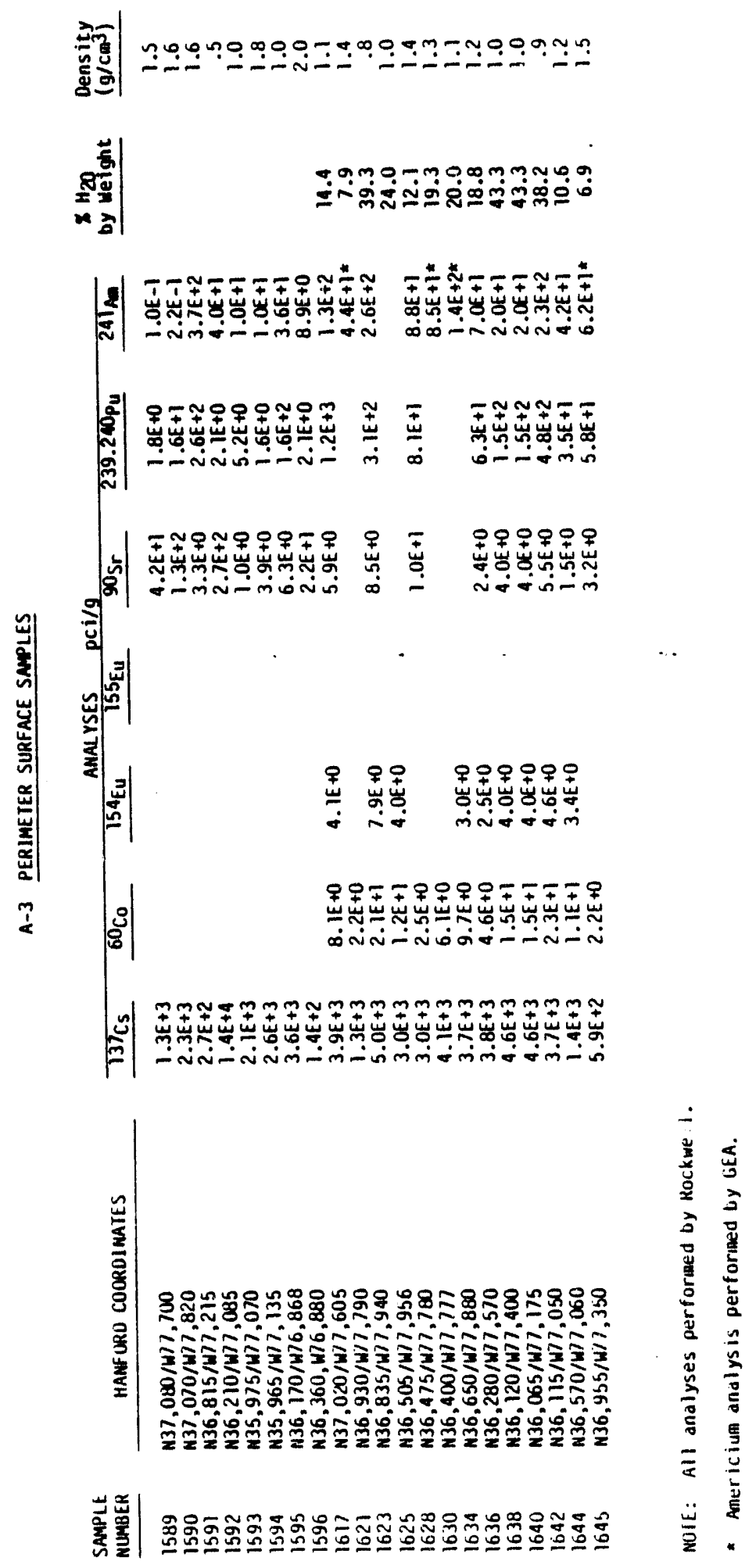

H. 8 
A-4 SIXTY METER SQUARE GRIO SAMPLES AMO ADOITIONAL INSITU MEASUREMEMTS

\begin{tabular}{|c|c|c|c|c|c|c|c|c|c|c|c|c|}
\hline \multirow{4}{*}{$\bullet$} & \multicolumn{4}{|c|}{ SAAYLE } & \multicolumn{6}{|c|}{ ANAL YSES IN pCi/g } & \multirow{2}{*}{$\begin{array}{l}\text { TOTAL U* } \\
\text { in ug/g }\end{array}$} & \multirow[b]{2}{*}{ COMENTS } \\
\hline & $\begin{array}{c}\text { HANFURD } \\
\text { COORDINATES }\end{array}$ & $\begin{array}{l}\text { TIW WETERST } \\
\text { ELEVATION }\end{array}$ & TYPE & DEPTH $(\mathrm{cm})$ & LABORATORY & ${ }^{137} \mathrm{Cs}$ & ${ }^{60} \mathrm{Co}$ & $90 \mathrm{sr}$ & $239.240 \mathrm{Pu}_{\mathrm{u}}$ & $241_{\mathrm{Am}}$ & & \\
\hline & $N 37,600 / W 79,000$ & 198.7 & $\begin{array}{l}\text { INSITU } \\
\text { C.C. a }\end{array}$ & $0-2.5$ & DEV VAN I & $9.4 E-1$ & $1.1 E+0$ & & & & & Not analyzed \\
\hline & $N 37,6011 / W 7 y, 000$ & 201.2 & $\begin{array}{l}\text { INSITU } \\
\text { C.C. } \\
\text { CORE }\end{array}$ & $\begin{array}{l}0-2.5 \\
0-5.0 \\
5.0-10 \\
10-20 \\
20-30\end{array}$ & ROCKWELL & $\begin{array}{l}4.6 E+0 \\
3.7 E+0\end{array}$ & $2.2 \mathrm{E}-1$ & $1.0 \mathrm{E}+0$ & $9.8 \mathrm{E}-1$ & 5. IE-1 & $1.2 \mathrm{E}+0$ & $\begin{array}{l}\text { Hot analyzed } \\
\text { Not analyzed } \\
\text { Not analyzed }\end{array}$ \\
\hline \multirow{4}{*}{ I } & $N 37,600 / W / 8,800$ & 200.3 & $\begin{array}{l}\text { InsIIU } \\
\text { C.C. }\end{array}$ & $0-2.5$ & DEV VAN 1 & $6.9 E+0$ & 1. IE+O & . & & & & Not analyzed \\
\hline & $N 37,600 . w 78,600$ & 200.9 & $\begin{array}{l}\text { INSITU } \\
\text { C.C. } \\
\text { COKE }\end{array}$ & $\begin{array}{c}0-2.5 \\
0-5 \\
5-10 \\
10-20 \\
20-30\end{array}$ & $\begin{array}{l}\text { DEV VAN I } \\
\text { ROCKWELL }\end{array}$ & $\begin{array}{l}1.6 \mathrm{E}+0 \\
9.2 \mathrm{E}+0\end{array}$ & $\begin{array}{l}1.1 \mathrm{E}+0 \\
1 . \mathrm{IE}-1\end{array}$ & $\begin{array}{c}1.1 E+0 \\
.\end{array}$ & $5.4 E+0$ & $4.4 E-1$ & $1.2 E+0$ & $\begin{array}{l}\text { Mot analyzed } \\
\text { Not analyzed } \\
\text { Not analyzed }\end{array}$ \\
\hline & $\mathrm{N} 37,60 \mathrm{~N} / \mathrm{W} / 8,400$ & 201.2 & $\begin{array}{l}\text { INSIIU } \\
\text { C.C. }\end{array}$ & $0-2.5$ & DEV VAN I & $4.2 E+0$ & 1. $1 E+0$ & & & & & $\begin{array}{l}\text { Not analyzed } \\
\text { Not analyzed }\end{array}$ \\
\hline & $N 37,600 / W 78,200$ & 202.1 & $\begin{array}{l}\text { INSI IU } \\
\text { C.C. } \\
\text { CORE }\end{array}$ & $\begin{array}{c}0=2.5 \\
0-5 \\
5=10 \\
10=20 \\
20=30\end{array}$ & $\begin{array}{l}\text { DEV VAN I } \\
\text { ROCKWELL }\end{array}$ & $\begin{array}{l}9.4 E-1 \\
2.3 E-1\end{array}$ & $\begin{array}{l}1.1 E+0 \\
8.9 E-1\end{array}$ & $5.0 \mathrm{E}-1$ & $1.7 E-0$ & $5.6 E-1$ & $1.2 E+0$ & $\begin{array}{l}\text { Not analyzed } \\
\text { Not analyzed } \\
\text { Not analyzed } \\
\text { Not analyzed }\end{array}$ \\
\hline
\end{tabular}

a Cookie cutter. 
A-4 SIXIY METER SQUARE GRIO SAMPLES AMD ADOITIOMAL INSITU MEASUREMEMTS

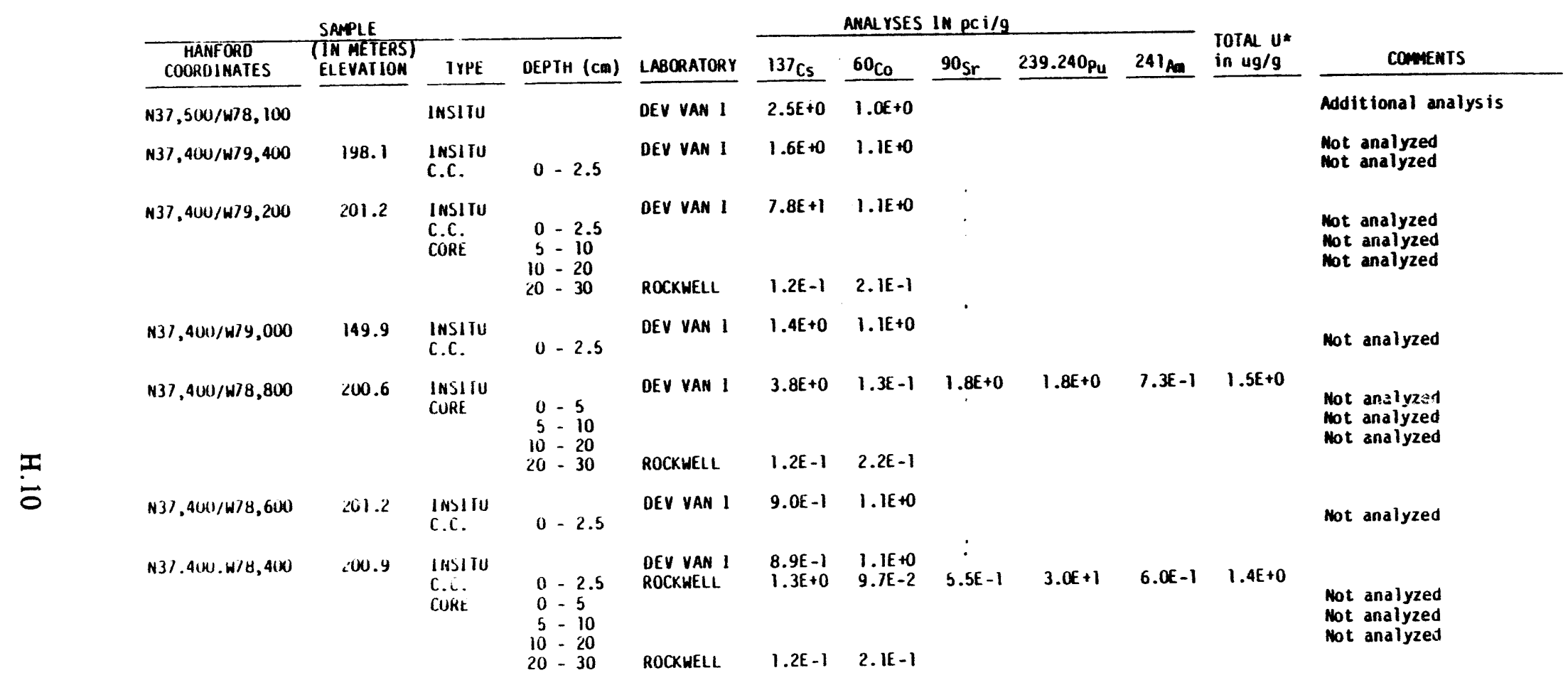


A-4 SIXIY METER SQUARE GRID SAMPLES AMO ADOITIOMAL IMSITU MEASUREMEMTS

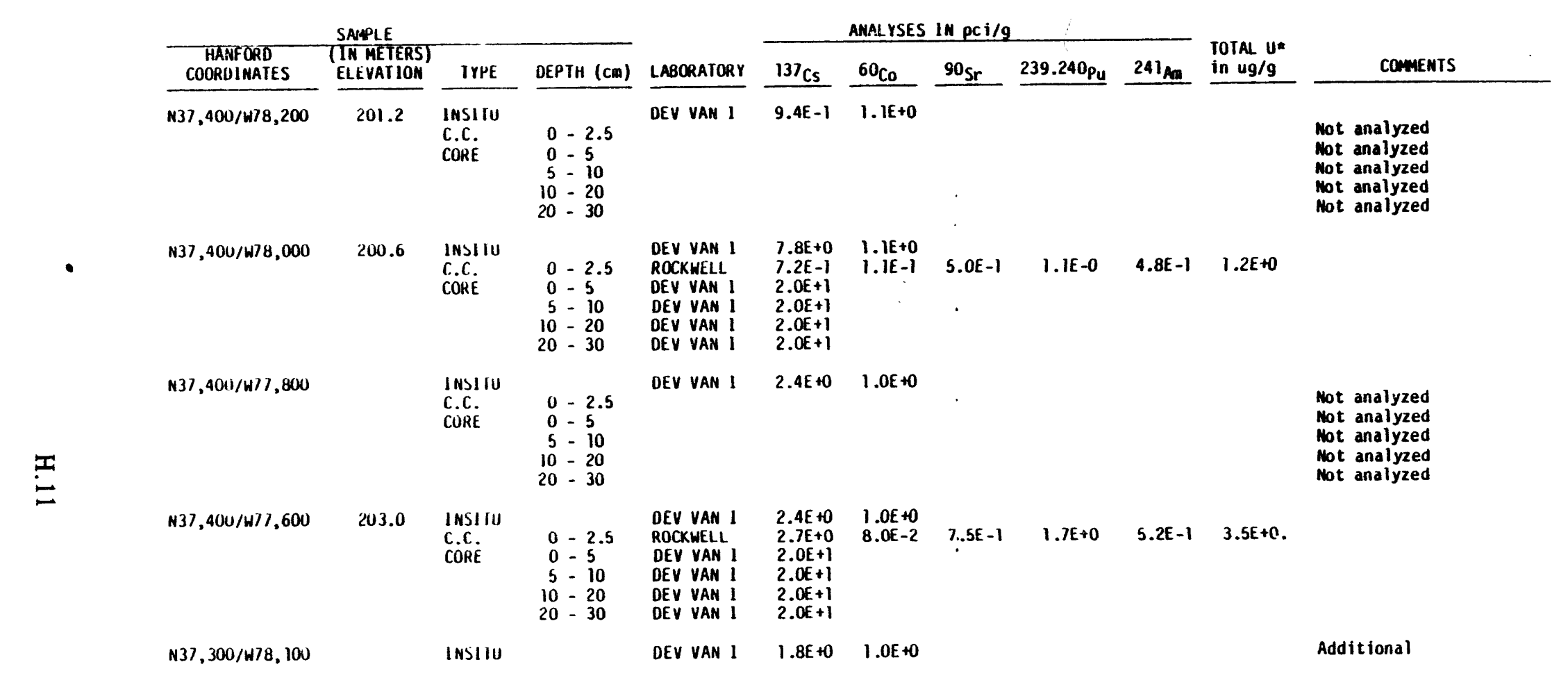


A-4 SIXTY METER SQUARE GRIO SAMPLES AMD ADDITIOMAL INSITU MEASUREREMTS

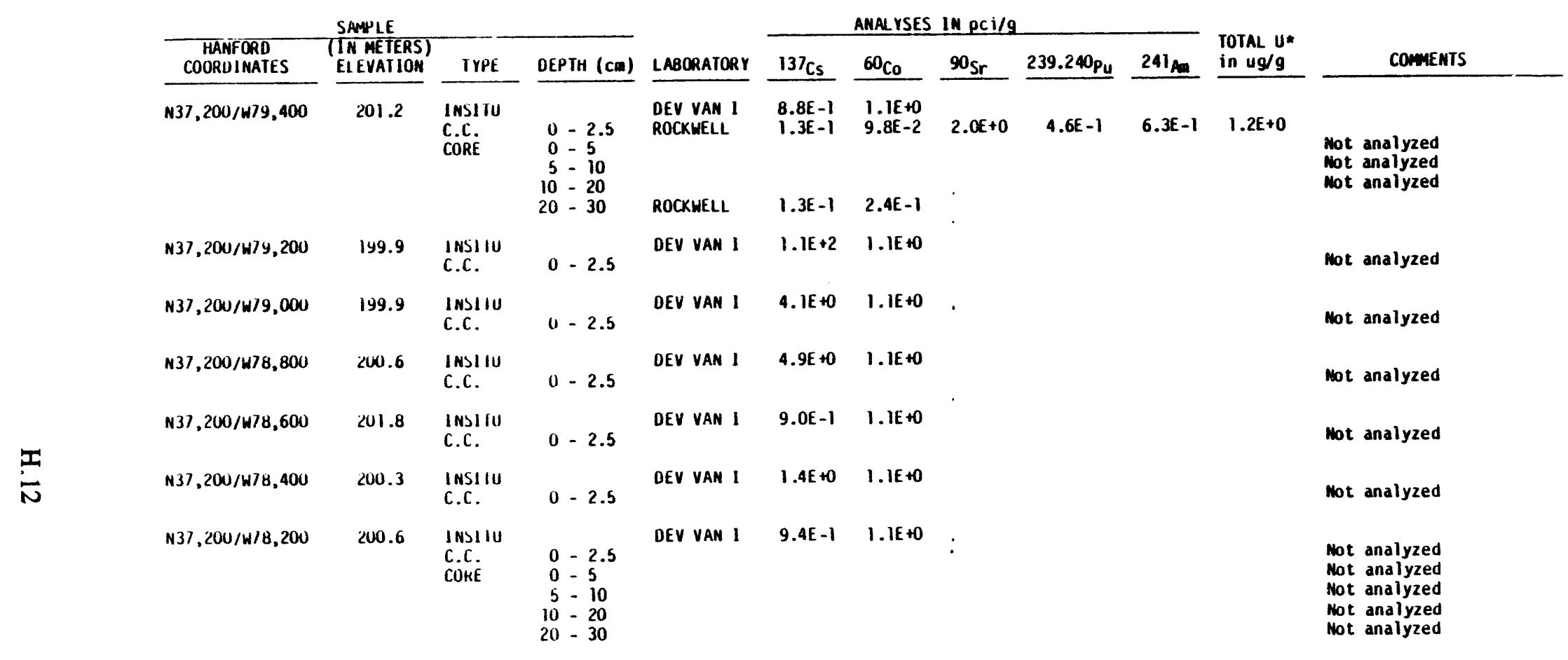


A-4 SIXTY METER SQUARE GRID SAMPLES AMD ADOITIOMAL IMSITU MEASUREMEMTS

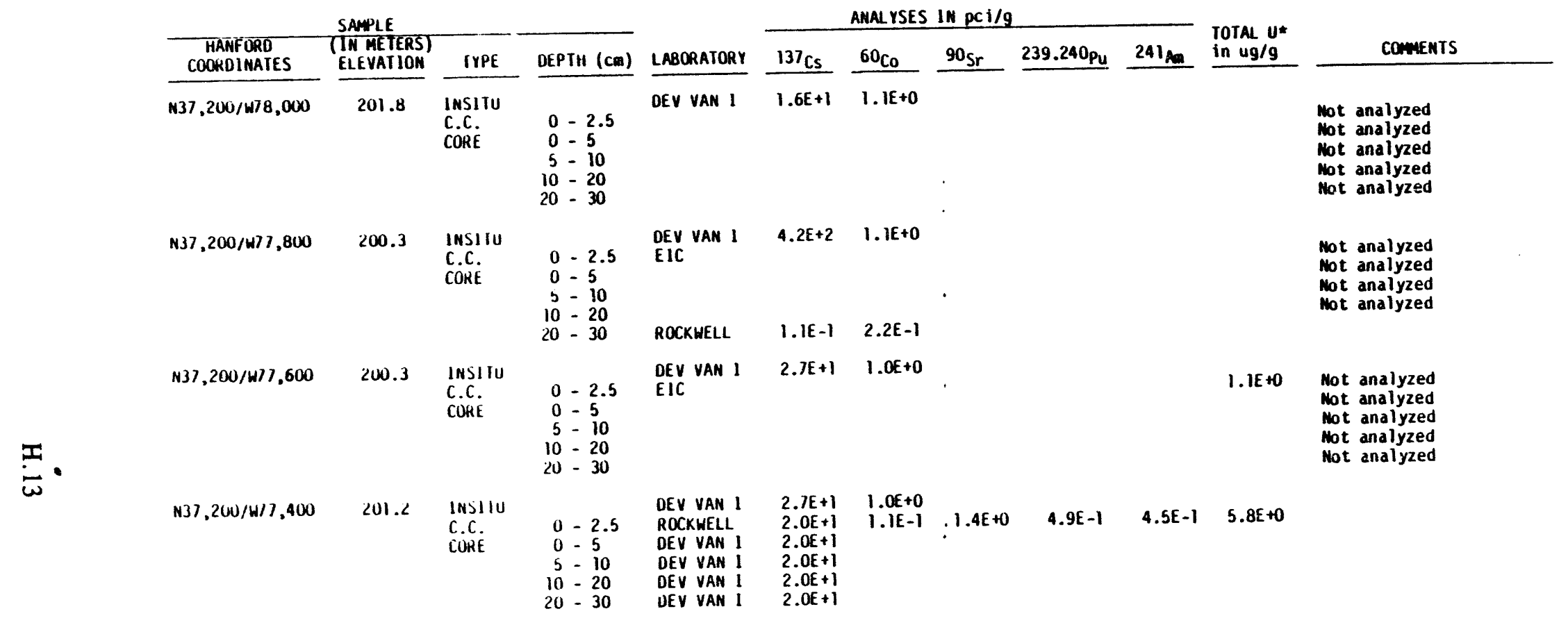


A-4 S1XTY METER SQUARE GRIO SAMPLES AMD ADOITIOMAL INSITU MEASUREMEMTS

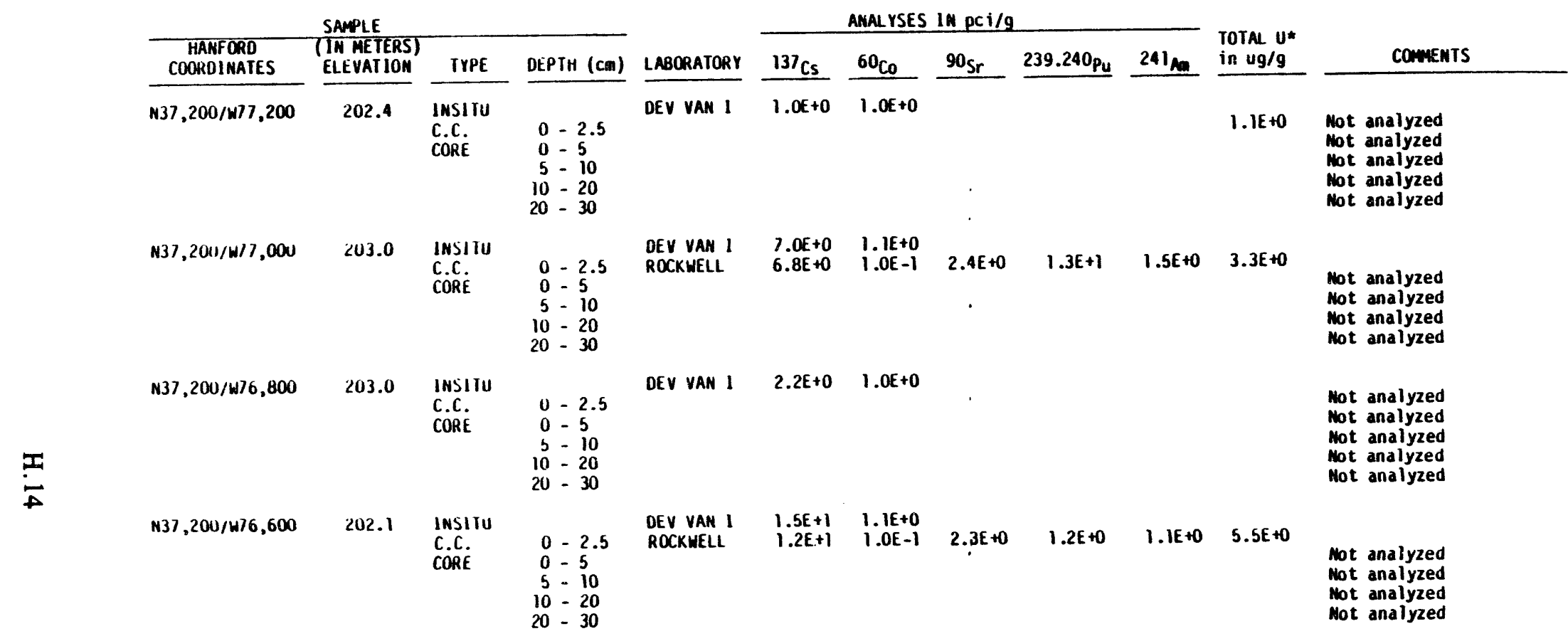


A-4 SIXTY MEIER SQUARE GRIO SAMPLES AMD ADOITIOMAL IMSITU MEASUREMEMTS

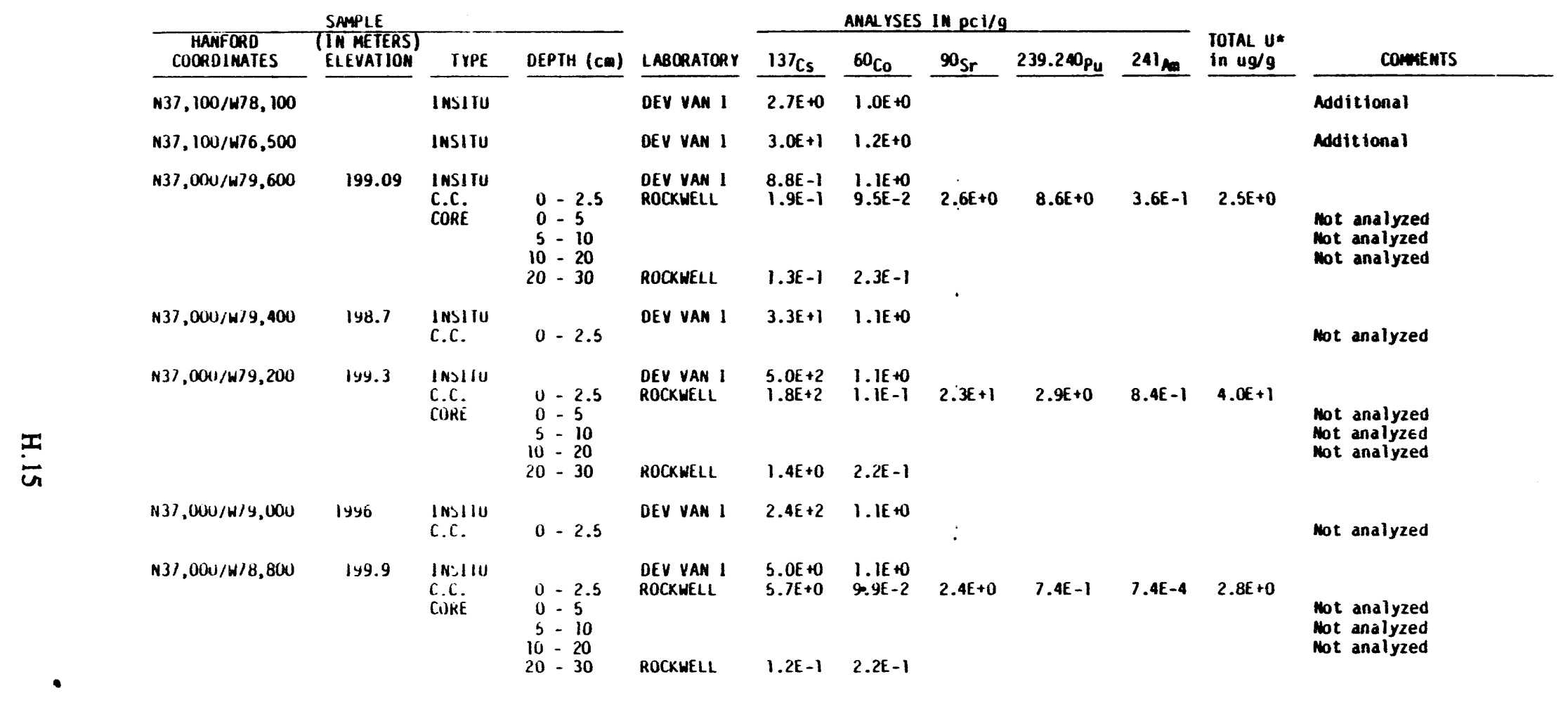


A-4 SIXIY METER SQUARE GR1D SAMPLES AMD ADOITIOMAL IMSITU MEASUREMEMTS

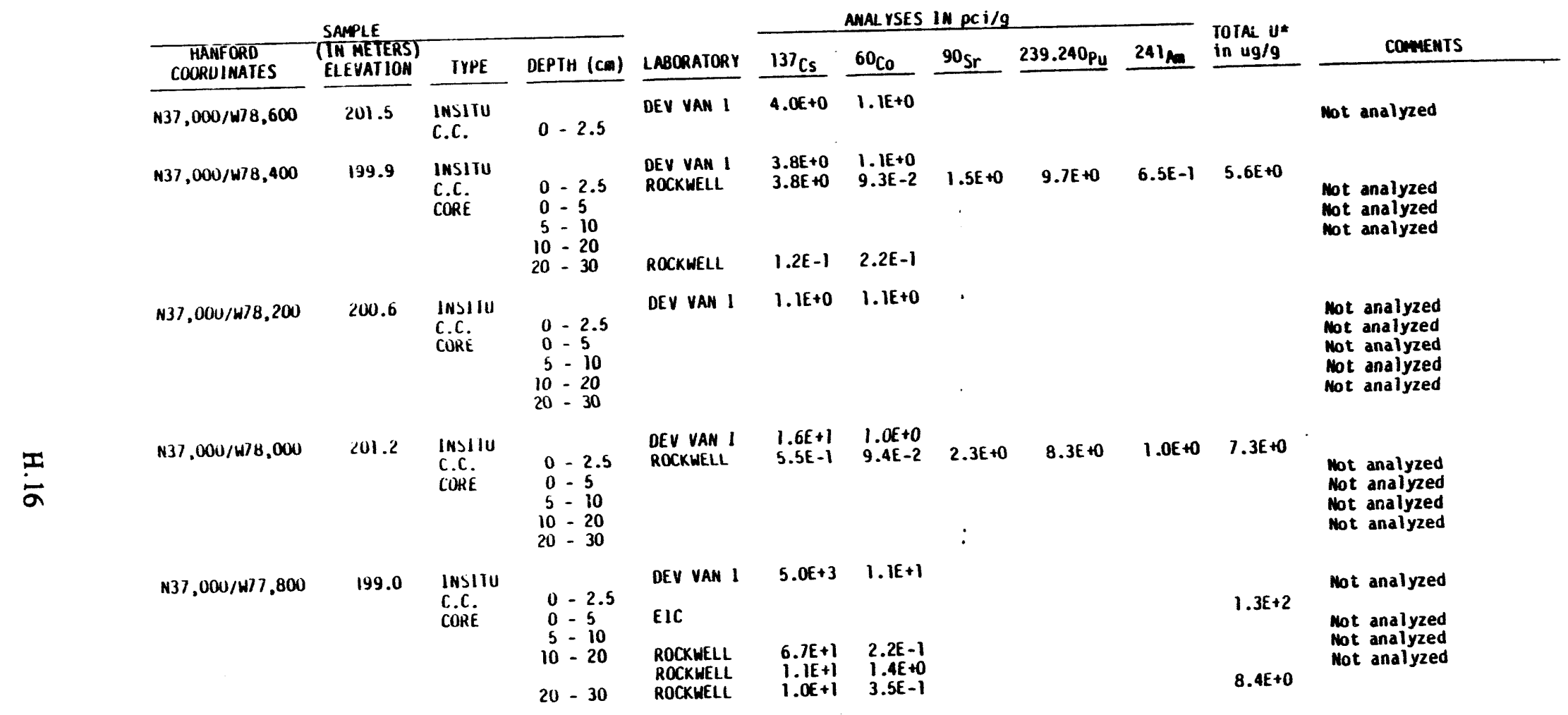


A-4 SIXIY METER SQUARE GRID SAMPLES AMD ADOITIOMAL INSITU MEASUREMEMTS

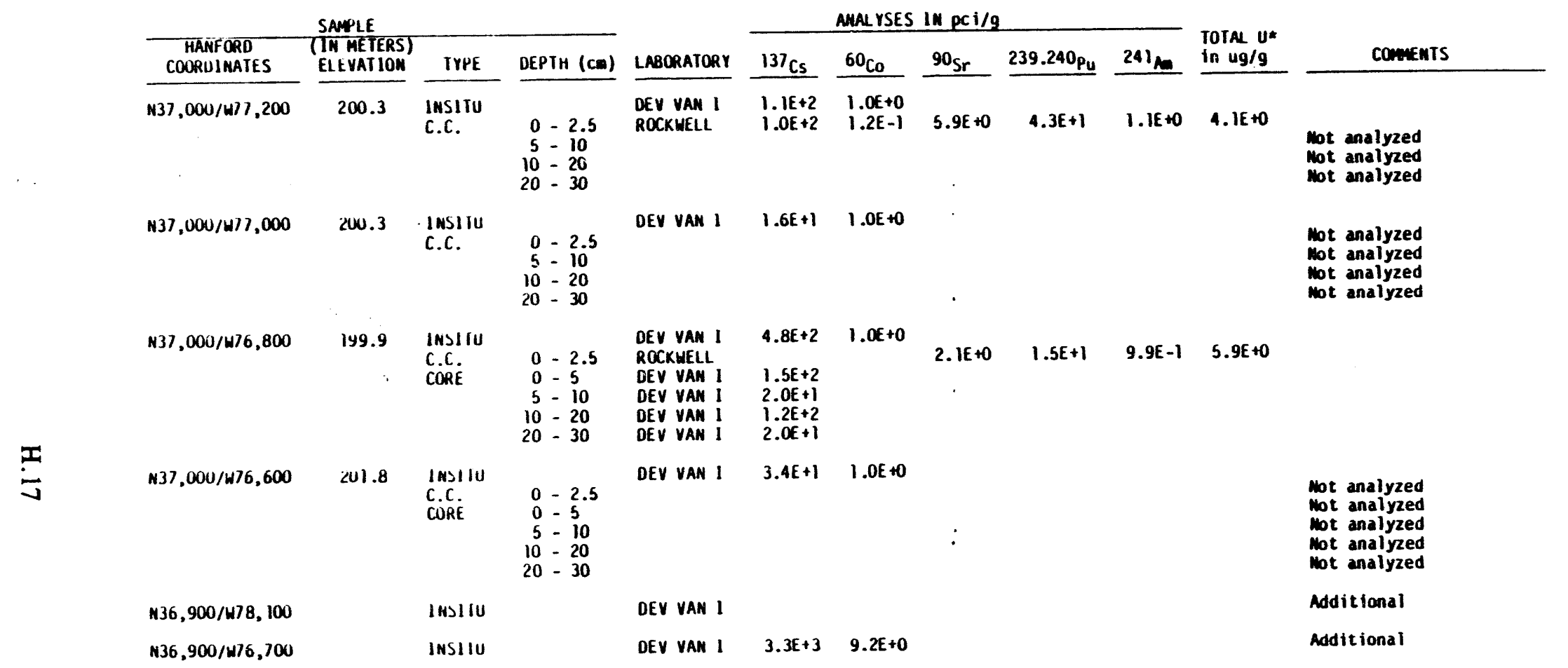


A-4 SIXTY METER SQUARE GRIO SAMPLES AMD ADOITIOMAL INSITU MEASUREMEMTS

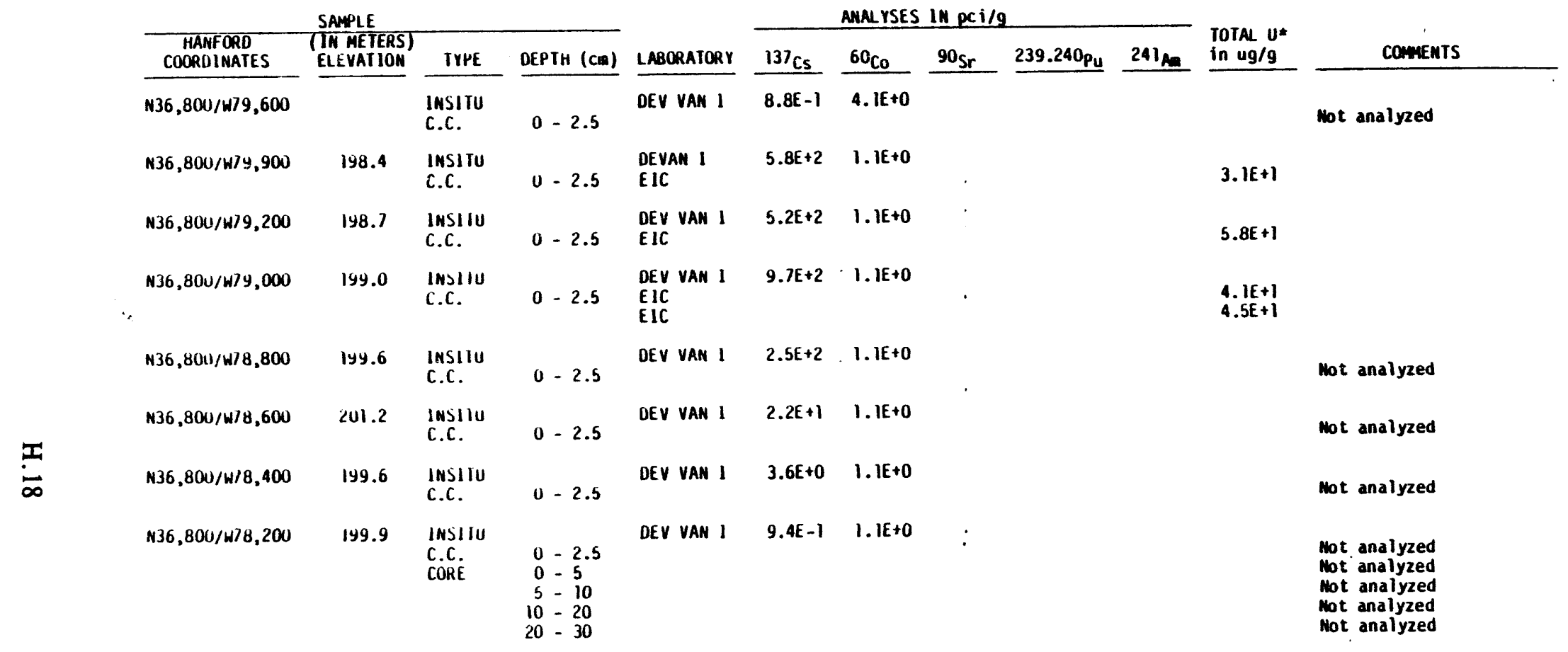


A-4 SIXTY METER SQUARE GRID SAMPLES AMD ADOITIOMAL INSITU MEASUREMEMTS

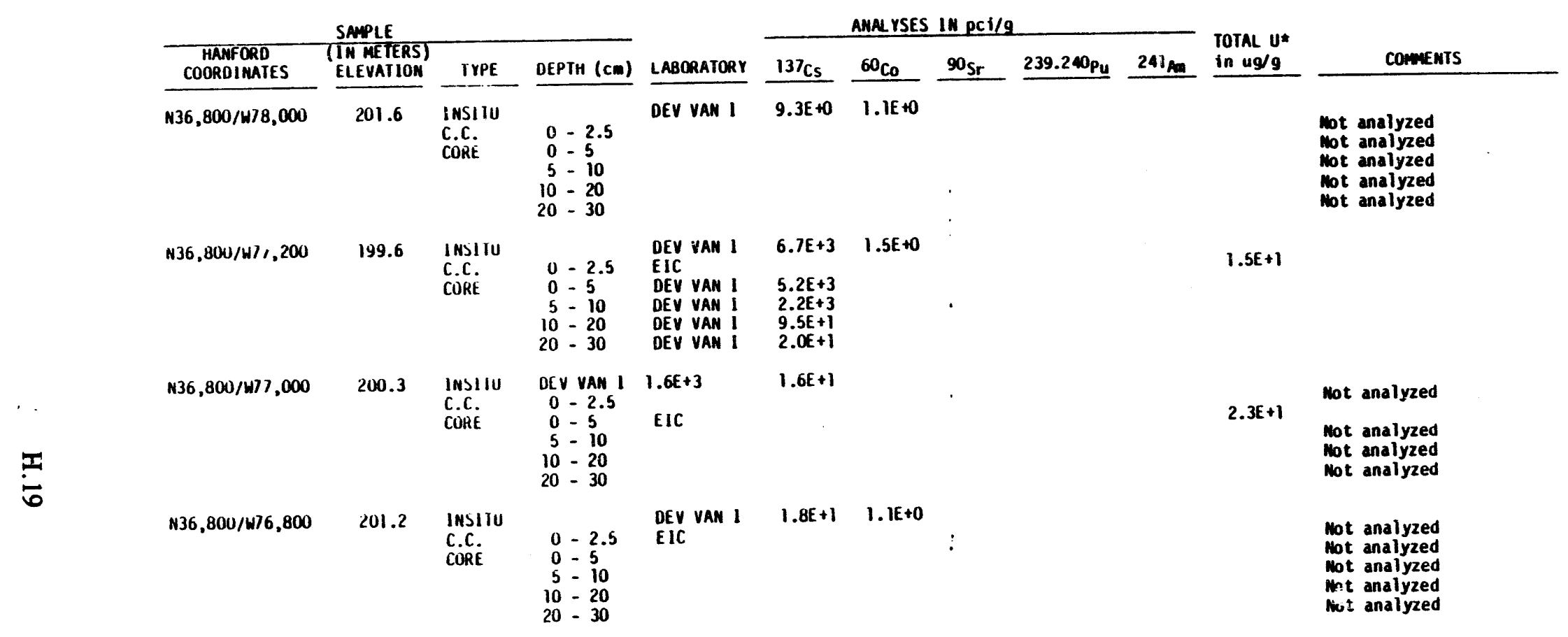


A-4 SIXTY METER SQUARE GR1D SAPPLES AMD ADOITLOMAL IMSITU MEASUREMEMTS

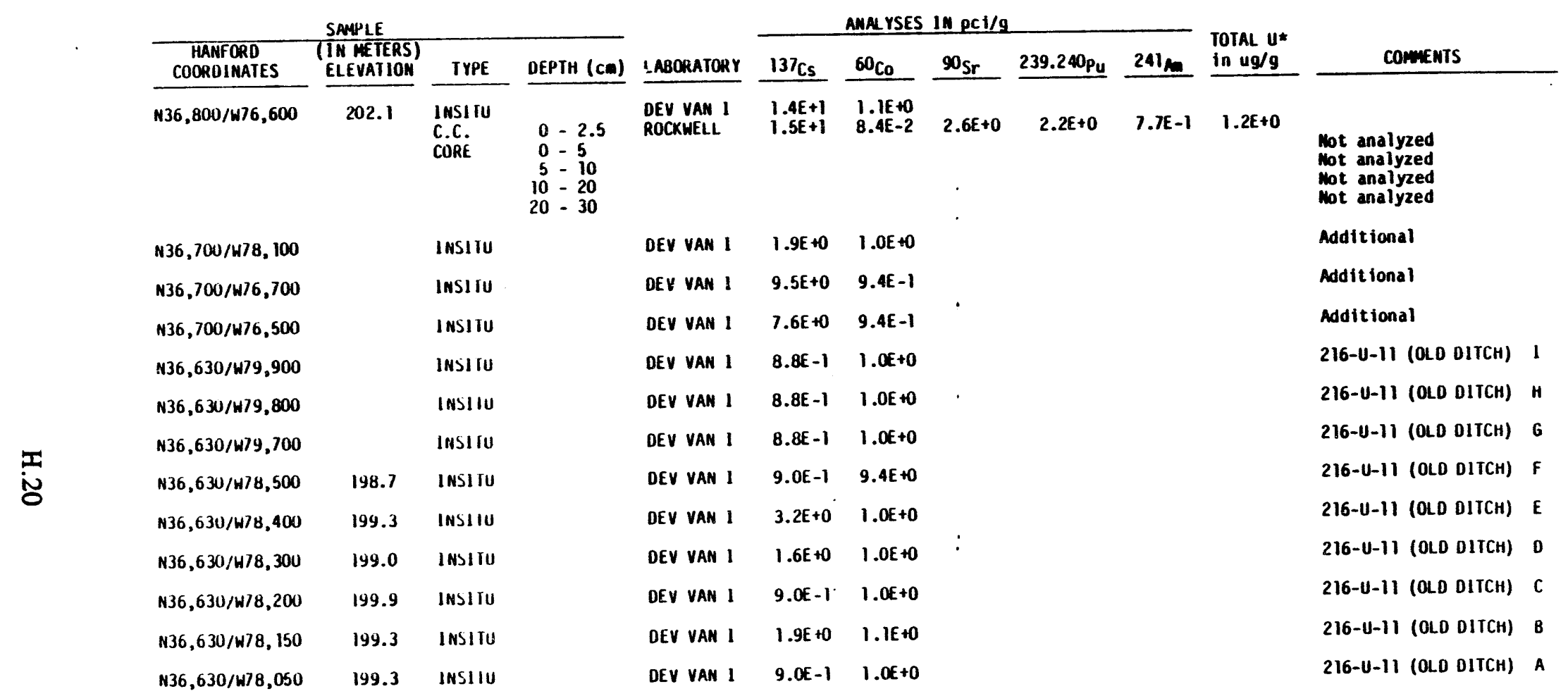


A-4 SIXTY METER SQUARE GRID SAMPLES AMD AODITIOMAL IMSITU MEASUREMEMTS

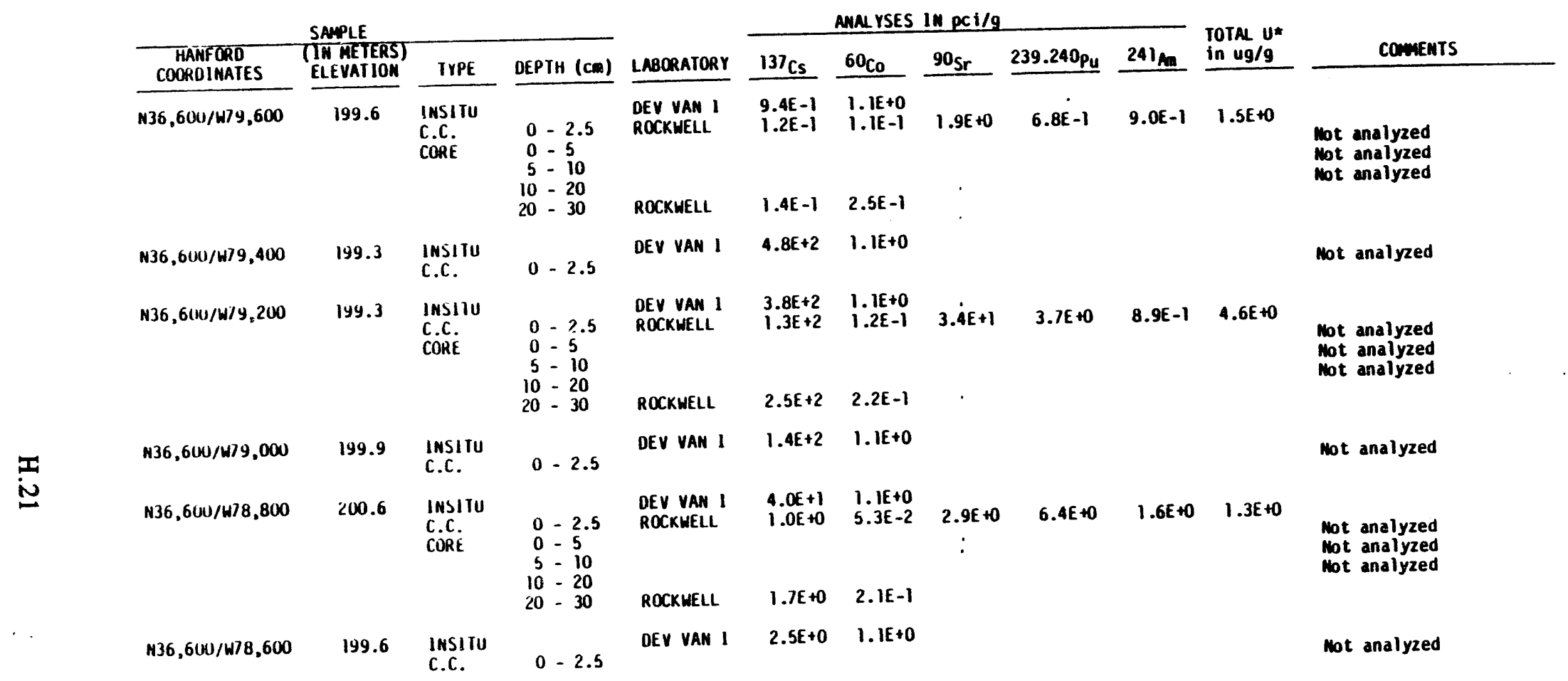


A-4 SIXTY METER SQUARE GRIO SAMPLES AMD ADDITIONAL IMSITU MEASLRERENTS

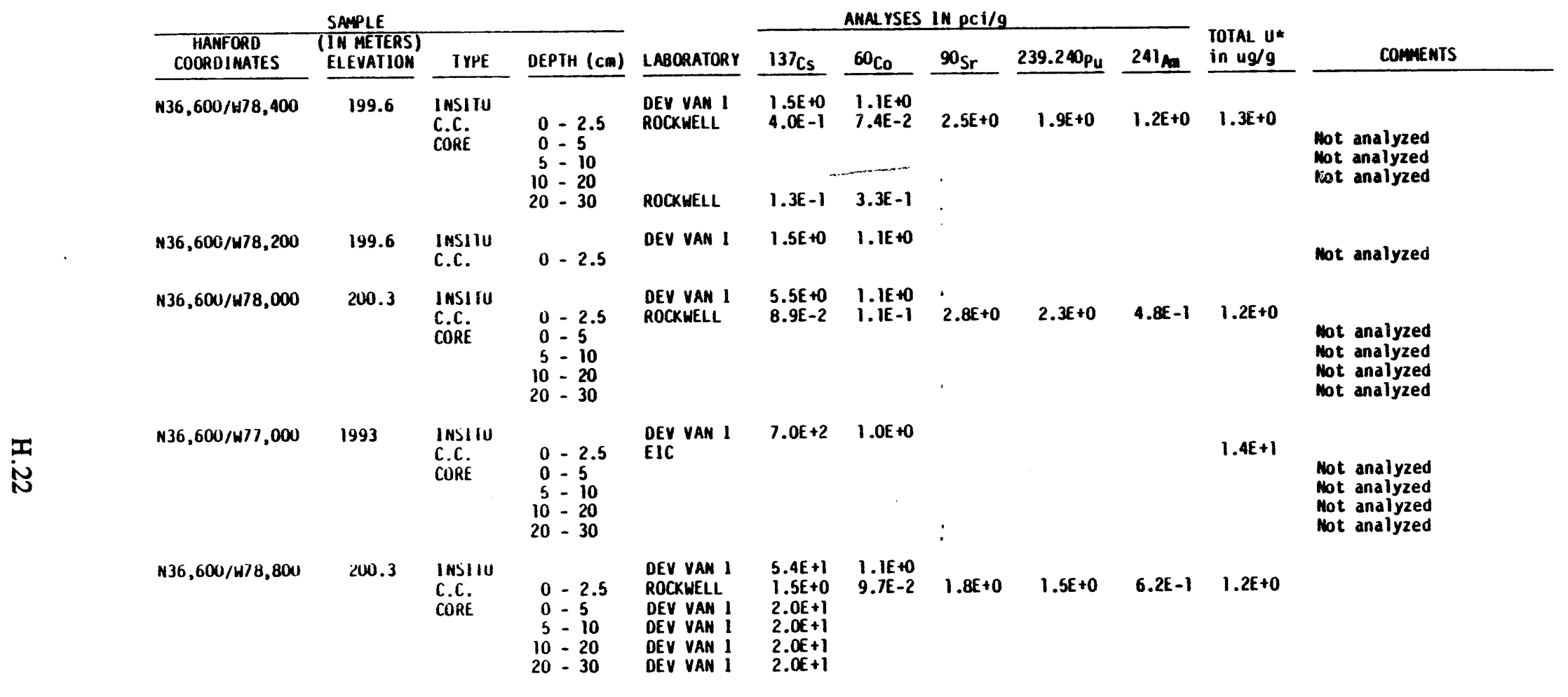


A-4 SIXTY METER SQUARE GR 10 SNPLES AMD ADOITIOMAL INSITU MEASUREMEMTS

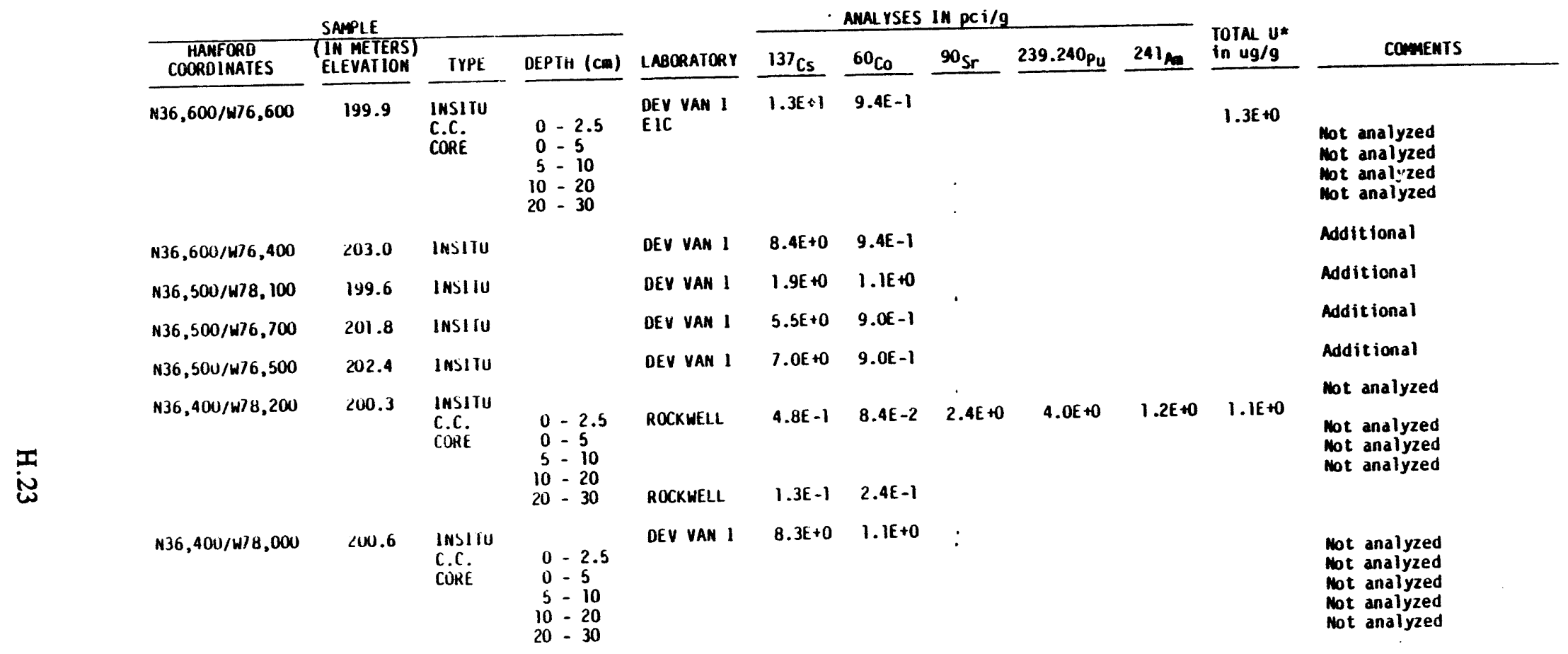


A-4 SIXTY METER SQULARE GRID SAMPLES AMO ADOITIONAL INSITU MEASUREMEMTS

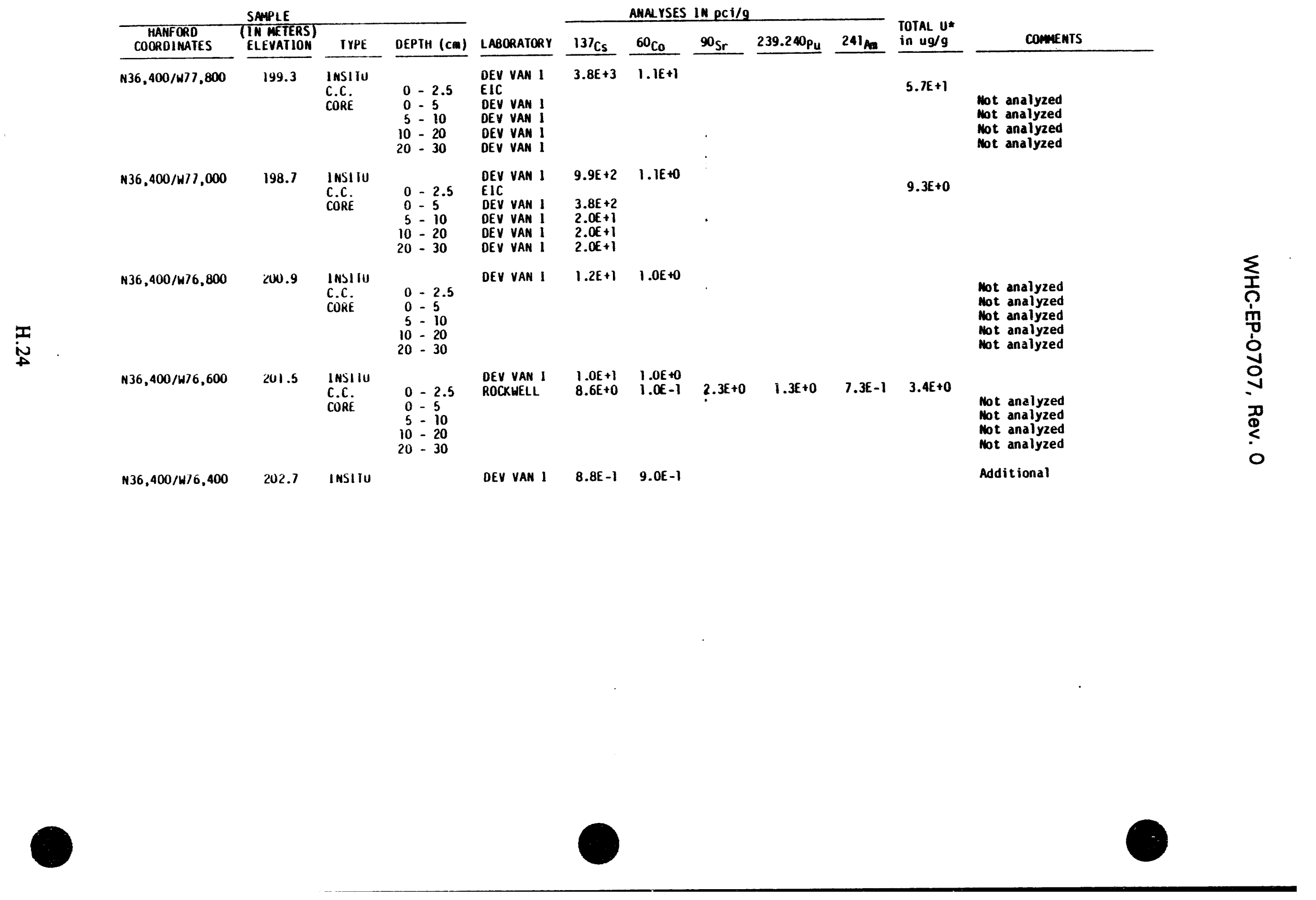


A-4 SIXTY METER SQUARE GRIO SAPLES AMD ADOITIOMAL IMSITU MEASUREREMTS

\begin{tabular}{|c|c|c|c|c|c|c|c|c|c|c|c|}
\hline \multicolumn{4}{|c|}{ SAPLE } & \multirow[b]{2}{*}{ LABORATORY } & \multicolumn{5}{|c|}{ AMAL YSES IN pCi/g } & \multirow{2}{*}{$\begin{array}{l}\text { TOTAL U* } \\
\text { in } u g / g\end{array}$} & \multirow[b]{2}{*}{ COMnents } \\
\hline $\begin{array}{l}\text { HAHFORD } \\
\text { COORDIMATES }\end{array}$ & $\begin{array}{l}\text { (IN METERS) } \\
\text { ELEVATION }\end{array}$ & IYPE & DEPIH (CD) & & $137 \mathrm{Cs}$ & ${ }^{60} \mathrm{Co}$ & ${ }^{90} \mathrm{Sr}$ & $239.240 \mathrm{Pu}$ & $241_{\mathrm{Am}}$ & & \\
\hline$N 36,300 / W 78,100$ & 199.6 & IHSITU & & DEY YAN 1 & $1.7 E+0$ & $1.1 E+0$ & & & & & Additional \\
\hline$M 36,300 / M 76,300$ & & INSIIU & & DEV YAN 1 & 4. $1 E+0$ & $9.0 \epsilon-1$ & & & & & Additional \\
\hline$N 36,200 / 4 / 8,000$ & 200.6 & $\begin{array}{l}\text { I MSI IU } \\
\text { C.C. } \\
\text { CORE }\end{array}$ & $\begin{aligned} 0 & -2.5 \\
0 & =5 \\
5 & =10 \\
10 & =20 \\
20 & =30\end{aligned}$ & $\begin{array}{l}\text { DEV VAM } 1 \\
\text { ROCKWELL }\end{array}$ & $\begin{array}{l}1.8 E+1 \\
5.1 E-1\end{array}$ & $\begin{array}{l}1.0 E+0 \\
1.1 E-1\end{array}$ & $1.7 E+0$ & $2.6 E+0$ & 1. IE+O & $2.7 E+0$ & $\begin{array}{l}\text { Not analyzed } \\
\text { Not analyzed } \\
\text { Hot analyzed } \\
\text { Hot analyzed }\end{array}$ \\
\hline$N 36,200 / w 77,800$ & 199.6 & $\begin{array}{l}\text { IHSIIU } \\
\text { C.C. } \\
\text { CORE }\end{array}$ & $\begin{array}{c}0=2.5 \\
0=5 \\
5=10 \\
10=20 \\
20=30\end{array}$ & DEY VAN 1 & $2.4 E+2$ & $1.0 E+0$ & & & & & $\begin{array}{l}\text { Not analyzed } \\
\text { Not analyzed } \\
\text { Hot analyzed } \\
\text { Hot analyzed } \\
\text { Hot analyzed }\end{array}$ \\
\hline$M 36,200 / w 77,600$ & 199.6 & $\begin{array}{l}\text { INSITU } \\
\text { C.C. } \\
\text { CORE }\end{array}$ & $\begin{array}{c}0=2.5 \\
0=5 \\
5=10 \\
10=20 \\
20=30\end{array}$ & $\begin{array}{l}\text { DEV VAN I } \\
\text { ROCKUELL } \\
\text { DEY VAM I } \\
\text { DEV VAN I } \\
\text { DEY VAM I } \\
\text { DEY VAN I }\end{array}$ & $\begin{array}{l}2.0 E+3 \\
1.9 E+3 \\
3.0 E+1 \\
2.0 E+1 \\
2.0 E+1\end{array}$ & $1.0 \mathrm{E}+0$ & $\begin{array}{c}9.7 E+1 \\
:\end{array}$ & $9.7 E+3$ & $1.9 E+3$ & $3.7 E+1$ & \\
\hline$N 36,200 / w 76,800$ & 199.3 & $\begin{array}{l}\text { I NSI IU } \\
\text { C.C. } \\
\text { CORE }\end{array}$ & $\begin{array}{c}0=2.5 \\
0=5 \\
5=10 \\
10=20 \\
20=30\end{array}$ & $\begin{array}{l}\text { DEV VAN I } \\
\text { ROCKMELL } \\
\text { DEV YAA } 1 \\
\text { DEV VAN I } \\
\text { DEV VAM } 1 \\
\text { DEV VAN I }\end{array}$ & $\begin{array}{l}3.7 E+3 \\
3.8 E+2 \\
1.8 E+3 \\
1.8 E+3 \\
6.2 E+2\end{array}$ & $1.1 E+0$ & $1.2 E+2$ & $1.1 E+1$ & $1.06+0$ & $1.4 E+1$ & \\
\hline
\end{tabular}


A-4 SIXTY METER SQUARE GRID SAMPLES AMD ADOIIIOMML IMSITU MEASUREMEMTS

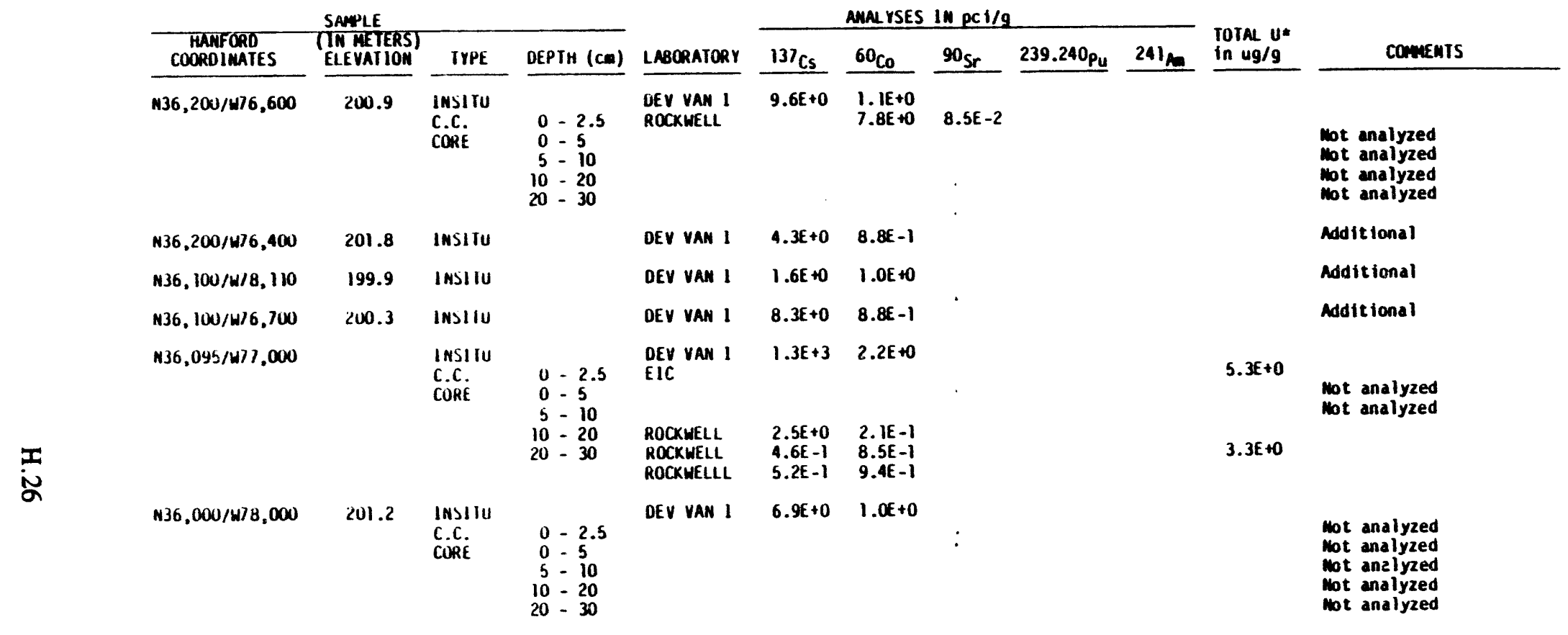


A-4 SIXIY METER SQUARE GRID SAYPLES AMO NOO1TIOMR: IMSITU MEASUREHEMTS

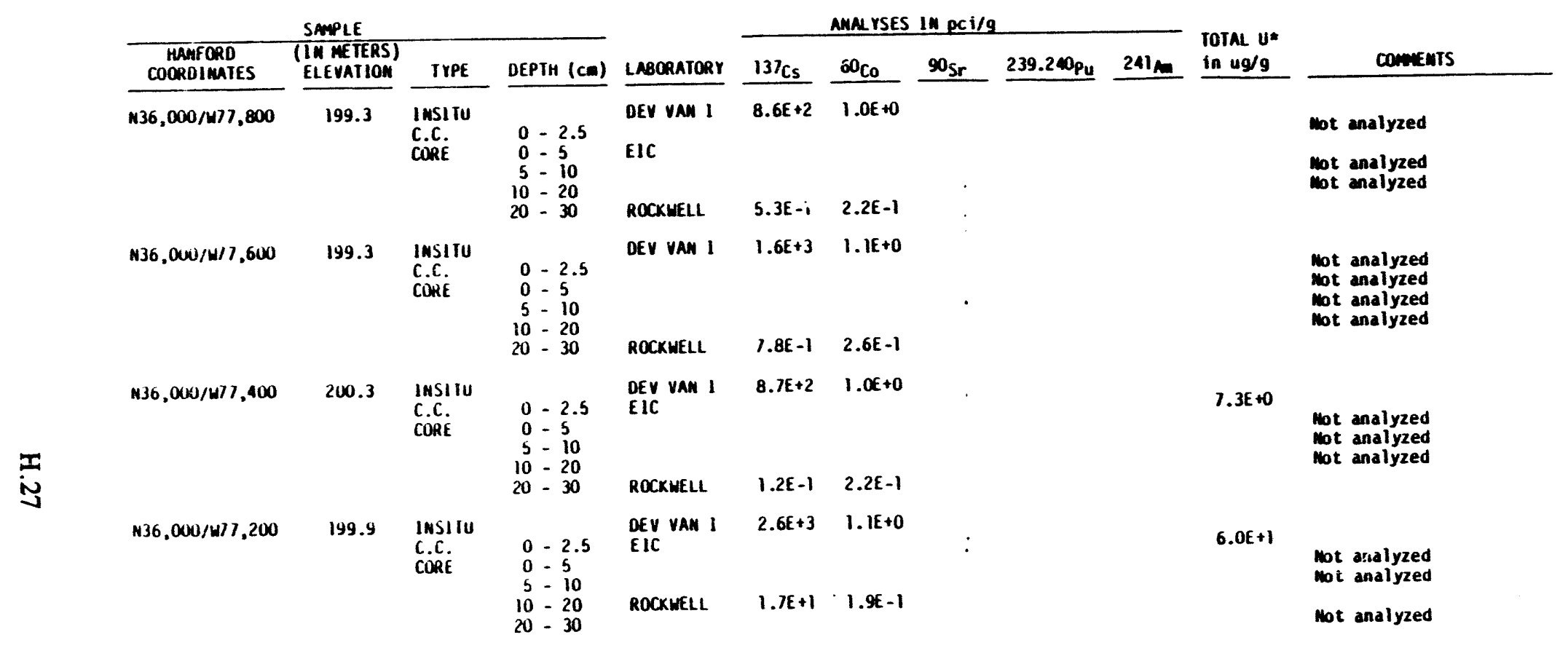


A-4 SIXTY METER SQUARE GRIO SAPLLS AMO ADOITIOMAL INSITU MEASUREMEWTS

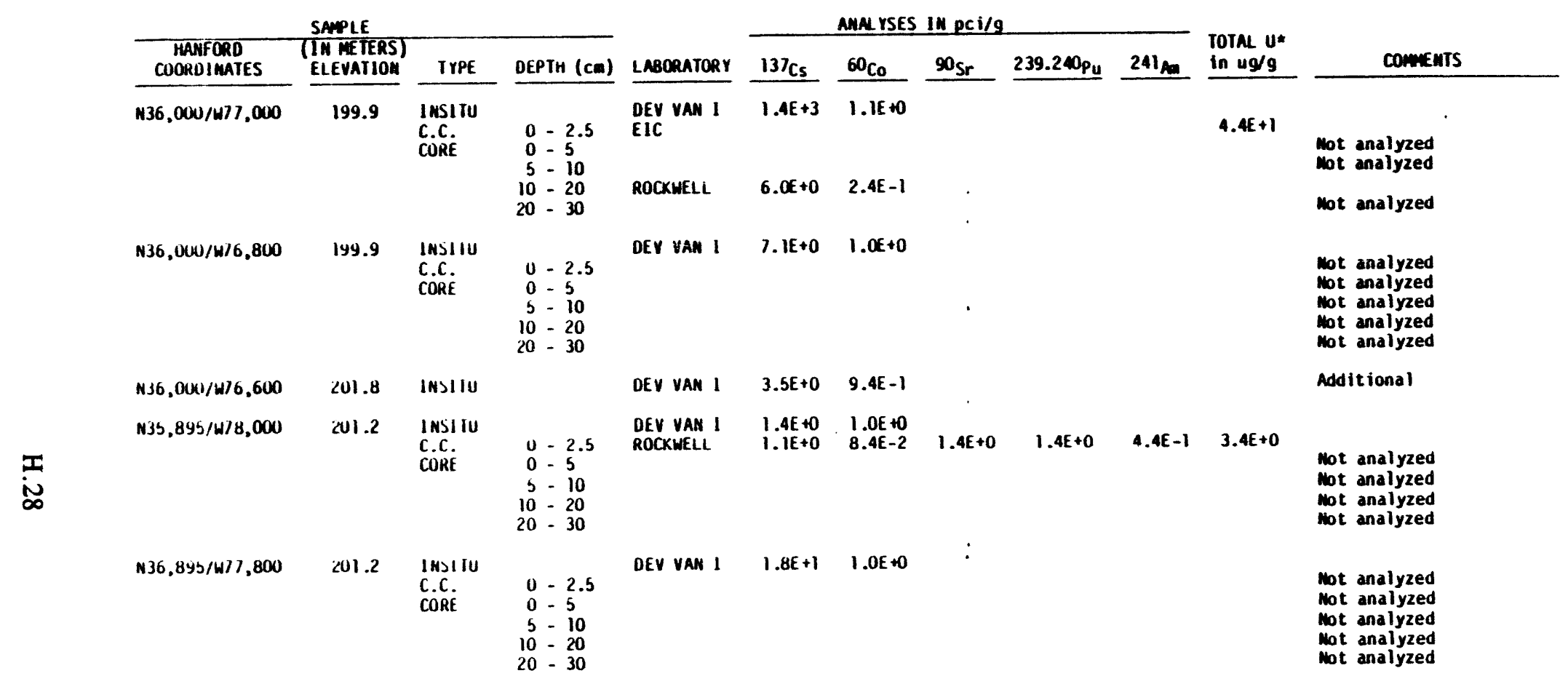


A-4 SIXIY METER SQUARE GRID SAMPLES AMD ADOITIOMML INSITU MEASUREMEMTS

\begin{tabular}{|c|c|c|c|c|c|c|c|c|c|c|c|}
\hline \multicolumn{4}{|c|}{ SAMPLE } & \multicolumn{6}{|c|}{ AWAL YSES IN PCi/g } & \multirow[b]{2}{*}{$\begin{array}{l}\text { TOTAL } u^{*} \\
\text { in } u g / 9\end{array}$} & \multirow[b]{2}{*}{ COMAEMTS } \\
\hline $\begin{array}{l}\text { HANFORD } \\
\text { COOROIMATES }\end{array}$ & $\begin{array}{l}\text { TIN METERS) } \\
\text { EI EVATION }\end{array}$ & IYPE & DEPTH $(\mathrm{cm})$ & LABORATORY & ${ }^{137} \mathrm{Cs}_{\mathrm{S}}$ & ${ }^{60} \mathrm{Co}$ & $90 \mathrm{Sr}$ & $239.240 \mathrm{Pu}$ & $241_{\mathrm{A}}$ & & \\
\hline$M 35,895 / W 77,600$ & 201.2 & $\begin{array}{l}\text { INSITU } \\
\text { C.C. } \\
\text { CORE }\end{array}$ & $\begin{array}{c}0-2.5 \\
0=5 \\
5=10 \\
10=20 \\
20=30\end{array}$ & $\begin{array}{l}\text { DEV VAM I } \\
\text { ROCKWELL }\end{array}$ & $\begin{array}{l}1.3 E+1 \\
2.0 E+0\end{array}$ & $\begin{array}{l}1.0 E+0 \\
1.0 E-1\end{array}$ & $2.0 E+0$ & $7.3 E+0$ & $1.7 E+0$ & $1.4 \mathrm{E}+1$ & $\begin{array}{l}\text { Not analyzed } \\
\text { Hot analyzed } \\
\text { not analyzed } \\
\text { Hot analyzed }\end{array}$ \\
\hline$N 35,895, / 477,400$ & 201.2 & $\begin{array}{l}\text { INSIIIU } \\
\text { C.C. } \\
\text { CORE }\end{array}$ & $\begin{array}{c}0=2.5 \\
0=5 \\
5=10 \\
10=20 \\
20=30\end{array}$ & DEV VAN I & $1.2 \mathrm{E}+1$ & $1.0 E+0$ & · & & & & $\begin{array}{l}\text { Mot analyzed } \\
\text { Mot analyzed } \\
\text { Mot analyzed } \\
\text { not analyzed } \\
\text { Not analyzed }\end{array}$ \\
\hline$N 35,895 / W 77,200$ & 201.2 & $\begin{array}{l}\text { IMSIIU } \\
\text { C.C. } \\
\text { CORE }\end{array}$ & $\begin{array}{c}0-2.5 \\
0-5 \\
5-10 \\
10-20 \\
20-30\end{array}$ & $\begin{array}{l}\text { DEV VAM I } \\
\text { ROCKUELLL } \\
\text { DEV VAN I } \\
\text { DEV VAN I } \\
\text { DEV VAN I } \\
\text { DEV VAN I }\end{array}$ & $\begin{array}{l}1.6 E+1 \\
1.1 E+0 \\
2.0 E+1 \\
2.0 E+1 \\
2.0 E+1 \\
2.0 E+1\end{array}$ & $\begin{array}{l}1.0 \mathrm{E}+0 \\
1.2 \mathrm{E}-1\end{array}$ & $1.8 E+0$ & $8.7 E-1$ & $1.2 E+0$ & $1.6 \mathrm{E}+0$ & \\
\hline$N 35,845 / W 77,000$ & 201.2 & $\begin{array}{l}\text { INSI IU } \\
\text { C.C. } \\
\text { CORE }\end{array}$ & $\begin{array}{l}0=2.5 \\
0=5 \\
5=10 \\
10=20 \\
20=30\end{array}$ & DEV VAN I & $7.7 E+0$ & $1.0 \mathrm{E}+0$ & : & & & & $\begin{array}{l}\text { Hot analyzed } \\
\text { Not analyzed } \\
\text { Hot analyzed } \\
\text { Mot analyzed } \\
\text { Not analyzed }\end{array}$ \\
\hline
\end{tabular}


A-4 SIXTY METER SQUARE GRID SAMLLS AMO ADOITIOMAL IUSITU MEASUREMEMTS

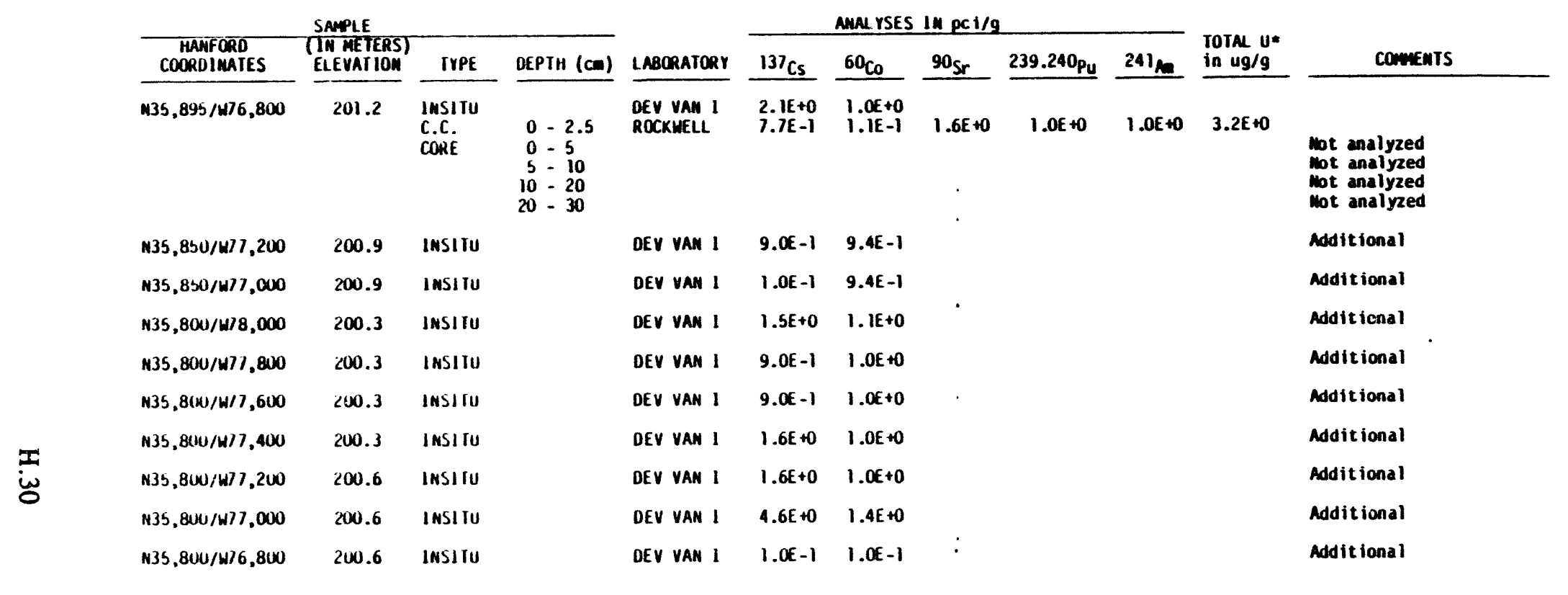

NOTE: All Uranium dnalyses were performed by EIC. 
A-5 LEACH TREMCH CORES AMD MEAR SURFACE PERIMETER SAMPLE

\begin{tabular}{|c|c|c|c|c|c|c|}
\hline SIIE & SAMPLE & LOCATION & DEPTH (cm) & $\frac{1 \mathrm{IN} p \mathrm{pc}}{137 \mathrm{Cs}}$ & $\frac{9 m}{60 \mathrm{Co}_{0}}$ & COMENTS \\
\hline$U N-216-4-15$ & 1 & $\begin{array}{l}N 36,590 / W 76,505 \\
N 36,590 / W 76,615 \\
N 36,590 / W 76,710\end{array}$ & $\begin{aligned} 0 & -10 \\
20 & -30 \\
0 & -10 \\
20 & =30 \\
0 & =10 \\
20 & -30\end{aligned}$ & $\begin{array}{l}2.6 E+3 \\
6.0 E+1 \\
1.2 E+2 \\
5.9 E+1 \\
6.3 E+2 \\
2.1 E+1\end{array}$ & $\begin{array}{l}9.2 E-1 \\
6.8 E+2 \\
7.6 E-2 \\
7.9 E-2 \\
1.3 E-1 \\
7.4 E-2 .\end{array}$ & $\begin{array}{l}\text { Hand dug crab sample } \\
\text { Hand dug crab sample } \\
\text { Hand dug crab sample } \\
\text { Hand dug crab sample } \\
30 \mathrm{~cm} \text { core; Eu-154 detected (5.7E-4 nci/g) } \\
\text { Hand dug crab sample }\end{array}$ \\
\hline$U N-216-H-16$ & $\begin{array}{l}1 \\
2 \\
3\end{array}$ & $\begin{array}{l}M 36,312 / W 76,454 \\
M 36,315 / w 76,542 \\
N 30,318 / w 76,672\end{array}$ & $\begin{aligned} 0 & -10 \\
20 & =30 \\
0 & =10 \\
20 & =30 \\
0 & =10 \\
20 & =30\end{aligned}$ & $\begin{array}{l}7.2 E+2 \\
4.0 E-1 \\
5.4 E+2 \\
5.3 E-1 \\
4.5 E+2 \\
1.4 E-1\end{array}$ & $\begin{array}{l}1.0 E-3 \\
1.0 E-3 \\
8.4 E-2 \\
9.9 E-2 \\
2.6 E-1 . \\
9.6 E-2\end{array}$ & $\begin{array}{l}30 \mathrm{~cm} \text { core } \\
30 \mathrm{~cm} \text { core; } \mathrm{Cs}-134 \text { detected }(1.3 \mathrm{E}-4 \mathrm{nci} / \mathrm{g}) \\
30 \mathrm{~cm} \text { core } \\
30 \mathrm{~cm} \text { core } \\
30 \mathrm{~cm} \text { core } \\
30 \mathrm{~cm} \text { core }\end{array}$ \\
\hline U-POMO PERIMIER & 1625 & $N 36,201 / W 77,450$ & $17.5-37.5$ & $3.6 E+1$ & $1.8 E-1$ & Hand augar \\
\hline
\end{tabular}


WHC-EP-0707, Rev. 0

\section{Appendix I}

Analytical Data from Subsurface Sediment Samples 
WHC-EP-0707, Rev. 0

A-6 WELL 299-W18-15 DATA

DEPTH

IN METERS

0

1.5

1.5

2.4

2.4

3.0

3.0

3.0

3.0

3.0

4.3

4.6

6.1

7.0

7.6

7.9

8.5

8.8

9.3

11.6

12.2

14.3

14.9

18.1

19.5

21.3

22.3

24.4

26.5

27.4

29.0

30.0

31.4

32.0

33.5

35.0
LABORATORY

ROCKWELL

ROCKWELL

LFE

ROCKWELL

LFE

ROCKWELL

LFE

LFE

EAL

EAL

ROCKWELL

LFE

ROCKWELL

LFE

ROCKWELL

LFE.

ROCKWELL

ROCKWELL

LFE

ROCKWELL

ROCKWELL

ROCKWELL

ROCKWELL

LFE

ROCKWELL

ROCKWELL

LFE

ROCKWELL

ROCKWELL

ROCKWELL

ROCKWELL

ROCKWELL

ROCKWELL

ROCKWELL

ROCKWELL

ROCKWELL

ROCKWELL

ROCKWELL

ROCKWELL

ROCKWELL

ROCKWELL

ROCKWELL
CONCENTRATION (pC $\mathrm{i} / \mathrm{g})$

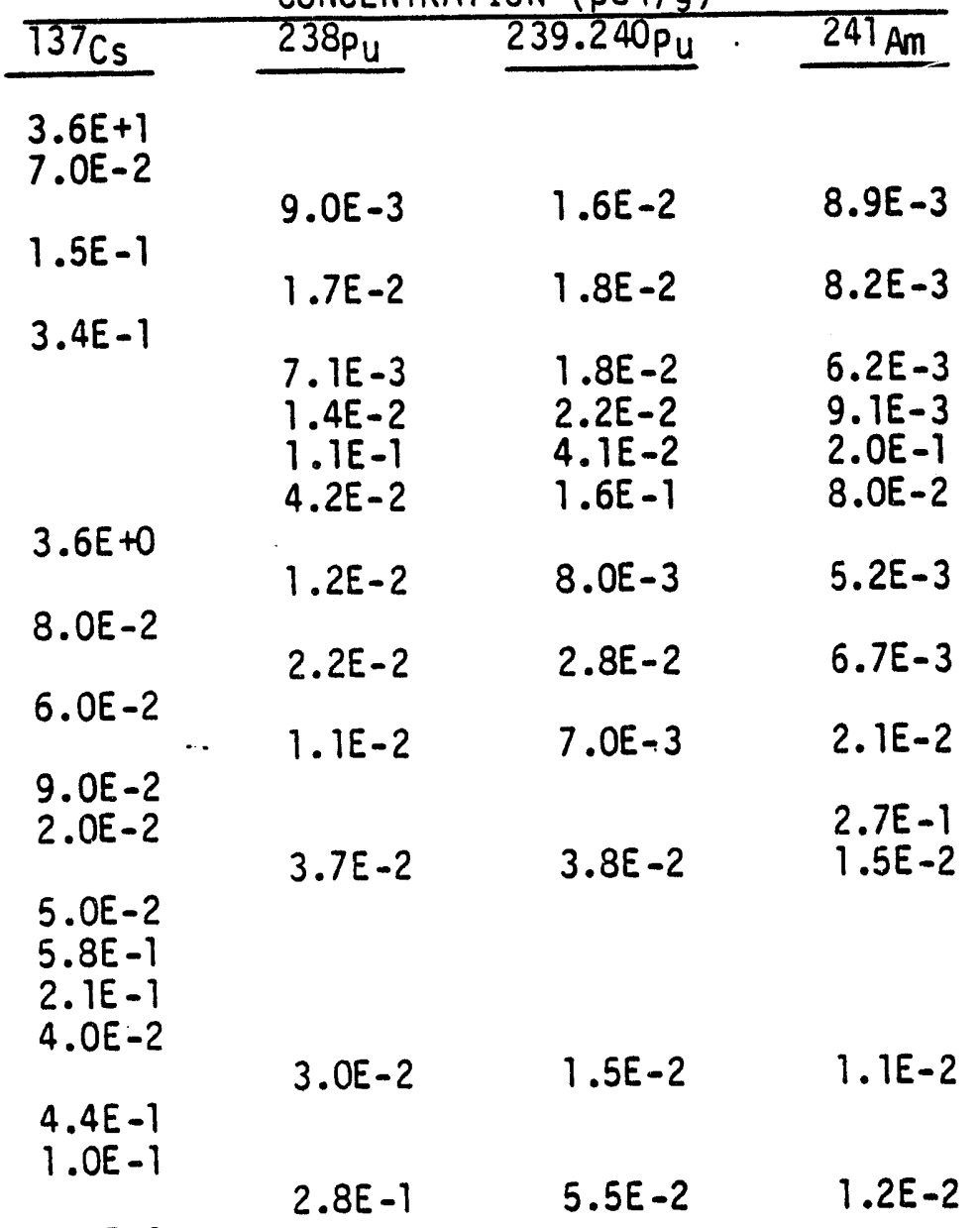

2. $0 E-1$

4. 3E - 1

1. $5 E-1$

$1.3 E-1$

2.7E-1

3. $O E-2$

1. $4 E-1$

$1.4 E-1$

$9.4 E-1$

$5.3 E-1$

1. $4 E-1$

6. OE-2

6. OE-2

5. OE -2

6. OE-2 
WHC-EP-0707, Rev. 0

A-6 WELL 299-W18-15 DATA

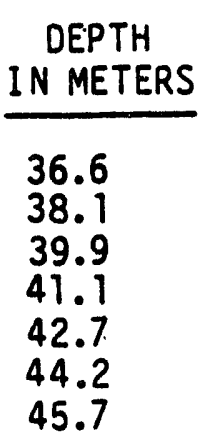

REFERENCE.

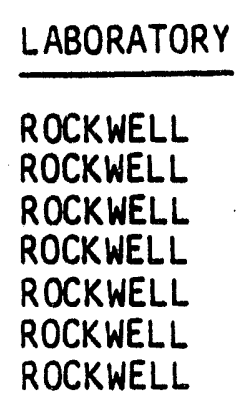

LFE EIC

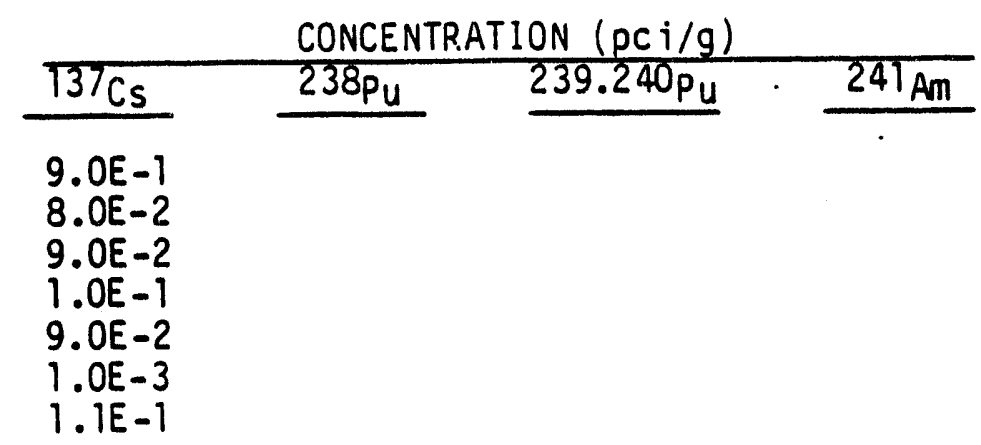

2.2E-2

$5.4 E-1$

2.6E-1

$7.4 E-2$

$3.8 E-1$

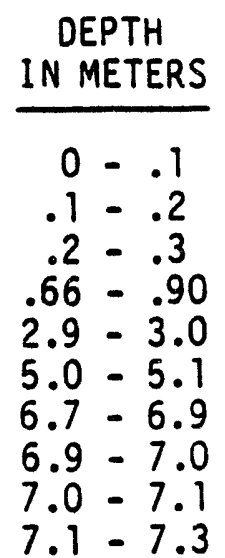

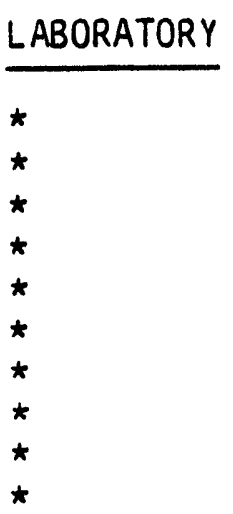

A-7 WELL 299-W23-228 DATA

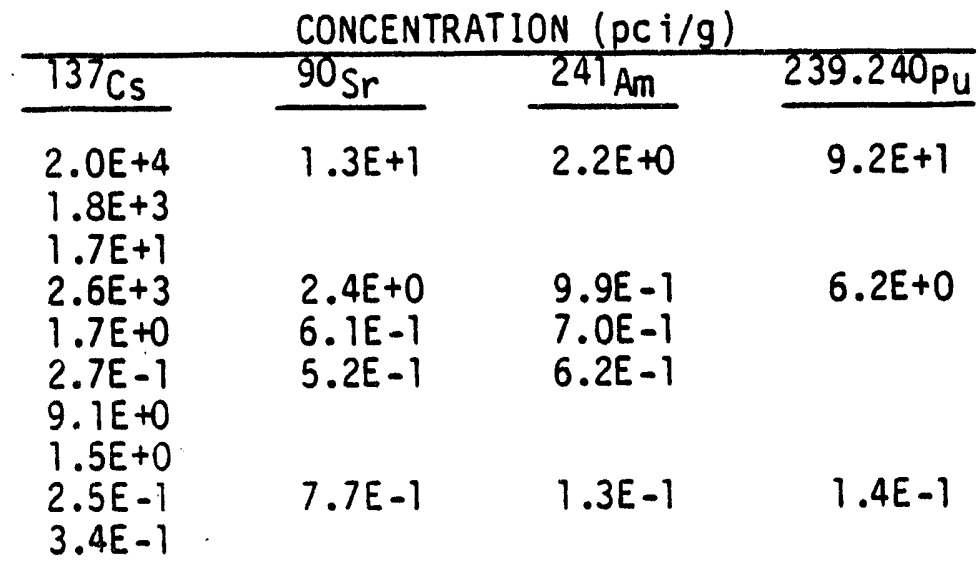

*NOTE: All analyses performed by Rockwell. 
WHC-EP-0707, Rev. 0

A-8 WELL 299-W18-177 DATA

\begin{tabular}{|c|c|}
\hline $\begin{array}{l}\text { DEPTH } \\
\text { I METERS }\end{array}$ & LABORATORY \\
\hline $\begin{array}{r}1.5 \\
2.4 \\
2.7 \\
4.6 \\
5.8 \\
6.1 \\
7.6 \\
9.1 \\
10.7 \\
12.2 \\
14.0\end{array}$ & $\begin{array}{l}\text { EIC } \\
\text { LFE } \\
\text { EIC } \\
\text { EIC } \\
\text { LFE } \\
\text { EIC } \\
\text { EIC } \\
\text { EIC } \\
\text { EIC } \\
\text { EIC } \\
\text { LFE }\end{array}$ \\
\hline
\end{tabular}

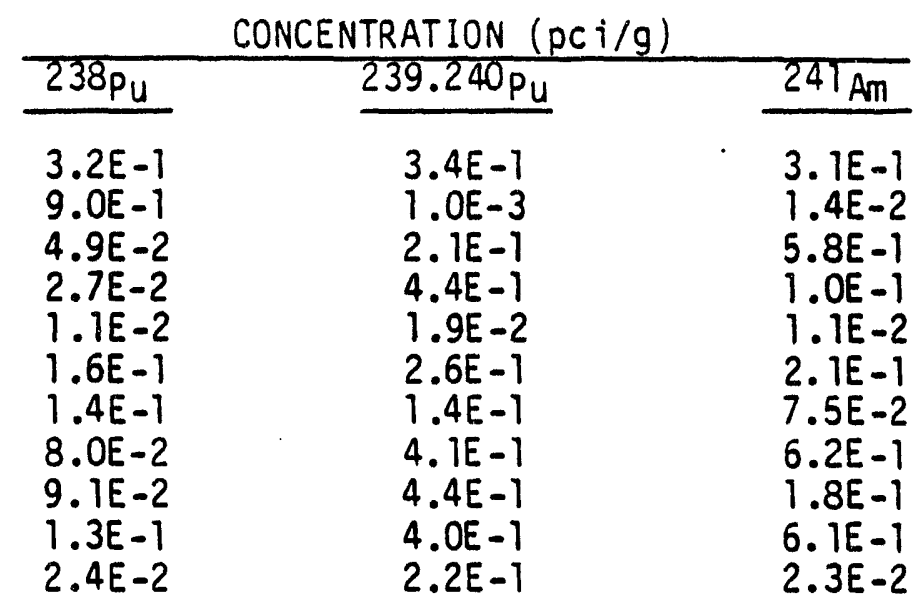

A-9 WELL 299-W18-178 DATA

DEPTH

IN METERS

LABORATORY

1.5

3.0

4.6

5.5

6.4

7.6

9.1

10.7

12.2

EIC

EIC

EIC

LFE

EIC

EIC

EIC

EIC

LFE

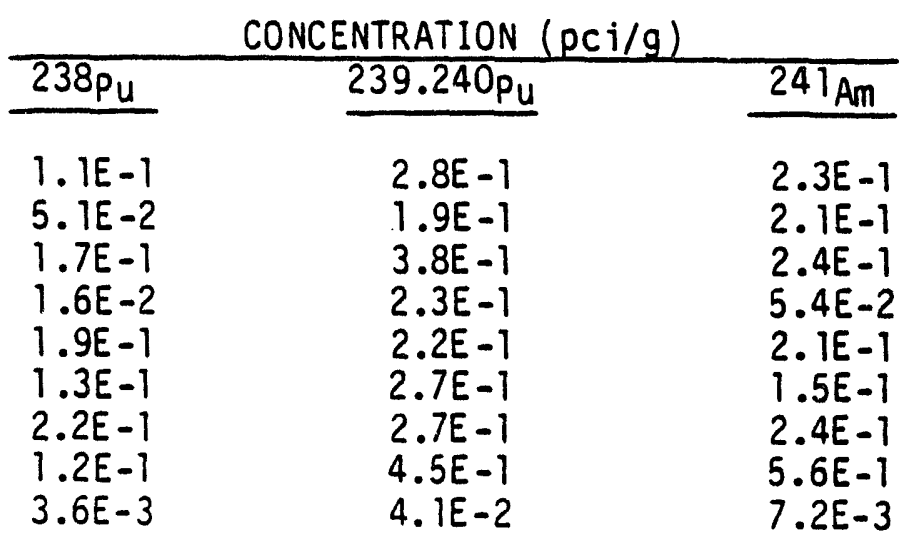


WHC-EP-0707, Rev. 0

\section{A-10 WELL 299-W18-186 DATA}

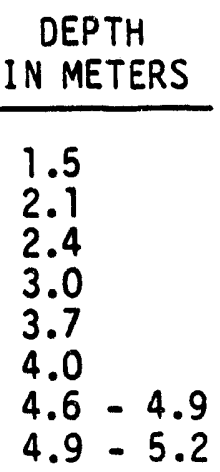

LABORATORY
DEV VAN I
DEV VAN I
DEV VAN I
DEV VAN I
DEV VAN I
DEV VAN I
DEV VAN I
EAL

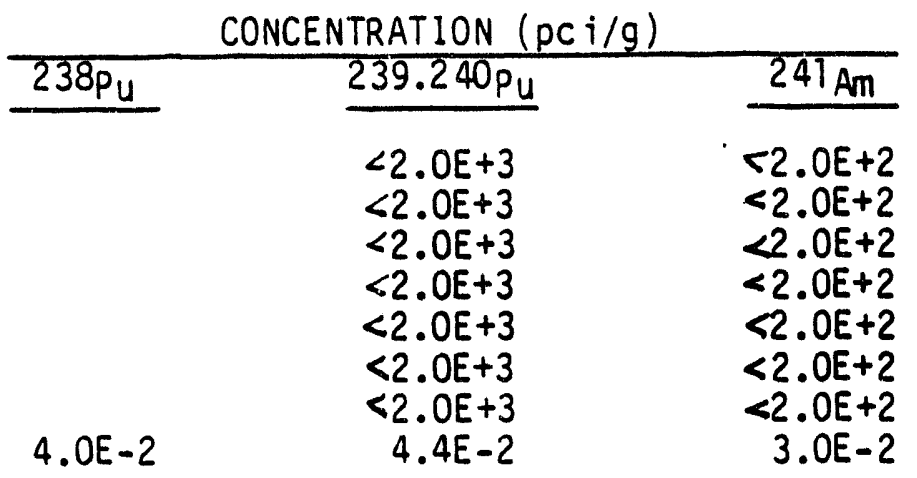

\section{A-11 WELL 299-W18-187 DATA}

\section{DEPTH \\ IN METERS}

1.8

2.1

2.4

2.7

3.0

3.2

3.4

3.7

4.0

4.3

4.6

4.9

5.0

5.2

\section{LABORATORY}

DEV VAN I

DEV VAN I

DEV VAN I

DEV VAN I

DEV VAN I

DEV VAN I

DEV VAN I

DEV VAN I

DEV VAN I

DEV VAN I

DEV VAN I

DEV VAN I

DEV VAN I

EAL

DEV VAN I

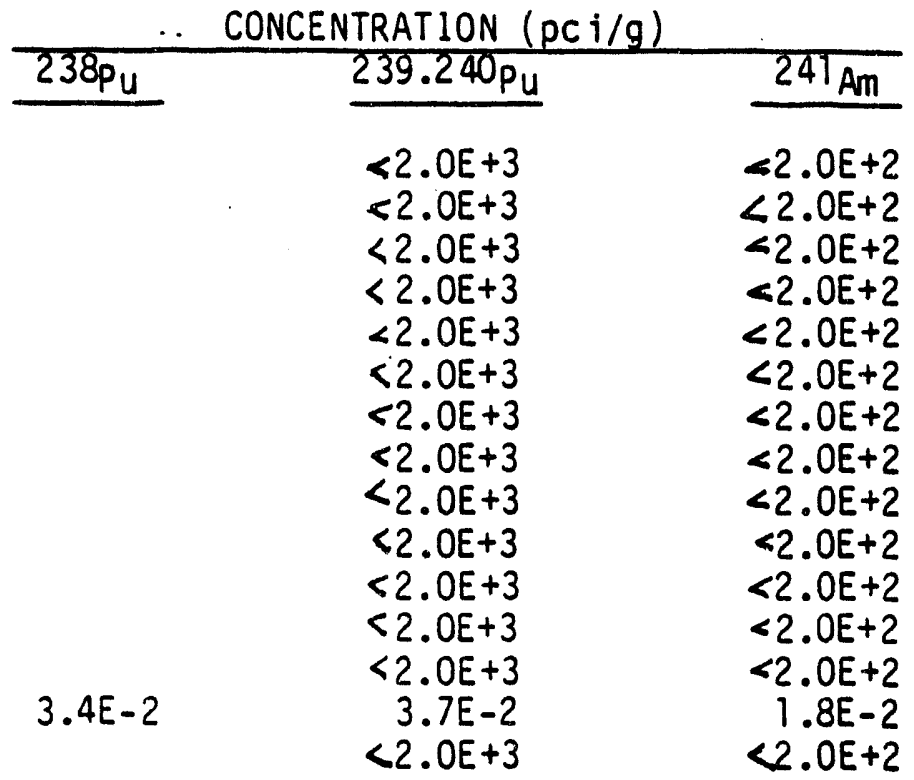


WHC-EP-0707, Rev. 0

\section{A-12 WELL 299-W18-188 DATA}

\begin{tabular}{|c|c|}
\hline $\begin{array}{c}\text { DEPTH } \\
\text { IN METERS }\end{array}$ & LABORATORY \\
\hline $\begin{array}{l}.6 \\
.9 \\
1.2 \\
1.5 \\
1.5+ \\
1.8 \\
2.1\end{array}$ & $\begin{array}{l}\text { DEV VAN I } \\
\text { DEV VAN I } \\
\text { DEV VAN I } \\
\text { DEV VAN I } \\
\text { OEV VAN I } \\
\text { DEV VAN I } \\
\text { DEV VAN I } \\
\text { ROCKWELL } \\
\text { ROCKWELL }\end{array}$ \\
\hline 2.4 & $\begin{array}{l}\text { DEV VAN I } \\
\text { ROCKWELL } \\
\text { ROCKWELL }\end{array}$ \\
\hline 2.7 & $\begin{array}{l}\text { DEV VAN } 1 \\
\text { ROCKWELL }\end{array}$ \\
\hline $\begin{array}{l}3.0 \\
3.4 \\
3.7 \\
4.0\end{array}$ & $\begin{array}{l}\text { DEV VAN I } \\
\text { DEV VAN I } \\
\text { DEV VAN I } \\
\text { DEV VAN I } \\
\text { EAL }\end{array}$ \\
\hline 4.3 & DEV VAN I \\
\hline
\end{tabular}

\begin{tabular}{rrr}
\multicolumn{3}{c}{ CONCENTRATION (pCi/g) } \\
\hline $238 P u$ & $239.240 P u$ & $\frac{241 A m}{2.0 E+2}$ \\
\cline { 2 - 3 } & $<2.0 E+3$ & $<2.0 E+2$ \\
& $<2.0 E+3$ & $<2.0 E+2$ \\
& $<2.0 E+3$ & $<2.0 E+2$ \\
& $<2.0 E+3$ & $<2.0 E+2$ \\
& $<2.0 E+3$ & $<2.0 E+2$ \\
& $<2.0 E+3$ & $<2.0 E+2$ \\
$8.0 E-1$ & $<2.0 E+3$ & $<2.0 E+2$ \\
$7.0 E-1$ & $2.9 E+0$ & $5.0 E-1$ \\
& $2.1 E+0$ & $4.0 E-1$ \\
$6.2 E+3$ & $1.7 E+5$ & $3.5 E+4$ \\
$3.5 E+3$ & $2.7 E+5$ & $3.3 E+4$ \\
& $1.8 E+5$ & $3.6 E+4$ \\
$3.4 E+0$ & $<2.0 E+3$ & $<2.0 E+2$ \\
& $1.7 E+2$ & $1.2 E+2$ \\
$\cdots$ & $<2.0 E+3$ & $<2.0 E+2$ \\
& $<2.0 E+3$ & $<2.0 E+2$ \\
$3.1 E-2$ & $<2.0 E+3$ & $<2.0 E+2$ \\
& $<2.0 E+3$ & $<2.0 E+2$ \\
& $3.1 E-1$ & $2.3 E-2$ \\
& $<2.0 E+3$ & $<2.0 E+2$
\end{tabular}


WHC-EP-0707, Rev. 0

\section{A-13 WELL 299-W18-189 DATA}

DEPTH

IN METERS

\section{.6}

$1.9-1.2$

1.5

1.8

2.1

2.4

2.7

3.0

3.7

4.9
LABORATORY

DEV VAN I

DEV VAN I

ROCKWELL

ROCKWELL

DEV VAN I

ROCKWELL

DEV VAN I

ROCKWELL

DEV VAN I

ROCKWELL

DEV VAN I

DEV VAN I

DEV VAN I

DEV VAN I

DEV VAN 1

DEV VAN 1 .
CONCENTRATION (pci/g)

\begin{tabular}{ccc}
\hline $238 P u$ & $\frac{239.240 P u}{241 A m}$ \\
\cline { 2 - 3 } & $<2.0 E+3$ & $<2.0 E+2$ \\
$8.2 E+0$ & $2.0 E+3$ & $<2.0 E+2 *$ \\
$1.2 E+2$ & $3.3 E+2$ & $5.5 E+1$ \\
& $3.2 E+3$ & $5.2 E+2$ \\
$6.4 E+0$ & $<2.0 E+3$ & $<2.0 E+2 *$ \\
& $3.5 E+2$ & $1.2 E+2$ \\
$1.0 E+0$ & $<2.0 E+3$ & $<2.0 E+2$ \\
& $3.4 E+1$ & $4.7 E+0$ \\
$1.0 E+0$ & $<2.0 E+3$ & $<2.0 E+2$ \\
& $2.2 E+0$ & $3.0 E-1$ \\
& $<2.0 E+3$ & $\angle 2.0 E+2$ \\
& $<2.0 E+3$ & $<2.0 E+2$ \\
& $<2.0 E+3$ & $<2.0 E+2$ \\
& $<2.0 E+3$ & $<2.0 E+2$ \\
$1.2 E-2$. & $<2.0 E+3$ & $<2.0 E+2$ \\
& $4.0 E-2$ & $3.3 E-2$
\end{tabular}

* Trace of 241 Am indicated. 
WHC-EP-0707, Rev. 0

\section{A-14 WELL 299-W18-192 DATA}

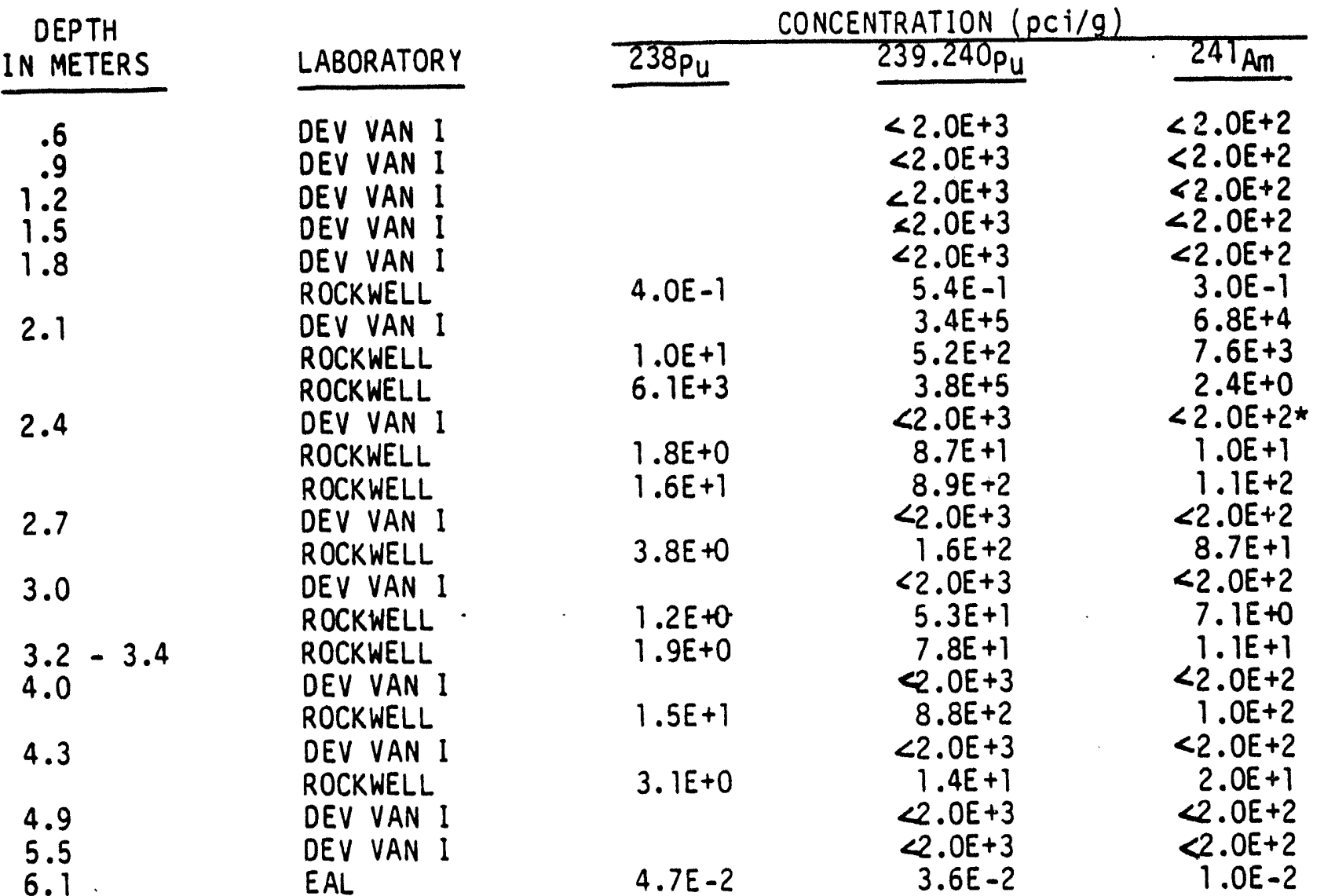

* Trace of $241_{A m}$ indicated. 
WHC-EP-0707, Rev. 0

A-15 WELL 299-W18-193 DATA

\begin{tabular}{|c|c|}
\hline $\begin{array}{c}\text { DEPTH } \\
\text { IN METERS }\end{array}$ & LABORATORY \\
\hline $\begin{array}{l}.6 \\
.9 \\
1.2 \\
1.2 \\
1.5 \\
1.8 \\
2.1 \\
2.4 \\
2.7 \\
3.0 \\
3.7 \\
4.3 \\
4.9 \\
5.5 \\
6.1\end{array}$ & $\begin{array}{l}\text { DEV VAN I } \\
\text { DEV VAN I } \\
\text { DEV VAN I } \\
\text { ROCKWELL } \\
\text { OEV VAN I } \\
\text { DEV VAN I } \\
\text { OEV VAN I } \\
\text { DEV VAN I } \\
\text { DEV VAN I } \\
\text { DEV VAN I } \\
\text { DEV VAN I } \\
\text { DEV VAN I } \\
\text { DEV VAN I } \\
\text { DEV VAN I } \\
\text { EAL }\end{array}$ \\
\hline
\end{tabular}

\begin{tabular}{ccc}
\multicolumn{3}{c}{ CONCENTRATION $(p C i / g)$} \\
\hline $238 p u$ \\
\cline { 2 - 3 } & $239.240 p u$ & $24 p_{A m}$ \\
\cline { 2 - 3 } & $<2.0 E+3$ & $<2.0 E+2$ \\
& $<2.0 E+3$ & $<2.0 E+2$ \\
$4.7 E+1$ & $<2.0 E+3$ & $<2.0 E+2 *$ \\
& $5.5 E+2$ & $9.6 E+1$ \\
& $<2.0 E+3$ & $<2.0 E+2$ \\
& $<2.0 E+3$ & $<2.0 E+2$ \\
& $<2.0 E+3$ & $<2.0 E+2$ \\
& $<2.0 E+3$ & $<2.0 E+2$ \\
& $<2.0 E+3$ & $<2.0 E+2$ \\
& $<2.0 E+3$ & $<2.0 E+2$ \\
& $<2.0 E+3$ & $<2.0 E+2$ \\
& $<2.0 E+3$ & $<2.0 E+2$ \\
& $<2.0 E+3$ & $<2.0 E+2$ \\
& $<2.0 E+3$ & $<2.0 E+2$ \\
& $3.6 E-2$ & $2.6 E-2$
\end{tabular}

* Trace of $241_{A m}$ indicated.

A-16 WELL 299-W18-194 DATA

\begin{tabular}{|c|c|}
\hline $\begin{array}{l}\text { DEPTH } \\
\text { N METERS }\end{array}$ & LABORATORY \\
\hline .6 & $\begin{array}{l}\text { DEV VAN I } \\
\text { ROCKWELL }\end{array}$ \\
\hline .9 & $\begin{array}{l}\text { DEV VAN I } \\
\text { ROCKWELL }\end{array}$ \\
\hline 1.2 & $\begin{array}{l}\text { DEV VAN I' } \\
\text { ROCKWELL }\end{array}$ \\
\hline $\begin{array}{l}1.5 \\
1.8 \\
2.1 \\
2.4 \\
2.7 \\
3.0 \\
4.9\end{array}$ & $\begin{array}{l}\text { DEV VAN I } \\
\text { DEV VAN I } \\
\text { DEV VAN I } \\
\text { DEV VAN I } \\
\text { DEV VAN I } \\
\text { DEV VAN I } \\
\text { EAL }\end{array}$ \\
\hline
\end{tabular}

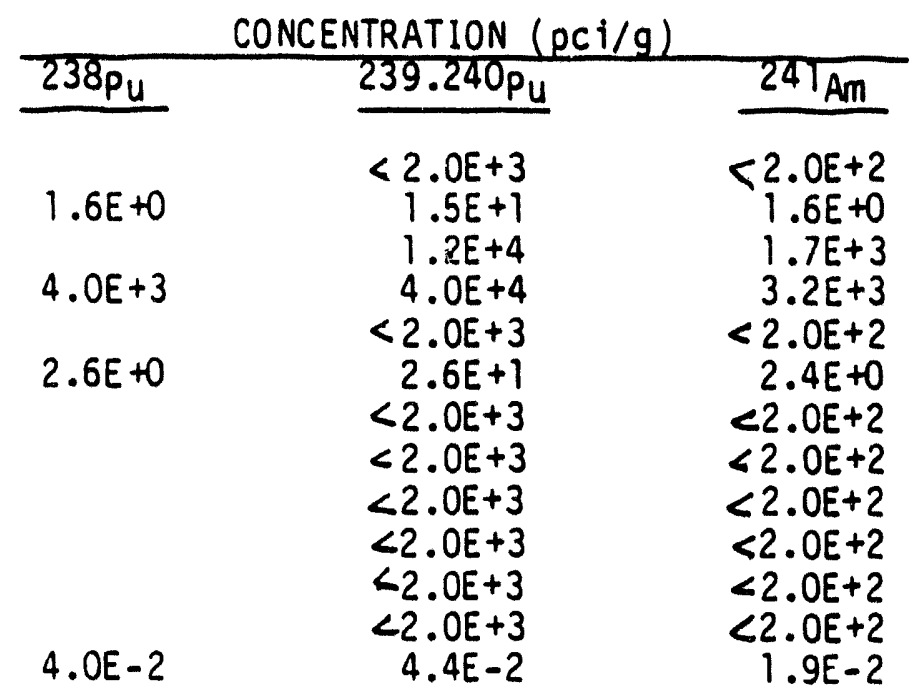


WHC-EP-0707, Rev. 0

\section{A-17 WELL 299-W18-195 DATA}

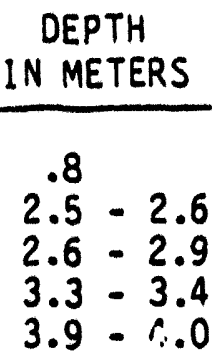

\begin{tabular}{l} 
LABORATORY \\
\hline ROCKWELLL \\
ROCKWELL \\
ROCKWELL \\
ROCKWELL \\
ROCKWELL
\end{tabular}

\begin{tabular}{lcc}
\multicolumn{3}{c}{ CONCENTRATION $(p c i / g)$} \\
\hline $238 p u$ & $239.240 p u$ & $\frac{241 A m}{1.9 E+2}$ \\
$2.5 E+1$ & $1.5 E+3$ & $4.1 E+2$ \\
$3.6 E+2$ & $2.2 E+4$ & $4.8 E+1$ \\
$7.2 E+0$ & $4.2 E+2$ & $2.2 E+1$ \\
$8.0 E-1$ & $3.0 E+1$ & $1.5 E+0$ \\
$2.5 E+0$ & $7.9 E+1$ &
\end{tabular}

A-18 WELL 299-W18-196 DATA

\begin{tabular}{|c|c|}
\hline $\begin{array}{c}\text { DEPTH } \\
\text { IN METERS }\end{array}$ & LABORATORY \\
\hline $\begin{array}{l}.6 \\
.9\end{array}$ & $\begin{array}{l}\text { ROCKWELL } \\
\text { DEV VAN I } \\
\text { ROCKWELL }\end{array}$ \\
\hline 1.2 & $\begin{array}{l}\text { DEV VAN I } \\
\text { ROCKWELL }\end{array}$ \\
\hline $\begin{array}{l}1.5 \\
3.7\end{array}$ & $\begin{array}{l}\text { DEV VAN I } \\
\text { EAL }\end{array}$ \\
\hline
\end{tabular}

\begin{tabular}{lrr}
\multicolumn{3}{c}{ CONCENTRATION $(p c i / g)$} \\
\hline $238 P_{U}$ & $\frac{239.240 P_{U}}{23}$ & $\frac{24 A m}{2.9 E+1}$ \\
\cline { 2 - 3 } $3.6 E+0$ & $<2.9 E+2$ & $<2.0 E+2$ \\
$8.4 E+0$. & $4.1 E+2$ & $3.4 E+1$ \\
& $<2.0 E+3$ & $<2.0 E+2$ \\
$2.2 E+0$ & $2.9 E+1$ & $6.0 E-1$ \\
$2.7 E-2$ & $<2.0 E+3$ & $<2.0 E+2$ \\
& $3.6 E-2$ & $2.1 E-2$
\end{tabular}

A-19 WELL 299-W18-197 OATA

DEPTH

IN METERS

.6

1.9

2.1

2.4

3.0

3.0

3.0

3.4

3.7

4.3
LABORATORY

DEV VAN I

DEV VAN I

DEV VAN I

OEV VAN I

DEV VAN I

DEV VAN I

ROCKWELL

ROCKWELL

ROCKWELL

ROCKWELL

$E A L$

\begin{tabular}{|c|c|c|}
\hline & NTRATION (pci/g) & \\
\hline $238 p_{u}$ & $239.240 p_{u}$ & $241_{A m}$ \\
\hline
\end{tabular}

1. $8 \mathrm{E}+1$

$2.4 E+1$

7. $7 E+0$

$6.0 E-1$

$5.4 E-2$

$\begin{aligned}< & 2.0 E+3 \\ < & 2.0 E+3 \\ < & 2.0 E+3 \\ < & 2.0 E+3 \\ < & 2.0 E+3 \\ < & 2.0 E+3 \\ & 5.6 E+2 \\ & 7.0 E+2 \\ & 1.7 E+2 \\ & 2.5 E+0 \\ & 4.5 E-1\end{aligned}$

$<2.0 E+2$

$<2.0 E+2$

$<2.0 \mathrm{E}+2$

$<2.0 \mathrm{E}+2$

$<2.0 \mathrm{E}+2$

$<2.0 E+2$

1. $4 E+2$

$1.7 E+2$

4. $0 E+1$

4.OE-1

$6.2 E-2$ 
WHC-EP-0707, Rev. 0

A-20 WELL 299-W18-198 DATA

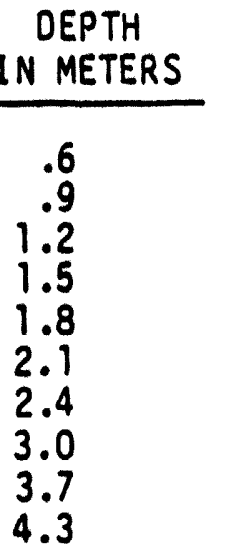

\begin{tabular}{l} 
LABORATORY \\
\hline OEV VAN I \\
OEV VAN I \\
DEV VAN I \\
DEV VAN I \\
DEV VAN I \\
DEV VAN I \\
DEV VAN I \\
DEV VAN I \\
DEV VAN I \\
DEV VAN I
\end{tabular}

CONCENTRATION (pCi/g)

\begin{tabular}{|c|c|c|}
\hline $238 p_{u}$ & $239.240 p_{u}$ & $24 T_{A m}$ \\
\hline & $\begin{array}{l}<2.0 E+3 \\
<2.0 E+3 \\
<2.0 E+3 \\
<2.0 E+3 \\
<2.0 E+3 \\
<2.0 E+3 \\
<2.0 E+3 \\
<2.0 E+3 \\
<2.0 E+3 \\
<2.0 E+3\end{array}$ & $\begin{array}{l}<2.0 E+2 \\
<2.0 E+2 \\
<2.0 E+2 \\
<2.0 E+2 \\
<2.0 E+2 \\
<2.0 E+2 \\
<2.0 E+2 \\
<2.0 E+2 \\
<2.0 E+2 \\
<2.0 E+2\end{array}$ \\
\hline
\end{tabular}

A-21 WELL 299-W18-199 DATA

\begin{tabular}{|c|c|}
\hline $\begin{array}{l}\text { DEPTH } \\
\text { N METERS }\end{array}$ & LABORATORY. \\
\hline $\begin{array}{l}.6 \\
.9 \\
1.2 \\
1.5 \\
1.8 \\
2.1 \\
2.4 \\
3.0 \\
3.7\end{array}$ & $\begin{array}{l}\text { DEV VAN I } \\
\text { DEV VAN I } \\
\text { DEV VAN I } \\
\text { DEV VAN I } \\
\text { DEV VAN I } \\
\text { DEV VAN I } \\
\text { DEV VAN I } \\
\text { DEV VAN I } \\
\text { DEV VAN I } \\
\text { EAL }\end{array}$ \\
\hline
\end{tabular}

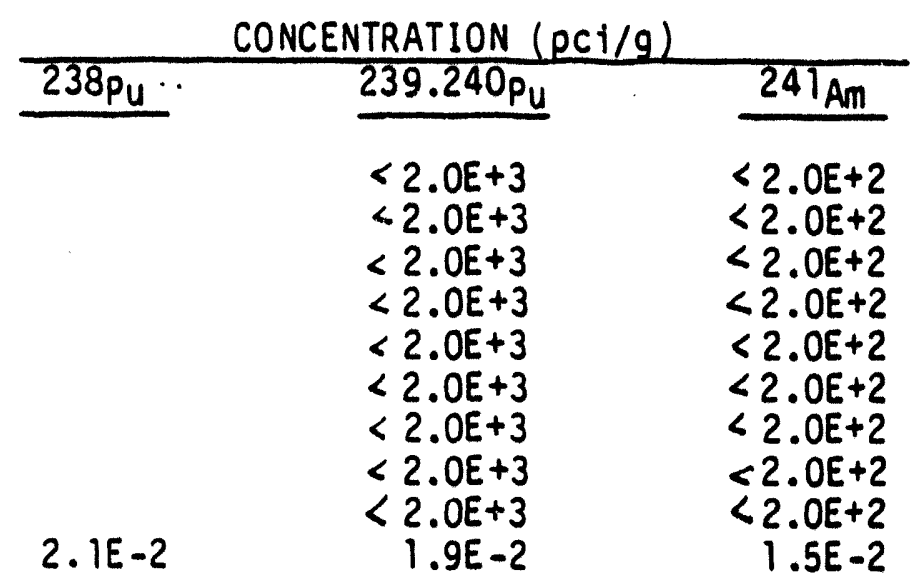

A-22 WELL 299-W18-200 DATA

DEPTH

IN METERS

.6

1.9

1.8

2.4

3.0

3.7

\begin{tabular}{l} 
LABORATORY \\
\hline DEV VAN I \\
DEV VAN I \\
DEV VAN I \\
DEV VAN I \\
DEV VAN I \\
DEV VAN I \\
DEV VAN I \\
EAL
\end{tabular}

CONCENTRATION (pCi/g)

\begin{tabular}{ccc}
\hline $238 P_{u}$ & $\frac{241 \mathrm{Am}}{239.240 P_{u}}$ & \\
\cline { 2 - 3 } & $<2.0 E+3$ & $<2.0 E+2$ \\
& $<2.0 E+3$ & $<2.0 E+2$ \\
& $<2.0 E+3$ & $<2.0 E+2$ \\
& $<2.0 E+3$ & $<2.0 E+2$ \\
& $<2.0 E+3$ & $<2.0 E+2$ \\
& $<2.0 E+3$ & $<2.0 E+2$ \\
& $<2.0 E+3$ & $<2.0 E+2$ \\
$4.6 E-2$ & $2.6 E-2$ & $<2.0 E-2$
\end{tabular}


WHC-EP-0707, Rev, 0

\section{A-23 WELL 299-W15-203 DATA}

DEPTH

IN METERS

\begin{tabular}{|c|c|}
\hline IN METERS & LABURAIUR \\
\hline $\begin{array}{r}.6 \\
.9 \\
1.2 \\
1.8\end{array}$ & $\begin{array}{l}\text { DEV VAN I } \\
\text { DEV VAN I } \\
\text { DEV VAN I } \\
\text { DEV VAN I } \\
\text { ROCKWELL }\end{array}$ \\
\hline $\begin{array}{l}2.1 \\
2.4 \\
3.0 \\
3.7 \\
4.3 \\
4.9\end{array}$ & $\begin{array}{l}\text { DEV VAN I } \\
\text { DEV VAN I } \\
\text { DEV VAN I } \\
\text { DEV VAN I } \\
\text { DEV VAN I } \\
\text { DEV VAN I }\end{array}$ \\
\hline $\begin{array}{l}5.5 \\
6.1\end{array}$ & $\begin{array}{l}\text { EAL } \\
\text { DEV VAN I } \\
\text { DEV VAN I }\end{array}$ \\
\hline
\end{tabular}

CONCENTRATION (pCi/g)

\begin{tabular}{|c|c|c|}
\hline $238 p_{u}$ & $239.240 \mathrm{pu}_{\mathrm{u}}$ & $241 \mathrm{Am}$ \\
\hline $3.6 E+1$ & $\begin{aligned}< & 2.0 E+3 \\
< & 2.0 E+3 \\
< & 2.0 E+3 \\
< & 2.0 E+3 \\
& 2.2 E+1 \\
< & 2.0 E+3 \\
< & 2.0 E+3 \\
< & 2.0 E+3 \\
< & 2.0 E+3 \\
< & 2.0 E+3 \\
< & 2.0 E+3 \\
& 2.0 E-2 \\
< & 2.0 E+3 \\
< & 2.0 E+3\end{aligned}$ & 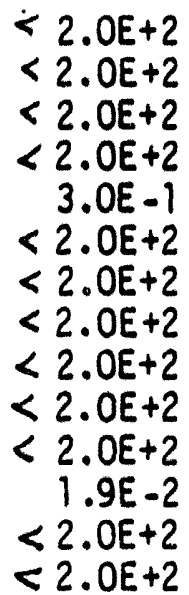 \\
\hline
\end{tabular}

A-24 WELL 299-W15-204 DATA

DEPTH

IN METERS

.6

.9

$1.5-1.8$

1.8

2.1

2.4

2.7

3.0

3.7

4.3

4.9

5.5

6.1
LABORATORY

DEV VAN I

DEV VAN I

DEV VAN I

DEV VAN I

ROCKWELL

DEV VAN I

DEV VAN I

DEV VAN I

DEV VAN I

EAL

DEV VAN I

DEV VAN I

DEV VAN I

DEV VAN I

DEV VAN I

DEV VAN I
CONCENTRATION (pCi/g)

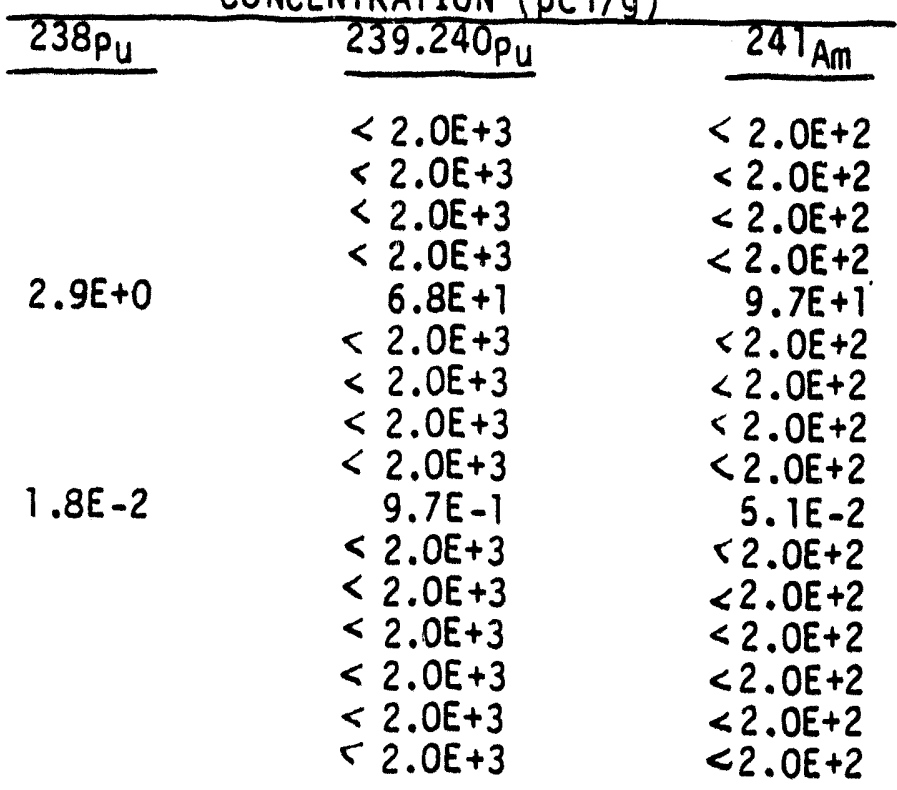


WHC-EP-0707, Rev. 0

A-25 WELL 299-W15-205 DATA

\begin{tabular}{l} 
DEPTH \\
IN METERS \\
\hline .6 \\
.9 \\
1.5 \\
1.8 \\
2.1 \\
2.4 \\
2.7 \\
3.0
\end{tabular}

LABORATORY

DEV VAN I

DEV VAN I

DEV VAN I

DEV VAN 1

DEV VAN I

OEV VAN I

DEV VAN I

DEV VAN I
CONCENTRATION (pCi/g)

\begin{tabular}{|c|c|c|}
\hline $238 p_{u}$ & $239.240 p_{u}$ & $241_{A m}$ \\
\hline & $\begin{array}{l}<2.0 E+3 \\
<2.0 E+3 \\
<2.0 E+3 \\
<2.0 E+3 \\
<2.0 E+3 \\
<2.0 E+3 \\
<2.0 E+3 \\
<2.0 E+3\end{array}$ & $\begin{array}{l}<2.0 E+2 \\
<2.0 E+2 \\
<2.0 E+2 \\
<2.0 E+2 \\
<2.0 E+2 \\
<2.0 E+2 \\
<2.0 E+2 \\
<2.0 E+2\end{array}$ \\
\hline
\end{tabular}

\section{A-26 WELL 299-W15-206 DATA}

DEPTH

IN METERS

.6
.9
1.2

1.5

1.8

2.1

2.4

2.7

3.0

\section{LABORATORY}

DEV VAN I

DEV VAN I

DEV VAN I

DEV VAN I

DEV VAN I

DEV VAN I

DEV VAN I

OEV VAN I

DEV VAN I

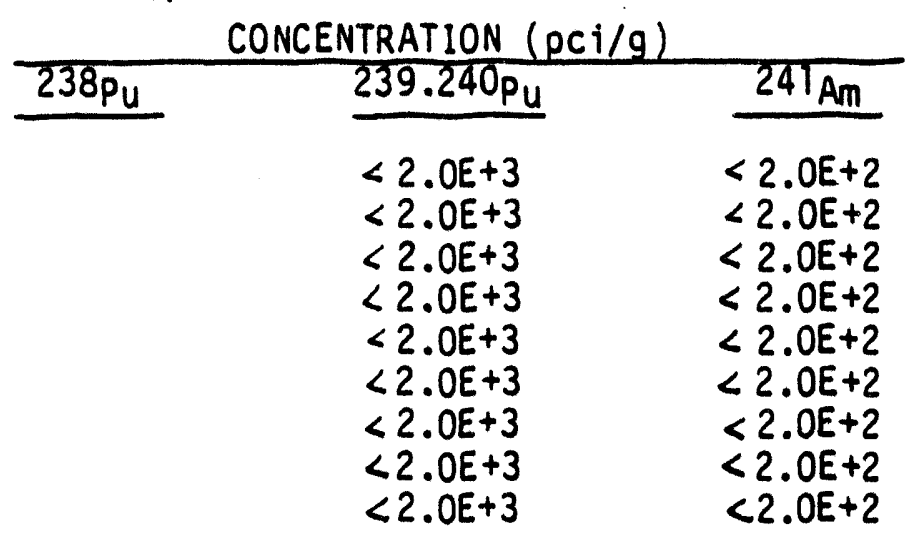


WHC-EP-0707, Rev. 0

\section{A-27 216-Z-19 DITCH TRANSECT SAMPLE ANALYSES}

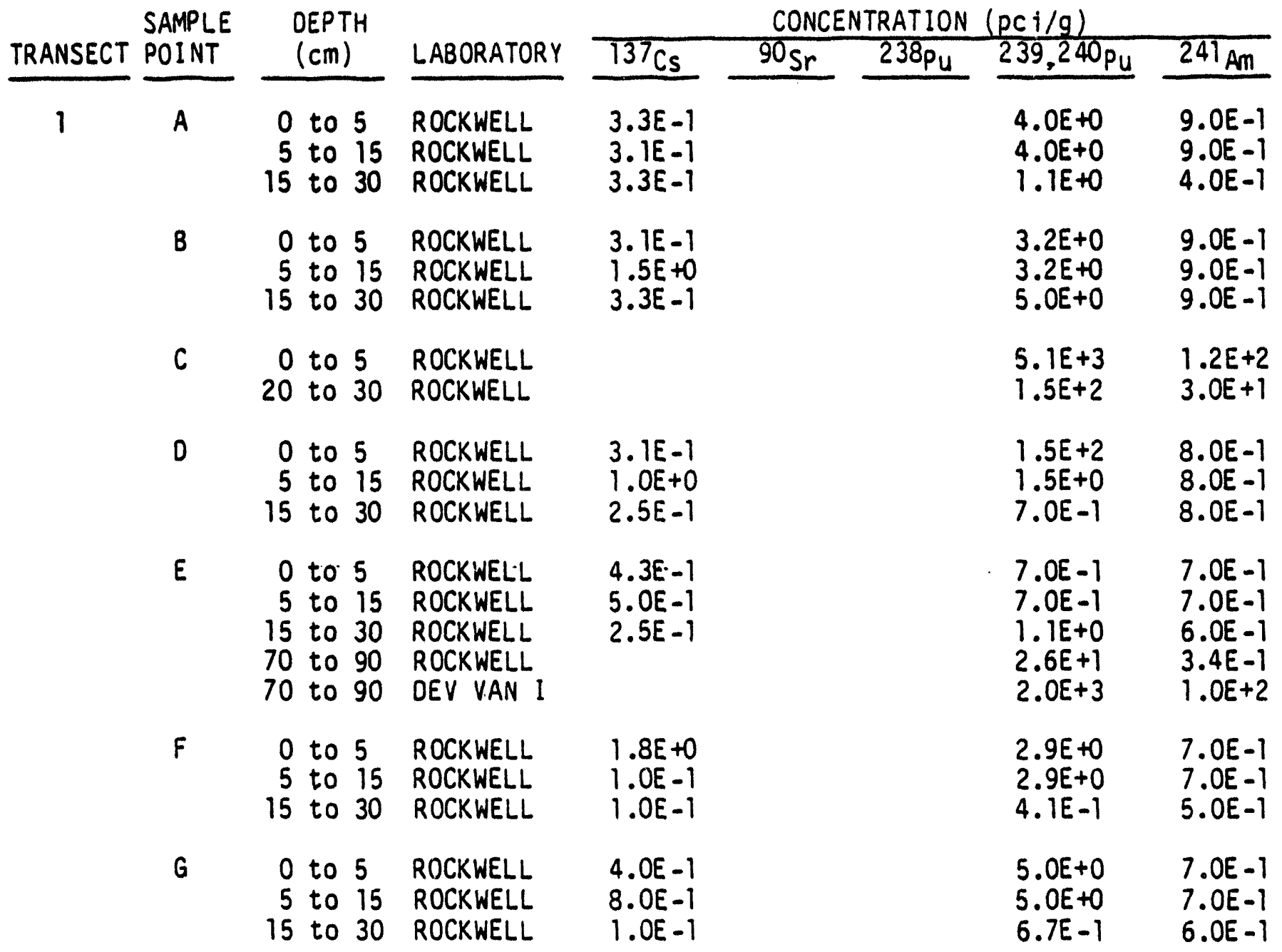




\section{A-27 216-2-19 O1TCH TRANSECT SAMPLE ANALYSES}

SAMPLE DEPTH TRANSECT POINT

$B$

15

C

0

E

$\begin{array}{rlll}0 \text { to } 5 & \text { ROCKWELL } & 9.7 E-1 \\ 5 & \text { to } 15 & \text { ROCKWELL } & 3.5 E-1 \\ 15 \text { to } 30 & \text { ROCKWELL } & 5.8 E-1 \\ 40 \text { to } 60 & \text { ROCKWELL } & \\ 40 \text { to } 60 & \text { DEV VAN I } & \end{array}$

F

$\begin{array}{rlll}0 & \text { to } 5 & \text { ROCKWELL } & 4.0 E-1 \\ 5 & \text { to } 15 & \text { ROCKWELL } & 1.0 E-1 \\ 15 & \text { to } 30 & \text { ROCKWELL } & 3.7 E-1\end{array}$

G

$3.6 E-1$

15 to 30 ROCKWELL

40 to 60 DEV VAN I

5 to 15 ROCKWELL

15 to 30 ROCKWELL

40 to 60 DEV VAN 1

$3.6 \mathrm{E}-1$
CONCENTRATION (pC $\mathrm{i} / \mathrm{g})$

\begin{tabular}{|c|c|c|c|c|}
\hline $137 \mathrm{Cs}$ & $90 S r$ & $238 p u$ & $239,240 \mathrm{Pu}$ & $241 \mathrm{Am}$ \\
\hline $\begin{array}{l}6.2 E-1 \\
3.4 E-1 \\
3.5 E-1\end{array}$ & $\begin{array}{l}9.6 E-1 \\
9.6 E-1\end{array}$ & & $\begin{array}{l}5.1 E+2 \\
5.1 E+2 \\
1.6 E+3 \\
1.2 E+2 \\
2.0 E+3\end{array}$ & $\begin{array}{l}6.4 E+1 \\
6.4 E+1 \\
1.6 E+0 \\
3.1 E+0 \\
1.0 E+2\end{array}$ \\
\hline
\end{tabular}

$5.9 E-1 \quad 1.0 E+0$

$4.8 E-1 \quad 1.0 E+0$

$2.9 E-1 \quad 9.0 E-1$

2.8E-1 9.0E-1

$2.0 \mathrm{E}+3$

$1.8 E+0$

$1.8 E+0$

9. $0 E-1$

$3.7 E+0$

$9.0 \mathrm{E}-1$

$2.0 E+3$

$6.0 \mathrm{E}-1$

$1 . \mathrm{OE}+2$

1. $3 \mathrm{E}+3$

2. $3 E+2$

$3.2 E+2 \quad 1.4 E+2$

3. $O E+0 \quad 7.0 E-1$

$3.0 E+0$

8. $0 E-1$

2. $0 E+3$

7. $0 E-1$

5.OE - 1

$1.0 E+2$

5. $0 E-1$

$5.0 E-1$

4. $O E+O$

$5.9 E+0$

$8.0 E-1$

$2.0 E+3$

$8.0 \mathrm{E}$

$4.0 E$

$7.9 \mathrm{E}-1$

$1.0 E+2$

$1.2 E+1$

$1.2 E+1$

7. OE - 1

$2.2 E+0$

$7.0 E-1$

$5.0 E-1$

$1.5 E+2$

1. $5 E+2$

2. $1 E+1$

3. $2 E+1$
2. $1 E+1$

5. $0 E-1$ 
WHC-EP-0707, Rev. 0

A-27 216-2-19 DITCH TRANSECT SAMPLE ANALYSES

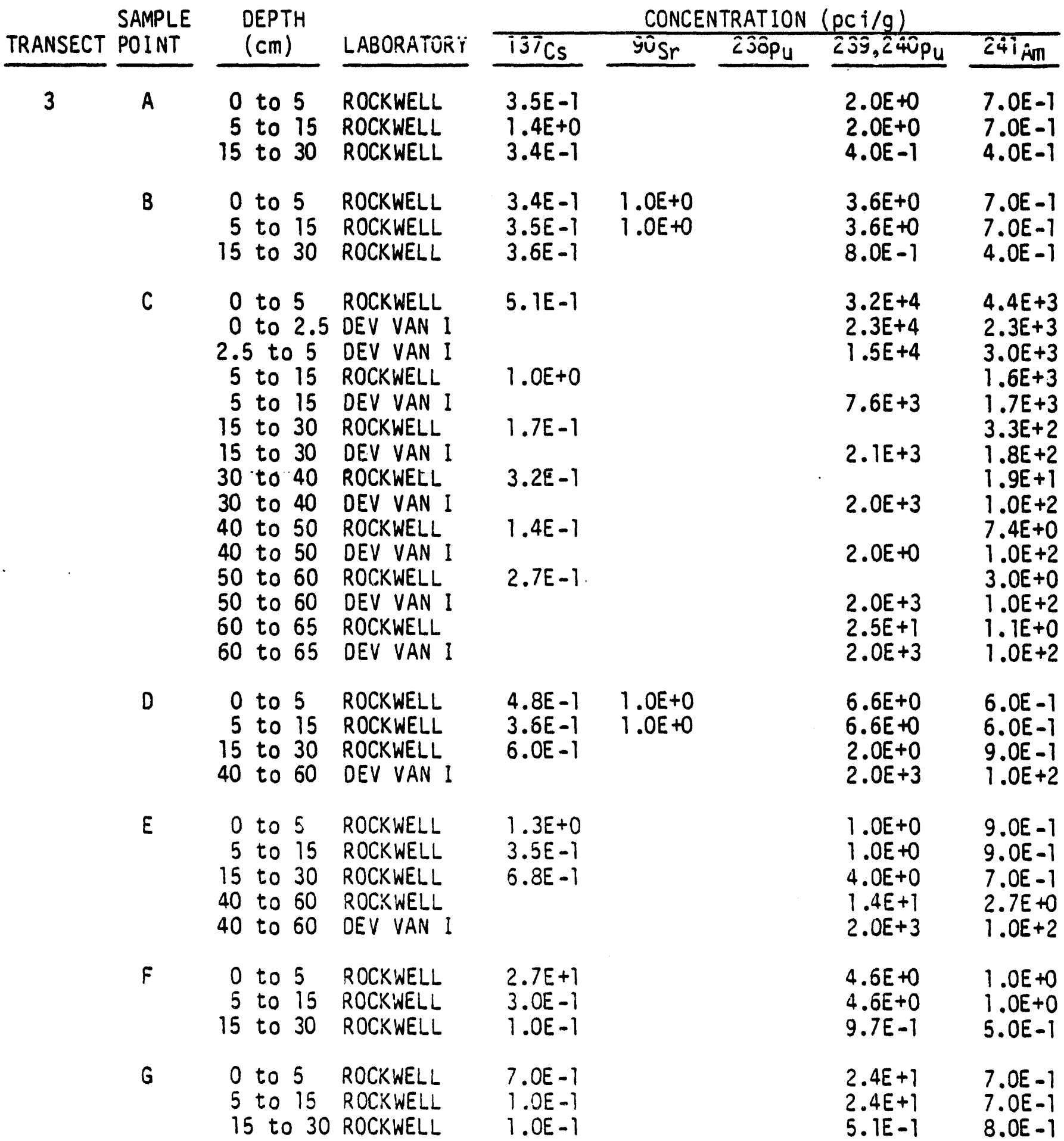




\section{A-27 216-Z-19 DITCH TRANSECT SAMPLE ANALYSES}

\begin{tabular}{|c|c|c|c|c|c|c|c|c|c|}
\hline & SAMPLE & & EPTH & & & CONCE & TRATION & $p c i / g)$ & \\
\hline TRANSECT & POINT & & $\mathrm{cm})$ & LABORATORY & $137 \mathrm{Cs}_{5}$ & $90 S r$ & $238 p_{u}$ & $239,240 \mathrm{Pu}$ & $241 \mathrm{Am}$ \\
\hline 4 & A & $\begin{array}{r}0 \\
5 \\
15\end{array}$ & $\begin{array}{l}\text { to } 5 \\
\text { to } 15 \\
\text { to } 30\end{array}$ & $\begin{array}{l}\text { ROCKWELL } \\
\text { ROCKWELL } \\
\text { ROCKWELL }\end{array}$ & $\begin{array}{l}3 \cdot 2 E-1 \\
3 \cdot 5 E-1 \\
3 \cdot 5 E-1\end{array}$ & $\begin{array}{l}7.3 E-1 \\
7.3 E-1\end{array}$ & & $\begin{array}{l}7.0 E+0 \\
7.0 E+0 \\
6.0 E-1\end{array}$ & $\begin{array}{l}9.0 E-1 \\
9.0 E-1 \\
1.0 E+0\end{array}$ \\
\hline & B & $\begin{array}{r}0 \\
5 \\
15\end{array}$ & $\begin{array}{ll}\text { to } & 5 \\
\text { to } & 15 \\
\text { to } & 30\end{array}$ & $\begin{array}{l}\text { ROCKWELL } \\
\text { ROCKWELL } \\
\text { ROCKWELL }\end{array}$ & $\begin{array}{l}3.5 E-1 \\
3.3 E-1 \\
3.6 E-1\end{array}$ & $\begin{array}{l}3.4 E+0 \\
3.4 E+0\end{array}$ & & $\begin{array}{l}\text { 4. OE +0 } \\
4.0 E+0 \\
1.0 E+0\end{array}$ & $\begin{array}{l}1.0 E-1 \\
1.0 E-1 \\
1.0 E-1\end{array}$ \\
\hline & C & $\begin{array}{l}0 \\
0 \\
5 \\
15 \\
30 \\
40 \\
50 \\
60 \\
70 \\
80 \\
80\end{array}$ & $\begin{array}{l}\text { to } 5 \\
\text { to } 5 \\
\text { to } 15 \\
\text { to } 30 \\
\text { to } 40 \\
\text { to } 50 \\
\text { to } 60 \\
\text { to } 70 \\
\text { to } 80 \\
\text { to } 88 \\
\text { to } 88\end{array}$ & $\begin{array}{l}\text { ROCKWELL } \\
\text { DEV VAN I } \\
\text { DEV VAN I } \\
\text { DEV VAN I } \\
\text { DEV VAN I } \\
\text { DEV VAN I } \\
\text { DEV VAN I } \\
\text { DEV VAN I } \\
\text { DEV VAN I } \\
\text { DEV VAN I } \\
\text { ROCKWELL }\end{array}$ & $\cdots$ & & & $\begin{array}{l}9.8 E+4 \\
1.3 E+4 \\
9.0 E+4 \\
2.0 E+3 \\
2.0 E+3 \\
2.0 E+3 \\
2.0 E+3 \\
2.0 E+3 \\
2.0 E+3 \\
2.0 E+3 \\
7.4 E+0\end{array}$ & $\begin{array}{l}5.0 E+2 \\
2.2 E+3 \\
4.4 E+3 \\
1.8 E+2 \\
1.0 E+2 \\
1.0 E+2 \\
1.0 E+2 \\
1.0 E+2 \\
1.0 E+2 \\
1.0 E+2 \\
4.3 E-1\end{array}$ \\
\hline & $D$ & $\begin{array}{r}0 \\
5 \\
15 \\
40\end{array}$ & $\begin{array}{ll}\text { to } & 5 \\
\text { to } 15 \\
\text { to } 30 \\
\text { to } 60\end{array}$ & $\begin{array}{l}\text { ROCKWELL } \\
\text { ROCKWELL } \\
\text { ROCKWELL } \\
\text { ROCKWELL }\end{array}$ & $\begin{array}{l}3.5 E-1 \\
3.5 E-1 \\
3.5 E-1\end{array}$ & $\begin{array}{l}1.0 E+0 \\
1.0 E+0\end{array}$ & & $\begin{array}{l}2.0 E+0 \\
2.0 E+0 \\
1.7 E+0 \\
2.0 E+3\end{array}$ & $\begin{array}{l}1.1 E \\
1.1 E \\
8.0 E-1 \\
1.0 E+2\end{array}$ \\
\hline & $E$ & $\begin{array}{r}0 \\
5 \\
15 \\
40 \\
40\end{array}$ & $\begin{array}{ll}\text { to } & 5 \\
\text { to } 15 \\
\text { to } 30 \\
\text { to } 60 \\
\text { to } 60\end{array}$ & $\begin{array}{l}\text { ROCKWELL } \\
\text { ROCKWELL } \\
\text { ROCKWELL } \\
\text { ROCKWELL } \\
\text { OEV VAN I }\end{array}$ & $\begin{array}{l}2.0 E+0 \\
5.4 E-1 \\
3.4 E-1\end{array}$ & & & $\begin{array}{l}7.0 E-1 \\
7.0 E-1 \\
3.1 E+0 \\
1.1 E+4 \\
6.2 E+3\end{array}$ & $\begin{array}{l}7.0 E-1 \\
7.0 E-1 \\
6.0 E-1 \\
3.5 E+3 \\
3.5 E+3\end{array}$ \\
\hline & $F$ & $\begin{array}{r}0 \\
5 \\
15\end{array}$ & $\begin{array}{l}\text { to } 5 \\
\text { to } 15 \\
\text { to } 30\end{array}$ & $\begin{array}{l}\text { ROCKWELL } \\
\text { ROCKWELL } \\
\text { ROCKWELL }\end{array}$ & $\begin{array}{l}4.0 E-1 \\
2.0 E-1 \\
1.0 E-1\end{array}$ & & & $\begin{array}{l}1.7 E+0 \\
1.7 E+0 \\
4.4 E-1\end{array}$ & $\begin{array}{l}5.0 E-1 \\
5.0 E-1 \\
5.0 E-1\end{array}$ \\
\hline & G & $\begin{array}{r}0 \\
5 \\
15\end{array}$ & $\begin{array}{ll}\text { to } & 5 \\
\text { to } & 15 \\
\text { to } & 30\end{array}$ & $\begin{array}{l}\text { ROCKWELL } \\
\text { ROCKWELL } \\
\text { ROCKWELL }\end{array}$ & $\begin{array}{l}4.0 E-1 \\
1.0 E-1 \\
1.0 E-1\end{array}$ & & & $\begin{array}{l}6.0 E-1 \\
6.0 E-1 \\
3.3 E-1\end{array}$ & $\begin{array}{l}9.0 E-1 \\
9.0 E-1 \\
5.0 E-1\end{array}$ \\
\hline
\end{tabular}




\section{A-27 216-Z-19 DITCH TRANSECT SAMPLE ANALYSES}

\begin{tabular}{|c|c|c|c|c|c|c|c|c|c|}
\hline \multirow{2}{*}{ TRANSECT } & \multirow{2}{*}{$\begin{array}{l}\text { SAMPLE } \\
\text { POINT } \\
\end{array}$} & \multirow{2}{*}{\multicolumn{2}{|c|}{$\begin{array}{l}\text { DEPTH } \\
(\mathrm{cm})\end{array}$}} & \multirow[b]{2}{*}{ LABORATORY } & \multicolumn{5}{|c|}{ CONCENTRATION $(p c i / g)$} \\
\hline & & & & & $137 \mathrm{Cs}$ & $90 \mathrm{Sr}$ & $238 p u$ & $239,240 p_{u}$ & $241_{A m}$ \\
\hline 5 & A & $\begin{array}{r}0 \\
5 \\
15\end{array}$ & $\begin{array}{l}\text { to } 5 \\
\text { to } 15 \\
\text { to } 30\end{array}$ & $\begin{array}{l}\text { ROCKWELL } \\
\text { ROCKWELL } \\
\text { ROCKWELL }\end{array}$ & $\begin{array}{l}4.6 E-1 \\
5.4 E-1 \\
3.4 E-1\end{array}$ & & & $\begin{array}{l}2.6 E+0 \\
2.6 E+0 \\
8.0 E-1\end{array}$ & $\begin{array}{l}7.0 E-1 \\
7.0 E-1 \\
6.0 E-1\end{array}$ \\
\hline & B & $\begin{array}{r}0 \\
5 \\
15\end{array}$ & $\begin{array}{l}\text { to } 5 \\
\text { to } 15 \\
\text { to } 30\end{array}$ & $\begin{array}{l}\text { ROCKWELL } \\
\text { ROCKWELL } \\
\text { ROCKWELL }\end{array}$ & $\begin{array}{l}3.6 E-1 \\
3.4 E-1 \\
3.4 E-1\end{array}$ & & & $\begin{array}{l}4.4 E-1 \\
4.4 E-1 \\
9.1 E-1\end{array}$ & $\begin{array}{l}1.0 E+0 \\
1.0 E+0 \\
6.0 E-1\end{array}$ \\
\hline & C & $\begin{array}{l}0 \\
0 \\
5 \\
15 \\
30 \\
40 \\
50 \\
60 \\
70 \\
80 \\
80\end{array}$ & $\begin{array}{ll}\text { to } 5 \\
\text { to } 5 \\
\text { to } 15 \\
\text { to } 30 \\
\text { to } 40 \\
\text { to } 50 \\
\text { to } 60 \\
\text { to } 70 \\
\text { to } 80 \\
\text { to } 90 \\
\text { to } 90\end{array}$ & $\begin{array}{l}\text { ROCKWELL } \\
\text { DEV VAN I } \\
\text { OEV VAN I } \\
\text { DEV VAN I } \\
\text { DEV VAN I } \\
\text { DEV VAN I } \\
\text { DEV VAN I } \\
\text { DEV VAN I } \\
\text { OEV VAN I } \\
\text { DEV VAN I } \\
\text { ROCKWELL }\end{array}$ & $\cdots$ & & & $\begin{array}{l}1.1 E+4 \\
6.2 E+3 \\
2.0 E+3 \\
2.0 E+3 \\
2.0 E+3 \\
2.0 E+3 \\
2.0 E+3 \\
2.0 E+3 \\
2.0 E+3 \\
2.0 E+3 \\
2.8 E+1\end{array}$ & $\begin{array}{l}3.5 E+3 \\
2.2 E+3 \\
5.1 E+2 \\
1.0 E+2 \\
1.0 E+2 \\
1.0 E+2 \\
1.0 E+2 \\
1 . O E+2 \\
1.0 E+2 \\
1.0 E+2 \\
2.6 E+0\end{array}$ \\
\hline & $D$ & $\begin{array}{r}0 \\
5 \\
15 \\
40\end{array}$ & $\begin{array}{ll}\text { to } & 5 \\
\text { to } 15 \\
\text { to } 30 \\
\text { to } 60\end{array}$ & $\begin{array}{l}\text { ROCKWELL } \\
\text { ROCKWELL } \\
\text { ROCKWELL } \\
\text { DEV VAN I }\end{array}$ & $\begin{array}{l}4.5 E-1 \\
4.8 E-1 \\
3.6 E-1\end{array}$ & & & $\begin{array}{l}8.7 E-1 \\
8.7 E-1 \\
1.1 E+0 \\
2.0 E+3\end{array}$ & $\begin{array}{l}8.0 E-1 \\
8.0 E-1 \\
9.0 E-1 \\
1.0 E+2\end{array}$ \\
\hline & E & $\begin{array}{r}0 \\
5 \\
15 \\
40 \\
40\end{array}$ & $\begin{array}{ll}\text { to } 5 \\
\text { to } 15 \\
\text { to } 30 \\
\text { to } 60 \\
\text { to } 60\end{array}$ & $\begin{array}{l}\text { ROCKWELL } \\
\text { ROCKWELLL } \\
\text { ROCKWELL } \\
\text { ROCKWELL } \\
\text { DEV VAN I }\end{array}$ & $\begin{array}{l}4.7 E-1 \\
3.4 E-1 \\
3.5 E-1\end{array}$ & & & $\begin{array}{l}6.5 E-1 \\
6.5 E-1 \\
3.0 E+0 \\
2.2 E+1 \\
2.0 E+3\end{array}$ & $\begin{array}{l}9.0 E-1 \\
9.0 E-1 \\
7.0 E-1 \\
2.8 E+1 \\
1.0 E+2\end{array}$ \\
\hline & $F$ & $\begin{array}{r}0 \\
5 \\
15\end{array}$ & $\begin{array}{ll}\text { to } & 5 \\
\text { to } 15 \\
\text { to } 30\end{array}$ & $\begin{array}{l}\text { ROCKWELL } \\
\text { ROCKWELL } \\
\text { ROCKWELL }\end{array}$ & $\begin{array}{l}4.0 E-1 \\
2.0 E-1 \\
2.0 E-1\end{array}$ & & & $\begin{array}{l}9.8 E+0 \\
9.8 E+0 \\
1.1 E+1\end{array}$ & $\begin{array}{l}1 . O E+0 \\
1 . O E+0 \\
6.0 E-1\end{array}$ \\
\hline & G & $\begin{array}{r}0 \\
5 \\
15\end{array}$ & $\begin{array}{ll}\text { to } & 5 \\
\text { to } & 15 \\
\text { to } & 30\end{array}$ & $\begin{array}{l}\text { ROCKWELL } \\
\text { ROCKWELL } \\
\text { ROCKWELL }\end{array}$ & $\begin{array}{l}2.0 E+0 \\
1.1 E+0 \\
1.0 E-1\end{array}$ & & & $\begin{array}{l}1.8 E+0 \\
1.8 E+0 \\
7.0 E-1\end{array}$ & $\begin{array}{l}6.0 E-1 \\
6.0 E-1 \\
7.0 E-1\end{array}$ \\
\hline
\end{tabular}


A-27 216-Z-19 DITCH TRANSECT SAMPLE ANALYSES

\begin{tabular}{|c|c|c|c|c|c|c|c|c|c|}
\hline \multirow{2}{*}{ TRANSECT } & \multirow{2}{*}{$\begin{array}{l}\text { SAMPLE } \\
\text { POINT }\end{array}$} & \multirow{2}{*}{\multicolumn{2}{|c|}{$\begin{array}{l}\text { DEPTH } \\
(\mathrm{cm})\end{array}$}} & \multirow[b]{2}{*}{ LABORATORY } & \multicolumn{5}{|c|}{ CONCENTRATION $(p C \mathrm{i} / \mathrm{g})$} \\
\hline & & & & & T37 Cs & $90 s r$ & $238 p u$ & $239,240 \mathrm{pu}$ & $241 \mathrm{Am}$ \\
\hline 6 & A & $\begin{array}{r}0 \\
5 \\
15\end{array}$ & $\begin{array}{l}\text { to } 5 \\
\text { to } 15 \\
\text { to } 30\end{array}$ & $\begin{array}{l}\text { ROCKWELL } \\
\text { ROCKWELL } \\
\text { ROCKWELL }\end{array}$ & $\begin{array}{l}3.4 E-1 \\
3.3 E-1 \\
2.6 E-1\end{array}$ & & & $\begin{array}{l}7.0 E-1 \\
7.0 E-1 \\
2.7 E+0\end{array}$ & $\begin{array}{l}7.0 E-1 \\
7.0 E-1 \\
7 . O E-1\end{array}$ \\
\hline & B & $\begin{array}{r}0 \\
5 \\
15\end{array}$ & $\begin{array}{l}\text { to } 5 \\
\text { to } 15 \\
\text { to } 30\end{array}$ & $\begin{array}{l}\text { ROCKWELL } \\
\text { ROCKWELL } \\
\text { ROCKWELL }\end{array}$ & $\begin{array}{l}3.3 E-1 \\
3.5 E-1 \\
3.5 E-1\end{array}$ & & & $\begin{array}{l}5.6 E-1 \\
5.6 E-1 \\
6.0 E-1\end{array}$ & $\begin{array}{l}8.0 E-1 \\
8.0 E-1 \\
9.0 E-1\end{array}$ \\
\hline & C & $\begin{array}{r}0 \\
20 \\
50 \\
80\end{array}$ & $\begin{array}{l}\text { to } 5 \\
\text { to } 30 \\
\text { to } 60 \\
\text { to } 90\end{array}$ & $\begin{array}{l}\text { ROCKWELL } \\
\text { ROCKWELL } \\
\text { ROCKWELL } \\
\text { ROCKWELL }\end{array}$ & & & $\begin{array}{l}1.1 E+2 \\
1.3 E+3\end{array}$ & $\begin{array}{l}2.5 E+4 \\
3.0 E+2 \\
1.5 E+5 \\
1.8 E+0\end{array}$ & $\begin{array}{l}1.2 E+3 \\
2.8 E+3 \\
1.6 E+1 \\
1.1 E+0\end{array}$ \\
\hline & D & $\begin{array}{r}0 \\
5 \\
15 \\
40\end{array}$ & $\begin{array}{l}\text { to } 5 \\
\text { to } 15 \\
\text { to } 30 \\
\text { to } 60\end{array}$ & $\begin{array}{l}\text { ROCKWELL } \\
\text { ROCKWELL } \\
\text { ROCKWELL } \\
\text { DEV VAN I }\end{array}$ & $\begin{array}{l}3.5 E-1 \\
3.4 E-1 \\
6.6 E-1\end{array}$ & & & $\begin{array}{l}2.7 E+0 \\
2.7 E+0 \\
1.2 E+0 \\
2.0 E+3\end{array}$ & $\begin{array}{l}8.0 E-1 \\
8.0 E-1 \\
6.0 E-1 \\
1.0 E+2\end{array}$ \\
\hline & $E$ & $\begin{array}{l}0 \\
5 \\
15 \\
40 \\
40\end{array}$ & $\begin{array}{ll}\text { to } & 5 \\
\text { to } & 15 \\
\text { to } & 30 \\
\text { to } & 60 \\
\text { to } & 60\end{array}$ & $\begin{array}{l}\text { ROCKWELL } \\
\text { ROCKWELL } \\
\text { ROCKWELL } \\
\text { ROCKWELL } \\
\text { DEV VAN I }\end{array}$ & $\begin{array}{l}3.2 E-1 \\
3.6 E-1 \\
3.5 E-1\end{array}$ & & & $\begin{array}{l}1.4 E+0 \\
1.4 E+0 \\
1.4 E+0 \\
4.6 E+0 \\
2.0 E+3\end{array}$ & $\begin{array}{l}1.0 E+0 \\
1.0 E+O \\
9.0 E \\
3.8 E \\
1.0 E+2\end{array}$ \\
\hline & $F$ & $\begin{array}{r}0 \\
5 \\
15\end{array}$ & $\begin{array}{l}\text { to } 5 \\
\text { to } 15 \\
\text { to } 30\end{array}$ & $\begin{array}{l}\text { ROCKWELL } \\
\text { ROCKWELL } \\
\text { ROCKWELL }\end{array}$ & $\begin{array}{l}2.2 E+0 \\
4.0 E-1 \\
1.0 E-1\end{array}$ & & & $\begin{array}{l}1.4 E+1 \\
1.4 E+1 \\
6.0 E-1\end{array}$ & $\begin{array}{l}2.8 E+0 \\
2.8 E+0 \\
6.0 E-1\end{array}$ \\
\hline & $G$ & $\begin{array}{r}0 \\
5 \\
15\end{array}$ & $\begin{array}{l}\text { to } 5 \\
\text { to } 15 \\
\text { to } 30\end{array}$ & $\begin{array}{l}\text { ROCKWELL } \\
\text { ROCKWELL } \\
\text { ROCKWELL }\end{array}$ & $\begin{array}{l}1.5 E+0 \\
2.0 E-1 \\
1.0 E-1\end{array}$ & & & $\begin{array}{l}4.0 E+0 \\
4.0 E+0 \\
2.0 E+0\end{array}$ & $\begin{array}{l}1.3 E+0 \\
1.3 E+0 \\
7.0 E-1\end{array}$ \\
\hline
\end{tabular}




\section{A-27 216-Z-19 OITCH TRANSECT SAMPLE ANALYSES}

\begin{tabular}{|c|c|c|c|c|c|c|c|c|c|}
\hline \multirow{2}{*}{ TRANSECT } & \multirow{2}{*}{$\begin{array}{l}\text { SAMPLE } \\
\text { POINT }\end{array}$} & \multirow{2}{*}{\multicolumn{2}{|c|}{$\begin{array}{l}\text { DEPTH } \\
(\mathrm{cm}) \\
\end{array}$}} & \multirow[b]{2}{*}{ LABORATORY } & \multicolumn{5}{|c|}{ CONCENTRATION (pci/g) } \\
\hline & & & & & $137 \mathrm{Cs}$ & $90 \mathrm{Sr}$ & $238 \mathrm{pu}$ & $239,240 p_{u}$ & $241_{\mathrm{Am}}$ \\
\hline 7 & A & $\begin{array}{r}0 \\
5 \\
15\end{array}$ & $\begin{array}{ll}\text { to } & 5 \\
\text { to } 15 \\
\text { to } 30\end{array}$ & $\begin{array}{l}\text { ROCKWELL } \\
\text { ROCKWELL } \\
\text { ROCKWELL }\end{array}$ & $\begin{array}{l}3.4 E-1 \\
5.9 E-1 \\
3.6 E-1\end{array}$ & & & $\begin{array}{l}8.5 E+0 \\
8.5 E+0 \\
5.0 E+1\end{array}$ & $\begin{array}{l}1.0 E+0 \\
1.0 E+0 \\
5.4 E+0\end{array}$ \\
\hline & B & $\begin{array}{r}0 \\
5 \\
15\end{array}$ & $\begin{array}{ll}\text { to } 5 \\
\text { to } 15 \\
\text { to } 30\end{array}$ & $\begin{array}{l}\text { ROCKWELL } \\
\text { ROCKWELL } \\
\text { ROCKWELL }\end{array}$ & $\begin{array}{l}3.6 E-1 \\
3.6 E-1 \\
3.6 E-1\end{array}$ & & & $\begin{array}{l}2.4 E+3 \\
2.4 E+3 \\
2.2 E+0\end{array}$ & $\begin{array}{l}1.5 E+2 \\
1.5 E+2 \\
1.0 E+0\end{array}$ \\
\hline & C & $\begin{array}{r}0 \\
20 \\
60\end{array}$ & $\begin{array}{l}\text { to } 5 \\
\text { to } 30 \\
\text { to } 69\end{array}$ & $\begin{array}{l}\text { ROCKWELL } \\
\text { ROCKWELL } \\
\text { ROCKWELL }\end{array}$ & & & $4.9 E+3$ & $\begin{array}{l}8.2 E+3 \\
8.0 E+3 \\
6.9 E+1\end{array}$ & $\begin{array}{l}1.2 E+3 \\
9.1 E+2 \\
3.5 E+2\end{array}$ \\
\hline & $D$ & $\begin{array}{r}0 \\
5 \\
15 \\
40\end{array}$ & $\begin{array}{ll}\text { to } & 5 \\
\text { to } 15 \\
\text { to } 30 \\
\text { to } 60\end{array}$ & $\begin{array}{l}\text { ROCKWELL } \\
\text { ROCKWELL } \\
\text { ROCKWELL } \\
\text { OEV VAAN I }\end{array}$ & $\begin{array}{c}3.6 E-1 \\
3.6 E-1 \\
3.6 E-1 \\
\cdots\end{array}$ & & & $\begin{array}{l}6.1 E+0 \\
6.1 E+0 \\
1.4 E+0 \\
2.0 E+3\end{array}$ & $\begin{array}{l}\text { 7. } .0 E-1 \\
7.0 E-1 \\
8.0 E-1 \\
1.0 E+2\end{array}$ \\
\hline & $E$ & $\begin{array}{r}0 \\
5 \\
15 \\
40 \\
40\end{array}$ & $\begin{array}{ll}\text { to } & 5 \\
\text { to } & 15 \\
\text { to } 30 \\
\text { to } 60 \\
\text { to } 60\end{array}$ & $\begin{array}{l}\text { ROCKWELL } \\
\text { ROCKWELL } \\
\text { ROCKWELL } \\
\text { ROCKWELL } \\
\text { DEV VAN I }\end{array}$ & $\begin{array}{l}6.5 E-1 \\
3.6 E-1 \\
3.5 E-1\end{array}$ & & & $\begin{array}{l}1.1 E+0 \\
1.1 E+0 \\
2.5 E+0 \\
2.7 E+1 \\
2.0 E+3\end{array}$ & $\begin{array}{l}8.0 E-1 \\
8.0 E-1 \\
2.0 E+0 \\
1.1 E+0 \\
1.0 E+2\end{array}$ \\
\hline & $F$ & $\begin{array}{r}0 \\
5 \\
15\end{array}$ & $\begin{array}{ll}\text { to } & 5 \\
\text { to } & 15 \\
\text { to } & 30\end{array}$ & $\begin{array}{l}\text { ROCKWELL } \\
\text { ROCKWELL } \\
\text { ROCKWELL }\end{array}$ & $\begin{array}{l}1.2 E+0 \\
2.0 E-1 \\
3.0 E-1\end{array}$ & & & $\begin{array}{l}2.1 E+1 \\
2.1 E+1 \\
4.4 E+2\end{array}$ & $\begin{array}{l}1.1 E+0 \\
1.1 E+0 \\
6.0 E-1\end{array}$ \\
\hline & G & $\begin{array}{r}0 \\
5 \\
15\end{array}$ & $\begin{array}{ll}\text { to } & 5 \\
\text { to } & 15 \\
\text { to } & 30\end{array}$ & $\begin{array}{l}\text { ROCKWELL } \\
\text { ROCKWELL } \\
\text { ROCKWELL }\end{array}$ & $\begin{array}{l}1.4 E+0 \\
1.0 E-1 \\
1.0 E-1\end{array}$ & & & $\begin{array}{l}7.6 E+0 \\
7.6 E+0 \\
2.0 E+0\end{array}$ & $\begin{array}{l}6.0 E-1 \\
6.0 E-1 \\
5.0 E-1\end{array}$ \\
\hline
\end{tabular}


A-27 216-Z-19 DITCH TRANSECT SAMPLE ANALYSES

\begin{tabular}{|c|c|c|c|c|c|c|c|c|}
\hline \multirow{2}{*}{ TRANSECT } & \multirow{2}{*}{$\begin{array}{l}\text { SAMPLE } \\
\text { POINT }\end{array}$} & \multirow{2}{*}{$\begin{array}{l}\text { DEPTH } \\
(\mathrm{cm})\end{array}$} & \multirow[b]{2}{*}{ LABORATORY } & \multicolumn{5}{|c|}{ CONCENTRATION (pci/g) } \\
\hline & & & & $137 \mathrm{Cs}$ & $90 \mathrm{sr}$ & $238 \mathrm{pu}$ & $239,240 p_{u}$ & $241_{\mathrm{Am}}$ \\
\hline 8 & A & $\begin{array}{rll}0 & \text { to } & 5 \\
5 & \text { to } & 15 \\
15 & \text { to } & 30\end{array}$ & $\begin{array}{l}\text { ROCKWELL } \\
\text { ROCKWELL } \\
\text { ROCKWELL }\end{array}$ & $\begin{array}{l}3.5 E-1 \\
3.5 E-1 \\
3.5 E-1\end{array}$ & & & $\begin{array}{l}1.1 E+1 \\
1.1 E+1 \\
8.4 E+0\end{array}$ & $\begin{array}{l}2.0 E+0 \\
2.0 E+0 \\
6.0 E-1\end{array}$ \\
\hline & B & $\begin{array}{rll}0 & \text { to } & 5 \\
5 & \text { to } & 15 \\
15 & \text { to } & 30\end{array}$ & $\begin{array}{l}\text { ROCKWELL } \\
\text { ROCKWELL } \\
\text { ROCKWELL }\end{array}$ & $\begin{array}{l}3.2 E-1 \\
3.6 E-1 \\
3.3 E-1\end{array}$ & & & $\begin{array}{l}5.7 E+0 \\
5.7 E+0 \\
2.3 E+0\end{array}$ & $\begin{array}{l}6.0 E-1 \\
6.0 E-1 \\
7.0 E-1\end{array}$ \\
\hline & c & $\begin{array}{r}0 \text { to } 10 \\
20 \text { to } 30 \\
50 \text { to } 51\end{array}$ & $\begin{array}{l}\text { ROCKWELL } \\
\text { ROCKWELL } \\
\text { ROCKWELL }\end{array}$ & & & $\begin{array}{l}6.1 E+1 \\
5.5 E+3 \\
2.3 E+1\end{array}$ & $\begin{array}{l}1.6 E+2 \\
8.6 E+3 \\
1.2 E+2\end{array}$ & $\begin{array}{l}2.9 E+4 \\
1.3 E+3 \\
3.5 E+1\end{array}$ \\
\hline & 0 & $\begin{array}{rll}0 & \text { to } & 5 \\
5 & \text { to } & 15 \\
15 & \text { to } & 30 \\
40 & \text { to } & 60\end{array}$ & $\begin{array}{l}\text { ROCKWELL } \\
\text { ROCKWELL } \\
\text { ROCKWELL } \\
\text { QEV VAN I }\end{array}$ & $\begin{array}{l}3.5 E-1 \\
3.6 E-1 \\
3.7 E-1\end{array}$ & & & $\begin{array}{l}4.5 E+0 \\
4.5 E+0 \\
7.8 E-1 \\
2.0 E+3\end{array}$ & $\begin{array}{l}1.0 E+0 \\
1.0 E+0 \\
1.0 E+0 \\
1.0 E+2\end{array}$ \\
\hline & $E$ & $\begin{array}{rll}0 & \text { to } & 5 \\
5 & \text { to } & 15 \\
15 & \text { to } & 30 \\
40 & \text { to } & 60 \\
40 & \text { to } & 60\end{array}$ & $\begin{array}{l}\text { ROCKWELL } \\
\text { ROCKWELLL } \\
\text { ROCKWELLL } \\
\text { ROCKWELLL } \\
\text { DEV VAN I }\end{array}$ & $\begin{array}{l}4.7 E-1 \\
3.5 E-1 \\
3.7 E-1\end{array}$ & & & $\begin{array}{l}1.0 E+3 \\
1.0 E+3 \\
3.0 E+1 \\
1.3 E+2 \\
2.0 E+3\end{array}$ & $\begin{array}{l}1.3 E+2 \\
1.3 E+2 \\
1.0 E+0 \\
1.3 E \\
1.0 E\end{array}$ \\
\hline & $F$ & $\begin{array}{rll}0 & \text { to } & 5 \\
5 & \text { to } & 15 \\
15 & \text { to } & 30\end{array}$ & $\begin{array}{l}\text { ROCKWELL } \\
\text { ROCKWELL } \\
\text { ROCKWELL }\end{array}$ & $\begin{array}{l}4.0 E-1 \\
1.0 E-1 \\
1.0 E-1\end{array}$ & & & $\begin{array}{l}7.7 E+1 \\
7.7 E+1 \\
4.9 E+1\end{array}$ & $\begin{array}{l}6.1 E+0 \\
6.1 E+0 \\
5.8 E+0\end{array}$ \\
\hline & G & $\begin{array}{rll}0 & \text { to } & 5 \\
5 & \text { to } & 15 \\
15 & \text { to } & 30\end{array}$ & $\begin{array}{l}\text { ROCKWELL } \\
\text { ROCKWELL } \\
\text { ROCKWELL }\end{array}$ & $\begin{array}{l}4.0 E-1 \\
1.0 E-1 \\
1.0 E-1\end{array}$ & & & $\begin{array}{l}3.2 E+0 \\
3.2 E+0\end{array}$ & $\begin{array}{l}8.0 E-1 \\
8.0 E-1 \\
4.7 E+0\end{array}$ \\
\hline
\end{tabular}




\section{A-27 216-2-19 DITCH TRANSECT SAMPLE ANALYSES}

\begin{tabular}{|c|c|c|c|c|c|c|c|c|c|}
\hline & SAMPLE & & EPTH & & & CONCE & TRATION & $p(i / g)$ & \\
\hline TRANSECT & POINT & & $\mathrm{cm}$ ) & LABORATORY & $137 \mathrm{Cs}$ & $90 s r$ & $238 \mathrm{pu}$ & $239,240 p_{u}$ & $241 \mathrm{Am}$ \\
\hline 9 & $A$ & $\begin{array}{l}0 t \\
5 t \\
15 t \\
40 t \\
40 t\end{array}$ & $\begin{array}{ll}\text { to } 5 \\
\text { to } 15 \\
\text { to } 30 \\
\text { to } 60 \\
\text { to } 60\end{array}$ & $\begin{array}{l}\text { ROCKWELL } \\
\text { ROCKWELL } \\
\text { ROCKWELL } \\
\text { ROCKWELL } \\
\text { DEV VAN I }\end{array}$ & $\begin{array}{l}3.4 E-1 \\
4.7 E-1 \\
3.5 E-1\end{array}$ & j & & $\begin{array}{l}4.2 E+0 \\
4.2 E+0 \\
2.6 E+0 \\
6.7 E+1 \\
2.0 E+3\end{array}$ & $\begin{array}{l}6.0 E-1 \\
6.0 E-1 \\
1.0 E+0 \\
4.6 E-1 \\
1.0 E+2\end{array}$ \\
\hline & B & $\begin{array}{l}0 t \\
5 t \\
15 t \\
40 t\end{array}$ & $\begin{array}{l}\text { to } 5 \\
\text { to } 15 \\
\text { to } 30 \\
\text { to } 60\end{array}$ & $\begin{array}{l}\text { ROCKWELL } \\
\text { ROCKWELL } \\
\text { ROCKWELL } \\
\text { DEV VAN I }\end{array}$ & $\begin{array}{l}1.3 E+0 \\
3.5 E-3 \\
3.5 E-1\end{array}$ & & & $\begin{array}{l}1.0 E+2 \\
1.0 E+2 \\
2.0 E+0 \\
2.0 E+3\end{array}$ & $\begin{array}{l}1.1 E+1 \\
1.1 E+1 \\
1.0 E+0 \\
1.0 E+2\end{array}$ \\
\hline & C & $\begin{array}{r}0 \\
20 \\
70\end{array}$ & $\begin{array}{l}\text { to } 10 \\
\text { to } 30 \\
\text { to } 71\end{array}$ & $\begin{array}{l}\text { ROCKWELL } \\
\text { ROCKWELL } \\
\text { ROCKWELL }\end{array}$ & & & $\begin{array}{l}1.6 E+1 \\
1.1 E+2 \\
2.8 E+2\end{array}$ & $\begin{array}{l}5.8 E+2 \\
2.0 E+2 \\
2.5 E+2\end{array}$ & $\begin{array}{l}8.9 E+1 \\
2.6 E+1 \\
1.2 E+1\end{array}$ \\
\hline & 0 & $\begin{array}{r}0 \\
5 \\
15 \\
40 \\
70\end{array}$ & $\begin{array}{l}\text { to } 5 \\
\text { to } 15 \\
\text { to } 30 \\
\text { to } 60 \\
\text { to } 90\end{array}$ & $\begin{array}{l}\text { ROCKWELL } \\
\text { ROCKWELL } \\
\text { ROCKWELL } \\
\text { DEV VAN I } \\
\text { DEV VAN I }\end{array}$ & $\begin{array}{l}2.0 E+0 \\
3.6 E-1 \\
1.8 E+0\end{array}$ & & & $\begin{array}{l}4.7 E+1 \\
4.7 E+1 \\
1.3 E+1 \\
2.0 E+3 \\
2.0 E+3\end{array}$ & $\begin{array}{l}4.0 E+0 \\
4.0 E+0 \\
8.0 E-1 \\
1.0 E+2 \\
1.0 E+2\end{array}$ \\
\hline & $E$ & $\begin{array}{r}0 \\
5 \\
15 \\
40 \\
40\end{array}$ & $\begin{array}{ll}\text { to } 5 \\
\text { to } 15 \\
\text { to } 30 \\
\text { to } 60 \\
\text { to } 60\end{array}$ & $\begin{array}{l}\text { ROCKWELL } \\
\text { ROCKWELL } \\
\text { ROCKWELL } \\
\text { ROCKWELL } \\
\text { OEV VAN I }\end{array}$ & $\begin{array}{l}3.5 E-1 \\
4.8 E-1 \\
3.4 E-1\end{array}$ & & & $\begin{array}{l}1.7 E+1 \\
1.7 E+1 \\
2.7 E+1 \\
1.1 E+2 \\
2.0 E+3\end{array}$ & $\begin{array}{l}8.0 E-1 \\
8.0 E-1 \\
1.0 E+0 \\
4.3 E+3 \\
1.1 E+2\end{array}$ \\
\hline & $F$ & $\begin{array}{r}0 \\
5 \\
15\end{array}$ & $\begin{array}{l}\text { to } 5 \\
\text { to } 15 \\
\text { to } 30\end{array}$ & $\begin{array}{l}\text { ROCKWELL } \\
\text { ROCKWELL } \\
\text { ROCKWELL }\end{array}$ & $\begin{array}{l}9.0 E-2 \\
1.0 E-1 \\
1.0 E-1\end{array}$ & & & $\begin{array}{l}1.0 E+1 \\
1.0 E+1 \\
1 . O E+0\end{array}$ & $\begin{array}{l}\text { 7. } 0 E-1 \\
7.0 E-1 \\
3.0 E+0\end{array}$ \\
\hline & $G$ & $\begin{array}{r}0 \\
5 \\
15\end{array}$ & $\begin{array}{ll}\text { to } & 5 \\
\text { to } & 15 \\
\text { to } & 30\end{array}$ & $\begin{array}{l}\text { ROCKWELL } \\
\text { ROCKWELL } \\
\text { ROCKWELL }\end{array}$ & $\begin{array}{l}1.6 E+0 \\
7.0 E-1 \\
1.0 E-1\end{array}$ & & & $\begin{array}{l}2.7 E+1 \\
2.7 E+1 \\
4.0 E-1\end{array}$ & $\begin{array}{l}2.7 E+0 \\
2.7 E+0 \\
5.0 E-1\end{array}$ \\
\hline
\end{tabular}


WHC-EP-0707, Rev. 0

A-28 216-2-19 DITCH SURFACE SAMPLES (30m INTERVALS)

SAMPLE

$-200$

$-100$

$0+0$

$+100$

$+200$

$+300$

$+400$

$+500$

$+600$

$+700$

$+800$

$+900$

$+1000$
CONCENTRATION $(\mathrm{pCi} / \mathrm{g})$

\begin{tabular}{cc}
$239.240 P u$ & $241 A m$ \\
\hline $8.0 E+3$ & $9.5 E+3$ \\
$2.8 E+3$ & $9.2 E+3$ \\
$1.3 E+7$ & $5.5 E+3$ \\
$4.9 E+4$ & $8.0 E+3$ \\
$1.8 E+3$ & $1.5 E+3$ \\
$9.6 E+3$ & $1.3 E+3$ \\
$1.9 E+4$ & $3.3 E+3$ \\
$8.9 E+3$ & $9.8 E+2$ \\
$1.9 E+4$ & $2.3 E+3$ \\
$4.9 E+3$ & $6.2 E+2$ \\
$2.1 E+3$ & $1.8 E+3$ \\
$1.1 E+4$ & $5.3 E+2$ \\
$2.8 E+3$ & $3.9 E+2$
\end{tabular}


WHC-EP-0707, Rev. 0

\section{A-31 216-U-14 O1TCH TRANSECT SAMPLES (pC $1 / \mathrm{g})$}

\begin{tabular}{|c|c|c|c|}
\hline TRANSECT & STATION & DEPTH $(\mathrm{cm})$ & $137 \mathrm{Cs}$ \\
\hline \multirow[t]{4}{*}{1} & $A$ & $\begin{array}{c}0=5 \\
5=15 \\
15=30\end{array}$ & $\begin{array}{l}3.9 E-1 \\
8.7 E-1 \\
7.7 E-1\end{array}$ \\
\hline & B & $\begin{array}{c}0-5 \\
5=15 \\
15-30\end{array}$ & $\begin{array}{l}3.2 E-1 \\
3.6 E+0 \\
1.3 E+0\end{array}$ \\
\hline & 0 & $\begin{array}{c}0=5 \\
5=15 \\
15=30\end{array}$ & $\begin{array}{l}5.4 E+2 \\
2.5 E+0 \\
3.7 E+2\end{array}$ \\
\hline & $E$ & $\begin{array}{c}0-5 \\
5=15 \\
15=30\end{array}$ & $\begin{array}{l}5.4 E+3 \\
4.4 E+3 \\
5.3 E+2\end{array}$ \\
\hline \multirow[t]{4}{*}{2} & $A$ & $\begin{aligned} 0 & -5 \\
5 & -15 \\
15 & -30\end{aligned}$ & $\begin{array}{l}3.4 E-1 \\
1.9 E+0 \\
1.2 E+0\end{array}$ \\
\hline & B & $\begin{aligned} 0 & -5 \\
5 & -15 \\
15 & -30\end{aligned}$ & $\begin{array}{l}1.8 E+0 \\
3.6 E-1 \\
1.5 E+1\end{array}$ \\
\hline & $D$ & $\begin{array}{c}0-5 \\
5=15 \\
15=30\end{array}$ & $\begin{array}{l}7.5 E+1 \\
3.8 E+1 \\
7.3 E+0\end{array}$ \\
\hline & $E$ & $\begin{array}{c}0=5 \\
5=15 \\
15=30\end{array}$ & $\begin{array}{l}1.2 E+3 \\
3.8 E+2 \\
2.1 E+0\end{array}$ \\
\hline \multirow[t]{4}{*}{3} & A & $\begin{array}{c}0=5 \\
5=15 \\
15=30\end{array}$ & $\begin{array}{l}4.7 E+0 \\
1.3 E+0 \\
1.0 E+0\end{array}$ \\
\hline & B. & $\begin{array}{c}0=5 \\
5=15 \\
15=30\end{array}$ & $\begin{array}{l}3.2 E-1 \\
1.1 E+0 \\
8.4 E+2\end{array}$ \\
\hline & 0 & $\begin{array}{c}0=5 \\
5=15 \\
15=30\end{array}$ & $\begin{array}{l}2.3 E+2 \\
7.9 E+0 \\
5.2 E+2\end{array}$ \\
\hline & $E$ & $\begin{array}{c}0-5 \\
5=15 \\
15=30\end{array}$ & $\begin{array}{l}1.1 E+3 \\
7.9 E+2 \\
5.8 E+0\end{array}$ \\
\hline
\end{tabular}




\section{A-31 216-U-14 OITCH TRANSECT SAMPLES (PC $1 / 9)$}

TRANSECT

4

5

6

\begin{tabular}{r} 
STAT \\
\hline$A$ \\
0
\end{tabular}

E

A

B

0

E

A

B

0

E

\begin{aligned} DEPTH $(\mathrm{cm}) \\$\hline $0=5 \\ 5=15 \\ 15=30 \\ 0=5 \\ 5=15 \\ 15=30 \\ 0=5 \\ 5=15 \\ 15=30 \\ 0=5 \\ 5=15 \\ 15=30\end{aligned}$

$0-5$

$5-15$

$15-30$

$0-5$

$5-15$

$15-30$

$0-5$

$5-15$

$15-30$

0 - 5

$5-15$

$15-30$

0 - 5

$5-15$

$15-30$

0 - 5

$5-15$

$15-30$

$0-5$

$5-15$

$15 \cdot 30$

J - 5

$5 \cdot 15$

$15 \cdot 30$
$137 \mathrm{Cs}$

3.1E-1

4. IE-1

1. $3 E-1$

$1.4 E+1$

$2.6 \mathrm{E}+0$

$1.0 E+0$

$1.8 \mathrm{E}+1$

4. $2 E+0$

$1.4 E+0$

$3.3 E+0$

$7.6 \mathrm{E}+2$

$1.2 E+3$

$3.7 E-1$

$1.9 E-1$

$1.0 E-3$

4. $1 E+0$

$6.8 \mathrm{E}+1$

$1.5 E+2$

$1.6 E+2$

$1.2 E+0$

$4.0 E-1$

$7.4 E+2$

$5.3 E+2$

$7.4 E+2$

$9.7 E-1$

$1.5 E+0$

1. $1 E-1$

$3.7 E-1$

$1.8 E+0$

$3.5 E-1$

4. $1 E-1$

$1.0 E+0$

$1.1 E+0$

$4.0 E+1$

$1.7 E+1$

$1.4 E+1$ 
WHC-EP-0707, Rev. 0

\section{A-31 216-U-14 DITCH TRANSECT SAMPLES (pC $1 / \mathrm{g}$ )}

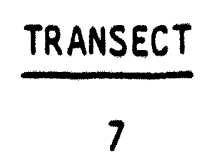

8

9

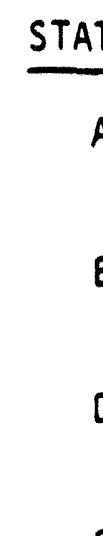

$\varepsilon$

A

B

0

E

A

8

0

$\varepsilon$

\begin{aligned} DEPTH $(\mathrm{cm}) \\$\hline $0-5 \\ 5=.15 \\ 15=30 \\ 0=5 \\ 5=15 \\ 15=30 \\ 0=5 \\ 5=15 \\ 15=30 \\ 0=5 \\ 5=15 \\ 15=30\end{aligned}$

$$
0-5
$$$$
5-15
$$$$
15 \cdot 30
$$$$
0-5
$$$$
5-15
$$$$
15 \cdot 30
$$$$
0-5
$$$$
5 \cdot 15
$$$$
15-30
$$$$
0 \text { - } 5
$$$$
5-15
$$$$
15-30
$$

\begin{tabular}{|c|c|}
\hline $\begin{array}{r}0-5 \\
5=15 \\
15=30\end{array}$ & $\begin{array}{l}5.0 E+0 \\
7.6 E+0\end{array}$ \\
\hline $\begin{aligned} 0 & =5 \\
5 & =15 \\
15 & =30\end{aligned}$ & $\begin{array}{l}3 \cdot 1 E-1 \\
7.5 E+0\end{array}$ \\
\hline $\begin{array}{c}0=5 \\
5=15 \\
15=30\end{array}$ & $\begin{array}{l}1.2 E+1 \\
8.2 E+0 \\
6.4 E+0\end{array}$ \\
\hline $\begin{array}{r}0-5 \\
5=15 \\
15-30\end{array}$ & $\begin{array}{l}8.0 E+1 \\
2.4 E+1 \\
1.4 E+1\end{array}$ \\
\hline
\end{tabular}




\section{A-31 216-U-14 OITCH TRANSECT SAMPLES (pC $1 / \mathrm{g}$ )}

TRANSECT

10

11

12

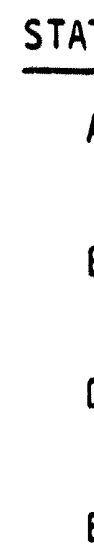

E

A

B

0

$\varepsilon$

A

B

D

E

A

B

0

$\varepsilon$

$$
\begin{aligned}
\text { DEPTH }(\mathrm{cm}) \\
\hline 0-5 \\
5=15 \\
15=30 \\
0=5 \\
5=15 \\
15=30 \\
0=5 \\
5=15 \\
15=30 \\
0=5 \\
5=15 \\
15=30
\end{aligned}
$$

$0-5$

$5 \cdot 15$

$15-30$

0 - 5

$5-15$

$15-30$

0 - 5

$5-15$

$15-30$

0 - 5

$5-15$

15 - 30

$\begin{aligned} 0 & =5 \\ 5 & =15 \\ 15 & =30\end{aligned}$

${ }^{137} \mathrm{Cs}$

$\therefore .6 E+0$

$1.1 E+0$

$1.1 E+0$

$3.6 E+0$

$3.5 E-1$

3. $6 E-1$

2.7E+1

$1.9 E+1$

$6.4 E+0$

$8.2 E+1$

$7.2 E+1$

$3.6 E+1$

2. $1 E+0$

$1.6 E+0$

9. $3 E-1$

$3.6 \mathrm{E}+0$

$7.9 \mathrm{E}-1$

$7.9 E-1$

5. $8 E-1$

4. $4 E+0$

$3.2 E+0$

6. IE-1

3. $3 E-1$

4.5E-1

3. $4 \mathrm{E}+1$

3. $6 E-1$

1. $1 E-1$

$5.0 E-1$

$4.2 E-1$

4. $9 E-1$

$1.3 E+1$

$4.7 E+0$

$9.4 E+0$

$7.7 E+0$

$7.2 \mathrm{E}+1$

$3.3 E+2$

NOTE: These analyses provided by Biological Sciences Unit. All analyses performed by Rockwell. 
A-29 216-U-14 01TCH CEMTER CORES (in pCi/g)

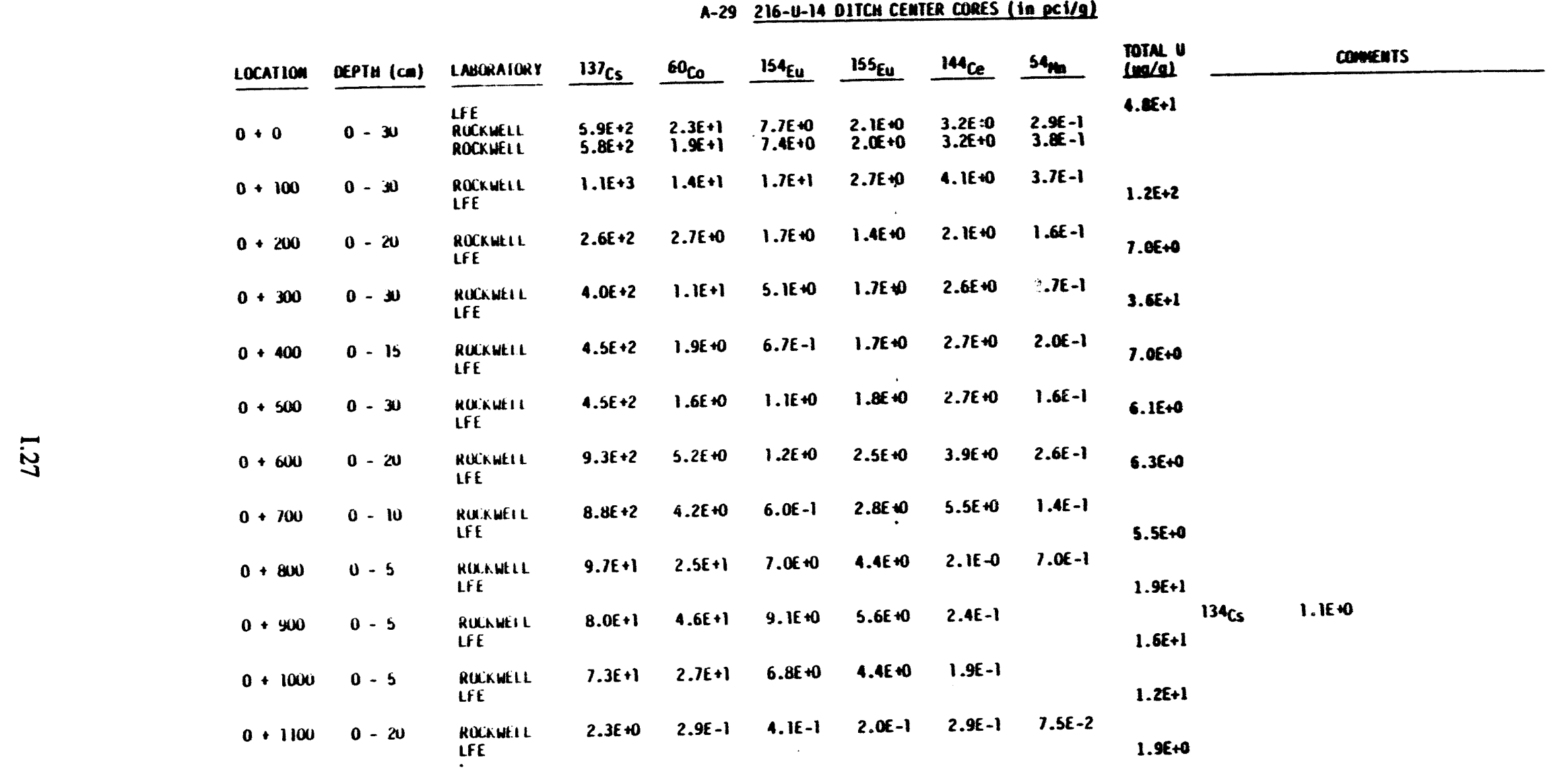




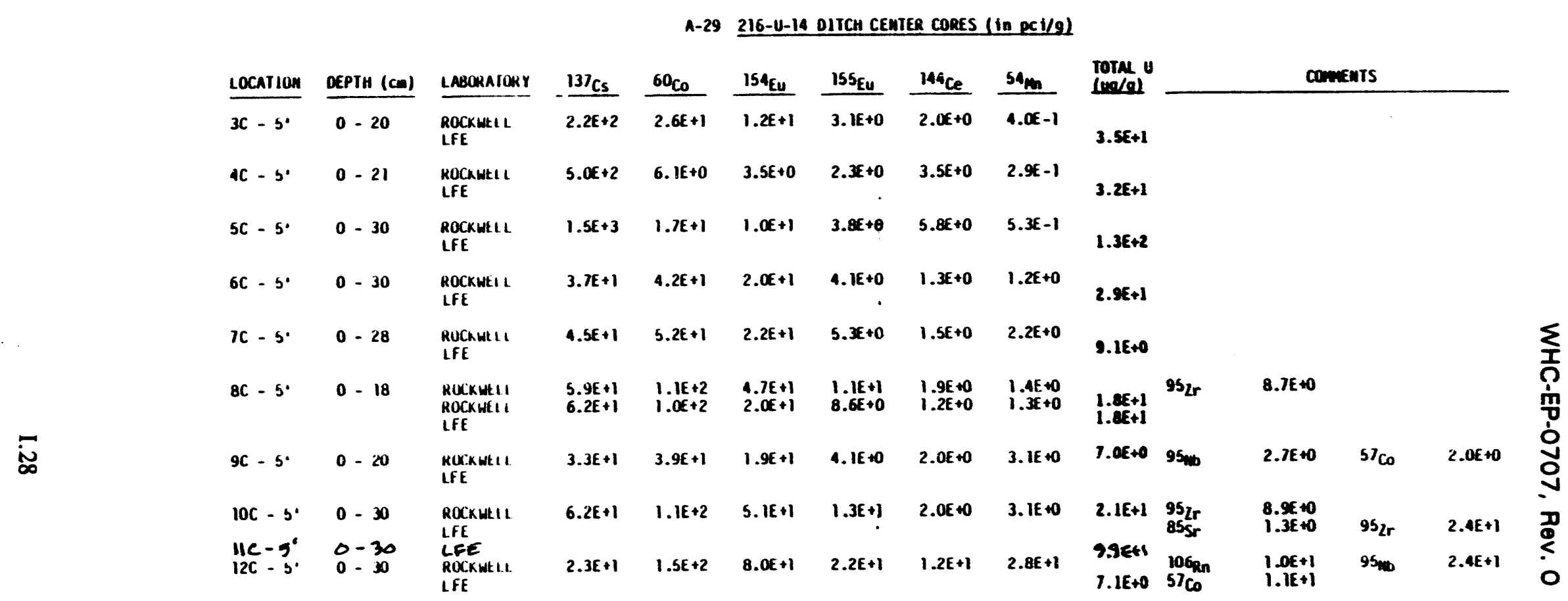


A-30 216-U-14 DITCH HEAD EMD CORES (In PCi/g)

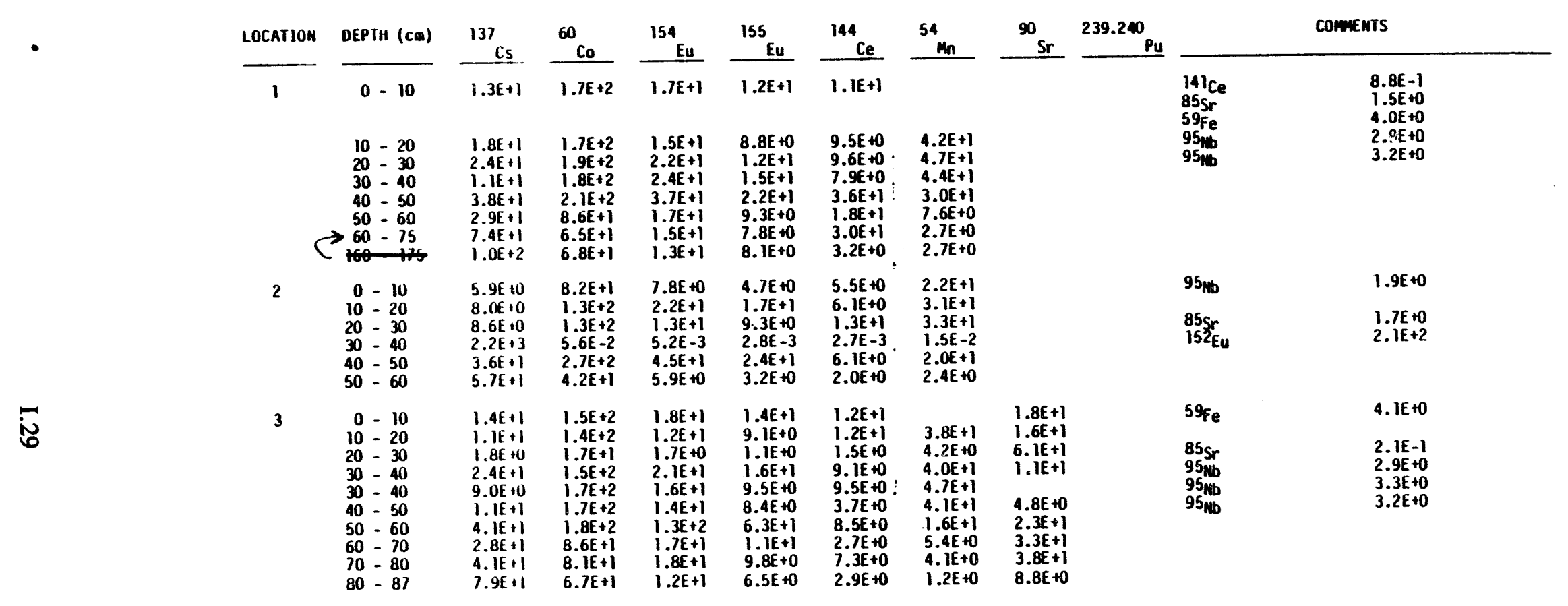


A-30 216-U-14 DITCH HEAD EMO CORES (in PCi/g)

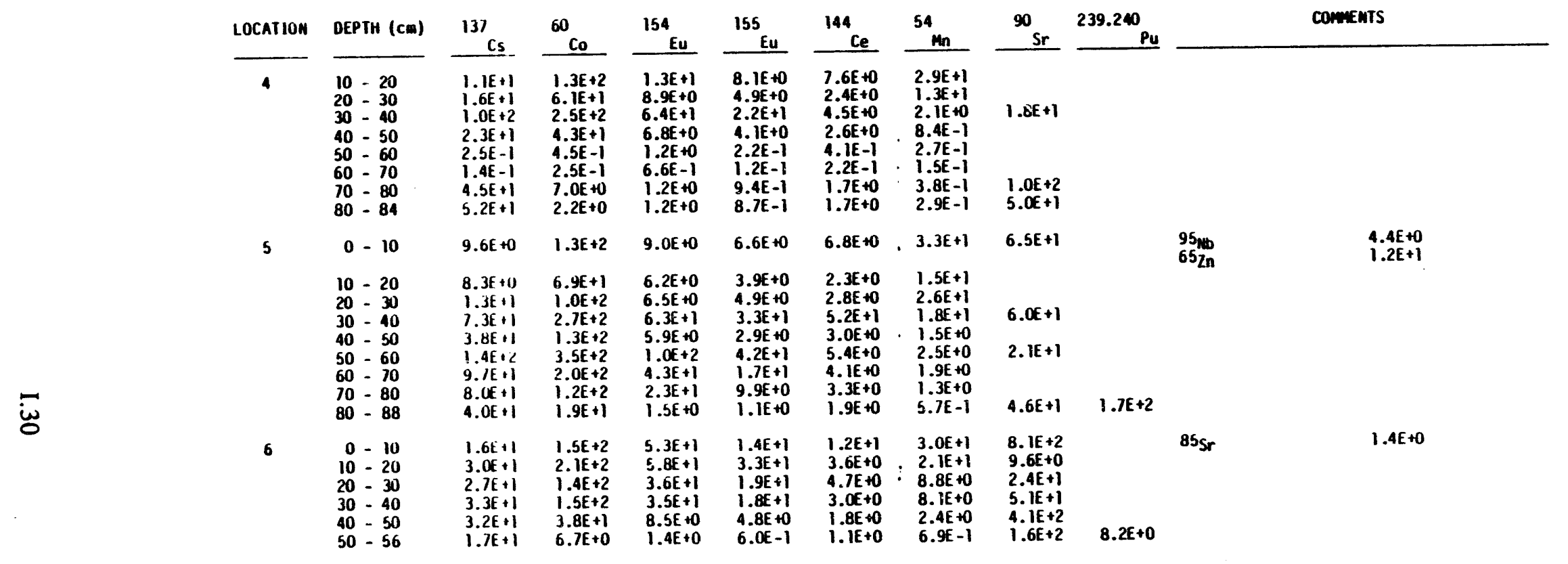

MOIE: All analyses perforwed by Rockwell.

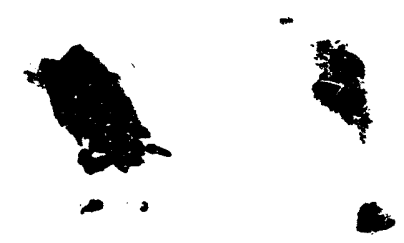


WHC-EP-0707, Rev. 0

Appendix $\mathbf{J}$

Geologic and Radioactivity Logs 
0

0
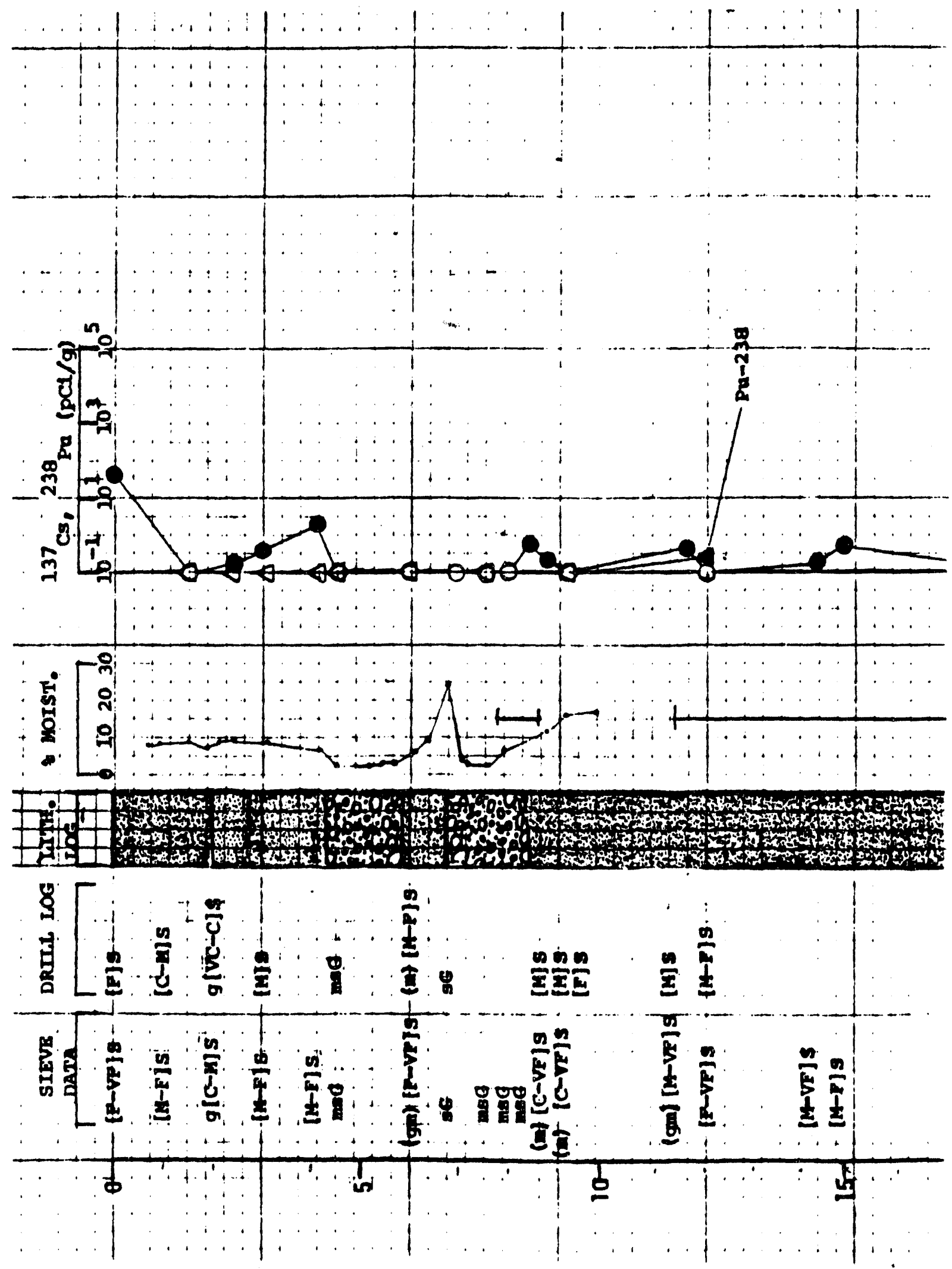


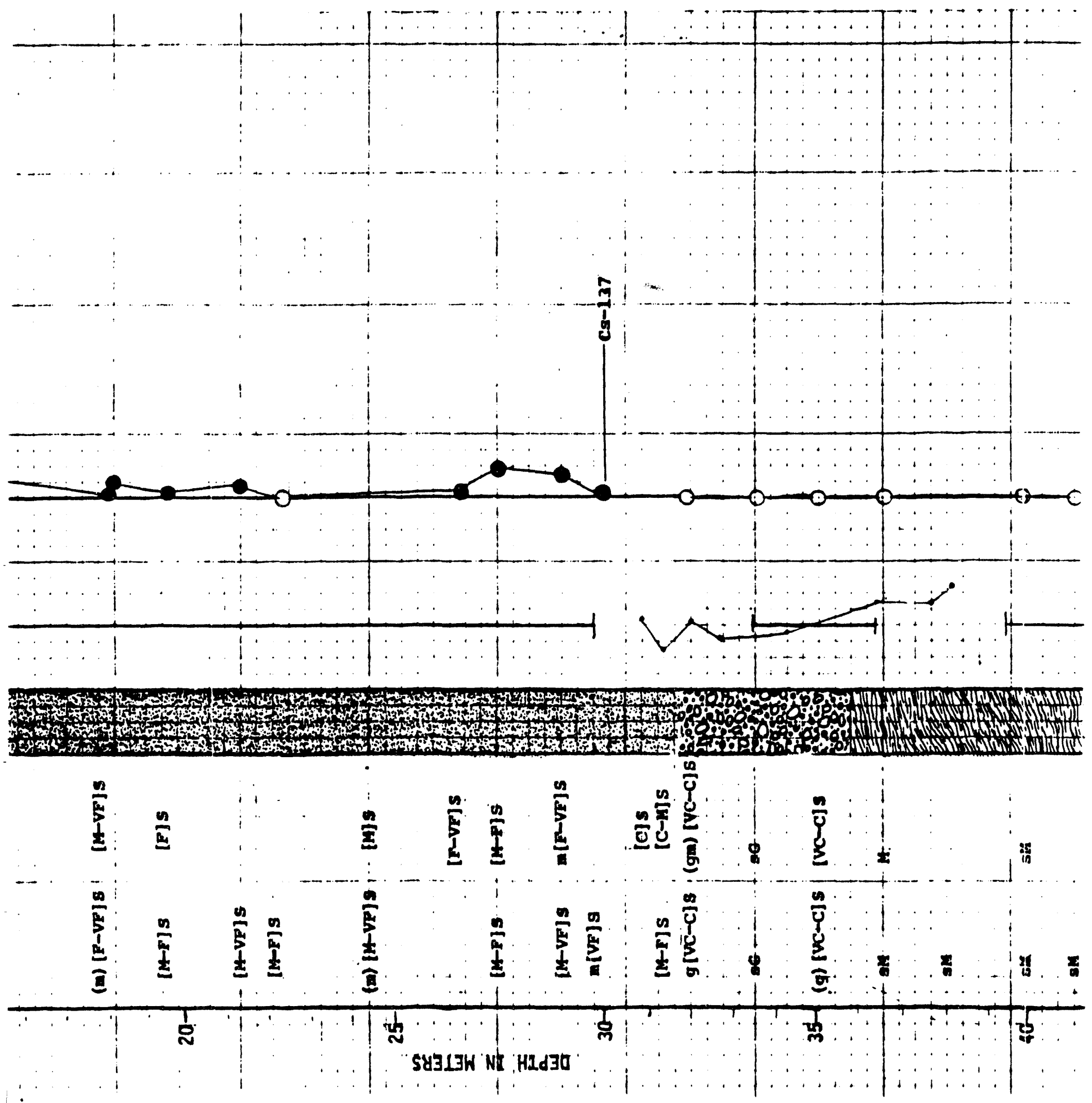


WHC-EP-0707, Rev. 0

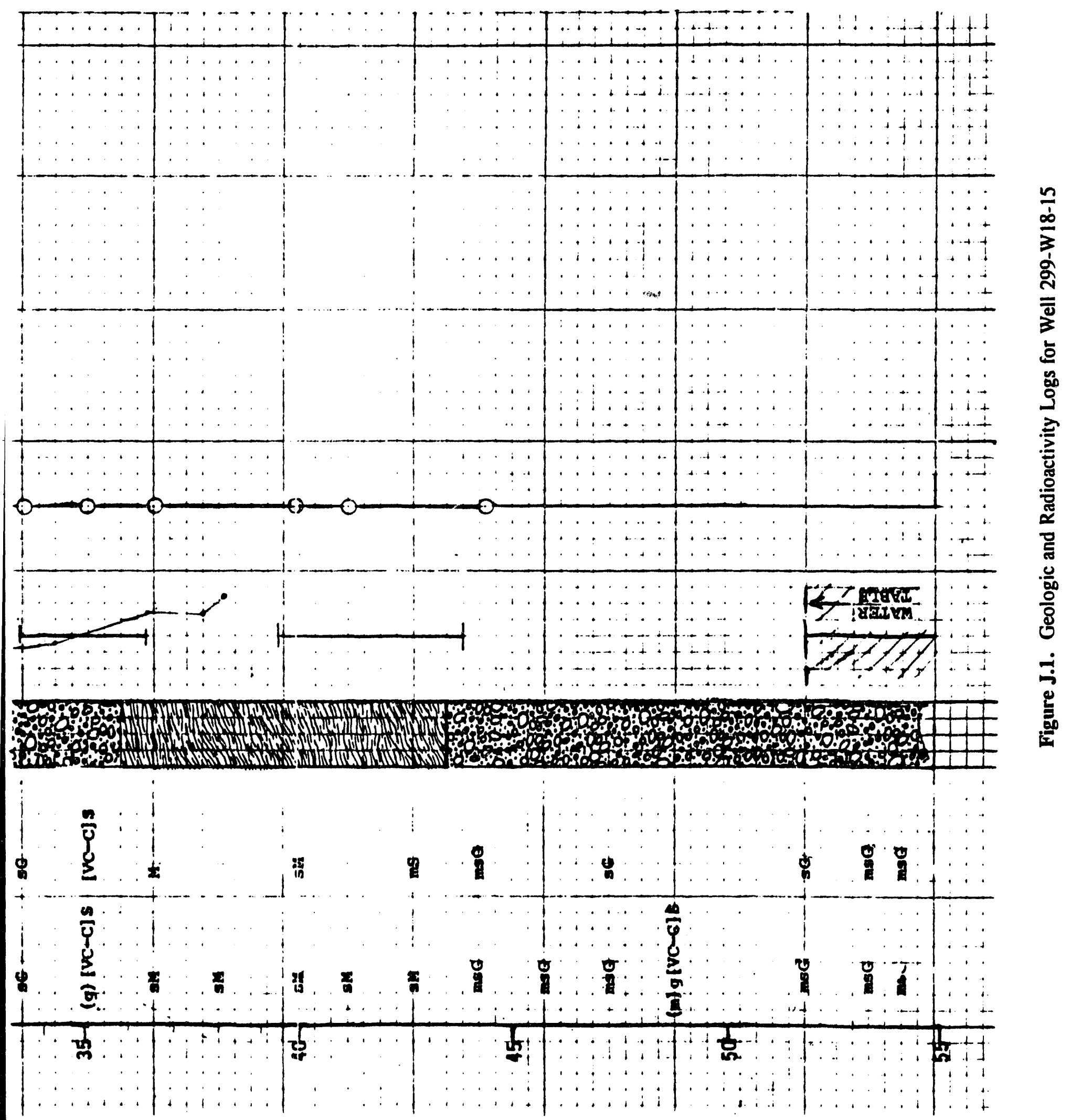




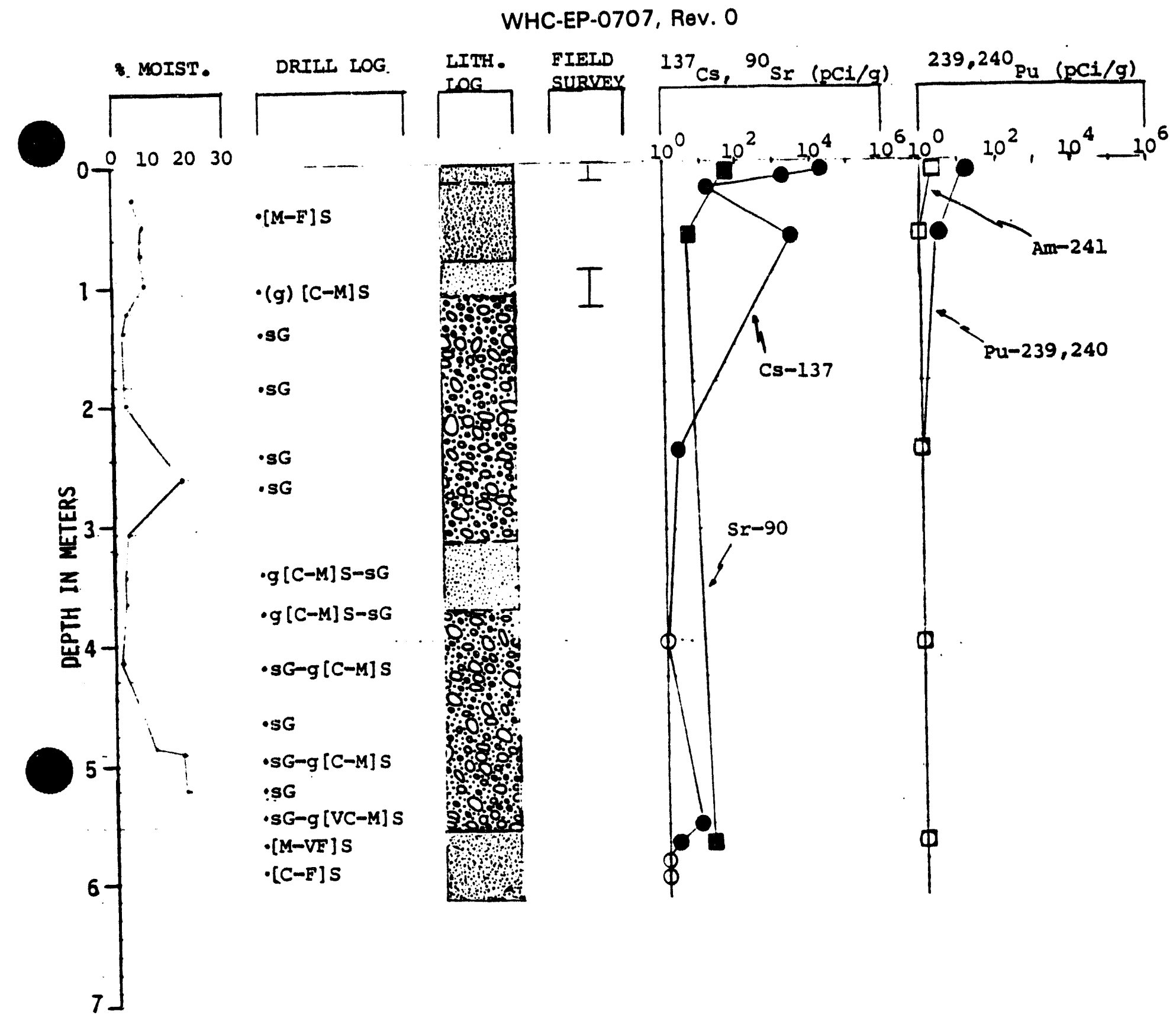

Figure J.2. Geologic and Radioactivity Logs for Well 299-W23-228 
WHC-EP-0707, Rev. 0

ELEVATION 204.8 METERS

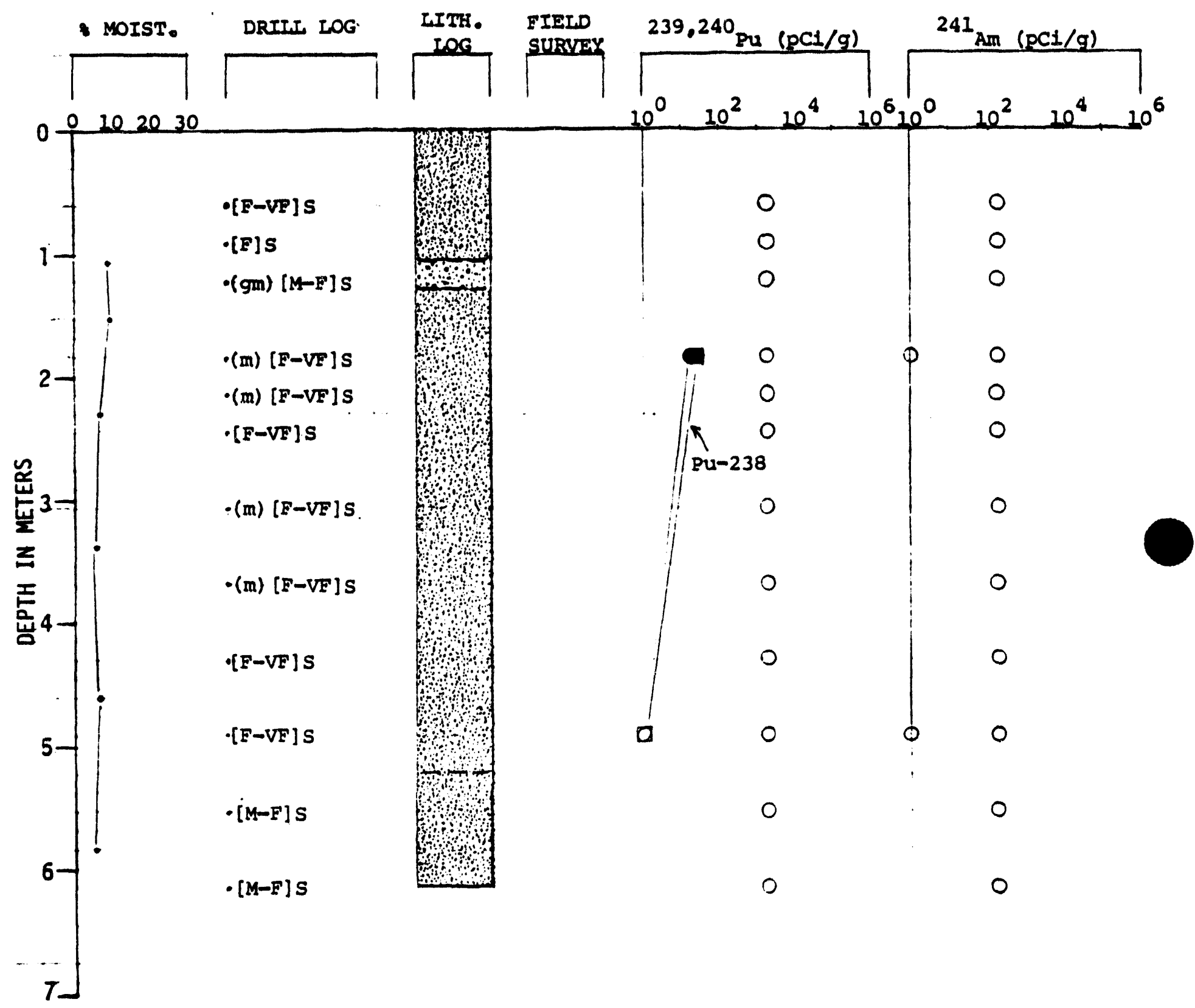

Figure J.3. Geologic and Radioactivity Logs for Well 299-W15-203 
WHC-EP-0707, Rev. 0

\section{ELEVATION 204.8 METERS}

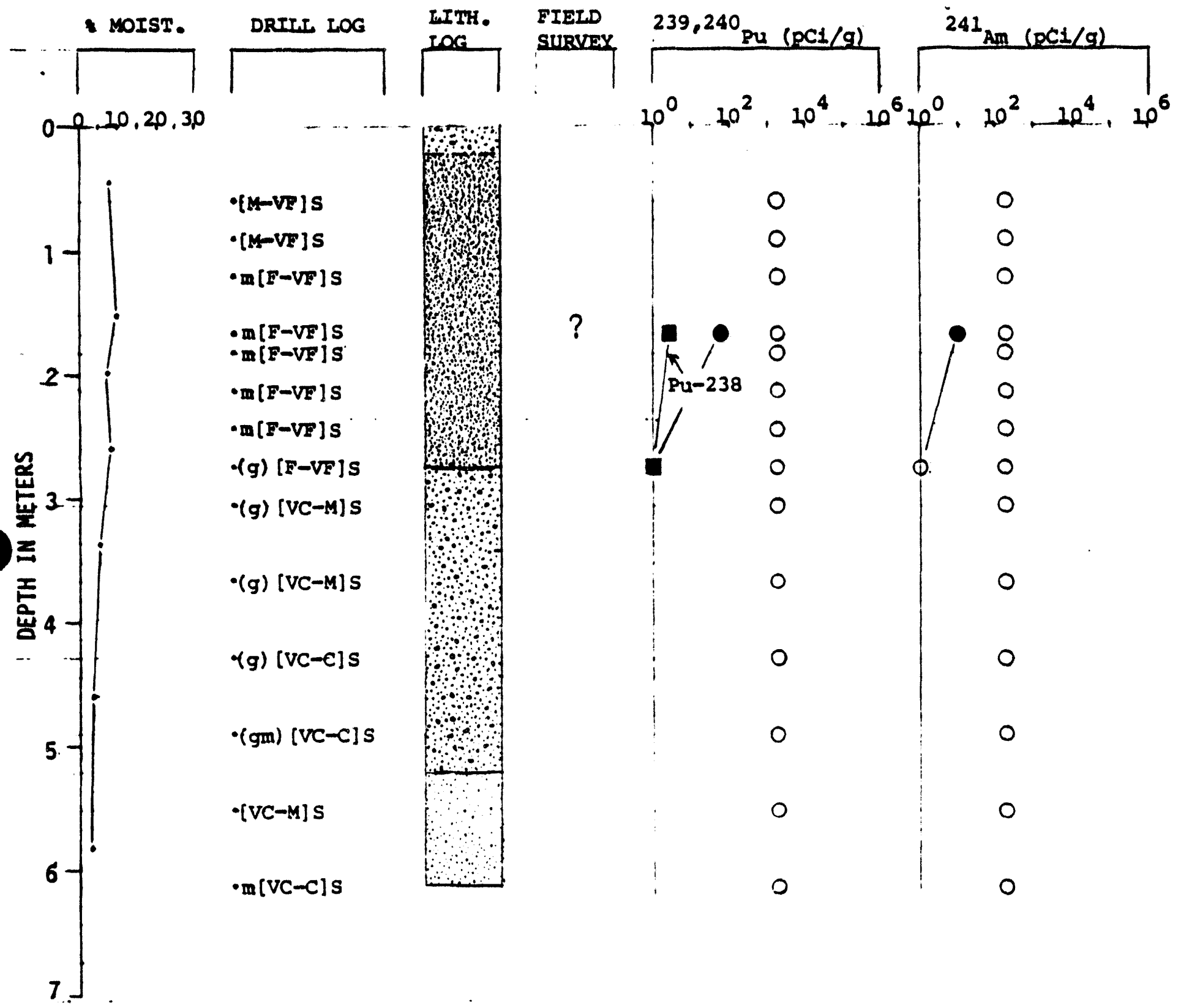

Figure J.4. Geologic and Radioactivity Logs for Well 299-W15-204 
WHC-EP-0707, Rov. 0

ELEVATION 204.7 METERS

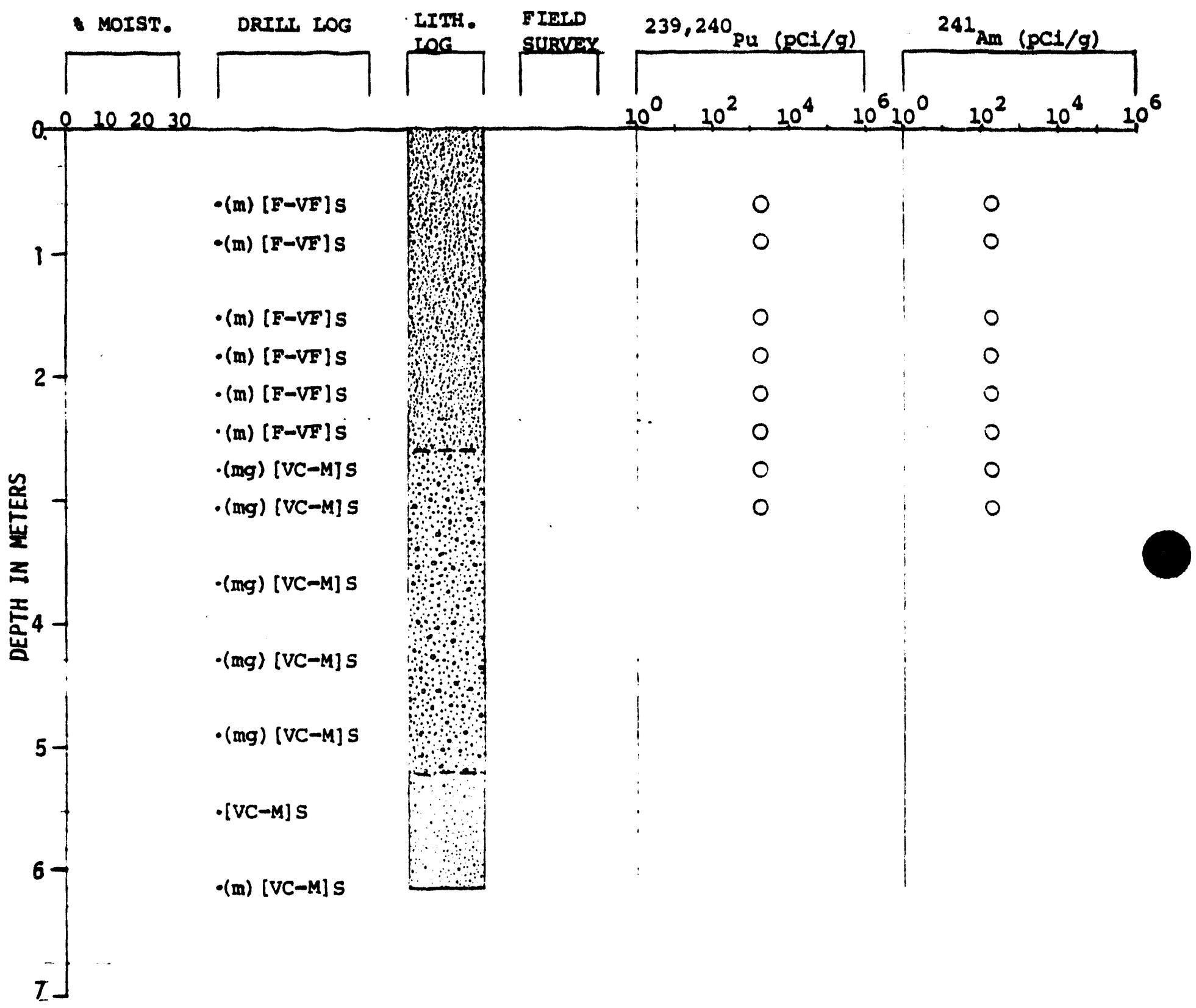

Figure J.5. Geologic and Radioactivity Logs for Well 299-W15-205 
WHC-EP-0707, Rev. 0

\section{ELEVATION 205.0 METERS}

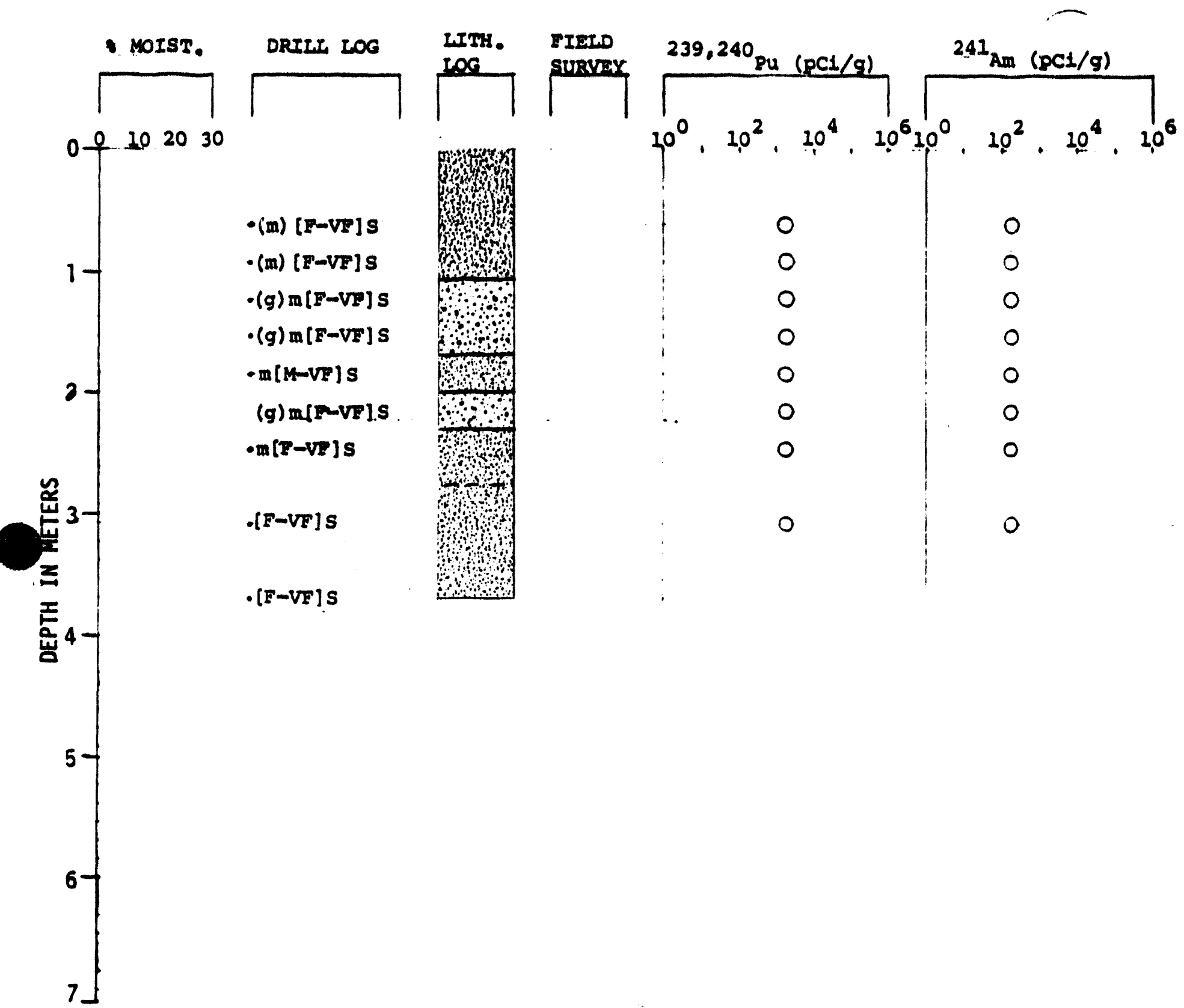

Figure J.6. Geologic and Radioactivity Logs for Well 299-W15-206 
WHC-EP-0707, Rev. 0

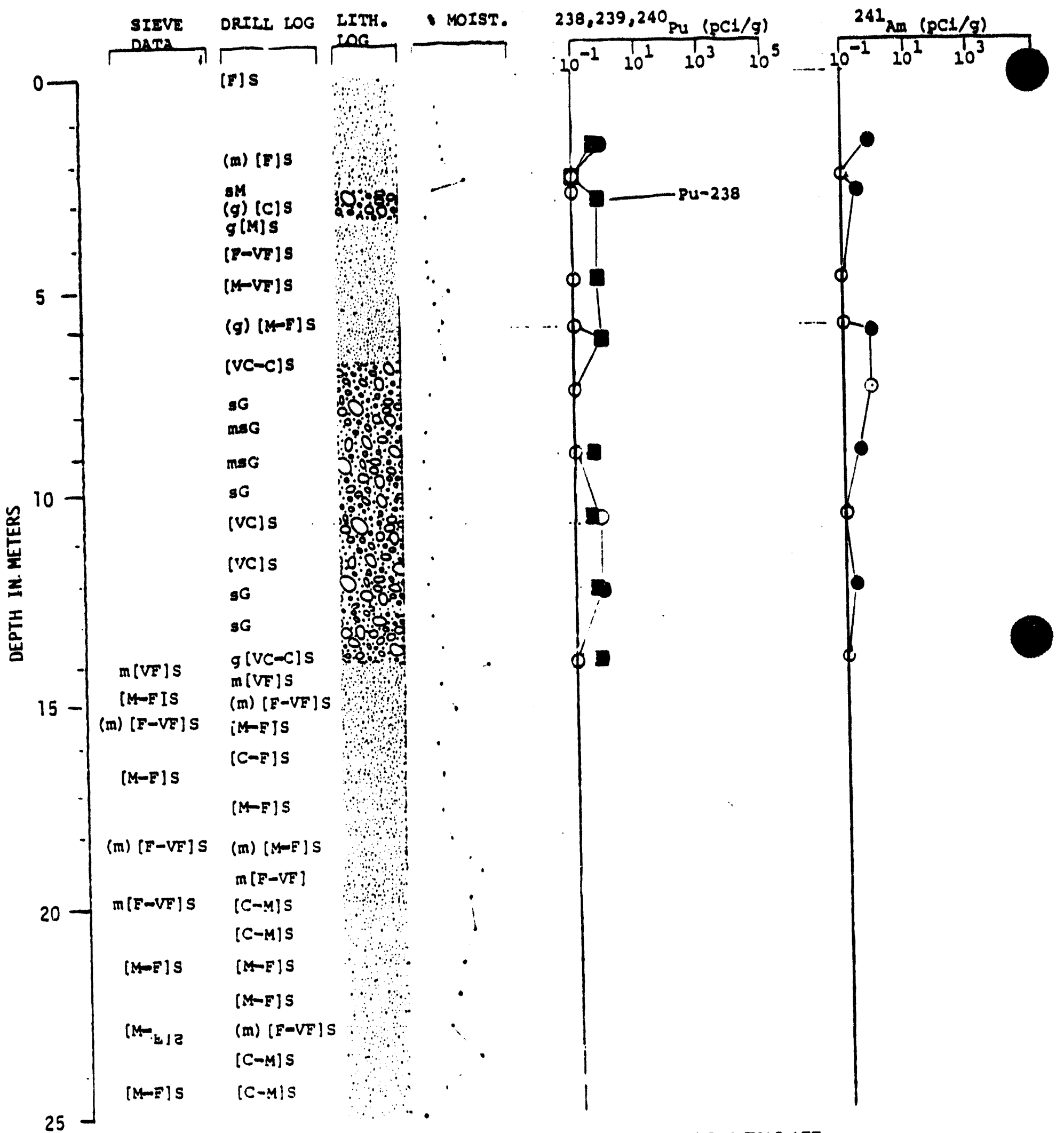

Figure J.7. Geologic and Radioactivity Logs for Well 299-W18-177 
WHC-EP-0707, Rev. 0

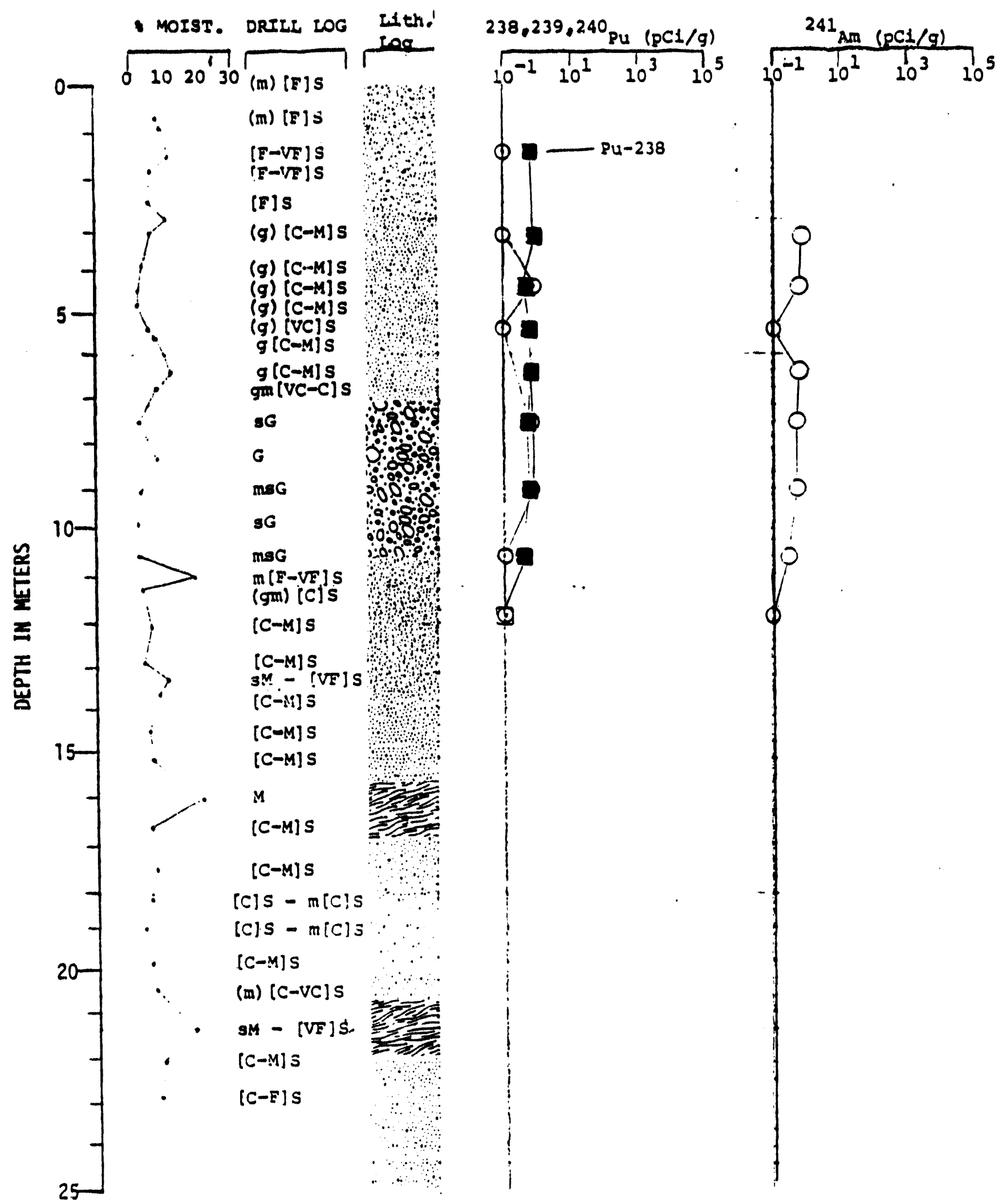

Figure J.8. Geologic and Radioactivity Logs for Well 299-W18-178 
WHC-EP-0707, Rev. 0

ELEVATION 203.5 METERS

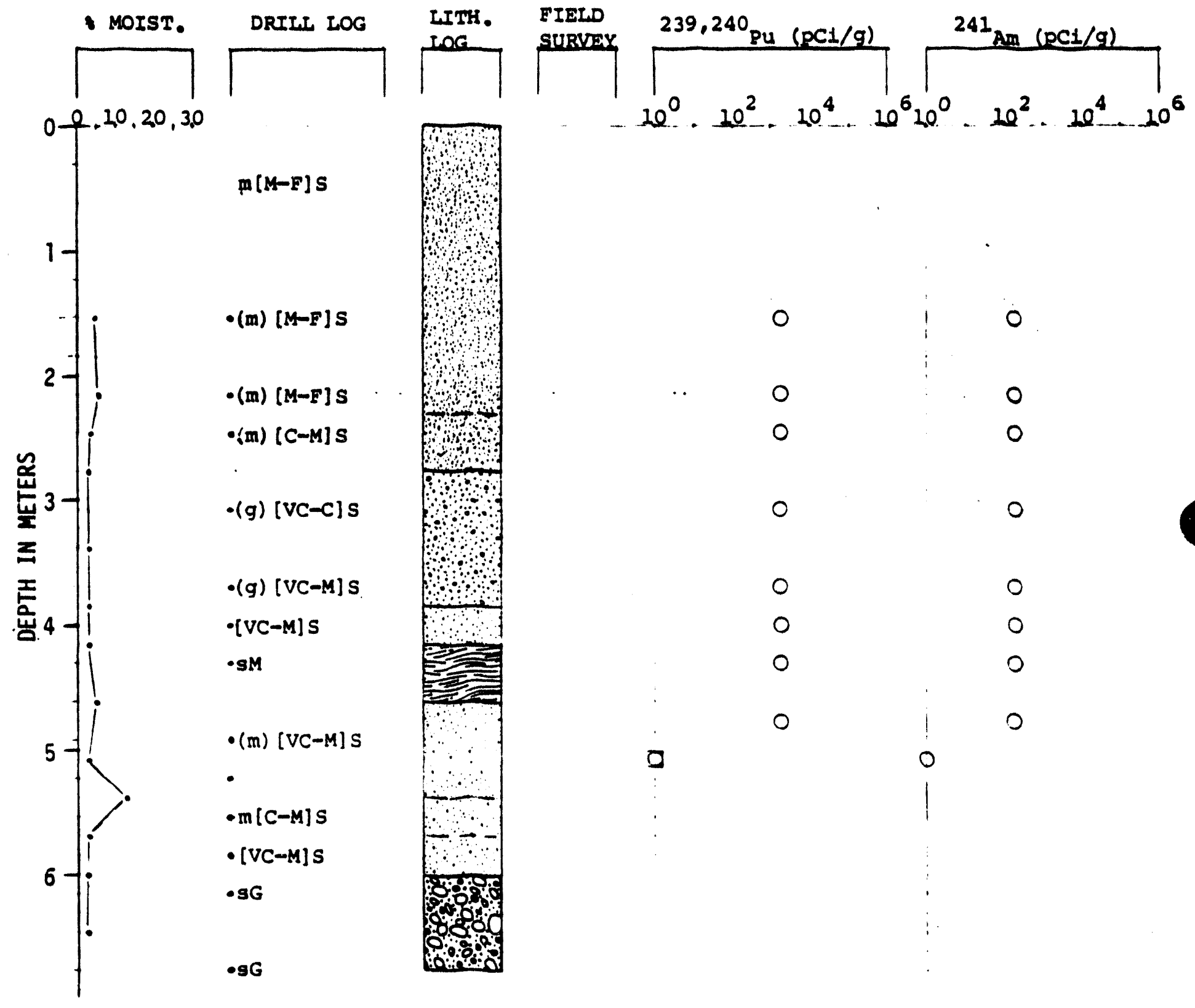

Figure J.9. Geologic and Radioactivity Logs for Well 299-W18-186 
WHC-EP-0707, Rev. 0

ELEVATION 203.4 METERS

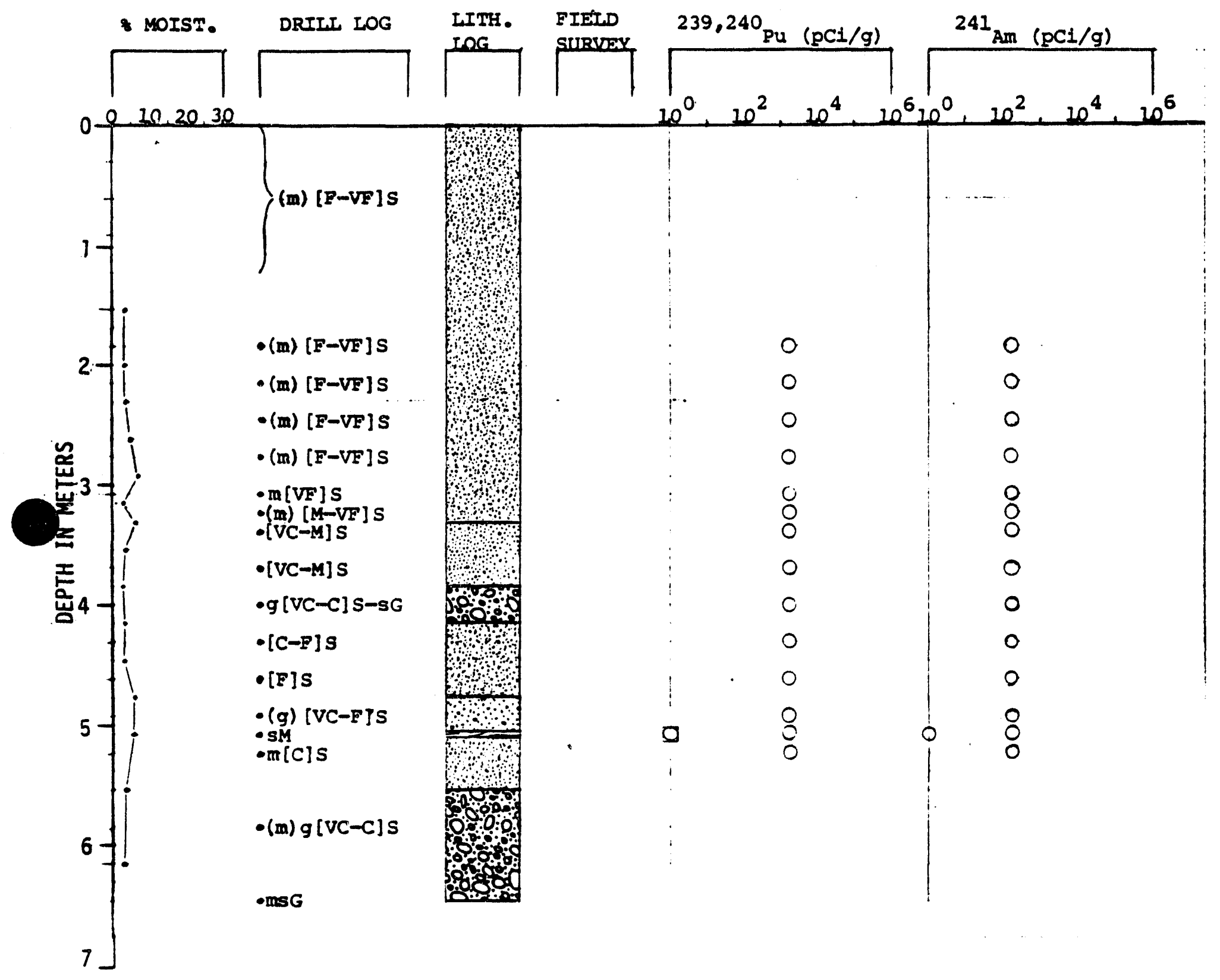

Figure J.10. Geologic and Radioactivity Logs for Well 299-W18-187 
WHC-EP-0707, Rev. 0

ELEVATION 203.0 METERS

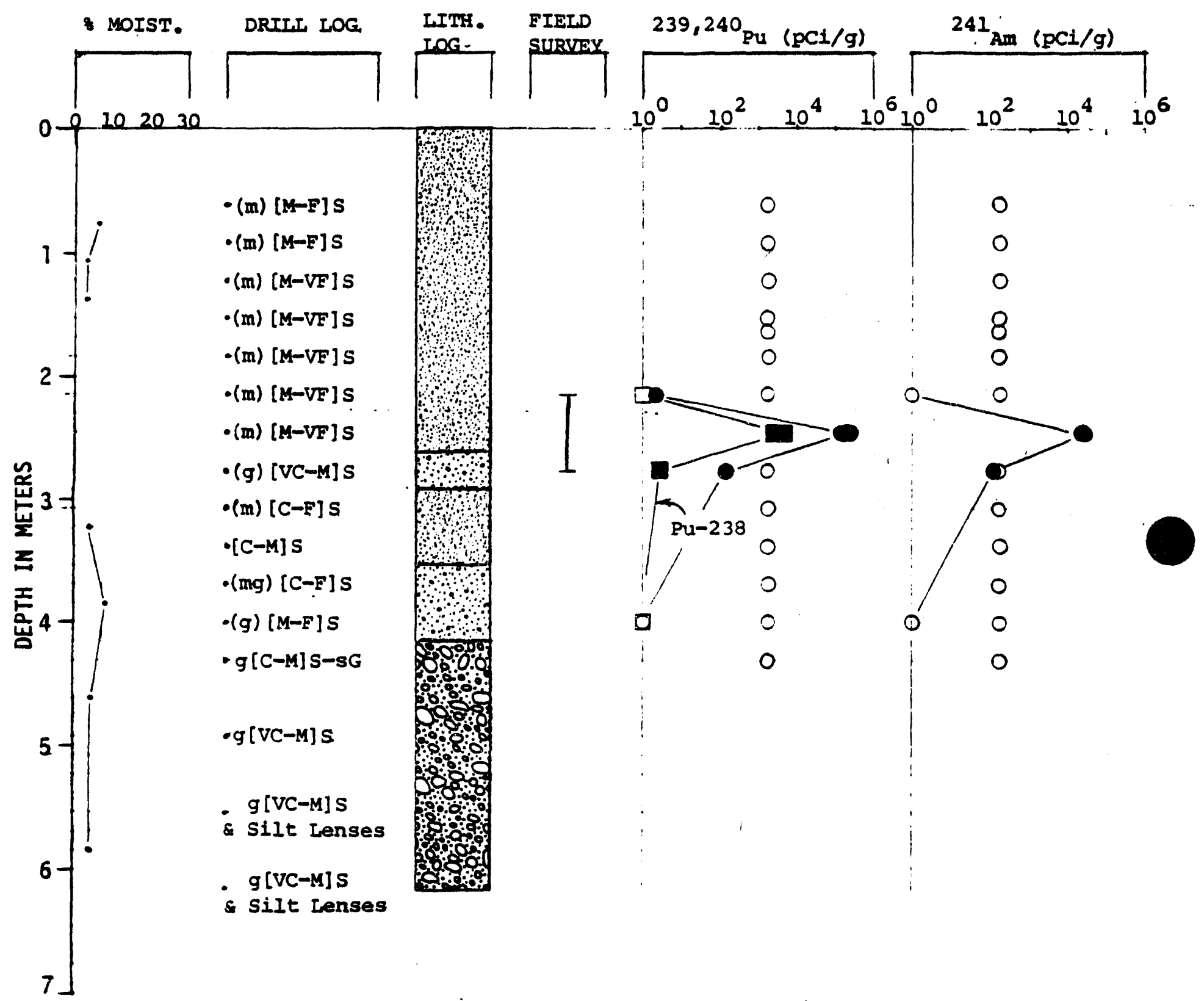

Figure J.11. Geologic and Radioactivity Logs for Well 299-W18-188 
WHC-EP-0707, Rev. 0

\section{ELEVATION 202.4 METERS}

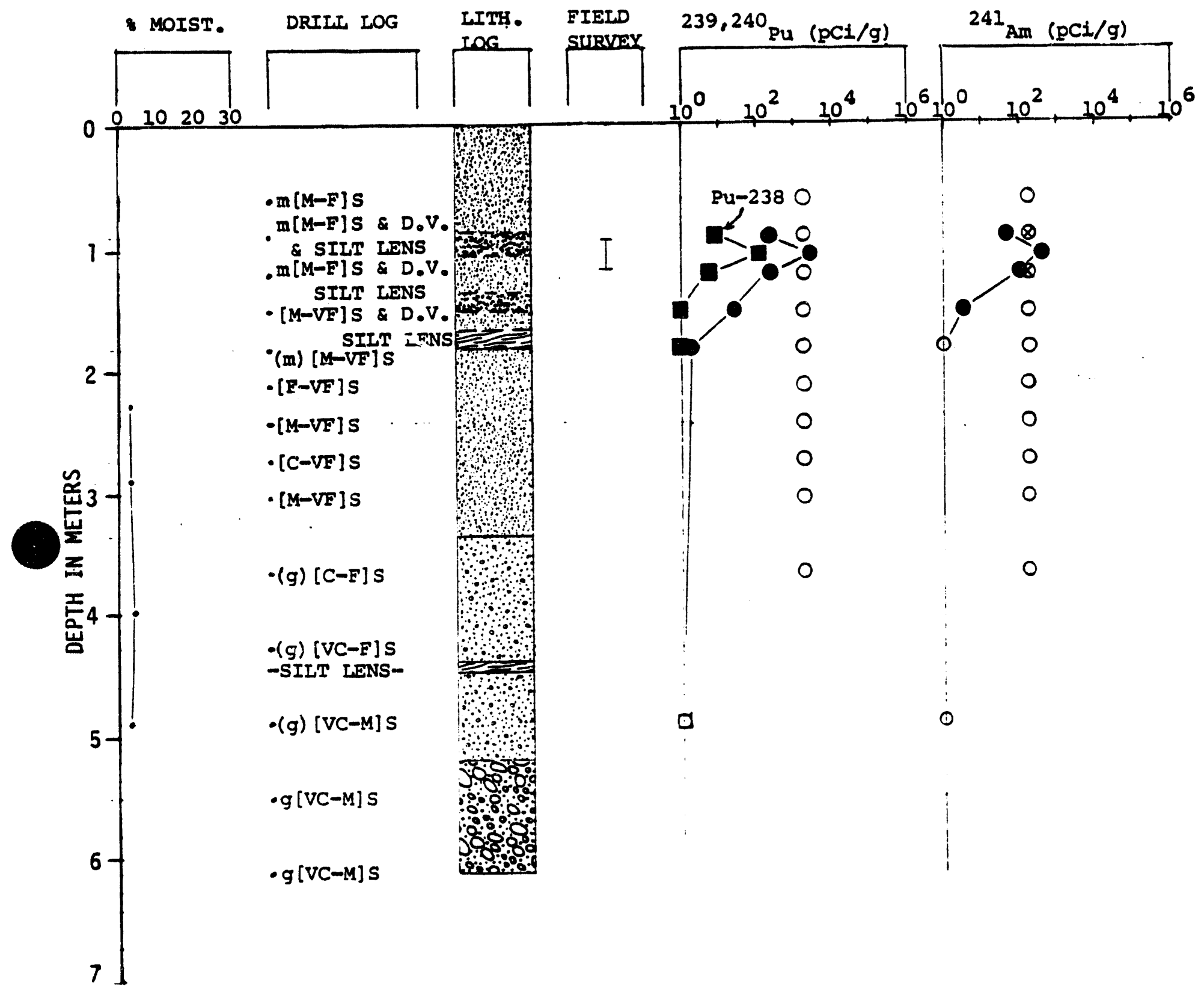

Figure J.12. Geologic and Radioactivity Logs for Well 299-W18-189 
WHC-EP-0707, Rev. 0

ELEVATION 203.4 METERS

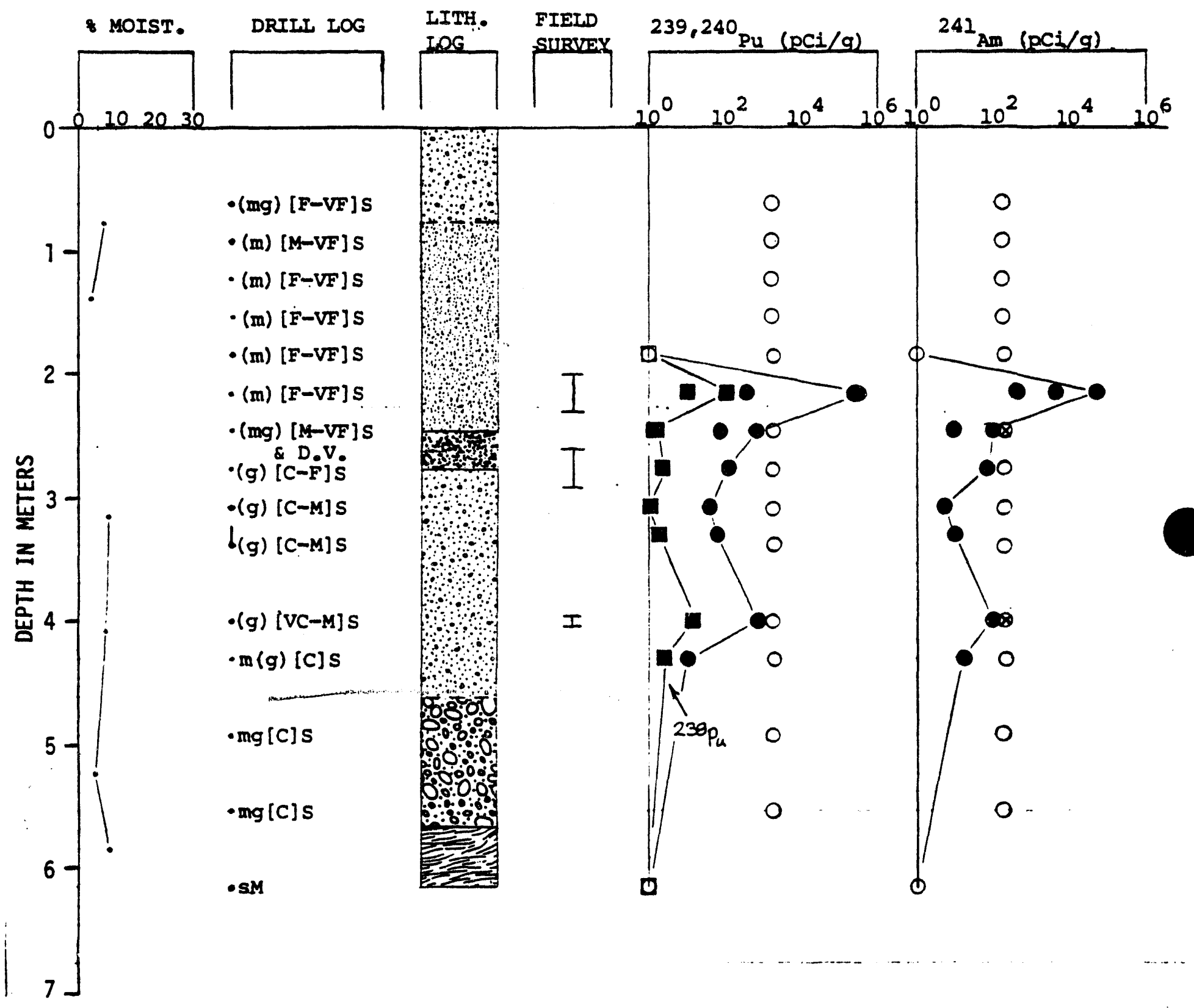

Figure J.13. Geologic and Radioactivity Logs for Well 299-W18-192 
WHC-EP-0707, Rev. 0

ELEVATION 203.1 METERS

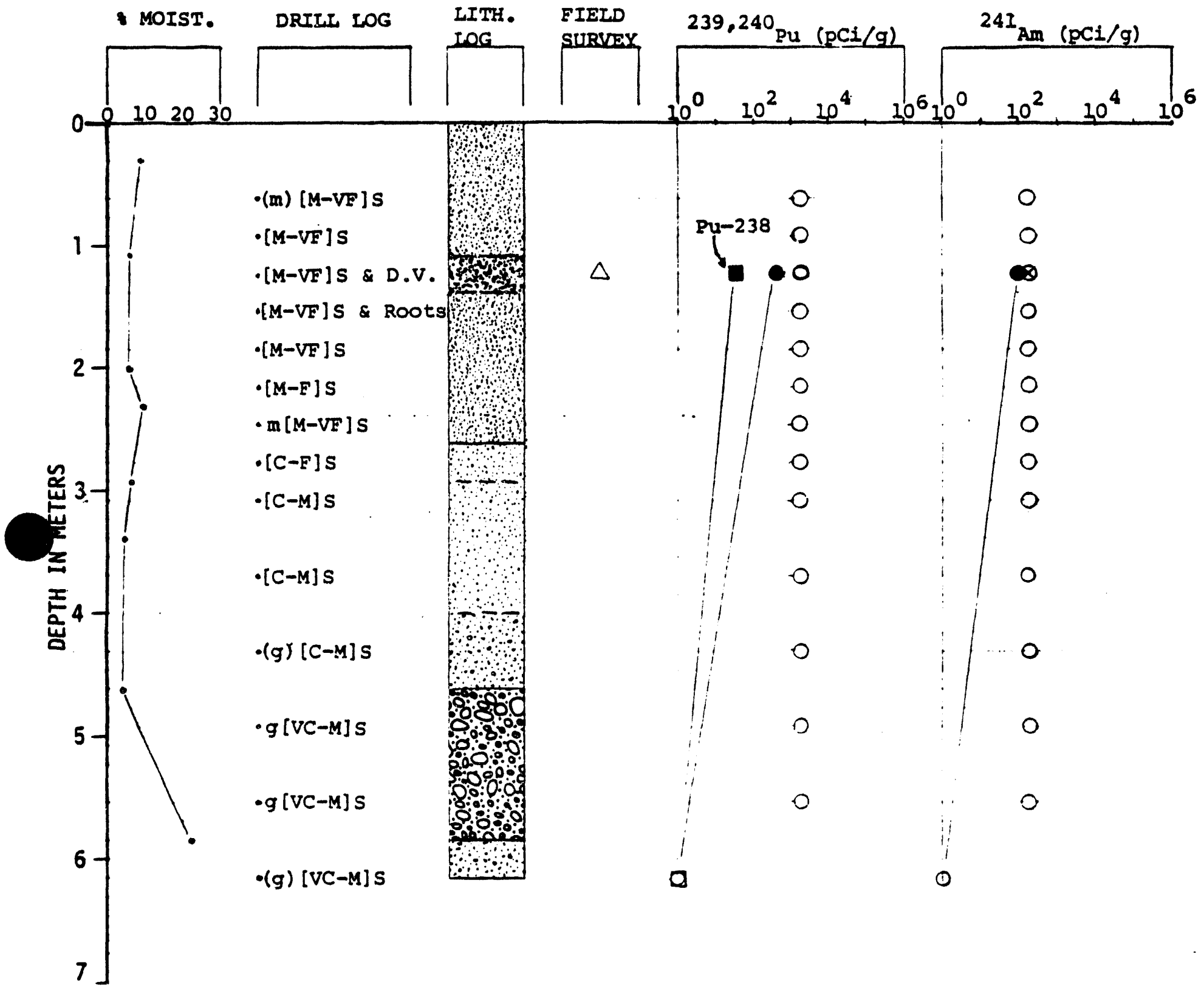

Figure J.14. Geologic and Radioactivity Logs for Well 299-W18-193 
ELEVATION 202.8 METERS

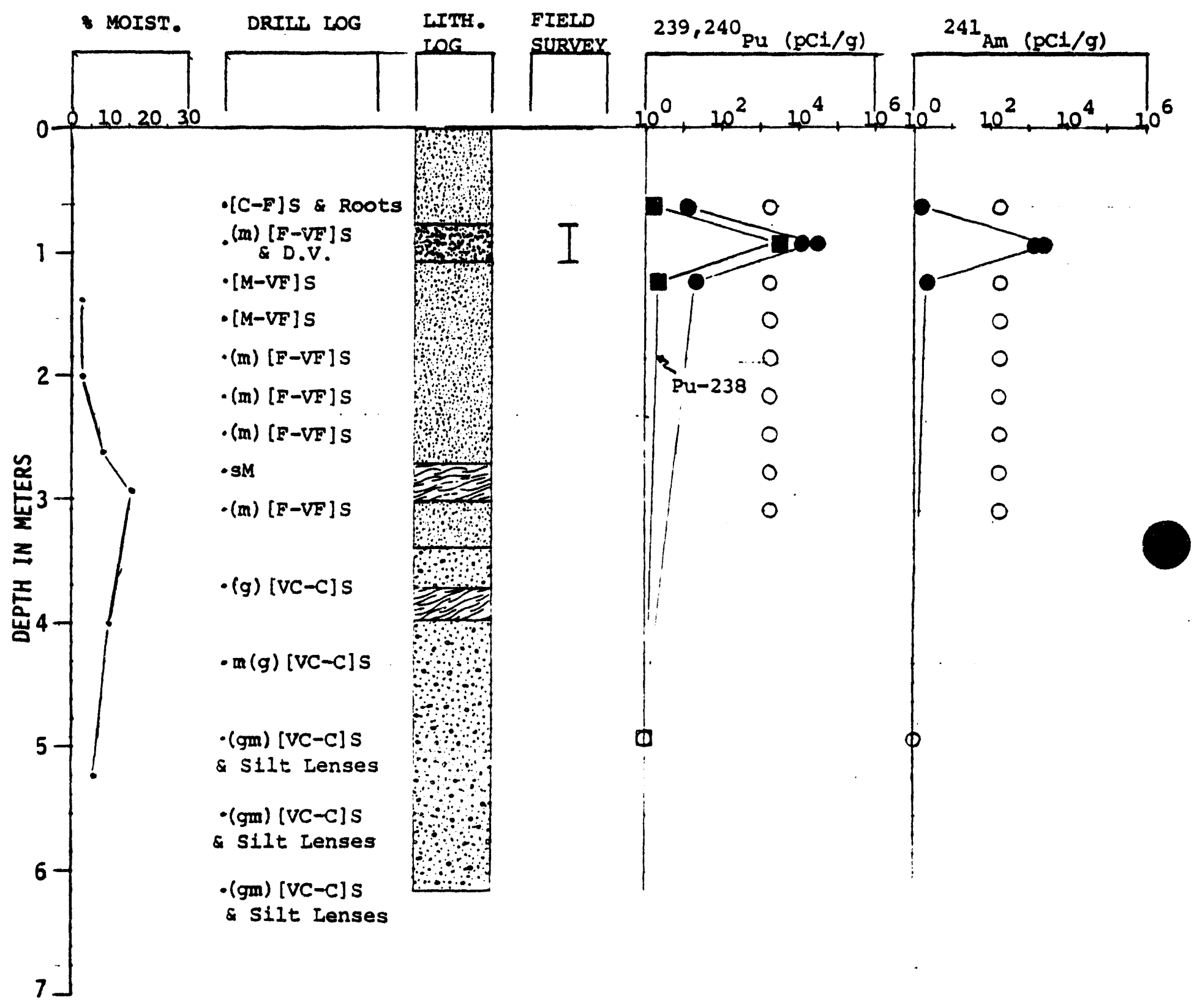

Figure J.15. Geologic and Radioactivity Logs for Well 299-W18-194 
WHC-EP-0707, Rev. 0

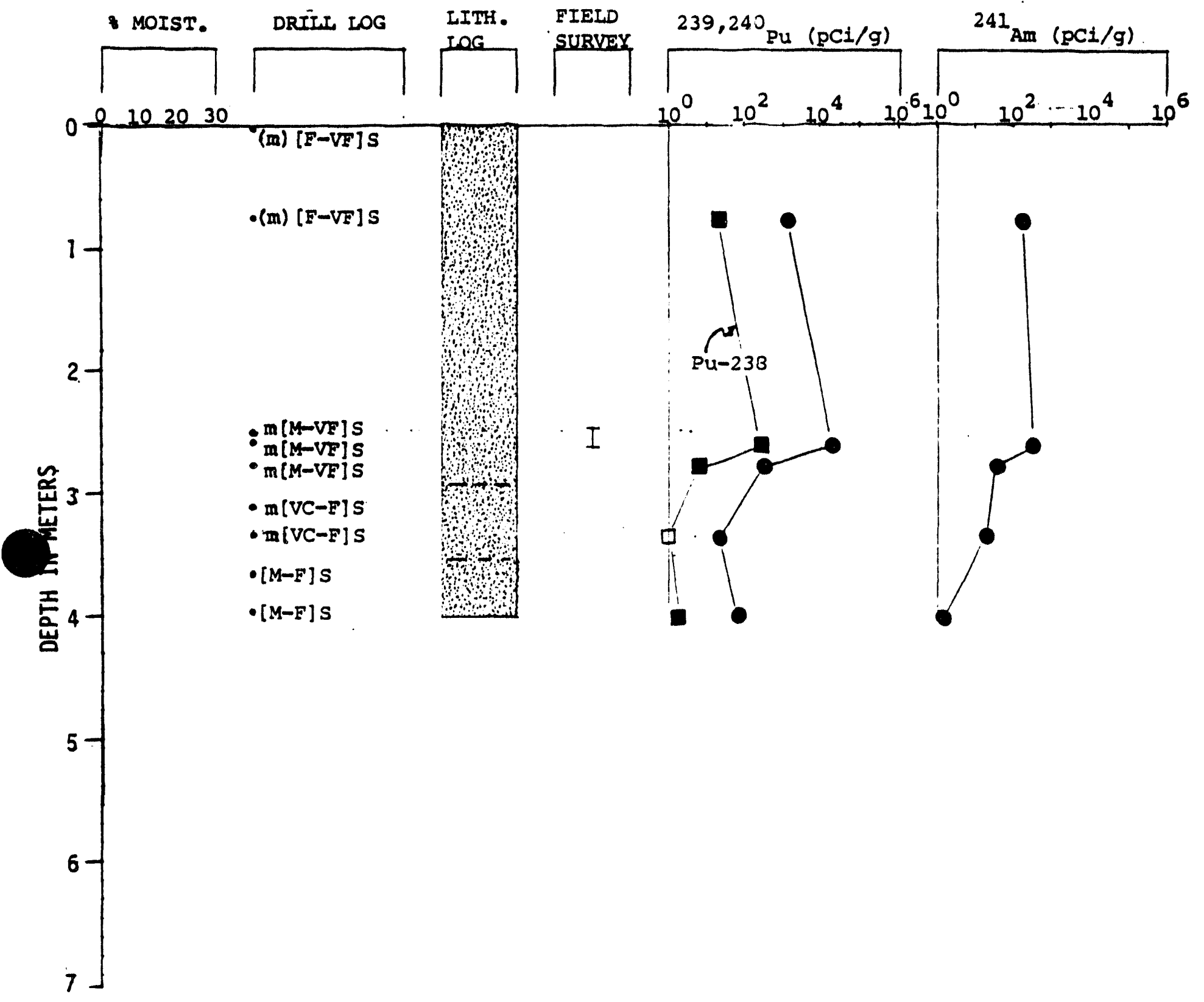

Figure J.16. Geologic and Radioactivity Logs for Well 299-W18-195 
WHC-EP-0707, Rev. 0

ELEVATION APPROXIMATELY 203:0 METERS.

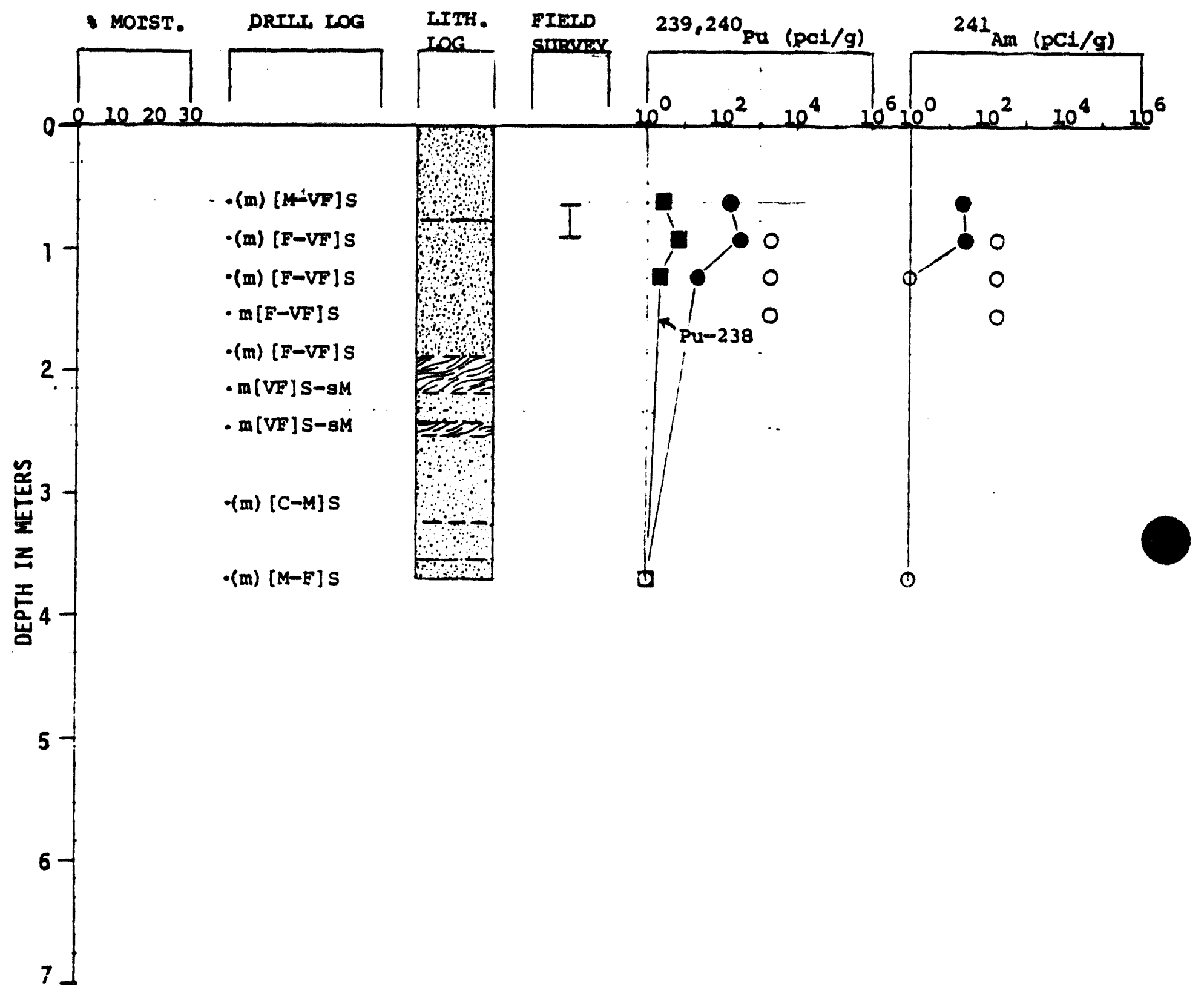

Figure J.17. Geologic and Radioactivity Logs for Well 299-W18-196 
WHC-EP-0707, Rev. 0

ELEVATION 203.5 METERS

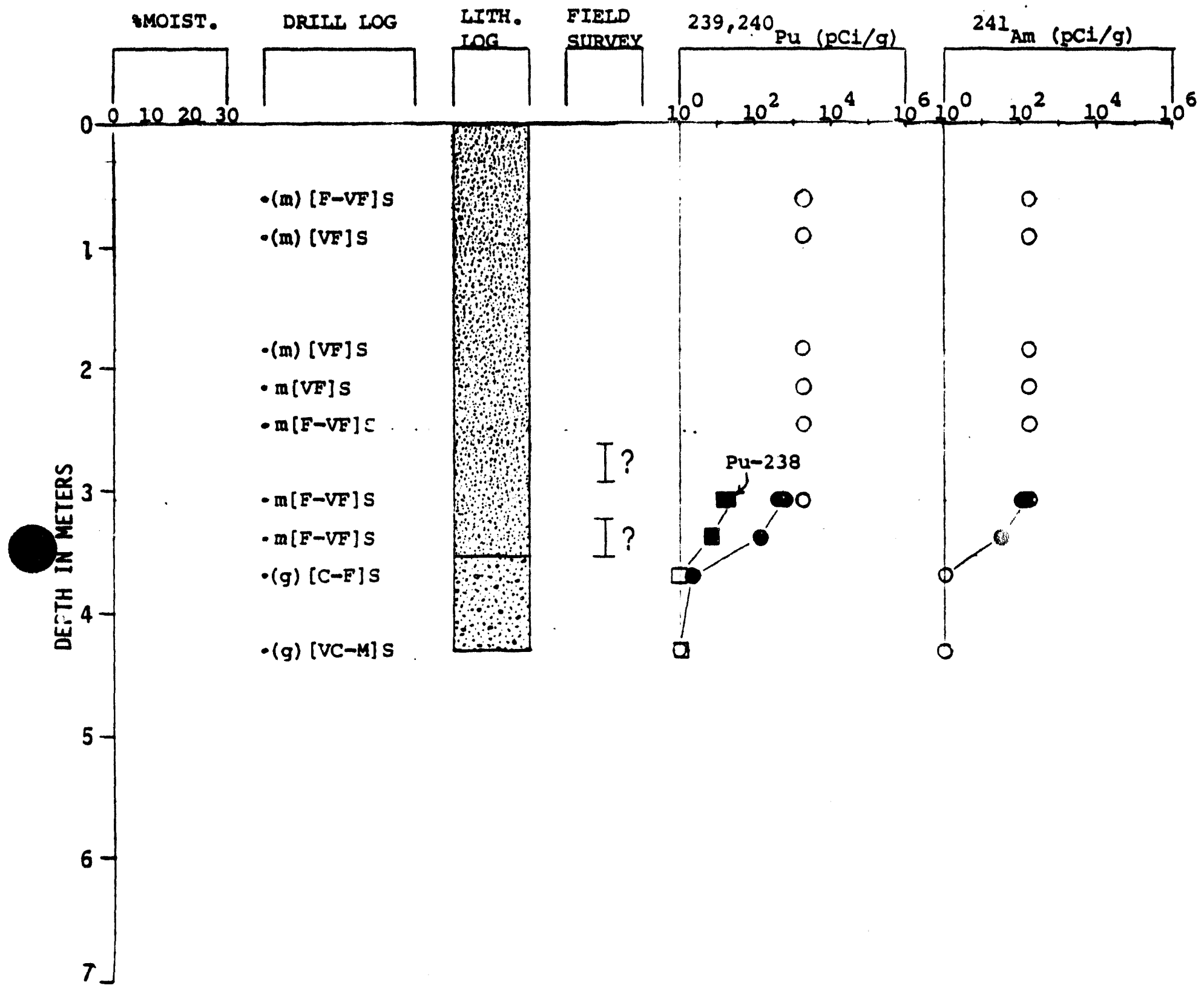

Figure J.18. Geologic and Radioactivity Logs for Well 299-W18-197 
WHC-EP-0707, Rov. 0

ELEVATION 203.4 METERS

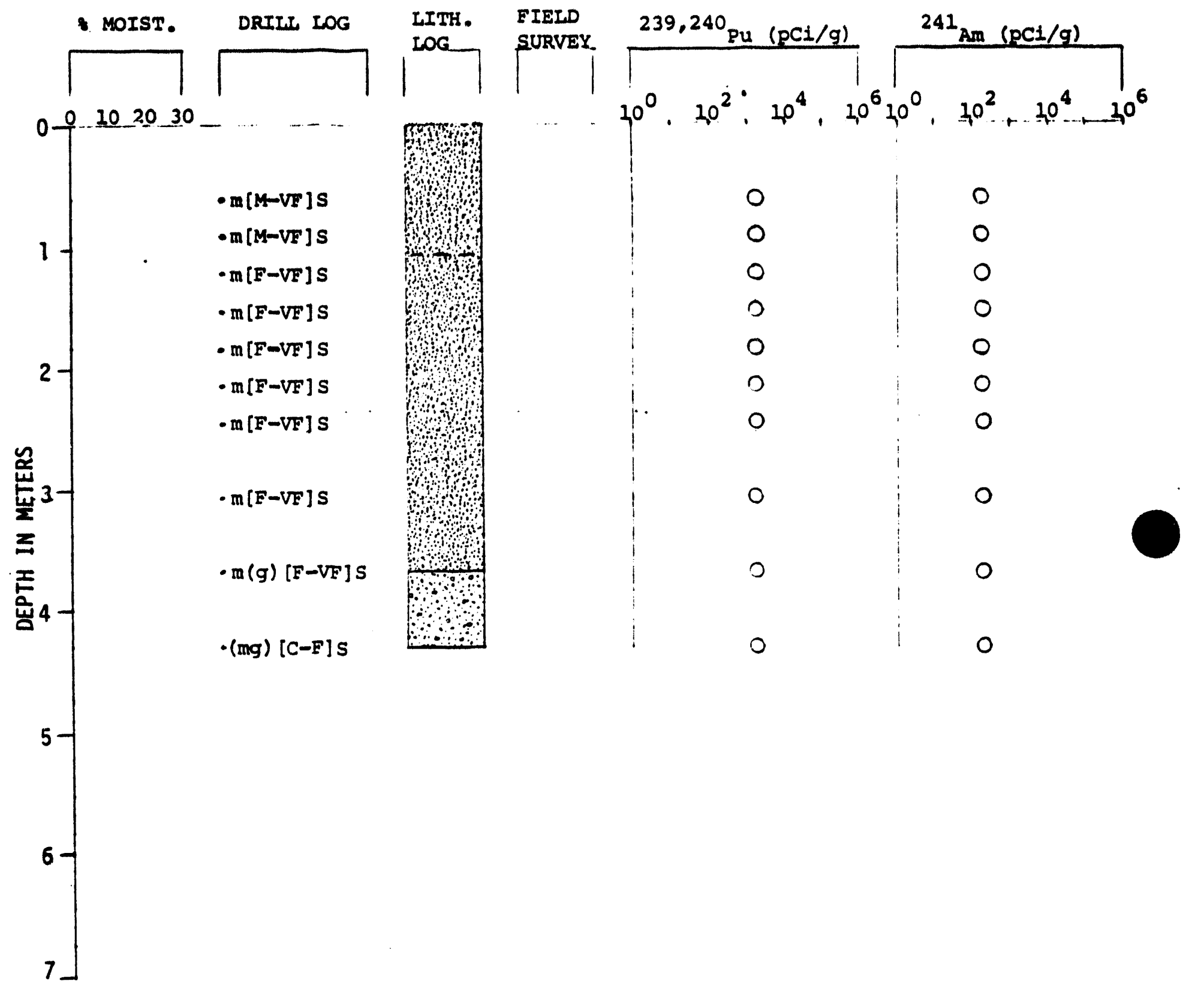

Figure J.19. Geologic and Radioactivity Logs for Well 299-W18-198 
WHC-EP-0707, Rov. 0

\section{ELEVATION 203.4 METERS}

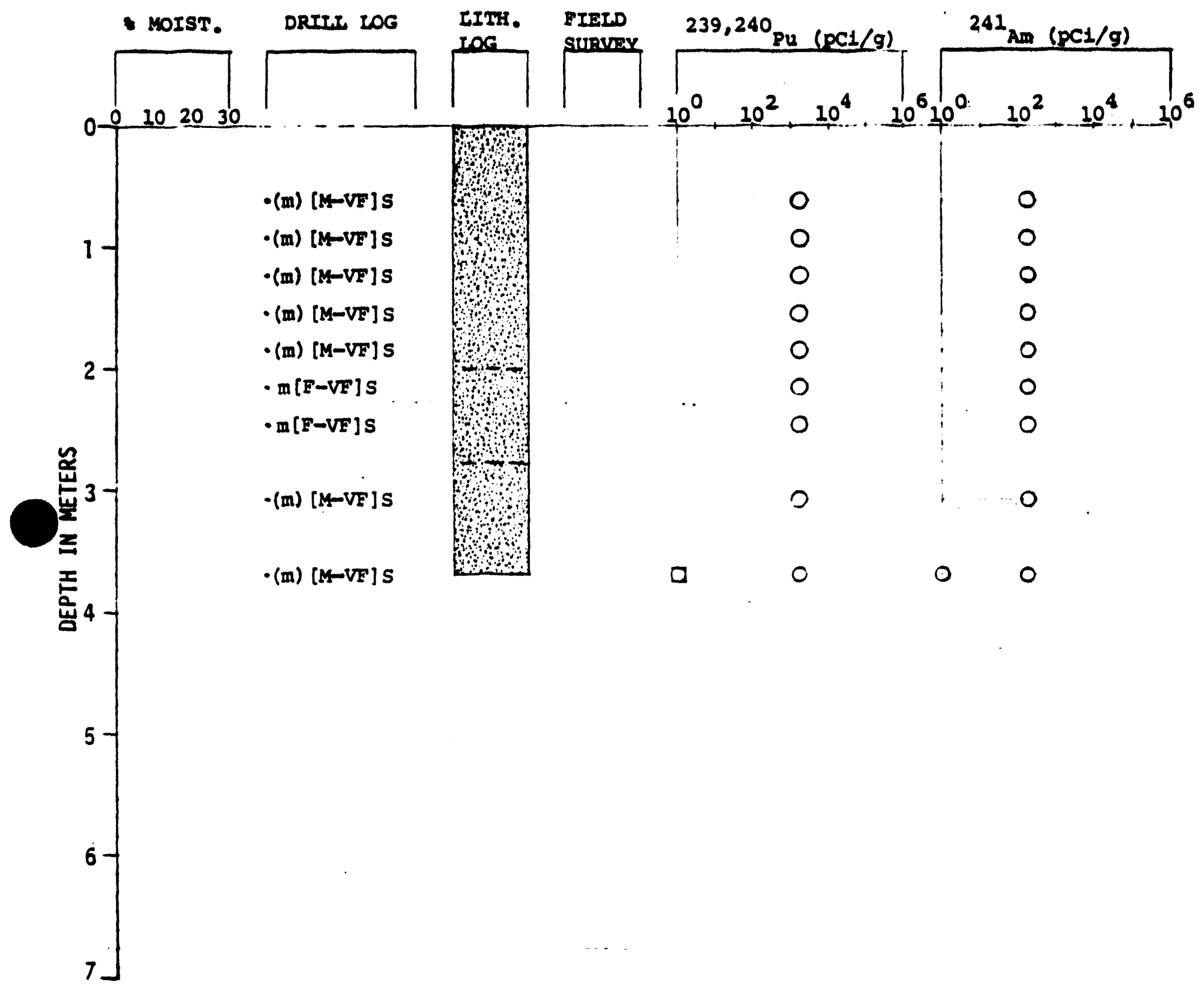

Figure J.20. Geologic and Radioactivity Logs for Well 299-W18-199 
WHC-EP.0707, Rev. 0

ELEVATION 203.5 METERS

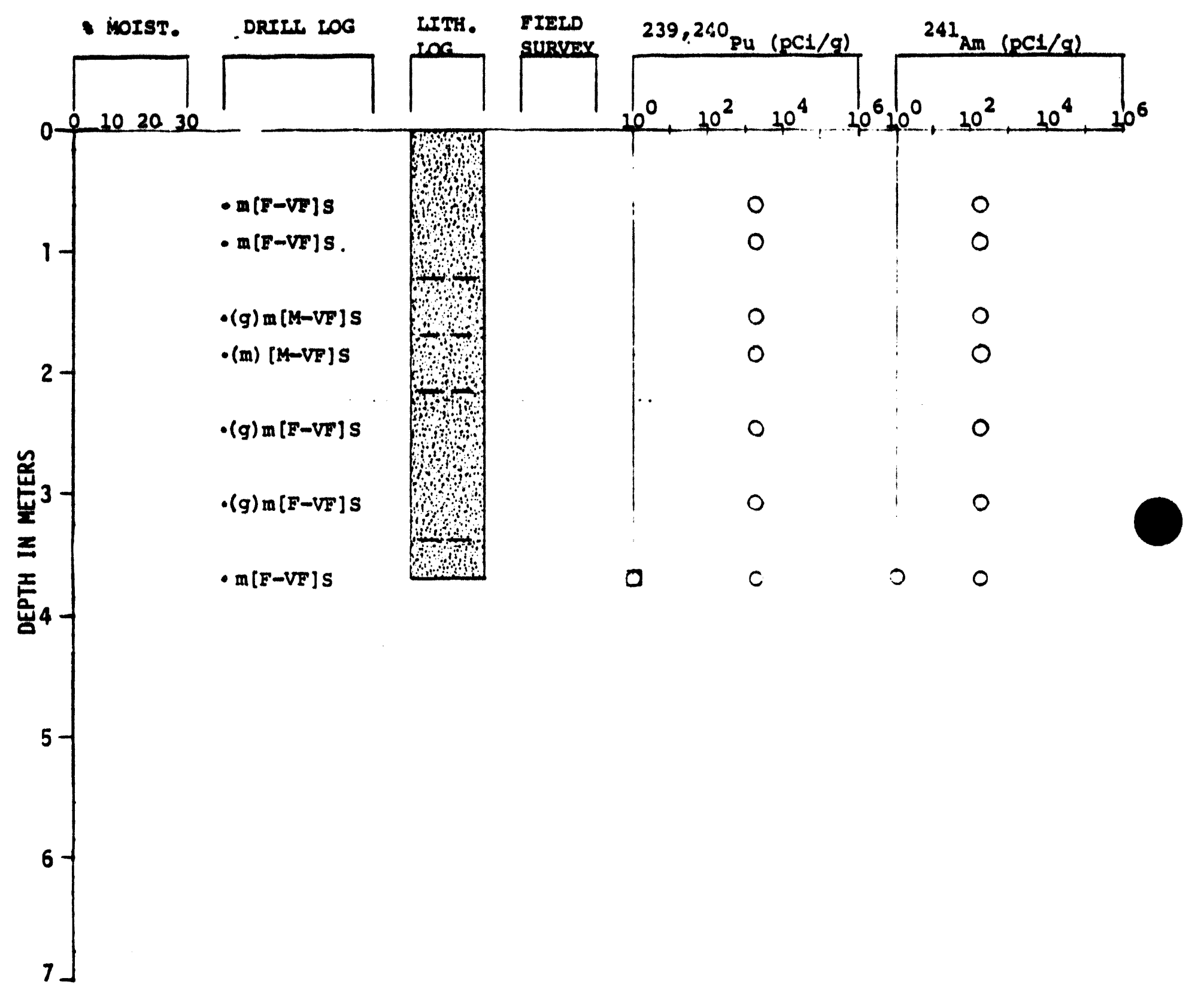

Figure J.21. Geologic and Radioactivity Logs for Well 299-W18-200 
WHC-EP-0707, Rev. 0

\section{DISTRIBUTION}

No. of Copies

\section{Onsite}

\section{Westinghouse Hanford Company}

23

L. D. Arnold

B2-35

J. A. Caggiano

H6-06

M. P. Connelly

H6-06

D. W. Duncan

G6-07

K. R. Fecht

G. E. Fitzgibbon

H6-06

M. J. Galgoul

V. W. Hall

V. G. Johnson

A. J. Knepp

D. S. Landeen

A. G. Law

K. A. Lindsey

P. J. Mackey

R. M. Mitchell

H6-07

H6-03

R2-85

H6-06

H6-06

H4-14

H6-06

H6-06

B3-06

S. P. Reidel

H6-04

V. J. Rohay

K. M. Singleton

D. K. Tyler

IRA (3)

H6-06

H6-06

H6-06

H6-06

H6-17

9

Pacific Northwest Laboratory

M. A. Chamness

K6-84

M. J. Graham

$\mathrm{K} 6-78$

G. V. Last (5)

K6-84

P. E. Long

K6-84

Hanford Technical Library

P8-55 

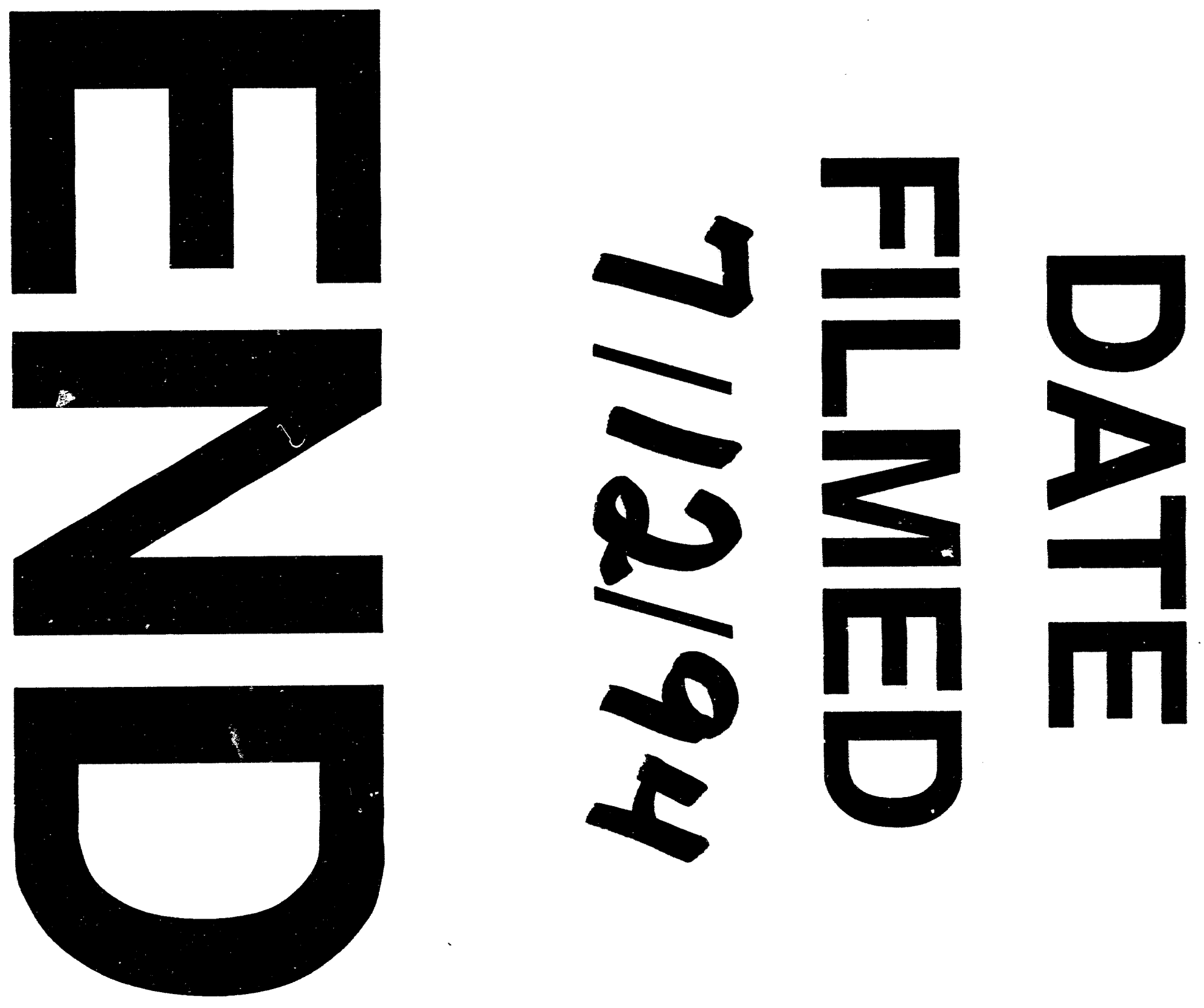

5 